\title{
3. BAJA CALIFORNIA PASSIVE MARGIN TRANSECT: SITES 474, 475, AND $476^{1}$
}

\author{
Shipboard Scientific Party²
}

\section{INTRODUCTION}

In the previous chapter, we briefly discussed current thought on the origin and evolution of passive continental margins, the geological problems that may be resolved by a combination of marine geology, geophysics, and scientific deep-sea drilling, and the philosophy and advantages of drilling in a youthful, passive continental margin. Current ideas on the origin and geological history of the Gulf of California were also reviewed and will not be repeated here.

Present tectonics of the Gulf are shown in Figure 1. The East Pacific Rise enters the mouth of the Gulf and extends to the triple junction at the first major transform, the Tamayo Fracture Zone. Of concern here is the geological history of the youthful passive or intraplate continental margin of the tip of Baja California (Fig. 2). Drilling this youthful continental margin was proposed early in the JOIDES and IPOD planning phases of scientific deep-sea drilling, because the margin's structure can be determined geophysically, and the sediment section overlying the crustal rocks is thin enough to be penetrated by drilling.

Subaerial geology of the southern end of the Baja California peninsula is shown in Figure 3. The crystalline basement rocks consist of probable Paleozoic metamorphics, mainly metasediments and metavolcanics, intruded by Cretaceous diorites, tonalites, and granodio-

\footnotetext{
${ }^{1}$ Curray, J. R., Moore, D. G., et al., Init. Repts. DSDP, 64: Washington (U.S. Govt. Printing Office).

2 Joseph R. Curray (Co-Chief Scientist), Geological Research Division, Scripps Institution of Oceanography, La Jolla, California; David G. Moore (Co-Chief Scientist). Deep Sea Drilling Project, Scripps Institution of Oceanography, La Jolla, California (present ad dress: Geological Research Division, Scripps Institution of Oceanography, La Jolla, California); J. Eduardo Aguayo, Instituto Mexicano del Petróleo, México 14, D. F. México: MarePierre Aubry. Woods Hole Oceanographic Institution, Woods Hole, Massach Metrs, and LabPierre Aubry, Wods Hole Oceanographic Institution, Woods Hole, Massachusetts, and Laboratoire de Geologie des Bassins Sedimentaires, Universite Pierre et Marie Curie, Paris. France; Gerhard Einsele, Geologisches Institut der Universität Tübingen, Tübingen, Federa Republic of Germany; Daniel Fornari, Lamont-Doherty Geological Observatory, Columbia University, Palisades, New York (present address: Department of Geology, State University of New York at Albany, Albany, New York); Joris Gieskes, Ocean Research Division, Scripps Institution of Oceanography, La Jolla, California; José Guerrero-Garcia, Instituto de Geología, Universidad de México, México, D. F., México: Miriam Kastner, Geological Research Division, Scripps Institution of Oceanography. La Jolla, California; Kery Kelts, Deep Sea Drilling Project, Scripps Institution of Oceano Drilling Project, Scripps Institution of Oceanography, La Jolla, California (present address: Eidgenössische Technische Hochschule, Geologisches Institut, Zürich, Switzerland); Mitchell Lyle, Department of Geology, Stanford University, Stanford, California (present address: School of Oceanography, Oregon State University, Corvallis, Oregon); Yasumochi Matoba, Department of Geology, Stanford University, Stanford, California (present address: Institute of Mining Geology, Mining College, Akita University, Akita, Japan); Adolfo Molina-Cruz, Instituto de Geología, Universidad de México, México, D. F., México; Jeffrey Niemitz. Department of Geology, Dickinson College, Carliste, Pennsylanias Jaime Rueda-Gaxiola, DeSaunders, Department of Geological Sciences, The University, Birmingham B15 2TT, United Kingdom (present address: Department of Geology, Bedford College, London, United Kingdom); Hans Schrader, School of Oceanography, Oregon State University, Corvallis, Oregon; Bernd R. T. Simoneit, Department of Geophysics and Planetary Physics, University of California, Los Angeles, California (present address: School of Oceanography, Oregon State University, Corvallis, Oregon); and Victor Vacquier, Graduate Division, Scripps Institution of Oceanography, La Jolla, California.
}

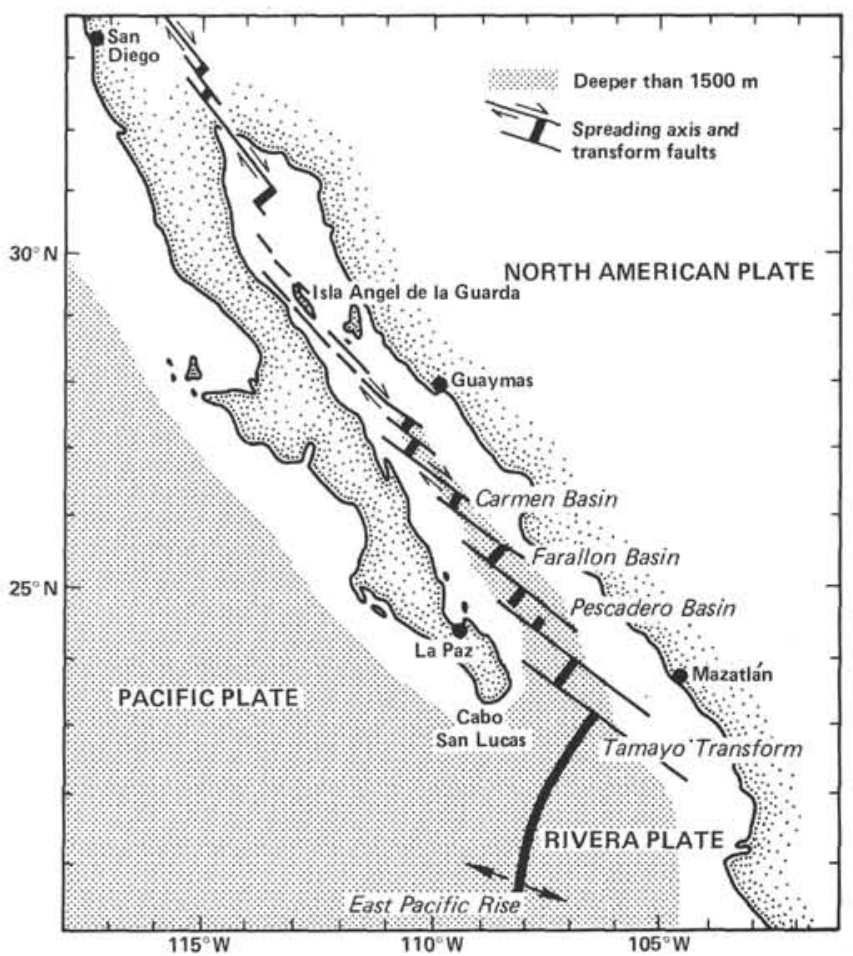

Figure 1. Simplified tectonic map, Gulf of California.

rites. Ages of the intrusives range from 54 to $88 \mathrm{~m} . \mathrm{y}$. (Gastil et al., 1976). The tip of the peninsula is uplifted relative to the Isthmus of $\mathrm{La} \mathrm{Paz}$ by the north-southtrending La Paz Fault system. Other faults east of, and parallel to, the La Paz Fault have formed a graben, in which early Miocene, Pliocene, and Quaternary sedimentary rocks have been deposited. These sedimentary rocks are mainly continental, but with some shallow marine facies, and generally contain considerable volcaniclastic material. West of the La Paz Fault, more of the section is shallow marine.

Normark and Curray (1968) were the first to map the offshore structure of the tip of Baja California. Their work was based on seismic reflection records, one seismic refraction station from Phillips (1964), and dredge hauls, mainly collected and reported by Shepard (1964). Their map of "basement rocks" (Fig. 4) shows a delineation of continental-versus-oceanic basement and a series of northeast-southwest-trending, normal and/or listric faults, dividing the offshore geology into a series of horst and grabens and rotated fault blocks. These faults approximately parallel the trend of the East $\mathrm{Pa}$ cific Rise in the mouth of the Gulf (Fig. 1) and the faults 


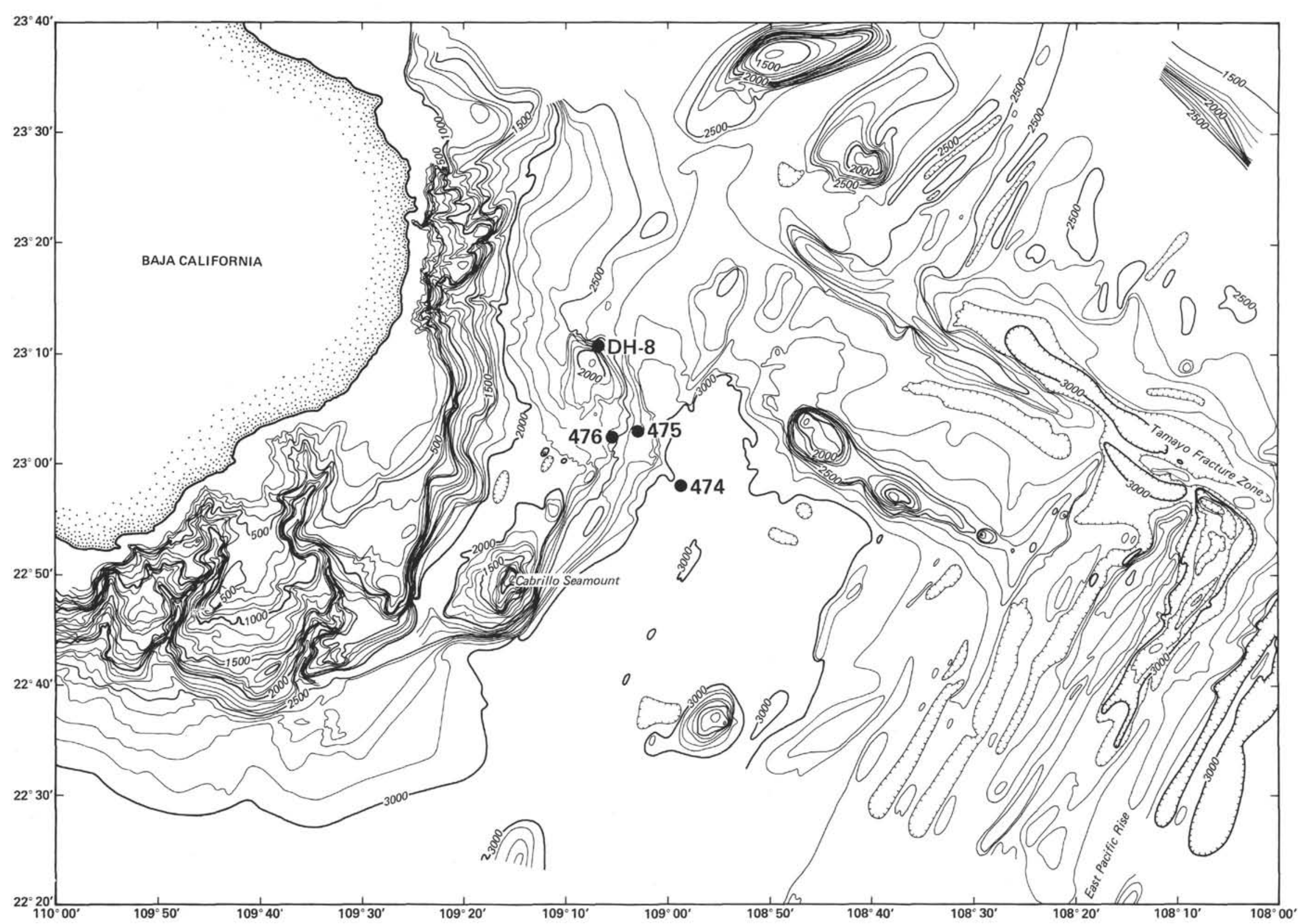

Figure 2. Regional bathymetry of the Baja California passive-margin transect (contours are in uncorrected meters, assuming $1500 \mathrm{~m} / \mathrm{s}$; drilling sites and one selected dredge sample are also shown). 


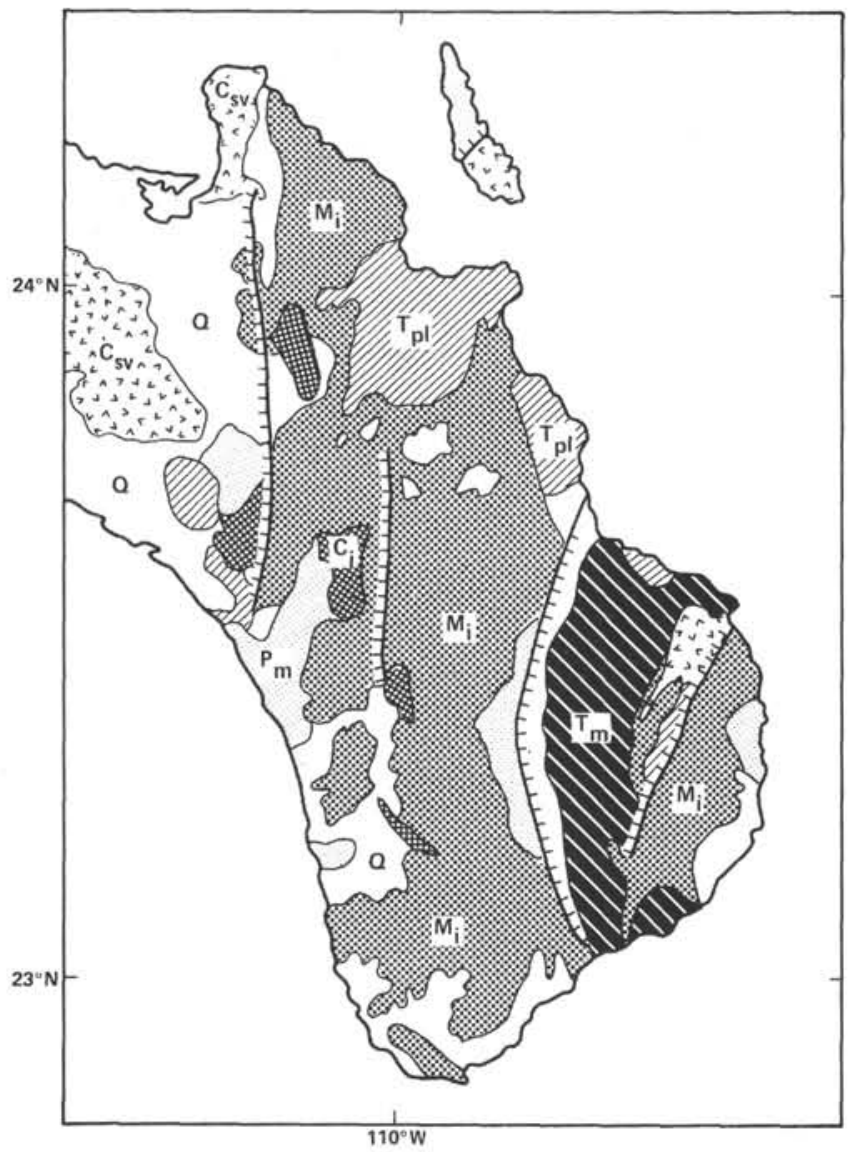

Figure 3. Simplified geology of the tip of Baja California (after Lopez Ramos, 1976; $\mathrm{Q}=$ Quaternary, principally alluvium; $\mathrm{T}_{\mathrm{pl}}=$ Pliocene coastal alluvium and marine deposits; $\mathrm{T}_{\mathrm{m}}=$ upper Miocene marine deposits; $\mathrm{C}_{\mathrm{sv}}=$ Miocene-to-Recent continental volcanics and pyroclastics, principally Comondu Formation in this area; $C_{i}=$ Cenozoic intrusives; $M_{i}=$ Mesozoic intrusives, principally late Cretaceous granite and granodiorite; $\mathrm{P}_{\mathrm{m}}=$ Paleozoic metasediments and metavolcanics).

forming the graben on land; they are probably the result of the extension or thinning of continental crust associated with opening of the Gulf. They also attempted to identify the onshore sedimentary formations in their offshore seismic reflection records.

Larson (1972), Larson et al. (1968), and Moore and Buffington (1968) delineated the magnetic anomalies in the mouth of the Gulf. They also identified the oldest anomaly at the foot of the continental slope off the tip of Baja California as approximately $3.5 \mathrm{~m} . \mathrm{y}$. Lewis et al. (1975) further refined the correlation of the anomalies (Fig. 5).

The geophysical, geological, and drilling objectives of studying a young passive margin such as this are to determine the structure of the continental crust associated with rifting and drifting, to delineate the precise contact between continental and oceanic crust, to determine the nature of the oldest oceanic crust adjacent to the continental crusts, to determine the nature and age of the sediments overlying the subsided continental crust and the oldest crust, and to determine rates of subsidence and geological history that occurred during the

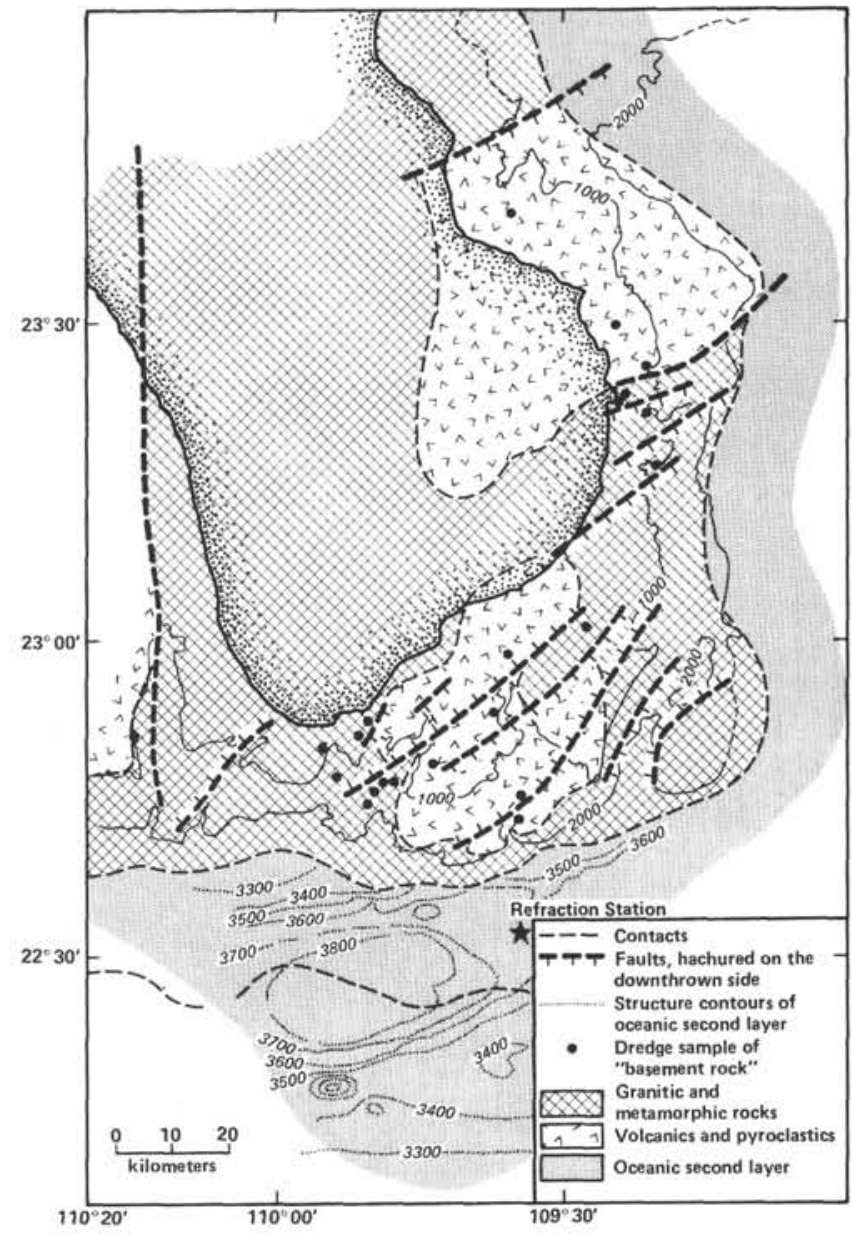

Figure 4. Configuration of "basement rocks" with sediments removed (Normark and Curray, 1968, with permission from the Geological Society of America).

rifting and drifting periods. The specific objectives of each site in this three-site transect will be discussed as background and objective for each site.

Our plan in drilling this transect was to ensure that we located the transition from continental to oceanic crust. We chose the first site (474; Planning Site GCA-5) such that drilling would penetrate the oldest oceanic crust at the foot of the continental slope (Figs. 5, 6). If we penetrated oceanic crust (as predicted), the next site or sites chosen (Sites 475, 476; Planning Sites GCA-6, GCA-7A, respectively; Fig. 6) would be those presumed to be the lowermost continental crust immediately landward of Site 474 . If drilling at the first site had bottomed in subsided continental crust, then a second attempt to find the oldest oceanic crust would be made at a site farther seaward (Planning Site GCA-3).

\section{BAJA CALIFORNIA MARGIN TRANSECT: PRINCIPAL RESULTS (Fig. 7)}

Drilling at Site 474 (Figs. 2, 7) penetrated about 500 meters of (mostly) mud turbidites, rich in diatoms; but the first 100 meters included a 66-meter debris flow of cobbles and sand, fining upward to silty clay. The deep- 


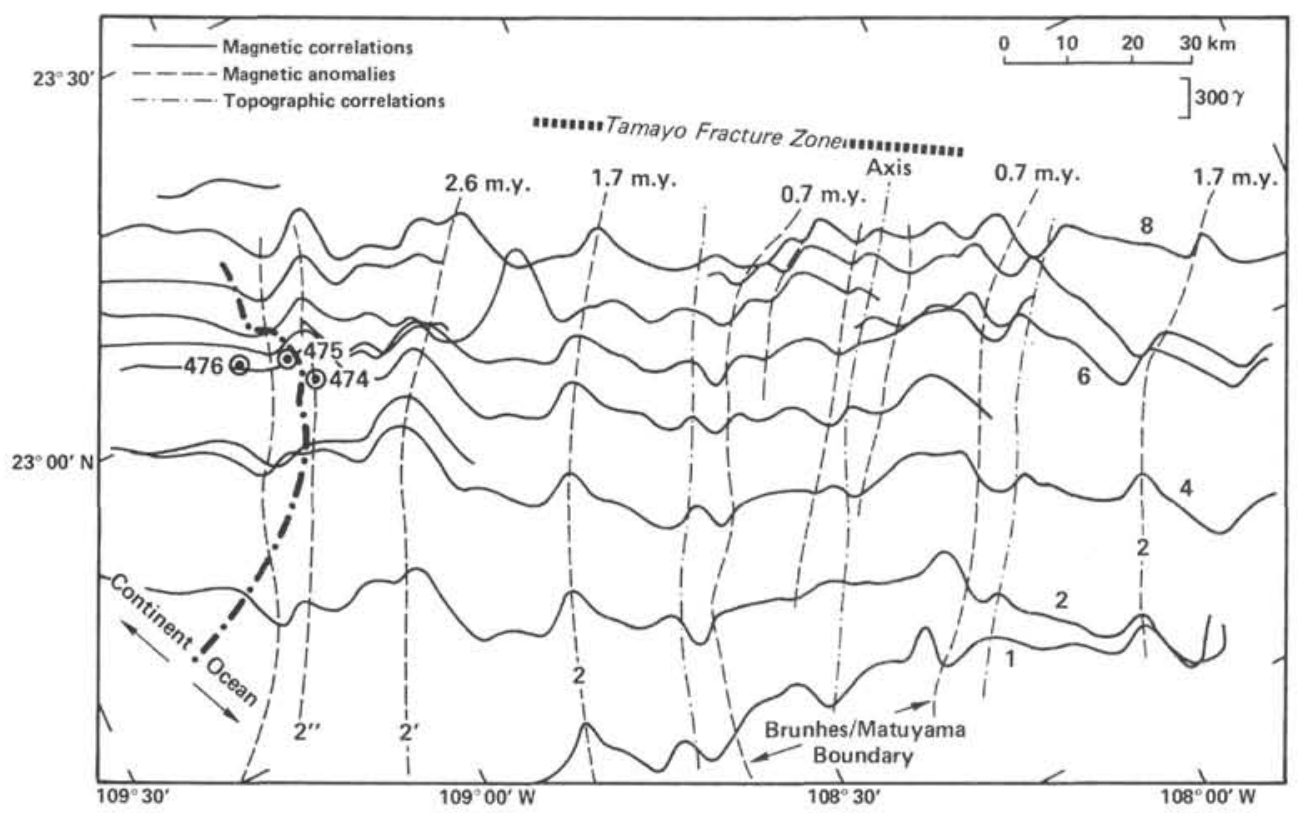

Figure 5. Magnetic anomaly correlations. (From Lewis et al., 1975, with permission of the authors.)

est hole bottomed in late Pliocene sediments between dolerite sills and a pillow lava.

At Site 475 , drilling penetrated mostly diatom-rich hemipelagic mud through early Pliocene dolomitic mud and glauconite; drilling was abandoned in a conglomerate of metavolcanic cobbles. Hole 476 penetrated essentially the same section as at Site 475 and bottomed in deeply subaerially weathered granite.

\section{HOLE 474}

Date occupied: 2 December 1978

Date departed: 4 December 1978

Time on hole (hr.): 22.23

Position: $22^{\circ} 57.72^{\prime} \mathrm{N}$; $108^{\circ} 58.84^{\prime} \mathrm{W}$

Water depth (sea level; corrected m, echo-sounding): 3023

Water depth (rig floor; corrected m, echo-sounding): 3033

Bottom felt (m, drill pipe): 3043

Penetration (m): 182.5

Number of cores: 20

Total length of cored section (m): 182.5

Total core recovered $(\mathrm{m}): 77.63$

Oldest sediment cored:

Depth sub-bottom (m): 182.5

Nature: Nannofossil clayey silt

Age: Quaternary (NN19)

Basement: Not reached

Principal results: Hole 474 is $55 \mathrm{~km}$ southeast of the tip of Baja California. Three sedimentary units are recognized in the Quaternary section. The uppermost unit $(0-21 \mathrm{~m})$ is hemipelagic diatomaceous mud and ooze. The second comprises a 66-meter-thick sequence of cobbles, gravel, and sand, fining upward to nannofossil-rich silty clay, probably a debris flow of older sediments from a shallower depth. It lies between the younger, deeper-water muddy diatom ooze of Unit I (above) and the younger deeper-water clayey silts, silty clays, nannofossil marls, and mud turbidites of Unit III (below).

\section{HOLE 474A}

Date occupied: 4 December 1978

Date departed: 10 December 1978

Time on hole (hr.): 152.37

Position: $22^{\circ} 57.56^{\prime} \mathrm{W}$; $108^{\circ} 58.68^{\prime} \mathrm{N}$

Water depth (sea level; corrected m, echo-sounding): 3022

Water depth (rig floor; corrected m, echo-sounding): 3032

Bottom felt (m, drill pipe): 3043

Penetration $(\mathrm{m}): 626$

Number of cores: 50

Total length of cored section (m): 465.6

Total core recovered $(\mathrm{m}): 283.8$

Core recovery $(\%): 61$

Oldest sediment cored:

Depth sub-bottom (m): 572

Nature: Mudstone between flows

Age: Late Pliocene (NN16)

Basement:

Depth sub-bottom (m): 562.5

Nature: Basalt flows and doleritic sills

Measured velocity $(\mathrm{km} / \mathrm{s}): 4.80-6.27$

Principal results: Hole $474 \mathrm{~A}$ was washed to 163.5 meters and then continuously cored to a total sub-bottom depth of 626 meters. The lowermost of the three sedimentary units of Hole 474 continued to 240 meters. Two other underlying units are recognized in this hole: Unit 4, a continuing Quaternary section of silty claystone to clayey siltstone and mudstone turbidites (to $480 \mathrm{~m}$ ); and Unit 5, early Pliocene to Quaternary clayey siltstone, sands, mud flows, calcitecemented sandstone, and silty claystones, intercalated between dolerite sills (to $553.2 \mathrm{~m}$ ). The oldest sediment, late Pliocene (NN16), is beneath the first basalt flow of the basement at just over 572 meters. A complete logging program followed the drilling.

\section{SITE 474: BACKGROUND AND OBJECTIVES}

Site 474 is east of the tip of the Baja California peninsula in a basin filled with deep-sea fan sediments (Figs. $2,7)$. It is on what was presumed to be the oldest ocean- 


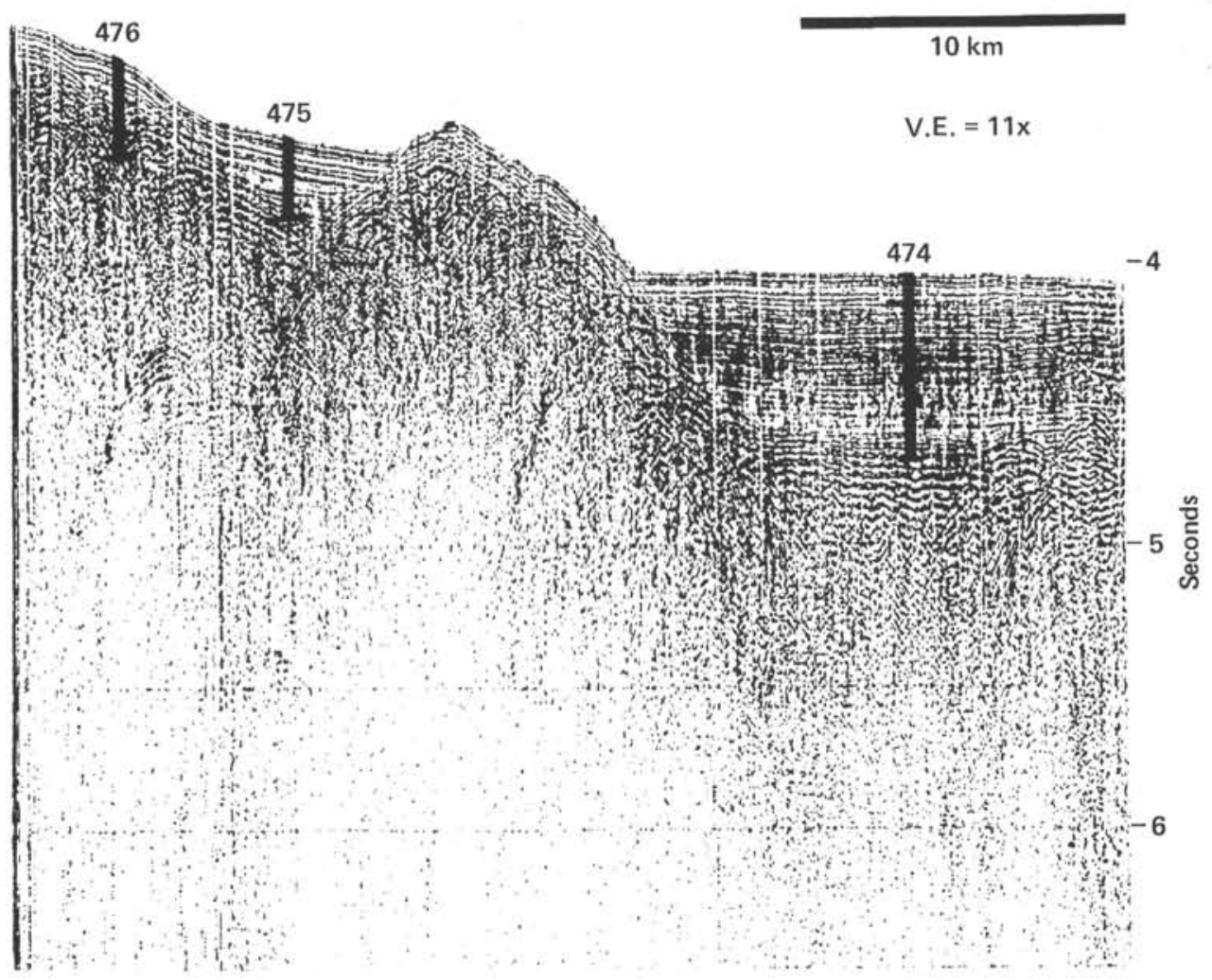

Figure 6. Single-channel analog seismic reflection record from Glomar Challenger across Sites 474 and 475 , with Site 476 projected into this section.

ic crust and closely adjacent to what was, presumably, the most deeply subsided continental crust of the peninsula. The site is seaward of the edge of continental crust as interpreted by Normark and Curray (1968) (Fig. 4) and is on the landwardmost correlatable magnetic anomaly from Larson et al. (1968) and Lewis et al. (1975) (Fig. 5). Its interpreted age is approximately $3.2 \mathrm{~m} . \mathrm{y}$.

Our specific drilling objectives for this site-in the context of the transect objectives outline in the previous chapter-included the following:

1) Basement rocks

a) Confirming that this site lies seaward of the continent/ocean crust transition

b) Determining the composition and character of the basement rocks, presumably the oldest created in this present phase of opening of the mouth of the Gulf, for comparison with progressively younger oceanic rocks to be drilled during Leg 65 on its transect to the crest of the East Pacific Rise

2) Nature of the sedimentary section

a) Determining general lithologic and biostratigraphic facies distributions

b) Determining the age of the oldest sediments on oceanic basement rocks for comparison with interpreted ages from magnetic anomalies

c) Determining water depth indicator changes downward in the section as a record of subsidence history

d) Obtaining a record of Pleistocene sea-level fluctuations e) Determining the diagenesis of organic and inorganic matter

3) Evidence for climatic and/or oceanic circulation changes

\section{OPERATIONS}

After lowering hydrophones and testing thrusters off Mazatlán harbor, we departed on 1 December 1978 at $2010 \mathrm{Z}$ for Site 474 , the first of three sites where we planned to study the early rifting history at the mouth of the Gulf of California. Our approach to the proposed site paralleled the Thomas Washington Guaymas 01 profile (Fig. 8) and continued beyond it to the lower continental slope southeast of the tip of Baja California; we then came about, returned, and dropped the beacon ( $1447 \mathrm{Z}$ on 2 December) about $1.8 \mathrm{~km}$ ENE of the proposed site. The quality of the seismic reflection collected on our approach (Fig. 30) enabled us to select a preferred site 900 meters northwest of the beacon in 3020 meters water depth. After returning to this site, the ship's dynamic positioning system was actuated, and we began running into the hole at $1630 \mathrm{Z}$. We spudded at $2150 \mathrm{Z}$ and located the mudline in the first core at 3043 meters, corresponding to the (PDR) depth of 3033 meters.

We cored continuously to a depth of 182.5 meters. Recovery was 47 to $99 \%$ to 68.5 meters, where we encountered probable boulders, cobbles, and loose sand. Only one cobble was recovered to 87.5 meters. Thereafter, recovery was 35 to $71 \%$, except in apparent coarse-sand and cobble zones at 125.5 to 135 meters and 

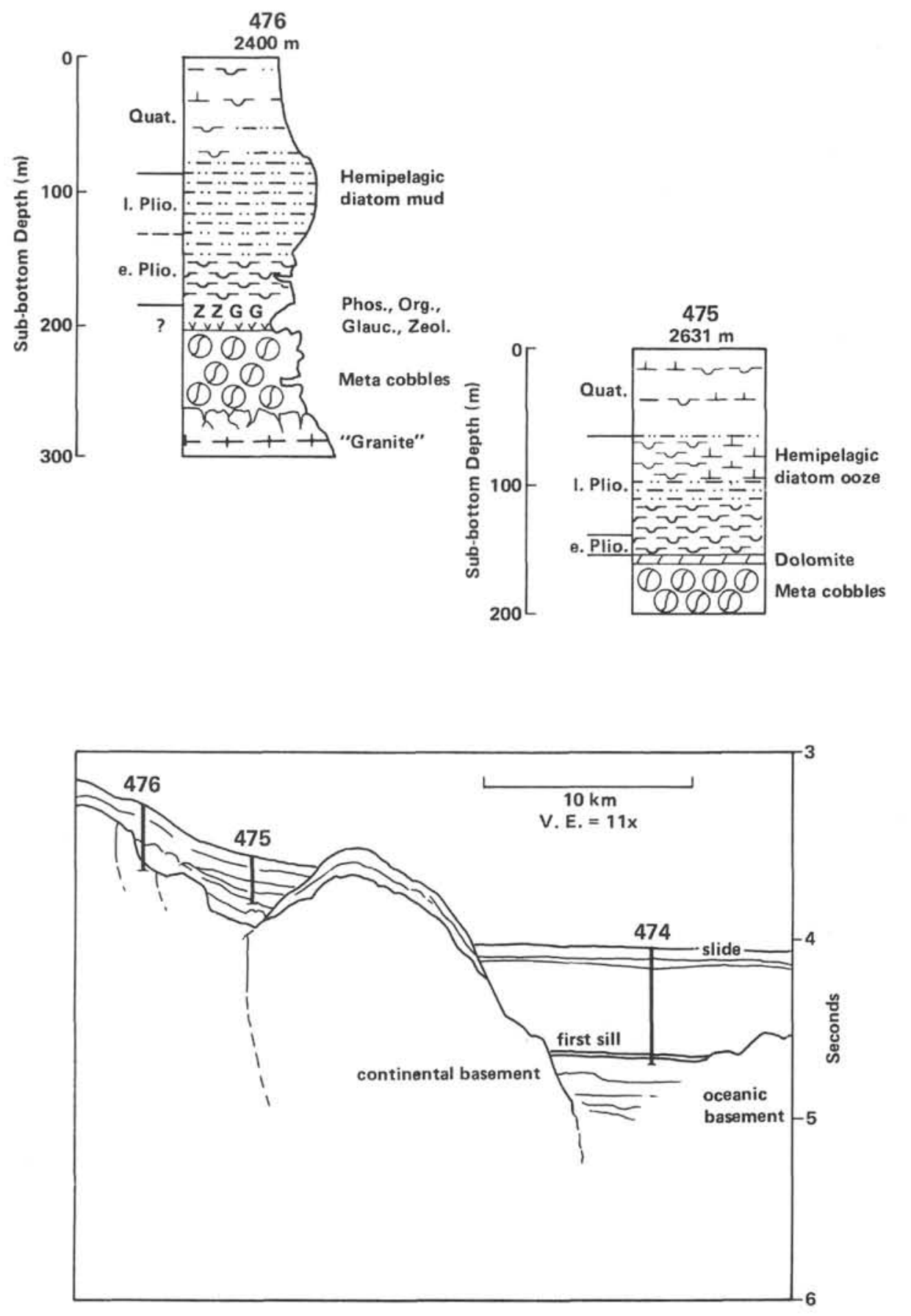

Figure 7. Simplified principal lithological results and line drawing through Baja California passive-margin transect sites.

173 to 182.5 meters, where only few pebbles were recovered. Overall recovery was $42.5 \%$ (Table 1 ).

Our principal operational problems occurred in deploying the heat-probe/pore-water sampler tool. The timing of the pore-water sampler and the caving of loose material around the bit from above caused failures on the first two attempts. A final attempt with the tool, after raising Core 474-20, resulted in our abandoning the hole: After latching, the tool could not be inserted into formation without first retracting, washing down, and then relatching. This bent the sampling tool; it could not be withdrawn, and we pulled the drill string to recover the tool.
At $1355 Z$, we moved 300 meters to the south of Hole 474 while lowering pipe. We used the mudline depth of 3043 meters established at Hole 474, because we planned to wash this hole (474A) to the equivalent depth of 161 meters before coring. This was accomplished routinely, and our first core from Hole 474A was on deck at $2310 \mathrm{Z}$. The next core was much the same as Core 474-20 (clayey silt, like the intervals above), confirming our suspicion that problems with the heat probe at Core 474-20 were the result of sand and pebbles caving in from uphole.

For the remainder of this hole, coring operations were routine, and our recovery was mostly in the 50$75 \%$ range. Drilling times increased sharply when we 


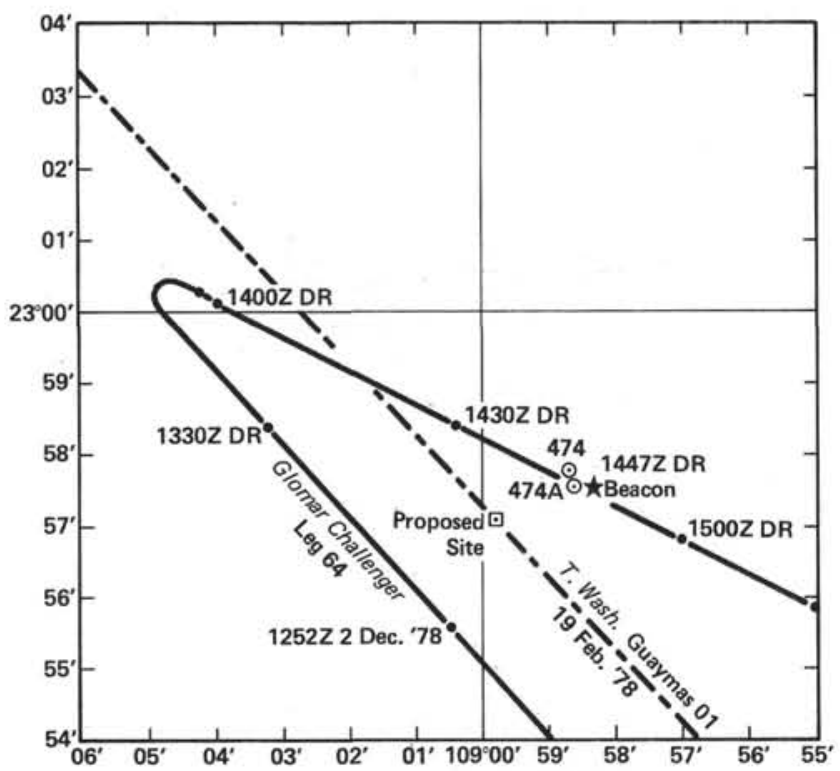

Figure 8. Track of Glomar Challenger: Approach and departure, Site 474. encountered our first dolerite sill at 521 meters. A potentially serious problem developed at Core $474 \mathrm{~A}-44$, when the core barrel stuck in the pipe and circulation was lost. After six hours' work, circulation was regained, and the core barrel was recovered. Thereafter, the hole was drilled to completion at 626 meters subbottom with more than 100 meters penetration below the top of the first sill at 521 meters.

On 9 December, after drilling ceased at 0350Z, we unsuccessfully attempted to operate the hydraulic-bitrelease mechanism; the drill pipe was also stuck in the hole: After the drill string was freed, a second go-devil was pumped down very slowly (four strokes on pump), and at $0900 \mathrm{Z}$ on 9 December, the bit released. The hole was prepared for logging and the drill string was pulled to 135 meters below the mudline.

Logging began at $0645 \mathrm{Z}$ and ended at $0830 \mathrm{Z}$ on 10 December; it consisted of four runs with eight tools:

1) density (gamma-ray back scatter), natural gamma radiation, caliper, temperature;

2) sonic (compressional wave velocity over $61-\mathrm{cm}$ interval), natural gamma radiation, caliper;

Table 1. Coring summary, Site 474.

\begin{tabular}{|c|c|c|c|c|c|c|c|}
\hline Core & $\begin{array}{c}\text { Date } \\
\text { (December, } \\
\text { 1978) }\end{array}$ & $\begin{array}{c}\text { Time } \\
(\mathrm{Z})\end{array}$ & $\begin{array}{c}\text { Depth from } \\
\text { Drill Floor } \\
\text { (m; top-bottom) }\end{array}$ & $\begin{array}{l}\text { Depth below } \\
\text { Sea Floor } \\
\text { (m; top-bottom) }\end{array}$ & $\begin{array}{l}\text { Length } \\
\text { Cored } \\
\text { (m) }\end{array}$ & $\begin{array}{l}\text { Length } \\
\text { Recovered } \\
\text { (m) }\end{array}$ & $\begin{array}{c}\text { Recovery } \\
(\%)\end{array}$ \\
\hline \multicolumn{8}{|c|}{ Hole 474} \\
\hline 1 & 2 & 1550 & $3043.0-3045.0$ & $0.0-2.0$ & 2.0 & 1.89 & 95 \\
\hline 2 & 2 & 1640 & $3045.0-3054.5$ & $2.0-11.5$ & 9.5 & 5.15 & 54 \\
\hline 3 & 2 & 1742 & $3054.5-3064.0$ & $11.5-21.0$ & 9.5 & 4.46 & 47 \\
\hline 4 & 2 & 1840 & $3064.0-3073.5$ & $21.0-30.5$ & 9.5 & 4.44 & 47 \\
\hline 5 & 2 & 2105 & $3073.5-3083.0$ & $30.5-40.0$ & 9.5 & 5.79 & 61 \\
\hline 6 & 2 & 2215 & $3083.0-3092.5$ & $40.0-49.5$ & 9.5 & 9.42 & 99 \\
\hline 7 & 2 & 2340 & $3092.5-3102.0$ & $49.5-59.0$ & 9.5 & 9.42 & 99 \\
\hline 8 & 3 & 0132 & $3102.0-3111.5$ & $59.0-68.5$ & 9.5 & 8.44 & 89 \\
\hline 9 & 3 & 0310 & $3111.5-3121.0$ & $68.5-78.0$ & 9.5 & 0.00 & 0 \\
\hline 10 & 3 & 0552 & $3121.0-3130.5$ & $78.0-87.5$ & 9.5 & 0.10 & 1 \\
\hline 11 & 3 & 0652 & $3130.5-3140.0$ & $87.5-97.0$ & 9.5 & 3.05 & 32 \\
\hline 12 & 3 & 0757 & $3140.0-3149.5$ & $97.0-106.5$ & 9.5 & 0.52 & 6 \\
\hline 13 & 3 & 1053 & $3149.5-3159.0$ & $106.5-116.0$ & 9.5 & 1.6 & 17 \\
\hline 14 & 3 & 1142 & $3159.0-3168.5$ & $116.0-125.5$ & 9.5 & 5.83 & 61 \\
\hline 15 & 3 & 1252 & $3168.5-3178.0$ & $125.5-135.0$ & 9.5 & 0.05 & $1 / 2$ \\
\hline 16 & 3 & 1600 & $3178.0-3187.5$ & $135.0-144.5$ & 9.5 & 3.96 & 42 \\
\hline 17 & 3 & 1717 & $3187.5-3197.0$ & $144.5-154.0$ & 9.5 & 6.27 & 66 \\
\hline 18 & 3 & 1820 & $3197.0-3206.5$ & $154.0-163.5$ & 9.5 & 3.90 & 41 \\
\hline 19 & 3 & 1919 & $3206.5-3216.0$ & $163.5-173.0$ & 9.5 & 3.33 & 35 \\
\hline 20 & 3 & 2020 & $3216.0-3225.5$ & $173.0-182.5$ & 9.5 & 0.01 & $<1$ \\
\hline \multicolumn{8}{|c|}{ Hole 474A } \\
\hline 0 & 4 & 1517 & $3190.0-3190.2$ & $147.0-147.2$ & - & 0.24 & - \\
\hline 1 & 4 & 1610 & $3206.5-3216.0$ & $163.5-173.0$ & 9.5 & 6.16 & 65 \\
\hline 2 & 4 & 1710 & $3216.0-3225.5$ & $173.0-182.5$ & 9.5 & 7.27 & 77 \\
\hline 3 & 4 & 1811 & $3225.5-3235.0$ & $182.5-192.0$ & 9.5 & 6.74 & 71 \\
\hline 4 & 4 & 1912 & $3235.0-3244.5$ & $192.0-201.5$ & 9.5 & 6.52 & 69 \\
\hline 5 & 4 & 2013 & $3244.5-3254.0$ & $201.5-211.0$ & 9.5 & 1.96 & 21 \\
\hline 6 & 4 & 2115 & $3254.0-3263.5$ & $211.0-220.5$ & 9.5 & 3.18 & 33 \\
\hline 7 & 4 & 2213 & $3263.5-3273.0$ & $220.5-230.0$ & 9.5 & 4.28 & 45 \\
\hline 8 & 4 & 2322 & $3273.0-3282.5$ & $230.0-239.5$ & 9.5 & 7.09 & 75 \\
\hline 9 & 5 & 0031 & $3282.5-3292.0$ & $239.5-249.0$ & 9.5 & 6.45 & 68 \\
\hline 10 & 5 & 0141 & $3292.0-3301.5$ & $249.0-258.5$ & 8.5 & 7.38 & 78 \\
\hline 11 & 5 & 0246 & $3301.5-3311.0$ & $258.5-268.0$ & 9.5 & 5.54 & 58 \\
\hline 12 & 5 & 0350 & $3311.0-3320.5$ & $268.0-277.5$ & 9.5 & 7.31 & 77 \\
\hline 13 & 5 & 0458 & $3320.5-3330.0$ & $277.5-287.0$ & 9.5 & 9.12 & 96 \\
\hline 14 & 5 & 0614 & $3330.0-3339.5$ & $287.0-296.5$ & 9.5 & 8.39 & 88 \\
\hline 15 & 5 & 0733 & $3339.5-3349.0$ & $296.5-306.0$ & 9.5 & 0.00 & 0 \\
\hline 16 & 5 & 0852 & $3349.0-3358.5$ & $306.0-315.5$ & 9.5 & 7.94 & 84 \\
\hline 17 & 5 & 1012 & $3358.5-3368.0$ & $315.5-325.0$ & 9.5 & 7.08 & 75 \\
\hline 18 & 5 & 1140 & $3368.0-3370.0$ & $325.0-327.0$ & 2.0 & 1.70 & 85 \\
\hline 19 & 5 & 1338 & $3370.0-3377.5$ & $327.0-334.5$ & 7.5 & 3.35 & 45 \\
\hline 20 & 5 & 1436 & $3377.5-3387.0$ & $334.5-344.0$ & 9.5 & 0.22 & 2 \\
\hline 1 & 5 & 1552 & $3387.0-3396.5$ & $344.0-353.5$ & 9.5 & 7.78 & 82 \\
\hline 22 & 5 & 1712 & $3396.5-3406.0$ & $353.5-363.0$ & 9.5 & 8.67 & 91 \\
\hline 46 & 8 & 0205 & $3624.0-3633.0$ & $581.0-590.0$ & 9.0 & 3.20 & 34 \\
\hline 47 & 8 & 0647 & $3633.0-3642.0$ & $590.0-599.0$ & 9.0 & 5.15 & 57 \\
\hline 48 & 8 & 1038 & $3642.0-3651.0$ & $599.0-608.0$ & 9.0 & 4.87 & 54 \\
\hline 49 & 8 & 1533 & $3651.0-3660.0$ & $608.0-617.0$ & 9.0 & 3.74 & 42 \\
\hline 50 & 8 & 2050 & $3660.0-3669.0$ & $617.0-626.0$ & 9.0 & 4.00 & 44 \\
\hline
\end{tabular}


3) guard (electric), natural gamma radiation, porosity (neutron back scatter);

4) temperature. ${ }^{3}$

After logging, the hole was plugged with cement from 3234.0 to 3134.0 meters and the remainder of the hole filled with mud. We left the site at $2320 \mathrm{Z}$ on 10 December.

\section{SEDIMENTARY LITHOLOGY}

\section{Introduction}

Holes 474 and 474A were drilled only 300 meters apart, and their stratigraphic sections are complementary (Fig. 9). A dolerite sill was encountered at 521 meters sub-bottom (see section on igneous petrology). Approximately 11 more meters of sediment were cored below this sill, and we recovered a small amount of claystone 553 meters below a second sill. The bottom of the sediment is defined as the top of the first basalt flow in Core $474 \mathrm{~A}-44$ at 562 meters. It is possible to correlate Holes 474 and $474 \mathrm{~A}$ by the presence of a thin layer of rhyolite ash at about 169 meters sub-bottom in Cores 474-19 and 474A-19 (Fig. 9). The oldest sediment (572 $\mathrm{m}$ ) is a small fragment of late Pliocene (NN16) intercalated claystone from below the first pillow basalts.

The site's lithology partly reflects its location at the outer fringe of a fan girdle that drains the rapidly denuding batholith terrain of southern Baja California (Figs. 3, 4). This site thus presents an opportunity to study distal fan sedimentation over time. The sediment section is predominantly hemipelagic mud and a thick sequence of mud turbidites and their more lithified counterparts. Nannofossils persist to the basement, but siliceous fossils disappear below 275 meters.

The five depositional units chosen for this section (Table 2) are based on diatom abundance for Unit I; a displaced fauna and lithology with coarse sand for Unit II; abundant muddy turbidite layers for Unit III; the change to lithified mudstone turbidites for Unit IV; and the Pleistocene/Pliocene transition for Unit V. Most of the section was deposited rapidly during the early Quaternary (NN19), although the last vestiges include evidence of late Pliocene (NN16, 3.0-2.3 m.y.) in claystones between flows.

Unit I (Cores 474-1-474-3, 0-21 m, late Pleistocene). Unit I sediments are highly disturbed but appear to comprise decimeter layers of grayish olive green (5GY $3 / 2)$ muddy diatomaceous ooze to olive-gray $(5 Y 5 / 3)$ hemipelagic muds. Nannofossils are present throughout and prominent $(20-30 \%)$ in alternating dusky yellow green (5GY 5/2) nannofossil diatomaceous clayey silts. These beds have a sharp basal contact but darken gradationally upward, suggesting episodic redeposition as turbidites. A thin arkosic sand $(474-4-1,89 \mathrm{~cm})$ contains displaced shell fragments from shallower water. Angular, silt-size quartz and feldspars are equally common terrigenous components in sands and silts. Glitter from abundant mica flakes is visible on the cut sediment sur-

\footnotetext{
${ }^{3}$ The induction tool intended for the last run was inoperative.
}

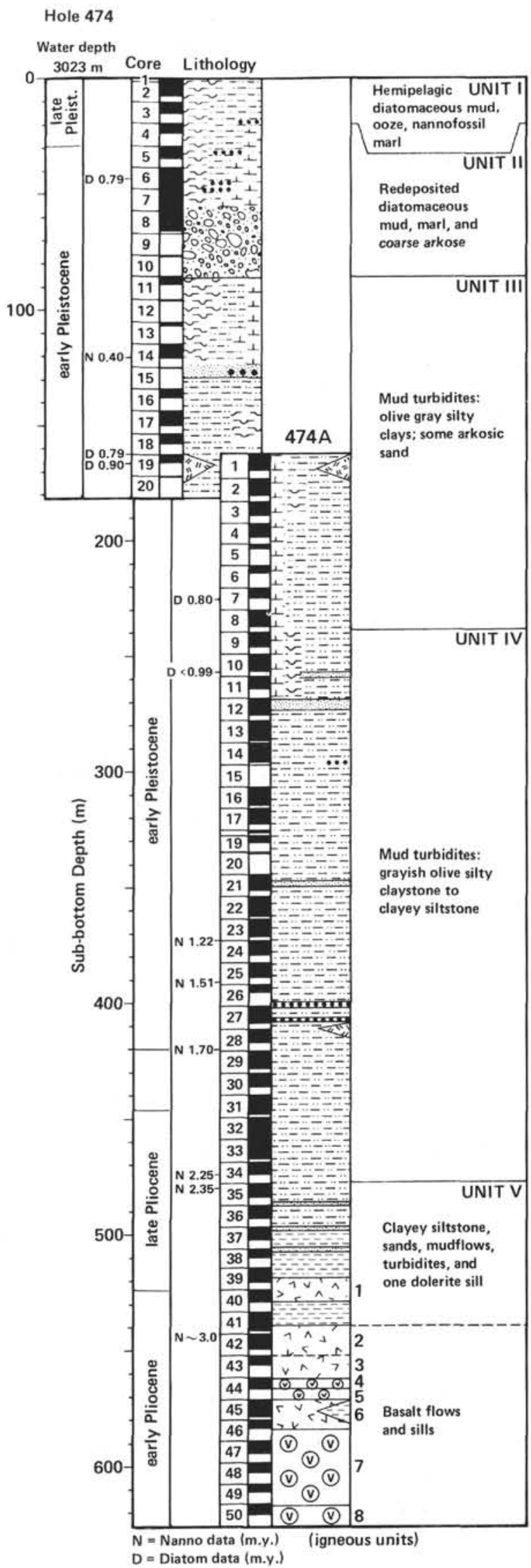

Figure 9. Lithology, lithologic units, and core recovery (shown in black), Site 474 . 
Table 2. Sedimentary lithological units, Site 474.

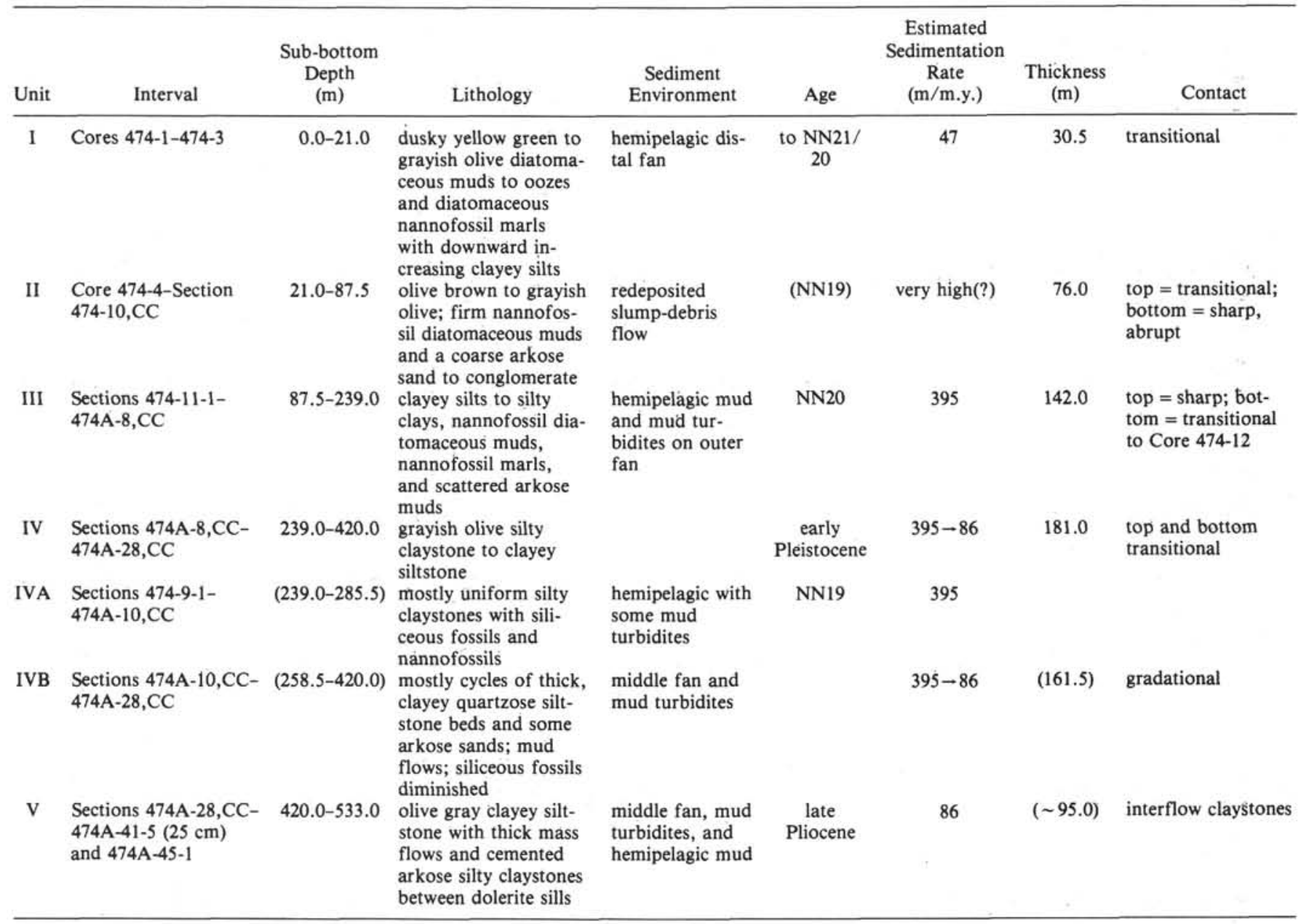

face. Apatite, hornblende, and zircons from a granitic terrain compose a conspicuous heavy mineral suite. Coarse fractions from mud contain abundant fecal pellets; coarse fractions from silt contain mostly arkosic mineral suites.

The sediments are reducing and, when cut, released a permeating odor of $\mathrm{H}_{2} \mathrm{~S}$. Pyrite is an ubiquitous auxiliary mineral accompanied by considerable woody organic matter.

Pelagic components $(10-50 \%)$ are well preserved. Siliceous fossils are dominated by diatoms (20-40\%) but also include many silicoflagellates, radiolarians, and sponge spicules. Sponge-spicule clusters occur as small white spots, visible on the core surface in more clayey zones. Smear slides indicate that, toward the base of Unit I $(210.0 \mathrm{~m})$, there is a gradual increase in the proportion of these sandy silts and opaque components.

The contact with Unit II is gradational and accompanied by an increase in coccolith abundance.

Unit II (Cores 474-4-474-10, 21-87 m, late Pleistocene [NN19]). Unit II is a redeposited section. Its upper part consists of drab, olive gray hemipelagic mud and mud turbidites, initially similar to Unit I but with a marked increase in the number of coarse silt to sandy beds (Fig. 10). The most prominent feature of the unit is a thick layer $(\sim 30 \mathrm{~m})$ of coarse, greenish gray, peppered arkosic sarid to conglomerate (Section 474-7-5-474-10, CC). Recovery was poor: only three granodiorite cobbles occur in Core 474-10 (Fig. 11); but seismic evidence suggests that this is a single bed, with lateral contihuity across the basin. Drilling disturbance was intense, but it appears that the arkose unit is an upward-fining bed of grain-supported clasts, little matrix, and moderate sorting. The direction of transport and the mechanism for this mass flow are discussed elsewhere in this volume (see Moore, Curray and Einsele, this volume, Pt. 2). Again, however, the seismic geometry suggests a more northerly source, because the bed appears to abut the nearest slopes to the northwest. Clasts are rounded and polished; biotite, feldspars, and rock fragments appear fresh. They include common mollusk debris, bryozoan fragments, benthic foraminifers, a snail shell, and calcareous algae, indicating a near-shore source. Some nannofossils occur in the fine matrix.

The overlying hemipelagic mud and sandy mud turbidites of Cores 474-4 to 474-8 are not contiguous with the arkosic sand layer. They are included nonetheless in Unit II, because they apparently contain a warmer- or shallower-water displaced nannofossil flora (NN19). Below the conglomerate contact, sediments are again 


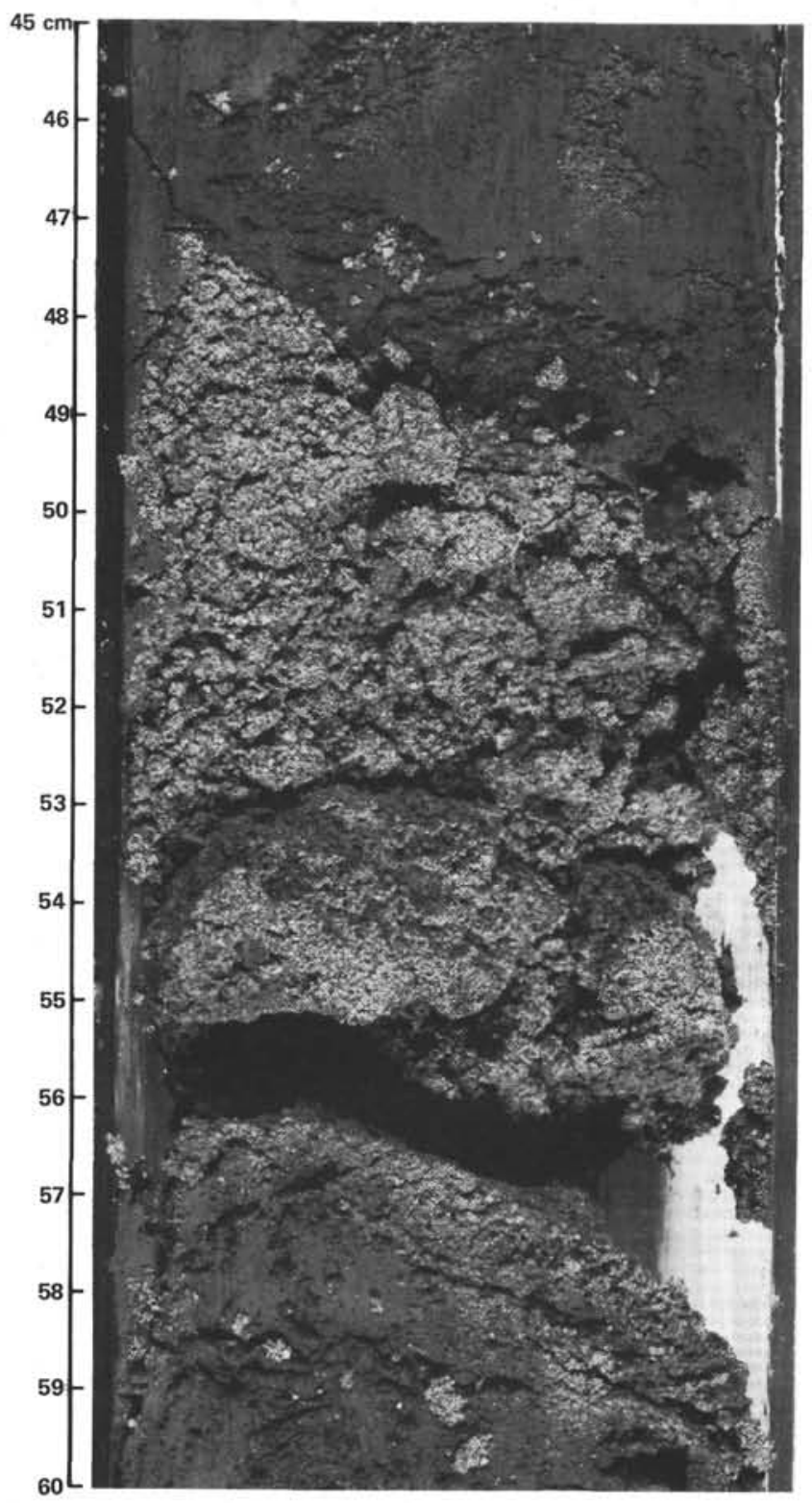

Figure 10. Sample 474-6-6, 45-60 cm, Unit II: Coarse, well-sorted, massively oxidized, yellow-brown arkosic sand with small mud pebbles and some pyroclastic components. (Contacts appear sharp, and grading is ill defined, including fragments of pecten and bryozoa.)

younger (NN20). Possibly, the upper section was redeposited during a lowered sea-level period, or as older sediments-laid bare by a mass-flow event-were further excavated.

These sediments are characterized by an interlayering of nannofossil-bearing diatomaceous clayey silt to diatomaceous nannofossil mud (dusky yellow green [5GY $5 / 2$ ] to moderate olive brown [5Y 4/4]) that grades downward into thin, grayish olive (10Y 4/4), sandy mud. Sediments become firm below Core 474-5, where nannofossils also become predominant $(20-60 \%)$ over siliceous components $(5-15 \%)$. Nannofossil-rich zones are closely related to numerous, interspersed silty sand layers, and the zones and layers may be part of multiple

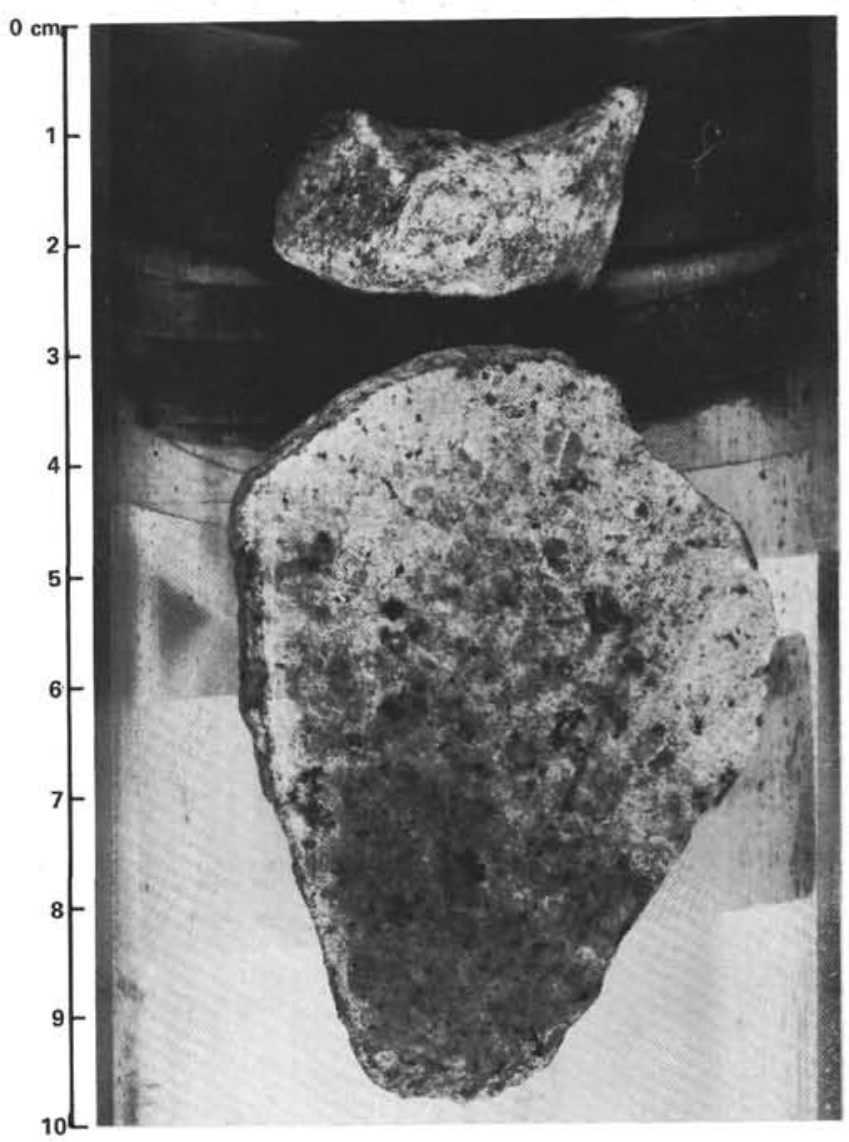

Figure 11. Sample 474-10,CC, Unit II: Large rounded pebbles of altered granodiorite.

mud turbidite cycles. Clayey silts have much lower carbonate content. Many of the sandier layers contain small, reworked shell fragments or matrix-supported pebbles, including quartz-feldspar porphyry and basalt (Section 474-6-1) or cemented sandstone (Section 474$7-3,130 \mathrm{~cm}$ ). Most sandy beds are poorly sorted, but a few discrete, well-washed, rounded-and-sorted yellow gray sands similar to beach sands are present (e.g., in Sample 474-6-5, 110-130 cm). Except in these sand layers, the sediments are reducing. There is an intense odor of $\mathrm{H}_{2} \mathrm{~S}$ in Cores 474-4 and 474-5, diminishing below Core 474-6. Wood bits and pyrite are common (1-5\%). Clayey beds may show surface pimples (after cutting) caused by intense degassing. Tiny spiculite blebs dot the surface of some beds.

The contact with Unit III is sharply defined by the base of the coàrse gravel.

Unit III (Sections 474-11-1-474A-8, CC, 87.5-239.0 $m$, early Pleistocene [NN20-19]). Below the redeposited Unit II, siliceous fossils occur with renewed vigor (10$40 \%$ ) and, initially, diatoms are more common than coccoliths. This part may even repeat the section from Cores 474-4 through 474-5. Sediments are mainly firm-tohard, nannofossil-bearing, siliceous clayey silts to hard silty clays, with some nannofossil marls (Core 474-13) and scattered silty sand layers. Thin silty sands generally mark the base of numerous thick mud turbidite cycles. 
Colors are generally grayish green $(10 \mathrm{GY} 5 / 2 ; 10 \mathrm{Y}$ $4 / 2)$, changing to dusky yellow green (10GY $3 / 2$ ) where more carbonate is found. Mica flakes glisten on much of the surface.

Cores 474-14, 474-15, 474-16, and 474-17 (116-154 m) contain numerous coarser mud turbidites; Cores 474-18 and 474-19 (114.5-163.5 m) are mainly uniform hemipelagic mud. The pebbles in Core 474-20 are probably caused by hole cavings, because none was recovered when this interval was recored in Hole 474A. Cores 474A-1 to 474A-8 (163-239.5 m), again, mostly comprise mud turbidites; more than 67 have thicknesses ranging from 40 to $60 \mathrm{~cm}$.

The two holes are correlated with the help of a single, centimeter-thin layer of white, vitric, rhyolitic ash at Section 474-19-2, $123 \mathrm{~cm}(\sim 166.2 \mathrm{~m})$ and again at Section $474 \mathrm{~A}-1-4,28 \mathrm{~cm}(\sim 168.3 \mathrm{~m})$.

Better induration enabled us to see evidence of burrowing and subtly upward-fining silt from the intermittent mud turbidites. They are best recognized by a thin, well-sorted sand at the base. Coarse fractions from sand show mainly quartz-feldspar-mica and weathered granitic rock fragments. A few sands are rich in heavy minerals (apatite, zircon, pyroxene, and hornblende). Pebbles of metavolcanics, a porphyrite, and a feldspar acid tuff in the core catcher of Core 474-15 may indicate another thick conglomerate layer (see thin-section descriptions on the barrel sheets and Fig. 12). Other coarse layers contain bryozoan fragments, shallow water carbonates, pelecypods (no coral!), and wood debris.

Unit IV (Core 474A-9-Section 474A-28, CC; 239.0$420.0 \mathrm{~m}$, early Pleistocene). The character of this thick unit is similar to that of Unit III. Downhole, the preservation of siliceous fossils becomes poorer and sediments firmer. The contact with Unit IV is gradational and based on the change in lithification to clayey siltstone and silty claystone; carbonate content decreases $(\sim 10 \%)$. These sediments mainly consist of rapidly deposited mud turbidites, typically 20 to $60 \mathrm{~cm}$ thick, with minor hemipelagic mud. The color of most of the section is grayish olive (10Y 4/2), and textures vary from claystones to clay siltstones and some sandy siltstones. The extent of bioturbation separates mud turbidites from background hemipelagic mud (Fig. 13). But, possibly, bioturbated claystones partly include lutite portions of the mud turbidites. The mudstones, which are burrowed by Planolites and meniscate types, are considered representative of the hemipelagic mud, whereas Chondrites are considered an indicator of turbidite lutite. Carbonate content varies with grain size; it is highest in siltier beds but remains low throughout the unit $(5-15 \%)$.

Sub-unit IVA (Cores 474-9 and 474A-10, 239-258 $m$ ). A predominantly finer-grained, slightly calcareous sequence of diatomaceous silty claystones containing nannofossils comprises this sub-unit. Siliceous microfossils diminish rapidly below it and disappear around 270 meters sub-bottom. These claystones have decimeter-scale cyclic development, visible by variations in burrowing intensity and color shades.

Sub-unit IVB (Cores 474A-11-474A-34, 258.5-420.0 $m$ ). The remainder of Unit IV is uniformly characterized by many thick turbidite mudstones and other di- verse resedimented beds, including some massive sands and minor debris flows. More than 200 turbidite units are recognized, forming beds typically $40-60 \mathrm{~cm}$ thick but which may exceed $320 \mathrm{~cm}$. Most cores consist of more than 50\% turbidite cycles (Einsele and Kelts, this volume, Pt. 2). Toward the base of the section, some thicker units and debris-flow deposits (Fig. 14) occur, although the sediment composition remains a uniform, terrigenous quartz-feldspar-mica assemblage. Land-derived wood fragments appear to increase downhole. Sediments are reducing but give off no $\mathrm{H}_{2} \mathrm{~S}$. Pyrite is common. Some sands have pyrite grain concentrations (commonly pyritized foraminifers) of more than $10 \%$. Some very hard layers occur in Cores $474 \mathrm{~A}-17$ and 474A-25. One ash bed was noted at 474A-28 $(411 \mathrm{~m})$.

Some 200 -cm-thick beds have pebbly sand basal sections; others are only slightly graded, poorly sorted sandy silt. A few of the clasts have oxide coatings. There is no prominent change in lithologic continuity between Units IV and V. The boundary was selected to coincide closely with the Pleistocene/Pliocene boundary. Gradational changes will be discussed later.

Unit $V$ (Section 474A-28,CC-Core 474A-41, 420$572.0 \mathrm{~m}$; late Pliocene [NN18/16]). The sediments are generally olive gray $(5 \mathrm{Y} 3 / 2)$, hard, silty claystones to clayey siltstones. Mud turbidites continue and include several thick beds ( $80 \mathrm{~cm}$ or more), some sandy layers with pelecypod shells, and cemented arkose with basalt clasts.

Calcareous nannofossils are rare, and siliceous fossils are absent; but carbonate content is about $5-10 \%$, and some rare beds of siltstone or sandstone are cemented by carbonate. Clay minerals $(50-60 \%)$ and quartz and feldspar $(\sim 30 \%)$ are predominant.

At 521 meters, a 4.5-meter-thick dolerite sill was encountered (see section on igneous rocks). On the upper and lower contacts, we recovered pieces of the same hard, coarse, carbonate-cemented arkose (Fig. 15). The sill had been injected along a single, coarse layer in a zone with numerous sandy beds.

Graded mud turbidite cycles continue below the upper dolerite, but grain size and thickness of the coarser layers decrease. Bioturbation is extensive, and sediments are harder. Diagenetic effects are as follows: pyritefilled burrows, some graded, calcite-cemented beds, barite concretions, and dark, vermillion olive, pyritic claystones near the lower dolerite contact. The oldest sediment is a fragment of late Pliocene (NN16?) claystone (at $572 \mathrm{~m}$ ) beneath the uppermost pillow basalts.

\section{Depositional Environment}

The overwhelming feature of the sedimentation at this site is the impressive thickness of rapidly sedimented, poorly graded mud turbidites. Throughout the sequence, they exhibit similar development. Silt sizes predominate. The main body of the thick bed (20-320 $\mathrm{cm}$ ) is structureless grayish olive clayey silt, which would be overlooked were it not for the generally bioturbated hemipelagic mud.

An idealized cycle begins at the base with a thin (1$10-\mathrm{mm}$ ), clean, moderately well-sorted sand that may erode into the substratum. The lower contact is sharp. A 

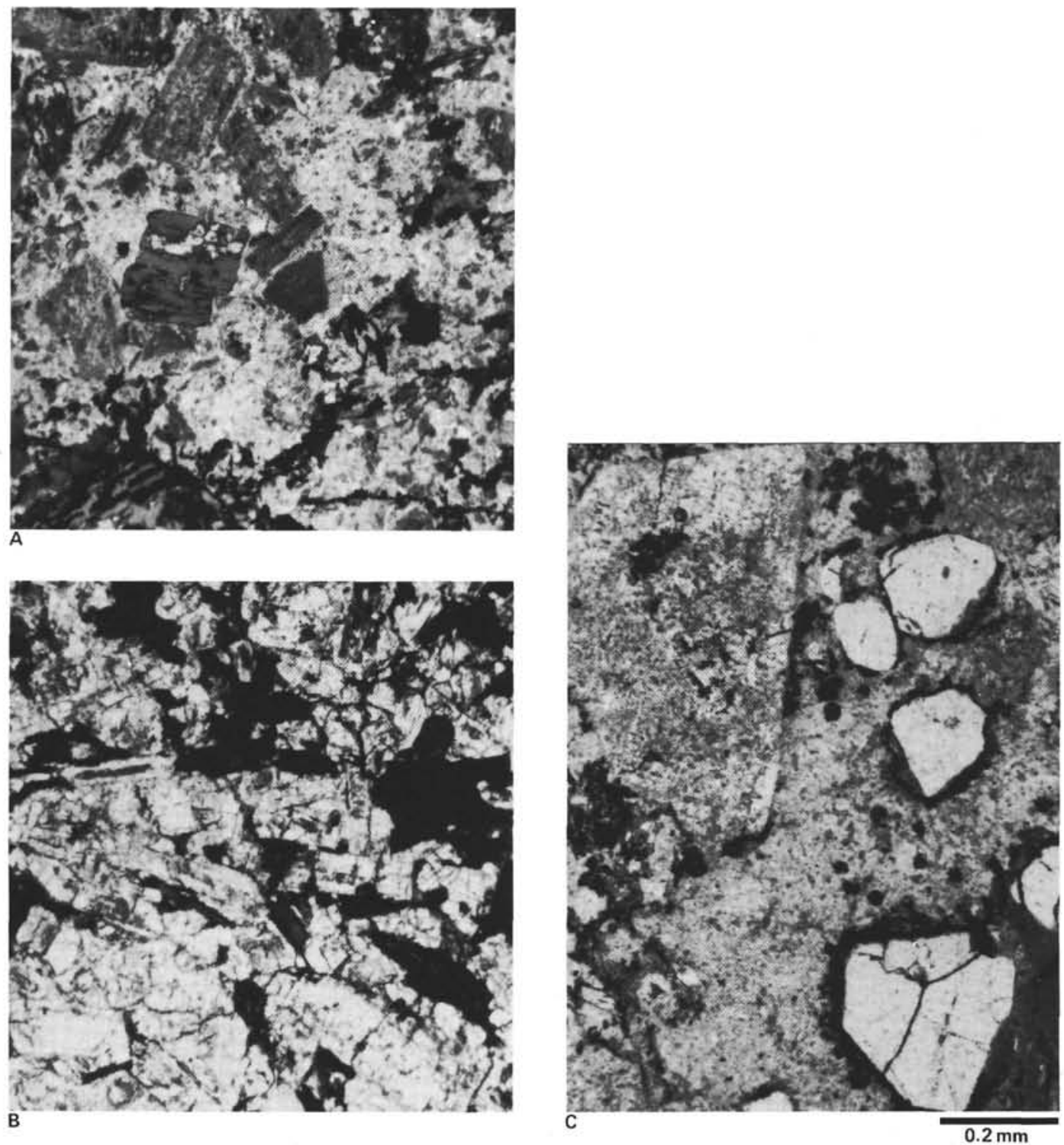

Figure 12. Thin-section photomicrographs of pebbles from Core 474A-15, Unit IV. A. Metamorphic quartzite with microcrystalline groundmass containing zoisite, green mica, phlogopite, and altered feldspars. B. Diorite with abundant, fresh-looking, zoned plagioclase and common hornblende. C. Metaignimbrite with euhedral plagioclase and quartz supported in a microcrystalline groundmass.

zone of poorly sorted silty sand, with some shallowwater debris, changes gradationally to the structureless silt of the mud section. Some scattered, large, round, sand-filled burrows from large, deep-scavenging individuals may occur in the homogeneous midsection. The classic Bouma sequence of sedimentary structures could not be observed in the freshly cut cores. Laminations are very rare. Near the top, the thin, silty lutite fraction is almost invariably burrowed by Chondrites below a heavily bioturbated zone, which is sometimes a lutite part of the mud turbidite (see Fig. 13). Carbonate, caused mostly by shelf carbonate but also by nannofossils, increases downward with grain size. Terrestrial plant matter is ubiquitous in the smear slides. Grayish olive colors also tend to be lighter in the sandy silt and darker in the basal sand and upper lutite (see Einsele and Kelts, this volume, Pt. 2).

In the silty basal third of the unit, floating clasts and pebbles may occur. A series of smear slides over a 250 cm-thick siltstone section confirms the presence of a subtle grading. This type of bed has been interpreted as indicating a distal fan-interchannel areas bordering abyssal plains (cf. Piper, 1978). The lack of clear grading may result from the formation of a stable clay floc (Piper, 1978), which behaves much as the silt particles. There are few detailed studies on the mechanism of transport of these beds, but rafted clasts and a close association with mud flow deposits suggest a rather quick deposition from a high-density flow. Similar mud turbidites are also known to be generated by slumping, 


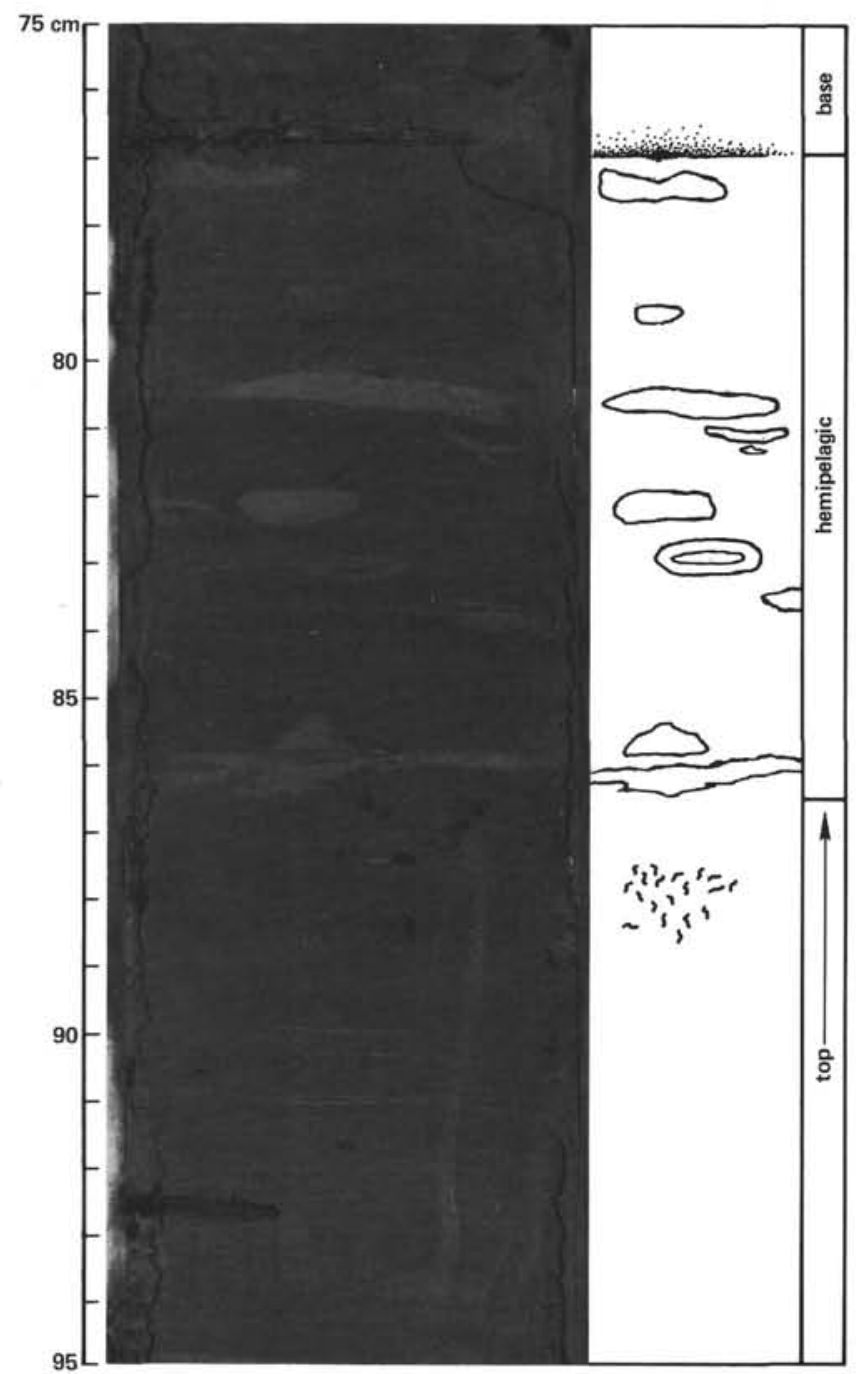

Figure 13. Sample 474A-13-3, 75-95 cm, Unit IV: An example of criteria for recognizing mud turbidite units (thin, basal sand layer; top marked by a few chondrite burrows; and the host hemipelagic sediment is generally spotted with meniscate or Planolites-type burrows [midsections are massive mud]).

from rapidly deposited deltaic regions in deep lakes. The sediments accumulating around southern Baja California today show a lack of clay fraction and a preponderance of arkose sands to silts characterized by abundant mica flakes (van Andel, 1964).

\section{Paleoenvironment}

When drilling ceased at Core $474 \mathrm{~A}-50$, the petrologic evidence suggested that this site was floored by oceanic crust. When rifting opened the area approximately 3.5 $\mathrm{Ma}$, it was already at bathyal depths. Coarse volcanogenics or continental conglomerates were not encountered. Although poorly recovered, late Pliocene sediments overlying the basement and the lower sill already indicate a distal-fan-to-hemipelagic character. During the early late Pliocene (NN17/18), a sedimentation pattern of mud turbidites, hemipelagic mud, and sporadic mud flows was established and continues to the present.

Although some sandy basal layers contain redeposited shallower-water material, the flora and the char-

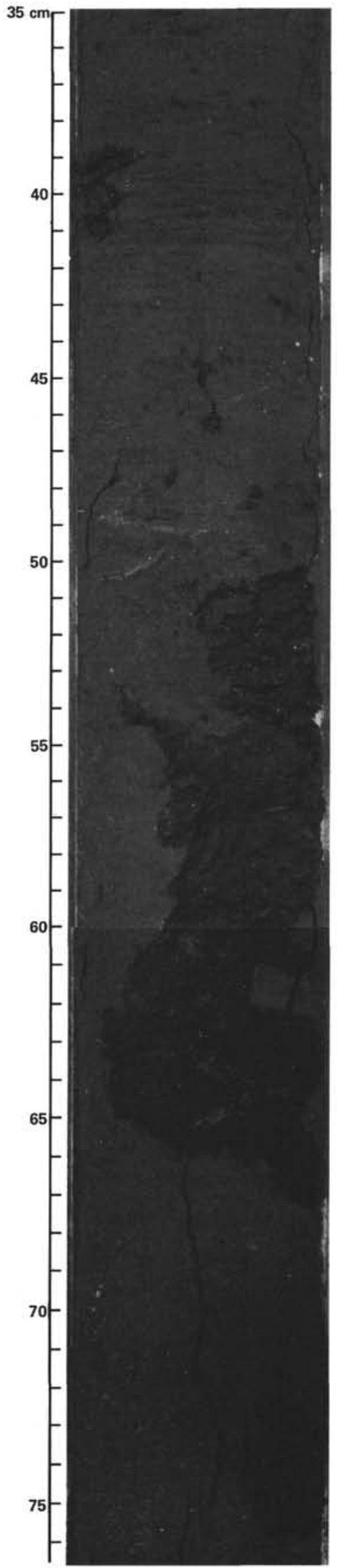

Figure 14. Sample 474A-21-5, 35-75 cm, Unit IV: example of large, fractured mud clast in a thick debris-flow bed. 


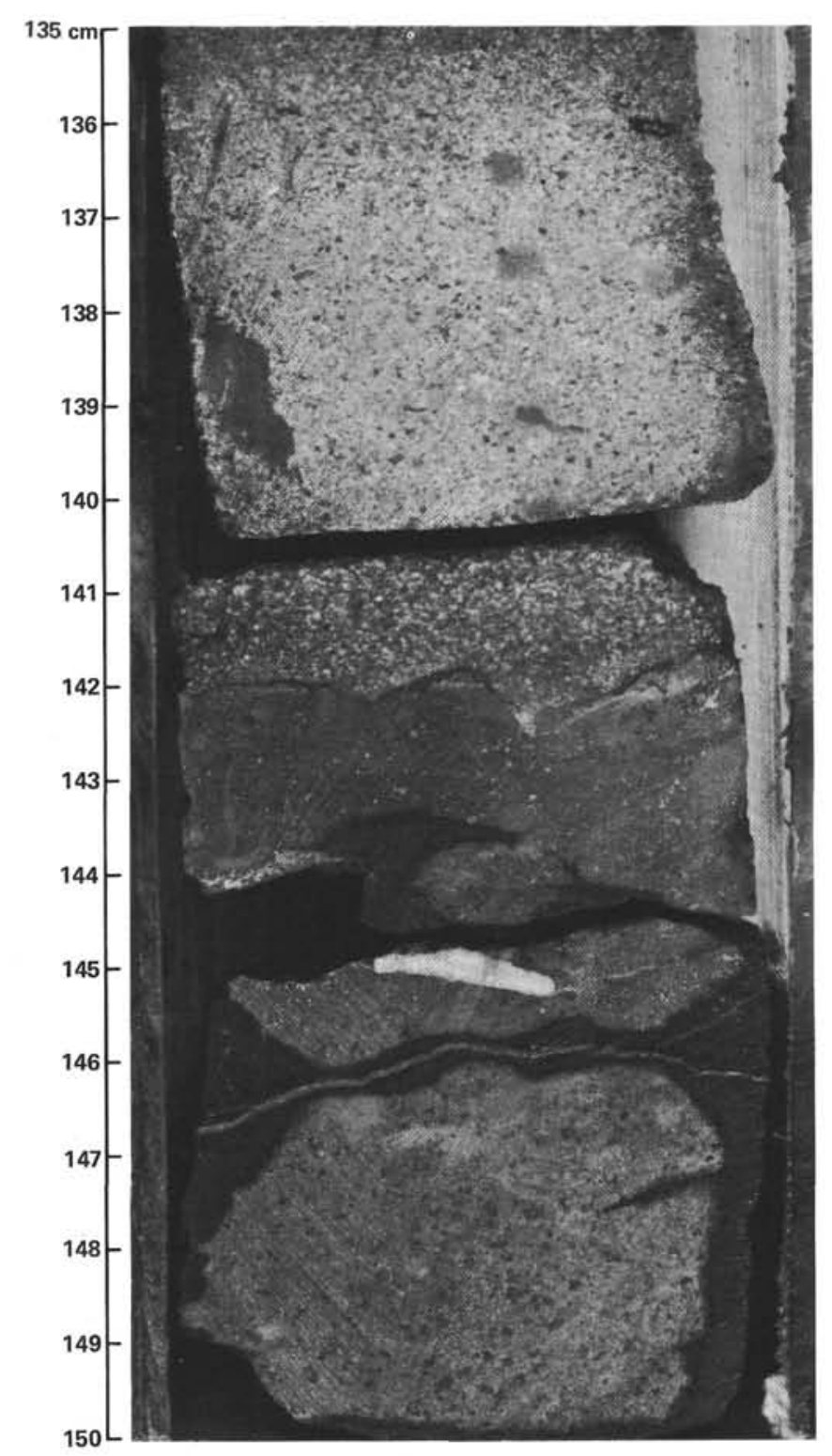

Figure 15. Sample 474A-39-3, 135-150 cm, Unit V: Contact of dolorite sill (Igneous Unit 1) with hard, carbonate-cemented, coarse basal sand of a turbidite. (Clasts are mainly arkosic but include weathered volcanic rock fragments.)

acter of burrowing indicate a prolonged depth and environment similar to that of the present environment. No linear development pattern was evident in the sediments. Coarsening and upward-fining cycles do occur in the sediment column, and fluctuations in thick and thin turbidites, coarse and fine sediment, and mass-flow deposits may derive from sea-level changes that moved more or less sediment into shelf-edge canyon heads. They may reflect tectonic control (growth faulting), produce multiple pathways to feeder channels in the distal fan environment. They may also reflect frequency of tectonic movement. Sedimentation rates of 300 to 400 $\mathrm{m} / \mathrm{m}$.y. suggest that pelagic sediments between mud turbidite events are comparatively thin.

The likely sources of this region's sandy material today are the Los Frailes, Salado, and Vinorama canyons.
Dredging and coring in these canyons (Shepard, 1964) mainly produced weathered granitic cobbles, typical Pecten mollusk fragments, and fine micaceous sand. These components also characterize most of the coarser basal turbidite layers in Hole 474A (Units I-V).

During the latest Pleistocene, terrigenous sedimentation rates-decreased, and less diluted pelagic nannofossil diatom ooze was deposited. This may reflect a sinking margin, rising sea level, or a diversion of sediment transport paths.

\section{Volcanic Sediments}

Most of the coarse fractions do not contain clasts from young volcanic rocks. One exception is the cemented sandstone that accompanies the sill at 521 meters sub-bottom. The source of these sands is unknown. In addition to granitic components, they contain many, apparently fresh, plagioclase clasts, rock fragments of basalt, and metamorphics. We recognized two thin ash layers derived from Quaternary rhyolite eruptions-most likely from the mainland side of the Gulf. The upper portion (Core 474-19) retained fresh glass and sanidine shards, whereas in the lower portion (Core 474A-28), glass was completely altered to montmorillonite.

\section{Diagenesis}

Pleistocene mud at this site was surprisingly well indurated. The hard mud-to-mudstone transition occurs at approximately 239 meters, parallel with increasingly poor preservation of siliceous fossils and their disappearance below 275 meters. This suggests that active silica diagenesis contributes to early lithification.

Cobbles of calcite-cemented sand to gravel are associated with the upper dolerite sill. They have apparently been cemented in situ as a result of the dolerite intrusion. Calcitic-graded siltstone layers in Core 474A-41, below the sill, also provide evidence for in situ cementation of coarser layers. Perhaps the barite, pyrite, and calcite below the sill are evidence of some hydrothermal effects.

Pyrite is the most common diagenetic mineral in the section. Near the top (Units I, II), it occurs as framboids and octahedra, commonly filling diatom frustules. It is less conspicuous in Unit III, where the permeating $\mathrm{H}_{2} \mathrm{~S}$ odor disappears. In Unit IV, pyrite grains may comprise $10 \%$ of some sandy silts, occurring commonly as coatings and replacements of foraminifers and, perhaps, wood debris. In Unit V, pyrite-filled burrows, pyrite sands, and pyrite-rich claystones are present.

\section{ORGANIC GEOCHEMISTRY}

\section{$\mathrm{C}_{1}-\mathrm{C}_{5}$ Hydrocarbon Analyses}

As drilling proceeded, methane and ethane were monitored on a Carle gas chromatograph (GC), and $\mathrm{C}_{2-}$ $\mathrm{C}_{5}$ hydrocarbons were measured intermittently on a Hewlett-Packard GC. The method for rapid gas analyses was evaluated on Leg 47 (von Rad, Ryan, et al., 1977; Whelan, 1979). Samples from core gas pockets were collected through the core liner in "vacutainers" immediately after the cores were brought on deck. Analyzing 
these samples for hydrocarbons of a molecular weight higher than $\mathrm{C}_{5} \mathrm{H}_{12}$ was not possible because of contamination from the rubber stopper in the vacutainer.

Shipboard analysis of $\mathrm{C}_{1}-\mathrm{C}_{5}$ hydrocarbons was conducted routinely on two gas chromatographs: $\mathrm{C}_{1}$ and $\mathrm{C}_{2}$ analysis on a Carle GC ( 3 min. analysis time) and $\mathrm{C}_{2}$-to$\mathrm{C}_{5}$ analyses on a dual-column Hewlett-Packard 5711A instrument equipped with temperature programming and dual flame ionization detectors used in the compensation mode (15 min. analysis time). Analyses of both $\mathrm{C}_{1}$ and $\mathrm{C}_{2}$ to $\mathrm{C}_{5}$ on the same sample were not possible in a reasonable time because of the appearance of the small $\mathrm{C}_{2}$-to- $\mathrm{C}_{5}$ peaks on the tail of the much larger methane peak. Amounts were obtained by measuring peak areas with an electronic integrator (CSI 38) for $\mathrm{C}_{1}$ to $\mathrm{C}_{5}$.

Sample introduction into the Hewlett-Packard GC was accomplished with a $1 / 8$ " $\times 8$ " loop packed with 60/80-mesh alumina (Analabs, Activated Alumina F-1) attached to a Carle sampling valve (microvolume valve 2014 or minivolume valve 2818; Whelan, 1979). A stream of dry helium, with the flow rate adjusted to $15 \mathrm{cc} / \mathrm{min}$. with a fine-metering valve, was passed through the alumina-filled loop. The sample to be analyzed (1-5 ml, depending on $\mathrm{CH}_{4}$ content) was withdrawn from the vacutainer and injected through a silicone-rubber septum into the helium stream flowing through the sample loop. The loop had been cooled in a propan-2 bath cooled to between $-72^{\circ} \mathrm{C}$ and $-68^{\circ} \mathrm{C}$ with a portable refrigeration unit (FTS Systems 80). Before analysis methane was stripped from the sample by allowing helium to flow through the loop (1 cc/3 s) for $2 \mathrm{~min}$. After stripping, the sample loop was shut off with toggle valves from helium flow and injection port and heated for $1 \mathrm{~min}$. in a 90 -to- $100^{\circ} \mathrm{C}$ water bath; the sample was injected by turning the sample valve. The GC analysis was carried out on a column of $1 / 8^{\prime \prime} \times 6^{\prime}$ spherosil $(40 / 100$ mesh; Supelco) attached to $1 / s^{\prime \prime} \times 12^{\prime} 20 \%$ OV-101 on Analabs AS (100/110 mesh), with temperature programming from 60 to $200^{\circ} \mathrm{C}$ at $8 \% \mathrm{~min}$. We left the loop in the carrier gas stream during GC analysis.

Sampling and GC separated methane, ethane, ethylene, propane, propylene, isobutane, $n$-butane, neopentane, isopentane, $n$-pentane, and cyclopentane in order of increasing retention time. The absolute sensitivity of the system was as determined by Whelan (1979).

At Site 474 , gas pockets and gas pressure appeared in the core liners from about 10 to 450 meters sub-bottom. They appeared less frequently in the more indurated sediments from about 275 to 500 meters; gas was absent from 270 to 310 meters. About $30 \mathrm{~min}$. after sealing, we also collected gas samples from the core caps of the more indurated sediments. High gas pressures occurred at about 150 to 175 and 220 to 270 meters. Poor core recovery, with no gas recovery, occurred in the sand sequence (about 75-100 m), and we observed no gas pressure above and below the first sill.

The results of the GC analyses are presented as the normalized concentrations of methane $\left(\mathrm{CH}_{4}\right)$ and ethane $\left(\mathrm{C}_{2} \mathrm{H}_{6}\right)$ and are plotted versus depth in Figure 16. Most of the $\mathrm{CH}_{4}$ values are between 90 and $100 \%$, indicating an essentially constant $\mathrm{CH}_{4}$ component of the

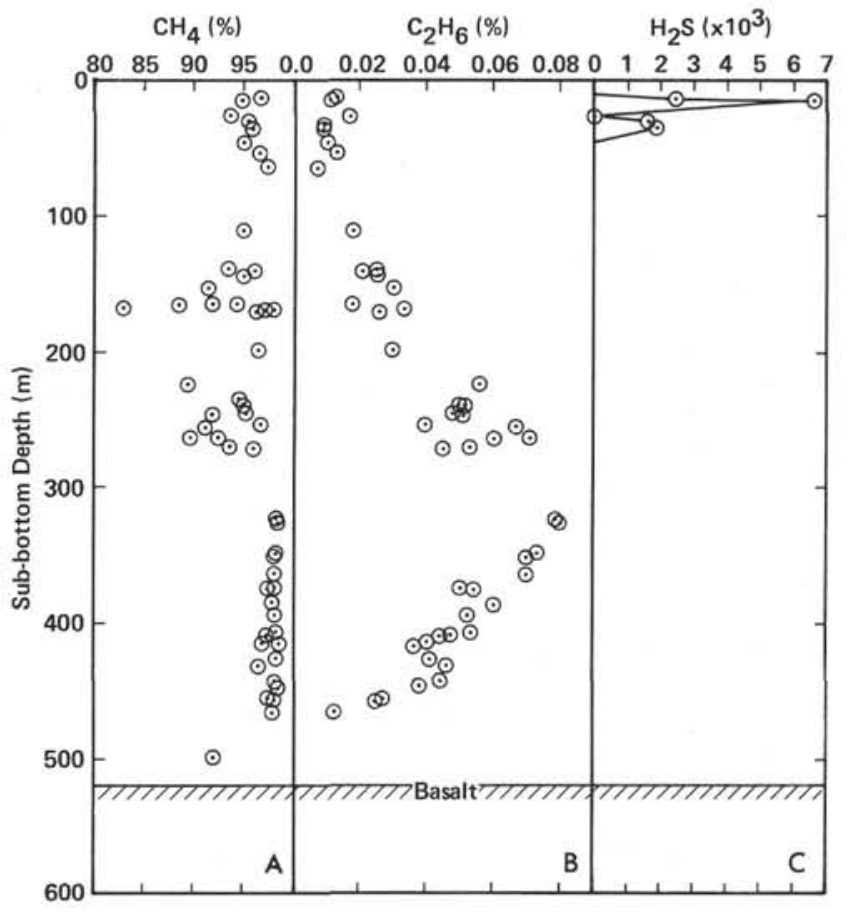

Figure 16. Results of gas chromatographic analyses for methane (A), ethane (B), and hydrogen sulfide (C) versus depth, Site 474. (Units of $\mathrm{H}_{2} \mathrm{~S}$ are arbitrary counts.)

interstitial gas, whereas the $\mathrm{C}_{2} \mathrm{H}_{6}$ shows a distinct increase to a maximum, followed by a decrease. This decrease in the $\mathrm{C}_{2} \mathrm{H}_{6}$ content reflects the slower diffusion of ethane from more indurated sediment. The ratios of $\mathrm{C}_{2} \mathrm{H}_{6}$ to $\mathrm{CH}_{4}$ are plotted in Figure 17. They show a normal linear increase (semilog scale) to about 300 meters and then a decrease from a maximum value of $8.5 \times$ $10^{-4}$. Sediment lithology indicates increasing lithification below 239 meters.

Carbon dioxide $\left(\mathrm{CO}_{2}\right)$ and hydrogen sulfide $\left(\mathrm{H}_{2} \mathrm{~S}\right)$ were also detected. We observed $\mathrm{H}_{2} \mathrm{~S}$ only in the upper sediment (about $10-40 \mathrm{~m}$ ), and it was not quantified but is expressed in arbitrary counts (Fig. 16C). The $\mathrm{CO}_{2}$ (normalized data; Fig. 18) exhibited a scattered distribution to about 300 meters and, at greater depths, a lower, more linear concentration.

The higher-weight hydrocarbon gases $\left(\mathrm{C}_{2}-\mathrm{C}_{4}\right)$ were analyzed to complement the $\mathrm{CH}_{4}$ data. The concentrations of ethane and propane (assuming $100 \% \mathrm{CH}_{4}$ by volume) are plotted in Figure 19; they increase to about 300 meters and then decrease. Isobutane and, to a certain extent, isopentane also follow this trend. The maximum amounts of $\mathrm{C}_{2}-\mathrm{C}_{4}$ hydrocarbons on an air-free basis are as follows: $\mathrm{C}_{2}=0.08 \%, \mathrm{C}_{3}=0.017 \%$, and $\mathrm{C}_{4}=0.007 \%$. The absence of thermogenic hydrocarbon gases (e.g., cyclopentane, neopentane, and 2,2-dimethylbutane), and the low concentrations of $n$-butane and $n$-pentane indicate that the $\mathrm{C}_{2}-\mathrm{C}_{5}$ hydrocarbons of these sediments have a biogenic origin. Nevertheless, it has not been unequivocally demonstrated that the methanogenic or other types of bacteria produce ethane, propane, and isobutane, although that has often been inferred. The $C_{2} / C_{1}$ data from the Carle GC were con- 


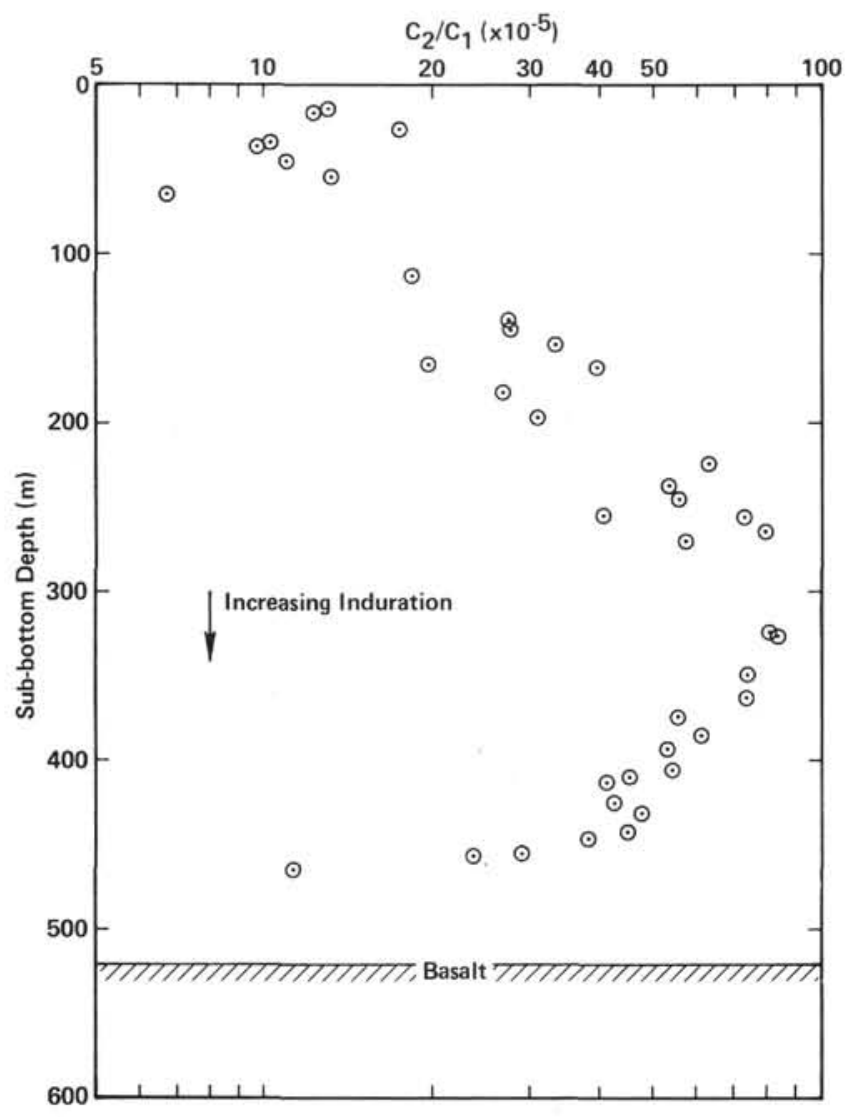

Figure 17. Ethane/methane ratios versus depth, Site 474 .

firmed by the ethane concentrations obtained on the Hewlett-Packard GC.

In general, the hydrocarbon gas of this sediment sequence is of biogenic origin and within safety and pollution limits.

\section{Fluorescence}

Fluorescence measurements can indicate the presence of aromatic compounds in, for example, petroleum and its products (e.g., Wyman and Castaño, 1974). Fluorescence in pyrolysis products is an approximate indicator of the petrogenic potential of a sediment. Fluorescence data were measured on raw sediment samples, trichloroethane extract solutions of raw samples, and pyrolized samples: All exhibited only faint, yellow fluorescence for the extract and yellow-to-blue or no-fluorescence for the pyrolysis extract. These sediments do not contain petroleum, nor do they appear to have a high potential for petrogenesis.

\section{Organic Carbon and Nitrogen}

The organic carbon and nitrogen content was determined aboard ship by the standard DSDP method (see Hays et al., 1972; Kulm, von Huene, et al., 1973) and plotted in Figure 20 (cf. Appendix I, this volume, Pt. 2, for data listing).

Shipboard analysis of cores for organic carbon and organic carbon versus total nitrogen atomic ratio was performed using a $\mathrm{CNH}$ analyzer. Samples containing

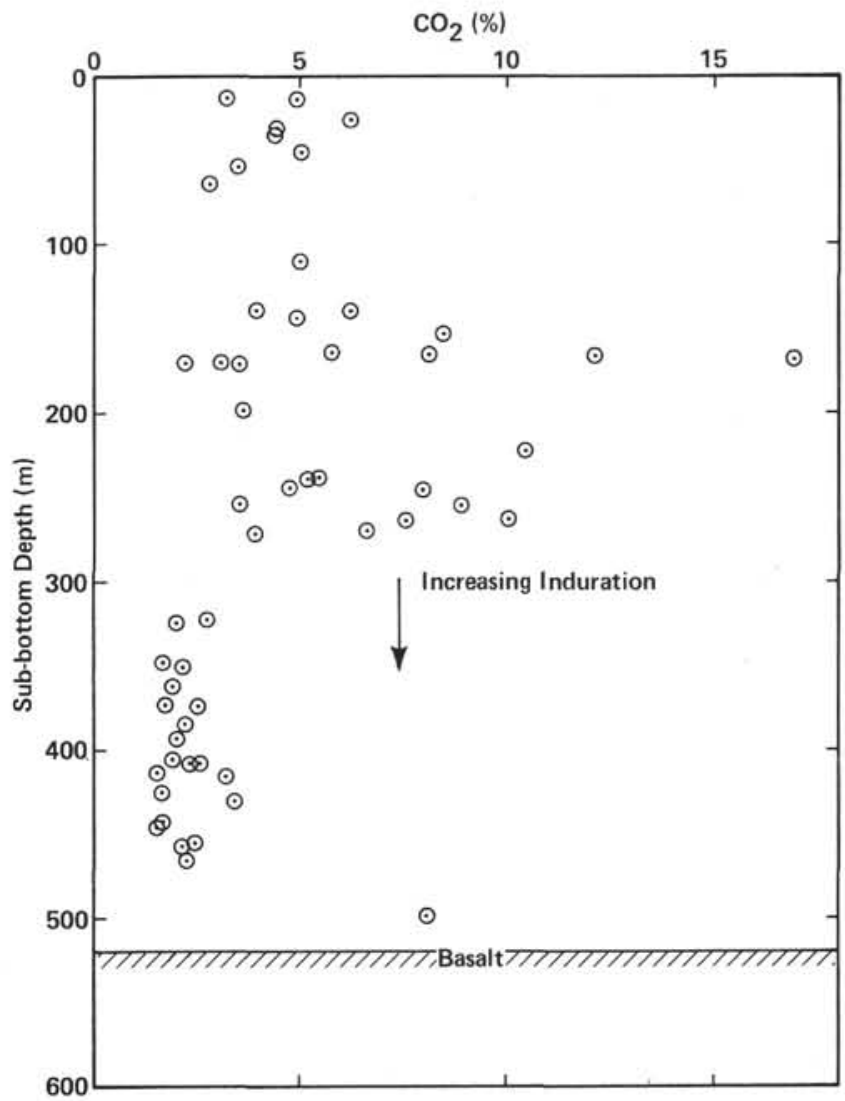

Figure 18. Carbon dioxide concentration versus depth, Site 474.

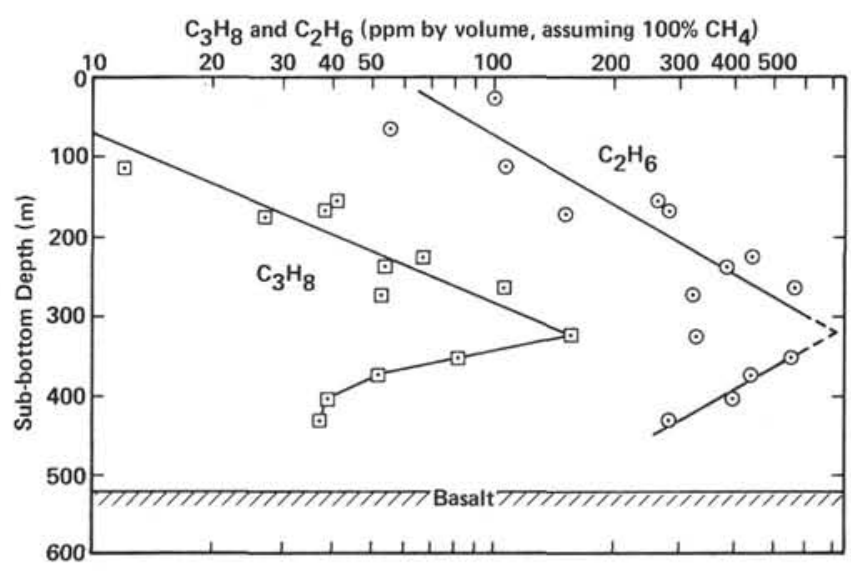

Figure 19. Ethane and propane concentrations versus depth, Site 474.

as little as $0.1 \%$ organic carbon could be analyzed reproducibly.

Aboard ship, a sample weighing 0.5 to $1 \mathrm{~g}$ was refrigerated immediated after collection. Prior to analysis the sample was homogenized, and $3 \mathrm{ml}$ of $6 \mathrm{~N} \mathrm{HCl}$ was added to remove carbonate carbon. The acid was evaporated on a hot plate, and the acidified sample was dried for at least $2 \mathrm{hr}$. at $105^{\circ} \mathrm{C}$. The sample was cooled in a desiccating cabinet and then weighed on a Cahn electrobalance, mounted on a gimballed table. We used a sample weight from 8 to $25 \mathrm{mg}$, depending on the suspected carbon content. 


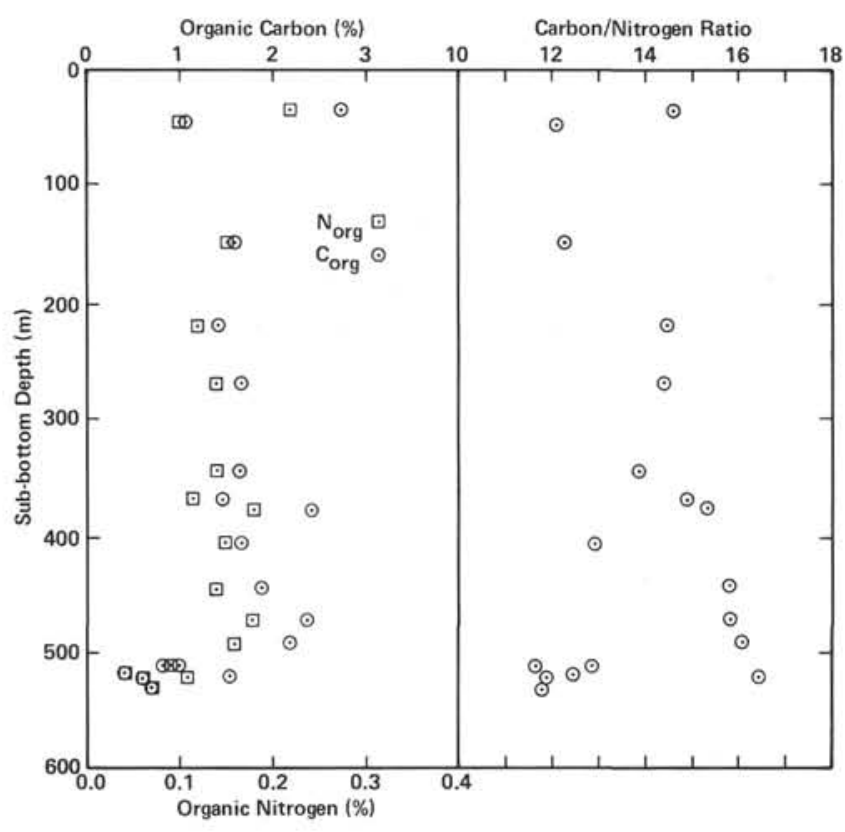

Figure 20. Organic carbon and nitrogen: content and ratios versus depth, Site 474 .

The sample (in an aluminum boat) was oxidized in the presence of a metal oxide catalyst at $1100^{\circ} \mathrm{C}$ in a Hewlett-Packard 185B CHN analyzer. Copper turnings reduced nitrogen oxides to nitrogen gas. The gas products were separated by a Porapack Q column attached to a thermal conductivity detector. Detector response, as measured by peak height, was calibrated daily with standard samples of cystine. Multiplying the ratio of weight percentages by 1.167 converted the weight ratio to atomic $\mathrm{C} / \mathrm{N}$ ratio.

Additional organic carbon and carbonate determinations were made by the Scripps Institution of Oceanography (Appendix I, this volume, Pt. 2).

The organic carbon ranges from 1 to $3 \%$ throughout the core; it drops, in the proximity of the dolerite, to about $1 \%$. Organic nitrogen ranges from about 0.1 to $0.25 \%$, and the plot, also dropping in the sill proximity to $<0.1 \%$, parallels that of organic carbon. The $\mathrm{C} / \mathrm{N}$ ratio is also plotted in Figure 20, and the values, with some scatter, range from 11 to 17 . The $\mathrm{C} / \mathrm{N}$ ratios for Recent sediments usually cluster around 12 (Ryther, 1956), which accords with data for the upper section of this sequence. Maturation of organic matter increases the $\mathrm{C} / \mathrm{N}$ ratio, and this trend is slightly discernible below about 200 meters. Both higher and lower values are observed near the dolerite sill, which values may indicate more altered (thermally) organic matter from various contributions.

\section{Conclusion}

The organic matter in this sediment sequence is of biogenic origin and immature (based on gas, fluorescence, and $\mathrm{C} / \mathrm{N}$ analyses). Despite the high thermal gradient, no typical petrogenic hydrocarbons occur, and the origin of the methane, ethane, propane, and isobutane is probably biogenic. Nevertheless, the increase in these $\mathrm{C}_{2}-\mathrm{C}_{4}$ hydrocarbons with depth may also indicate an onset of low-temperature $\left(<120^{\circ} \mathrm{C}\right)$ thermal decomposition of biogenic organic matter. This same increase was observed near a diorite intrusion into the Cretaceous black shales at Site 368 (Leg 41; about 600$900 \mathrm{~m}$ ) and at depth in Hole 369A (Leg 41; below about $400 \mathrm{~m}$; Doose et al., 1978).

The decrease in $\mathrm{C}_{2}-\mathrm{C}_{4}$ hydrocarbon concentrations below about 300 meters is caused by the increasing induration of the sediment and the associated slower outgassing of the lighter-weight hydrocarbons. This induration is also confirmed by the silica concentration in the interstitial water, which drops to a value of $<400$ $\mu \mathrm{M}$ (see section on inorganic chemistry for additional confirming data). The overall amounts of hydrocarbon gas are well within safety and pollution limits.

\section{INORGANIC GEOCHEMISTRY}

\section{Interstitial Water Chemistry (Fig. 21)}

High values of alkalinity, ammonia, and phosphate in the upper 100 to 200 meters indicate the importance of bacterial oxidation of organic matter. High concentrations of dissolved ammonia have led to significant ion exchange with the clay matrix, thus yielding an intermediate maximum in dissolved magnesium at about 100 meters sub-bottom.

Profiles of dissolved calcium and magnesium below 200 meters indicate a zone of reaction near 300 meters, which can be understood in terms of alteration processes of igneous material associated with a silicification front. The latter front is clearly delineated by the sharp drop in silica concentrations below 250 meters. The intermediate maximum in salinity reflects the sharp increase in bicarbonate concentration (alkalinity).

\section{BIOSTRATIGRAPHY}

Nannofossil and diatom datum planes indicate that the Quaternary/Pleistocene boundary occurs between Cores 474-28 and 474-29. On the basis of a few nannofossils in claystones between igneous units, the basement age is placed at the lower boundary of upper Pliocene (between 2.3 and 3.0 m.y.).

\section{Coccoliths}

Although the frequency and preservation of the nannofossils vary greatly at Site 474 , a good biostratigraphic control was possible. The upper Pliocene assemblages are sparse, mainly composed of those forms most resistant to solution. A thin, upper Pleistocene section (Cores 474-1-474-14) was recovered, followed by a 360meter-thick lower Pleistocene section (Cores 474-16474A-28) and a 40-meter-thick section of upper Pliocene (Cores 474A-29 through 474A-41). A few mudstone pebbles in Core $474 \mathrm{~A}-45$ were also assigned to the late Pliocene. The Pleistocene/Pliocene boundary is sharply marked between Cores 474A-28 and 474A-29. Pseudoemiliania lacunosa first occurs in Core 474-16; Helicosphaera sellii in Sample 474A-23-3, 122-123 cm; and Cyclococcolithus macintyre in Sample 474A-25-1, 16-17 $\mathrm{cm}$. Discoaster brouweri becomes abundant at the top 

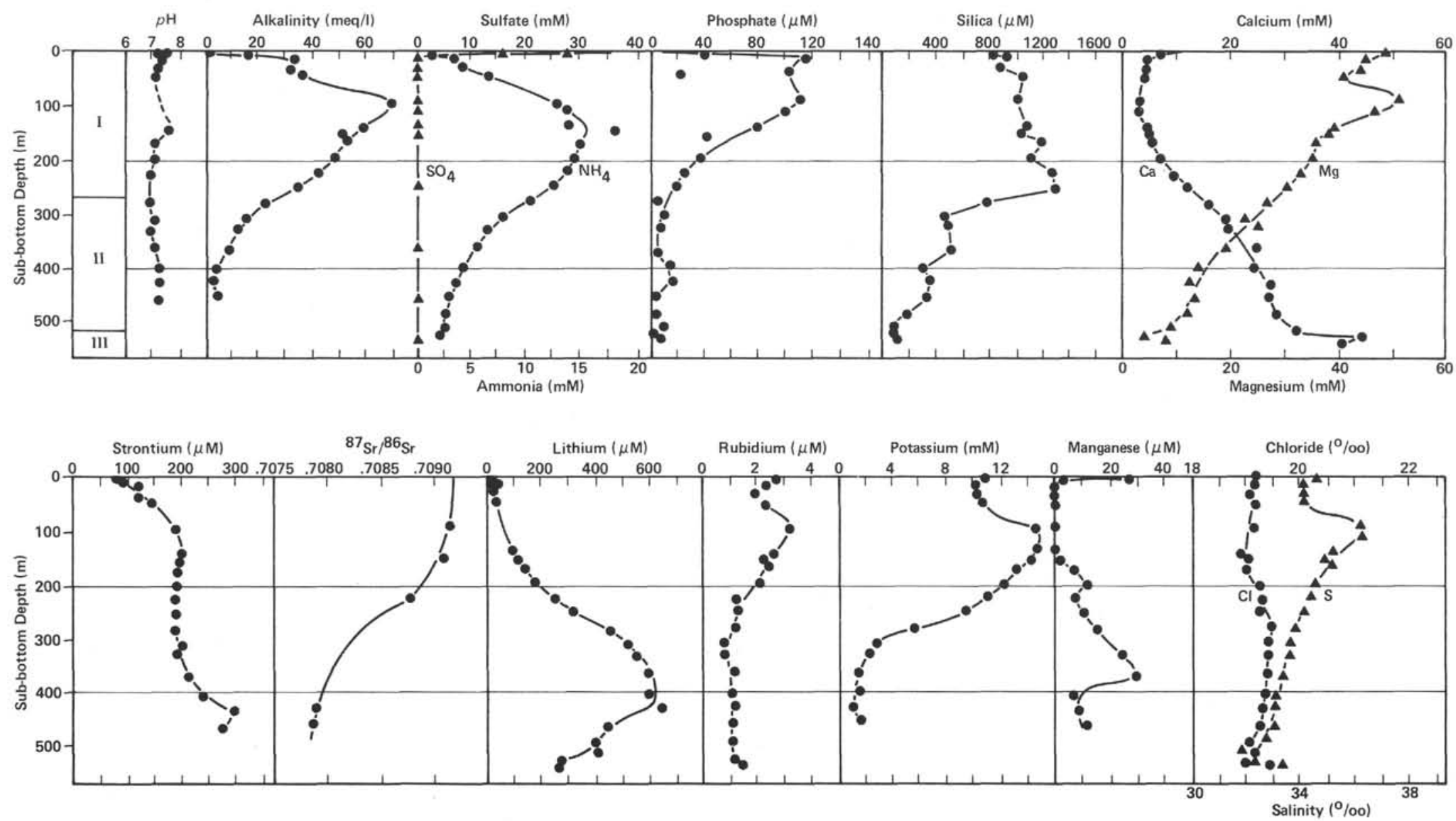

Figure 21. Interstitial water chemistry, Site 474. 
of Core 474A-29 and is ubiquitous downhole. Discoaster pentaradiatus first occurs in Sample 474A-35-1, $72-73 \mathrm{~cm}$, D. surculus in Sample 474A-35-4, 28-29 cm.

\section{Diatoms}

Open marine tropical to subtropical planktonic diatoms are abundant to rare and generally well to moderately preserved in the hemipelagic sediment from Cores 471-1 through 474-11. The mixture of marine benthic species is highly variable but never exceeds 1 to $2 \%$ of the total diatom assemblage. Samples below Core 474A-11 contain no diatoms. The following important diatom biostratigraphic species occurred at Site 474 . Nitzschia reinholdii (Sample 474-6-2, 36-38 cm); Mesocena quadrangula (Sample 474-6-3, 56-58 cm; both species were found in Samples 474-7-1, 77-79 cm and 474$7-5,114-116 \mathrm{~cm}$ ); $N$. reinholdii (Samples 474-11-1, 64$66 \mathrm{~cm}$ to $474-17-2,17-19 \mathrm{~cm}$ ); M. quadrangula (Sample 474-18-1, 125-127 cm; since these species are absent in Samples 474-18-3, 8-10 to 474-19-2, 102-104 cm, these occurrences are interpreted as reworking); common $M$. quadrangula and $N$. reinholdii associated with Rhizosolenia barboi (Sample 474A-1-1, 107-109); R. matuyama (Samples 474-7-3, 53-55 cm to 474-10-1, 30-32 cm.

No key species were detected below the two remaining samples; diatoms are rare. Distinct cold-water intrusions into the Gulf were detected at the following levels (the occurrence of $R$. barboi is common to rare): 474A$1-1,107-109 \mathrm{~cm} ; 474 \mathrm{~A}-9-1,93-95 \mathrm{~cm} ; 474 \mathrm{~A}-9-3,50-53$ $\mathrm{cm}$. Mass occurrences of Thalassiothrix longissima at $474-17-2,17-19 \mathrm{~cm}$ and $474 \mathrm{~A}-10-1,30-32 \mathrm{~cm}$ also indicate colder surface-water temperatures during times of deposition.

\section{Planktonic Foraminifers}

No planktonic foraminifer zonation was established for Holes 474 and 474A, because neither Globorotalia truncatulinoides nor other stratigraphical diagnostic taxa were found along the cores. Furthermore, the sediments from Section 474-26,CC to the bottom of the hole are barren of planktonic foraminifers.

It appears that the planktonic foraminifers in these holes record geographical shifting of water masses. Most of the samples along the core sustain a "subtropical" population in which Neogloboquadrina dutertrei group B (Srinivasan and Kennett, 1976), Globigerinoides ruber, and Orbulina universa are the "dominant" species. In certain intervals, however, such as those corresponding to Sections 474-14,CC, 474-19, CC, 474A$10, \mathrm{CC}, 474 \mathrm{~A}-12, \mathrm{CC}, 474 \mathrm{~A}-14, \mathrm{CC}$, and $474 \mathrm{~A}-16, \mathrm{CC}$, an apparent increase of the population, dwelling recently in the California Current, was observed. The "California Current" population is mostly Globoquadrina pachyderma right coiling and Globigerina bulloides.

The planktonic foraminifers were retained in the portion larger than $149 \mu \mathrm{m}$. The samples (about $3 \mathrm{~cm}^{3}$ ) were treated only with distilled water.

\section{Radiolarians}

Slides to analyze radiolarian remains were prepared from core-catcher samples from Holes 474 and 474A.
The preparation employed a special settling technique (Moore, 1973; Molina-Cruz, 1978) that yielded slides with evenly and randomly distributed grains.

In Holes 474 and $474 \mathrm{~A}$, radiolarian remains are common only in the top cores (474-1 and 474-2); rare to few in the subsequent cores (474-3-474-19 and 474A-1474A-13); and absent in Core 474A-14 through the bottom; the remains are well to moderately preserved.

Radiolarians such as Theoconus minythorax, Tetrapyle octacantha, Pterocanium praetextum, Ommatartus tetrathalamus, Theocorythium trachelium, Amphirhopalum ypsilon, and Liriospyris toxarium, among others, clearly indicate the subtropical character of the Recent water mass.

Nigrini (1971) proposed a Quaternarian biozonation for the equatorial Pacific, and Hays (1970) and Kling (1973) proposed others for the North Pacific. None of these Quaternarian zonations, however, was used for Holes 474 and 474A, because index species such as Anthocyrtidium angulare, Buccionosphaera invaginata, Collosphaera tuberosa, and Eucyrtidium matuymai were not detected.

Radiolarian remains in Holes 474 and 474A have been preserved only during the Quaternary. Index species older than Quaternary were not found.

\section{SEDIMENT ACCUMULATION RATES}

We observed apparently continuous sedimentation at Site 474 , without any suggestion of hiatuses. We assume the emplacement of the debris flow, Unit II, from 22 to 85 meters was essentially instantaneous on this time scale. The apparent rate of sediment accumulation (Fig. 22) averaged $86 \mathrm{~m} / \mathrm{m} . \mathrm{y}$. from the base of the sediment section to about 375 meters, in early Pleistocene time. The rate then seems to have increased significantly during most of the Pleistocene to almost $400 \mathrm{~m} / \mathrm{m}$.y., but must have been much slower during the late Quaternary after emplacement of the debris flow.

\section{IGNEOUS ROCKS}

Igneous rocks were first encountered at 521 meters sub-bottom (Section 474A-36-3, $132 \mathrm{~cm}$ ). The rocks were divided into eight units (Table 3; Fig. 23). The main rock types are olivine-rich dolerite and sparsely porphyritic to plagioclase-rich porphyritic varieties of basalt.

\section{Unit 1}

Unit 1 is a dolerite body with well-preserved chill zones at both its upper and lower contacts with sediment. A brecciated, thermally altered claystone above the upper contact indicates that the body is intrusive in origin. The dolerite contains variable quantities of olivine $(5-30 \%)$, plagioclase $(5-15 \%)$, and (minor) red chrome spinel phenocrysts; there is a noticeable concentration of olivine-rich dolerite in the lower one meter of the unit (Section 474-40-2). The groundmass comprises olivine $(10 \%)$, plagioclase $\left(30-40 \%, \mathrm{An}_{60}\right)$ subophitically enclosed by pale brown augite $(30-35 \%)$, and magnetite $(<5 \%)$. The olivine (phenocryst and groundmass phases) has been variably altered to a green clay 


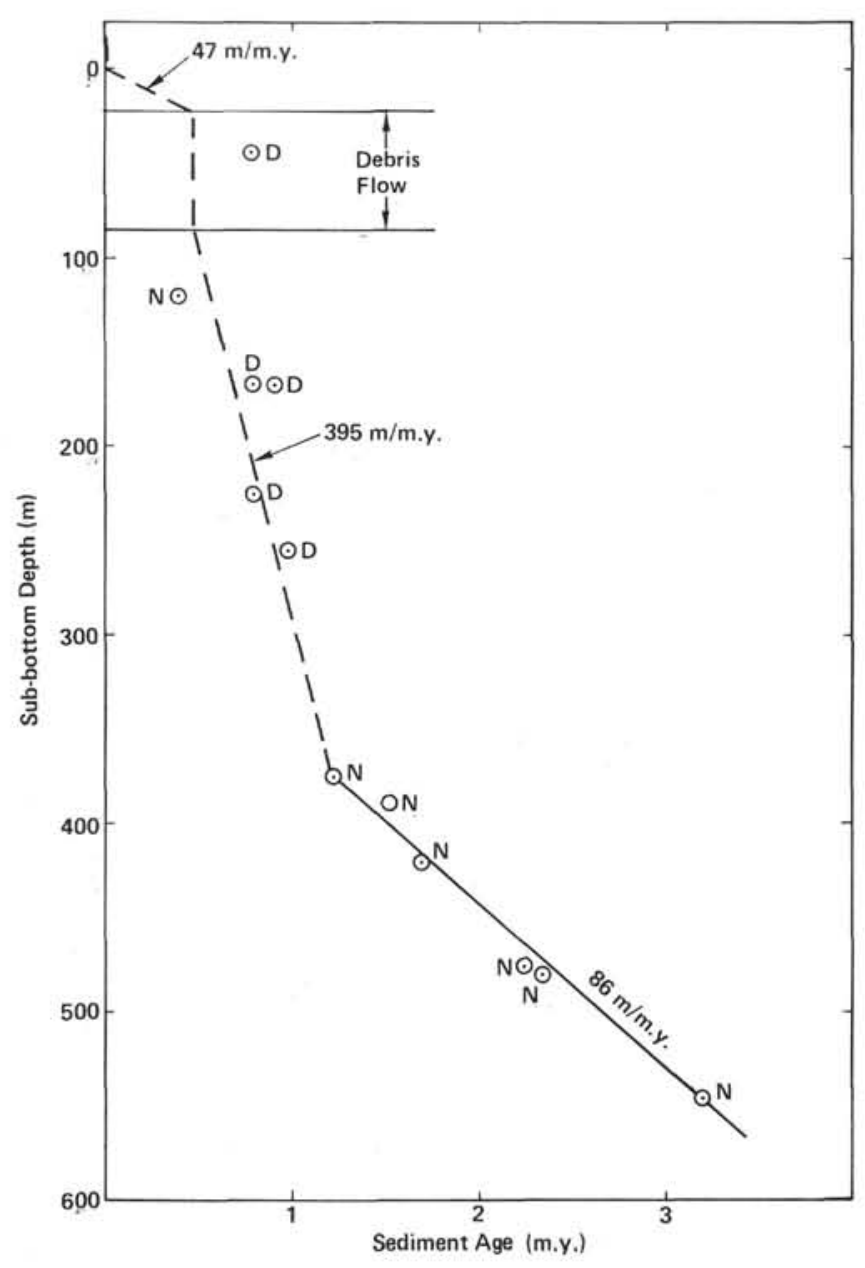

Figure 22. Sediment accumulation rates, Site 474. (Dotted lines indicate insecure sedimentation rates.) mineraloid, particularly in areas adjacent to sporadic calcite veins, although neither the feldspars nor the pyroxene show evidence of alteration. Unit 1 intrudes sediments containing nannofossils, indicating a maximum age of emplacement of approximately $2.3 \mathrm{~m} . \mathrm{y}$.

\section{Unit 2}

Unit 2, a massive dolerite body, is separated from Unit 1 by about 15 meters of sediment. Thermally altered sediments adjacent to the upper contact indicate an intrusive origin for Unit 2, and petrographic studies show that it closely resembles Unit 1 . The dolerite of Unit 2 is olivine rich, with occasional plagioclase phenocrysts and frequent olivine-rich segregations (up to $25 \%$ olivine phenocrysts). The groundmass is subophitic, comprising plagioclase, clinopyroxene (pale brown augite with a purplish tint indicating a titaniferous component), and opaques. Alteration is restricted to the olivines, which may be partly or completely replaced by green clay mineraloids, particularly in the vicinity of the abundant calcite- and zeolite-filled veins. Some vesicles are filled with expanding nontronite (see Fig. 24).

\section{Unit 3}

A small quantity of claystone at the top of Core 474A-43 suggests that Units 2 and 3 are separated by a thin sedimentary intercalation. The upper contact between the sediment and Unit 3 was not recovered, so we could not ascertain whether the unit is a sill or a flow. Petrographically, Unit 3 is distinct from Units 1 and 2. The rock is finer grained-almost basaltic-and contains as much as $5 \%$ equant- and lath-shaped plagioclase $\left(\mathrm{An}_{60-70}\right)$ phenocrysts and about $5 \%$ olivine microphenocrysts. The groundmass comprises olivine, plagioclase in variolitic clusters $(40 \%)$, and an altered, sparsely vesicular mesostasis. Altered olivine pheno-

Țable 3. Igneous lithological units, Hole 474A.

\begin{tabular}{|c|c|c|c|c|c|c|c|}
\hline Unit & $\begin{array}{l}\text { Core/Section } \\
\text { (level in cm) }\end{array}$ & $\begin{array}{l}\text { Top } \\
\text { (m) }\end{array}$ & $\begin{array}{l}\text { Base } \\
(\mathrm{m})\end{array}$ & $\begin{array}{l}\text { Thickness } \\
\text { (m) }\end{array}$ & $\begin{array}{l}\text { Recovery } \\
(\mathrm{m})\end{array}$ & Cooling Unit & $\begin{array}{l}\text { Phenocryst } \\
\text { Assemblage }\end{array}$ \\
\hline 1 & $41-5,142-40-2,120$ & $520.5^{\mathrm{a}} / 522^{\mathrm{b}}$ & $526^{\mathrm{a} / 526.5^{\mathrm{b}}}$ & $5.5^{\mathrm{a} / 4.5^{\mathrm{b}}}$ & 3.9 & massive dolerite sill & $\mathrm{Ol}, \mathrm{Pl}, \mathrm{Sp}$ \\
\hline \multicolumn{8}{|c|}{ sedimentary intercalation [NN15(?)] } \\
\hline 2 & $41-5,127-42-5,100$ & $543^{\mathrm{a}} / 542^{\mathrm{b}}$ & $551^{\mathrm{a} / 550.5^{\mathrm{b}}}$ & $8.0^{\mathrm{a}} / 8.5^{\mathrm{b}}$ & 6.9 & massive dolerite sill & $\mathrm{Ol}, \mathrm{Pl}, \mathrm{Sp}$ \\
\hline \multicolumn{8}{|c|}{ sedimentary intercalation (barren) } \\
\hline 3 & $43-1,3-43-4,62$ & $552^{\mathrm{a}} / 550.5^{\mathrm{b}}$ & $558^{\mathrm{a}} / 561^{\mathrm{b}}$ & $6.0^{\mathrm{a}} / 10.5^{\mathrm{b}}$ & 3.8 & $\begin{array}{l}\text { massive dolerite or } \\
\text { coarse basalt }\end{array}$ & $\mathrm{Ol}, \mathrm{Pl}$ \\
\hline \multicolumn{8}{|c|}{ sedimentary intercalation (none recovered) } \\
\hline 4 & $44-1,0-44-2,10$ & $562.5^{\mathrm{a}} / 562.5^{\mathrm{b}}$ & $566.5^{\mathrm{a} / 567^{\mathrm{b}}}$ & $4.0^{\mathrm{a} / 4.5^{\mathrm{b}}}$ & 1.5 & pillow basalt & $\mathrm{Pl}$ \\
\hline \multicolumn{8}{|c|}{ sedimentary intercalation(?) } \\
\hline 5 & $44-2,11-44-5,125$ & $567^{\mathrm{a} / 567^{\mathrm{b}}}$ & $571^{a} / 571^{b}$ & $4.0^{\mathrm{a}} / 4.0^{\mathrm{b}}$ & 3.4 & pillow basalt & $\mathrm{Pl}, \mathrm{Ol}, \mathrm{Sp}$ \\
\hline \multicolumn{8}{|c|}{ sedimentary intercalation ( $\leq 3.2 \mathrm{~m} . \mathrm{y}$.) } \\
\hline 6 & $45-1,0-46-2,19$ & $572.5^{\mathrm{a} / 574^{\mathrm{b}}}$ & $584^{\mathrm{a}} / 585^{\mathrm{b}}$ & $11.5^{\mathrm{a} / 11.0^{\mathrm{b}}}$ & 9.5 & massive basalt & $\mathrm{Pl}, \mathrm{Ol}$ \\
\hline \multicolumn{8}{|c|}{ sedimentary intercalation(?) } \\
\hline $\begin{array}{l}7 \\
8\end{array}$ & $\begin{array}{l}46-2,20-50-2,110 \\
50-2,111-50-4,10\end{array}$ & $\begin{array}{c}589(?)^{\mathrm{a}} / 588^{\mathrm{b}} \\
619.5^{\mathrm{a}} / 619^{\mathrm{b}}\end{array}$ & $\begin{array}{r}619.5^{\mathrm{a}} / 619^{\mathrm{b}} \\
626^{\mathrm{a}} / 626^{\mathrm{b}}\end{array}$ & $\begin{array}{l}30.5^{\mathrm{a} / 31.0^{\mathrm{b}}} \\
6.5^{\mathrm{a} / 7.0^{\mathrm{b}}}\end{array}$ & $\begin{array}{r}15.6 \\
2.0\end{array}$ & $\begin{array}{l}\text { pillow basalt } \\
\text { massive basalt }\end{array}$ & $\begin{array}{l}\mathrm{Pl}, \mathrm{Ol}, \mathrm{Sp} \\
\mathrm{Ol}, \mathrm{Pl}\end{array}$ \\
\hline
\end{tabular}

${ }^{a}$ Estimated from downhole log.

$\mathrm{b}$ Estimated from drilling rate and core logs. 


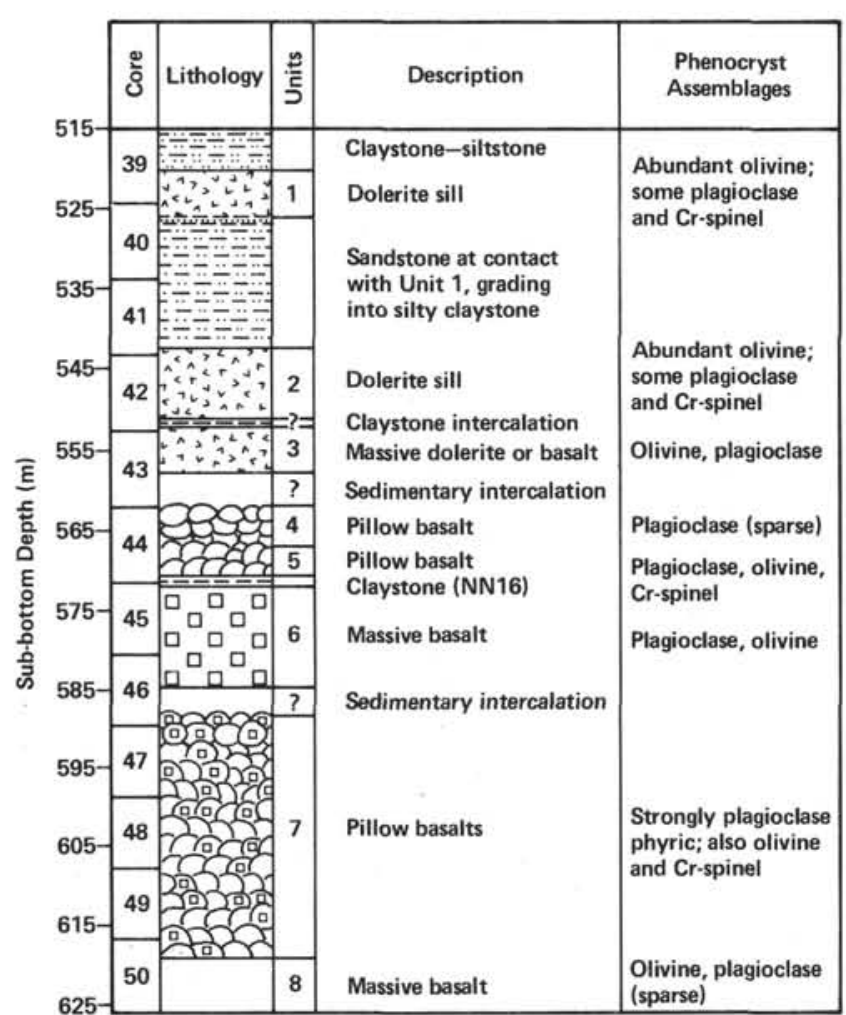

Figure 23. Igneous rock column, Site 474.

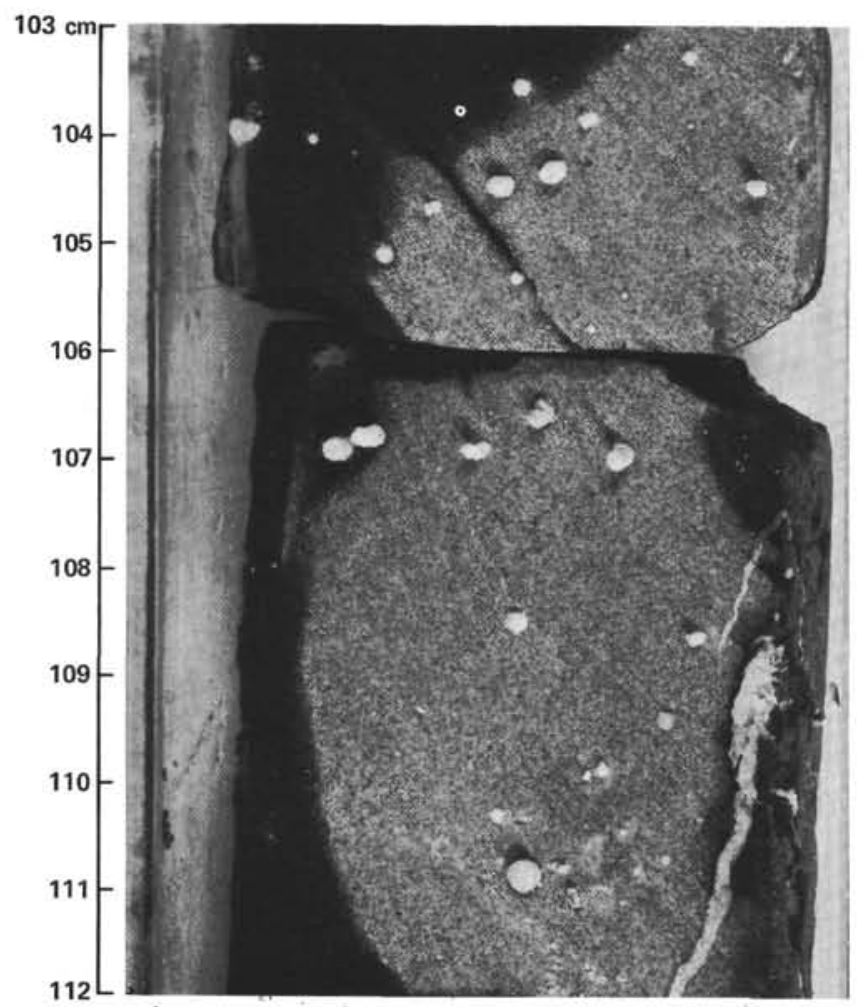

Figure 24. Sample 474A-42-2, 103-112 cm: alteration in Unit-2 dolerite. crysts, however, are profuse (10-15\%) at several intervals in Section 474A-43-1-a distribution similar to that observed in Units 1 and 2. Calcite veining occurs throughout Unit 3, frequently resulting in fragmentation of the basalt.

Fine-grained basalts with glassy chill zones and baked mudstone selvages were first encountered in Section 474A-44-1 at 562.5 meters sub-bottom. These are interpreted as being part of a pillow-lava sequence and probably represent the shallowest level of the true basement.

\section{Unit 4}

Unit 4 represents the upper 1.5 meters of the lava sequence and comprises moderately altered aphanitic basalts and sparsely plagioclase-phyric basalt. The basalt is cut by rare, thin calcite veins and is somewhat fractured. In thin section, the basalt contains less than $5 \%$ plagioclase phenocrysts $(0.5-1.0 \mathrm{~mm})$ in a quenched, variolitic groundmass of plagioclase, clinopyroxene, and disseminated magnetite. The mesostasis is partially replaced by yellow brown clay minerals, and the small, abundant $(0.2-1.0 \mathrm{~mm})$ vesicles $(15-20 \%)$ are filled with clay minerals and zeolites.

\section{Unit 5}

Unit 5 comprises slightly altered plagioclase-phyric basalt. Glassy selvages as much as $2 \mathrm{~mm}$ wide are abundant, and the rock is considerably fractured. The basalt contains two generations of plagioclase phenocrysts. Large, tabular, subhedral, and zoned $\left(\mathrm{An}_{80-90}\right)$ plagioclase crystals, forming multicrystal aggregates as long as $5 \mathrm{~mm}$ across, compose about $5 \%$ of the rock. The second plagioclase phase consists of elongate lath-shaped crystals as much as $2.5 \mathrm{~mm}$ long $\left(\mathrm{An}_{70-80}\right)$, comprising as much as $30 \%$ of the rock. Other phenocryst phases include olivine (as much as $5 \%$ ), which has been completely replaced by green clay mineraloids, and cubes of red chrome spinel lying in the groundmass and as inclusions in the plagioclase phenocrysts. The groundmass is generally very fine grained, containing olivine $(5 \%)$, plagioclase microlites $(20 \%)$, clinopyroxene $(15 \%)$, and disseminated opaques. The mesostasis has been replaced by brown clay minerals, and occasional vesicles are filled with clay minerals, calcite, or zeolites.

\section{Unit 6}

Unit 6 appears to be overlain by a thin sediment intercalation containing nannofossil assemblage NN16. The absence of a recovered contact at the top of the unit, however, means that we could not ascertain whether Unit 6 represents an intrusive or extrusive body. The rock is a fresh, homogeneous, fine-grained dolerite; it has good recovery and an absence of fractures or quench zones, suggesting that it is either a thick flow or a sill. In thin section, the rock has a subophitic texture and is sparsely plagioclase phyric $(5 \%$, as wide as $2 \mathrm{~mm}$ across). The groundmass comprises olivine $(5 \%)$, plagioclase $(40 \%, \mathrm{An})$, pale brown augite $(40 \%)$, and opaques. Alteration is restricted to the olivines, which are replaced by green clay mineraloids. 


\section{Unit 7}

Unit 7 is part of a 36-meter sequence of fresh plagioclase-phyric basalts which, from the presence of numerous glassy selvages, probably represent successive submarine eruptions (pillow basalts). Approximately $5 \%$ of the rock consists of large $(2-20 \mathrm{~mm})$, partially resorbed, zoned (An), and glass-inclusion-filled plagioclase phenocrysts or megacrysts. In addition, smaller lath-shaped plagioclase $(10 \%, 0.5-1.0 \mathrm{~mm}$ ) and olivine (up to $5 \%$ ) phenocrysts and euhedral red chrome spinel microphenocrysts lie in the pilotaxitic groundmass of plumose pyroxene, plagioclase microlites, and a glassy mesostasis containing approximately $5 \%$ clay minerals.

\section{Unit 8}

Unit 7 grades downward through a narrow amygdular zone into Unit 8-2 meters of sparsely plagioclase $(5 \%)$ - and olivine $(5 \%)$ - phyric coarse-grained basalt. The phenocrysts lie in an intergranular-to-subophitic groundmass of approximately equal proportions of pale brown augite and plagioclase and about $15 \%$ olivine. The olivine in the rock has been altered to green clay mineraloids. Unit 8 contains no glassy selvages, indicating that it may be part of a massive flow.

The depth to true basement has been estimated by the glassy selvages in Unit 4 at 563 meters sub-bottom. A minimum age of about $3.0 \mathrm{~m}$.y. for the basement rocks is suggested by a nannofossil-bearing claystone intercalation in Core $474 \mathrm{~A}-45$. This agrees with the magnetic lineation data showing that Hole 474A lies on anomaly $2^{\prime \prime}$ (ca. 3.2 m.y.). Unit 1 is probably a sill, postdating the basement by at least $1.0 \mathrm{~m} . \mathrm{y}$. The petrographically similar Unit 2 is also intrusive in origin and probably of a similar age to Unit 1 .

\section{PALEOMAGNETISM}

We collected 115 samples from Holes 474 and 474A for paleomagnetic examination. Of these samples, 79 were collected from sedimentary cores beginning at Core 474-11. Because the sediments were soft and greatly disturbed in the upper 150 meters, only a few samples were suitable for paleomagnetic studies. In Hole 474A, the density of sampling was greater, because the sediments were more compacted. We collected 36 additional samples from the igneous basement.

The routine shipboard sampling procedure was followed. Before sampling, an orientation arrow, pointing uphole, was traced on the rock. Igneous rocks were measured on shipboard with a Digico balanced-fluxgate spinner magnetometer, an alternating field (AF) GSD-1 demagnetizer, and a Bison magnetic susceptibility meter.

\section{Basalts}

Each igneous unit was sampled, and the natural remanent magnetization (NRM) and bulk susceptibility were measured. Rather than establishing the ideal range of AF demagnetization with a pilot set, the whole set was subjected to an alternating-field (AF) demagnetization procedure in increasing steps at $25,50,75,100$,
$150,200,250,300$, and 350 Oe. By 350 Oe, most of the samples had lost more than $90 \%$ of their original NRM.

\section{Results}

The $J_{0}$ values range from $0.977 \times 10^{-3} \mathrm{emu} / \mathrm{cm}^{3}$ to $20.629 \times 10^{-3} \mathrm{emu} / \mathrm{cm}^{3}$, although two-thirds of them fall within 2 to $5 \times 10^{-3} \mathrm{emu} / \mathrm{cm}^{3}$. Curiously enough, some of the higher values come from samples in the uppermost part of the cores $(474 \mathrm{~A}-44,474 \mathrm{~A}-48,474 \mathrm{~A}$ 49 , and $474 \mathrm{~A}-50$ ) and apparently bear no relation to the petrological or magnetic unit boundaries. Drilling may have caused this phenomenon. Negative and positive inclinations range from -61.2 to $+60.2^{\circ}$ (Fig. 25). Upon demagnetization, 7 samples remained positive and 15 negative; 12, which first showed a positive inclination, became negative as demagnetization proceeded. Two samples changed polarity from negative to positive. Usually these changes occurred within the first two or three steps (as far as $75 \mathrm{Oe}$ ), and then no major changes occurred in the declination or inclination values. In general, most of the samples remained very close to their stable inclination.

Unit 1 (three specimens) displays a normal polarity in two samples, but the third is reversed. This last sample is very close to the lower chilled margin of the sill. It may be that the sill intruded the sediments during a period of reversed polarity (which was "frozen" at the margins) shortly before a shift to normal polarity, which has registered in the inner parts of the sill. According to the age of the sediments above and below, the sill must have been emplaced sometime between 1.8 and $2.8 \mathrm{Ma}$, in the first half of the Matuyama Reversed

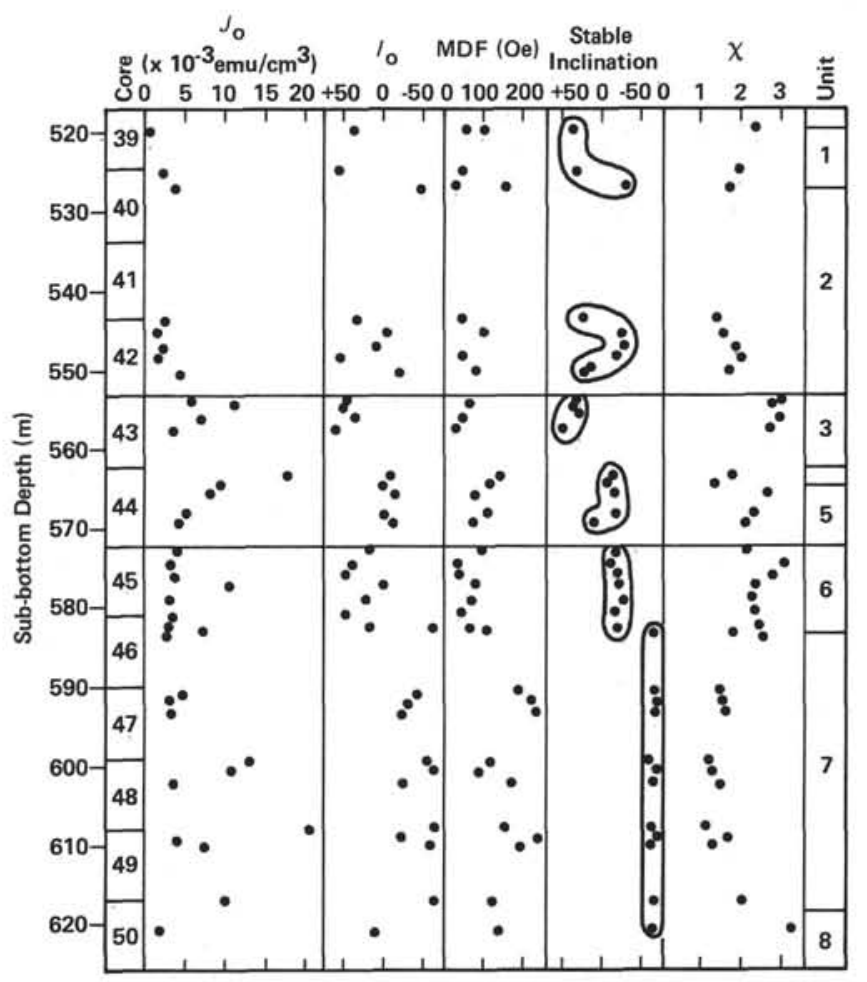

Figure 25. Paleomagnetism results, Site 474. 
Epoch; several normal events occurred in that period. The stable inclination values agree with the expected values for this latitude $\left(23^{\circ} \mathrm{N}\right)$.

Petrographically, Units 2 and 3 appear to be different. On paleomagnetic grounds (Table 4, Fig. 25), Units 2 and 3 display different polarities: Unit 3 shows a normal polarity throughout; the stable inclination for Unit 2 is $-23.1^{\circ}$, somewhat shallower than expected, and Unit 3 has three samples with an average of $33^{\circ}$ and one sample with a steeper positive inclination of $51.9^{\circ}$.

Units 4,5 , and 6 are magnetically similar; negative stable inclinations vary from -8.6 to -23.5 . An abrupt change occurs between Units 6 and 7 (Table 4; Fig. 25). The stable inclination values of Units 7 and 8 are the steepest of this site: $-59^{\circ}$ to $-66^{\circ}$. The median destructive field (MDF), varying from 90 to $250 \mathrm{Oe}$, is higher than in any other units. The $x$ values are smaller than in other samples, and the $Q_{n}$ values are therefore higher. All the samples increase in intensity during the first step of demagnetization, indicating that a normal component is being erased (Fig. 26).

Except for Units 1 and 3, which exhibit an inclination value agreeing with the one expected for this latitude $\left(23^{\circ} \mathrm{N}\right)$, the units have inclinations either too shallow or too steep. Several alternatives include secular variation, tectonic disturbance, or some drilling remanence. Another puzzling fact is that Hole $474 \mathrm{~A}$ was drilled on a positive magnetic anomaly, NR2, but most of the units have a reversed polarity. One reason for this may be that the source of the anomaly is deeper than 100 meters. Similar situations have been encountered in DSDP Legs 45, 37, and 39 .

\section{PHYSICAL PROPERTIES}

Most of the methods and procedures that determine physical properties aboard Glomar Challenger have been described. References and some remarks on the validity and reliability of these determinations, as well as a description of some additional techniques, are presented in a summary of physical properties (Einsele, this volume, Pt. 2). For all measurements, we tried to choose the least-disturbed samples (generally from the lowermost core sections) from sediments representing the predominant sediment type. Special layers, such as mud turbidites, were, as far as possible, avoided or sampled separately. Sand layers were usually very much disturbed or completely lost in drilling. Therefore, all the data presented here are valid only for cohesive muds.

When the sediment was stiff enough, chunks were taken and weighed in air and under water to determine "wet" water content, wet-bulk density, and porosity. In soft sediments not stiff enough for the chunk method, we used special steel cylinders (about $5 \mathrm{~cm}^{3}$ volume) to remove undisturbed samples from the center of the split core. All porosity data were corrected for salt content. According to the chemical analyses on interstitial water,

Table 4. Paleomagnetism, Hole 474A.

\begin{tabular}{|c|c|c|c|c|c|c|c|c|c|c|c|}
\hline \multirow{2}{*}{$\begin{array}{c}\text { Core/ } \\
\text { Section } \\
\text { (level in } \mathrm{cm} \text { ) }\end{array}$} & \multirow{2}{*}{$\begin{array}{l}\text { Sub-bottom } \\
\text { Depth } \\
\text { (m) }\end{array}$} & \multirow{2}{*}{$\left(\times 10^{-3^{J_{0}}} \mathrm{emu} / \mathrm{cm}^{3}\right)$} & \multirow[b]{2}{*}{$I_{0}$} & \multirow[b]{2}{*}{$D_{0}$} & \multirow{2}{*}{$\begin{array}{l}\text { MDF } \\
(\mathrm{Oe})\end{array}$} & \multicolumn{2}{|c|}{ Stable } & \multirow[b]{2}{*}{ Polarity } & \multirow{2}{*}{$\left(\times 10^{-3} \mathrm{emu}\right)$} & \multirow{2}{*}{$\begin{array}{c}Q_{n} \\
(F=0.45)\end{array}$} & \multirow{2}{*}{$\begin{array}{c}\text { Igneous } \\
\text { Unit }\end{array}$} \\
\hline & & & & & & Inclination & Declination & & & & \\
\hline $39-4,55$ & 520.05 & 0.977 & 38.1 & 96.2 & 65 & 37.2 & 83.8 & $\mathrm{~N}$ & 2.364 & 0.91 & \\
\hline $40-1,70$ & 525.20 & 2.432 & 56.2 & 121.6 & 50 & 34.3 & 112.8 & $\mathrm{~N}$ & 1.945 & 2.77 & 1 \\
\hline $40-2,106$ & 527.06 & 3.621 & -51.0 & 347.7 & 40 & -32.7 & 344.9 & $\mathrm{R}$ & 1.752 & 4.59 & \\
\hline $42-1,3$ & 543.53 & 2.642 & 35.7 & 249.7 & 45 & 24.7 & 253.6 & $\mathrm{~N}$ & 1.395 & 4.20 & \\
\hline $42-2,48$ & 545.48 & 1.506 & -1.9 & 168.8 & 100 & -23.1 & 161.2 & $\mathbf{R}$ & 1.527 & 2.19 & \\
\hline $42-3,66$ & 547.16 & 2.189 & 8.9 & 67.9 & 135 & -25.8 & 65.5 & $\mathrm{R}$ & 1.821 & 2.67 & 2 \\
\hline $42-4,37$ & 548.37 & 1.768 & 56.1 & 195.1 & 45 & -17.8 & 183.6 & $\mathrm{R}$ & 1.935 & 2.03 & \\
\hline $42-5,98$ & 550.48 & 4.538 & -18.6 & 139.7 & 80 & 22.4 & 140.5 & $\mathrm{~N}$ & 1.557 & 6.47 & \\
\hline $43-1,110$ & 554.10 & 5.644 & 49.7 & 172.9 & 65 & 33.1 & 174.9 & $\mathrm{~N}$ & 2.962 & 4.23 & sediment \\
\hline $43-2,13$ & 554.63 & 11.251 & 49.3 & 34.4 & 62 & 35.7 & 40.8 & $\mathrm{~N}$ & 2.727 & 9.16 & \\
\hline $43-3,19$ & 556.19 & 7.467 & 36.8 & 239.5 & 50 & 31.9 & 233.9 & $\mathrm{~N}$ & 2.894 & 5.73 & 3 \\
\hline $43-4,29$ & 557.79 & 3.333 & 60.2 & 271.9 & 25 & 51.9 & 258.8 & $\mathrm{~N}$ & 2.676 & 2.76 & \\
\hline $44-1,106$ & 563.56 & 17.609 & -6.3 & 212.3 & 140 & -9.6 & 210.7 & $\mathbf{R}$ & 1.715 & 22.81 & 4 \\
\hline $44-2,56$ & 564.56 & 9.525 & 1.2 & 269.6 & 115 & -8.6 & 271.7 & $\mathrm{R}$ & 1.312 & 16.13 & \\
\hline $44-3,39$ & 565.89 & 8.382 & -12.8 & 351.8 & 80 & -12.5 & 347.6 & $\mathrm{R}$ & 2.673 & 6.96 & 5 \\
\hline $44-4,124$ & 568.24 & 5.230 & 2.3 & 134.6 & 105 & -18.0 & 128.8 & $\mathbf{R}$ & 2.250 & 5.16 & \\
\hline $44-5,107$ & 569.57 & 4.066 & -12.2 & 84.5 & 75 & 14.5 & 80.8 & $\mathrm{~N}$ & 2.081 & 4.34 & \\
\hline $45-1,86$ & 572.86 & 4.177 & 18.5 & 226.9 & 95 & -13.9 & 225.8 & $\mathrm{R}$ & 2.113 & 4.39 & sediment \\
\hline $45-2,121$ & 574.71 & 3.188 & 39.5 & 57.8 & 35 & -12.3 & 53.4 & $\mathrm{R}$ & 2.994 & 2.36 & \\
\hline $45-3,92$ & 575.92 & 3.499 & 50.1 & 40.3 & 40 & -15.8 & 32.1 & $\mathbf{R}$ & 2.771 & 2.80 & \\
\hline $45-4,67$ & 577.17 & 10.515 & 3.9 & 98.0 & 80 & -18.7 & 97.8 & $\mathbf{R}$ & 2.321 & 10.06 & 6 \\
\hline $45-5,101$ & 579.01 & 2.764 & 25.4 & 142.1 & 65 & -23.5 & 147.5 & $\mathbf{R}$ & 2.237 & 2.74 & \\
\hline $46-1,10$ & 581.10 & 3.285 & 50.1 & 287.4 & 40 & -15.4 & 301.6 & $\mathrm{R}$ & 2.295 & 3.18 & \\
\hline $46-1,124$ & 582.24 & 2.577 & -20.5 & 266.4 & 65 & -14.8 & 267.6 & $\mathrm{R}$ & 2.509 & 2.28 & \\
\hline $46-2,68$ & 583.18 & 7.122 & -60.6 & 25.6 & 105 & -65.4 & 19.3 & $\mathrm{R}$ & 1.174 & 13.48 & \\
\hline $47-1,116$ & 591.16 & 4.715 & -42.2 & 315.5 & 190 & -63.5 & 322.7 & $\mathbf{R}$ & 1.495 & 7.00 & \\
\hline $47-2,51$ & 592.01 & 2.955 & -29.1 & 218.1 & 215 & -66.0 & 223.9 & $\mathrm{R}$ & 1.522 & 4.31 & \\
\hline $47-3,32$ & 593.32 & 2.915 & -24.5 & 277.6 & 235 & -63.0 & 289.7 & $\mathbf{R}$ & 1.537 & 4.21 & \\
\hline $48-1,69$ & 599.69 & 13.108 & -53.6 & 359.4 & 110 & -59.2 & 1.3 & $\mathbf{R}$ & 1.161 & 25.08 & 7 \\
\hline $48-2,19$ & 600.69 & 10.853 & -57.7 & 96.6 & 95 & -64.4 & 100.0 & $\mathrm{R}$ & 1.228 & 19.63 & 7 \\
\hline $48-3,30$ & 602.30 & 3.472 & -23.9 & 138.1 & 160 & -61.0 & 137.1 & $\mathbf{R}$ & 1.464 & 5.27 & \\
\hline $49-1,8$ & 608.08 & 20.629 & -60.6 & 248.5 & 150 & -62.1 & 249.1 & $\mathrm{R}$ & 1.046 & 43.82 & \\
\hline $49-2,14$ & 609.64 & 3.790 & -20.4 & 168.4 & 225 & -66.1 & 155.6 & $\mathrm{R}$ & 1.555 & 5.41 & \\
\hline $49-2,68$ & 610.18 & 7.318 & -54.0 & 121.7 & 190 & -60.3 & 124.3 & $\mathrm{R}$ & 1.275 & 12.75 & \\
\hline $50-1,29$ & 617.29 & 9.767 & -61.2 & 327.8 & 115 & -66.3 & 326.9 & $\mathrm{R}$ & 2.006 & 10.81 & \\
\hline $50-3,113$ & 621.13 & 1.534 & 15.6 & 38.4 & 135 & -61.1 & 9.4 & $\mathrm{R}$ & 3.282 & 1.03 & 8 \\
\hline
\end{tabular}



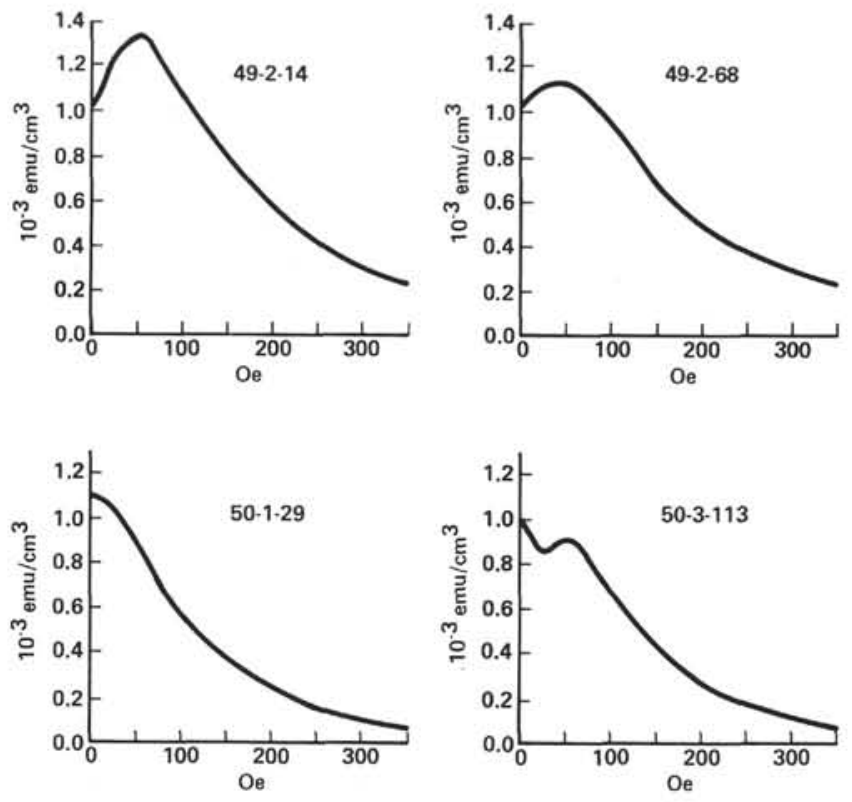

Figure 26. Demagnetization curves, Site 474.

the total salt content of the pore water-down to the oceanic crust-varies only slightly. Therefore, no further corrections for changing salt content were necessary. Loss of volume by shrinkage was determined on the dried samples from the cylinders and expressed in percentages of the original volume of the wet samples. In about 10 to 200 meters below the sediment surfaceand to some smaller extent in deeper cores-part of the pore water was removed and cavities were formed by expanding methane gas. Since calculations for bulk density and porosity assume that the samples are watersaturated, the values in this part of the sequence are somewhat too low. This especially applies to the cylinder method, whereas the chunks could take up some of their lost water during weighing under water.

The Hamilton Frame could not measure sound velocity in the upper and middle part of the sediment sequence, probably (again) because of the gas content of the samples. We routinely determined GRAPE wet-bulk density on each or each second core section within the plastic liner. Vane shear tests, using the Wykeham Farrance apparatus and, in more consolidated sediment, the hand-operated, soil-test, high-capacity vane tester and a newly developed cone vane tester, were performed on the split cores. From Core 474-34 downward, the sediments became so hard that the coherent parts of the section cracked during penetration of the vane. Nevertheless, we finished the test by holding the split pieces together by hand. We took the highest value from several tests at the same core section.

Besides the well-known general relation between physical properties and depth in core, at Site 474 some special major trends can be recognized-trends mostly related to the composition of the sediments and the first stages of diagenesis. The data gained from the uppermost 60 meters of the hole show unusually strong gradients of all physical properties (Fig. 27), especially in
Cores 474-1 and 474-2. "Wet" water content and porosity decrease from about 65 to $85 \%$ to about 45 and $65 \%$, respectively. Bulk density increases from 1.3 to $1.55 \mathrm{~g} / \mathrm{cm}^{3}$, and vane shear strength versus depth appears to grow very fast. In the same interval, shrinkage of dried samples decreases from 40 to $50 \%$ to about $30 \%$. These strong gradients in the upper 10 to $20 \mathrm{me}-$ ters of a sedimentary column are to some extent normal, but at Site 474 they are amplified by the decrease of biogenic silica and the increase of the coccoliths as important constituents of the sediment. Biogenic silica (mainly in the form of delicate diatom frustules) tends to preserve high porosity, whereas the calcareous remnants of coccoliths do not prevent compaction to such an extent. The sediments of this depth range also have a comparatively high silt content. Thus, the dotted trend lines in Figure 27 are drawn somewhat apart from the actual data points.

In the sandy section from depths of about 60 to 90 meters, no physical properties could be determined. From about 90 to 250 meters, water content, porosity, and bulk density are changing slowly versus depth-as expected. The data, however, scatter considerably in this range, which is also true of the density log. This scattering is partly caused by expanded gas and the initial difficulties in distinguishing mud from the "background" sediments from mud from the upper part of mud turbidites.

Since biogenic silica (opal) and calcareous nannofossils are still present in considerable quantities, recrystallization appears hardly to have occurred in this interval. Shrinkage drops, however, from 30 to $5 \%$. Why this great change falls into an interval of otherwise minor variations is not quite clear. It appears that first diagenetic bonds between single grains are being established within this depth range.

From about 260 to 360 meters, water content and porosity decrease fairly rapidly from 37 to 27 and 60 to $48 \%$, respectively. In the same interval, bulk density increases from 1.67 to nearly $1.90 \mathrm{~g} / \mathrm{cm}^{3}$, whereas shear strength scarcely changes, and shrinkage remains very low. From 240 meters downward, the sediments are silty claystones or clayey siltstones. Beginning with Core 474A-10 (250 m sub-bottom), the cores had to be split with a saw. Furthermore, in the sequence below 260 to 270 meters, scarcely any biogenic silica could be detected in the smear slides, and the nannofossils decrease to very small percentages. At about the same depth, the concentration of dissolved silica in the pore fluid is very low compared with the higher sections, where opal is still present. This signifies that the formation of chalcedony and authigenic clay minerals may have begun and contributed to the lithification of the sediment.

In the lower part of the sediment sequence, between 360 and 540 meters, the data for water content, bulk density, and porosity are relatively consistent and show only a small scattering (Fig. 27). Lithification, however, also proceeds in this interval. The vane shear strength increases considerably with depth. From about 400 meters downward, only small, high-capacity, hand-operated vanes could be used. Though the vane was pressed only 


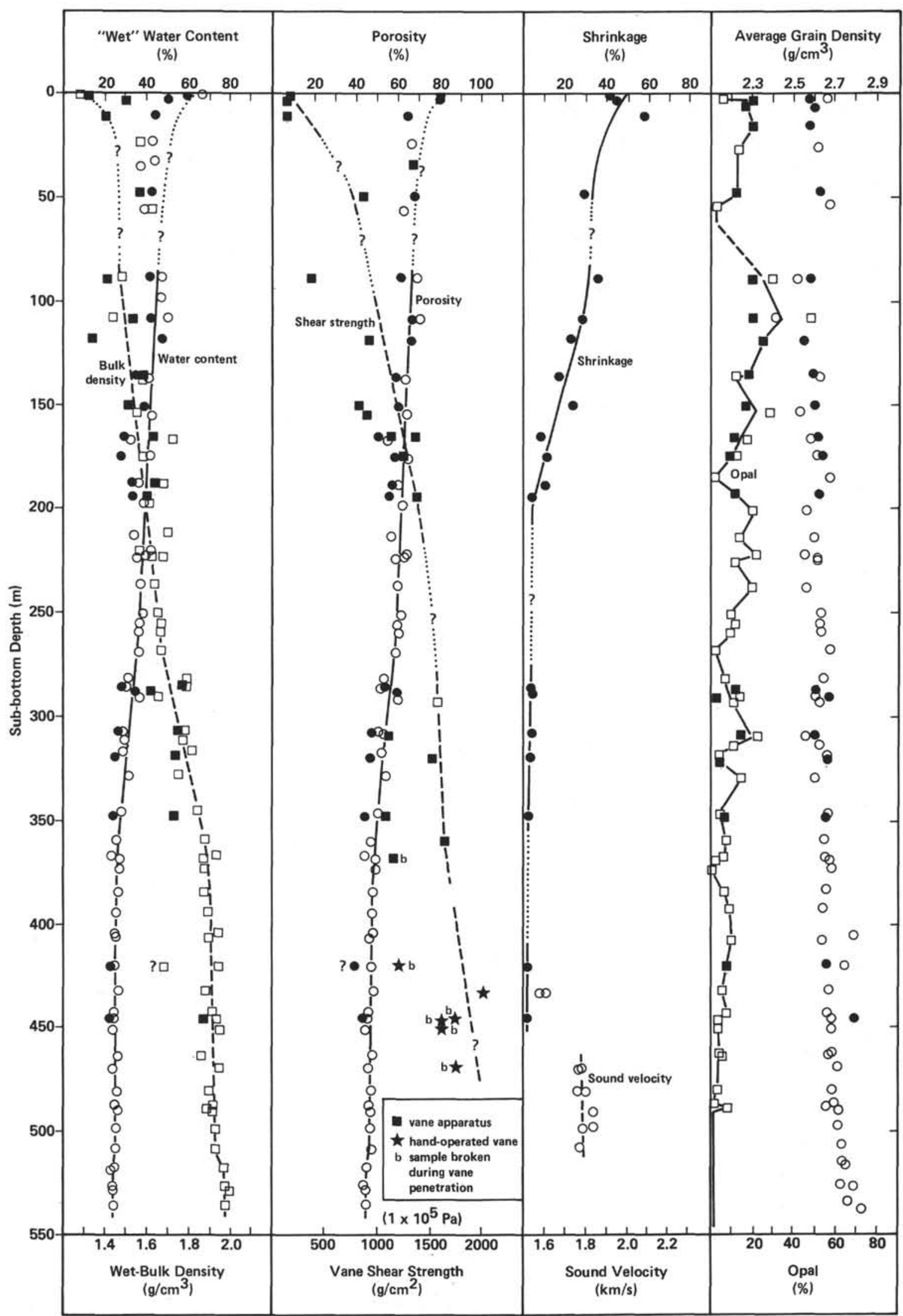

Figure 27. Mass physical properties, shrinkage, and proportion of opaline silica sediments, Holes 474 and 474A. (Closed symbols are cylinder samples. Open symbols are chunk samples.) 
$5 \mathrm{~mm}$ into the split core, the material broke during penetration. Highest values for vane shear strength or cohesion measured by this method are near $2 \times 10^{5} \mathrm{~Pa}$ $\left(\sim 2 \mathrm{~kg} / \mathrm{cm}^{2}\right)$. In the sequence below 470 meters, no further vane measurements were possible, and small cylinders could no longer be used for sampling.

The trend line of the vane shear strength (Fig. 27) for 0 to 480 meters is very uncertain because of the wide scatter of data. One of the reasons for this scatter is differential lithification, which does not affect all sediment layers the same way. For example, vane shear strength at about 34 meters is very high. Nevertheless, some vane tests are affected by partially saturated conditions caused by expanding gas after the high in situ pressure on the sediment had been released.

On some selected chunks from the lower part of the sediment sequence, the sound-velocity data were measured perpendicular to the bedding (Fig. 27). From about 430 to 500 meters, the sound velocity increases from 1.6 to about $1.8 \mathrm{~km} / \mathrm{s}$. Similarly, acoustic impedance varies between 3.05 and $3.52 \times 10^{5} \mathrm{~g} / \mathrm{cm}^{2} \mathrm{~s}$. Additional sound velocity measurements, not represented in Figure 27, are listed in Table 5. The acoustic impedance of the dolerites (Cores 474A-40 through $474 \mathrm{~A}-42$ ) varies between 17.66 and $18.51 \times 10^{5} \mathrm{~g} / \mathrm{cm}^{2} s$. (See also section on Correlation of Drilling Results and Seismic Data, this chapter).

Bulk density curves obtained gravimetrically were compared with the GRAPE data from unsplit cores. Because the thickness of the cores varied, only the highest values in the hard copy of the GRAPE data were used for comparison. Though the GRAPE measurements appear to be not very accurate, they generally agree fairly well with the gravimetric determinations of bulk density.

As already mentioned, the physical properties are also somewhat related to short, vertical changes in the

Table 5. Sound velocity $\left(v_{\mathrm{S}}\right)$, wet-bulk density (BD), and acoustic impedance $(\mathrm{AI})$ of some hard rock samples from Hole 474A.

\begin{tabular}{|c|c|c|c|c|c|}
\hline $\begin{array}{c}\text { Sample } \\
(\text { level in } \\
\mathrm{cm})\end{array}$ & Rock Type & Orientation & $\begin{array}{c}v_{\mathrm{s}} \\
(\mathrm{km} / \mathrm{s})\end{array}$ & $\underset{\left(\mathrm{g} / \mathrm{cm}^{3}\right)}{\mathrm{BD}}$ & $\left(\times 10^{5} \stackrel{\left.\mathrm{gl} / \mathrm{cm}^{2} \mathrm{~s}\right)}{ }\right.$ \\
\hline $474 \mathrm{~A}-38-1,37$ & $\begin{array}{l}\text { arkosic sandstone, } \\
\text { cemented }\end{array}$ & & $\begin{array}{l}4.29 \\
5.04 \\
4.33\end{array}$ & & \\
\hline $474 A-40-1,70$ & dolerite & $\begin{array}{l}\text { parallel } \\
\text { parallel }\end{array}$ & $\begin{array}{l}6.09 \\
6.12 \\
6.12\end{array}$ & 2.97 & $\begin{array}{l}18.09 \\
17.88 \\
18.18\end{array}$ \\
\hline $474 \mathrm{~A}-42-1,32$ & dolerite & $\begin{array}{l}\text { parallel } \\
\text { parallel }\end{array}$ & $\begin{array}{l}6.67 \\
6.42\end{array}$ & 2.87 & $\begin{array}{l}19.14 \\
18.43\end{array}$ \\
\hline $474 A-42-3,66$ & dolerite & parallel & $\begin{array}{l}6.07 \\
6.09\end{array}$ & 2.91 & $\begin{array}{l}17.66 \\
17.71\end{array}$ \\
\hline $474 A-42-5,98$ & dolerite & $\begin{array}{l}\text { parallel } \\
\text { parallel }\end{array}$ & $\begin{array}{l}6.30 \\
6.29 \\
6.34\end{array}$ & 2.92 & $\begin{array}{l}18.40 \\
18.37 \\
18.51\end{array}$ \\
\hline $474 A-43-3,19$ & dolerite & $\begin{array}{l}\text { paralle! } \\
\text { parallel }\end{array}$ & $\begin{array}{l}5.82 \\
6.04 \\
5.92 \\
5.70\end{array}$ & & \\
\hline $474 \mathrm{~A}-44-3,39$ & basalt & $\begin{array}{l}\text { parallel } \\
\text { parallel }\end{array}$ & $\begin{array}{l}4.80 \\
4.97 \\
4.95\end{array}$ & & \\
\hline $474 \mathrm{~A}-45-3,60$ & basalt & & 5.56 & & \\
\hline $474 \mathrm{~A}-46-1,124$ & fine-grained basalt & parallel & $\begin{array}{l}6.09 \\
5.99\end{array}$ & & \\
\hline $474 \mathrm{~A}-47-3,48$ & plagioclase-phyric basalt & parallel & $\begin{array}{l}6.24 \\
6.27\end{array}$ & & \\
\hline $474 A-49-2,68$ & $\begin{array}{l}\text { plagioclase-phyric } \\
\text { pillow basalt }\end{array}$ & $\begin{array}{l}\text { parallel } \\
\text { parallel }\end{array}$ & $\begin{array}{l}5.77 \\
5.79 \\
5.95 \\
5.88\end{array}$ & & \\
\hline
\end{tabular}

Note: All samples from Cores $474 \mathrm{~A}-40$ through $474 \mathrm{~A}-49$ were soaked in water before sound velocity measurement. texture and composition of silty and clayey sediments. In Hole 474, some values for bulk density appear to be as much as 0.05 to $0.1 \mathrm{~g} / \mathrm{cm}^{3}$ lower than the average values at the corresponding depth, although water content and porosity are about normal. All samples contain large portions of siliceous, mostly diatomaceous, ooze. The relatively low bulk density is probably caused by the high content of biogenic opal with specific gravity values between 2.0 and $2.20 \mathrm{~g} / \mathrm{cm}^{3}$; this contrasts with the much higher values of quartz, feldspar, and clay minerals. For that reason, the average grain density also decreases with increasing opaline silica. If we assume an average specific gravity of $2.70 \mathrm{~g} / \mathrm{cm}^{3}$ for "normal" grains such as quartz, feldspar, carbonate, and clay minerals and $2.10 \mathrm{~g} / \mathrm{cm}^{3}$ for opaline silica, the percentage (per volume of solid particles) of opaline silica can be taken from Figure 28. The results of this procedure, and the corresponding data of grain density determinations aboard Glomar Challenger and in a shore-based laboratory (see Einsele on physical properties, this volume, Pt. 2), are plotted in Figure 27. The possible error in determining the percentage of biogenic silica-an error caused by specific gravities deviating from the values of the two principal "pure" constituents-can also be seen in Figure 28. A further source of error is organic matter, but since its percentage usually is low, it is not considered here. Generally, the curve for the biogenic silica versus depth (Fig. 28) confirms visual estimations from smear slides used for the core descriptions. Below about 260 meters, the content of opaline silica approaches zero, because this constituent is transformed to chalcedony (specific gravity $=\sim 2.60 \mathrm{~g} / \mathrm{cm}^{2}$ ).

Nevertheless, clayey silts or clayey siltstones poor in, or devoid of, opaline silica may have, in relation to their sub-bottom depth, lower water contents and porosities but higher bulk densities than the average samples at the corresponding depth. Most of these samples are from the lower part of mud turbidites, whereas the samples from the upper part of these beds contain more water, have higher porosities, and have lower bulk densities

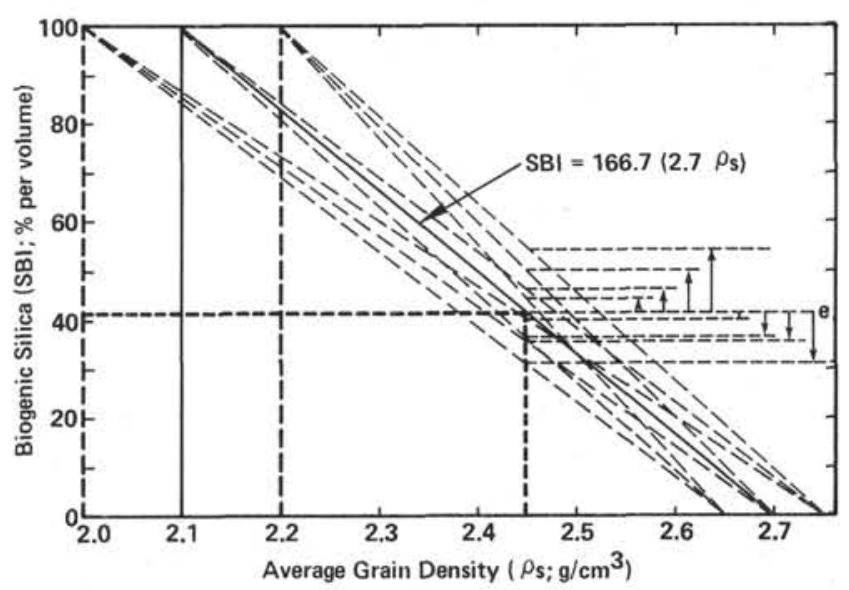

Figure 28. Graph to determine opaline silica content from average grain density $\left(\varrho_{s}\right)$, Holes 474 and $474 \mathrm{~A}$. (The solid line and the SBI formula are valid for mixtures of "normal" grains $\left[\varrho_{\mathrm{s}}=2.70\right.$ $\mathrm{g} / \mathrm{cm}^{3}$ and opal of $\varrho_{\mathrm{s}}=2.10 \mathrm{~g} / \mathrm{cm}^{3} ; \mathrm{e}=$ possible errors if grain densities of end members deviate from values assumed above].) 
than the average samples. (For special information on physical properties of mud turbidites see Einsele and Kelts, this volume.) The differences between samples of changing texture and composition decrease downhole.

Therefore, in the lower part of the sediment sequence, the physical property data are surprisingly constant. Slight deviations of single data points from the general trend line are, however, still caused by sampling from different positions within single mud turbidites. The trend lines of Figure 27 correspond more or less with the middle part of mud turbidites.

\section{HEAT FLOW AND THERMAL CONDUCTIVITY}

Logging in Hole 474A provided one usable bottom temperature during the second temperature-logging run, $28 \mathrm{hr}$. after circulation was stopped in the hole. A temperature of $58.5^{\circ} \mathrm{C}$ was reached after the logging tool sat $15 \mathrm{~min}$. at 509 meters sub-bottom. The temperature was still slowly rising when the tool was pulled up, suggesting an equilibrium temperature of about $60^{\circ} \mathrm{C}$.

No thermal conductivity measurements were made in this hole. Above 509 meters, where the sub-bottom temperature was taken, the lithology can be approximated by two lithologic units-the claystone below 239 meters and the silty clay above this depth. We assume a thermal conductivity of about $3 \mathrm{mcal} / \mathrm{cm} \mathrm{s}{ }^{\circ} \mathrm{C}$ for the claystone and $2.5 \mathrm{mcal} / \mathrm{cm} \mathrm{s}{ }^{\circ} \mathrm{C}$ for the silty clay.

Heat flow can be estimated by the equation

$$
T_{z}=T_{0}+q \sum_{i} D_{i} / K_{i}
$$

where $T_{z}=$ temperature at depth $z=\sum_{i} D_{i}, K_{i}$ is the thermal conductivity of the $i$ th homogeneous section of thickness $D_{i}, T_{0}=$ a constant bottom-water temperature, and $q=$ heat flow (Beck, 1965). The calculation for Site 474 yields a heat flow of $3.1 \mu \mathrm{cal} / \mathrm{cm}^{2} \mathrm{~s}$, slightly low for oceanic crust around 4 m.y. old.

\section{CORRELATION OF DRILLING RESULTS AND SEISMIC DATA}

Extensive seismic reflection profiling has been done in the vicinity of Site 474 . The site was selected at the crossing of two lines run on Thomas Washington in February 1978 on the Guaymas site-survey expedition (Moore et al., 1978) and a dense network of other lines, including some run by the University of Washington group in a 1975 site survey (Lewis et al., 1975). In addition, reflection records with 2 - and 10 -s sweeps and different bandpasses $(40-160 \mathrm{~Hz}$ and $10-40 \mathrm{~Hz}$, respectively) were collected on approaching the site. A sonobuoy wide-angle and refraction run was made while on the site, and a cross line with 5 -s and $10-80-\mathrm{Hz}$ bandpass was run after leaving the site. This section correlates drilling results with these various seismic records and information from the downhole logging.

The key to correlating this information is an estimation of seismic velocities to calculate depths. Because of the high gas content, laboratory measurements of veloc- ity could not be made for most of the sediment section. We thus used the sonic log to estimate interval velocities, and the correlation between the sonic and the drilling lithologies is shown in Figure 29. The upper 135 meters of the hole could not be run with the sonic log, because the drill pipe was pulled out of the hole only to this depth, and the sonic log of the section down to about 200 meters was unusable because of poor correlation between the emitted and received pulses. Using these velocities, and assuming velocities of 1.60 and 1.70 $\mathrm{km} / \mathrm{s}$ for the upper $0-60$ and $60-200$ meters of section, the lithologic section correlates well with seismic reflection records run through this site (Figs. 30, 31, 32).

Some details of lithology correlate with specific reflectors or groups of reflectors (Fig. 30). The most prominent reflecting horizons that appear to correlate are contact between Units I and II, the top and bottom of the sand and gravel debris-flow unit at 58 to 87 meters, changes in lithology at about 125 and 180 meters, a sand layer at 275 meters, and the tops of igneous units at 521 and 543 meters. Some of these same reflectors can be seen in the processed 24-channel reflection record from the Scripps Institution of Oceanography Guaymas Expedition run about $1.8 \mathrm{~km}$ from this site (Fig. 31) and in a 2-s sweep cross line from the Guaymas Expedition (Fig. 32). The debris flow from 58 to 87 meters shows up especially well, as do the sill and basement.

A sonobuoy run was made while drilling Hole 474A. Two airguns, 120 and 20 in. ${ }^{3}$, were buoyed off the stern of Glomar Challenger and fired at 10-s intervals, while a Fairfield sonobuoy, with a large plastic box acting as a sail, drifted away on a heading of $105^{\circ}$. Two sweeps were recorded, 5 and $10 \mathrm{~s}$, with bandpass set at 5 to 40 $\mathrm{H}_{3}$ (Figs. 33, 34). The wide-angle reflection part of the records was analyzed ashore by $\mathrm{R}$. T. Bachman of NOSC, San Diego. He obtained a solution for a singlelayer-to-sub-bottom depth of 460 meters with a mean velocity of $1.69 \mathrm{~km} / \mathrm{s}$. This compares with about 1.75 $\mathrm{km} / \mathrm{s}$ obtained from the velocities in Figure 29. A sonobuoy run during the multichannel survey of Guaymas Expedition-abeam of and about $1.8 \mathrm{~km}$ away from the site-gave a wide-angle velocity of $1.98 \mathrm{~km} / \mathrm{s}$ for the sediments (and the one sill) above the reflector we interpret to be the dolerite at 543 meters depth. This compares with a mean velocity of $1.77 \mathrm{~km} / \mathrm{s}$ obtained from the sonic log and the correlations already described.

Both sonobuoys run from Glomar Challenger and the Guaymas Expedition had strong refracted arrivals that gave apparent velocities of about 6.0 and $6.6 \mathrm{~km} / \mathrm{s}$, respectively. Simple layer solutions put this refracting horizon well below the dolerites drilled in Hole 474A. Both sonobuoy runs were at a heading of about $105^{\circ}$, and the shoaling of the "basement" in this direction would cause the apparent velocity to be greater than the true velocity and the apparent depth to be too great. Thus the refracted arrivals undoubtedly represent either the upper sill at 521 meters or the sequence of sills and flows starting at 543 meters. In retrospect, we now believe there is a good possibility that older sediments may exist in this stratified-layer-2 complex to depths as great 


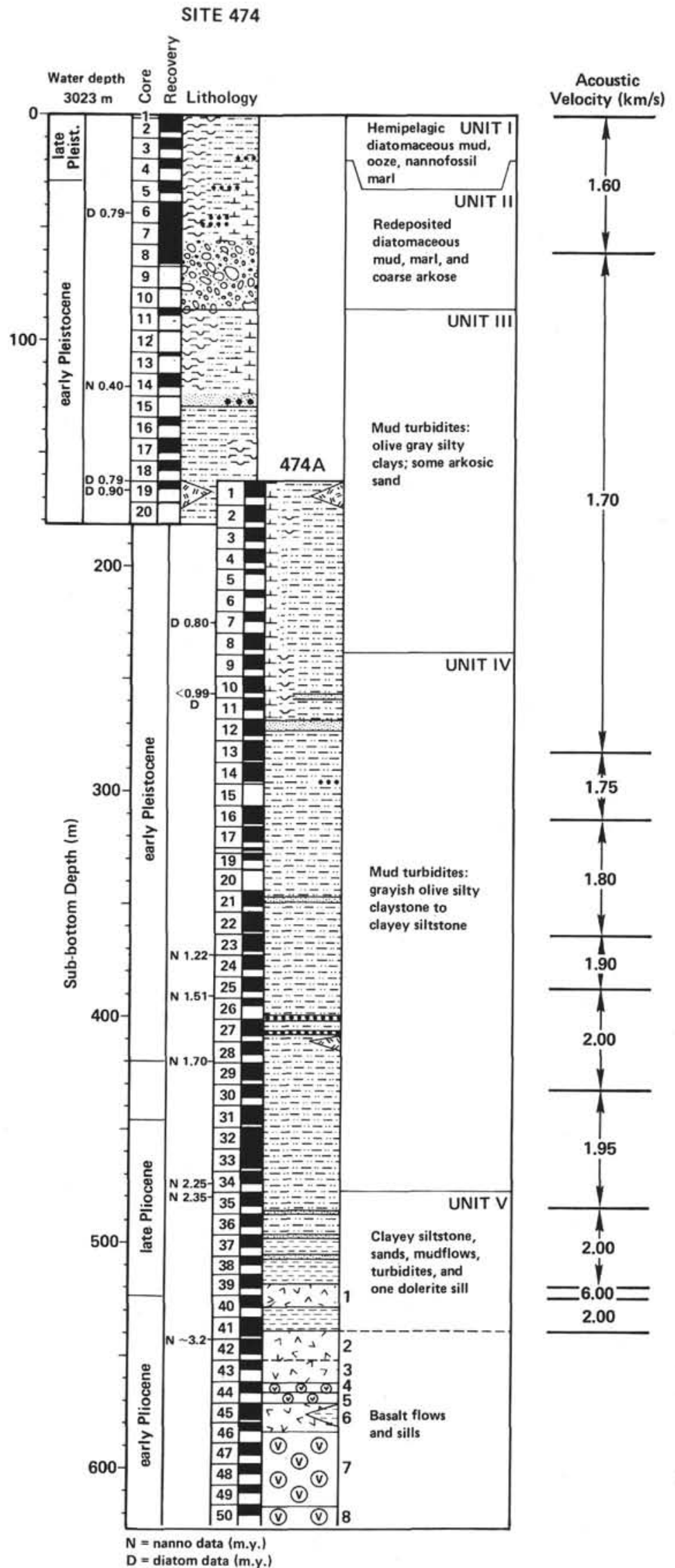

Figure 29. Correlation between lithology and acoustic velocities, Site 474 . 


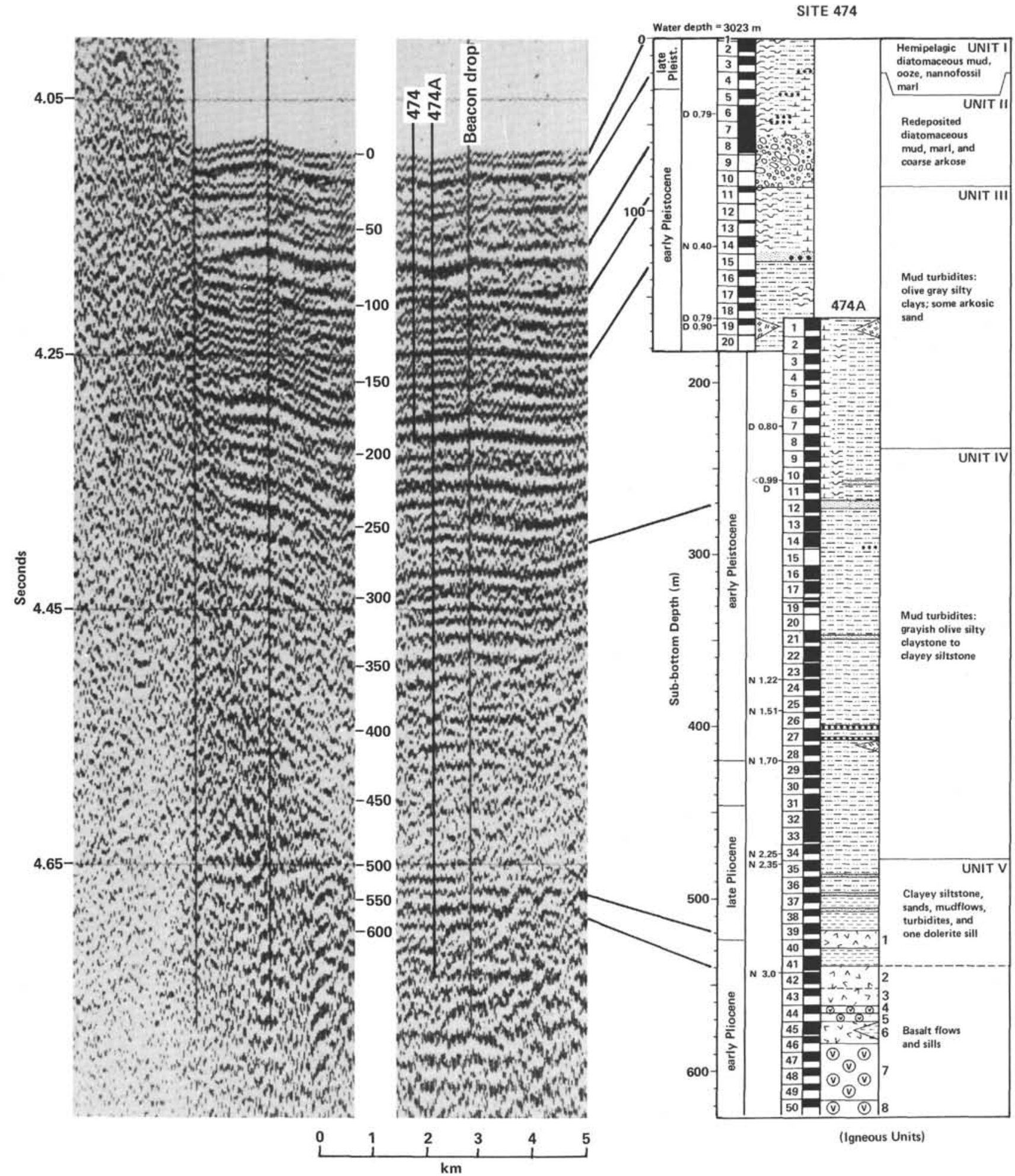

Figure 30. Correlation of drilling results with seismic reflection record from Glomar Challenger, Site 474.

as about $0.8 \mathrm{~s}$ below the sea floor or a total depth of about 1200 meters below the sea floor.

\section{DOWNHOLE LOGGING FOR SITE 474}

Results of downhole logging, compared to lithology, calcium carbonate, and physical properties, are shown in Figure 35. Original tapes are available from storage at the DSDP Information Handling Group. These provide significant information on the depth relationships of sills and their sub-unit boundaries, the position and thickness of various mass flow beds, the onset of diagenesis, the width of contact zones around sills, and clues to hard and soft lithologies that were disturbed during drilling or were not recovered. 


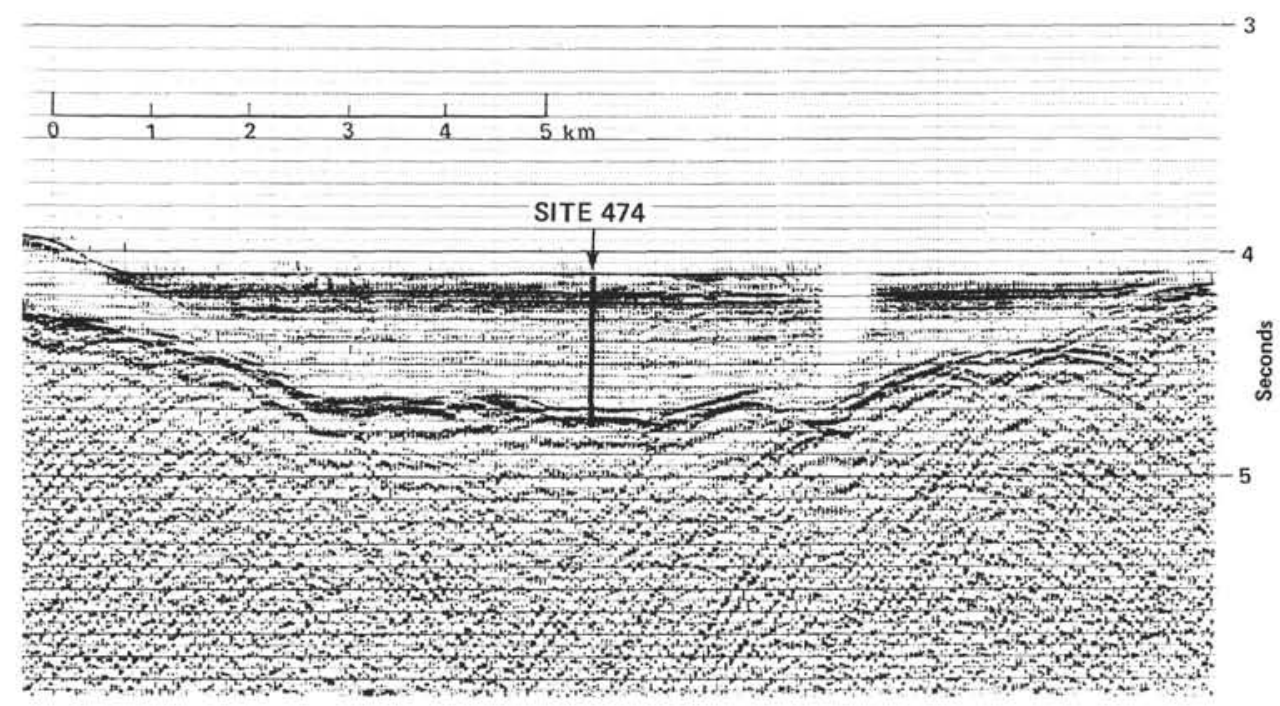

Figure 31. Correlation of Site 474 drilling with processed 24-channel reflection record from SIO Guaymas Expedition.

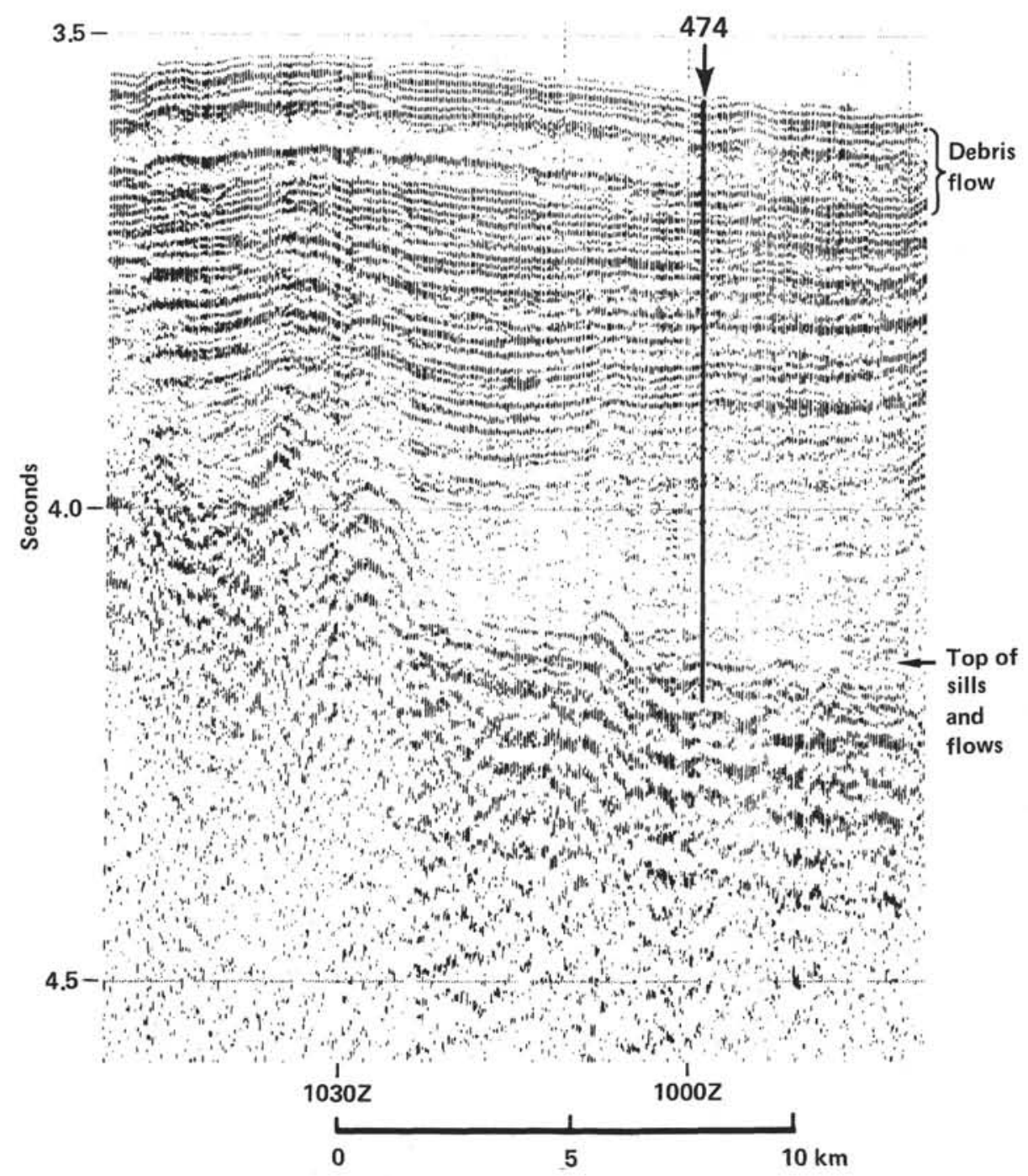

Figure 32. Correlation of Site 474 drilling with single-channel analog seismic reflection record from SIO Guaymas Expedition. 


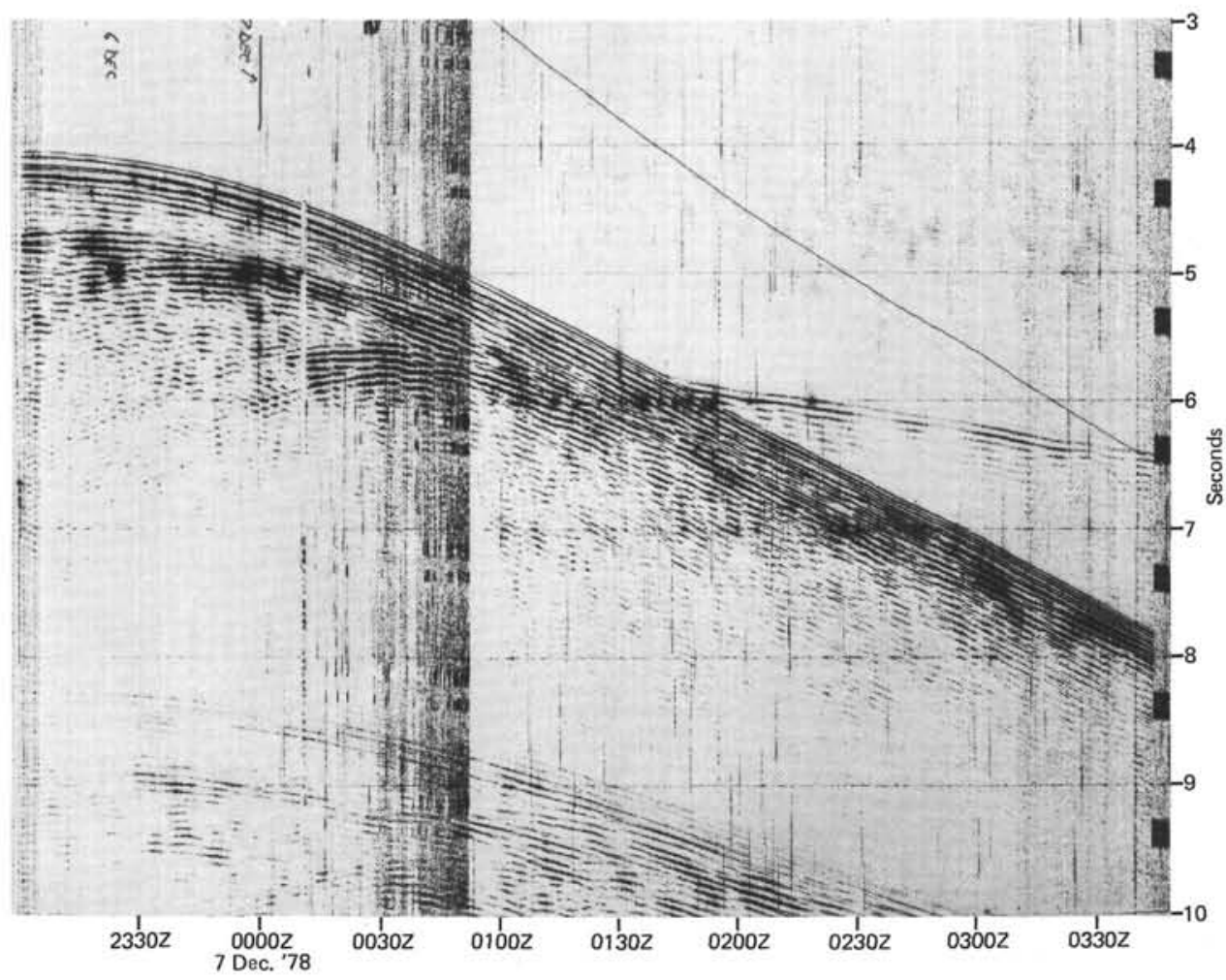

Figure 33. Airgun sonobuoy wide-angle reflection and refraction record from Glomar Challenger, Site 474 (10-s sweep).

\section{SUMMARY AND CONCLUSIONS}

\section{Drilling Summary and Objectives}

Site 474 , in a basin at the base of the continental slope and $55 \mathrm{~km}$ southeast of the tip of Baja California, is the first of a three-site transect to study the evolution of a young, passive continental margin.

Specific objectives at Site $\mathbf{4 7 4}$ were as follows: to confirm that the site lies seaward of the continent/oceancrust transition and to determine characteristics of the basement rocks; to determine the lithologic and biostratigraphic facies distribution; to look for evidence of Pleistocene sea-level fluctuations, and the subsidence history of the area; to study the nature and age of the oldest sediments on the oceanic basement and the extent of diagenesis of mineral and organic matter; and to seek evidence for changes in the paleoenvironment.

Two holes were drilled at Site 474. The first, in a water depth of 3023 meters, was continuously cored to 182.5 meters. Drilling terminated at that depth because of a bent heat-probe/pore-water sampler; this necessitated pulling the drill string. Hole $474 \mathrm{~A}$ was offset 300 meters to the southeast and washed to 161 meters before being continuously cored to a total depth of 626 meters. Two dolerite sills were encountered between 521 meters and the first pillow basalt "basement" at $\mathbf{5 6 2 . 5}$ meters. Sediments were recovered from between these sills, and the oldest sediment was a small fragment of late Pliocene (NN16; 2.3-3.0 m.y.) claystone beneath the first pillow basalt flow at $\mathbf{5 7 2}$ meters. We penetrated 105 meters after encountering the first dolerite sill and 63.5 meters into the oceanic basement. The possibility remains, however, that older, intercalated sediment lies still deeper within the pillowed flows and that we did not penetrated to oldest sediment.

\section{The Sedimentary Section}

Five depositional units are recognized within the 562-meter sedimentary section. The units are based on lithologic, faunal, genetic, and age considerations and were not specifically selected to correlate with seismic or logging data. The sediment section at this site is mostly hemipelagic mud and a thick sequence of mud turbidites, indicating its position on the lower part of a submarine fan, fed primarily by the well-developed submarine canyon system of the southeastern tip of Baja California. A feature of the upper section is the redeposited slump-debris-flow-turbidite units from 21 to 87.3 meters (see Moore et al., this volume, Pt. 2). The base of this flow is coarse sand and conglomerates, and the upper nannofossil-diatomaceous mud contains evidence of warmer, shallower-water fauna than occurs in the sediments either above or below the slide deposit. The rate of accumulation from the oldest sediment to the top of the Pliocene is about $86 \mathrm{~m} / \mathrm{m}$.y. In the thick turbidites above the Pliocene/Quaternary contact, the rate dramatically increases to $395 \mathrm{~m} / \mathrm{m}$.y. Above the slide mass, the rate again decreases to about $47 \mathrm{~m} / \mathrm{m}$.y.

Biostratigraphy was determined primarily by the presence of nannofossils, which persist to the basement, whereas siliceous radiolarians and planktonic foraminifers are preserved only to 275 meters in the Quaternary 


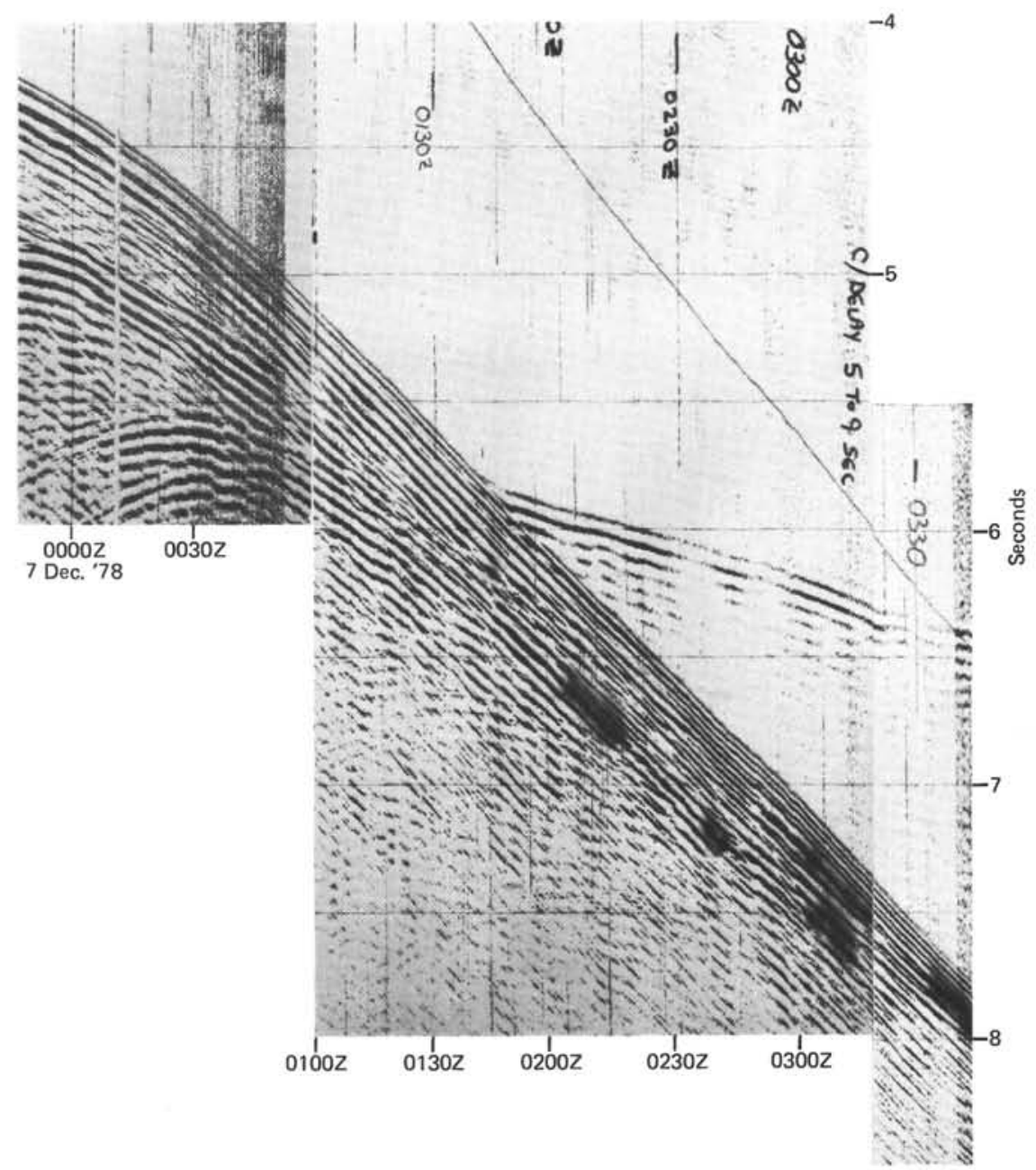

Figure 34. Airgun sonobuoy wide-angle reflection and refraction record from Glomar Challenger, Site 474 (5-s sweep).

section. Values for dissolved silica clearly indicate the abundance of siliceous materials in the upper 275 meters (Fig. 21). The drop to lower values at 300 meters may be related to the recrystallization of silica associated with the weathering of plagioclase feldspars (source for calcium) and the formation of smectites (sink for magnesium). Values of dissolved calcium increase and dissolved magnesium decrease in this same section.

Ratios of ethane to methane follow a similar pattern: There is a normal linear increase (semilog scale) to about 300 meters and then a decrease from the maximum of $8.5 \times 10^{-4}$ to about $11.5 \times 10^{-5}$ in the lower part of the section. Methane is an essentially constant component of interstitial gas, whereas ethane increases to a maximum and then decreases, reflecting the slower diffusion of ethane from the more indurated sediments below 300 meters. The organic matter of this sediment sequence is of biogenic origin. No typical petrogenic hydrocarbons occur, despite the high thermal gradient. The observed increase in the $\mathrm{C}_{2}-\mathrm{C}_{4}$ hydrocarbons (methane, ethane, propane, and isobutane) with depth may result from low-temperature decomposition of biogenic organic matter near the intruded dolerite in the lower sedimentary section. This phenomenon has been observed under similar circumstances on Leg 41.
Physical properties of the sediments also indicate a similar history of compaction and lithification. Strong gradients of increasing bulk density and shear strength and decreasing porosity in the upper 20 meters are normal but possibly amplified by the abundant biogenic silica in the sediment. From 20 to 100 meters, all data remain relatively constant, and between 100 and 250 meters water content, bulk density, and porosity change slowly with increasing overburden pressure. Recrystallization appears insignificant in this interval, because biogenic silica and calcareous nannofossils still occur in considerable quantities. From about 200 to 275 meters to about 360 meters, water content and porosity decrease rapidly, and bulk density increases from 1.67 to nearly $1.80 \mathrm{~g} / \mathrm{cm}^{3}$. In about this same interval, the

\section{Igneous Rocks}

We identified eight igneous lithologies at Site 474 and placed them in five petrologic units. These include several intrusive units, probably sills, and a pillow-lava sequence. Units 1 and 2 are intrusive, olivine dolerite sills concentration of dissolved silica is relatively very low, signifying that formation of chalcedony and authigenic clay minerals may have contributed to lithification of the sediments. 


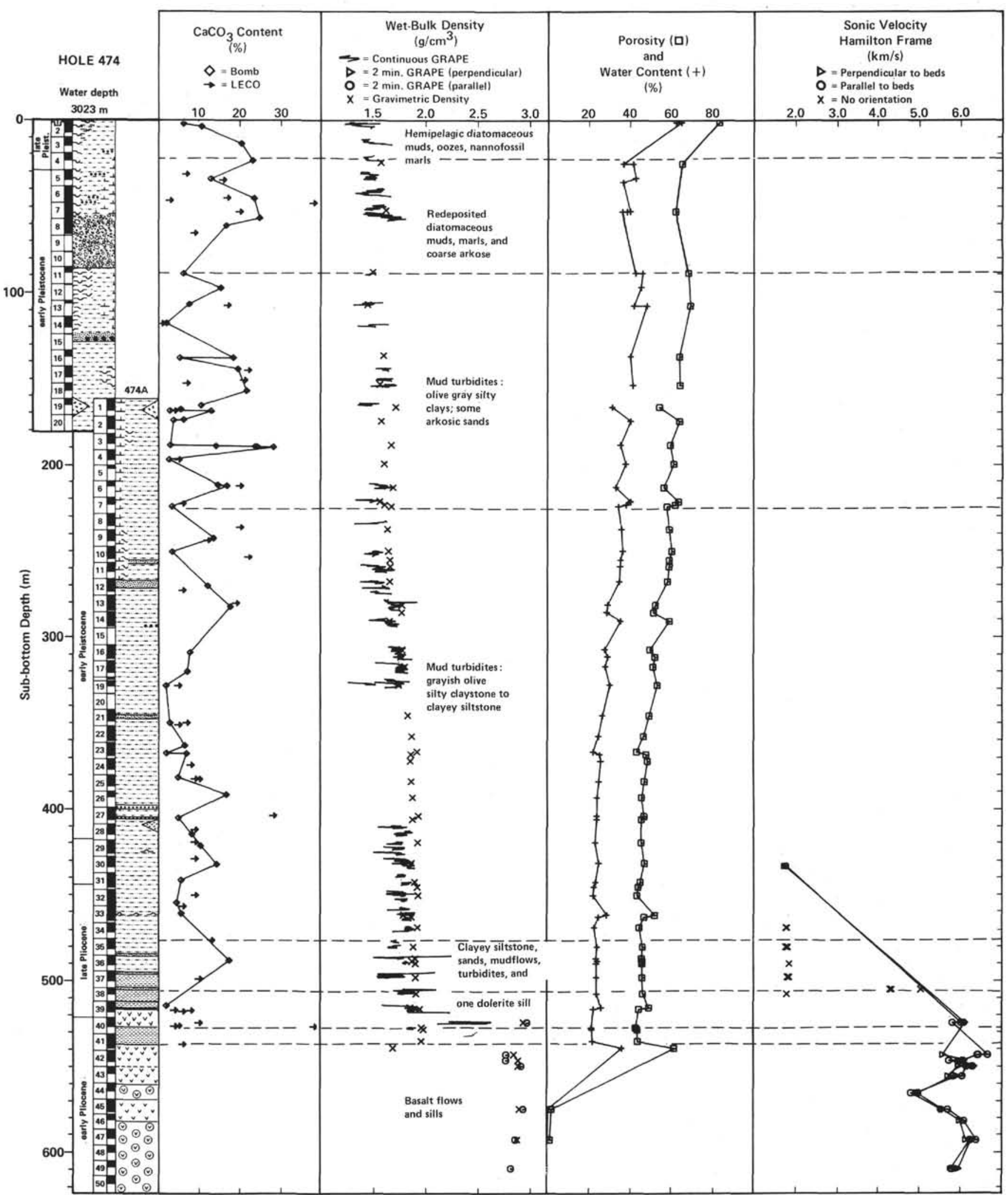

Figure 35. Results of downhole logging compared to lithology, calcium carbonate, and physical properties, Site 474. 


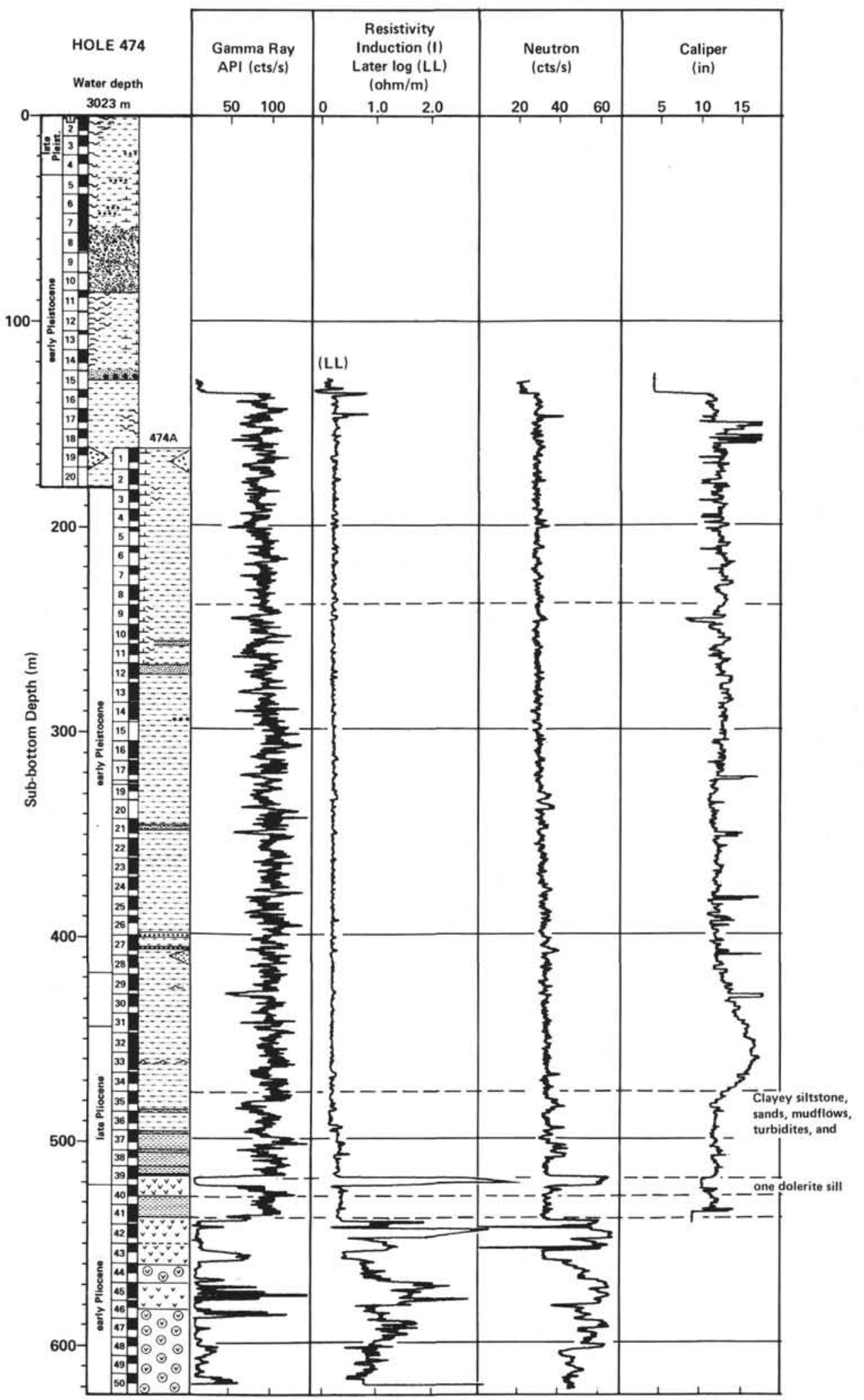

Figure 35. (Continued). 


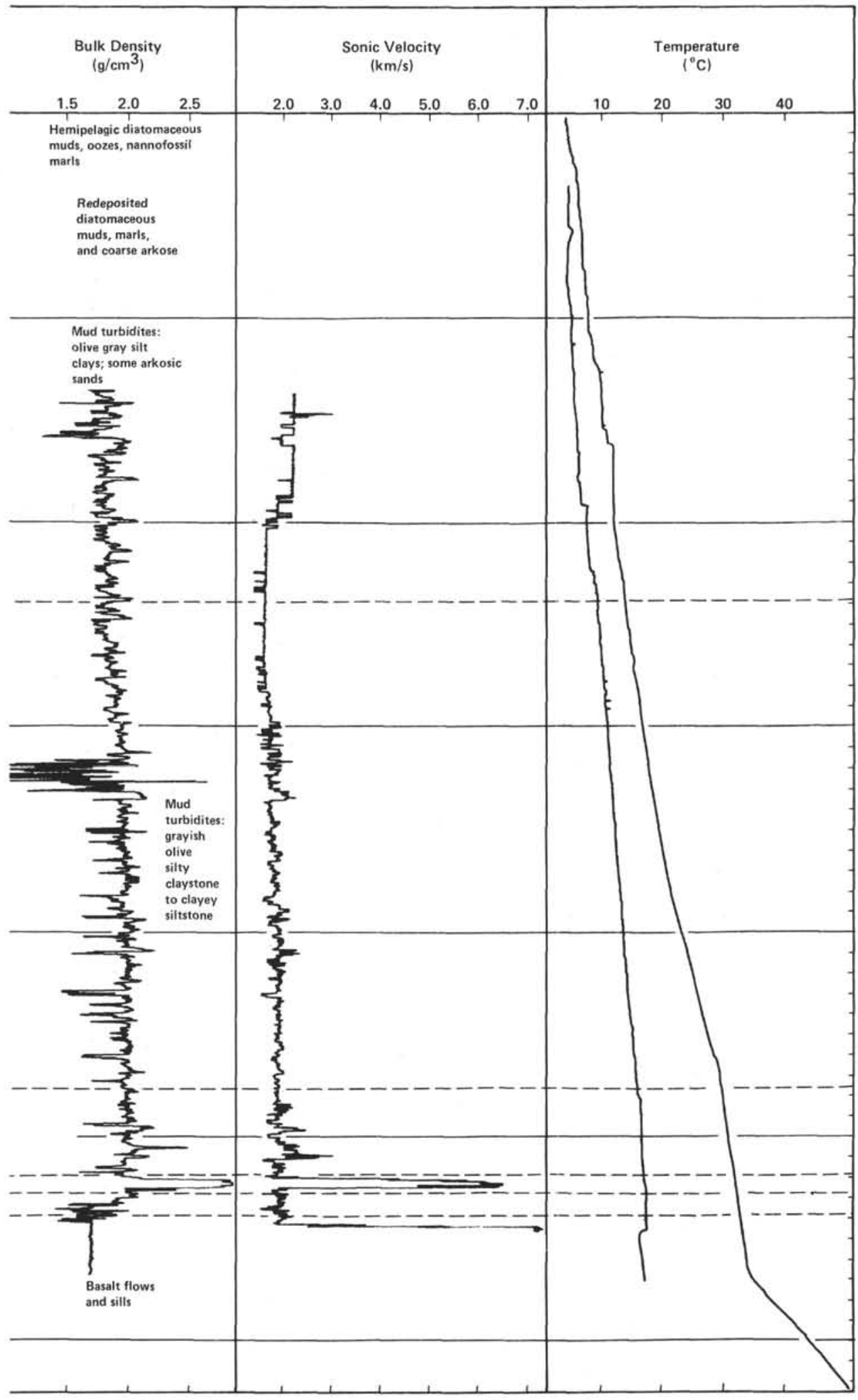

Figure 35. (Continued). 
within the lower 43 meters of the sedimentary section. Unit 3 comprises two distinct pillow basalt flows. Unit 4 is a dolerite sill within the pillow-lava sequence, and Unit 5 comprises pillow basalt and coarse basalt or dolerite that may be a sill. The pillow-basalt sequences are predominantly plagioclase-phyric with minor olivine phenocrysts; clinopyroxene is not a phenocryst phase in any of the basalts. The pillow basalts are therefore similar to abyssal basalts from other ocean ridges and basins.

\section{Correlation of Drilling Results with Seismic and Logging Data}

This site lies in a network of previous underway geophysical surveys, and additional seismic reflection and sonobuoy wide-angle refraction lines were run before and after drilling. The downhole logging program included temperature, sonic, density, and porosity, caliper, natural gamma radiation, and guard (electric) measurements. On shipboard, the sonic log derived acoustic velocities for correlation with the seismic reflection records over the site. Correlations are generally good, and some major lithologic changes and depositional events can be observed in the records, principally the redeposited slump-debris-flow-turbidite unit. Reflection records suggest the possibility of an additional half kilometer of stratified material below the basement rock sampled. Intercalated sediments may be incorporated in these stratified units.

\section{Geological History and Paleoenvironment}

The petrologic and biostratigraphic evidence indicates that this site is floored by oceanic crust generated by rifting approximately $3.2 \mathrm{Ma}$ with the initiation of the present phase of opening of the Gulf of California. These observations agree well with the magnetic chronology of the current spreading at the Gulf mouth (Larson et al., 1968; Lewis et al., 1975). At this initial rifting, the sea floor at this site was already at abyssal depths. No coarse volcaniclastic or continental conglomerates were recovered, and late Pliocene sediments overlying the basement already indicate a distal fan to hemipelagic character. During the late Pliocene (NN17/ $18 ; 2.2-1.8 \mathrm{~m} . \mathrm{y}$.$) , a sedimentation pattern of turbidites,$ hemipelagic mud, and sporadic mud flows was established and continues through the present.

Planktonic foraminifers in the Quaternary sections of this site record geographical shifting of water masses. Most of this section contains a "subtropical" population, but in certain intervals we observed an apparent increase in the population of species that recently dwelled in the California Current.

\section{SITE 475 (HOLE 475)}

Date occupied: 10 December 1978

Date departed: 12 December 1978

Time on hole (hr.): 33.83

Position: $23^{\circ} 03.03^{\prime} \mathrm{N}$; $109^{\circ} 03.19^{\prime} \mathrm{W}$

Water depth (sea level; corrected m, echo sounding): 2631
Water depth (rig floor; corrected m, echo sounding): 2641

Bottom felt (m, drill pipe): 2650

Penetration (m): 196

Number of cores: 21

Total length of cored section (m): 196.0

Total core recovered $(\mathrm{m}): 127.9$

Core recovery ( $\%): 65$

Oldest sediment cored:

Depth sub-bottom (m): 196

Nature: Polymictic conglomerate

Age: Pliocene (NN15 or older)

Basement: Not reached

Principal results: Hole 475 is in a slope basin $21 \mathrm{~km}$ southeast of the tip of Baja California; it was continuously cored to a depth of 196 meters. A cobble conglomerate at 158 meters eventually stopped the drilling. Recovery was nearly $80 \%$ in the sediment column but only $5 \%$ in the conglomerate. Five lithologic units are recognized: Unit I, from the mudline to 34 meters, is late Quaternary nannofossil diatomaceous mud; Unit II, 34-130 meters, is late Pliocene to early Pleistocene clayey silt to silty clay; Unit III, 130-153 meters, is early Pliocene diatomaceous mud. These units accumulated at a rate of about $40 \mathrm{~m} / \mathrm{m}$.y. Unit IV, 153-158 meters, is early Pliocene zeolite-bearing and dolomite mudstone of unknown but slow depositional rate; and Unit V, 158-196 meters, is an early Pliocene(?) conglomerate of metavolcanics, and metasedimentary, rhyolite, and ignimbrite cobbles.

Heat flow and thermal conductivity measurements give a heat flow value of 3.9 heat flow units. No in situ basement was recovered, but the conglomerates are interpreted as a subaerial deposit that rapidly subsided as the first opening of the Gulf of California began.

\section{SITE 475 (HOLE 475A)}

Date occupied: 12 December 1978

Date departed: 12 December 1978

Time on hole (hr.): 5.33

Position: $23^{\circ} 03.44^{\prime} \mathrm{N} ; 109^{\circ} 03.83^{\prime} \mathrm{W}$

Water depth (sea level; corrected $\mathrm{m}$, echo sounding): 2545

Water depth (rig floor; corrected m, echo sounding): 2555

Bottom felt (m, drill pipe): 2591.5

Penetration (m): 16

Number of cores: 1

Total length of cored section $(\mathrm{m}): 9.5$

Total core recovered $(\mathrm{m}): 0.15$

Core recovery $(\%): 1.6$

Oldest sediment cored:

Depth sub-bottom (m): 16

Nature: Hard dolomitic mudstone

Age: Older than late Pliocene (NN15/16)

Basement: Not reached

Principal results: To avoid drilling conglomerate and to reach the assumed granitic basement, Hole 475A was drilled upslope of (1.34 $\mathrm{km} \mathrm{NW}$ ), and adjacent to, Hole 475. At 16 meters submudline, the bit hit a hard layer and only a small piece of hard mudstone was recovered.

SITE 475 (HOLE 475B)

Date occupied: 12 December 1978

Date departed: 13 December 1978 
Time on hole (hr.): 12.08

Position: $23^{\circ} 03.36^{\prime} \mathrm{N}$; $109^{\circ} 03.57^{\prime} \mathrm{W}$

Water depth (sea level; corrected m, echo sounding): 2593

Bottom felt (m, drill pipe): 2629.5

Penetration (m): 96

Number of cores: 4

Total length of cored section (m): 38

Total core recovered $(\mathrm{m}): 10.4$

Core recovery $(\%): 27$

Oldest sediment cored:

Depth sub-bottom (m): 9.5

Nature: Diatomaceous mud/basalt

Age: Late Pleistocene (NN21/?)

Basement: Not reached

Principal results: Drilling in Hole 475B recovered a mudline core of Quaternary nannofossil diatomaceous silty clay. The hole was washed to 76 meters before basalt cobbles were encountered; we cored 20 meters in cobbles and recovered a few percent. Basalts are of subaqueous extrusion and petrographically similar to midocean ridge basalts but are not part of an in situ flow.

\section{SITE 475: BACKGROUND AND OBJECTIVES}

Site 475 (Planning Site GCA-6) was the second site in the passive continental margin transect off Baja California. The general objectives of drilling this transect are outlined elsewhere in the volume. More specific objectives are listed here.

This site lies on the lowermost continental slope, southeast of the tip of Baja California (Figs. 2, 7); it was selected as one of the sites to bracket the continent/ ocean crust transition. From geophysical surveying and rock dredging we presumed that the transition was between Site 474 and this site, which lies on a ridge in line with the northeasterly trend of Cabrillo Seamount (Fig. 2). Granodiorites and quartz diorites have been dredged from the Cabrillo Seamount (Shepard, 1964; Moore et al., 1978), but Lewis et al. (1975) dredged basalt from another location (DH-8 in Fig. 2).

Our plan was to drill at this site if oceanic crust had been reached at Site 474; if continental crust were recovered at Site 474, we would move farther seaward.

The specific objectives of this site included, but were not limited to, the following:

1) Basement rocks

a) Determining whether this site lies seaward or landward of the continent/ocean transition

b) Determining the composition, character, andif possible-the age of the basement rocks, which were presumed to be either the oldest oceanic basement or the most seaward continental rocks near the transition

2) Nature of the sedimentary section

a) Determining general lithologic and biostratigraphic facies distributions

b) Determining water depth indicator changes downward in the section as a record of subsidence history and age of the oldest marine sediments

c) Determining the nature and age of the oldest sediments on basement d) Obtaining a record of Pleistocene sea-level fluctuations

e) Determining the diagenesis of organic and inorganic matter

3) Evidence of climatic or oceanic circulation changes

4) Evidence relating to the proto-Gulf of California history.

\section{OPERATIONS}

From Site 474, we made a seismic survey for Site 475 (Figs. 7, 36). We passed over our Site 474 beacon on 10 December 1978 at $0000 \mathrm{Z}$. Our course was $010^{\circ} \mathrm{T}$, and at $0022 \mathrm{Z}$ we changed to $298^{\circ} \mathrm{T}$, profiling up the slope approximately parallel to the track of the Thomas Washington Guaymas 01 record of 19 February 1978. At $0114 \mathrm{Z}$ we dropped a $13-\mathrm{kHz}$ beacon on Site 475 and continued on course until $0134 \mathrm{Z}$, when we retrieved equipment to return to the beacon. No signal strong enough to verify was found, however, and we had to wait for a satellite fix at $0420 \mathrm{Z}$ before returning to the DR position of the beacon. We were able to position directly over the weak $13-\mathrm{kHz}$ beacon and drop a new $16-\mathrm{kHz}$ beacon; at $0640 \mathrm{Z}$ we were in automatic positioning over Site 475 . At $1412 \mathrm{Z}$ on 10 December, we spudded in the hole. The mud line was found on the second core at 2650 meters, corresponding to a PDR depth of 2641 meters (Table 6).

We cored continuously to a depth of 196 meters. Recovery was unusually good, averaging $79 \%$ for the first 158 meters. At that depth, we encountered a thin, lithified dolomitic mudstone overlying cobbles of various metamorphic rock types that reduced recovery to a few

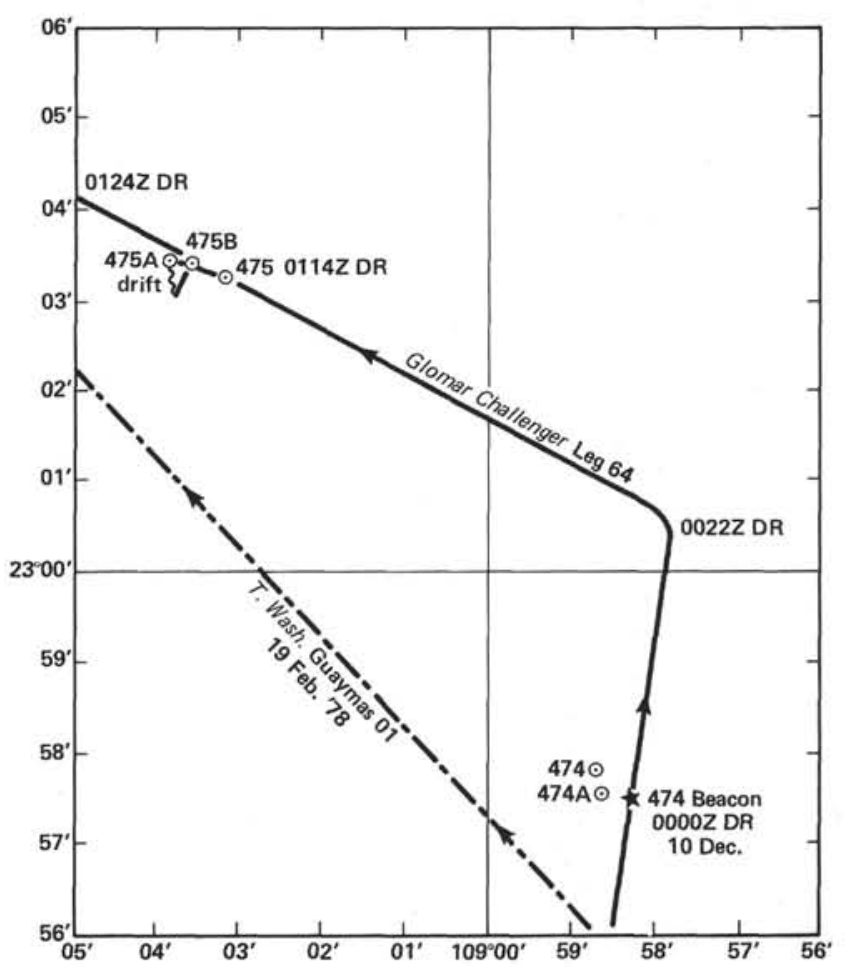

Figure 36. Track of Glomar Challenger: Site 474 to Site 475 . 
Table 6. Coring summary, Site 475.

\begin{tabular}{|c|c|c|c|c|c|c|c|}
\hline Core & $\begin{array}{c}\text { Date } \\
\text { (December. } \\
\text { 1978) }\end{array}$ & $\begin{array}{c}\text { Time } \\
(\mathrm{Z})\end{array}$ & $\begin{array}{c}\text { Depth from } \\
\text { Drill Floor } \\
\text { (m; top-bottom) }\end{array}$ & $\begin{array}{l}\text { Depth below } \\
\text { Sea Floor } \\
\text { (m; top-bottom) }\end{array}$ & $\begin{array}{l}\text { Length } \\
\text { Cored } \\
\text { (m) }\end{array}$ & $\begin{array}{l}\text { Length } \\
\text { Recovered } \\
\text { (m) }\end{array}$ & $\begin{array}{c}\text { Recovery } \\
(\% ; 0)\end{array}$ \\
\hline \multicolumn{8}{|c|}{ Hole 475} \\
\hline 1 & 11 & 0831 & $2650.0-2656.0$ & $0.0-6.0$ & 6.0 & 2.91 & 49 \\
\hline 2 & 11 & 0921 & $2656.0-2665.5$ & $6.0-15.5$ & 9.5 & 9.40 & 99 \\
\hline 3 & 11 & 1012 & $2665.5-2675.0$ & $15.5-25.0$ & 9.5 & 9.80 & 103 \\
\hline 4 & i1 & 1102 & $2675.0-2684.5$ & $25.0-34.5$ & 9.5 & 8.20 & 86 \\
\hline 5 & ii & 1153 & $2684.5-2694.0$ & $34.5-44.0$ & 9.5 & 8.45 & 89 \\
\hline 6 & 11 & 1243 & $2694.0-2703.5$ & $44.0-53.5$ & 9.5 & 9.39 & 99 \\
\hline 7 & i1 & 1329 & $2703.5-2713.0$ & $53.5-63.0$ & 9.5 & 8.10 & 85 \\
\hline 8 & ii & 1450 & $2713.0-2722.5$ & $63.0-72.5$ & 9.5 & 7.89 & 83 \\
\hline 9 & ii & 1545 & $2722.5-2732.0$ & $72.5-82.0$ & 9.5 & 5.99 & 63 \\
\hline 10 & 11 & 1635 & $2732.0-2741.5$ & $82.0-91.5$ & 9.5 & 1.10 & 12 \\
\hline 11 & 11 & 1735 & $2741.5-2751.0$ & $91.5-101.0$ & 9.5 & 9.02 & 95 \\
\hline 12 & ii & 1825 & $2751.0-2760.5$ & $101.0-110.5$ & 9.5 & 7.32 & 77 \\
\hline 13 & ii & 2051 & $2760.5-2770.0$ & $110.5-120.0$ & 9.5 & 5.89 & 62 \\
\hline 14 & 11 & 2147 & $2770.0-2779.5$ & $120.0-129.5$ & 9.5 & 9.57 & 101 \\
\hline 15 & 11 & 2245 & $2779.5-2789.0$ & $129.5-139.0$ & 9.5 & 9.34 & 98 \\
\hline 16 & ii & 2333 & $2789.0-2798.5$ & $139.0-148.5$ & 9.5 & 7.04 & 74 \\
\hline 17 & 12 & 0240 & $2798.5-2808.0$ & $148.5-158.0$ & 9.5 & 6.41 & 67 \\
\hline 18 & 12 & 0435 & $2808.0-2817.5$ & $158.0-167.5$ & 9.5 & 0.72 & 8 \\
\hline 19 & 12 & 0607 & $2817.5-2827.0$ & $167.5-177.0$ & 9.5 & 0.25 & 3 \\
\hline 20 & 12 & 0730 & $2827.0-2736.5$ & $177.0-186.5$ & 9.5 & 0.57 & 6 \\
\hline 21 & 12 & 0903 & $2736.5-2746.0$ & $186.5-196.0$ & 9.5 & 0.50 & 5 \\
\hline \multicolumn{8}{|c|}{ Hole 475A } \\
\hline 1 & 12 & 2040 & $2598.0-2607.5$ & $6.5-16.0$ & 9.5 & 0.15 & 1.6 \\
\hline \multicolumn{8}{|c|}{ Hole 475B } \\
\hline 1 & 12 & 2333 & $2629.5-2639.0$ & $0.0-9.5$ & 9.5 & 9.84 & 103 \\
\hline 2 & 13 & 0326 & $2705.5-2715.0$ & $76.0-85.5$ & 9.5 & 0.35 & 4 \\
\hline 3 & 13 & 0656 & $2715.0-2724.5$ & $85.5-95.0$ & 9.5 & 0.15 & 2 \\
\hline 4 & 13 & 0920 & $2724.5-2725.5$ & $95.0-96.0$ & 1.0 & 0.05 & 5 \\
\hline
\end{tabular}

percent and eventually resulted in loss of the hole. The heat probe was deployed successfully in stiff mud at 110.5 meters and again at 148.5 meters.

As we penetrated the cobble zone, drilling times increased sharply from 6 to 8 to 22 to $60 \mathrm{~min}$. per core. After Core 475-21 was retrieved from 196 meters at $1603 \mathrm{Z}$ on 12 December, the drill string became stuck as we attempted to resume drilling. The drill string was worked free with difficulty and pulled above the cobble zone. At $1900 \mathrm{Z}$ we decided to abandon the hole and move to a position presumably beyond the cobble zone. The bit was not released and no logging was attempted; we believed that the new position would allow basement penetration and result in more useful logging. The drill string was therefore pulled above the mud line and trailed 914 meters upslope (bearing $298^{\circ} \mathrm{T}$ ). The depth at this position did not correspond to that of the seismic line made on our original, dead reckoning approach to Site 475. An attempt to collect in-place seismic data-to check the section against the approach line-was precluded by thruster noise.

By $2230 Z$ on 12 December, the ship was in automatic positioning over the proposed Hole $475 \mathrm{~A}$. We found the mud line at 2591.5 meters, and it corresponded to the corrected PDR depth of 2554 meters. We began washing to reach the equivalent Hole 475 depth. At 16 meters, however, we encountered hard drilling. At $0340 \mathrm{Z}$ on 13 December, we recovered the barrel and found a short section of the same stiff mud overlying the cobble zone of Hole 475.

Having drifted to the south-southeast, we moved to a new locality midway between Holes 475 and $475 \mathrm{~A}$ with the drill string pulled above the mudline and the seismic gear deployed. We profiled in this way across the proposed site to a more desirable position somewhat north of a line between the two previous holes; at $0440 \mathrm{Z}$, we were in position above the proposed Hole 475B. At
$0545 \mathrm{Z}$, we spudded and found the mudline at $2629.5 \mathrm{me}-$ ters. We then washed to 76 meters and again encountered a very hard basalt formation. Subsequently, we cored continuously to 96 meters, recovering only $3 \%$ of the 20 meters eventually cored in basalt rubble. The hole was caving badly, and we abandoned the site, without attempting a downhole logging program, to avoid possible loss of the bottom hole assembly. Orientation of the three holes at this site is shown in Figure 36. At $2245 Z$ on 13 December, we departed for Site 476.

\section{SEDIMENTARY LITHOLOGY}

Site 475 includes Holes 475, 475A, and 475B, but the following description is based only on the complete section from 475. Five lithologic units (Fig. 37; Table 7) were selected on the basis of microfossil abundance, primary sedimentary structures, and mineralogy.

Unit I: Nannofossil diatomaceous hemipelagic mud (Cores 475-1-475-4, 0-34.5 m). Unit I consists of a rather uniform, drab grayish olive to moderate olive brown nannofossil diatomaceous mud. Drilling disturbance is intense, obliterating most sedimentary structures; bedding is indistinct and color boundaries are gradational. Carbonate content-as high as $15 \%$-is from nannofossils. Coccoliths are abundant in Cores 475-1 through 475-4, as are discoasters in Cores $475-5$ through $475-11$. Diatoms average as high as $25 \%$ of the total sediment. Foraminifers, silicoflagellates, radiolarians, and sponge spicules are rare. Sponge spiculites occur sporadically throughout the unit as thin, white laminae or lenses (1-2 mm thick). Dusky yellow green mottling and black reduction spots are common. These lighter zones are characterized by more nannofossils and fewer diatoms.

Minor, angular, silt-size quartz and feldspar range from $5-30 \%$ and $2-10 \%$, respectively. Clays range from 


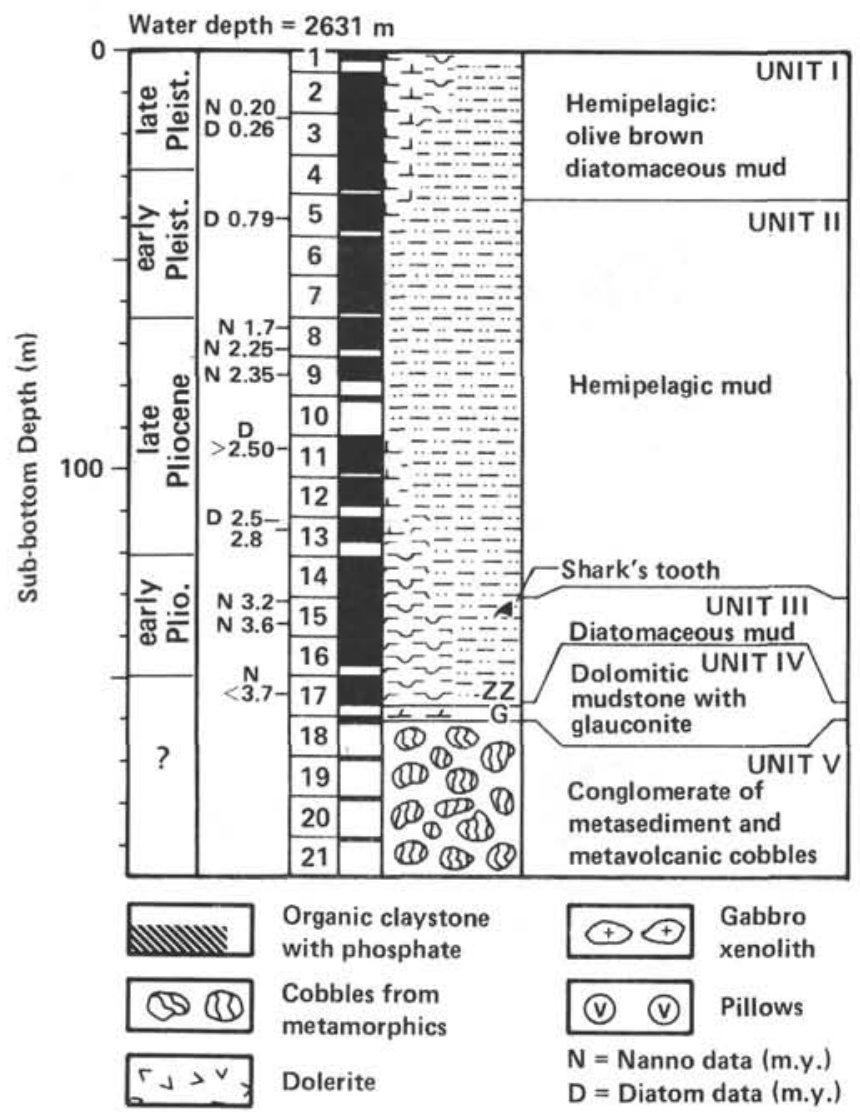

Figure 37. Lithology, lithologic units, and core recovery (shown in black), Site 475 .

$15-60 \%$. Pyrite is rare but occurs as black, opaque framboids, commonly as a filling in diatom frustules or, rarely, in foraminifer tests. Rare, scattered glauconite occurs as 1-2-mm-thin, bright green lenses set against the grayish olive of the host sediment. Glauconite is commonly associated with the spiculites.

Sporadic undisturbed sections show evidence of decimeter-scale mud turbidites with thin basal sands grading subtly up into grayish olive silty clay.

Unit II: hemipelagic mud (Cores 475-5-475-14, 34.5$130.2 \mathrm{~m}$ ). Unit II is a firm, grayish olive green to grayish olive clayey silt to silty clay. The contact to Unit I is gradational and best defined by the disappearance of the biogenic components. Biogenic components mostly compose less than $5 \%$ of the total sediment but increase again below Core 475-12.

Quartz and feldspar percentages are similar to Unit I. Clay percentages are higher, ranging from 55 to $70 \%$ of the total sediment. Black reduction streaks and spots are common.

Drilling disturbance is intense, with brecciation of Cores $475-6,475-7$, and 475-14. Where disturbance is less severe (Cores 475-8 and 475-11), we observed a distinct layering delineated by alternating sediment colors. The color changes are subtle but contacts are sharp. The colors alternate between a dark grayish olive and a lighter color, either moderate olive brown, dusky yellow green, or grayish green. We infer that the mottling observed in Unit $\mathrm{I}$ is a more disturbed equivalent to these layers in Unit II-with one exception: The lighter, mottled sediments in Unit I are overshadowed by a nannofossil-rich biogenic component, whereas the lighter layers in Unit II are mostly barren. The darker layers in Unit II contain more silt-size grains and a greater abundance of pyrite (as high as $8 \%$ ). Some pyrite concretions appear to be cemented burrows. A large nodule from Section $475-13-1$ is shaped like Planolites. Small discontinuous lenses of sandy silt occur in Sections 475 $5-2,475-6-2$, and 475-7-1, possibly as remnants of basal sands from mud turbidites. Above these silty pockets, there is little evidence of grading. A small fragment of

Table 7. Lithological units, Site 475.

\begin{tabular}{|c|c|c|c|c|c|c|c|}
\hline Unit & Interval & $\begin{array}{l}\text { Depth } \\
\text { (m) }\end{array}$ & $\begin{array}{l}\text { Thickness } \\
\text { (m) }\end{array}$ & Lithology & $\begin{array}{c}\text { Paleo- } \\
\text { environment }\end{array}$ & $\begin{array}{c}\text { Age } \\
\text { (m.y.) }\end{array}$ & $\begin{array}{c}\text { Approximate } \\
\text { Accumulation } \\
\text { Rate } \\
(\mathrm{m} / \mathrm{m} . \mathrm{y} .)\end{array}$ \\
\hline I & Cores 475-1-475-5 & $0.0-34.5$ & 34.5 & $\begin{array}{l}\text { grayish olive }(10 \mathrm{Y} 4 / 2) \text { to moderate } \\
\text { olive brown }(5 \mathrm{Y} 4 / 2) \text { nannofossil } \\
\text { diatomaceous mud; gradational } \\
\text { contacts }\end{array}$ & $\begin{array}{l}\text { hemipelagic with } \\
\text { minor mud tur- } \\
\text { bidites }\end{array}$ & $\begin{array}{l}\text { late } \\
\text { Pleistocene } \\
(\sim 0-0.7)\end{array}$ & 40 \\
\hline II & Cores $475-6-475-14$ & $34.5-130.2$ & 95.7 & $\begin{array}{l}\text { grayish olive to drab grayish olive } \\
\text { green clayey silts to silty clays; } \\
\text { firm; sparse biogenic components } \\
(<5 \%) \text { increasing below Core } \\
475-11\end{array}$ & $\begin{array}{l}\text { hemipelagic with } \\
\text { mud turbidites }\end{array}$ & $\begin{array}{l}\text { late Pliocene } \\
\text { to early } \\
\text { Pleistocene } \\
(\sim 0.7-2.8) \\
(\sim 0.7-2.8)\end{array}$ & 40 \\
\hline III & $\begin{array}{l}\text { Sections 475-15-1- } \\
475-17-4\end{array}$ & $130.2-154.2$ & 23.0 & $\begin{array}{l}\text { bioturbated to homogeneous dia- } \\
\text { tomaceous moderate olive brown } \\
\text { ( } 5 \text { Y } 5 / 4 \text { ) to dusky yellow ( } 5 \text { Y 6/4) } \\
\text { muds with graded cycles }\end{array}$ & $\begin{array}{l}\text { diatomaceous } \\
\text { mud turbidites }\end{array}$ & $\begin{array}{l}\text { early } \\
\text { Pliocene }\end{array}$ & $\sim 40+$ \\
\hline IV & $\begin{array}{l}\text { Sections } 475-17-5- \\
475-17, \mathrm{CC}\end{array}$ & $154.2-158.0$ & 4.8 & $\begin{array}{l}\text { brown gray (5YR } 4 / 1) \text { zeolite- } \\
\text { bearing clay, overlying a dusky } \\
\text { yellow }(5 Y \text { Y } 6 / 4) \text { dolomitic mudstone } \\
\text { with glauconite grains }\end{array}$ & $\begin{array}{l}\text { isolated of fshore } \\
\text { bank within the } \\
\mathrm{O}_{2} \text {-minimum } \\
\text { zone }\end{array}$ & $\begin{array}{l}\text { early } \\
\text { Pliocene(?) }\end{array}$ & slow(?) \\
\hline v & $\begin{array}{l}\text { Section } 475-18-1- \\
\text { Core } 475-21\end{array}$ & $158.0-196.0$ & 38.0 & $\begin{array}{l}\text { polymictic conglomerate, consisting } \\
\text { of metavolcanics, metasedimentary } \\
\text { rocks, rhyolite, and ignimbrites and } \\
\text { some fresh basalts (Hole } 475 \mathrm{~B} \text { ) }\end{array}$ & $\begin{array}{l}\text { subaerial alluvial } \\
\text { plain; later rifted }\end{array}$ & $?$ & rapid \\
\hline
\end{tabular}


wood is embedded in the homogeneous silty clay of Section 475-9-4. Unit II appears to be a series of distal-fan, fine-grained, graded beds in the undisturbed section differing from Unit I only by the lack of biogenic components and turbidites.

Single, well-rounded andesite tuff (pumice) pebbles occur in the hemipelagic sediment of Sections 475-11-5, 475-12-1, and 475-14-1, but drill disturbance leaves their stratigraphic context unclear.

Unit III: mud turbidites (Cores 475-15-475-17, 130.2-154.2). The sharp contact between Unit II and Unit III is defined by a layer of fine, gray white sand, 1-2 cm thick. Drilling disturbance in Unit III is slight, revealing sedimentary structures only inferred in Units I and II.

Unit III is characterized by bioturbated diatom-bearing, moderate, olive brown to dusky yellow silt-clay and homogeneous, moderate olive brown, light olive gray to olive-gray-brown diatomaceous mud. Evidence of subtle grading is common. Most graded beds have a thin basal sand (30-60\% quartz; $15-25 \%$ feldspar; $6-8 \%$ pyrite; $5-20 \%$ biogenic material), grading upward to a muddy ooze ( $20-70 \%$ clay; $20-45 \%$ diatoms). The top of each graded bed has a "waxy" appearance and is commonly and extensively bioturbated. Bioturbation is often so intense in a graded bed that basal sands deposited in the next graded bed above have been drawn down into the bed below, causing an apparent reverse grading. Some of the basal sands appear winnowed, although this may result from drilling disturbance. This sequence of graded beds, ranging in thickness from 10 to $200 \mathrm{~cm}$ and averaging $30 \mathrm{~cm}$, is probably a sequence of distal mud turbidites. A shark's tooth is imbedded in one of these mud turbidites at Section 475-15-3 $(36 \mathrm{~cm})$.

Diatoms show a steady increase from $\sim 20 \%$ at the top of the unit to $45 \%$ in Section 475-17-2 (151.5 m). Diatoms then rapidly decrease, and the sediment is barren by Section 475-17-4 $(153.7 \mathrm{~m})$. The basal part of Unit III contains a glauconite- and pyrite-bearing silty clay, underlain by a zeolitic clay and basal sand. The presence of $10 \%$ glauconite and pyrite and $30 \%$ zeolite suggests a rapid change in sedimentary environment.

Unit IV: dolomitic mudstone with glauconite (Cores 475-17-475-18, 154.2-158.0). This basal sedimentary stratigraphic unit is in sharp contact with the overlying Unit III. A hard zeolite-bearing (clinoptilolite) brown gray clay with glauconite grains characterizes the upper part of this unit and is underlain by a hard, dusky yellow dolomitic mudstone (Fig. 38). The dolomitic mudstone contains quartz clasts and glauconite grains within an equigranular, limpid dolomite rhomb matrix constituting $40 \%$ of the total sediment (see Kelts and Lyle, this volume, Pt. 2).

Zeolitic clay and dolomite mudstone are firm but friable, show faint evidence of bioturbation, and are unfossiliferous.

\section{Unit V (Cores 475-18-475-21; 158.0-196.0 meters)}

Unit $\mathrm{V}$ is characterized by a poorly recovered sequence of polymictic pebbles to cobbles. Most are rounded and partially weathered, but any rinds have

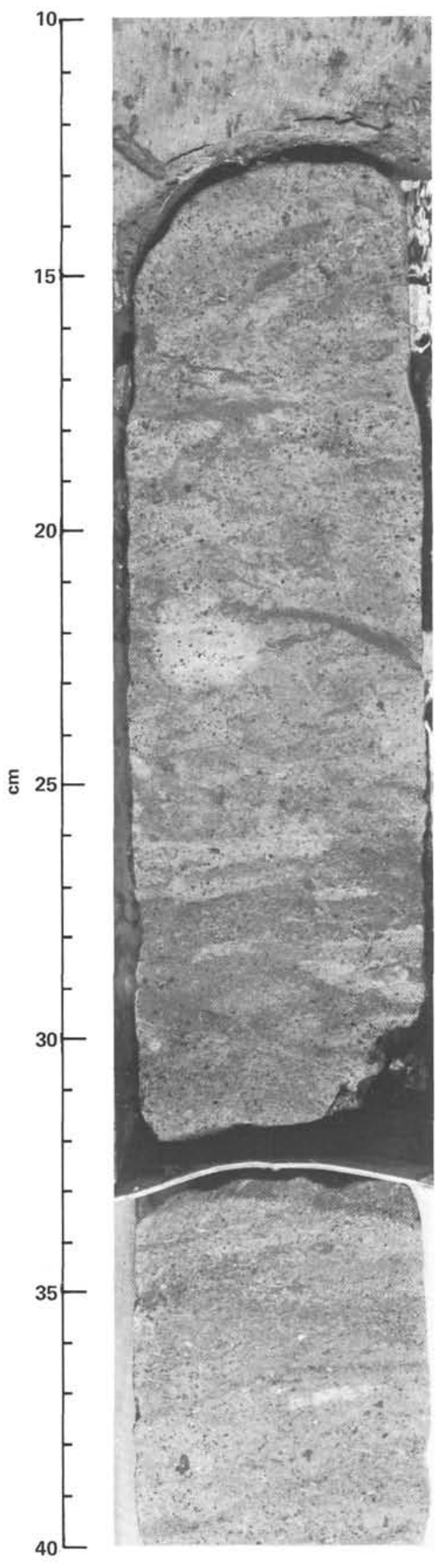

Figure 38. Sample $475-17-5,10-40 \mathrm{~cm}$, Unit IV: dolomitic mudstone with glauconite pellets and evidence of bioturbation. 
been removed by drilling abrasion. Component clasts include ignimbrites, fine-grained volcanics, graywacke, low-grade metasediments, perlitic rhyolite, quartzite, shale, schist, and a quartzose metaconglomerate.

Thin sections indicate that some of the metavolcanics include basalts with abundant opaque minerals, altered clinopyroxenes and olivine phenocrysts, small white calcite veins, and no foliations. Metagraywackes are medium grained and poorly sorted.

None of the matrix was recovered, but it is assumed that the conglomerate is clast supported, with a sandy matrix.

In Hole 475B, cobbles were also cored, but these are composed of basalt (see section on igneous petrology, this volume). The basalt cobbles have brown-stained rinds, indicating weathering; this suggests that they are not in place basement rocks.

\section{ORGANIC GEOCHEMISTRY}

The monitoring program was carried out aboard ship. No hydrocarbon gases were detected in this sediment sequence (i.e., no gas pockets in the core liners; no pressure buildup in the core caps). Hydrogen sulfide (detected only by odor) occurs from about 11 to $35 \mathrm{me}-$ ters in significantly lower amounts than in Hole 474.

\section{Fluorescence}

Fluorescence data were measured on raw sediment samples, trichloroethane extract solutions of raw samples, and pyrolized samples. Most raw samples and trichloroethane solutions exhibited no fluorescence; some pyrolized sample extracts exhibited yellow fluorescence, indicating the absence of petroleum.

\section{Organic Carbon and Nitrogen}

The results from the $\mathrm{CHN}$ analyzer are summarized in Appendix I, this volume, Pt. 2. The organic carbon and nitrogen values and their ratios are plotted versus depth in Figure 39. The organic carbon ranges from about 1 to $3 \%$ with considerable scatter throughout the core; the organic nitrogen parallels the distribution of organic carbon and ranges from about 0.1 to $0.26 \%$. The $\mathrm{C} / \mathrm{N}$ ratio does exhibit a slight trend to higher values with depth. The upper section exhibits $\mathrm{C} / \mathrm{N}$ values of 10 to 15, typical of Recent, unaltered, and immature sediments. The onset of diagenetic alteration of the organic matter is reflected by this $\mathrm{C} / \mathrm{N}$ increase with depth.

\section{INORGANIC GEOCHEMISTRY}

\section{Interstitial Water Chemistry (Fig. 40)}

This site shows only relatively small increases in alkalinity, ammonia, and phosphate, indicating that only sulfate reduction is an important process for organic matter decomposition. Dissolved calcium shows a typical minimum - a result of calcium carbonate precipitation. Decreases in dissolved magnesium are caused by an uptake in the solid phases of the sediment. Gradual increases in dissolved silica reflect higher solubilities of opaline silica-a result of increased temperatures with depth.

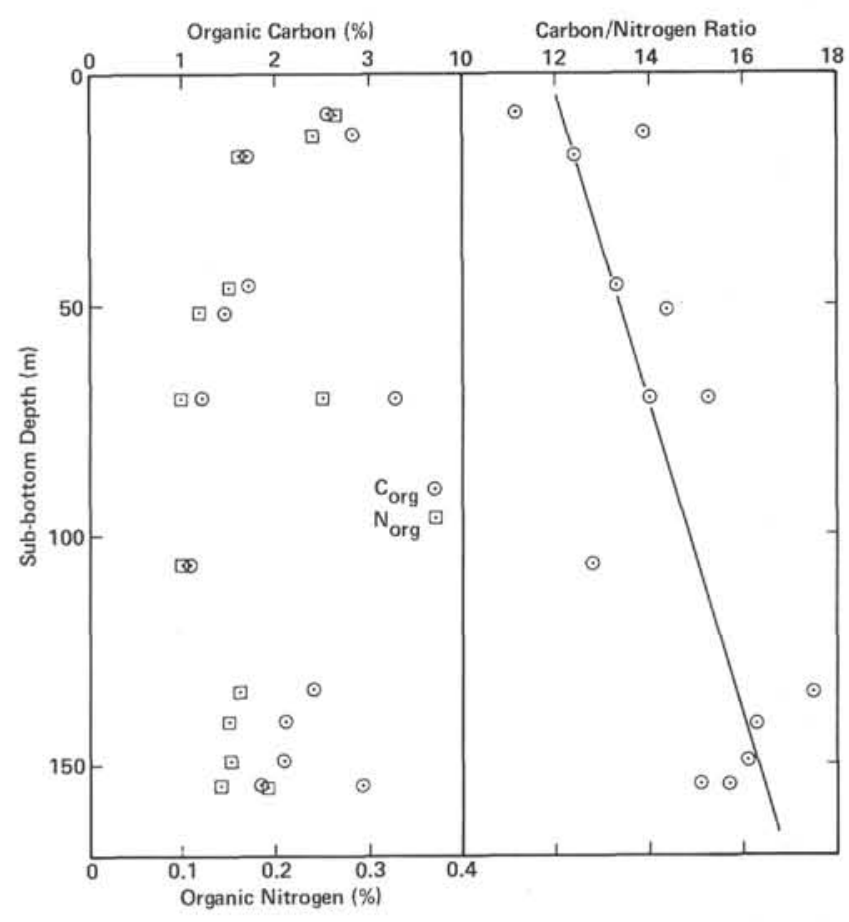

Figure 39. Organic carbon and nitrogen: content and ratios versus depth, Site 475 .

\section{BIOSTRATIGRAPHY}

Hole 475 has a complete sequence of sediments from late Pleistocene through early Pliocene (Fig. 41). No fossils occur in either the dolomitic mudstone of Unit IV or in the conglomerates of Unit V.

\section{Coccoliths}

Sediments from Hole 475 yielded common calcareous nannofossils in various states of preservation and of moderate to high diversity. A complete sequence was recognized from the upper Pleistocene to the lower Pliocene. Because of reworking, however, a biostratigraphic assignment was often difficult. Mixtures of well- and poorly-preserved coccoliths, discontinuous occurrences of marker species, and occurrences of extinct species are evidence of reworking. Sediment from Core 475-1 to Section 475-3-1 is late Pleistocene; Section 475-3-2 to Core $475-4$ is early Pleistocene. The Pleistocene/Pliocene boundary occurs between Cores 475-7 and 475-8. Cores 475-8 to 475-14 are late Pliocene, and Cores 475-15 through 475-17 are early Pliocene. Pseudoemiliania lacunosa first occurs in Sample 475-3-2, 92-93. Discoaster brouweri occurs with a sudden abundance in Sample 475-8-1, 19-20. D. pentaradiatus first occurs in Sample 475-8-6, 4-5, and D. surculus first occurs in Sample 475-9-4, 34-35. Typical Reticulofenestra pseudoumbilica first occurs at the top of Core 475-15, and Amaurolithus tricorniculatus appears first in Sample 475-15-5, 26-27; the last occurrence of $D$. asymmetricus is in Sample 475-17-2, 76-77. In the Pleistocene sequence, a sphenolith with close affinities to Sphenolithus abies occurs abundantly. 

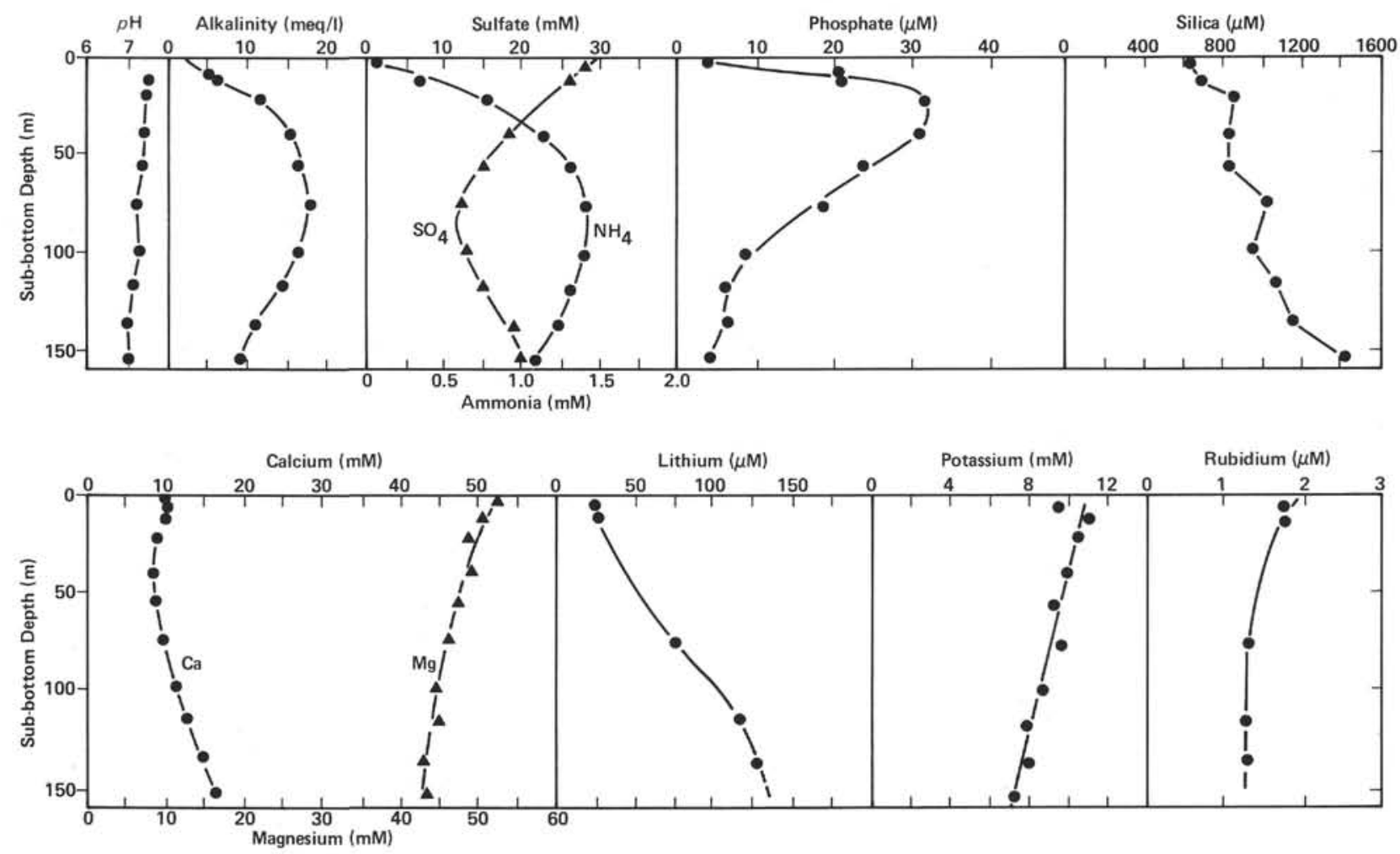

Figure 40. Interstitial water chemistry, Site 475.

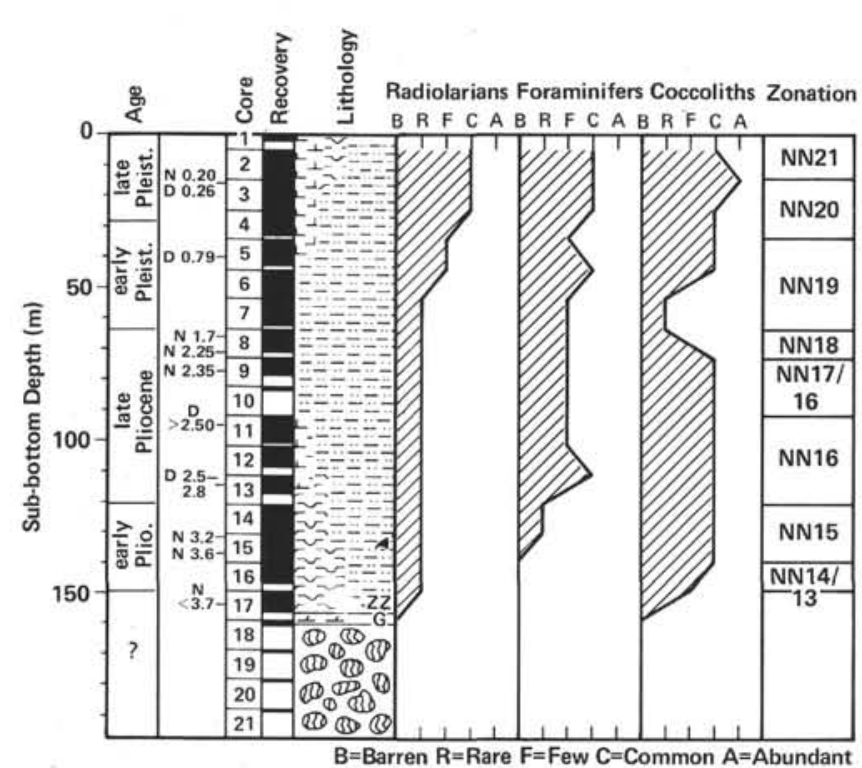

Figure 41. Biostratigraphy, Site 475 .

Helicosphaera sellii and Cyclococcolithus macintyrei occur sporadically and thus are not used to provide biostratigraphic data.

\section{Diatoms}

Open marine tropical to subtropical planktonic diatoms are abundant and well preserved to rare and poorly preserved in the hemipelagic sediments at Site 475 (Core 475-1-Core 475-17; lowest available sample). The mixture of marine benthic species is generally very small- less than $1 \%$ of the total assemblage. Important biostratigraphic marker species include Nitzschia reinholdii, 475-3-1, 70-72 cm; Rhizosolenia curvirostris, 4753-3, 116-118 cm; Mesocena quadrangula, 475-5-2, 37$39 \mathrm{~cm}$; Cussia tatsunokuchiensis, 475-11-6, 45-47 cm, Thalassiosira convexa, 475-13-2, 75-77 cm (or 475-15-1, 93-95 cm); and $N$. jouseae, 475-16-2, 60-62 cm.

\section{Radiolarians}

Radiolarian remains consistently occur downhole. Nevertheless, their unusual abundance in the Pliocene and the absence of a recognized index species (worldwide or regional) precludes establishing a radiolarian biozonation for Hole 475. But the scarce index species, which do occur downhole, apparently coincide with the nannoplankton zonation. In the Quaternary sequence, Axoprunum angelinum occurs from Sections 475-3,CC to $475-6, C C$ and Stichocorys peregrina from Nannoplankton Zones 13 to 16 (Sections 475-11,CC, 475-12,CC, $475-16, C C)$, thus providing further evidence for the early Pliocene age of the sedimentary sequence at the bottom of Hole 475 .

The species occurring more abundantly downhole are typical of subtropical continental margin zones; among others: Tetraphyle octacantha, the Botryostrobus auritus-australis group, Duppatractus cf. pyriformis, Lithelius minor, Ommatodiscus sp., D. irregularis, Teocalyptra davisiana, and Echinomma delicatulum.

\section{Planktonic Foraminifers}

Planktonic foraminifers consistently occur nearly to the bottom of Hole 475. Insufficient diagnostic species for biostratigraphy and the lack of a shipboard plank- 
tonic foraminifer specialist precluded establishing a zonation for Hole 475-thus far. Nevertheless, the Quaternary (defined by the nannoplankton zonation) is characterized by abundant Neogloboquadrina dutertrei, whereas the Pliocene is characterized by Globigerinoides obliquus extremus(?).

Like the radiolarian population, the planktonic foraminifer population also suggests that a subtropical environment with occasional incursions of the California Current prevailed at Site $\mathbf{4 7 5}$ during the Pliocene and Quaternary.

The species that commonly do occur downcore are $N$. dutertrei, G. ruber, Globoquadrina pachyderma, Globigerina bulloides, Pulleniatina obliquiloculata, Orbulina universa, and Globigerinoides obliquus extremus(?).

\section{SEDIMENT ACCUMULATION RATES}

The sediments from Hole 475 seem to have been continuously deposited during the late Pliocene and Pleistocene. Nannofossil and diatom datum planes (Fig. 42) indicate that the average rate of accumulation is about 40 $\mathrm{m} / \mathrm{m} . \mathrm{y}$.

The rate of accumulation of the lower Pliocene dolomitic mudstone, zeolitic claystone, and Unit V conglomerates can be estimated only on sedimentologic grounds. Unit IV must have been deposited very slowly (perhaps less than $5 \mathrm{~m} / \mathrm{m} . \mathrm{y}$.), whereas Unit V must have been deposited very rapidly.

\section{IGNEOUS ROCKS}

Drilling in Hole 475B encountered basalt at 76 meters sub-bottom; and coring continued for an additional 20 meters until the hole was finally abandoned. The basalt is extensively fragmented, and the brown-stained, weathered rims that follow the outline of individual fragments suggest that the basalt was in the form of cobbles prior to drilling. All of the basalt recovered at Hole 475B is mineralogically similar and may be considered as a single type. It comprises approximately $10 \%$ euhedral-to-anhedral phenocrysts of olivine $(0.2-$ $2.0 \mathrm{~mm}$ ), dispersed throughout a variolitic-to-intersertal groundmass of plagioclase microlites, skeletal olivine, and clinopyroxene, and an iron-rich mesostasis. In addition to olivine, a pale red chrome spinel appears to be a phenocryst phase. No vesicles are present, and alteration is very slight. Fresh, black sideromelane selvages on Samples 475B-2-1 (Piece 3, 20-25 cm), 475B-2-1 (Piece $5,30-40 \mathrm{~cm}$ ), 475B-3-1 (Piece 1, 0-8 cm), and 475B-3-1 (Piece 3, 15-21 cm) provide strong evidence of subaqueous extrusion and concomitant rapid quenching.

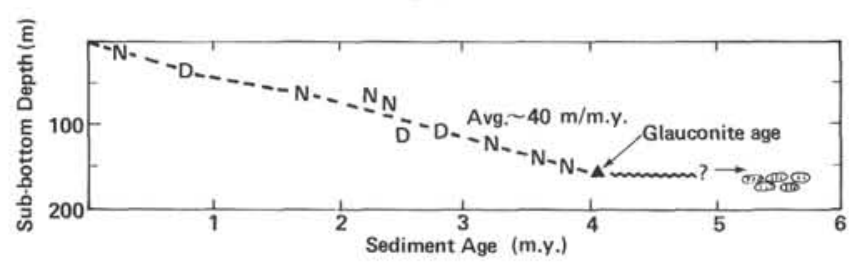

Figure 42. Sediment accumulation rates, Site 475.

\section{PHYSICAL PROPERTIES ${ }^{4}$}

The relationship of physical properties to depth in the range of 0 to 155 meters sub-bottom is better established at Site $\mathbf{4 7 5}$ than at Site $\mathbf{4 7 4}$. The Site $\mathbf{4 7 5}$ data show less scatter, and the clayey sequence is not interrupted by thick sand or gravel deposits. Cores 475-1 through 475-5, however, also were rather disturbed. Because the less-disturbed sections were always measured, wet-water content, wet-bulk density, and porosity probably were not seriously affected. Nevertheless, the shear-strength and sound-velocity values may be too low for this depth range $(0-50 \mathrm{~m})$ (Figs. 43, 44).

Water content, bulk density, and porosity begin near the surface and have the same values (ca. $60 \%$, ca. 1.3 $\mathrm{g} / \mathrm{cm}^{3}$, ca. $80 \%$, respectively) as those at Site 474 , but they decrease more slowly downhole. Thus, between 110 and 120 meters, water content is still $50 \%$ or higher, bulk density is $1.5 \mathrm{~g} / \mathrm{cm}^{3}$ or less, and porosity is at least $70 \%$. Shrinkage of the dried cylinder samples also remains high ( $40 \%$ and more) to this depth, and sound velocity barely exceeds $1.5 \mathrm{~km} / \mathrm{s}$.

From 110 to 120 meters down, all physical-property values show the same remarkable change as at Site $\mathbf{4 7 4}$ (there from about $260 \mathrm{~m}$ ). At 130 meters the sediment appears to be distinctly firmer than in the higher sections. The highest shear strength measured is about $1.4 \times 10^{5} \mathrm{~Pa}\left(1.4 \mathrm{~kg} / \mathrm{cm}^{2}\right)$. Within the same interval, sound velocity and acoustic impedance increase to 1.54 $\mathrm{km} / \mathrm{s}$ and $2.42 \times 10^{5} \mathrm{~g} / \mathrm{cm}^{2} \mathrm{~s}$, respectively. A hard dolomitic mudstone $(155 \mathrm{~m})$ directly on top of the cobble bed had a sound velocity of $2.78 \mathrm{~km} / \mathrm{s}$.

Unlike Site 474 , at Site 475 the comparatively strong gradients of the physical properties below 110 meters are apparently not related to changes in the composition of sediment or interstitial water. In Hole 475, from 110 to 150 meters, the sediments again become rich in opaline microfossils, and the concentration of dissolved silica is very high. Nevertheless, lithification by solution and recrystallization of silica may also have begun here. This is also indicated by relatively high values of average grain density (about $2.55 \mathrm{~g} / \mathrm{cm}^{3}$ ), incompatible with a large proportion of opaline silica (as assumed from smear slide descriptions).

At Site 475 , two thick ( $1 \mathrm{~m}$ and $1.4 \mathrm{~m}$ ) mud turbidite samples with fining-upward grain-size distribution were measured for physical properties (Fig. 43). The results and those from similar studies at other sites are summarized in the chapter on turbidite sedimentation and physical properties (Einsele and Kelts, this volume, $\mathrm{Pt}$. 2 ). To evaluate the trend curves in Figure 43, it is important to realize that part of the mud turbidites show strong gradients of physical properties from bottom to top; but others do not and do not differ very much from the "background" sedimentation. Thus, host sediments and mud turbidites are often difficult to distinguish during sampling, and in the visual description of wet cores. Therefore, at least some of the scattering of the physi-

\footnotetext{
${ }^{4}$ For general remarks on physical properties, see site description for Site 474 , earlier, or Einsele (this volume, Pt. 2).
} 


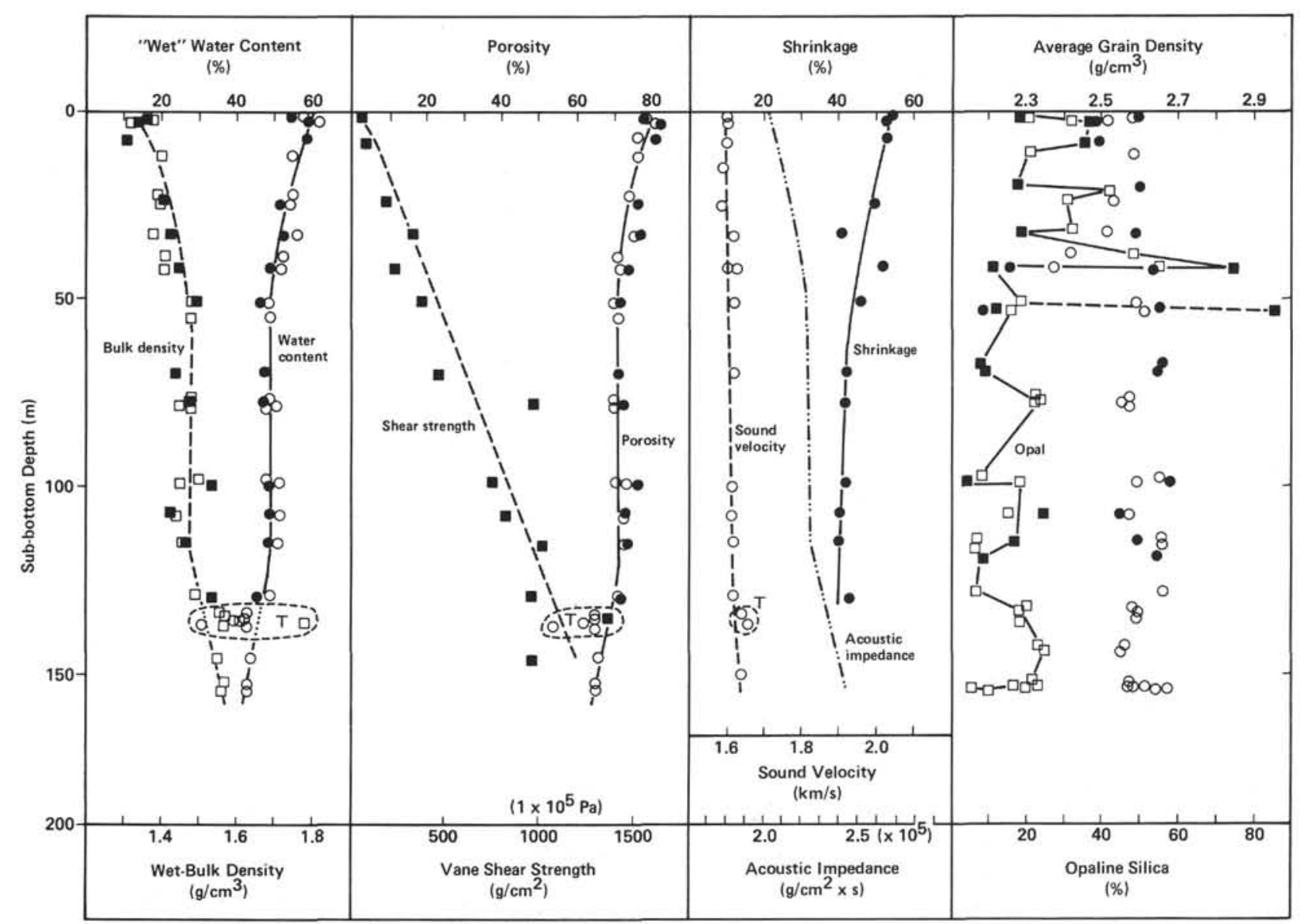

Figure 43. Mass physical properties, shrinkage, and proportion of opaline silica of Site 475 sediments $(\mathrm{T}=$ samples from mud turbidites. Closed symbols are cylinder samples. Open symbols are chunk samples.)

cal-property data is caused by the intermixing of layers of somewhat differing composition. Similarly, layers of different color may be caused by changes in their composition and, therefore, have somewhat differing physical properties. A light olive gray silty clay from Section 475-9-4 contained about $2 \%$ less water and had a lower porosity by $1.5 \%$ but a somewhat higher $\left(0.03 \mathrm{~g} / \mathrm{cm}^{3}\right)$ bulk density than an adjacent dark brown silty clay containing more siliceous microfossils and organic matter. If the cores are little disturbed, thick mud turbidites with marked changes in bulk densities can be identified in the GRAPE logs. Hence, the corresponding deductions from the Site 474 data are confirmed.

\section{HEAT FLOW AND THERMAL CONDUCTIVITY}

Thermal conductivity was measured at 12 intervals downcore using a procedure similar to the needle-probe method described by von Herzen and Maxwell (1959); the instrument employed was designed by V. Vacquier. The thermal conductivities were calibrated using a variety of standards. Remeasurement of standards during the actual sample measurements suggests that the conductivities reported in Table 8 may be about $0.15 \times$ $\mathrm{mcal} / \mathrm{cm} \mathrm{s}{ }^{\circ} \mathrm{C}$ high. The measurements have a precision of better than $10 \%$. Thermal conductivities are shown in Table 8 and Figure 45. Low thermal conductivity $\left(\sim 2.45 \mathrm{mcal} / \mathrm{cm} \mathrm{s}^{\circ} \mathrm{C}\right)$ in the upper sediment column correlates with the column's higher water content (see Bullard, 1963 for discussion of this phenomenon). Sediments from below 30 meters have a relatively constant thermal conductivity of about $2.6 \mathrm{mcal} / \mathrm{cm} \mathrm{s}{ }^{\circ} \mathrm{C}$.

Heat flow was measured by the Uyeda/Kinoshita downhole temperature probe. This instrument takes an in situ temperature reading one meter deeper than the drill bit. The two measurements roughly describe a linear temperature gradient to a bottom-water temperature of $3.5^{\circ} \mathrm{C}$; measured temperatures were approximately $14.0^{\circ} \mathrm{C}$ at 110.5 meters and $25.5^{\circ} \mathrm{C}$ at 148.5 meters. The temperature probe did not equilibrate completely in either measurement, so the temperature values are slightly extrapolated.

Three different temperature gradients can be calculated for Hole 475 using: (1) temperature at $110.5 \mathrm{me}-$ ters and bottom-water temperature; (2) temperature at 148.5 meters and bottom-water temperature: or (3) temperature at 148.5 and 110.5 meters. Heat-flow calculations based on these three gradients and measured thermal conductivities yielded $2.5,3.9$, and $7.9 \mathrm{HFU}$, respectively. The high heat flow calculated from the two in situ measurements (7.9 HFU) suggests that the 110.5meter temperature may be low. We therefore believe that heat flow at Site 475 should be about 4 HFU. 

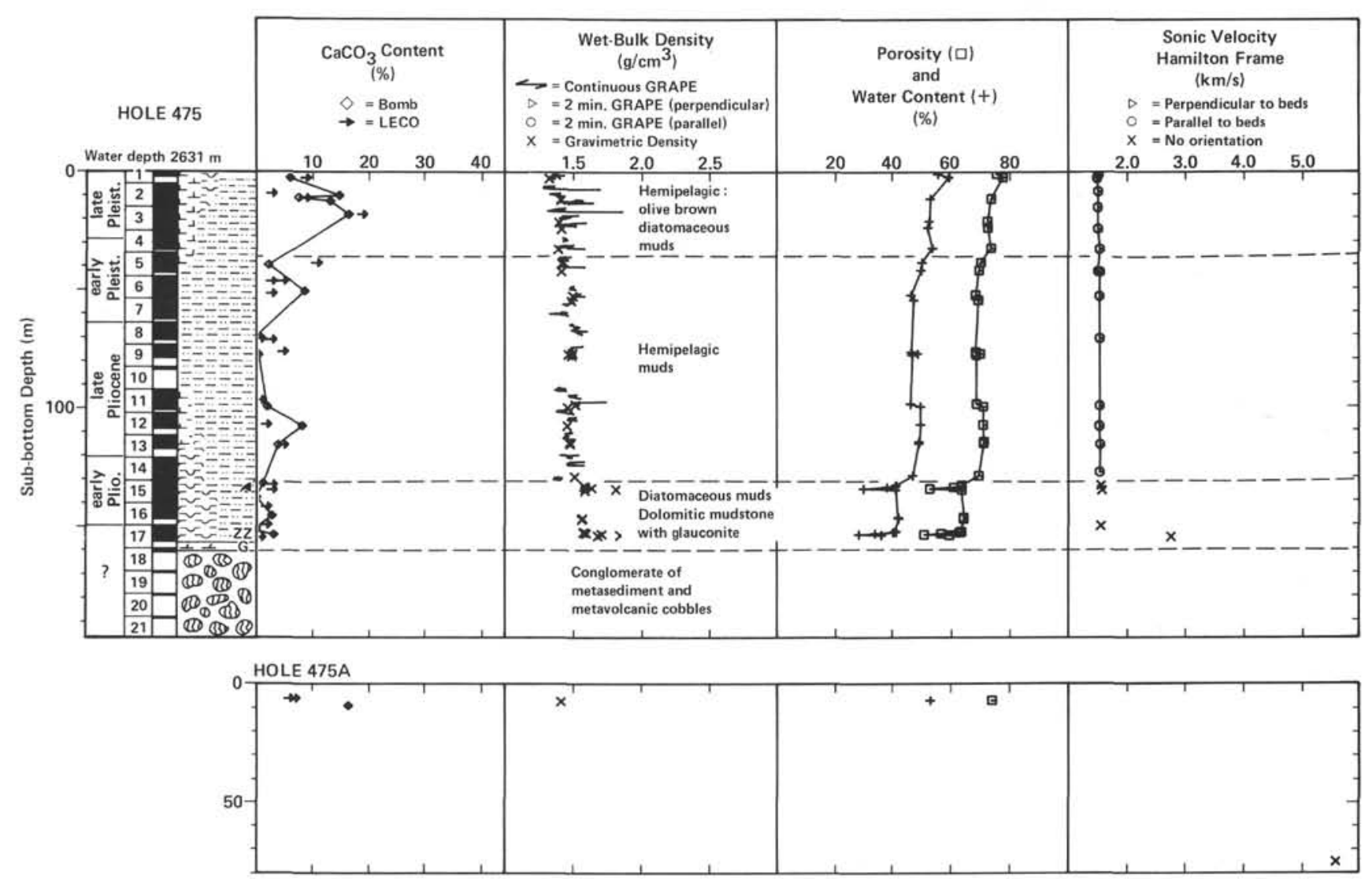

Figure 44. Calcium carbonate and physical properties, Site 475. Analyzed ashore at Scripps Institution.

Table 8 . Thermal conductivity, Hole 475 .

\begin{tabular}{lc}
\hline $\begin{array}{c}\text { Sample } \\
\text { (interval in cm) }\end{array}$ & $\begin{array}{c}K \\
\left(\mathrm{mcal} / \mathrm{cm} \mathrm{s}{ }^{\circ} \mathrm{C} \text { ) }\right.\end{array}$ \\
\hline $475-2-4,33-35$ & 2.47 \\
$475-3-1,95-97$ & 2.40 \\
$475-4-6,3-5$ & 2.59 \\
$475-5-6,53-55$ & 2.53 \\
$475-6-6,57-59$ & 2.71 \\
$475-7-1,74-76$ & 2.69 \\
$475-8-5,139-141$ & 2.66 \\
$475-9-4,86-88$ & 2.62 \\
$475-11-6,90-92$ & 2.72 \\
$475-12-5,49-51$ & 2.52 \\
$475-13-4,12-14$ & 2.61 \\
$475-16-4,72-74$ & 2.61 \\
fused quartz & \\
$\quad$ standard & 3.46 \\
\hline
\end{tabular}

\section{CORRELATION OF DRILLING RESULTS AND SEISMIC DATA}

Our velocity control for Site $\mathbf{4 7 5}$ is very poor. Because of the sloping sea floor and limited extent of the basin, we have no sonobuoy records on which to base velocity estimates - and neither did we run downhole logs. We have only laboratory velocity measurements on a limited number of samples; these samples give very low velocities, apparently because the sediments are not well consolidated, have high water content, and gener- ally contain high proportions of siliceous microfossils. Using the measured velocities as guides, the following acoustic velocities were developed for the correlations: $0-100$ meters $-1.50 \mathrm{~km} / \mathrm{s} ; 100-150$ meters $-1.52 \mathrm{~km} / \mathrm{s}$; and $>150$ meters $-1.55 \mathrm{~km} / \mathrm{s}$.

The seismic reflection record of our approach to the site is shown in Figure 46. Because of the failure of the first beacon and because Hole 475 was about 366 meters approximately southeast of the beacon, positioning the site in this survey line may not be precise. Holes $475 \mathrm{~A}$ and $475 \mathrm{~B}$ do not lie in this section.

Correlation with drilling results is shown in Figure 46. The boundaries between the lithologic units appear to correlate with the indicated reflectors. The dolomite (Unit IV) and the top of the conglomerates (Unit V) appear as a meniscus-like fill in the bottom of this slope basin. The base of Unit II shows a downlap relation. There is a prominent reflector within Unit II, although we cannot determine what horizon in the section correlates with it.

The relation between Hole 475 and the sections drilled in Holes 475A and 475B was especially confusing during the occupation of this site. The $3.5-\mathrm{kHz}$ record (Fig. 47) run to relate these holes after leaving Site 475 and before occupying Site 476 helps to show the relationship. (See operations section, Site 476).

The total depths of Holes 475, 475A, and 475B are plotted in Figure 48. The hard rock at 16 meters in Hole 475A may coincide with the reflecting horizon that appears at that depth in Figures 47 and 48 . The top of the 


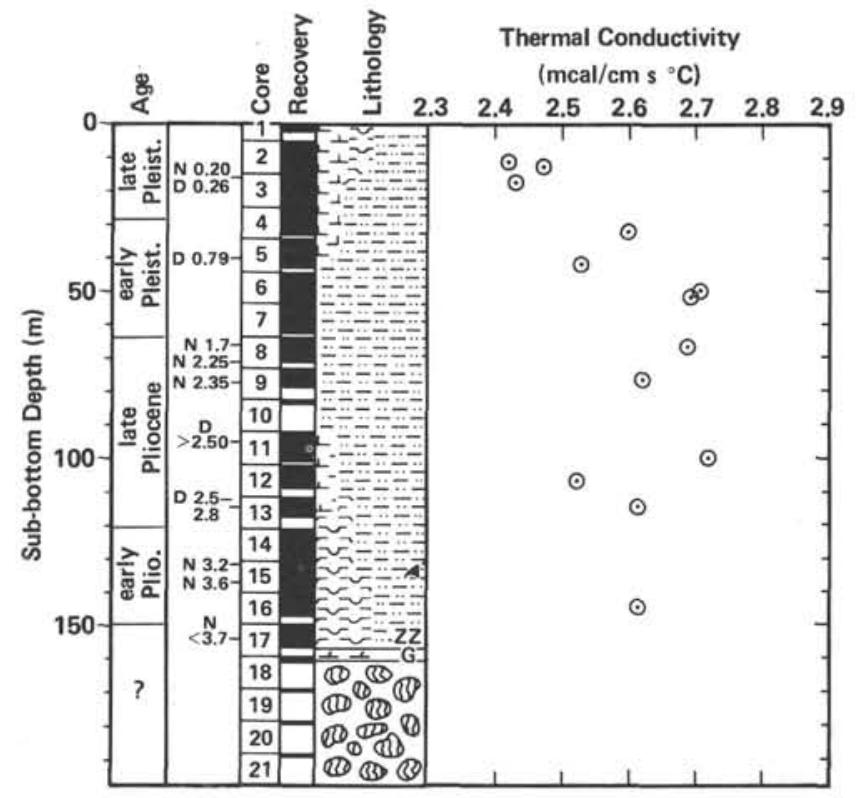

Figure 45. Thermal conductivity of sediment, Site 475 .

basalt rubble at 76 meters in Hole 475B also appears to be a reflector, especially as it is shown in the $3.5-\mathrm{kHz}$ record of Figure 47. The 2-s-sweep seismic record may be interpreted to fit the drilling results as indicated in Figure 46.

The reflection line in Figure 49 was made while in transit from Hole 475A to Hole 475B. Survey speed was very slow because more than 2500 meters of drill string were hanging beneath the ship. Drilling in Hole 475B encountered the top of the basalt rubble at the level that is indicated on the figure.

\section{SUMMARY AND CONCLUSIONS}

\section{Drilling Summary and Objectives}

Site 475 , the second in the passive margin transect, is in a slope basin $21 \mathrm{~km}$ southeast of the tip of Baja California. Drilling objectives were the same as those of Site 474. By studying the composition, character, and age of the basement, we wanted to determine whether the site is seaward or landward of the ocean/continental-crust transition. In the sedimentary section, our goals were to determine the general lithologic and biostratigraphic facies distribution, to obtain the record of Pleistocene sea-level fluctuations and subsidence history, to learn the nature and age of oldest sediments on basement, and to study diagenesis of organic and inorganic matter. Three holes were drilled. Hole 475 was drilled in a water depth of 2631 meters and continuously cored to a depth of 196 meters below the mudline. A cobble conglomerate at 148 meters eventually stopped the drilling. Above the conglomerate, the drilling operations were routine, and an unusually good recovery $(79.6 \%)$ was obtained. The heat probe was successfully deployed in stiff mud at 110.5 meters and again at 148.5 meters. Drilling times increase sharply (from 6-8 to 22-60 min. per core) as we penetrated the conglomerate zone; and our average re-

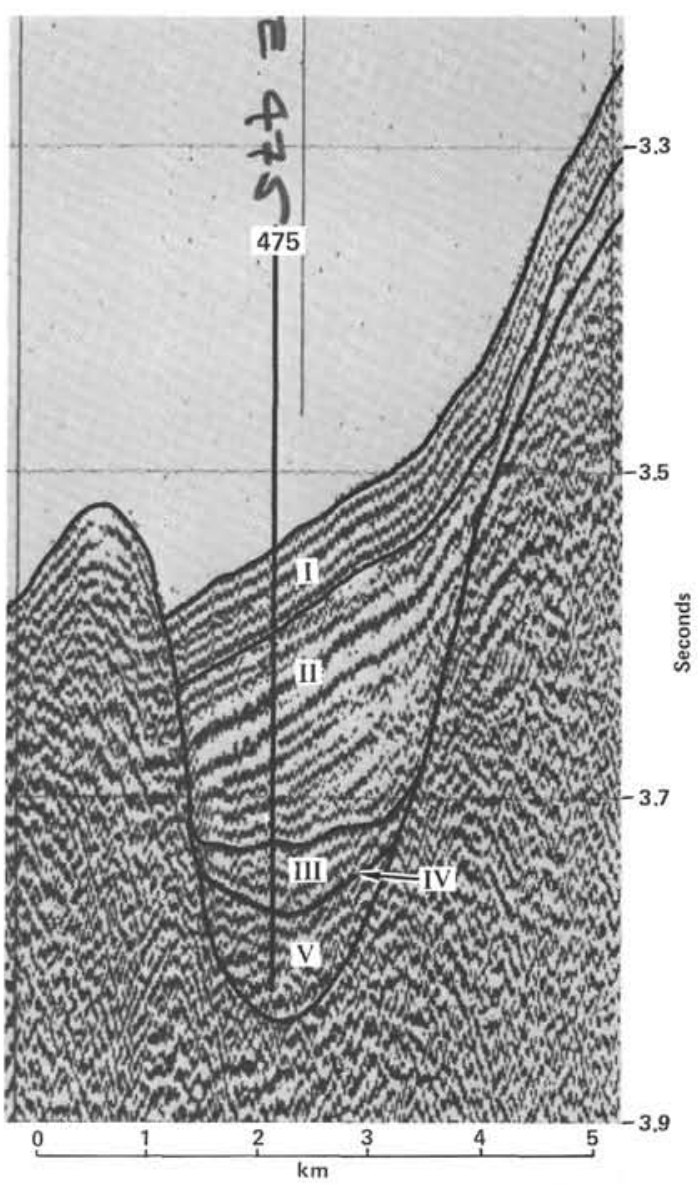

Figure 46. Correlation of lithological units with seismic reflection record from Glomar Challenger, Site 475.

covery decreased to only $5.3 \%$. The two other holes at this site were selected upslope of Hole 475 to avoid the conglomerate and to attempt to sample the presumed granite basement. Both holes were washed to the equivalent depth reached in Hole 475. Drilling in Hole 475A, in 2545 meters of water, hit a hard layer at 16 meters below mudline. Drilling in Hole 475B, in 2593 meters of water, washed to 76 meters before encountering basalt cobbles. These were cored to 96 meters total depth (TD) with only $3 \%$ recovery, before caving of the hole forced us to abandon the site.

\section{Lithology and Sediment Properties}

Microfossil abundances, sedimentary structures, and mineralogical components indicate five lithological units in Hole 475.

Unit I (0-34.5 m)-hemipelagic pelagic diatomaceous muds

Unit II (130.2 m)-hemipelagic mud

Unit III (154.2 m) -mud turbidites

Unit IV (a thin basal stratigraphic element to 158 m)-dolomitic mudstone

Unit V (196 m TD)-a conglomerate of metasediment and metavolcanic cobbles

Organic geochemistry showed hydrogen sulfide present from 11 to 35 meters but in much lower amounts 


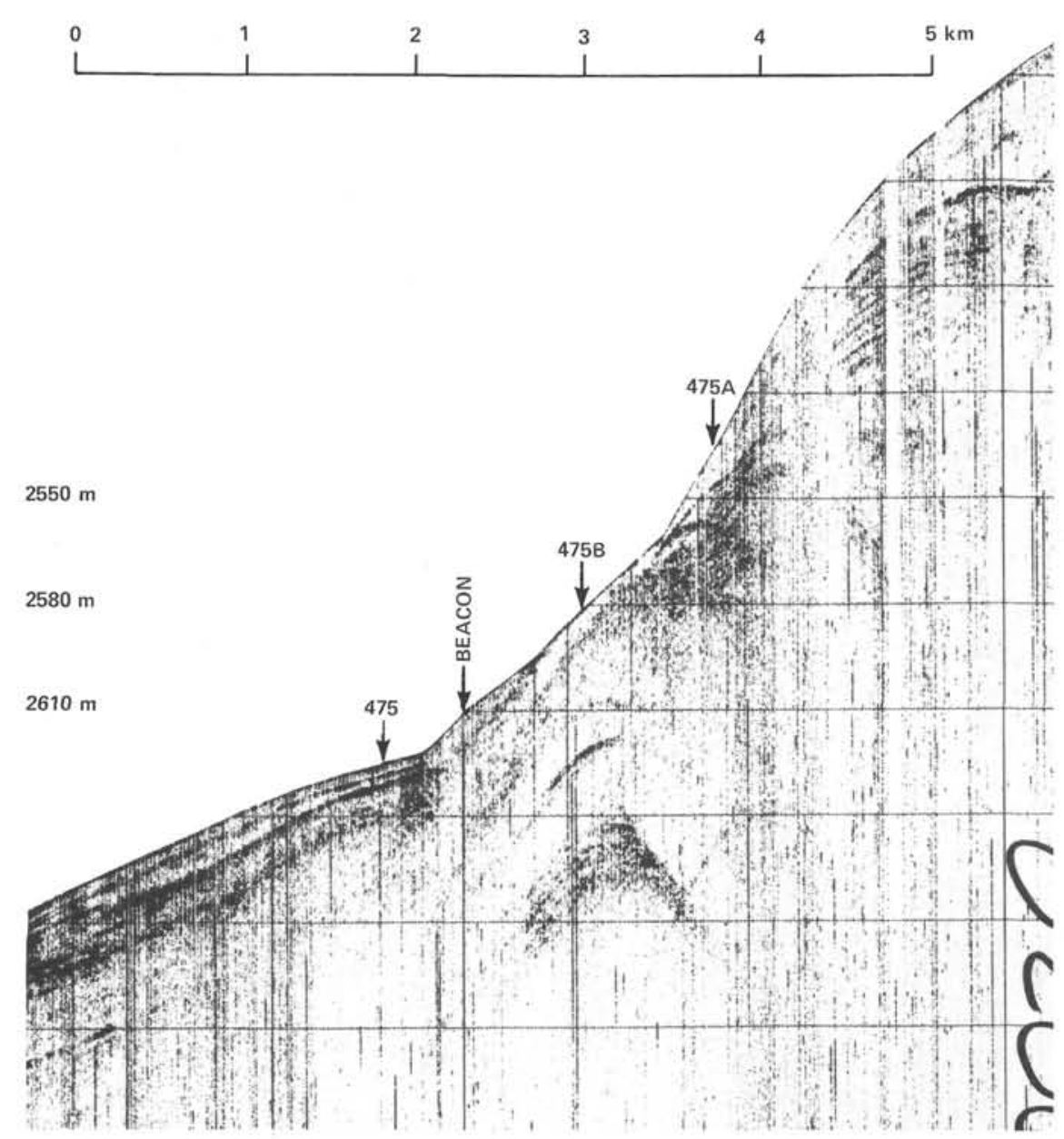

Figure 47. Correlation of drilling results with $3.5-\mathrm{kHz}$ record, Site 475.

than at Site 474. No hydrocarbon gases were detected. Dissolved calcium passes through a typical minimum in the upper section, indicating precipitation of calcium carbonate. Dissolved silica values are high at this site and increase progressively downhole; this may be associated with a progressive increase in biogenic silica. Calcium carbonate content is moderate in the upper diatomaceous ooze but relatively low throughout the rest of the hole. No increase occurred in the lower diatomaceous section, suggesting a lack of calcite microfossil deposition. Comparatively strong gradients in the water content, bulk density, and porosity from 110 meters to the base of the sediments above the conglomerate are apparently not related to sediment composition or interstitial water. The concentration of dissolved silica is high, and the sediments become richer in opaline microfossils. This contrasts with the sediment characteristics at Site 474 , where a correlation between sediment chemistry and physical properties is apparent. Only a very small piece of the dolomitic mudstone cored at Hole 475 was recovered from Hole $475 \mathrm{~A}$, just above the metamorphic cobble conglomerate. Olivine basalt occurs in Hole $475 \mathrm{~B}$ at 76 meters sub-bottom. Drilling continued 20 meters into the basalt and recovered 0.55 meters of basalt cobbles. The basalt has quenched textures and glassy selvages, indicating subaqueous extrusion; but concentric weathering auras on the cobbles indicate that in situ flows were probably not sampled. The basalts are petrographically similar to mid-ocean ridge basalts.

\section{Correlation of Drilling Results with Seismic Reflection}

No sonobuoy record or downhole acoustic logging was available for this site. Thus, to calibrate the seismic reflection records with drilling results, we were forced to rely on sound velocities measured in the laboratory. The velocities were quite low, and we need them to develop the following velocities for correlating the section: 1.50 $\mathrm{km} / \mathrm{s}$ to 100 meters, $1.52 \mathrm{~km} / \mathrm{s}$ from 100 to 150 meters, and $1.55 \mathrm{~km} / \mathrm{s}$ beyond 150 meters to the base of the sediments above the lithified dolomitic unit at the top of the conglomerate. With these velocities, the sedimentary units correlate well with the reflection record. The relations among Holes 475, 475A, and 475B-as seen in the seismic record collected during a short survey on leaving Site 475 -show that the sedimentary units of Site 475 can be well correlated within the section, and that the metamorphic rock cobbles of Hole 475B and the basalt rubble of Hole 475A are indeed related to the apparent basement reflector recorded. The occurrence of planktonic foraminifers throughout the section in Site 475 and above the hard claystone/cobble contact suggests that a subtropical environment, with periodic incursions 


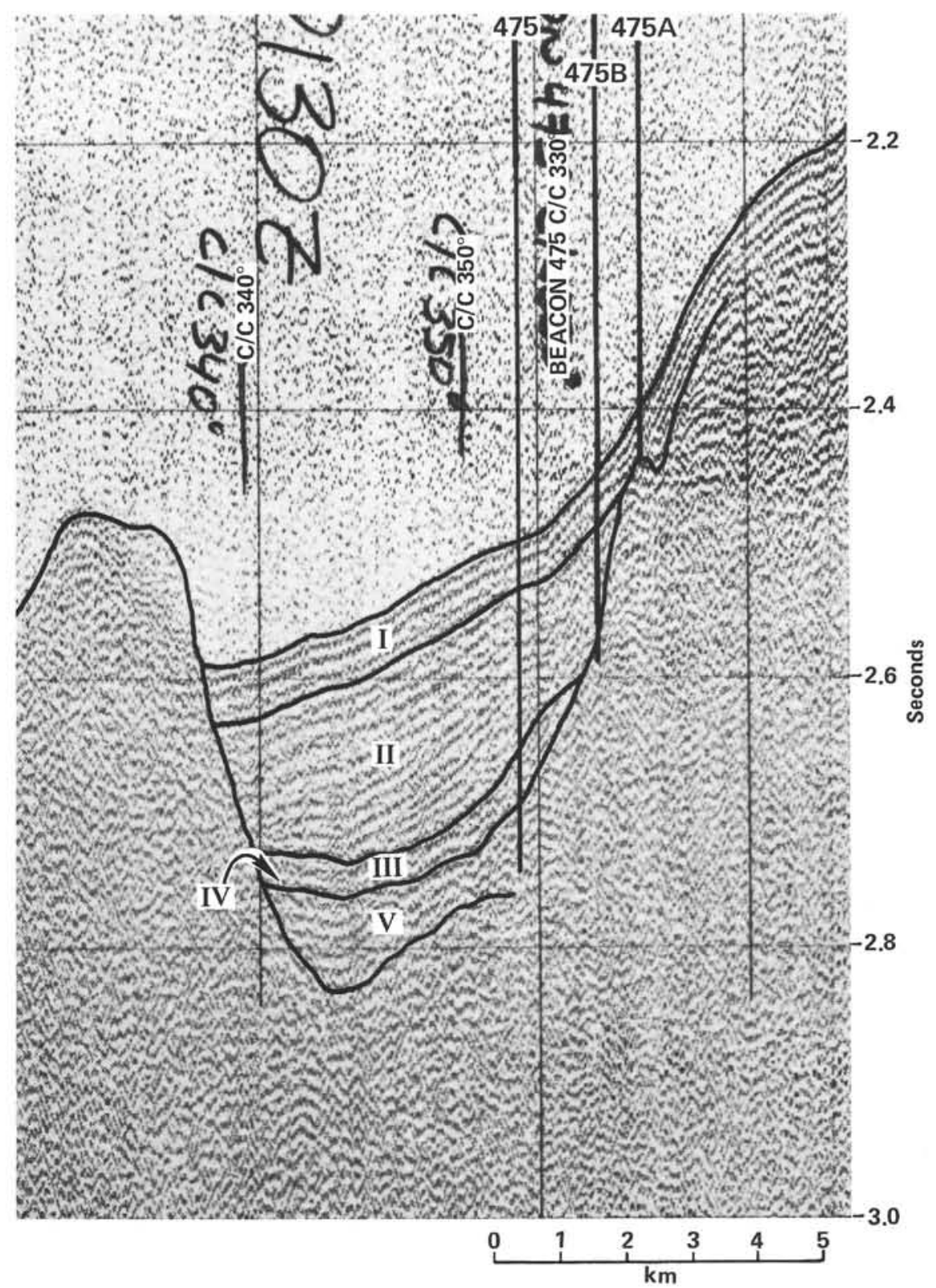

Figure 48. Correlation of seismic reflection record from Glomar Challenger with Holes 475, $475 \mathrm{~A}$, and $475 \mathrm{~B}$. $(\mathrm{C} / \mathrm{C}=$ course change. $)$

of the California Current, prevailed during the Pliocene and Quaternary.

Geological history and paleoenvironment for Sites 475 and 476 will be discussed in the Site 476 summary and in the chapter on the geological history of this transect region (Curray et al., this volume, Pt. 2).

\section{SITE 476}

Date occupied: 14 December 1978

Date departed: 16 December 1978

Time on hole (hr.): 36.07

Position: $23^{\circ} 02.43^{\prime} \mathrm{N}$; $109^{\circ} 05.35^{\prime} \mathrm{W}$

Water depth (sea level; corrected m, echo-sounding): 2403

Water depth (rig floor; corrected m, echo-sounding): 2413
Bottom felt (m, drill pipe): 2429

Penetration (m): 294.5

Number of cores: 32

Total length of cored section (m): 294.50

Total core recovered $(\mathrm{m}): 164.78$

Core recovery $(\%): 81.7$; total 56.0

Oldest sediment cored:

Depth sub-bottom (m): 256

Nature: Gray quartzose sandy clay

Age: Pliocene/late Miocene (NN14) or older

Basement:

Depth sub-bottom (m): 256.5

Nature: Weathered granite

Measured velocity $(\mathrm{km} / \mathrm{s}): 4.53$

Principal results: Site 476 , the landward end of a three-site transect across the ocean/continent transition, was spudded-in on a small 


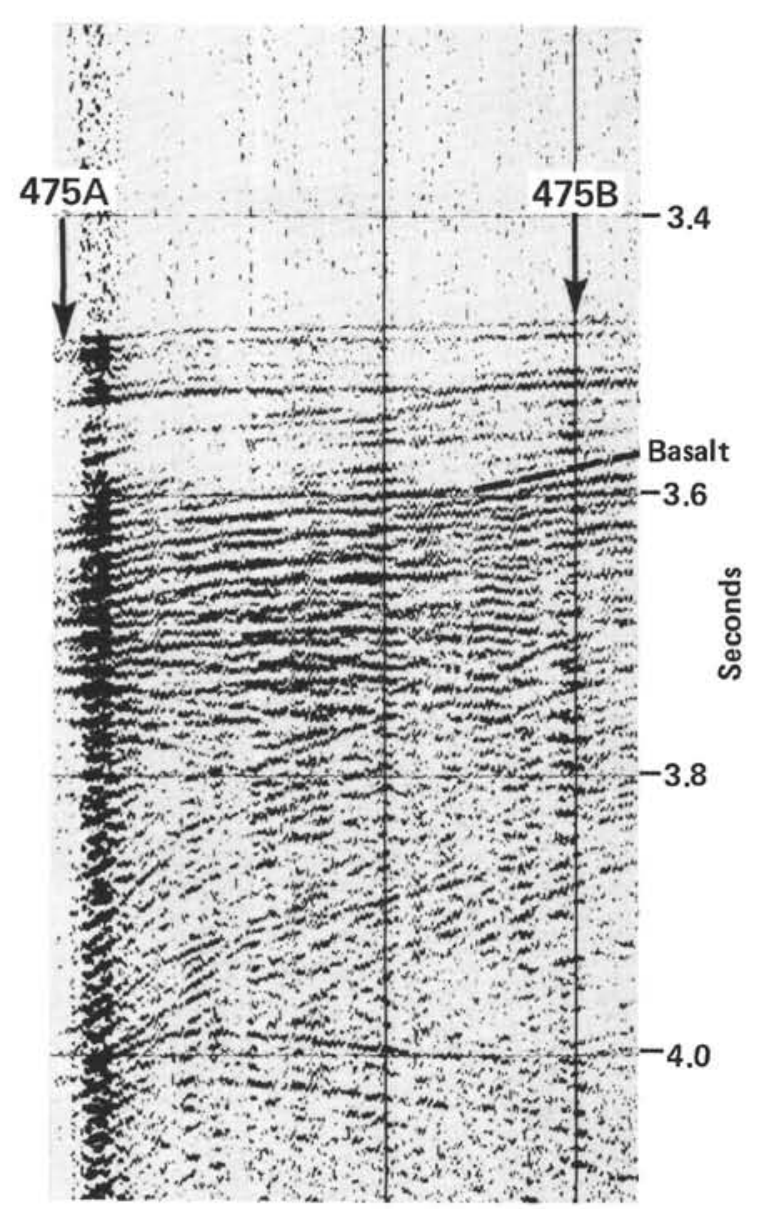

Figure 49. Seismic reflection record made while in transit from Hole $475 \mathrm{~A}$ to Hole $475 \mathrm{~B}$ at extremely slow ship speed ( $2500 \mathrm{~m}$ of drill string beneath the ship).

terrace on the lower continental slope, southeast of the tip of Baja California. Our objectives were to establish basement type, subsidence history, and sedimentary record. The hole was continuously cored to a depth of 294.5 meters. Six lithological units provide evidence for deposition on a subsiding continental margin. The last four cores $(256.5-294.5 \mathrm{~m})$ contain weathered granite. The basement is overlain by cobbles $(199.0-256.5 \mathrm{~m})$ from a subaerial conglomerate, containing metamorphic clasts and gray sandy clay. Deposited above the conglomerate were shallow (183.0$199.0 \mathrm{~m}$ ) early Pliocene to Miocene marine claystones, glauconite sands, and barren zeolitic clays. Subsequently, early Pliocene diatom oozes with turbidites $(145.0-183.0 \mathrm{~m}$ ) to late Pliocene hemipelagic silty clays $(66.0-145.0 \mathrm{~m})$ and then fluctuating amounts of Pleistocene muds and nannofossil and diatom oozes $(0.0-66.0 \mathrm{~m})$ were deposited at a rate of $42 \mathrm{~m} / \mathrm{m}$.y. Recovery was excellent $(82 \%)$ in the marine sediment section to 199 meters but less than $4 \%$ in the coarse rubble below.

\section{SITE 476: BACKGROUND AND OBJECTIVES}

Site 476 (Planning Site GCA-7A) is the third site of the continental margin transect at the mouth of the Gulf of California. It lies on the continental slope (Figs. 2, 7) about $40 \mathrm{~km}$ southeast of the tip of Baja California and about $3.6 \mathrm{~km}$ west-southwest of Site 475 . It is on the same northeast-southwest-trending ridge as Site 475 and about $30 \mathrm{~km}$ northeast of the crest of the Cabrillo Seamount (Fig. 2). Granodiorite, quartz diorite, and basalts have been dredged from the Cabrillo Seamount (Shepard, 1964; Moore et al., 1978), and basalt was dredged from DH-8 (Fig. 2; Lewis et al., 1976). Site 474 bottomed in oceanic basalt basement, and one Site 475 hole bottomed in basalt rubble.

Our primary objective at this site was to establish the basement type and thus delineate the ocean/continental crust transition. ${ }^{5}$ If oceanic rather than granitic continental basement had been recovered here, another site would have been chosen farther up on the continental slope, thus continuing our attempt to delineate the ocean/continent transition.

\section{OPERATIONS}

On leaving Hole 475 B at $2245 Z$ on 13 December, we began a seismic reflection survey to link all of our sites and an earlier dredge-haul site on this transect. Five-and two-second sweep records were recorded. We began the survey from Hole $474 \mathrm{~A}$, using the beacon at that site for navigation. We passed the beacon at $2346 \mathrm{Z}$ and made our turn at $2357 \mathrm{Z}$ to begin the survey (Fig. 50). On 14 December, we passed Hole $474 \mathrm{~A}$ at $0025 \mathrm{Z}$, were over the beacon of Site 475 at $0147 \mathrm{Z}$, and crossed the dredge site at $0310 \mathrm{Z}$. After a short loop to the NW, we returned to our desired position for Site 476, dropped the beacon at $0551 \mathrm{Z}$, and selected on an open-slope locality in 2413 meters of water with a 0.30 -s section of sediment overlying the basement.

After positioning over the site we lowered drill pipe, and at $1552 \mathrm{Z}$ on 14 December we spudded-in, finding the mudline in the second core at 2429 meters, corrected PDR depth. Our first core from Hole 476 was on deck

\footnotetext{
${ }^{5}$ Other objectives are the same as those for Site 475.
}

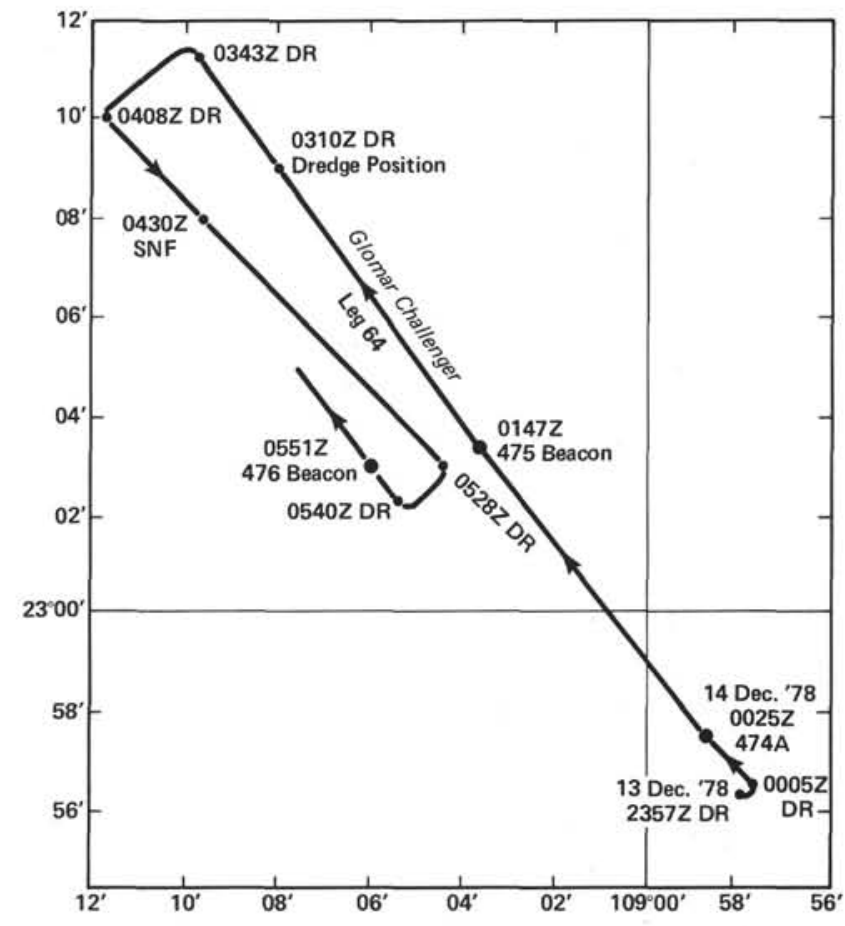

Figure 50. Track of Glomar Challenger from Sites 474 and 475 to Site 476. 
at $0921 \mathrm{Z}$. Thereafter, we continuously cored to a total depth of 294.5 meters. Within the section and to a depth of 199.0 meters, six lithological units were recognized. With an average of $81.7 \%$, our recovery was excellent. Two successful heat-flow measurements were made in this interval: one at 47 meters and another at 132.5 meters. At 199 meters we apparently encountered a sand zone and recovered only a trace of sand and a pebble of sandstone. Thereafter, recovery was very poor and drilling difficult as we cored through metamorphic rock cobbles until reaching deeply weathered granite below 256 meters. We drilled into this granite wash to 294.5 meters before decomposed granite caused sticking problems, loss of circulation, and finally required that we discontinue drilling.

Between 0500 and $0745 \mathrm{Z}$, the hole was washed and flushed with 100 barrels of mud to prepare for logging, and the go-devil was pumped down to release the bit. Unfortunately, even with as much pressure as $2500 \mathrm{psi}$ the bit would not release. We could not retrieve the godevil; it too was stuck fast, and two pins were sheared on the sand-line coupling in the attempted recovery. Thereafter, until $0845 \mathrm{Z}$, four stands of pipe were pulled and the bit release again attempted to no avail. We were now forced to abandon the site with no logging. Pipe was pulled out of the hole, the hole was filled with mud, and at $1330 \mathrm{Z}$ the bit was on deck. The hydraulic bit release did not shift because it was jammed with sand. At $1344 \mathrm{Z}$ on 16 December we abandoned Site 476 and were underway for Site 477 (Table 9).

\section{SEDIMENTARY LITHOLOGY}

Site 476 is on a small slope terrace a few kilometers northwest of, and 191 meters shallower than, the outer slope basin of Site 475 . The last four cores contained weathered granite and granite wash.

The sediments at Site 476 provide evidence for deposition on a subsiding, granitic, continental margin. Subaerial conglomerates are overlain with laminated, organic, shallow-marine claystones with phosphorite, pyrite, and abundant glauconite. These are followed by barren zeolitic clays, diatom oozes with turbidites, hemipelagic clay, and then fluctuating amounts of terrigenous mud, nannofossil ooze, and diatom ooze to mud in the upper Pleistocene.

The sediment section has been subdivided into six units summarized in Table 10 and the stratigraphic section (Fig. 51). The subdivision is based on compositional differences, which group the sediments into units with similar paleoenvironmental settings. Hemipelagic muds from Units I, II, and III are separated by the relative abundance of diatoms, nannofossils, and graded sandy silts. Unit IV is a barren but distinguished by a sudden drop in siliceous fossils in Core 476-20 and then a change to fine zeolitic claystone. At the base of Core 476-21, organic claystones mark the change to the poorly recovered metamorphic cobbles of Unit V and the weathered granite of Unit VI. There is good correlation with the units at Site 475.

Unit I: nannofossil-diatom ooze, (Cores 476-1-4767, 0-66 m, Pleistocene). Below the first two cores, the sediments are highly disturbed, but remnants of diffuse, lighter-and-darker beds on a centimeter to decimeter scale are recognizable. Unit I comprises mostly nannofossil ooze, nannofossil-diatom ooze, and diatomaceous ooze to nannofossil-diatom-bearing mud. Subtle variations in color seem to reflect fluctuations in biogenic components. Some, but not all, of the lighter beds are richer in nannofossils. Colors vary among grayish olive green (5GY $3 / 2$ ), light olive (10Y 5/4), grayish olive $(10 \mathrm{Y} 4 / 2)$, and dusky yellow green $(5 \mathrm{GY} 5 / 2)$ or moderate olive brown (5Y 4/4). Brownish layers tend to be richer in diatoms. Nannofossils range from 10 to $60 \%$; diatoms range from 15 to $40 \%$ and are accompanied by minor amounts of radiolarians, sponge spicules, or silicoflagellates. Foraminifers are concentrated in some scattered, well-sorted sand layers. These ungraded (2-3 cm-thick) sandy beds are common in Cores 476-5 to 476-7 near the base of the unit and consist of about $50 \%$ foraminifers and $50 \%$ angular quartzosefeldspathic sand. Benthic and planktonic foraminifers are abundant; some are filled with pyrite or glauconite.

The carbonate content varies from about 10 to $50 \%$, and the terrigenous suite, with clear, angular quartzose, partly weathered feldspars, and biotite with apatite, zircon, and some epidote, is similar to that at Sites 474 and 475. Pyrite is a ubiquitous accessory because the sediments are reducing. Dark gray spots are common, as is a slight $\mathrm{H}_{2} \mathrm{~S}$ odor from Section 476-1-2 through Core 476-7-consistent with a relatively high sedimentation rate.

Near the boundary with Unit II, the color lightens to grayish yellow (5GY 6/2). Carbonate content and both the quantity and quality of microfossil preservation decrease.

Unit II: silty clay (Core 476-8-Section 476-16-3, 66.0-145.0 m; late Pliocene). Unit II sediments form a homogeneous layer and have a uniform color scale indicating reducing conditions-grayish olive green (5GY $3 / 2$ ) to dusky yellow green ( $5 \mathrm{GY} 5 / 2$ ) to grayish green $(10$ GY $5 / 2)$ slightly siliceous silty clays. Bedding has been nearly obliterated by drill disturbance, although the sediments tend to be firm toward the base of the unit. Nannofossils are rare, and siliceous fossils occur as thin, poorly preserved fragments. There are minor mottles and reduction spots. Carbonate content is less than $5 \%$, clay ranges from 60 to $75 \%$; the remainder is fine quartz-feldspar $(20-30 \%)$ or siliceous debris $(\sim 5 \%)$ and pyrite $(1-5 \%)$. Other sandy patches in this unit (Core 476-10) are very poorly sorted, faintly graded, and, because they are also associated with micaceous, silty zones, may be parts of mud turbidites.

Minor lithologies in this unit include a thin, vitric, rhyolitic ash bleb and pyritized burrow fillings (Core 476-12) and some scattered pumice and tuff pebbles (Cores 476-13, 476-14).

Unit III: muddy diatomaceous ooze (Sections 47616-3-476-20-3, 145-183 m, early Pliocene). In Section 476-16-3, the lithology changes rather abruptly to muddy diatomaceous ooze with sand interlayers. Colors become predominantly dusky yellow green ( $5 \mathrm{GY} 5 / 2)$, dusky yellow (5Y 6/4), or moderate olive brown (5Y 
Table 9. Coring summary, Hole 476.

\begin{tabular}{|c|c|c|c|c|c|c|c|}
\hline Core & $\begin{array}{c}\text { Date } \\
\text { (December, 1978) }\end{array}$ & $\begin{array}{l}\text { Time } \\
\text { (Z) }\end{array}$ & $\begin{array}{c}\text { Depth from } \\
\text { Drill Floor } \\
\text { (m; top-bottom) }\end{array}$ & $\begin{array}{c}\text { Depth below } \\
\text { Sea Floor } \\
\text { (m; top-bottom) }\end{array}$ & $\begin{array}{l}\text { Length } \\
\text { Cored } \\
\text { (m) }\end{array}$ & $\begin{array}{l}\text { Length } \\
\text { Recovered } \\
\text { (m) }\end{array}$ & $\begin{array}{c}\text { Recovery } \\
(\%)\end{array}$ \\
\hline 1 & 14 & 0921 & $2428.5-2438.0$ & $0.0-9.0$ & 9.0 & 9.03 & 100 \\
\hline 2 & 14 & 1003 & $2438.0-2447.5$ & $9.0-18.5$ & 9.5 & 6.05 & 64 \\
\hline 3 & 14 & 1044 & $2447.5-2457.0$ & $18.5-28.0$ & 9.5 & 8.95 & 94 \\
\hline 4 & 14 & 1132 & $2457.0-2466.5$ & $28.0-37.5$ & 9.5 & 7.15 & 75 \\
\hline 5 & 14 & 1216 & $2466.5-2476.0$ & $37.5-47.0$ & 9.5 & 8.44 & 89 \\
\hline 6 & 14 & 1412 & $2476.0-2485.5$ & $47.0-56.5$ & 9.5 & 6.10 & 64 \\
\hline 7 & 14 & 1500 & $2485.5-2495.0$ & $56.5-66.0$ & 9.5 & 9.83 & 103 \\
\hline 8 & 14 & 1547 & $2495.0-2504.5$ & $66.0-75.5$ & 9.5 & 4.32 & 45 \\
\hline 9 & 14 & 1635 & $2504.5-2514.0$ & $75.5-85.0$ & 9.5 & 8.89 & 94 \\
\hline 10 & 14 & 1733 & $2514.0-2523.5$ & $85.0-94.5$ & 9.5 & 9.87 & 104 \\
\hline 11 & 14 & 1819 & $2523.5-2533.0$ & $94.5-104.0$ & 9.5 & 9.82 & 104 \\
\hline 12 & 14 & 1915 & $2533.0-2542.5$ & $104.0-113.5$ & 9.5 & 8.82 & 93 \\
\hline 13 & 14 & 2015 & $2542.5-2552.0$ & $113.5-123.0$ & 9.5 & 9.85 & 104 \\
\hline 14 & 14 & 2124 & $2552.0-2561.5$ & $123.0-132.5$ & 9.5 & 7.55 & 79 \\
\hline 15 & 14 & 2340 & $2561.5-2571.0$ & $132.5-142.0$ & 9.5 & 4.93 & 52 \\
\hline 16 & 15 & 0030 & $2571.0-2580.5$ & $142.0-151.5$ & 9.5 & 5.51 & 58 \\
\hline 17 & 15 & 0128 & $2580.5-2590.0$ & $151.5-161.0$ & 9.5 & 3.95 & 42 \\
\hline 18 & 15 & 0225 & $2590.0-2599.5$ & $161.0-170.5$ & 9.5 & 8.76 & 92 \\
\hline 19 & 15 & 0330 & $2599.5-2609.0$ & $170.5-180.0$ & 9.5 & 9.94 & 105 \\
\hline 20 & 15 & 0453 & $2609.0-2618.5$ & $180.0-189.5$ & 9.5 & 9.61 & 101 \\
\hline 21 & 15 & 0633 & $2618.5-2628.0$ & $189.5-199.0$ & 9.5 & 5.20 & 55 \\
\hline 22 & 15 & 0811 & $2628.0-2637.5$ & $199.0-208.5$ & 9.5 & $\operatorname{tr}$ & $>0$ \\
\hline 23 & 15 & 1005 & $2637.5-2647.0$ & $208.5-218.0$ & 9.5 & 0.10 & 1 \\
\hline 24 & 15 & 1245 & $2647.0-2656.5$ & $218.0-227.5$ & 9.5 & 0.03 & $>1$ \\
\hline 25 & 15 & 1617 & $2656.5-2666.0$ & $227.5-237.0$ & 9.5 & 0.25 & 3 \\
\hline 26 & 15 & 1804 & $2666.0-2675.5$ & $237.0-246.5$ & 9.5 & 0.70 & 7 \\
\hline 27 & 15 & 1930 & $2675.5-2685.0$ & $246.5-256.0$ & 9.5 & 0.015 & $>1$ \\
\hline 28 & 15 & 2050 & $2685.0-2694.5$ & $256.0-265.5$ & 9.5 & 0.06 & $>1$ \\
\hline 29 & 15 & 2231 & $2694.5-2704.0$ & $265.5-275.0$ & 9.5 & 0.65 & 7 \\
\hline 30 & 15 & 2354 & $2704.0-2713.5$ & $275.0-284.5$ & 9.5 & 0.06 & 1 \\
\hline 31 & 16 & 0135 & $2713.5-2723.0$ & $284.5-294.0$ & 9.5 & 0.09 & 1 \\
\hline 32 & 16 & 0300 & $2723.0-2723.5$ & $294.0-294.5$ & 0.5 & 0.25 & 25 \\
\hline 33 & 16 & 0523 & $2685.0-2723.5$ & $256.0-294.5$ & NA & - & NA \\
\hline
\end{tabular}

Note: The last "core" is washings and cavings-a sample of the "matrix" from the "granite wash."

Table 10. Lithological units, Site 476.

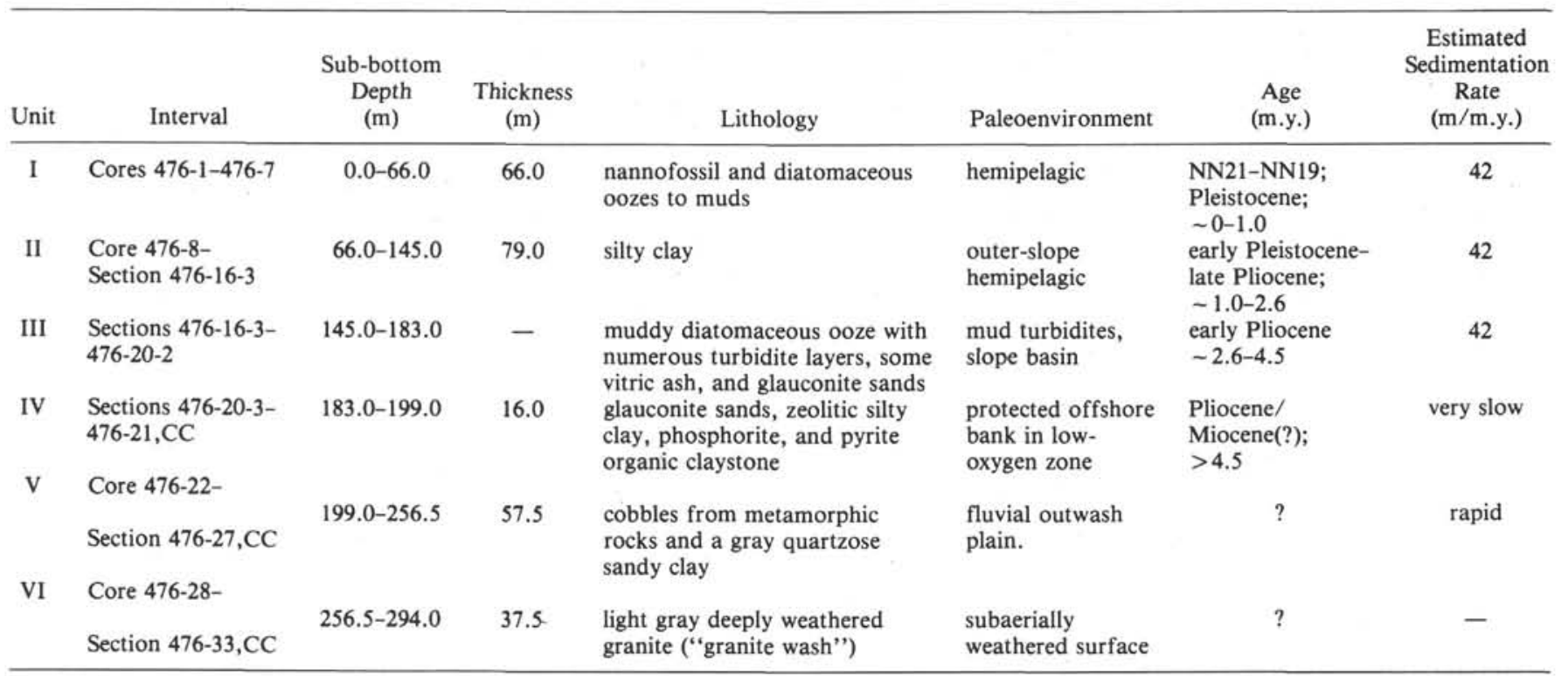

$5 / 4)$ with shades and faint mottles of pale olive (10Y $6 / 2$ ) to light olive gray $(5 Y 5 / 2)$. The fine-grained sediments are structureless but have a color banding with diffuse boundaries. Scattered white specks and sandy patches suggest extensive bioturbation. Darker shades appear slightly siltier and subtly "fine upward." Dia- tom frustules $(40-70 \%)$ again are a main component, but silicoflagellates and some radiolarians are also conspicuous. Except in sand layers, carbonate content is minimal, but nannofossils persist. The siliceous fossils show excellent preservation, which may indicate rather rapid deposition. The evidence for multiple mud tur- 


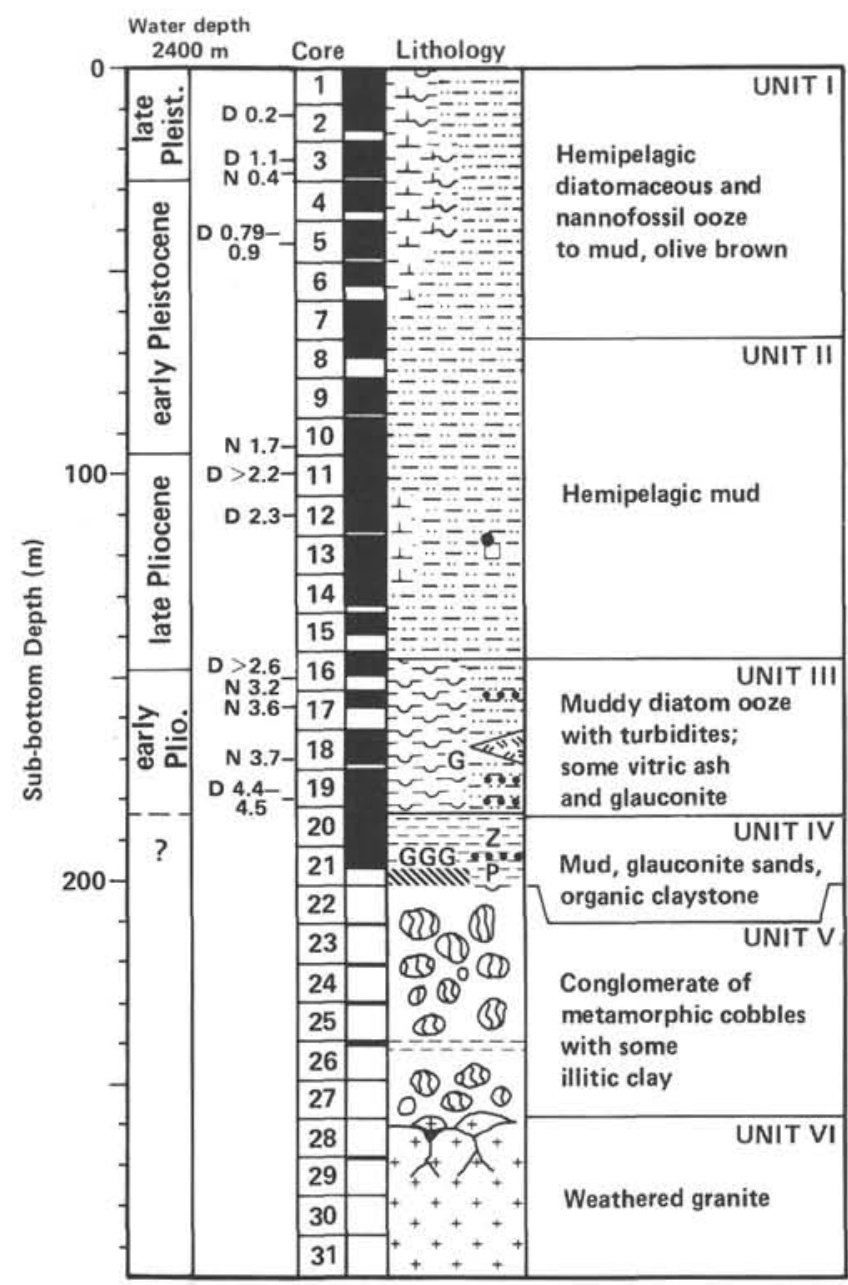

Figure 51. Simplified stratigraphic column, Site 476.

bidites is obscure, because bioturbation has erased contacts. Still, there are numerous traces of possible grading of components and color (e.g., Sections 476-18-6, 476-33-96). Unfortunately, core disturbance is intense in key places. Interspersed within Unit III are unconsolidated dark gray (N2) sand layers, mostly 1 to $2 \mathrm{~cm}$ but as thick as $25 \mathrm{~cm}$. Typically, they are well-sorted, grain-supported, discrete beds with very sharp basal contacts, although drilling may have winnowed out some of the fines. The components in coarse fractions are diverse. At the top of the section they comprise mainly angular quartz-feldspar-biotite grains with accessory foraminifers; others are mostly benthic and planktonic foraminifers $(20-50 \%)$ and rounded glauconite grains $(30-40 \%)$ within coincidental pyrite, radiolarians, and other miscellanea. Pelagic foraminifers are commonly filled with glauconite or pyrite. The condition of the glauconite grains suggests that they are not transported very far but may have been winnowed and redeposited from local submarine highs.

The most compelling evidence for regional early Pliocene subaerial rhyolitic volcanism is a 45 -cm-thick dark gray (N4) vitric ash layer from Sections 476-18-3 (130 $\mathrm{cm})$ to $476-18-4(15 \mathrm{~cm})$. Shards are lacy, well-sorted glass $(100-200 \mu \mathrm{m})$; they are fresh, clear, have a re- fractive index (RI) of 1.50 to 1.51 , and have no feldspar fragments. The uniform character suggests a windborne sediment (see Fig. 52). Similar vitric ash layers also occur in lower Pliocene sediments from DSDP Site 473, which at that time may have been quite near. A $45-\mathrm{cm}$ thick ash fall suggests a not-too-distant source.

Unit IV: organic claystones, glauconite sands, and zeolitic silty clay (Sections 476-20-3 [10 cm]-476-21, CC; 183-199.0 m, late Miocene-early Pliocene[?]). Unit IV is only 16.0 meters thick but contains a varied and complex group of sediments that possibly indicate a shallow shoal environment. As diatom debris dwindles, there is a gradational but rapid transition downward from the overlying sediments. The lithology changes to hard, light olive gray (5Y 5/2) silty clay with a brownish cast.

Smear slides show abundant, very fine-grained $(\sim 4$ $\mu \mathrm{m})$, low RI, low-birefringent, elongated, ragged minerals identified as clinoptilolite, possibly an alteration product of disseminated, vitric ash. Bedding is disturbed to vertical, and some sandier zones contain glauconite sands, which are also more calcareous. Three well-preserved, rhythmic units (Section 476-20-6) show grading color shades but lack clear evidence of size grading. Some hard, silty lumps seem to have a carbonate cement. Below Section 476-21-2, these zeolitic clays are mixed (as a drilling breccia) with massive, coarse glauconite sands. The sands form a loose fill around claystone chunks. There are abundant quartz grains with the glauconite pelloids, but benthic foraminifers are rare. In Section 476-21-3, the glauconite sand fills the section, and two rhythmic beds at the base grade from clay to glauconite sand. The sands are grainsupported and apparently winnowed of fines. An or-

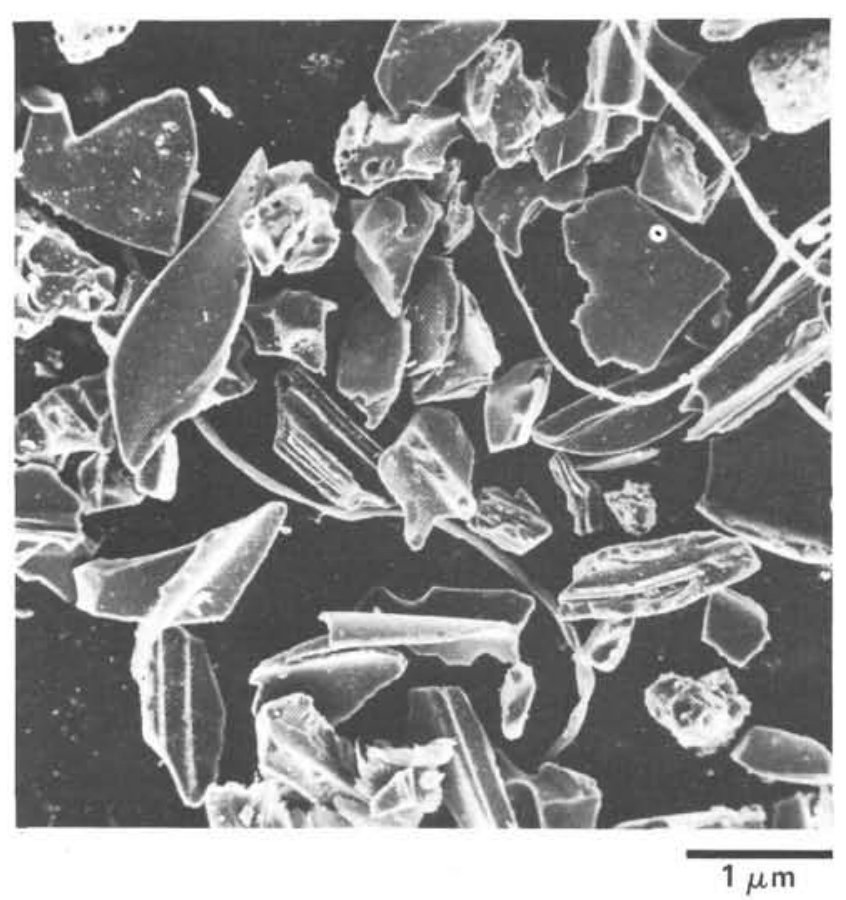

Figure 52. Photomicrograph of rhyolitic vitric ash, Section 476-18-3, $130 \mathrm{~cm}$. 
ganic claystone with a petroliferous odor marks the bottom $70 \mathrm{~cm}$ of this unit, but there is a thin $(2 \mathrm{~mm})$, hard, brown phosphorite layer at Section 476-21-4 (2 cm), pyrite-cemented sand concretions, green-cemented siltstone, and three rhythms of thin sandy clays with large quartz grains, some possibly analcime, and glauconite, just above $20 \mathrm{~cm}$ of olive black (5Y 2/1) claystone.

The organic claystone is centimeter-banded to thinly laminated and contains $7.5 \%$ total carbon, along with quartz silt, sparse glauconite, and many blue-green algal threads. Pollen grains and fungi spores are rare, which also suggests a marine origin.

Unit V: cobble conglomerate with metamorphic clasts (Core 476-22-Section 476-22, CC; 199.0-256.5 m, age unknown). Less than two meters were recovered from this 57-meter thick unit, which contains a diverse suite of lower greenschist-facies metamorphic clasts. These are probably part of a thick, coarse conglomerate unit with an inferred fine-sand matrix. Most are very quartzrich and show various levels of weathering. They include a green metagranite, metavolcanics, rhyolite, welded tuffs, metabreccia, metasedimentary siltstones, a graywacke, metasandstone, a metaconglomerate, and quartzite. Some were cored, which means some original cobbles may have been $30 \mathrm{~cm}$ or greater, indicating relatively short transport distance. None of the clasts consisted of batholith-type granite or granodiorite.

Sandwiched between two cobbles in Section 476-26-1, are $45 \mathrm{~cm}$ of a dark gray (N4), disturbed sandy clay. The origin of this clay is conjectural, but it resembles the granite below; it comprises very angular chips of quartz, highly weathered feldspars, and a moderately high birefringent, coarse clay with a ragged splinter appearance. With minor dessication, the sandy clay hardens to a solid rock. This clay is tentatively identified as hydromuscovite (illite), and its presence supports a waterlain continental setting for this bed. An alternative interpretation is that the clay represents a fault gauge from the granite. A single, well-preserved fungus spore in a smear side is further evidence of a continental sediment.

Unit VI: weathered, gray granite and rubble ("granite wash') (Cores 476-28-476-33, 256.5-294.0 m, Upper Cretaceous [?]). This unit is not strictly a sediment, but it appears to partially comprise weathered granitic boulders on a deeply weathered granitic basement. Many feldspars have been pervasively sericitized, and biotites and hornblendes are chloritized. Two harder pieces are described in the igneous rocks section. In most pieces there is flow structure, and quartz grains are highly fractured, suggesting proximity to a fault. The characteristics and type of weathering indicate an in situ subaerial weathering in an arid environment.

\section{Paleoenvironment}

Unit I sediments are considered to be typically hemipelagic, open-ocean, outer-slope sediments, with climatically induced pulses of diatom and nannofossil productivity or fluctuating terrigenous contributions. The sands are mostly winnowed lag deposits from periods of increased bottom currents, including times of lowered sea level.
Unit II is probably an outer-slope hemipelagic sequence. Sediments accumulated relatively slowly (40-50 $\mathrm{m} / \mathrm{m} . \mathrm{y}$.) with episodic winnowing and redeposition.

The exact paleoenvironmental setting is not clear, but sediments from Unit III suggest an upper-slope fringe or plateau, perhaps protected from continuous terrigenous contributions and periodically winnowed by current. Intense upwelling may also have generated high diatom productivity. Local highs could have provided episodic influxes of spill-over lag deposits of benthic foraminifers, glauconite, angular quartz, and diatoms. Sporadically, muddy turbidites from other sources might have reached this area.

The environment of deposition for Unit IV is unclear, but it must represent moderately shallow water (initially in the photic zone) in a restricted, protective setting. Intertidal algal mats are unlikely settings because of the presence of glauconite grains and the lack of shallow-water carbonate. We envisage an offshore bank, subsiding in a restricted setting or $\mathrm{O}_{2}$-minimum zone and isolated from the mainland. It is, however, difficult to explain the source of coarse quartz silt in the interlayered muds, unless they are storm deposits or the product of winnowing. The association of phosphorite, pyrite, and glauconite also points to an isolated, offshore bank, about 200 meters or deeper, near the zone of upwelling bottom waters. From the thickness of this facies, we suggest that Site 476 moved fairly rapidly through this sediment regime.

One interpretation for the Unit V metamorphic cobble beds and quartz-illite clay invokes large arroyos draining from the "Paleozoic," metamorphic cover on the Baja batholith, dumping the rocks at the mouth of an outwash, braided river plain. Similar rock assemblages outcrop along the tip of Baja California-for example, near San José del Cabo. After only a short transport distance, the present rivers have few granite cobbles-most of them crumble quickly from semiarid weathering.

In general, recent examples of almost all the sediment facies cored at Site 476 can be found in regions on, or offshore from, present-day Baja California. The lithological units also correlate closely with the drilled sequence at Site 475 .

\section{ORGANIC GEOCHEMISTRY}

The monitoring program was conducted aboard ship. Hydrocarbon gases were not detected in this sediment sequence, since no gas pockets formed in any core liner. In some sections, however, slow gas diffusion built up a pressure under the caps, and these were sampled and analyzed. The results are plotted in Fig. 53. This increase in gas pressure was caused by outgassing of $\mathrm{CO}_{2}$, and the data are very scattered; there is a possible decreasing trend in concentration with depth. The odor of $\mathrm{H}_{2} \mathrm{~S}$ was evident in the sediments from about 3 to 66 meters sub-bottom, and it was strongest in the shallower cores. The concentration was below the GC-detection limit, and the qualitative odor strength was Hole $474>$ Hole $476>$ Hole 475 . 


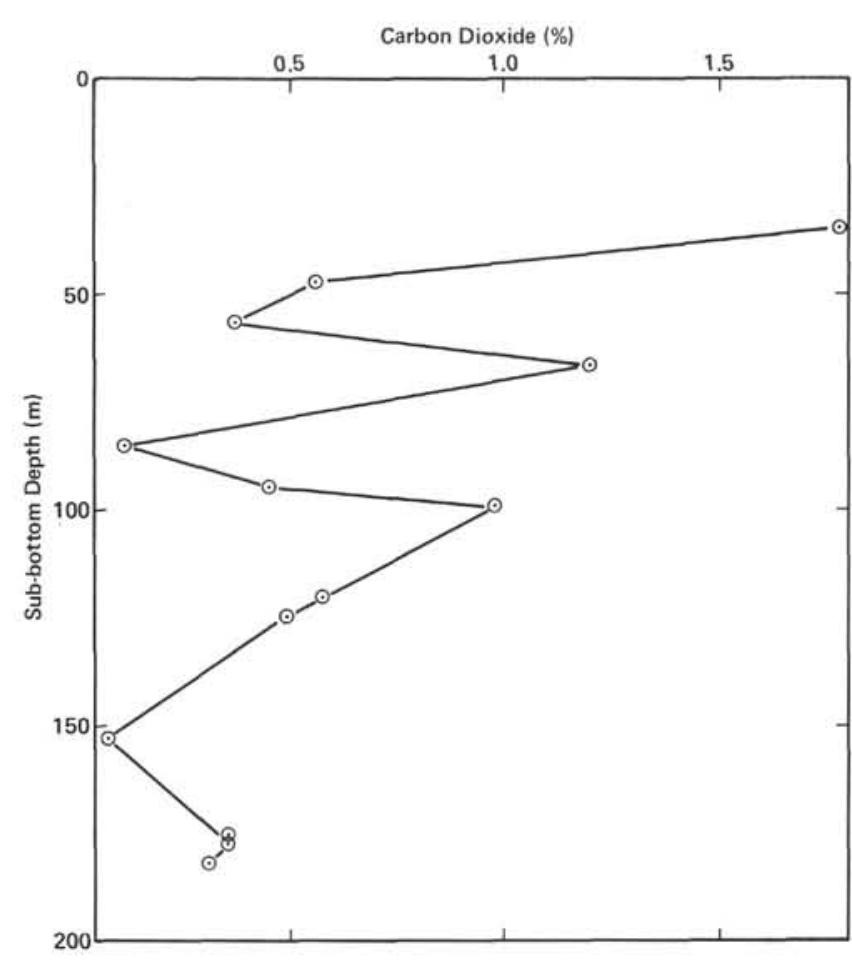

Figure 53. Carbon dioxide concentration versus depth, Site 476.

\section{Organic Carbon and Nitrogen}

The samples were analyzed as before and the results from the CHN analyzer are summarized in Appendix I, this volume, Pt. 2. The organic carbon and nitrogen values and ratios are plotted versus depth in Fig. 54. The organic carbon content ranges from about 0.7 to $7 \%$, with three maxima downhole. In Units I (a nannoplankton ooze) and II (a silty clay), the values range to a maximum of about $3 \%$, and in the base of Unit IV (pyritic

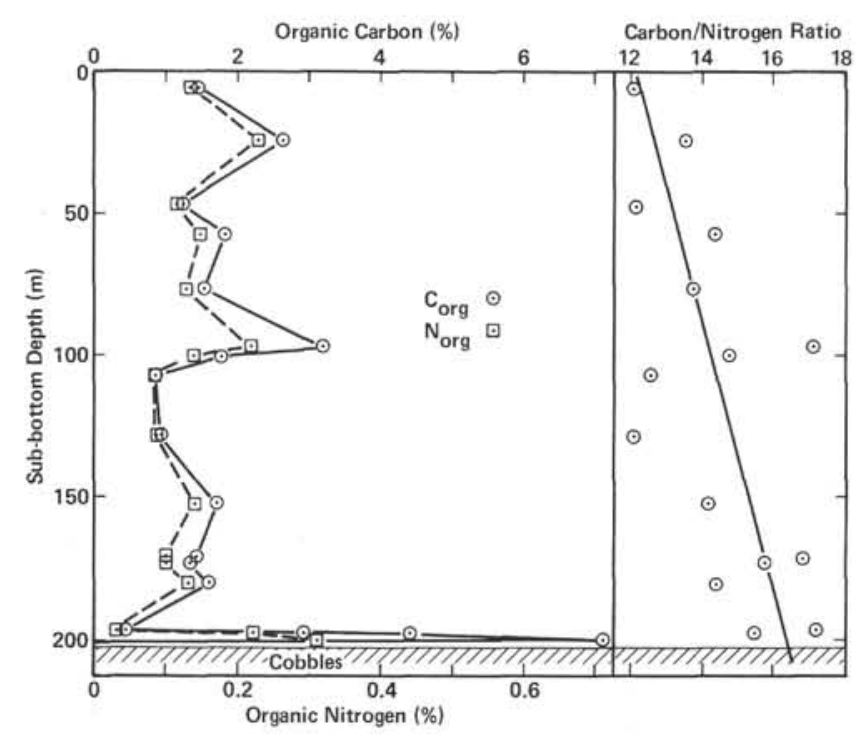

Figure 54. Organic carbon and nitrogen: content and ratios versus depth, Site 476. claystone) the values range to about $7 \%$. The organic nitrogen content parallels the organic carbon distribution and ranges from about 0.03 to $0.23 \%$ with the same maxima. The $\mathrm{C} / \mathrm{N}$ ratio exhibits a trend to higher values with depth, and the values of the upper section are within the range (about 12) typical for Recent, unaltered, and immature sediments (Ryther, 1956). The onset of diagenetic alteration of the organic matter is indicated by the trend of the $\mathrm{C} / \mathrm{N}$ increase with depth.

\section{Fluorescence}

Fluorescence data were obtained from dried sediment samples, trichloroethane extract solutions of dried sediment, and pyrolized samples. Most of the samples exhibited no fluorescence for the extract and raw sediment, and most exhibited yellow fluorescence for the pyrolized sample extracts. The pyritic organic claystones (Sections 476-21-4 and 476-21,CC) exhibited very strong, yellow blue fluorescence for the pyrolysis extract. With the exception of the organic claystone section, the samples contain no petroleum; under the present in situ environmental conditions they lack a high potential as source material for petrogenesis.

\section{Bromide Determination}

The organic claystones (Sections 476-21-4 and 476$21, \mathrm{CC}$ ) may contain algal detritus as found in sapropels (indicated by color and visual and microscopic examination), and therefore a test for bromide was carried out. This is a qualitative spot test based on the reaction:

$$
2 \mathrm{MnO}_{4}^{-}+10 \mathrm{Br}^{-}+16 \mathrm{H}^{+} \rightarrow 2 \mathrm{Mn}^{++}+5 \mathrm{Br}_{2}+8 \mathrm{H}_{2} \mathrm{O} \text {. }
$$

The samples were first leached with water and then digested with nitric acid (conc.). Clear supernatant was taken from each treatment and acidified or diluted to yield about a $0.5-\mathrm{M} \mathrm{HNO}_{3}$ solution. Potassium permanganate $(0.02 \mathrm{M})$ was added dropwise until no further oxidation took place (loss of $\mathrm{MnO}_{4}^{-}$purple color). Tetrachloroethane was added to extract any resulting $\mathrm{Br}_{2}$.

Both samples, as well as seawater, showed no $\mathrm{Br}_{2}$ formation. This negative result may have been caused by the poor sensitivity of the test, or it may be that the organobromides accumulated by living algae have undergone diagenesis or decomposition with loss of $\mathrm{Br}^{-}$.

The sedimentation rate at Site 476 was relatively slow, thus the potential for endogenous biogenic gas is low. Only $\mathrm{H}_{2} \mathrm{~S}$ and $\mathrm{CO}_{2}$ were detected. The organic carbon and nitrogen contents were typical for biogenic ooze and silty clay. At the base of the sequence (in Unit IV) the $\mathrm{C}$ and $\mathrm{N}$ values increased in the pyritic organic claystone. The petrogenic potential of the organic matter is immature.

\section{INORGANIC GEOCHEMISTRY}

\section{Interstitial Water Chemistry (Fig. 55)}

Alkalinity values and ammonia and phosphate concentrations show maxima in the upper 100 meters of the sediment column and are a result of biochemical degradation of organic matter. Dissolved calcium shows a 

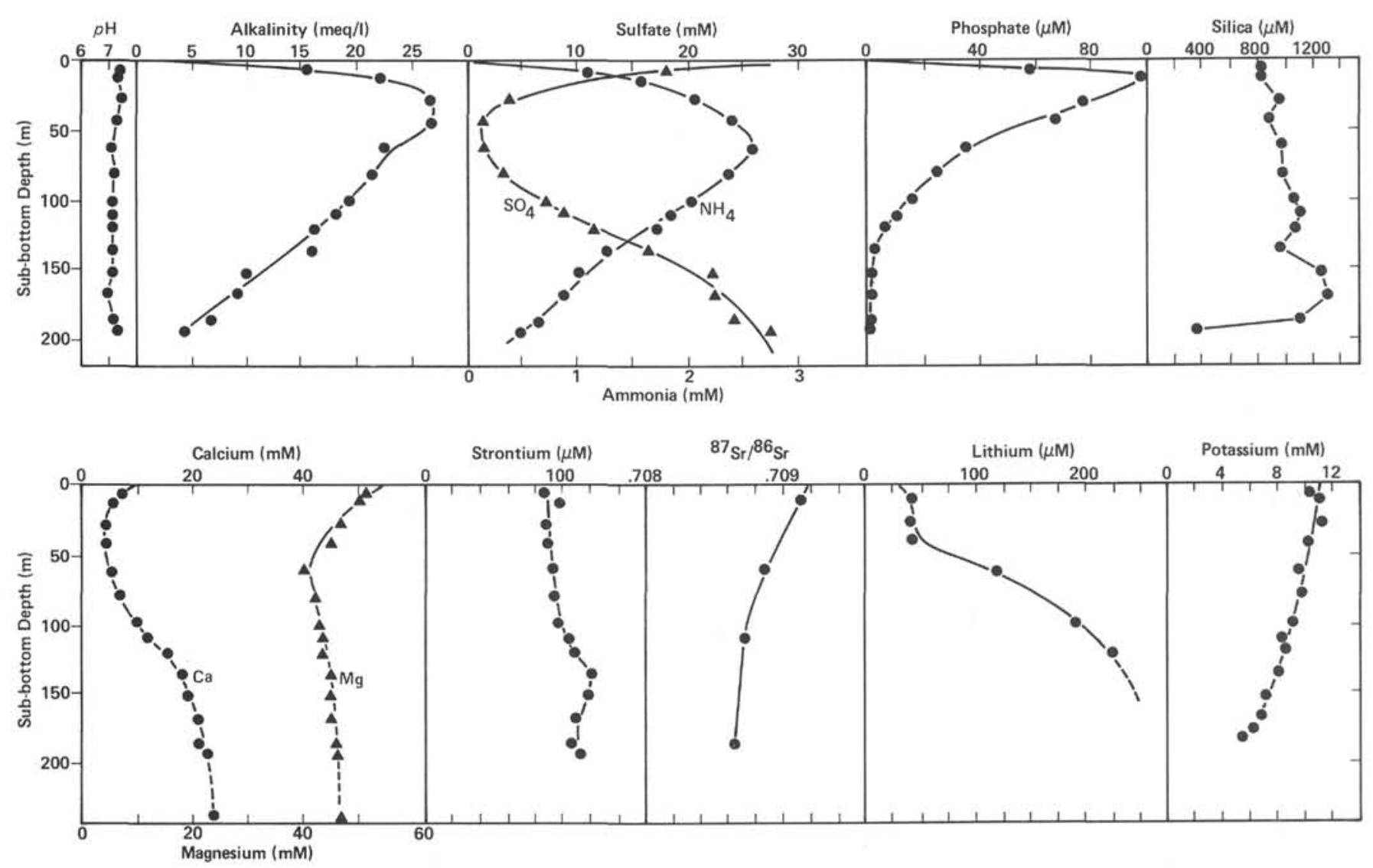

Figure 55. Interstitial water chemistry, Site 476.

minimum - from calcium carbonate precipitation-at about $\mathbf{4 0}$ meters. Below this, calcium concentrations increase rapidly and are probably related to weathering involving underlying continental basement rocks. Of special interest is the reversal in the magnesium concentrations, a phenomenon rarely observed at DSDP sites. This can best be explained by the weathering of underlying granitic rocks. Dissolved silica concentrations indicate the presence of biogenic silica, and the overall increase in concentrations with depth is the result of higher opaline silica solubilities caused by increased temperatures.

\section{BIOSTRATIGRAPHY}

The sedimentary sequence at Site 476 (Fig. 56) contains calcareous nannofossil assemblages similar to those at Site 475. Abundance, preservation, and composition of these assemblages are also very similar at both sites.

\section{Coccoliths}

Cores 476-1, 476-2, and 476-3 are late Pleistocene. Core 476-4 through Section 476-10-5 is early Pleistocene. The Pleistocene/Pliocene boundary, less sharply marked than at Site 475, occurs between Sample 476$10-5,82-83 \mathrm{~cm}$ and $476-11-1,70-71 \mathrm{~cm}$. Sample 476$11-1,70-71 \mathrm{~cm}$ through Section $476-16-2$ is late Pliocene, and Section 476-16-3 through Core 476-21 is early Pliocene.

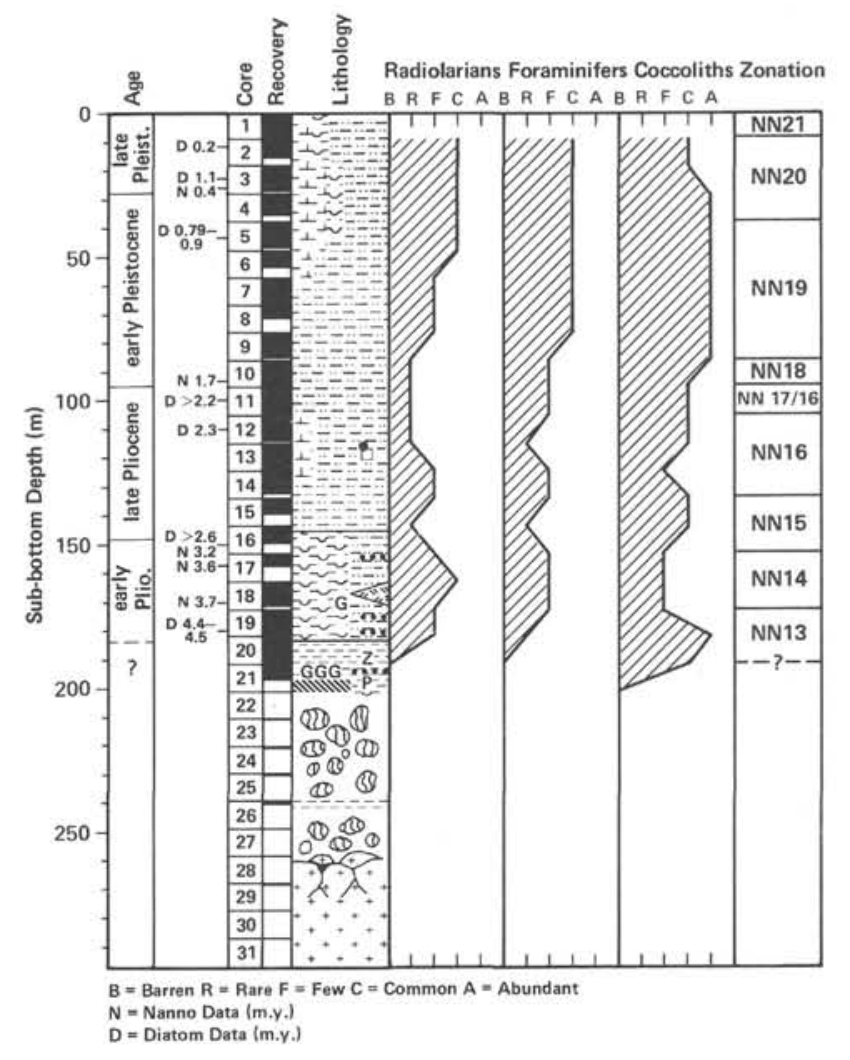

Figure 56. Biostratigraphy, Site 476. 
Pseudoemiliania lacunosa first occurs in Sample 4764-5, 37-28 cm. Because of reworking the occurrences of Helicosphaera sellii and Cyclococcolithus macintyrei are sporadic and therefore do not provide biostratigraphic data. Discoaster brouweri increases in abundance in Sections 476-10-5, 476-10-6, and 476-10-7. Discoaster pentaradiatus occurs in Sample 476-11-3, 74-75 cm, where it may be reworked; it occurs again in Core 47612 with $D$. surculus. Typical Reticulofenestra pseudoumbilica first occurs in Sample 476-16-3, 58-59 cm, Amaurolithus tricorniculatus in Sample 476-17-3, 51-52 cm.

\section{Diatoms}

Open-marine-tropical-to-subtropical planktonic diatoms are abundant and well preserved to rare and poorly preserved in the hemipelagic sediment sequence in Cores 476-1 through 476-20; samples below Section 476-20-5, are barren of diatoms. The following key biostratigraphic species were found: Nitzschia reinholdii, 4762-1, 95-97 cm; Mesocena quadrangula, 476-5-5, 36-38 $\mathrm{cm}$; Rhizosolenia barboi/curvirostris, 475-8-1, 72-74 $\mathrm{cm}$; Thalassiosira convexa, 476-11-5, 93-95 cm; Cussia tatsunokuchiensis and $N$. jouseae, 476-16-4, 34- $36 \mathrm{~cm}$; Cosmiodiscus insignis, 476-19-3, 84-86 cm; N. cylindrica, 476-19-6, 84-86 cm. Distinct colder intervals, determined by the presence of $R$. barboi/curvirostris occur at the following levels: 476-3-4, 49-51 cm and $476-8-1,72-74 \mathrm{~cm}$. The assemblage correlates with that of Site 475 .

\section{Radiolarians}

Hole 476 has index species for biostratigraphical control only in the lowermost part of the fine-grained sedimentary sequence (Sections 476-16-476-20). The species are Stichocorys peregrina, Ommatartus avitus, and $O$. penultimus and are dated late Miocene to early Pliocene. Such an age agrees with the nannoplankton zonation (NN15-13).

The fine-grained lowermost sedimentary sequence in Hole 476 is a diatomaceous ooze. Within this sequence, we observed a bloom of Euchitonia spp. and Spongodiscus biconcavus.

The composition of species in the radiolarian population in the Quaternary is typical of subtropical continental margins; among others: Tetrapyle octacantha, Botryostrobus auritus-australis group, Euchitonia furcata, O. tetrathalamus, Stylochlamydium asteriscus, and Lithelius minor. This radiolarian population shows some effect of coastal upwelling, as is suggested by the relative abundance of Duppatractus cf. pyriformis, $D$. irregularis, and Polysolenia murrayana.

The relative abundance of radiolarians in the upper two-thirds of Hole 476 has a trend similar to the record in Hole 475.

\section{Planktonic Foraminifers}

A planktonic foraminiferal zonation for Hole 476 has not been established, because "typical" index species for biostratigraphic control have not been found. Nevertheless, the Pliocene portion of the hole is characterized by the presence of Globigerinoides obliquus extremus(?). In the Quaternary, a subtropical planktonic foraminiferal population is common, probably affected by the California Current and coastal upwelling. This population is dominated by Neogloboquadrina dutertrei, G. ruber, Globigerina bulloides, and Globoquadrina pachyderma right coiling.

The composition of the foraminiferal population in Hole 476 is similar to that in Hole 475. Also, the relative abundance of planktonic foraminifers in the upper twothirds of Hole 476 resembles the record in Hole 475.

\section{SEDIMENT ACCUMULATION RATES}

The sediment accumulation rates (Fig. 57) are slightly higher at Site 476 than at Site $\mathbf{4 7 5}$. This may reflect its location nearer to an outer slope basin axis. Despite varying abundances of plankton, the overall rate for Units I, II, and III is fairly uniform $(42 \mathrm{~m} / \mathrm{m}$.y.).

Glauconitic-phosphoritic claystones in Unit IV probably had a much lower rate of accumulation, but if the hemipelagic rates are projected further, deposition of the conglomerates could have occurred before the latest Miocene and they were probably rapidly emplaced.

\section{IGNEOUS PETROLOGY}

Weathered granite was encountered in the core catcher of Core 476-28 (256.0-265.0 m sub-bottom), although drilling an additional 29.0 meters recovered only 1.14 meters of rock. The samples (Fig. 58) in Cores 476-28 through 476-31 are a biotite- and hornblende-bearing granite that is medium-grained, inequigranular, and light gray $(5 \mathrm{~B} 7 / 1)$. In the fresher samples, the major mineralogical components are anhedral-to-subhedral feldspar, comprising albite $(15 \%)$ and perthitic orthoclase $(40 \%)$, although no microcline was observed; anhedral, rounded, fractured, and strained quartz ( $35 \%)$; equant and acicular grains of hornblende $(<5 \%)$, now variably replaced by chlorite; and biotite and muscovite $(<5 \%)$ also now replaced by chlorite and containing zircon. Minor amounts of euhedral pyrite crystals occur in veins and clusters; apple green epidote fills a few small cavities. Drusy quartz commonly lines small microlitic cavities (as large as $5 \times 2 \mathrm{~mm}$ ).

Within the granite, texture varies considerably. Pieces 5 and 12 of Section 476-29-1 are the freshest samples, exhibiting hypidiomorphic textures and slight alteration of the biotite and hornblende. Most pieces, however, show replacement of the mafic minerals by chlorite, sericitization of the albite, and cataclastic textures indicating intense deformation. In the most deformed samples, the minerals form isolated fragments within a streaky, aphanitic, mylonitized matrix.

Many of the samples are cobbles that lack drilling surfaces and therefore have no orientation. This is par-

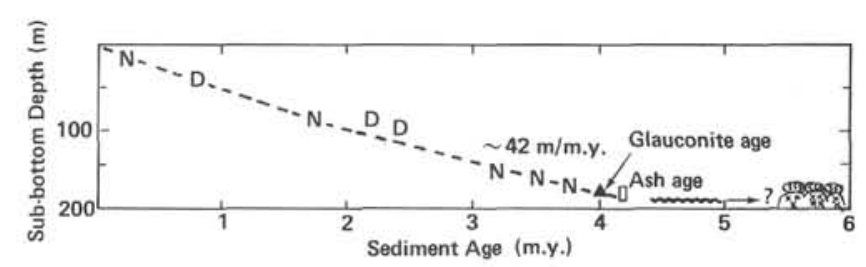

Figure 57. Sediment accumulation rates, Site 476. 


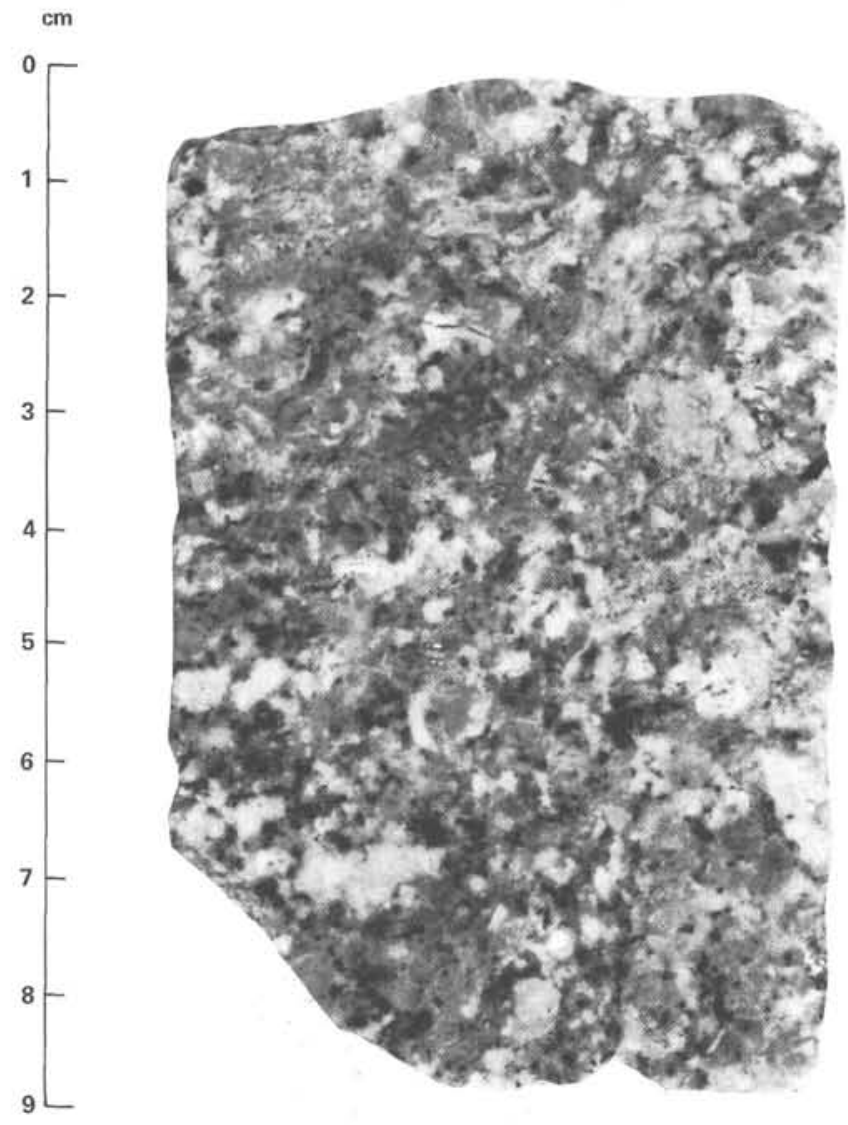

Figure 58. Hornblende, biotite granite from Section 476-29-1, Piece 6.

tially explained by the drilling record which indicates that the bit encountered mostly unconsolidated material, thereby allowing each 9.5-meter core to be drilled quickly (20-28 min.). Perhaps we drilled through a sequence of granite blocks interspersed with weathered granite or granitic detritus-an association common in subaerially exposed terrains. Because granite is easily weathered by subaerial (or subaqueous) processes, the samples from Hole 476 probably were not transported very far, if at all, from their site of exposure.

\section{PHYSICAL PROPERTIES}

As at the previous sites, the uppermost and some deeper cores (e.g., Cores 476-6, 476-8, 476-9, 476-21) are strongly and rather continuously disturbed. Therefore, in general, only samples for determining water content were taken from these cores. The lowermost part of the hole (from $200 \mathrm{~m}$ down), where cobbles, some highly disturbed clayey silt, and quartz silt were encountered, is not represented in Figure 59.

In the upper 130 to 140 meters of the Pliocene to Quaternary sediments, the trend curves for the different physical properties are very similar to those of Site 475 (Figs. 59, 60). At the transition from Sedimentary Unit I (diatomaceous nannofossil-bearing silty clay) to Unit II (a rather pure silty clay at about $70 \mathrm{~m}$ ), water content and porosity distinctly decrease, whereas bulk density increases. Farther downhole, to about 140 meters, these physical properties remain more or less constant.
Unlike Sites 474 and 475 , in a section from 150 to 180 meters, water content and porosity again increase from 45 to $55 \%$ and 70 to $75 \%$, respectively. Bulk density drops from 1.53 to $1.40 \mathrm{~g} / \mathrm{cm}^{3}$, and vane shear strength and sound velocity are also somewhat reduced. This unusual change of physical properties is caused by the high content of diatoms (diatomaceous ooze of Unit III), which are not strongly affected by diagenesis. The proportion of opaline silica-as determined from the average grain density of the total samples-is plotted in Figure 59 (for further details, see Site 474 remarks, earlier). The shrinkage of dried $\left(110^{\circ} \mathrm{C}\right)$ cylinder samples, which ranges from about 35 to $40 \%$ in upper Sedimentary Units I and II, is now, however, limited to $10 \%$, indicating that the grain packing must have been somewhat stabilized. Yet sediments very rich in biogenic silica appear to shrink less than samples with higher clay content, provided that the initial water content or porosity was about the same. Unfortunately, the transition to the deeper Unit IV, consisting of firm zeolite-bearing clay, could not be tested because of strong core disturbances. Several samples within this unit now show very low water contents (about $30 \%$ ), porosities of $55 \%$ and less, high bulk densities of $1.8 \mathrm{~g} / \mathrm{cm}^{3}$, and an increase in shear strength (more than $1.3 \times 10^{5} \mathrm{~Pa}=\sim 1300 \mathrm{~g} / \mathrm{cm}^{2}$ ) and sound velocity $(1.63 \mathrm{~km} / \mathrm{s})$. At 200 meters, acoustic impedance is nearly $3.0 \times 10^{5} \mathrm{~g} / \mathrm{cm}^{2} \mathrm{~s}$. The marked change of all physical properties in Unit IV is confirmed by the observation that in some silty layers cementation by calcite has already begun (Sample 476-20-4, 25-30 $\mathrm{cm})$. Whether this is caused solely by the presumably higher age of this material (NN11-NN13) or whether a former sediment column on top of Unit IV has been removed by erosion before the present Units III to I were accumulated cannot be resolved.

As at Site 476, a light olive gray, nannofossil-rich layer and a dark brownish layer rich in diatoms from the same depth were compared (Samples 476-1-3, 23-25 cm and 476-1-3, 44-46 cm). The results are as follows:

\begin{tabular}{lccc}
\hline & $\begin{array}{c}\text { Water } \\
\text { Content } \\
(\%)\end{array}$ & $\begin{array}{c}\text { Porosity } \\
(\%)\end{array}$ & $\begin{array}{c}\text { Bulk } \\
\text { Density } \\
\left(\mathrm{g} / \mathrm{cm}^{3}\right)\end{array}$ \\
\hline Dark layer, high in diatoms & 65.5 & 82.1 & 1.28 \\
Light layer & 56.1 & 76.7 & 1.40 \\
\hline
\end{tabular}

Although the sediments were disturbed, the difference in physical properties between these very common "subunits" of the Pliocene-Quaternary sediment sequence appears to be well established (e.g., see Tucholke et al., 1976).

From selected samples from the lowermost part of the hole (but not represented in Fig. 59), we determined sonic velocity (by the Hamilton Frame), wet-bulk density, and acoustic impedance (Table 11).

\section{HEAT FLOW AND THERMAL CONDUCTIVITY}

Thermal conductivities at Site 476 are low $(\sim 2.2$ $\mathrm{mcal} / \mathrm{cm} \mathrm{s}^{\circ} \mathrm{C}$ ) in the surface 30 meters of diatomaceous ooze, are higher $(2.4-2.5 \mathrm{mcal})$ in the silty claystone ex- 


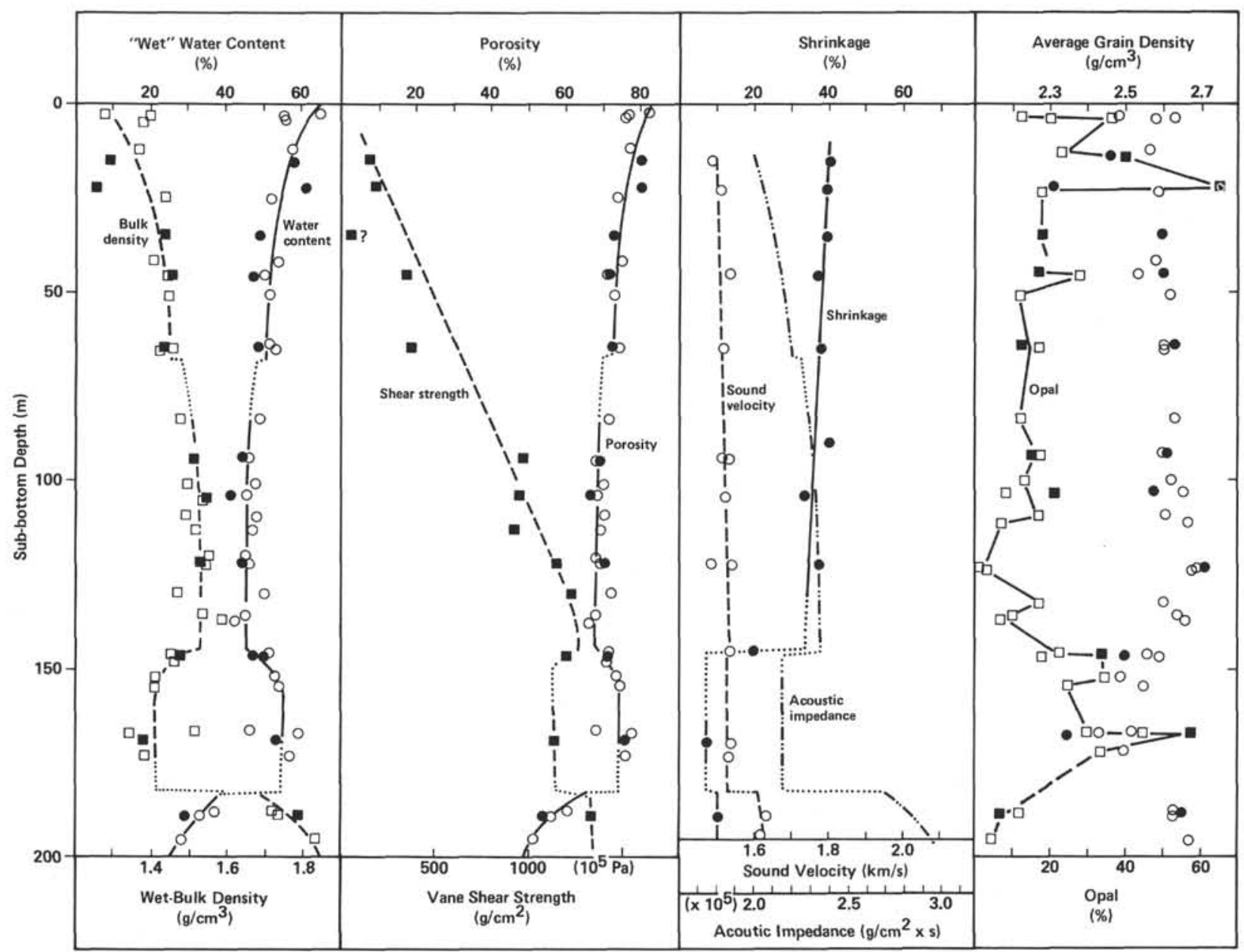

Figure 59. Mass physical properties, shrinkage, and proportion of opaline silica, Site 476 sediments. (Note the pronounced changes [140-180 m] caused by high content of opaline silica; note also the unusual increase of compaction in the section from 180-200 m. Closed symbols are cylinder samples. Open symbols are chunk samples.)

tending to 145 meters, and are again low (2.1-2.2 mcal) in the lower diatomaceous ooze (see Fig. 61A). The highest thermal conductivity is in the lowest clay (Core 476$21 ; 2.94 \mathrm{mcal} / \mathrm{cm} \mathrm{s}^{\circ} \mathrm{C}$ ). Thermal conductivities are again inversely correlated with the water content of the units.

In situ temperatures were measured in Hole 476 at depths of 47.0 and 123.0 meters and plotted versus depth (Fig. 61B).

Three distinct temperature gradients can be calculated using the temperature at 47.0 meters and the bottom-water temperature, the temperature at 123.0 meters and the bottom water temperature, and the temperatures at 123.0 and 47.0 meters. Heat flow calculations, taking thermal conductivity changes into account, yield heat flows of 4.0, 2.4, and 1.4 HFU, respectively.

The low heat flow calculated using the two in situ temperatures (1.4 HFU) suggests that the temperature measured at 47.0 meters may be high and that heat flow at this site is approximately $2.4 \mathrm{HFU}$. If this is true, the transect from oceanic to continental crust is marked by moderate-to-low heat flows for the young oceanic crust (3.1 HFU at Site 474), high heat flow in the transition zone (4.0 HFU at Site 475), and lower heat flow on the continental site (2.4 HFU at Site 476).

\section{CORRELATION OF DRILLING RESULTS AND SEISMIC DATA}

Site 476 is in an area with extensive seismic-reflection coverage from the Scripps Institution of Oceanography, the University of Washington International Program on Oceanic Drilling (IPOD) Site-Survey cruises, and other studies. We will attempt later (Curray et al., this volume, Pt. 2) to relate results of drilling at this and the previous two sites, 474 and 475 , to regional structure and tectonics. We intend now only to relate the lithological column to the reflection record obtained when the beacon was dropped.

No multichannel moveout velocities and no sonobuoy wide-angle reflection velocity information is available; neither were downhole logs run. The only velocity information is the laboratory measurements reported in this chapter. Accepting these values and assuming velocities for the other units, we assign velocities to the lithological units as follows:

Unit I: 0-66 meters; Pleistocene nannofossil and diatom ooze; $1.51 \mathrm{~km} / \mathrm{s}$

Unit II: $66-145$ meters; late Pliocene silty clay; 1.53 $\mathrm{km} / \mathrm{s}$ 


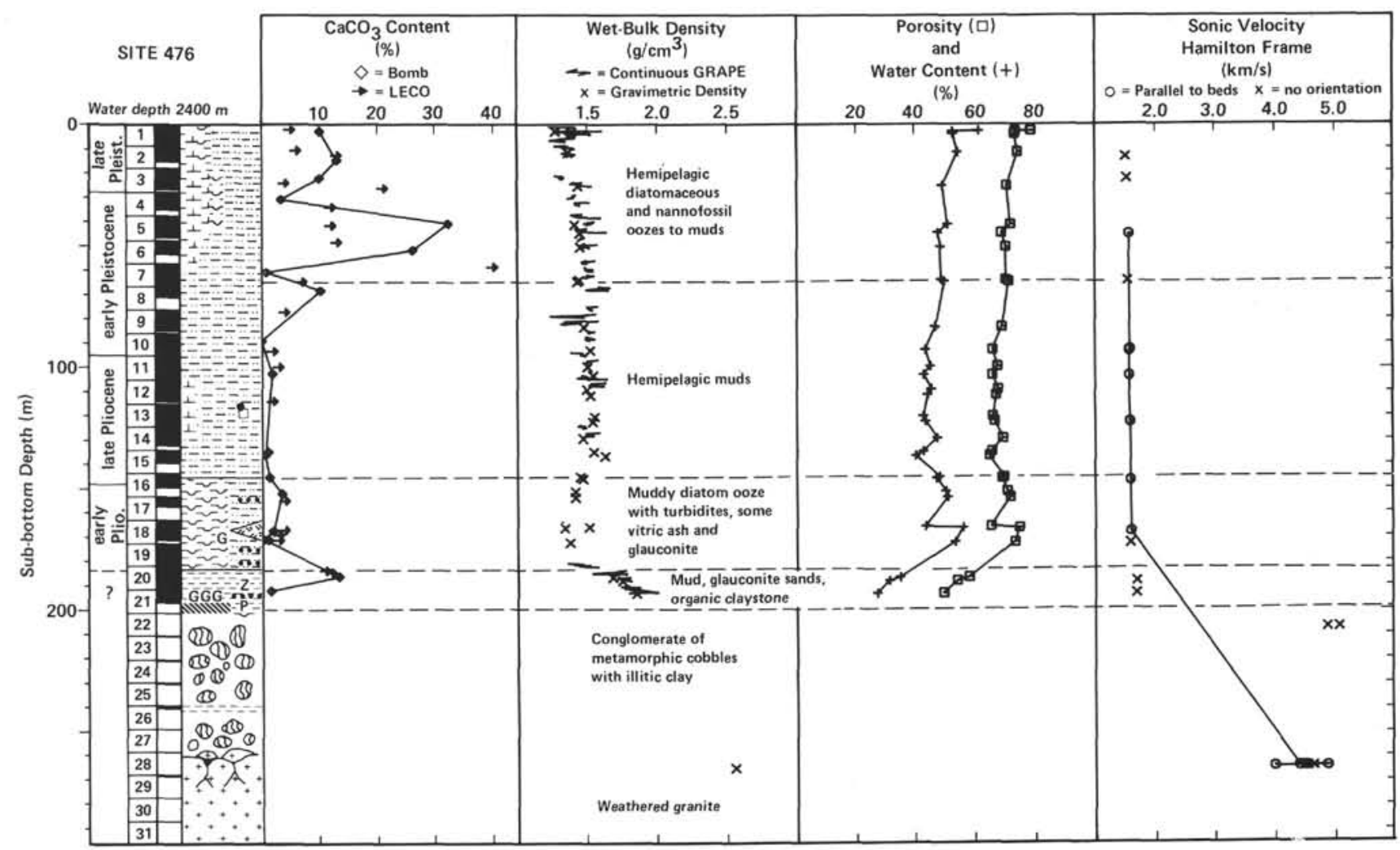

Figure 60. Calcium carbonate and physical properties, Site 476. Analyzed ashore at Scripps Institution.

Table 11 . Sonic velocity $\left(v_{\mathrm{S}}\right)$, wet-bulk density (BD), and acoustic impedance (AI) of some samples from Unit V, Site 476.

\begin{tabular}{|c|c|c|c|c|}
\hline $\begin{array}{c}\text { Sample } \\
\text { (level in } \mathrm{cm} \text { ) }\end{array}$ & Description & $\begin{array}{c}v_{\mathrm{s}} \\
(\mathrm{km} / \mathrm{s})\end{array}$ & $\underset{\left(\mathrm{g} / \mathrm{cm}^{3}\right)}{\mathrm{BD}}$ & $\left(\times 10^{5} \mathrm{~g} / \mathrm{cm}^{2} \mathrm{~s}\right)$ \\
\hline $476-23, \mathrm{CC}$ & $\begin{array}{l}\text { metamorphic sandy } \\
\text { siltstone }\end{array}$ & 5.13 & - & - \\
\hline $476-23, \mathrm{CC}$ & $\begin{array}{l}\text { metamorphic sandy } \\
\text { siltstone }\end{array}$ & 4.92 & - & - \\
\hline $476-29-1,20$ & fresher granite & 4.42 & - & - \\
\hline $476-29-1,20$ & fresher granite & 4.53 & - & - \\
\hline $476-29-1,37$ & $\begin{array}{l}\text { cataclastic granite, } \\
\text { weathered }\end{array}$ & 4.91 & 2.51 & 11.4 \\
\hline $476-29-1,37$ & $\begin{array}{l}\text { cataclastic granite, } \\
\text { weathered }\end{array}$ & 3.99 & 2.51 & 11.4 \\
\hline $476-29-1,37$ & $\begin{array}{l}\text { cataclastic granite, } \\
\text { weathered }\end{array}$ & 4.66 & 2.51 & 11.4 \\
\hline $476-29-1,37$ & $\begin{array}{l}\text { cataclastic granite, } \\
\text { weathered }\end{array}$ & 4.57 & 2.51 & 11.4 \\
\hline
\end{tabular}

Unit III: 145-183 meters; early Pliocene diatom ooze; $1.54 \mathrm{~km} / \mathrm{s}$

Unit IV: 183-199 meters; Pliocene-Miocene glauconitic sand, phosphorite, and the like; $1.61 \mathrm{~km} / \mathrm{s}$

Unit V: 199-256 meters; cobble conglomerate; 1.61 $\mathrm{km} / \mathrm{s}$

Unit VI: 256-294 meters; weathered granite: 1.61 $\mathrm{km} / \mathrm{s}$.

The two-second sweep record across this site, without interpretation or correlation, is shown in Figure 62A. Figure 62B shows the same record with an interpretation of structure and a correlation with the units as defined. The overall structure is a series of low-angle normal

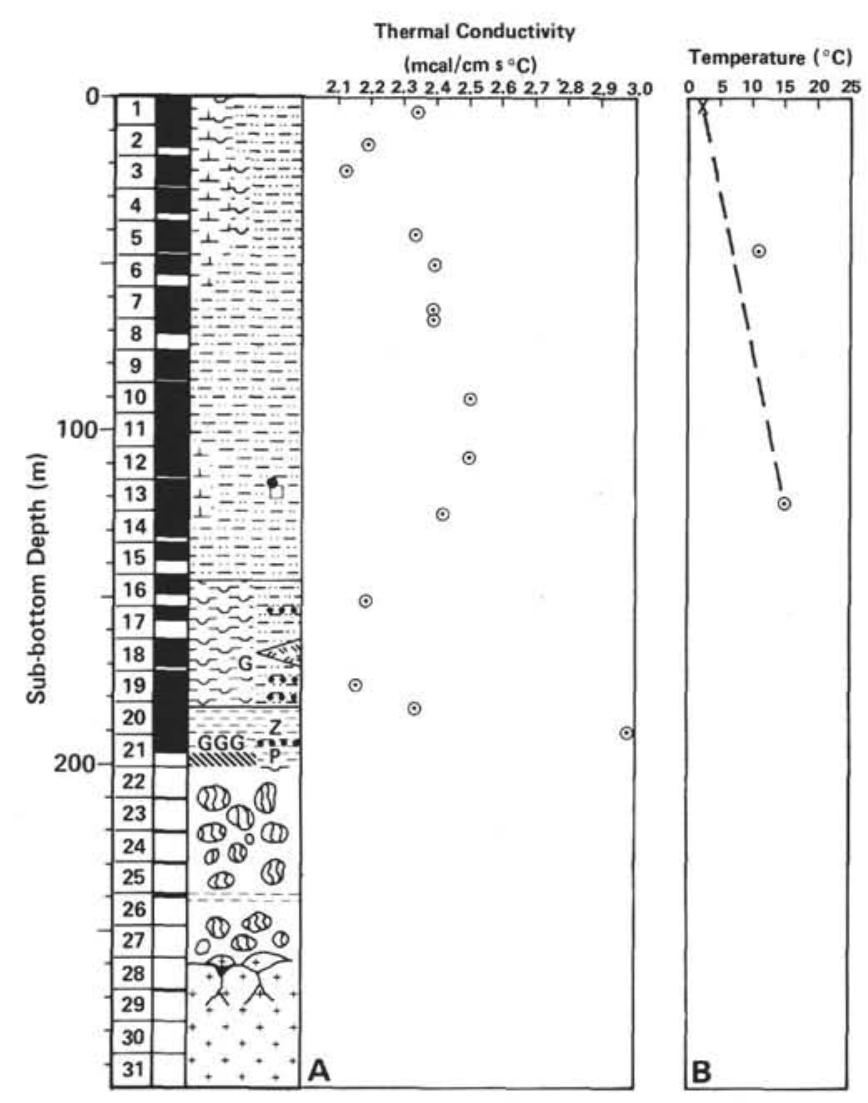

Figure 61. Thermal conductivities (A) and in situ temperatures (B), Site 476. 

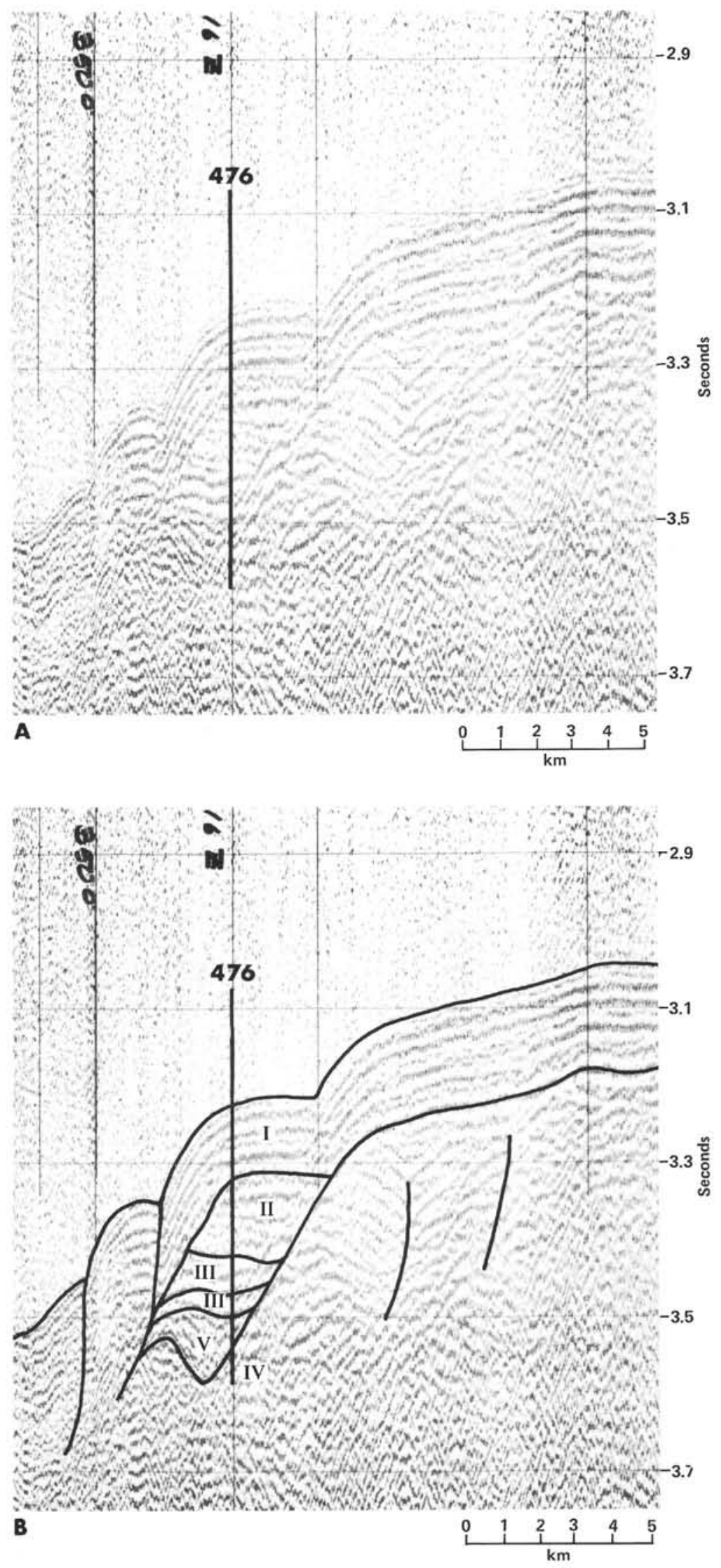

Figure 62. A. Single-channel analog seismic reflection record across Site 476 (from Glomar Challenger). B. Same record, showing interpreted correlations of drilling results with structure and stratigraphy. 
faults separating rotational fault blocks and covered with a drape of younger hemipelagic sediments. Some of the normal faults may surface and demonstrate recent or continuing movement of the underlying slump blocks.

Possible unconformable relations may exist between Units I and II and between Units II and III. Unit V, the cobble conglomerate, appears to rest at the foot of a fault scarp as a talus accumulation. The sharp contact between the conglomerate may have been caused by the penetration of the fault that formed the scarp.

\section{SUMMARY AND CONCLUSIONS}

Site 476 is the third and most landward site of the three-site transect across the youthful passive continental margin of the tip of Baja California. The site is on a terrace, low on the continental slope, and about 42 $\mathrm{km}$ southeast of the peninsula in 2400 meters of water. The seismic record indicates that this terrace overlies one of a series of small rotational slump blocks. Specific objectives at this site were to confirm the existence of continental crust, to learn the nature of the sediments, and to obtain evidence for subsidence and changes in environmental factors. All were realized. We drilled to a depth of 294.5 meters and bottomed in a basement of deeply weathered granite. The failure of the newly developed hydraulic bit-dropping mechanism precluded any logging.

The lithological section is divided into six units, including the sedimentary and igneous material.

Unit I (0-66 m) is hemipelagic Pleistocene nannofossil and diatomaceous ooze to mud;

Unit II $(66-145 \mathrm{~m})$ is late Pliocene hemipelagic mud;

Unit III (145-183 m) is early Pliocene, upper-continental-slope, muddy diatomaceous ooze with turbidite layers, vitric ash, and glauconite sands;

Unit IV (183-199 m) is late Miocene-early Pliocene(?) organic claystone, glauconitic sands, and silty clay. This thin unit suggests the existence of an isolated shallow bank environment in the oxygen minimum.

Unit V (199-256 m) comprises a metamorphic cobble conglomerate of unknown age. It was probably deposited in a continental arroyo, outwash, or alluvial fan environment;

Unit VI (256-294 m) is a deeply weathered granite.

Physical properties are difficult to determine because of severe coring deformation, but water content and porosity trends reverse their normal downhole decrease with higher values in the diatomaceous ooze of Unit III; bulk density and sound velocity decrease in the same unit. Sonic velocity is generally low in Units I through III at just above water velocity, with values of about 1.51 to $1.54 \mathrm{~km} / \mathrm{s}$. It increases in Unit IV to over 1.60 $\mathrm{km} / \mathrm{s}$. Granite cobble velocities are 4.0 to $4.9 \mathrm{~km} / \mathrm{s}$, but the in situ velocity of this weathered zone must be much lower.

The amount of organic material is generally low, and this sedimentary section would not constitute a good hydrocarbon source rock. The interesting increase in $\mathrm{Mg}$ content with depth below about 60 meters is probably an upward flux from the weathering of the continental basement and the terrigenous constituents of the basal conglomerates. Most oceanic DSDP sites show a continuing decrease in $\mathrm{Mg}$ with depth.

Measurements of heat flow suggest higher than average heat flow-about $2.4 \mathrm{HFU}$.

The only velocity information available is the shipboard laboratory measurements. To correlate the drilling results with our seismic data, we utilized the measured velocities and assumed others for units not covered; we derived the following velocity structure: Unit $\mathrm{I}=1.51 \mathrm{~km} / \mathrm{s}$; Unit $\mathrm{II}=1.53 \mathrm{~km} / \mathrm{s}$; Unit $\mathrm{III}=1.54$ $\mathrm{km} / \mathrm{s}$; Unit IV $=1.61 \mathrm{~km} / \mathrm{s}$, Unit $\mathrm{V}=1.61 \mathrm{~km} / \mathrm{s}$, and Unit VI $=1.61 \mathrm{~km} / \mathrm{s}$. With these velocities the lithology can be correlated with the seismic data. To link the three holes, we conducted a seismic survey while departing Site 475 . It shows that our drilled sections are within one block of a series of fault blocks draped with younger hemipelagic sediments. Units I, II, and III appear to have possible unconformable relations. Unit V, the cobble conglomerate, rests at the foot of a fault scarp probably as a talus accumulation.

Our drilling at Sites 475 and 476 provides evidence for depositions on a subsiding, granitic continental margin. Subaerial conglomerates of possible middle to late Miocene are overlain by shallow-marine mudstones and claystones with abundant glauconite. This is followed by diatom ooze or mud, hemipelagic clay, and fluctuating amounts of terrigenous mud, nannofossil, and diatom ooze in the upper Pleistocene.

A comprehensive discussion of the geological history of the young passive margin off the tip of Baja California is presented elsewhere in the volume.

\section{REFERENCES}

Beck, A. E., 1965. Techniques of measuring heat flow on land. In Lee, W. H. K. (Ed.), Terrestrial Heat Flow: Geophysical Monograph 8: Washington (American Geophysical Union), pp. 24-51.

Doose, P. R., Sandstrom, M. W., Jodele, R. Z., et al., 1978. Interstitial gas analysis of sediment samples from Site 368 and Hole 369A. In Lancelot, Y., Seibold, E., et al., Init. Repts. DSDP, 41: Washington (U.S. Govt. Printing Office), 861-863.

Gastil, G., et al., 1976. La zona batolitica del Sur de California y el Occidente de México. Bol. Soc. Geol. Mex., 37:84-90.

Hays, J. D., 1970. Stratigraphy and evolutionary trends of radiolaria in North Pacific deep sea sediments. In Hays, J. D. (Ed.), Geological Investigations of North Pacific. Geol. Soc. Am. Mem., 126:185-218.

Hays, J. D., et al., 1972. Init. Repts. DSDP, 9: Washington (U.S. Govt. Printing Office).

Kling, S. A., 1973. Radiolaria from the eastern North Pacific. Deep Sea Drilling Project, Leg 18. In Kulm, L. D., von Huene, R., et al., Init. Repts. DSDP, 18: Washington (U.S. Govt. Printing Office), 617-671.

Kulm, L. D., von Huene, et al., 1973. Init. Repts. DSDP, 18: Washington (U.S. Govt. Printing Office).

Larson, R. L., 1972. Bathymetry, magnetic anomalies, and plate tectonic anomalies, and plate tectonic history of the mouth of the Gulf of California. Geol. Soc. Am. Bull., 83:3345-3360.

Larson, R. L., Menard, H. W., and Smith, S. M.,1968. Gulf of California: A result of ocean-floor spreading and transform faulting. Science, 161:781-784.

Lewis, B. T. R., McClain, J., Snydsman, W. E., et al., 1975. Gulf of California IPOD site survey, final report. (Unpublished)

Lopéz Ramos, E., 1976. Carta Geologica de la Republica de México (4th ed.). Comite de la Carta Geologica de Mexico.

Molina-Cruz, A., 1978. Late Quaternary circulations along the Pacific coast of South America [Ph.D. dissert]. Oregon State University. 
Moore, D. G., 1973. Plate-edge deformation and crustal growth, Gulf of California structural province. Geol. Soc. Am. Bull., 84: 1883-1906.

Moore, D. G., and Buffington, E. C., 1968. Transform faulting and growth of the Gulf of California since the late Pliocene. Science, $161: 1238-1242$.

Moore, G. F., Becker, K., Bibee, L. D., et al., 1978. Gulf of California IPOD site summary, final report. (Unpublished)

Nigrini, C. A., 1971. Radiolarian zones in the Quaternary of the equatorial Pacific Ocean. In Funnell, B. M., and Riedel, W. R. (Eds.), The Micropaleontology of Oceans: Cambridge (Cambridge University Press), pp. 443-461.

Normark, W. R., and Curray, J. R., 1968. Geology and structure of the tip of Baja California, Mexico. Geol. Soc. Am. Bull., 69: 1589-1600.

Phillips, R. P., 1964. Seismic refraction studies in Gulf of California. In van Andel, Tj. H., and Shor, G. G. (Eds.), Marine Geology of the Gulf of California: A Symposium: Tulsa (American Association of Petroleum Geologists), pp. 90-121.

Piper, D. J. W., 1978. Turbidite muds and silts on deep sea fans and abyssal plains. In Stanley, D. J., and Kelling, G. (Eds.), Sedimentation in Submarine Canyons, Fans, and Trenches: (Dowden, Hutchinson, and Ross), pp. 163-176.

Ryther, J. H., 1956. Photosynthesis in the ocean as a function of light intensity. Limnol. Oceanogr., 1:6-70.

Shepard, F. P., 1964. Sea floor valleys of Gulf of California. In van Andel, Tj. H., and Shor, G. G. (Eds.), Marine Geology of the
Gulf of California: A Symposium: Tulsa (American Association of Petroleum Geologists), pp. 157-193.

Srinivasan, M. S., and Kennett, J. P., 1976. Evolution and phenotypic Neogloboquadrina dutertrei plexus. In Takayanasi, Y., and Saito, T. (Eds.), Progress in Micropaleontology: New York (American Museum of Natural History), pp. 329-355.

Tucholke, B. D., Edgar, N. T., and Boyce, R. E., 1976. Physical properties of sediments and correlations with acoustic stratigraphy: Leg 35, Deep Sea Drilling Project. In Hollister, C. D., Craddock, C., et al., Init. Repts. DSDP, 35: Washington (U.S. Govt. Printing Office), 229-249.

van Andel, Tj. H., 1964. Recent marine sediments of Gulf of California. In van Andel, Tj. H., and Shor, G. G. (Eds.), Marine Geology of the Gulf of California: A Symposium: Tulsa (American Association of Petroleum Geologists), pp. 216-311.

Von Herzen, R., and Maxwell, A. E., 1959. The measurement of thermal conductivity of deep-sea sediments by a needle probe method. J. Geophys. Res., 64:1557-1563.

von Rad, U., Ryan, W. B. F., et al., 1977. Init. Repts. DSDP, 47, Pt. 1: Washington (U.S. Govt. Printing Office).

Whelan, J. K., 1979. $C_{1}$ to $C_{7}$ hydrocarbons from IPOD Holes 397 and 397A. In von Rad, U., Ryan, W. B. F., et al., Init. Repts. DSDP, 47, Pt. 1: Washington (U.S. Govt. Printing Office), 531-539.

Wyman, R. E., and Castaño, J. R., 1974. Show descriptions from core, sidewall and ditch samples. SPWLA 15th Ann. Logging Symp., pp. 1-21. 


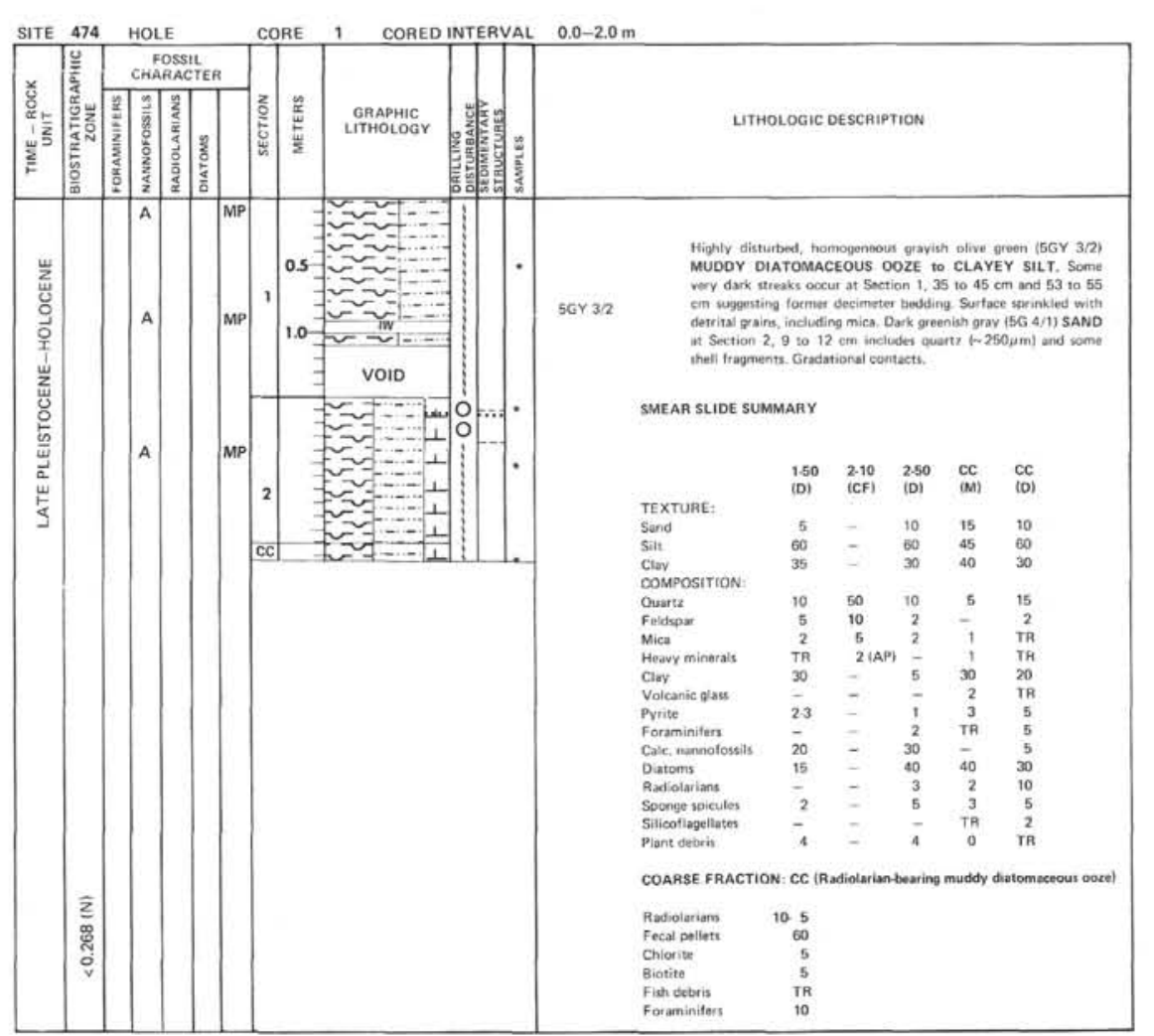

Information on core description sheets, for ALL sites, represents field notes taken aboard ship under time pressure. Some of this information has been refined in accord with post cruise findings, but production schedules prohibit definitive correlation of these sheets with subsequent findings. Thus the reader should be alerted to the occasional ambiguity or discrepancy.

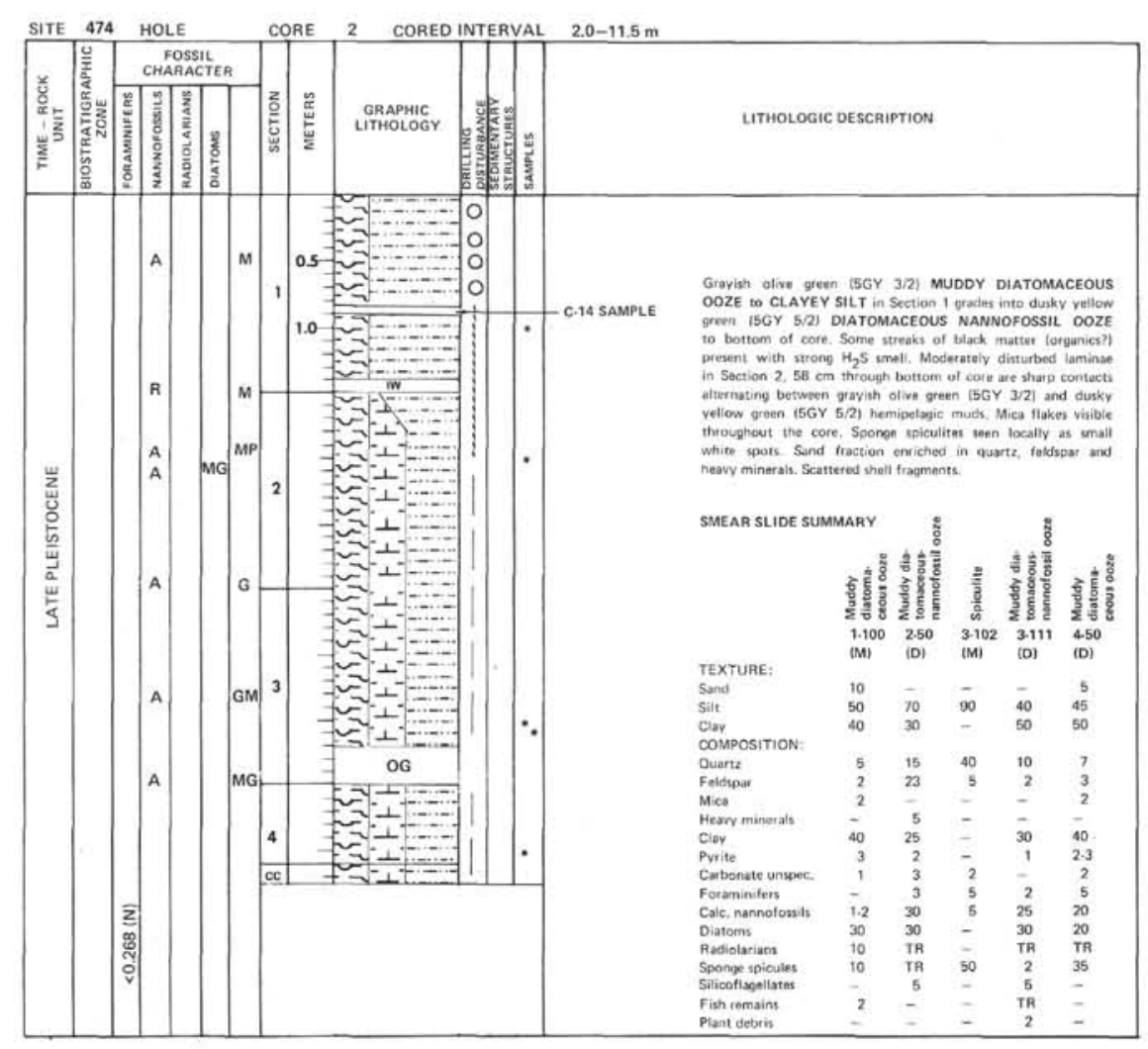



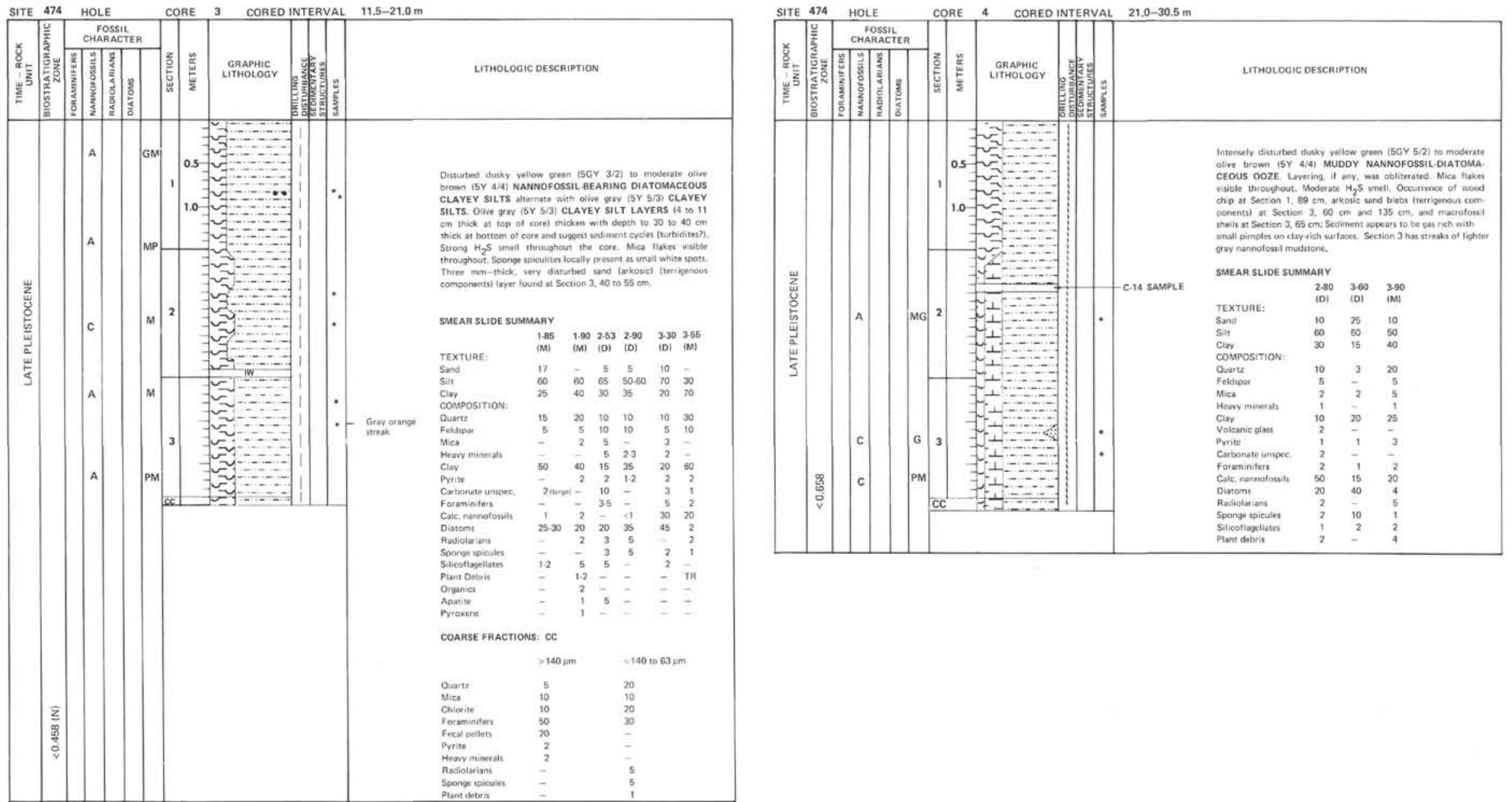

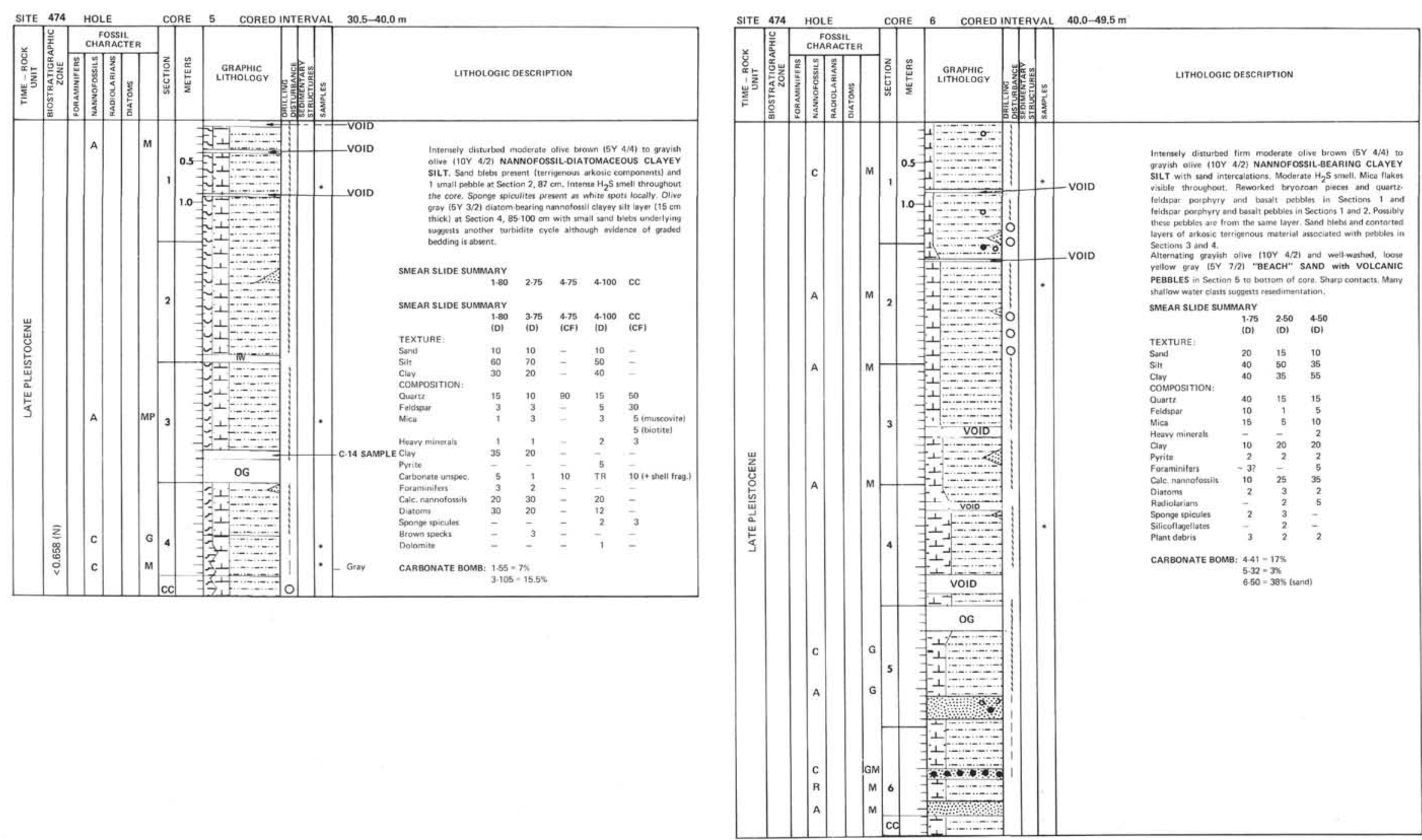

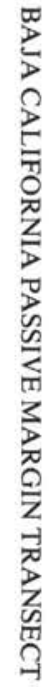



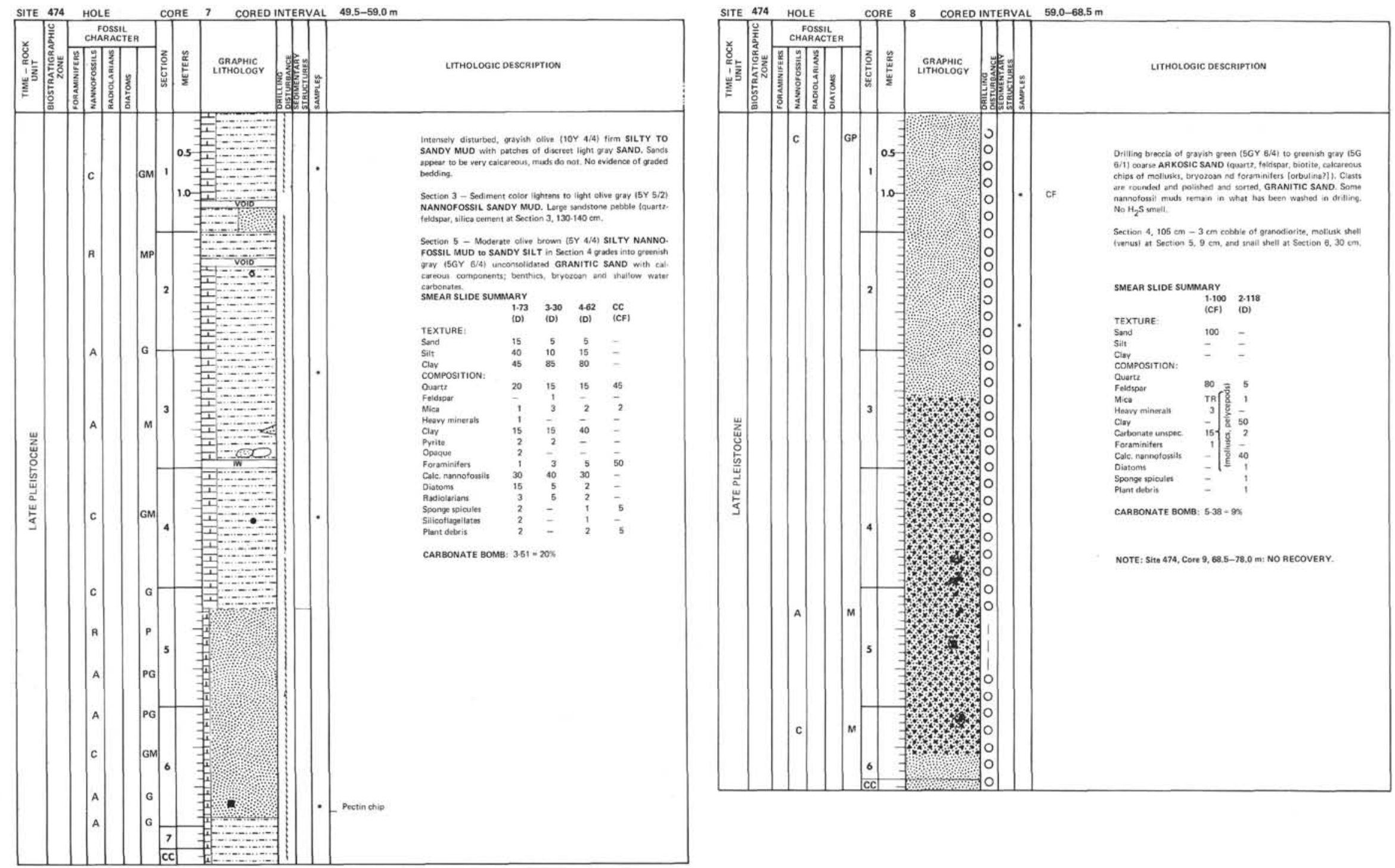

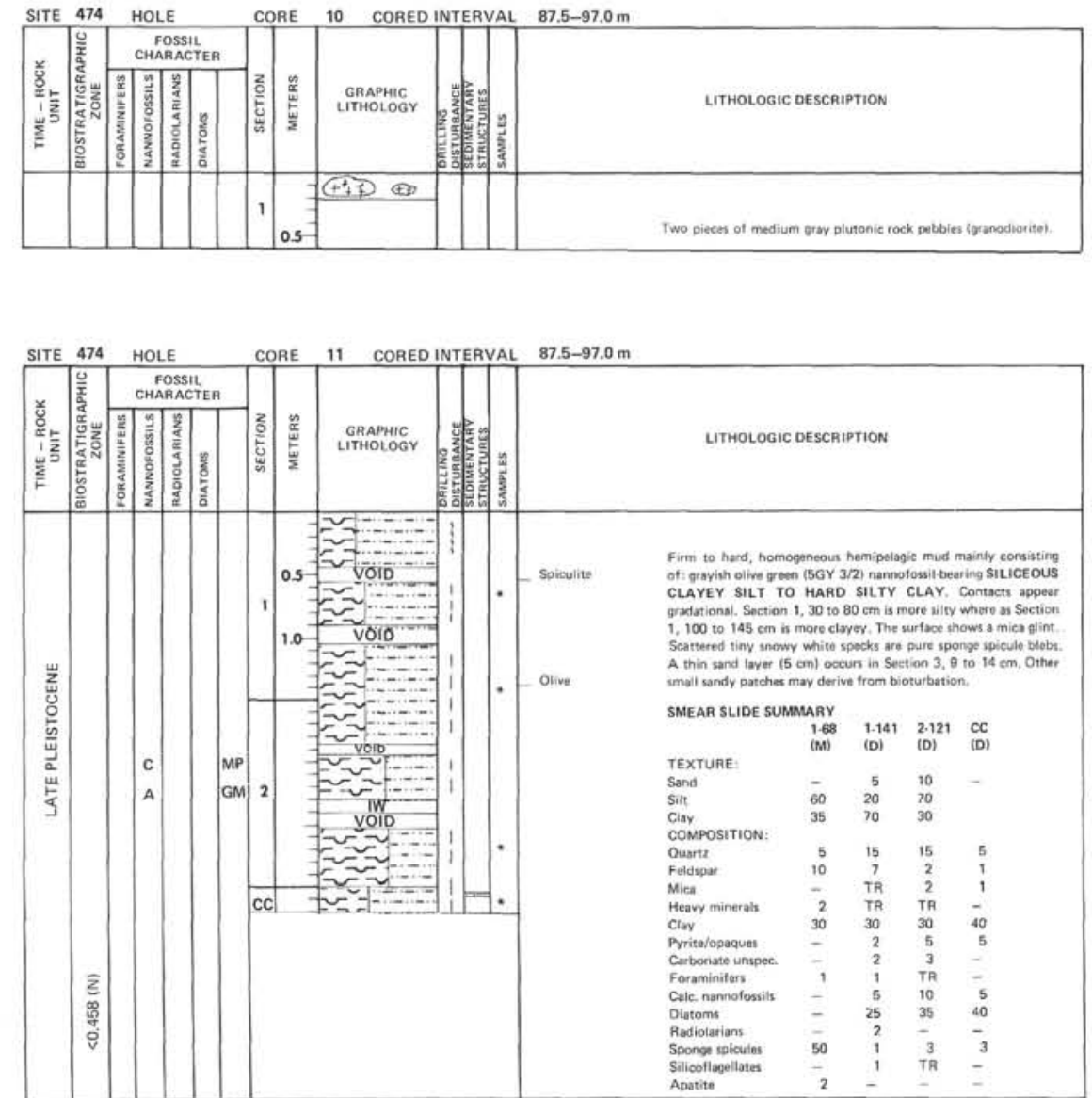
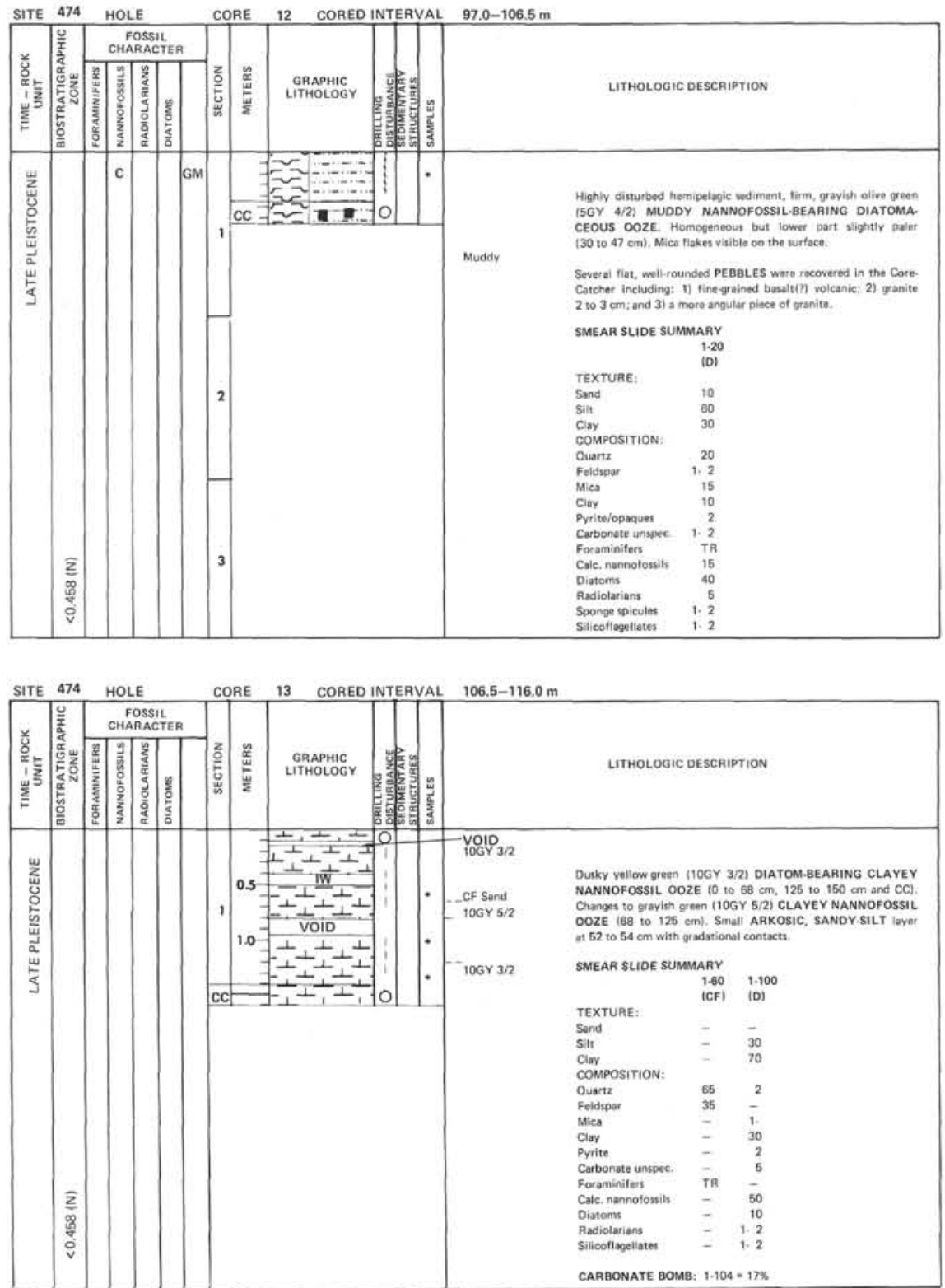

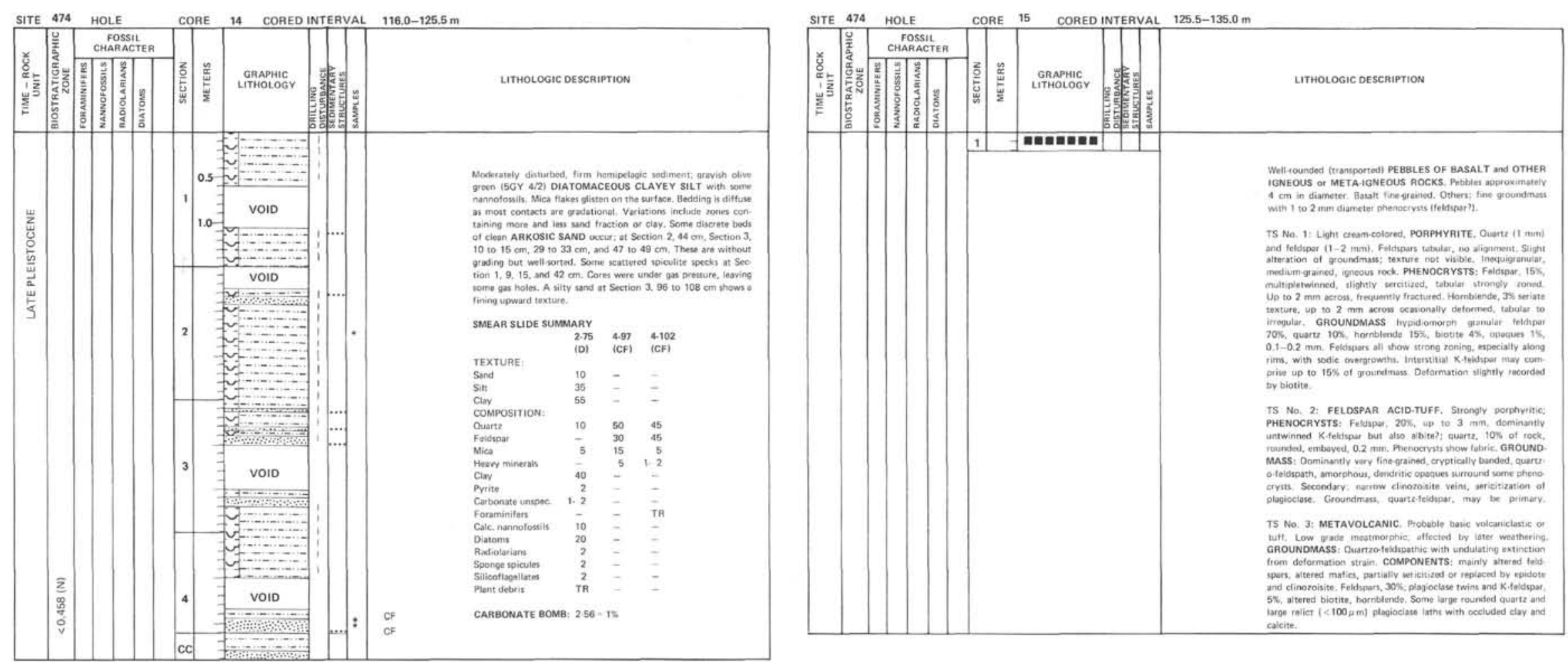

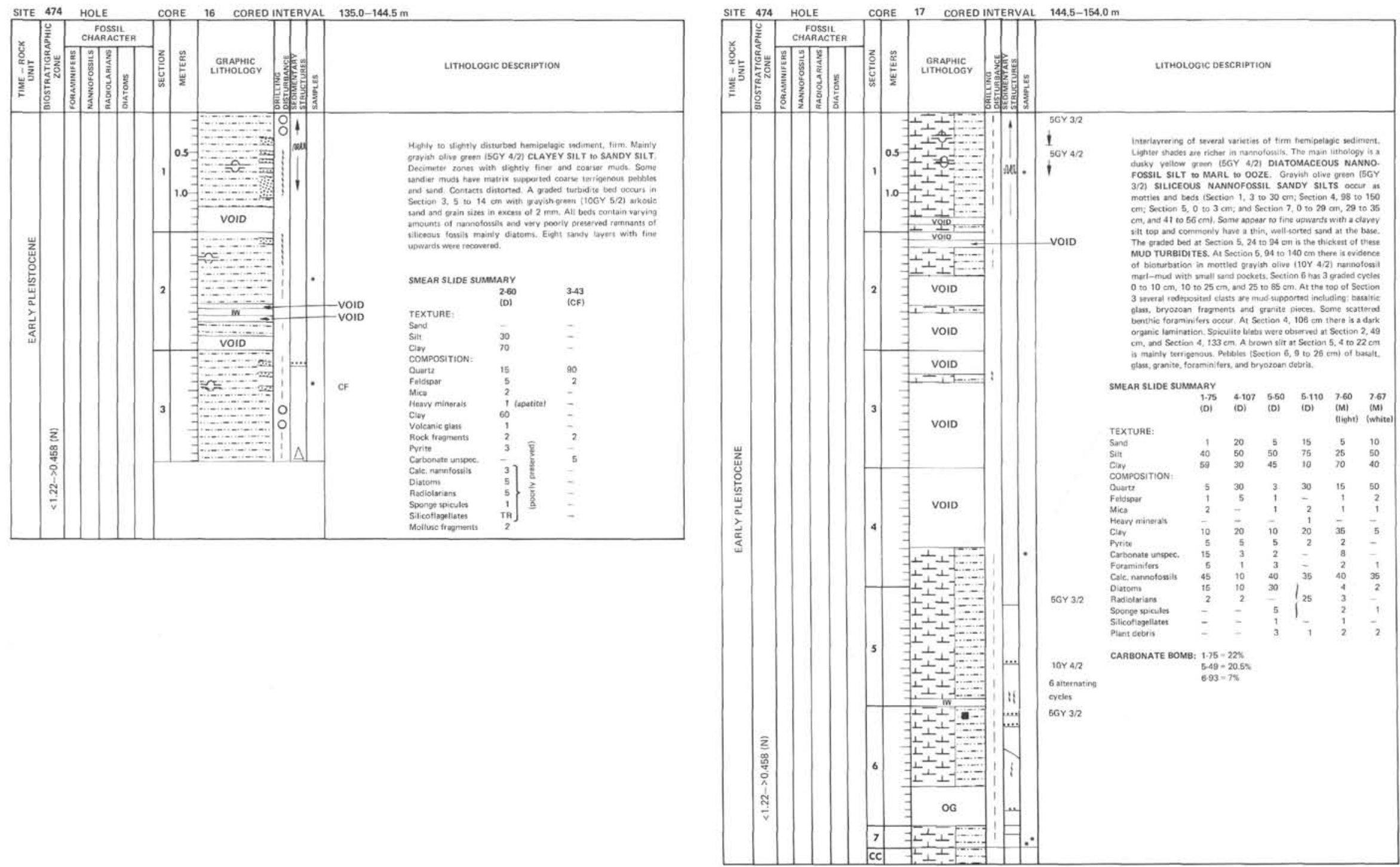

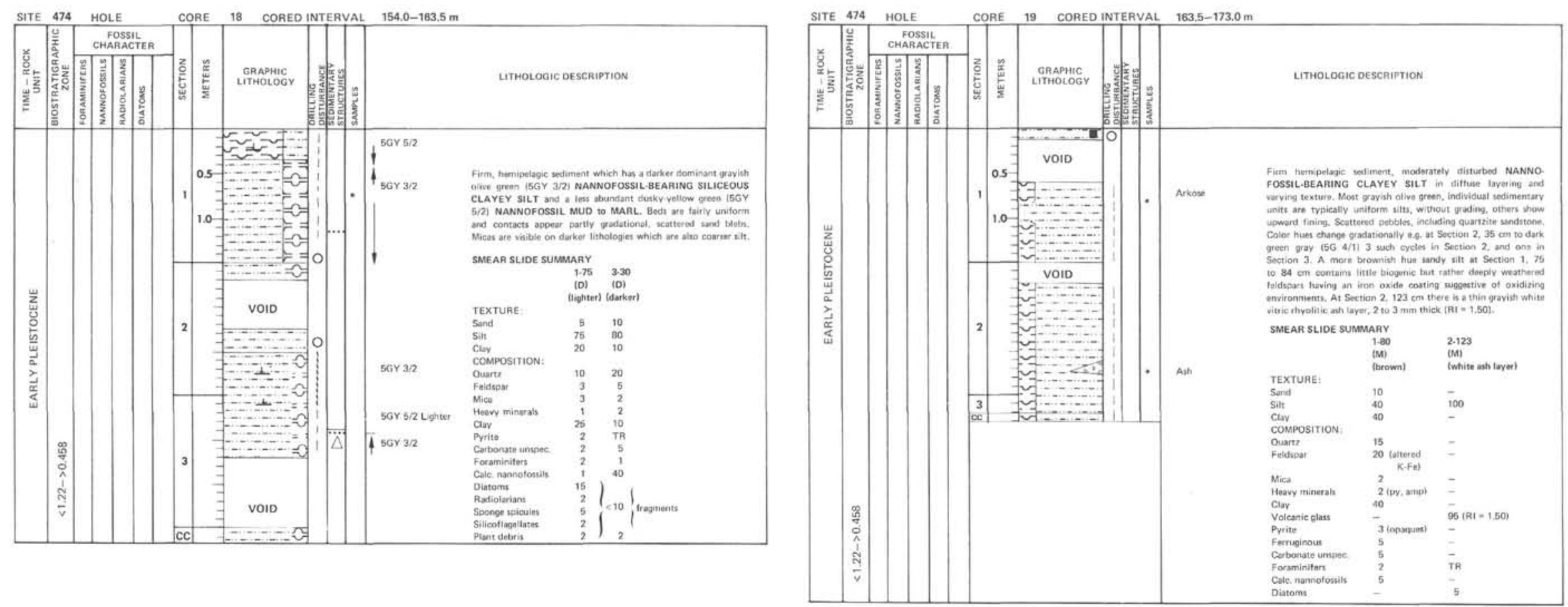

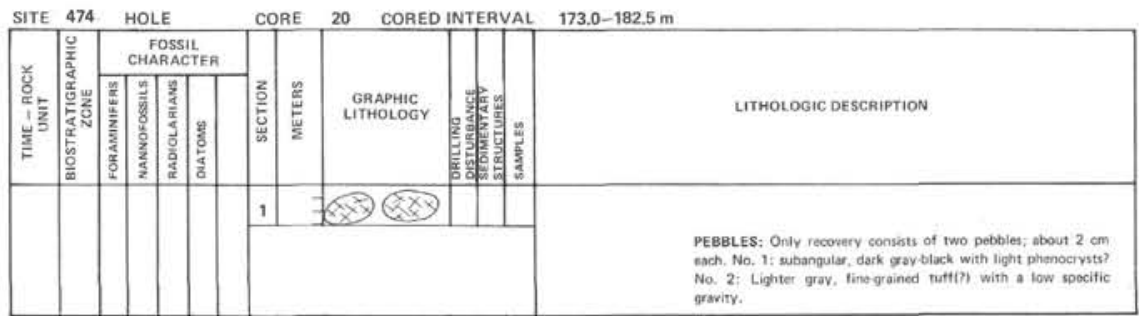




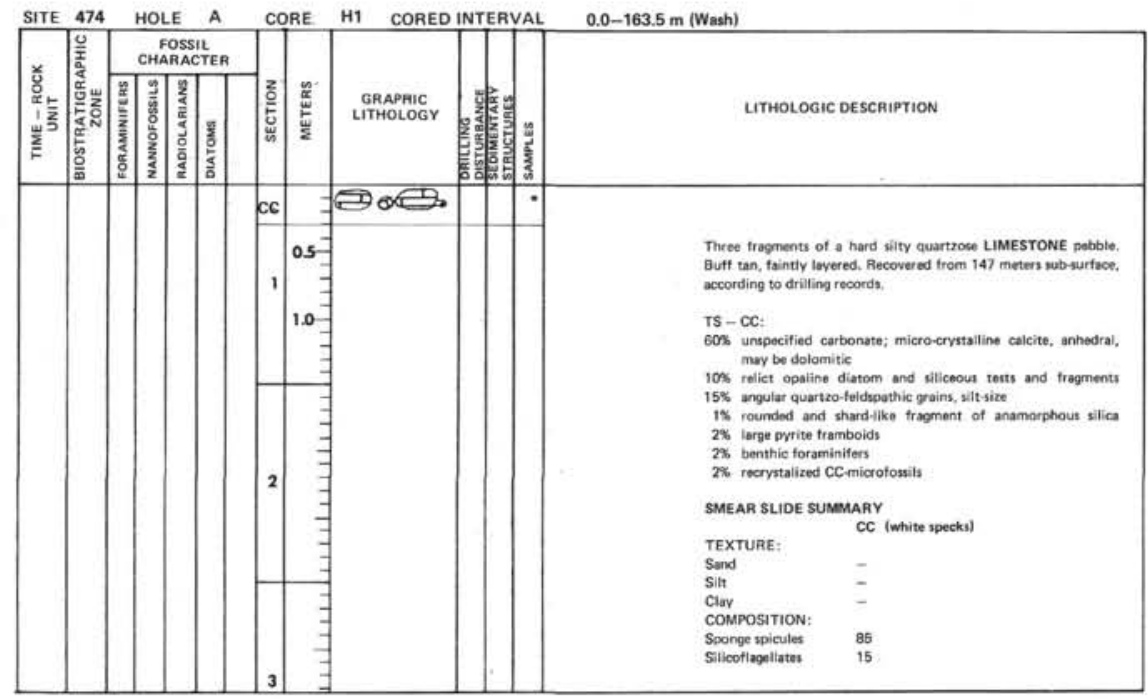

SITE 474 HOLE A CORE 1 CORED INTERVAL 163.5-173.0

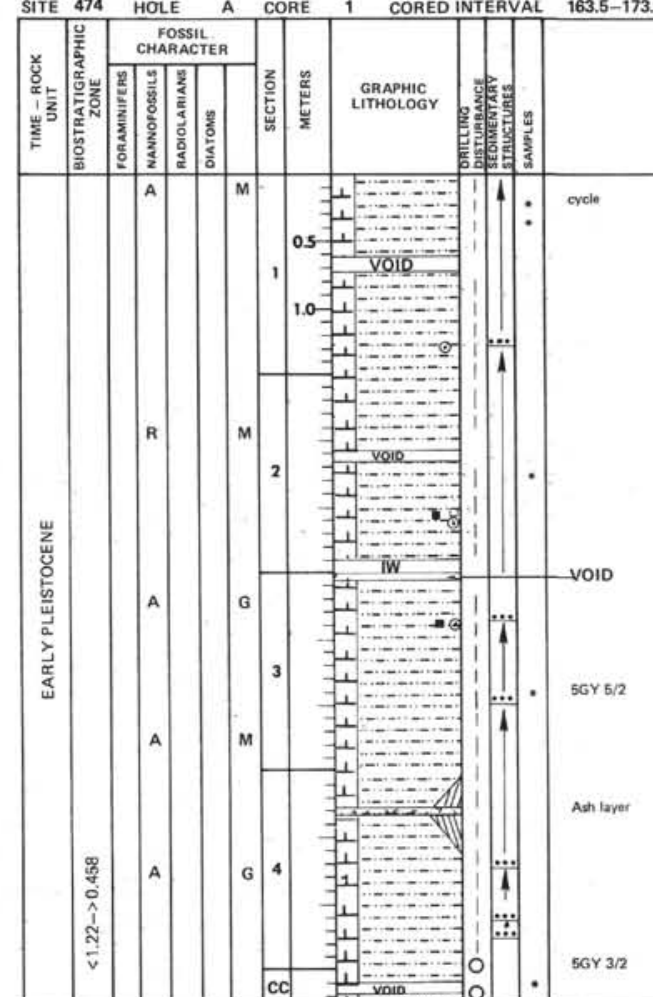

LITHOLOGIC DESCRIPTION

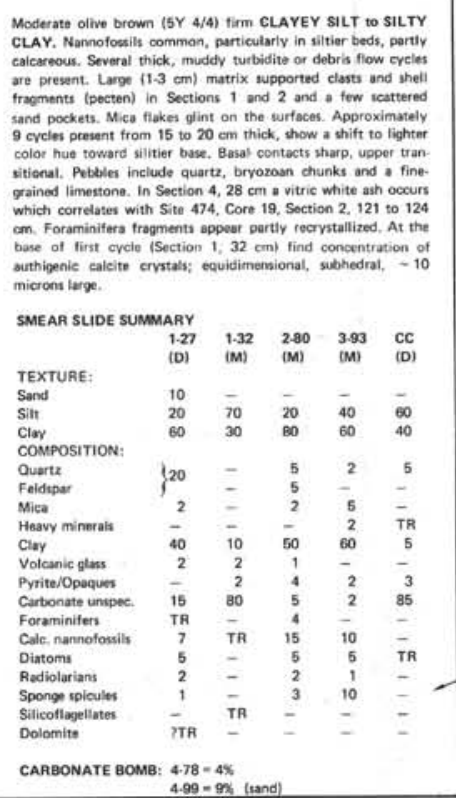

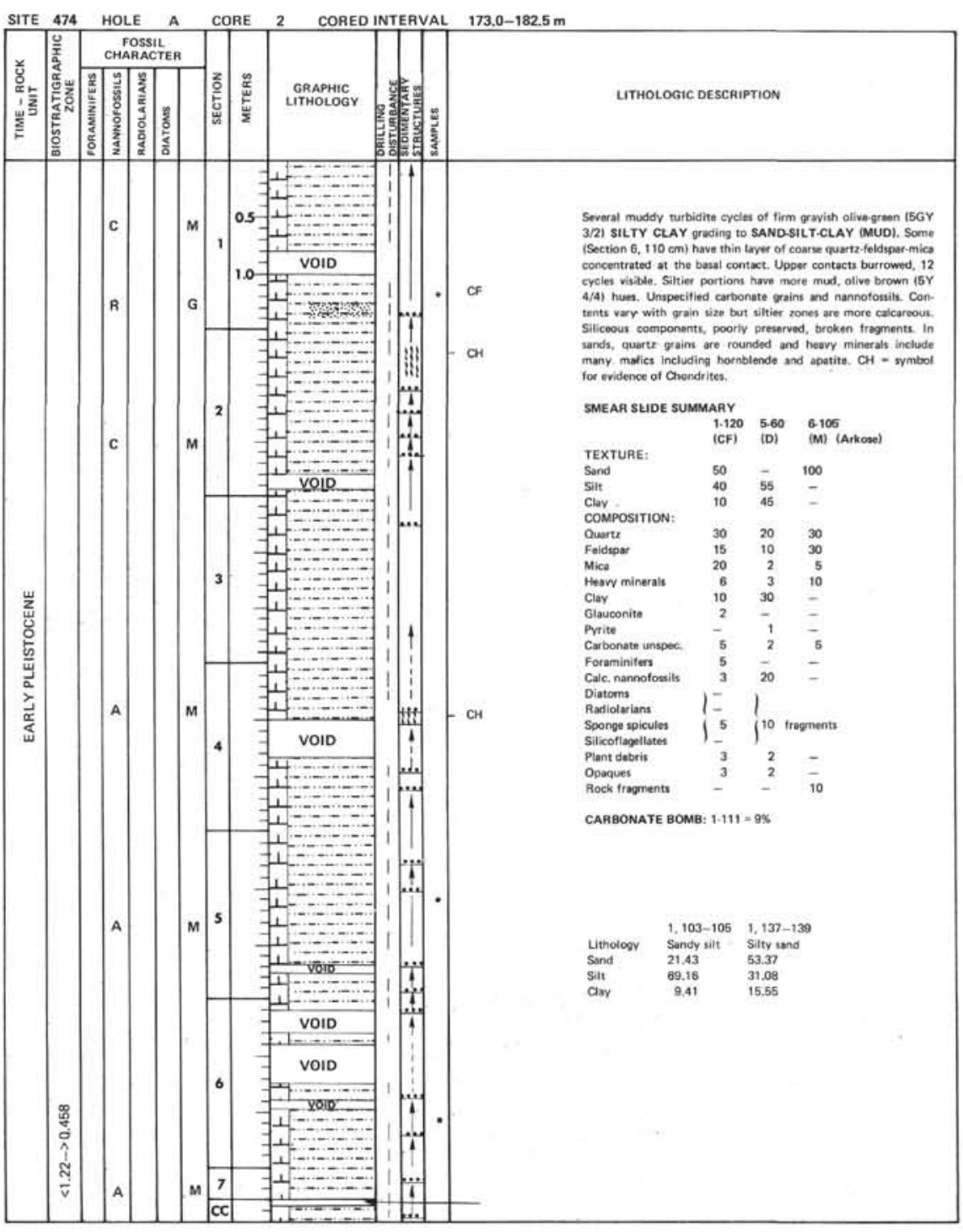

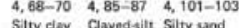

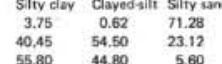



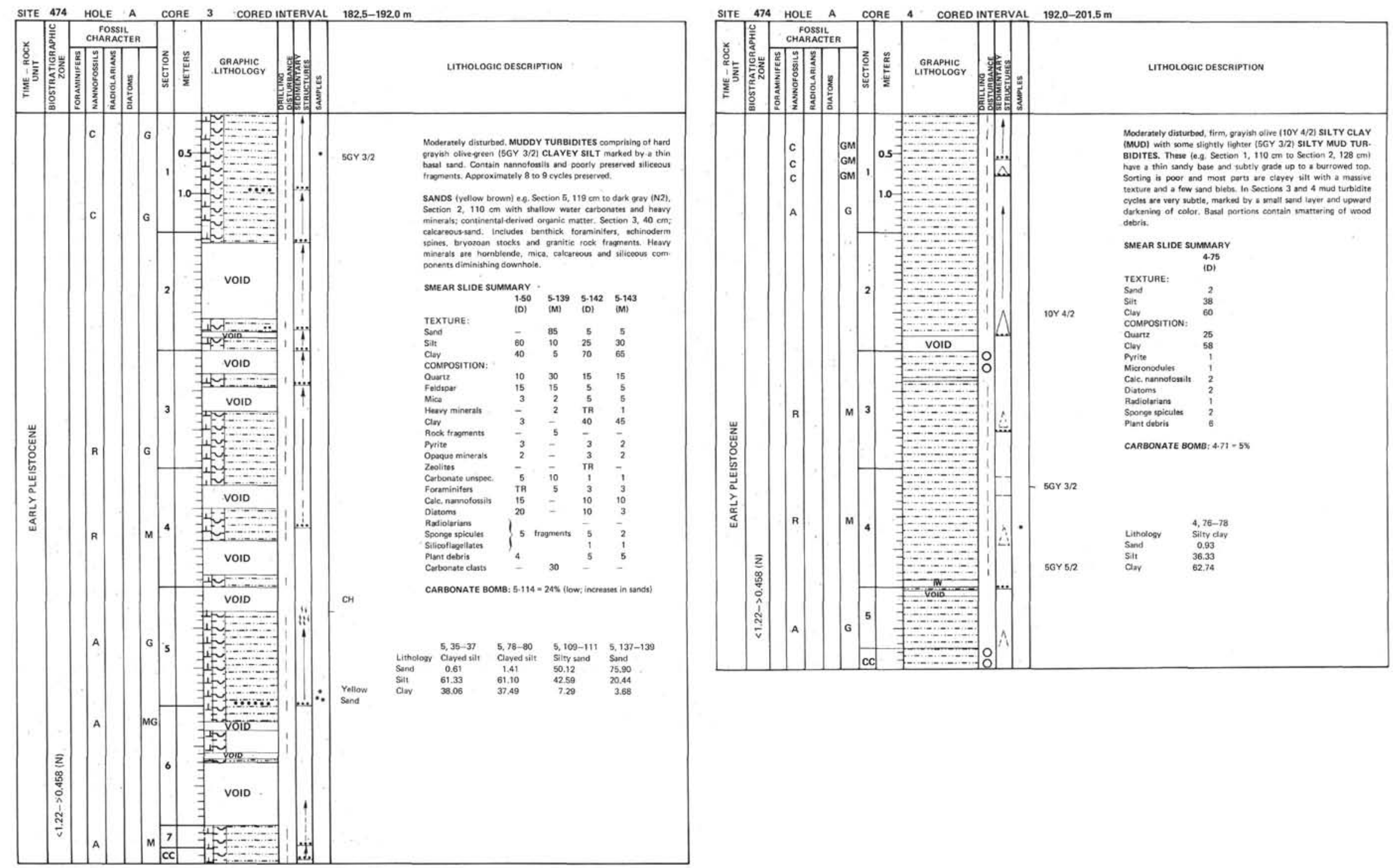

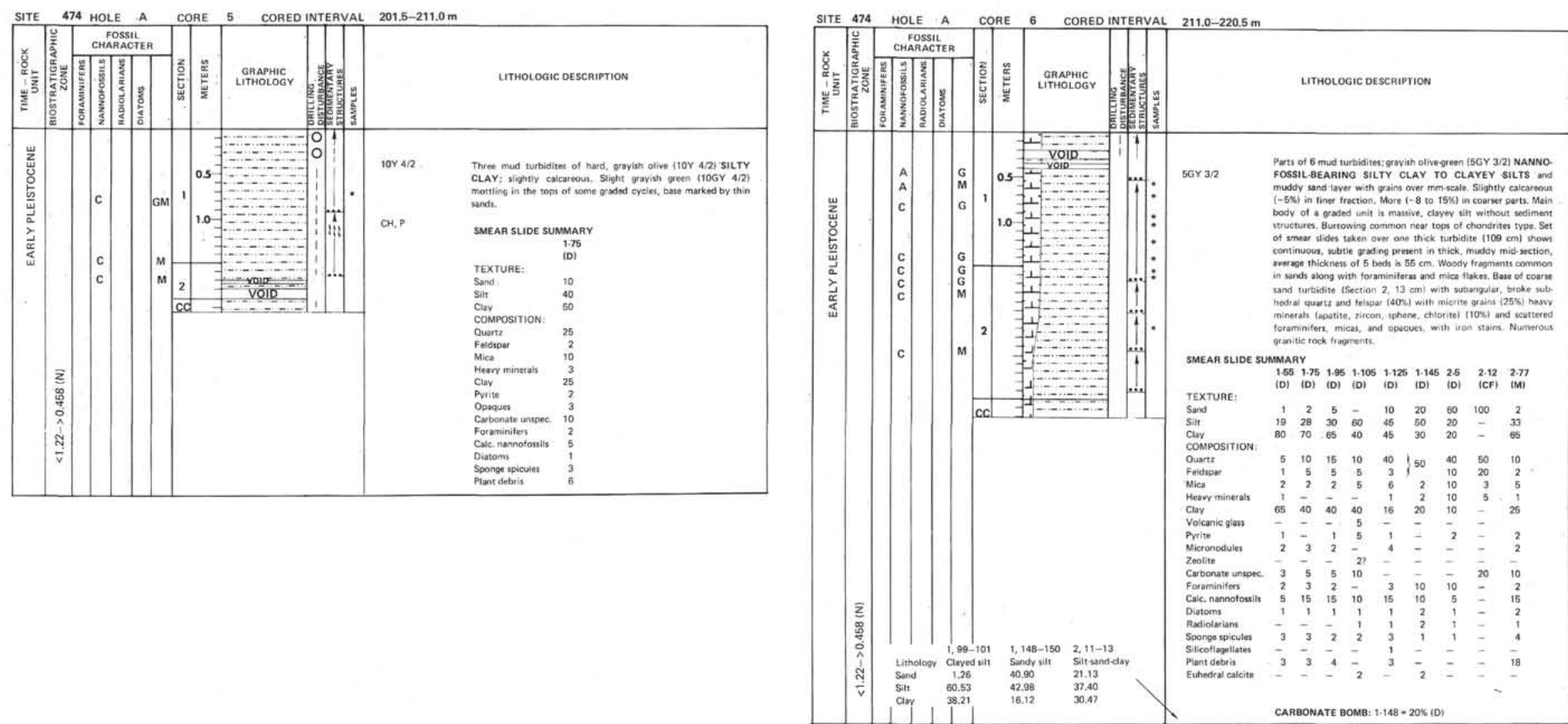

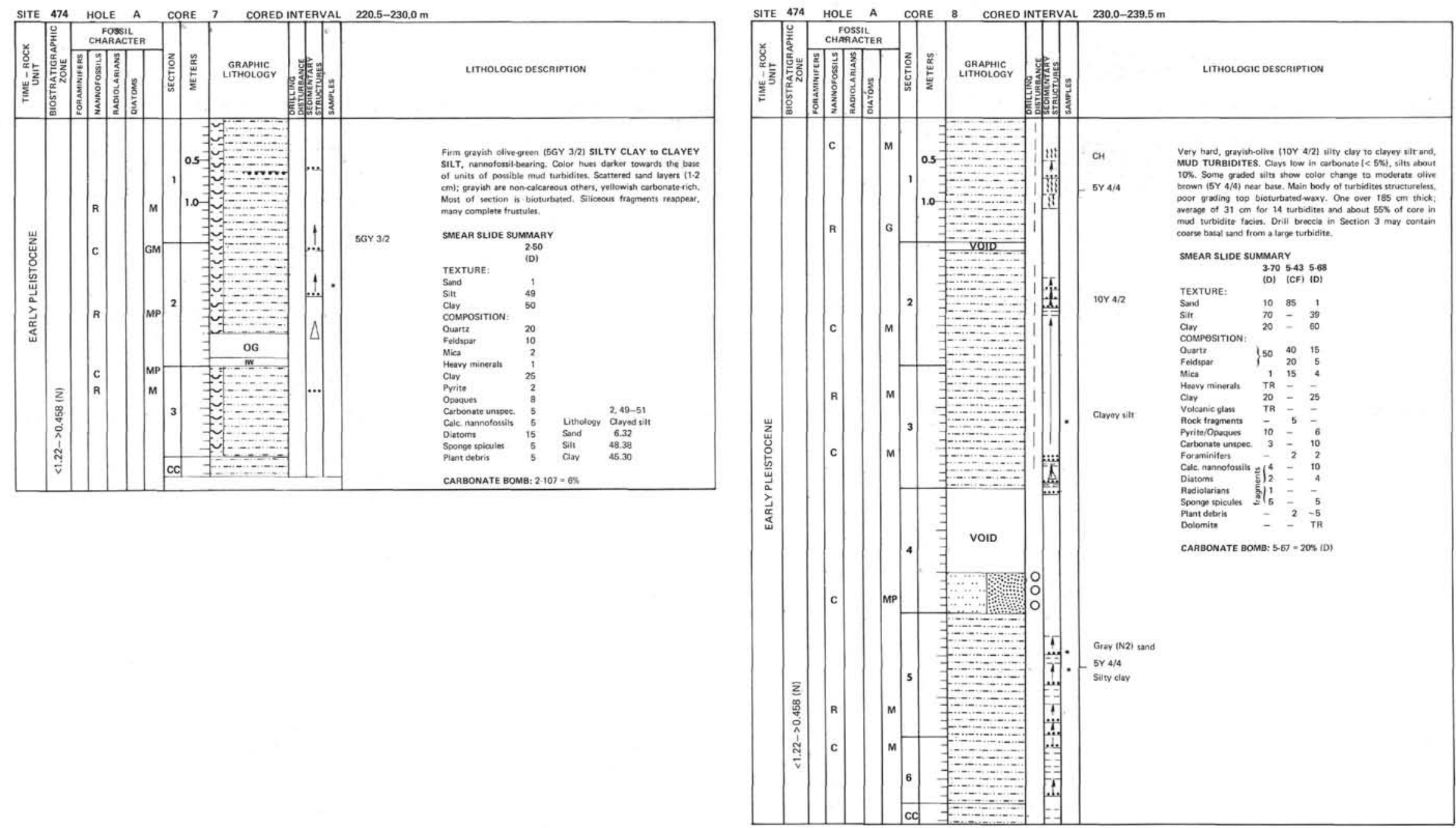


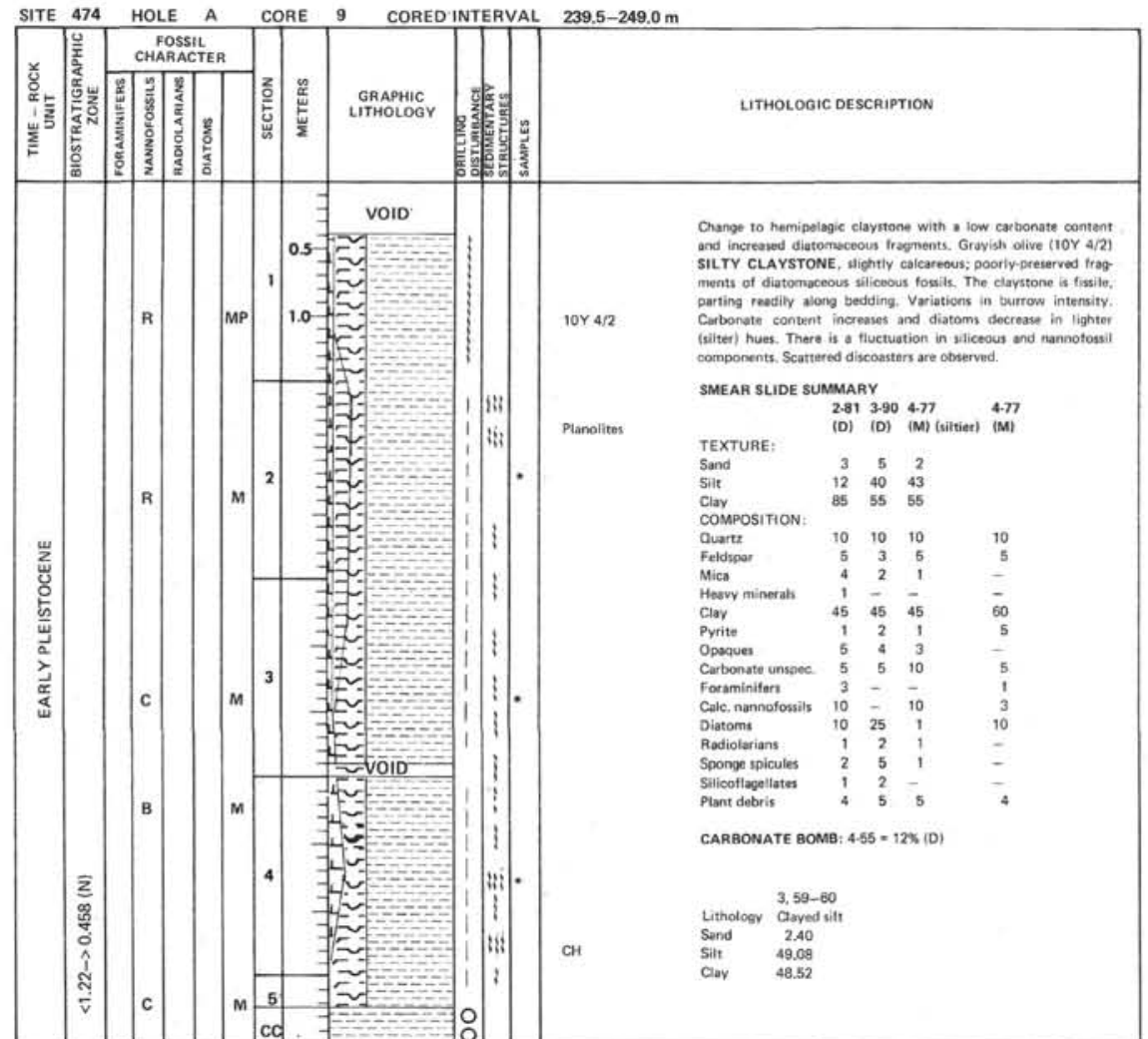



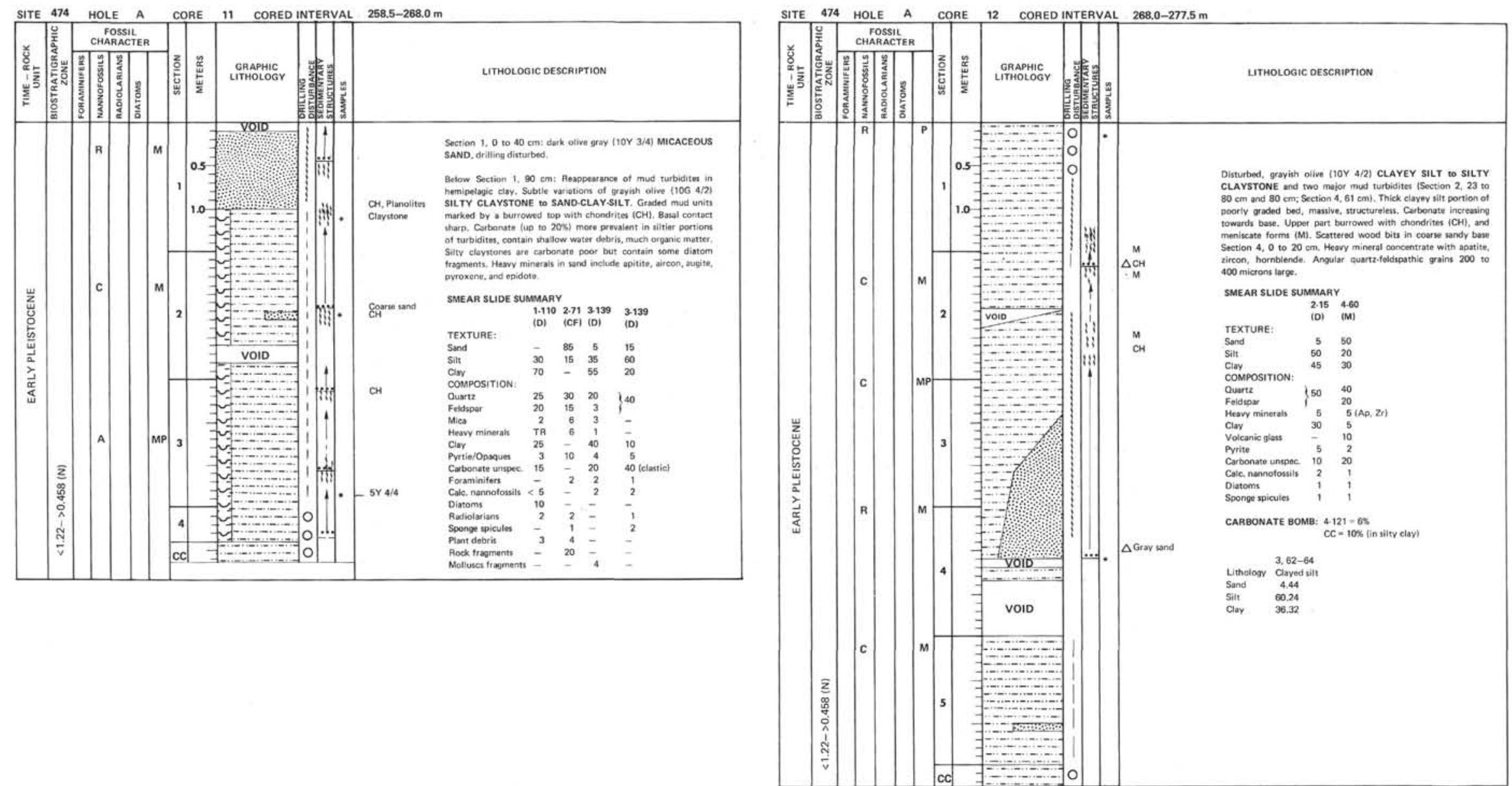

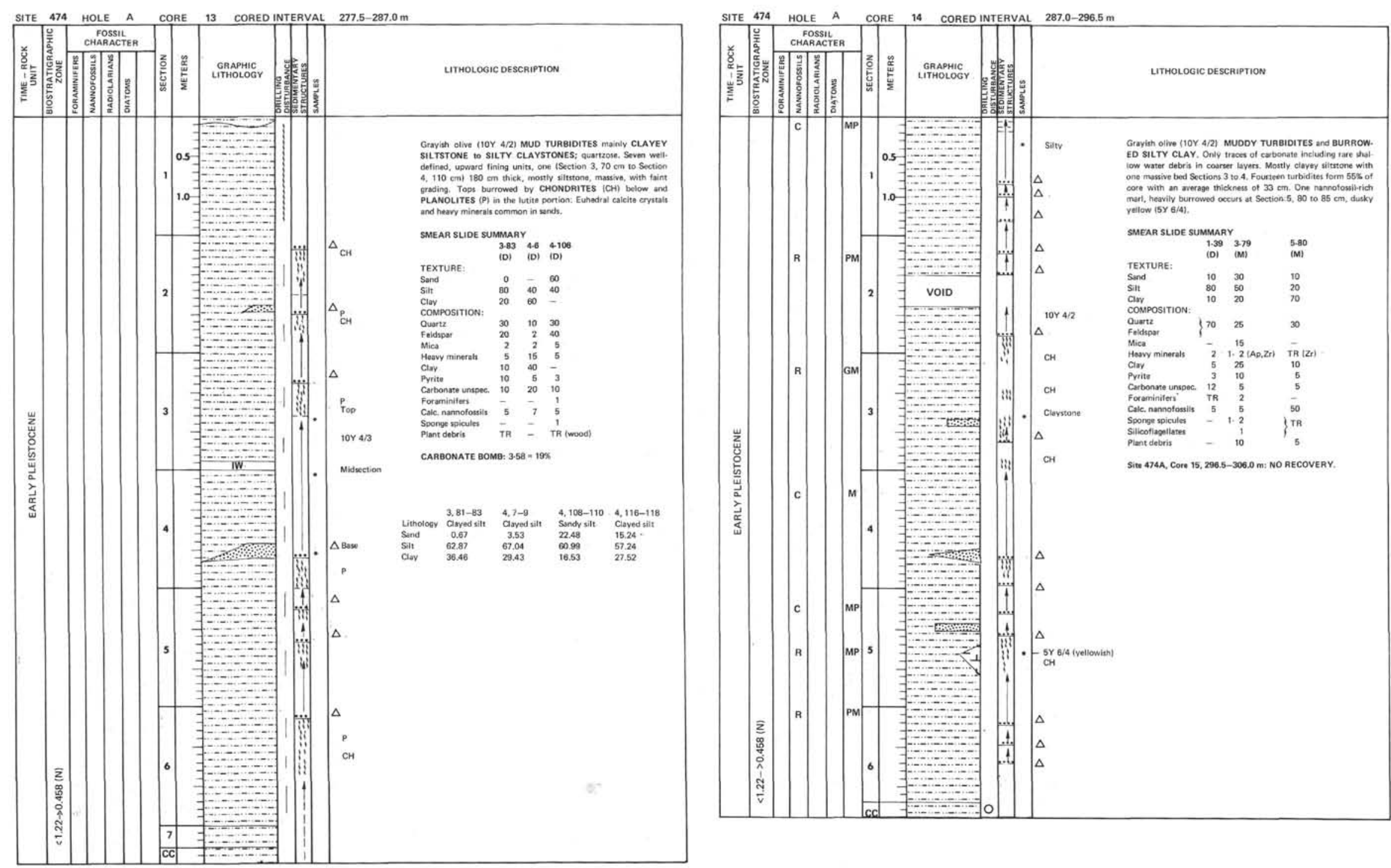

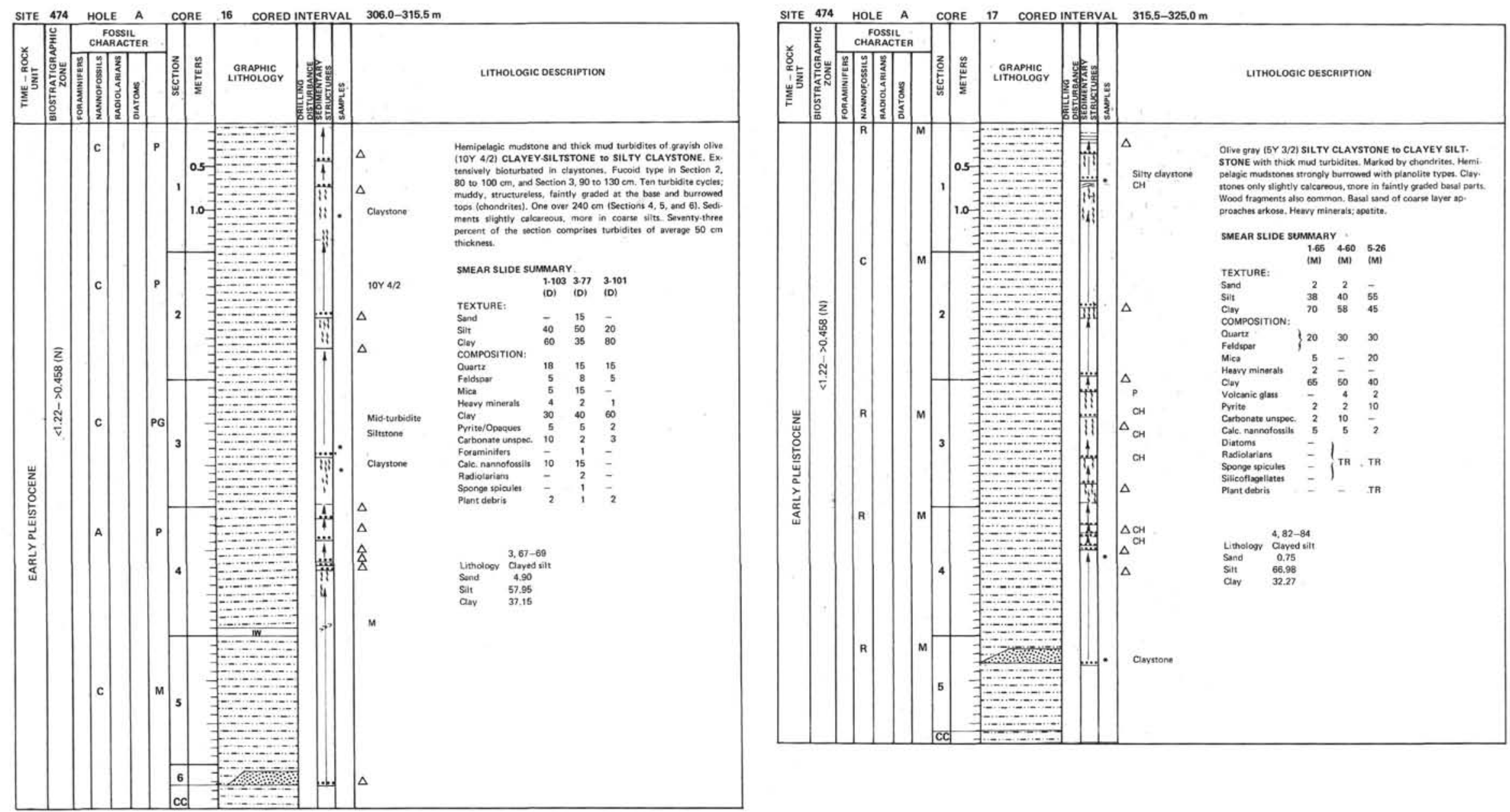

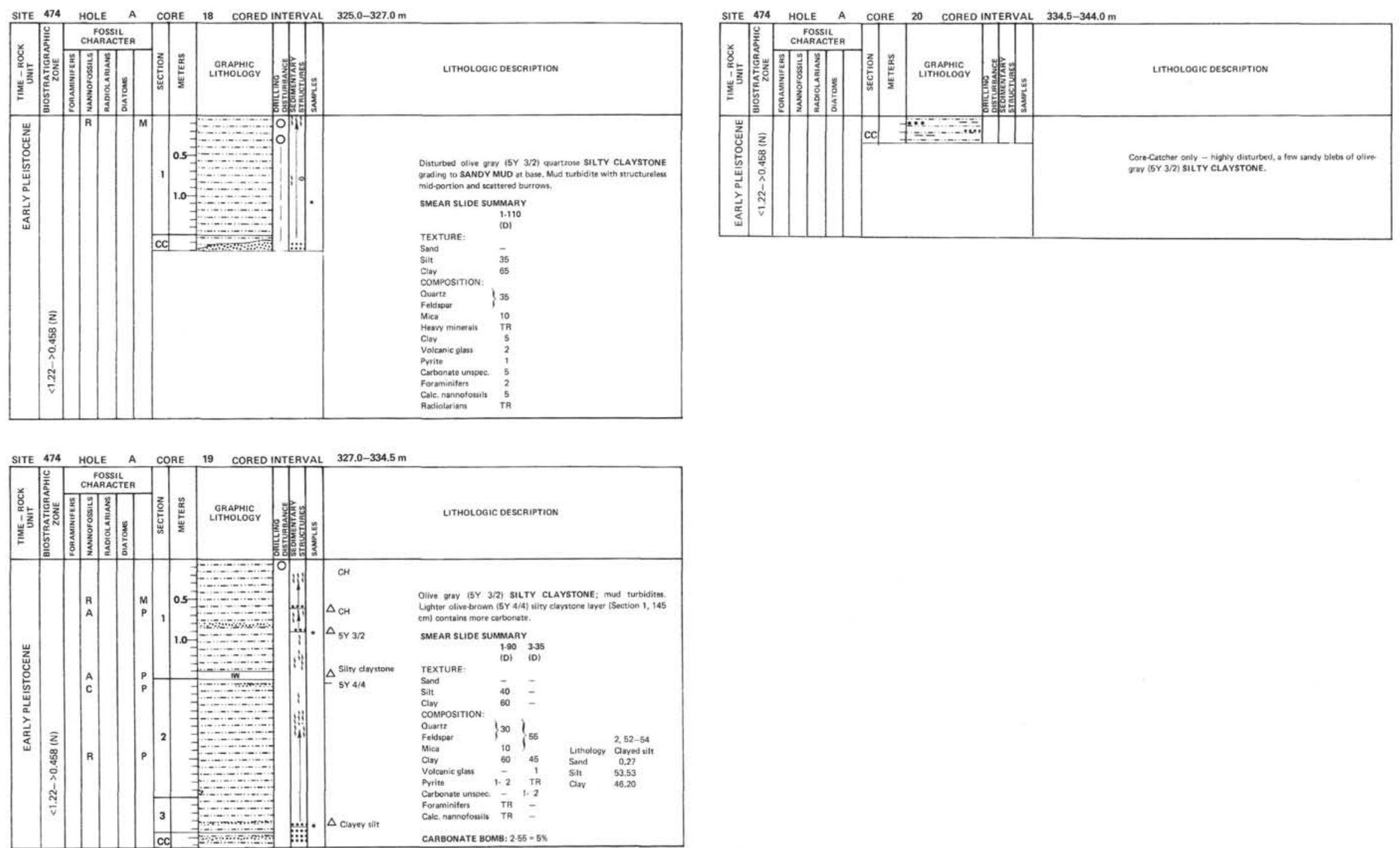

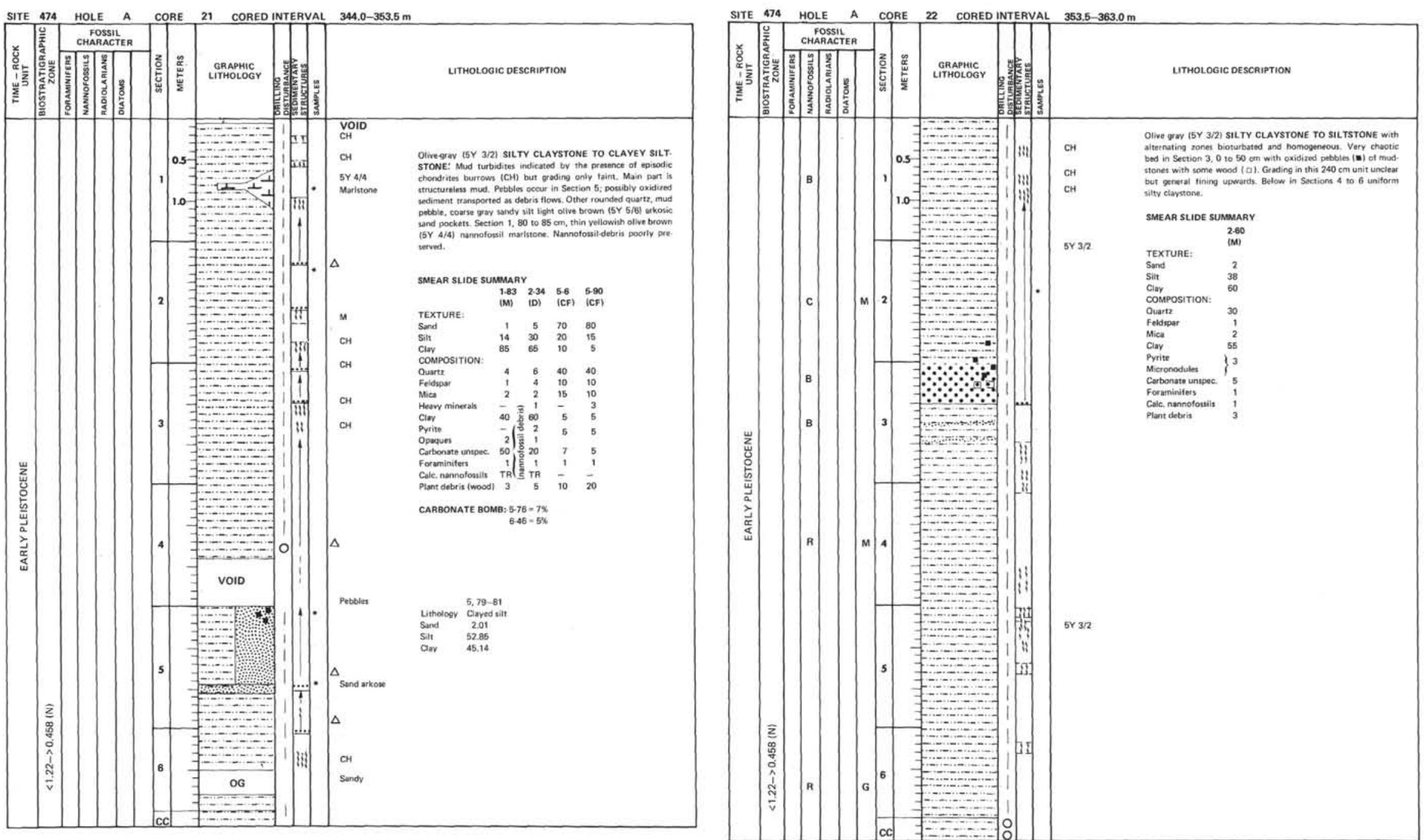

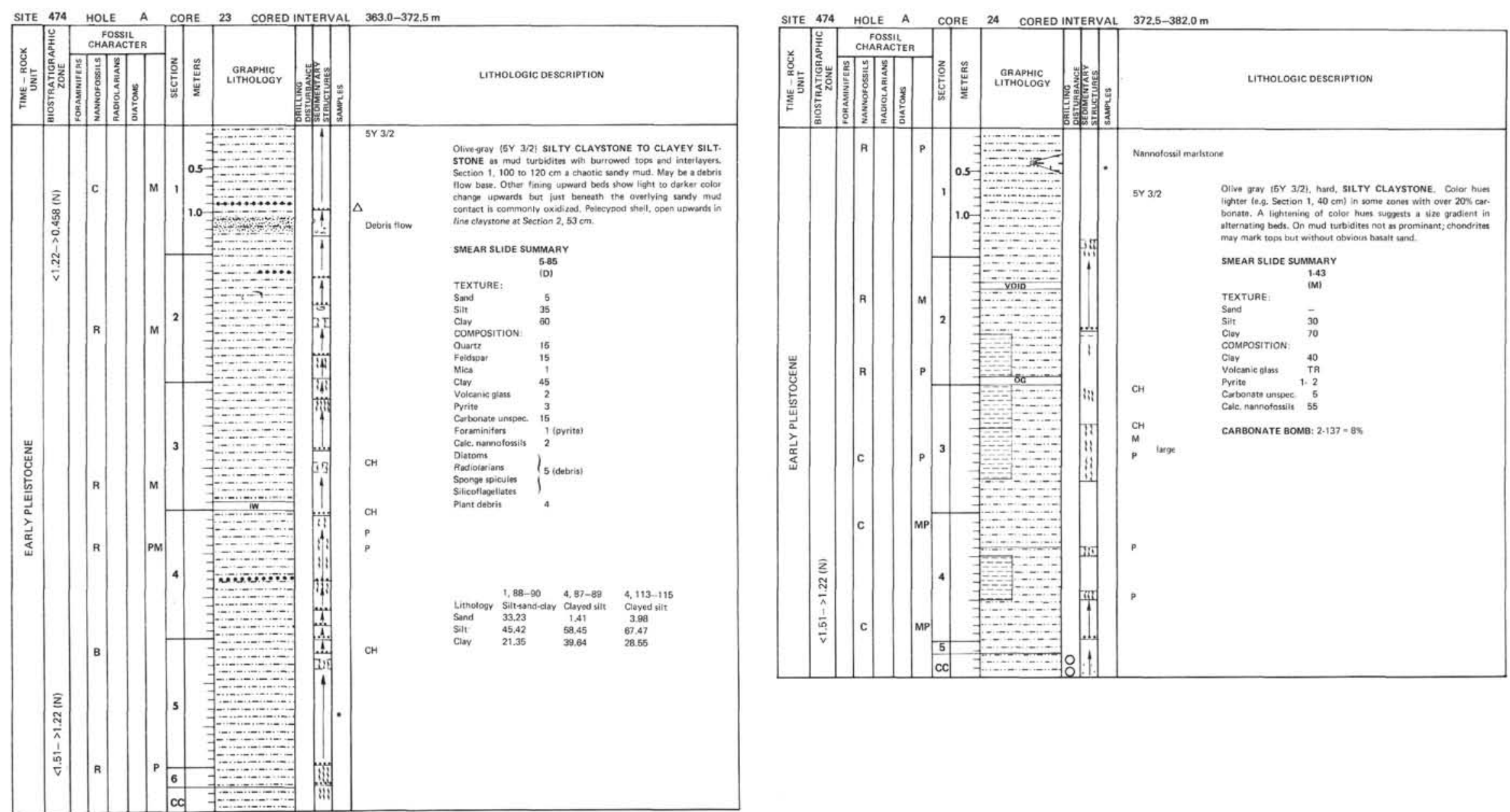

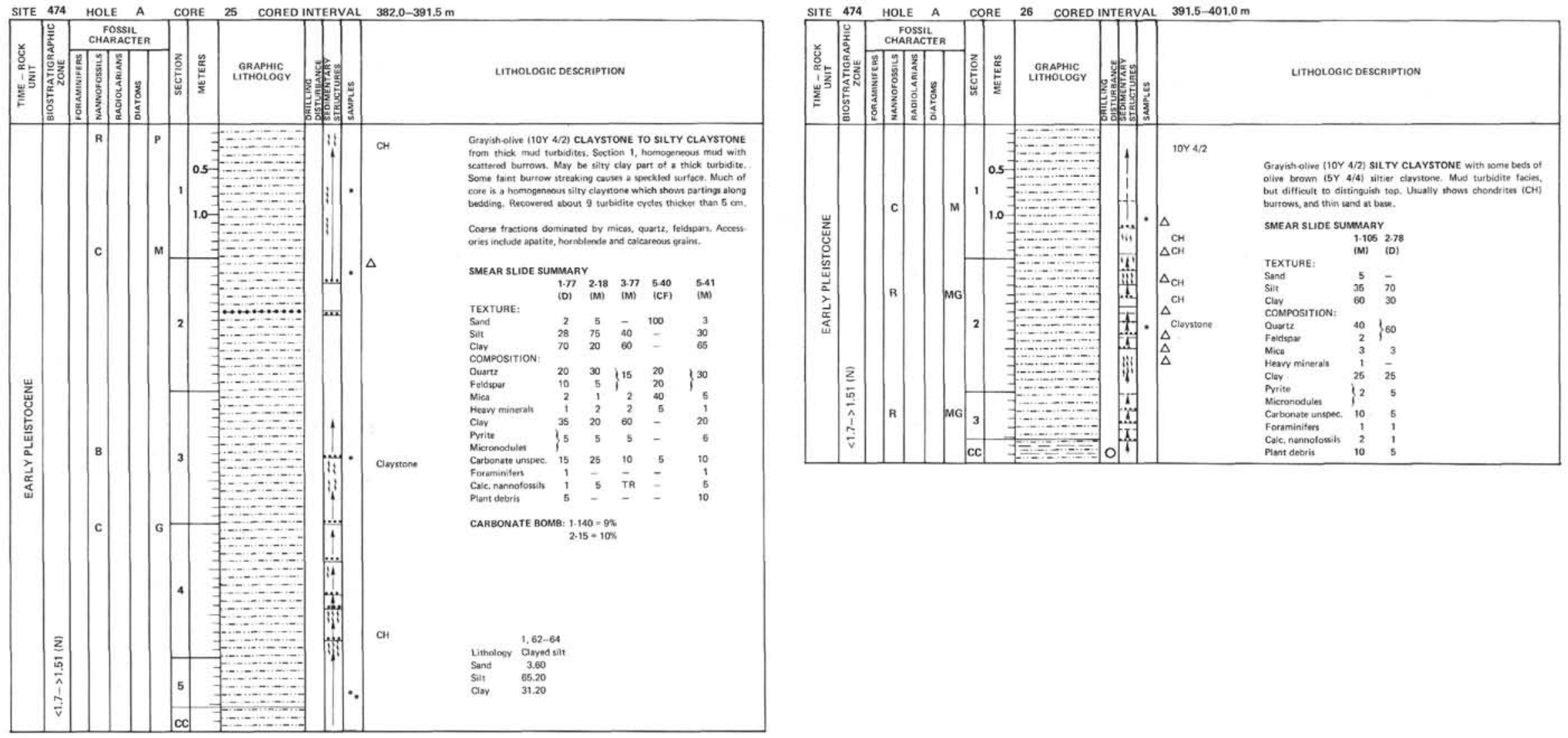

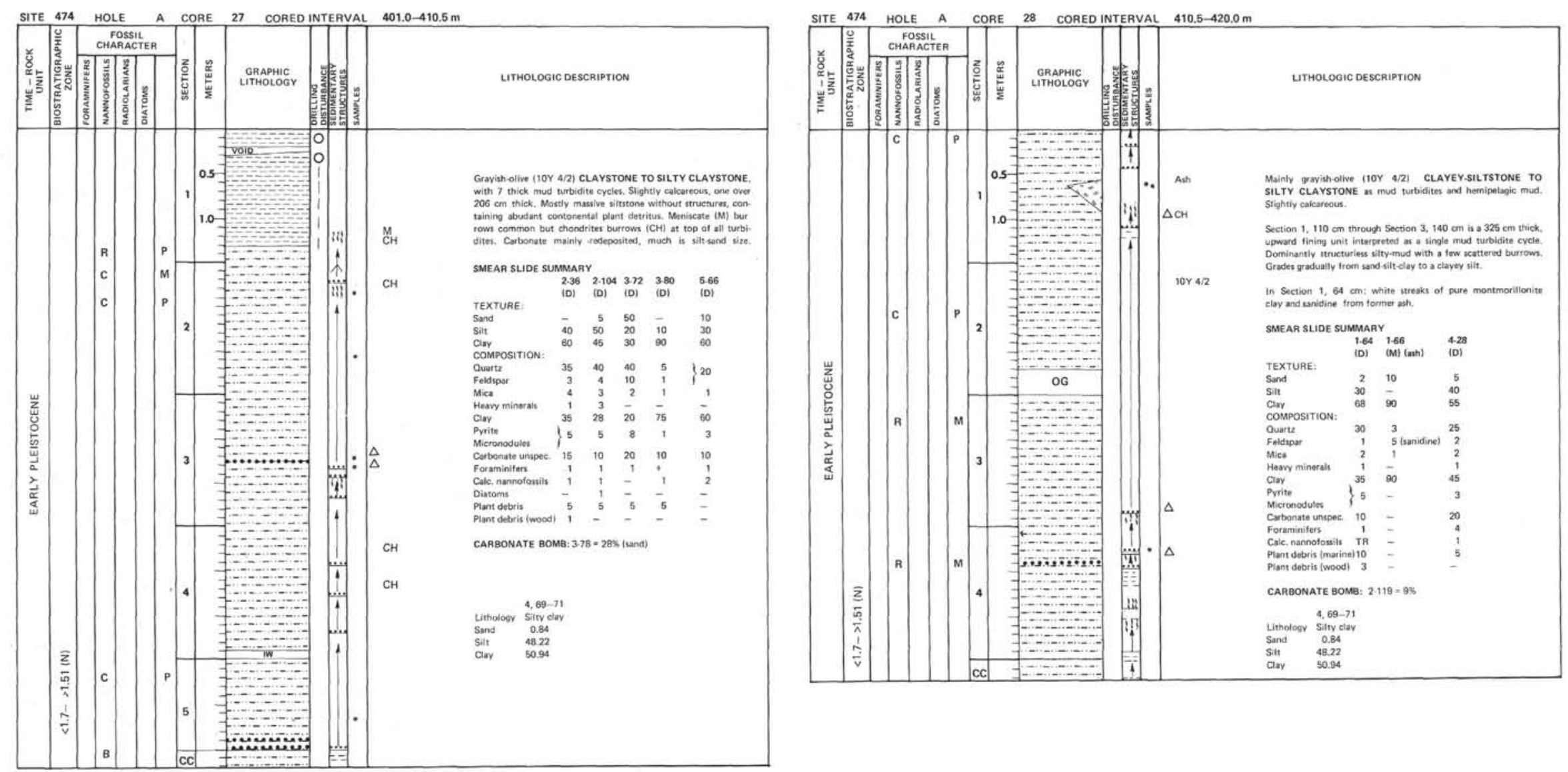

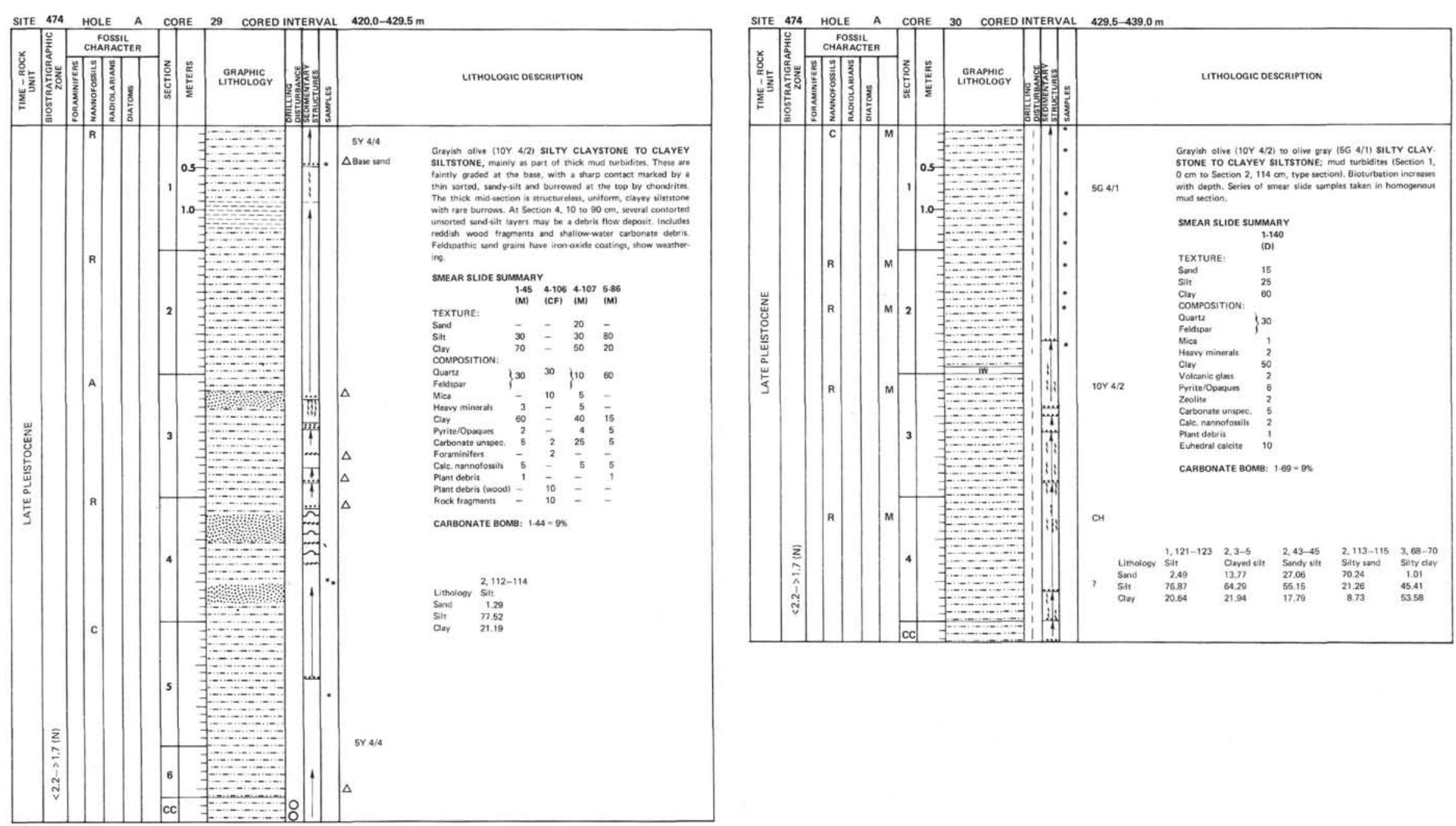

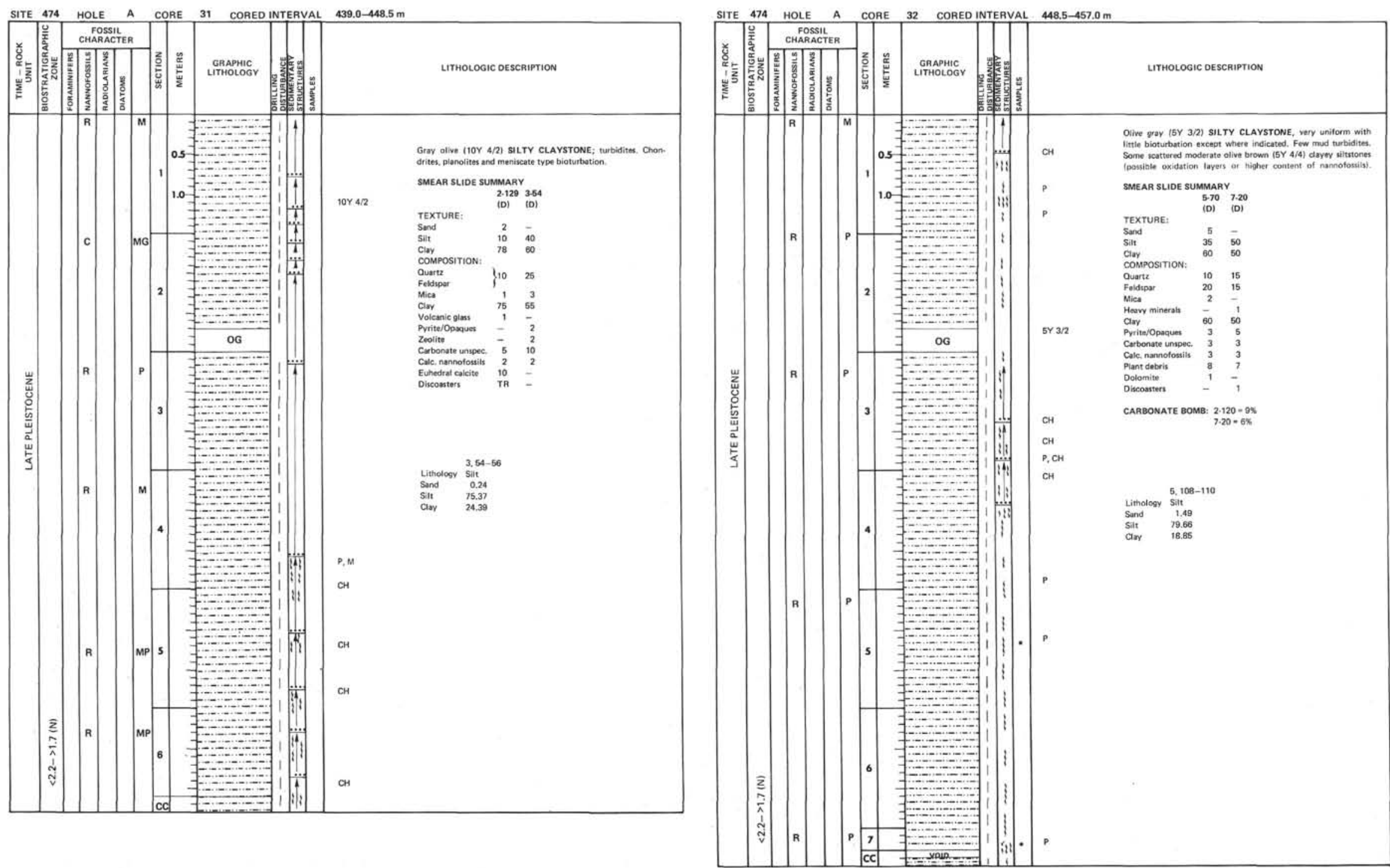

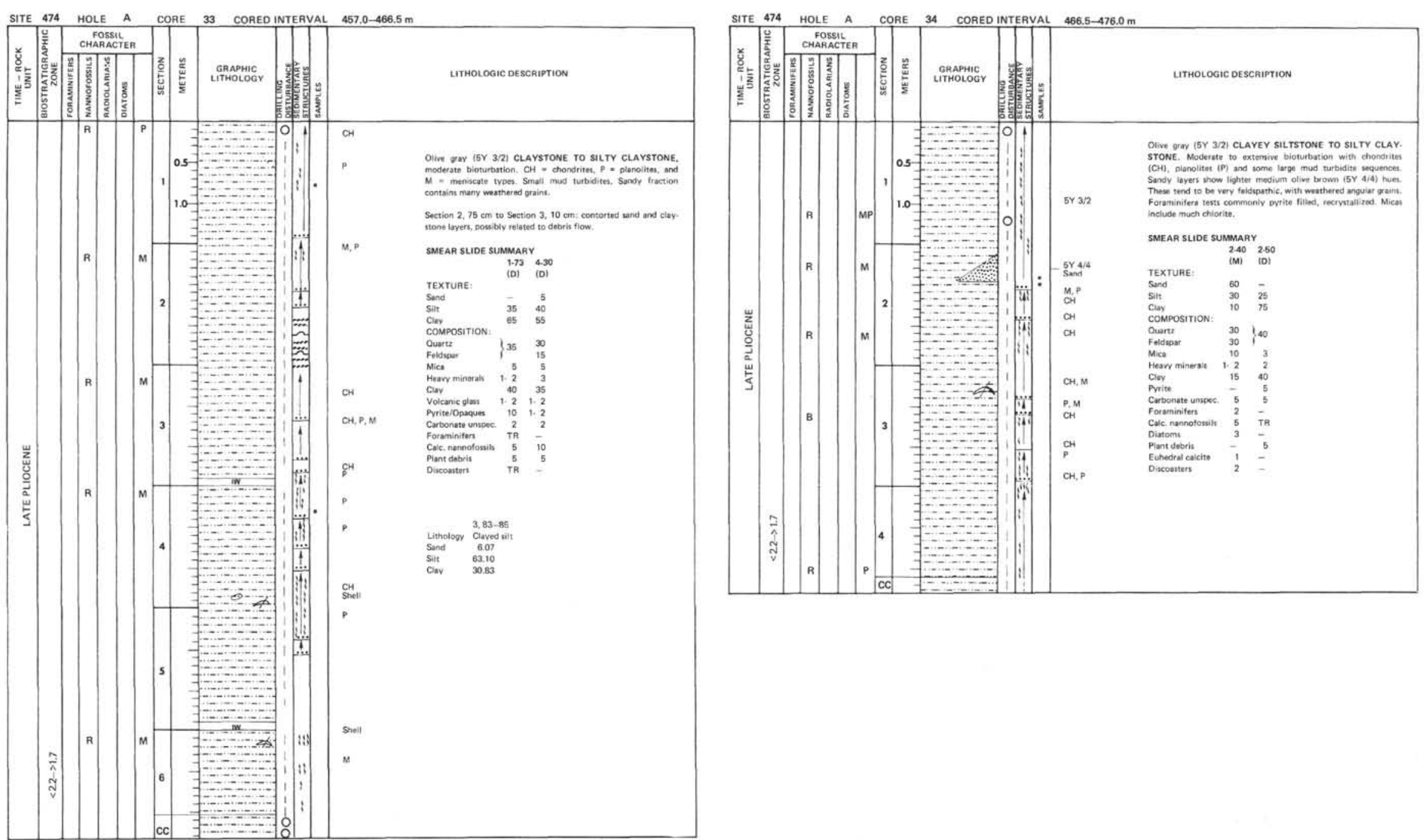

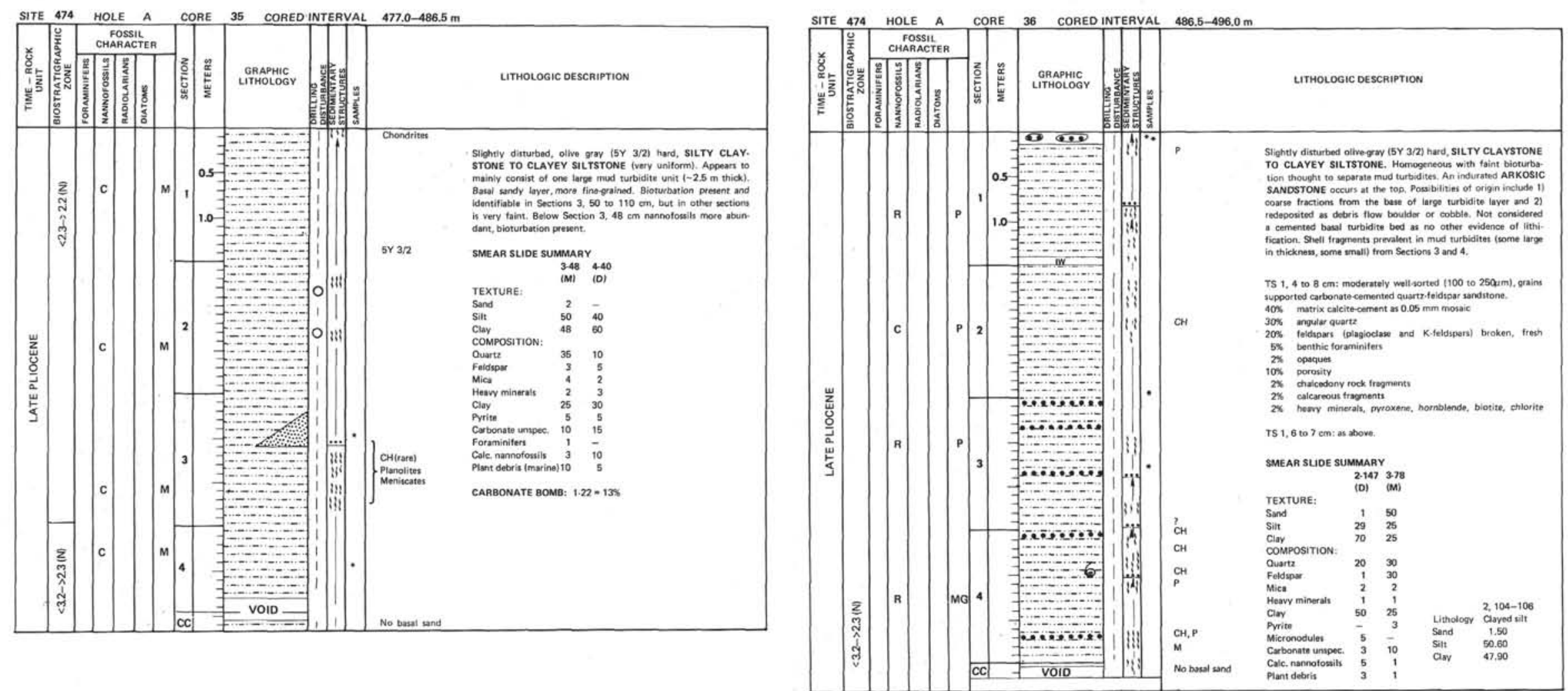

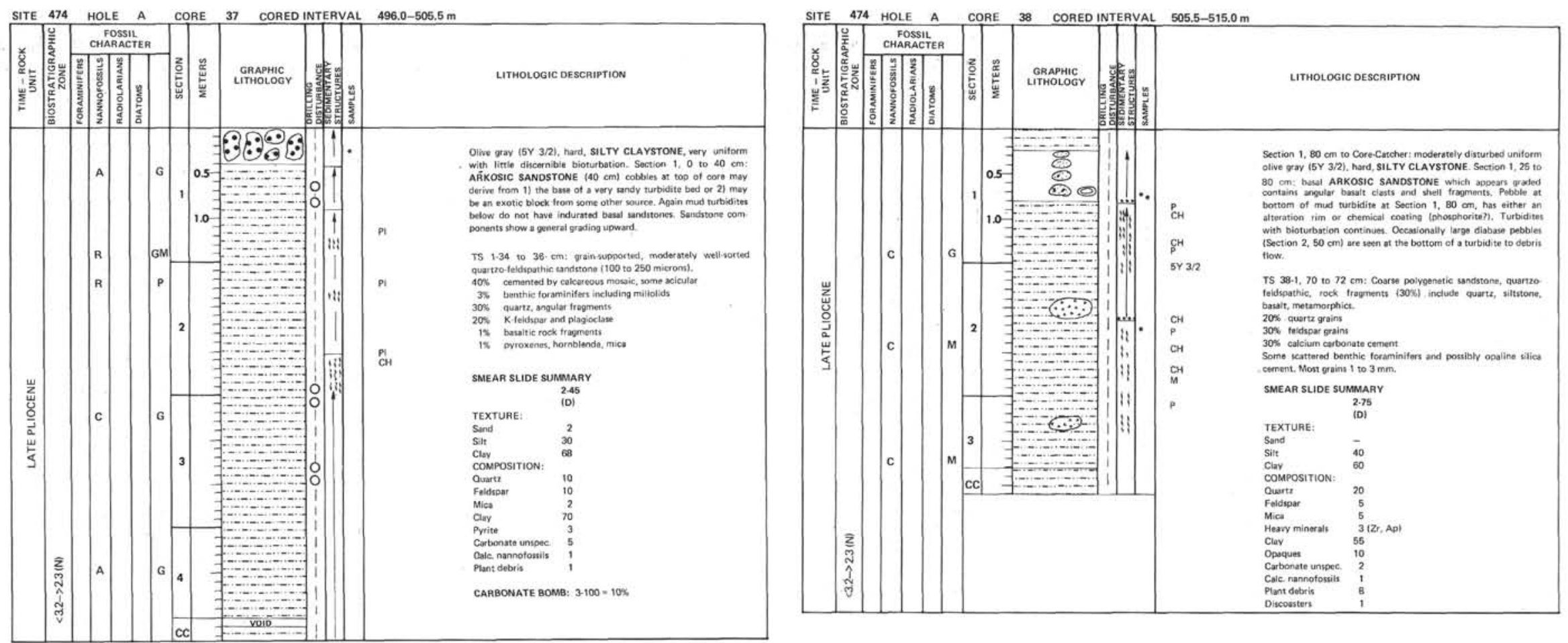

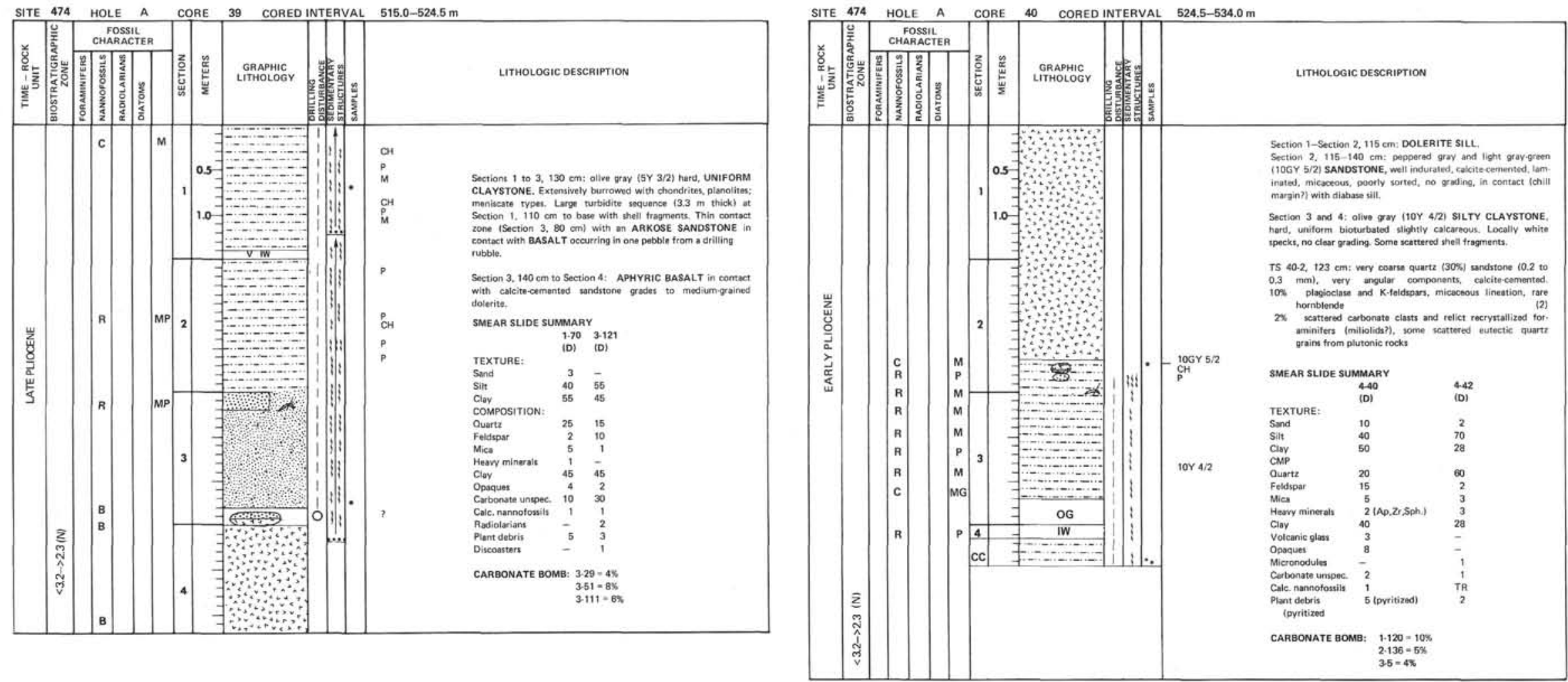
64.474A.39 Depth 515.0 to $524.5 \mathrm{~m}$ SECTION 3: DOMINANT LITHOLOGY: APHYAIC BASALT CON. TACT with sandstone.

Macroscopic Deteription

Aphrric basolt with $1 \mathrm{~mm}$ calcite vein and $5 \mathrm{~mm}$ calcite vug, Distinct

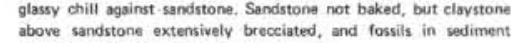
have been atiered in areas sojjcent to basalt:

TS $149 \mathrm{~cm}$ (Piicece 1B): Porphyritic BASALT, sampled adjacent to chillod margin, Phenocrysts: plagiociase approximuteily $15 \%$, up to
$2 \mathrm{~mm}$ actross, subhedral tabulate and lath th

appoximately $2 \%, 0.1-0.2 \mathrm{~mm}$, euhedral red dromessiat; Gione

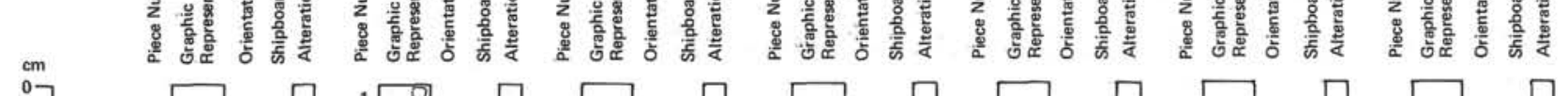

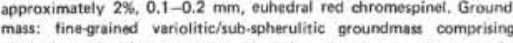
plagioclase microlites, pyroxene, disseminated opaques and mesostasis. omorohs of an widentified mineral probusy neplecing olivine. SECTION 4: DOMINANT LITHOLOGY: DOLERITE.

$$
\text { Macroscopic Description }
$$
Fine. to mediumprgained equigranular dolerite; fresth appearance,
$1-2 \mathrm{~mm}$ wide veins of $\mathrm{CaCO}_{3}$ (rock with $\mathrm{HCll}$ in Pieces 2 and 3 . TS $65 \mathrm{~cm}$. (Piicese 8): DOLERITE, Texture: subophitic, with seriate - olivine, ranging in size up to $2 \mathrm{~mm}$; subhedral, fractured, slightly

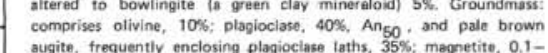
$0.2 \mathrm{~mm}$. occurs interstitially, Grainsize varies from $0.1-1.0 \mathrm{~mm}$. No vesicles are seen. Alteration restricted to rims and

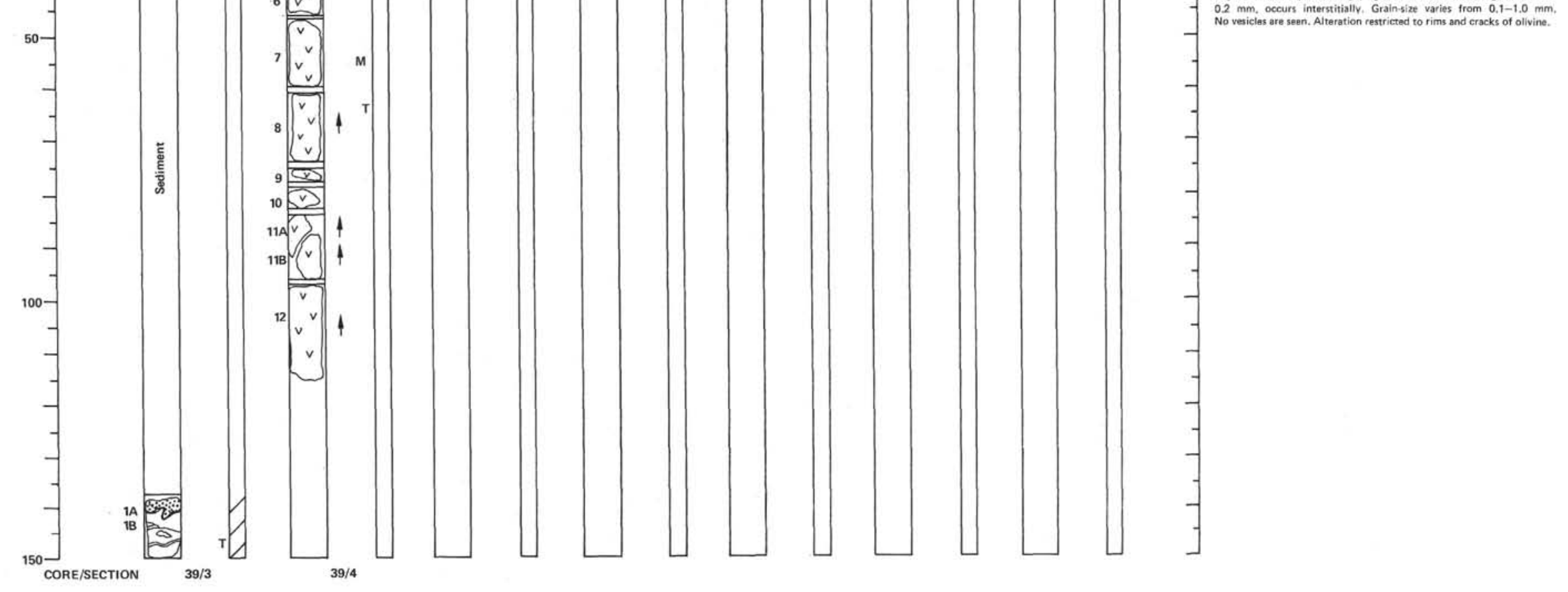



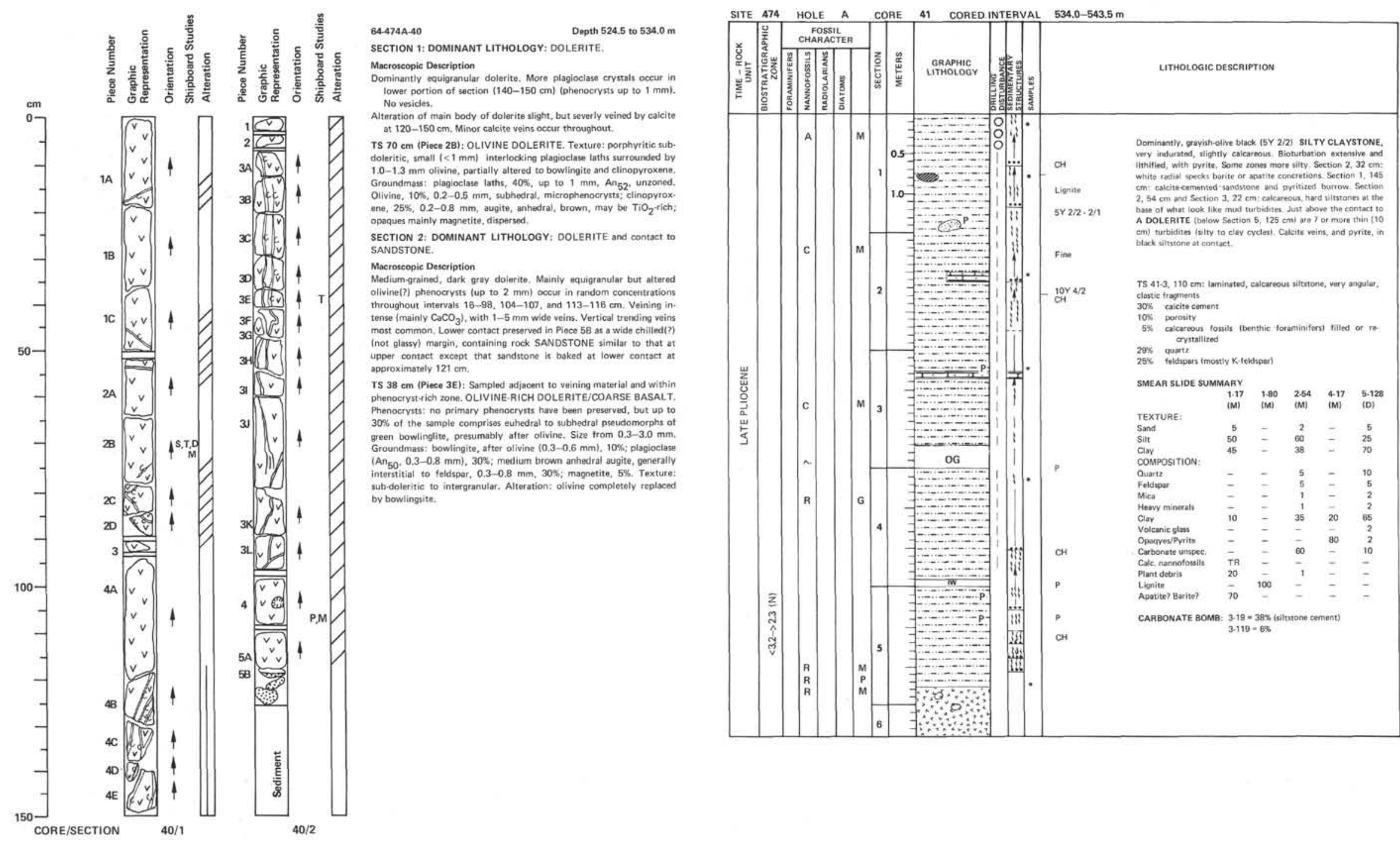


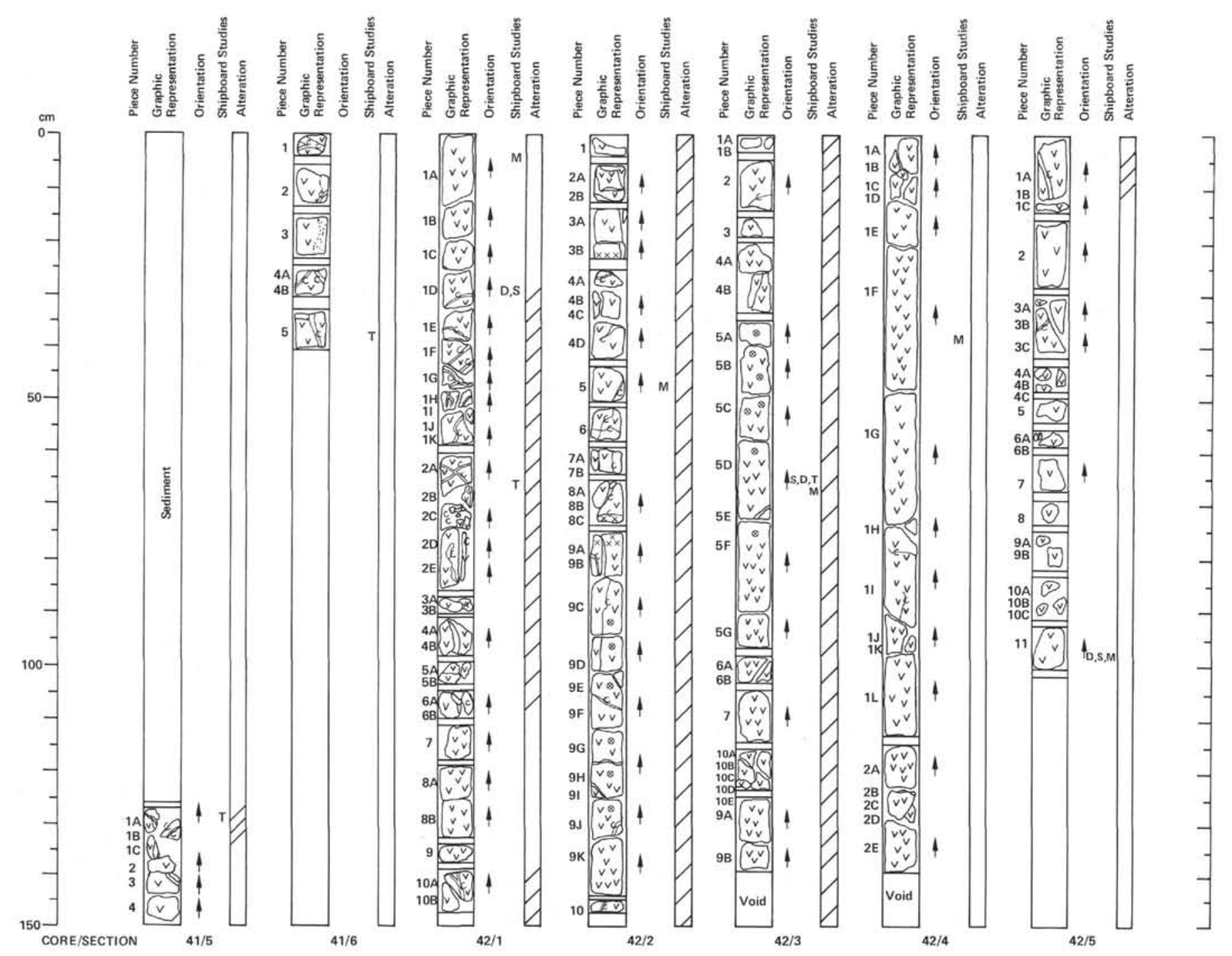



Depth 534.0 to $543.5 \mathrm{~m}$
64.474A-41
SECTION 5: DOMINANT LITHOLOGY: DOLERITE AND BAKED

Macroscopic Description
$128-129 \mathrm{~cm}$ : boked contact between overlying sediment and top of
dolectite from contact where it is ollivine (i) phyric 11 mm resinst to more (ine-grained at about $145 \mathrm{~cm}$. Large $(8 \mathrm{~mm})$ calcite vein occurs between $131-132 \mathrm{~cm}$, Below appoximately $145 \mathrm{~cm}$ dolectite is

(Piecen 1 A): section taken in chilled margin. Variotitic to BASALT. Phenocrysts of euhedral oilvine $115 \%$,

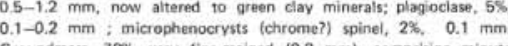
feldspar microlites in a dork, iron-rich mesostasis, Glassy. Minor clay. Narrow veins $1 \sim 0.5 \mathrm{~mm}$ wide) cross-cut glassy margin and sediment.

SECTION 6: DOMINANT LITHOLOGY: DOLERITE veins with

Macroscopic Description
Large, $1.2 \mathrm{~cm}$ thick calcito vein cuts across Piece 1 - equigranula dolerite showing some tendency towards altered olivine phyric bases near calcite veins. Other pieces $2-5$; doletitic.

is 38-40 cm (Pince 5): OLIVINE DOLERITE/COAASE BASALT.

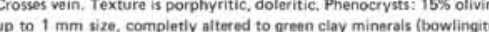
Groundmas: olivine, 5\%, now completetly altered; plagioclase, 45\% $0.10-0.5 \mathrm{~mm}, \mathrm{An}_{50}$ : clinopyroxene, $-30 \%, 0.1-0.5 \mathrm{~mm}$, augite
(possibly titaniferous) and magnetite, $\sim 2 \%$. Veins consist of $5 \%$ Caco and $95 \%$ zooitite (trigiparal? chababitite)

64.474A.42 Depth 543.5 to $553.0 \mathrm{~m}$

Macroocopic Description
Fine-graned deccipranular gray-doierite for most of the section. Dark $40-118 \mathrm{~cm}$, in the vicinity of calcite green clay (?) veins. These veins aut acrous in a subverticas dirrection, with a maximum with of $1 \mathrm{~cm}$ -140 cm dolerite is tain erately altered veining occurs at intervals $31-110 \mathrm{~cm}$ and $139-146 \mathrm{~cm}$ TS $68 \mathrm{~cm}$ (Piece 2A): : ine-graned olivine-rich do iefite. Texture: subophitic.porphyrritice. Phenocrysts: olivine $25 \%, 0.5-2.0 \mathrm{~mm}$, mostly $28,0.05-0.1 \mathrm{~mm}$, red diromite. Groundmass: oflivine, $10 \% 1<0.5$ $\mathrm{mm}$ ), altered to grean clay minerast; plagiochase $40 \%, 02-10 \mathrm{~mm}$. An $n_{56}$; clinopyroxene, $20 \%(0.2-1.0 \mathrm{~mm}$ ), pale brown avgite; and (5)

TETION 2: DOMINANT LITHOLOGY: DOLERITE,

Macroscopic Description
Fine-grained dark gray eq

attered olivine occurreving atrentalar dolerite, with some phenocrysts of veins cut in verrical trends. At interval $92-134 \mathrm{~cm}$ variolitic covities are filled with redial fibrous zeoliticl?) Material. Moderate aiterastion

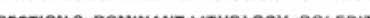

Mocroscopie Desceription
Fine grained dark gray eo

is present. The whole gection looks very homogeneoust. At internal
35-75 $\mathrm{cm}$. some vesichs are filled with calcite-zeolite(?). Alteration is TS $66 \mathrm{~cm}$ (Piece 5D):-dolerite with subophitic texture, No phenocrys phasese. Groundamass: olvine, $10 \%, 0.1-0.2 \mathrm{~mm}, 50 \%$ of which $\mathrm{mm}$; sugite, $40 \%, 0.1-0.2 \mathrm{~mm}$, pale brown; and magnetite, $3 \%$, 0.1 . $0.2 \mathrm{~mm}$. Alteration restrictod to green clay minerals around olivine gtains. Pyroxenes very fresh.
SECTION 4: DOMINANT LITHOLOGY: DOLERITE.

SECTION 4: DOMINANT

Macroscopic Deseription
Fine-grained dark grary equigranular tresh dolerite, sphyric, very massive

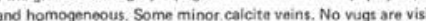

64.474A-42 Depth: 543.5 to $553.0 \mathrm{~m}$

SECTION 5: DOMINANT LITHOLOGY: DOLERITE,

Macroscopic Description

Fine-grained, equigranular, dark gray dolerite, massive, homogeneovis
Some calcite veining; largest ones <1 min thick. Similar to Section 4 
64.474A.43 Depth 553.0 to $562.5 \mathrm{~m}$

CTION 1: DOMINANT LITHOLOGY: DOLERITE.

Macroscopic Description

No chilled contact seet.

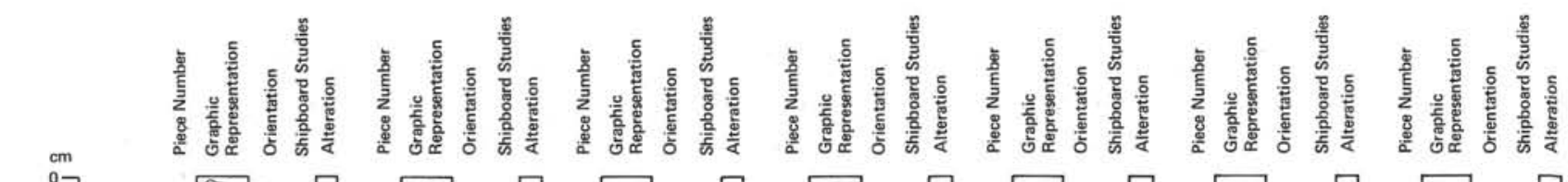

Essentially equigranular, although from $32-78$ and $105-150 \mathrm{~cm}$

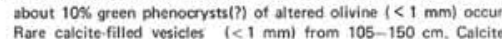
veining has caused considerable break-up of the dolerite in teggione 93-97 cm. Fraeturing commonon, resulting in many small tragments in intervalis 24-29, 84-70, 81-87 cm. Slickensides in fractures -
-
-
-
-
-
-
-
-
-
-
-
-
-
-
-
-
-
-
-
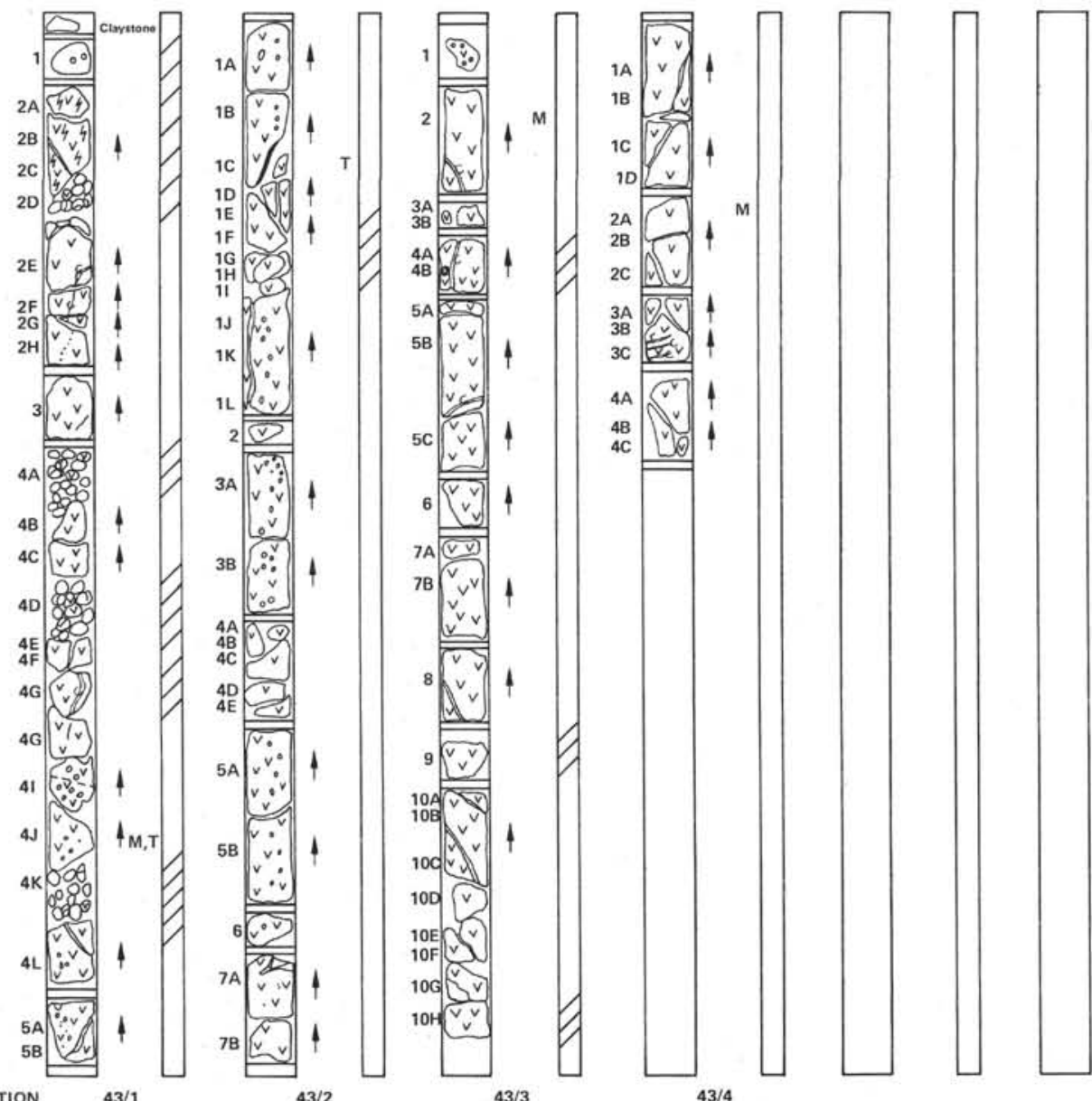

around $10-28 \mathrm{~cm}$.

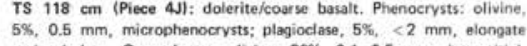
and tabulate. Groundmass: olivine, $20 \%$, $0.1-0.5 \mathrm{~mm}$, interstitial. subhedral, probably growing in situ; plagiociase, $40 \%, 0.2-1.0 \mathrm{~mm}$
laths, radial cluster (vartioles): laths, radial clustert (varioless): clinopyroxene in meostasis; and altered
groundmass, mainly altered to vellow clay mineraloids. Texture is fine-grained almost basaltic with occasional vesicles. SECTION 2. DOMINANT LITHOLOGY: dolesite.

Mocroscopic Description
Dark gray equigranular

dolerite. Green crystals noted in previo Poes 1 a Pieces 18 and $1 \mathrm{C}$ at $12-25 \mathrm{~cm}$, and $1 \mathrm{~T}, 1 \mathrm{~K}$ and $\mathrm{IL}$ at $40-55 \mathrm{~cm}$ have

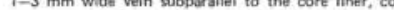
crvptocrystalline material, possibly attered glass, probably to clay up to $7.0 \mathrm{~mm}$, elongate

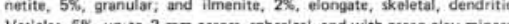

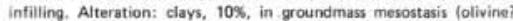
and zeolite, 20\%, in vein. SECTION 3: DOMINANT

$$
\begin{aligned}
& \text { Macroscopic Description } \\
& \text { Dark gray equigranular }
\end{aligned}
$$

Dark gray equigranular dolerite, medium-grained, with sporadic green Compose material las in Core 43 , Section $2,12-25 \mathrm{~cm}$ and $40-55 \mathrm{~cm}$ ) with PYrite.

SECTION 4: DOMINANT Mocroscopic Deseription

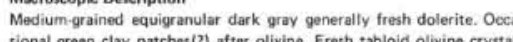
(up to $3 \mathrm{~mm}$ longi) clearly visibib. 


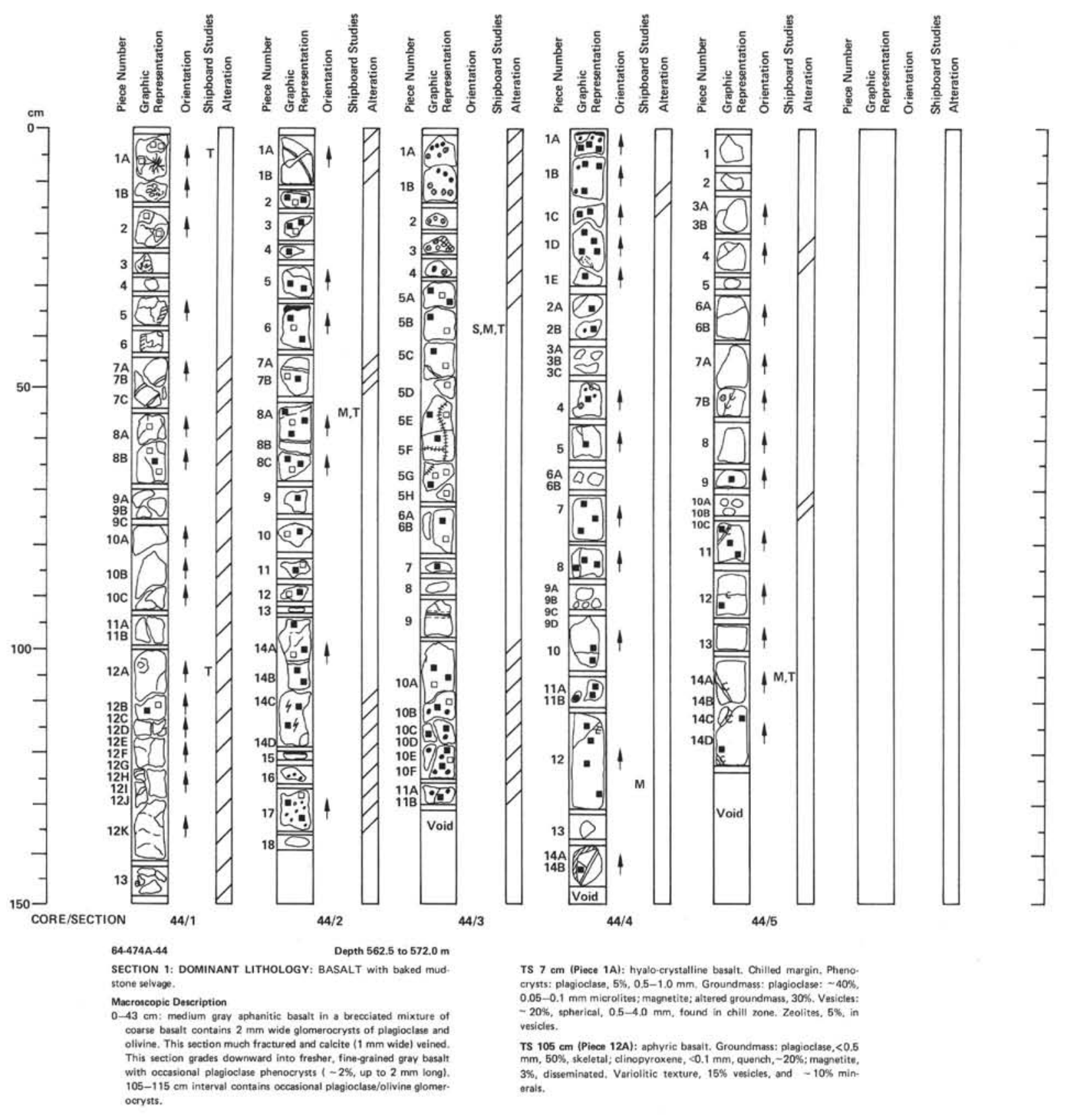

SECTION 2: DOMINANT LITHOLOGY: BASALT

Macroscopic Description

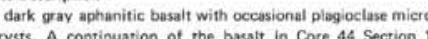
Baked mudstone selvages at $0-10 \mathrm{~cm}$ and Piece $7 \mathrm{~A}$.

(116 cm: light to medium grav aphanitic basalt with numetrod ats phenocrysts as indicated. Glassy salvage at $34 \mathrm{~cm}$ (Core 44 , Sec tion 2, Pioce 61.

16-140 cm: dark grav basalt, fine-grained, with abundant $1 \sim 20 \%$ present. Glassy seivage at $119 \mathrm{~cm}$ (Core 44 , Section 2, Piece 15 . Alteration: green clay. filled veins in Piceces 1, 7, and 14 (vesicles filled with clays:

IS $56 \mathrm{~cm}$ (Piece 8A): Intersertol to hyalopilitic pillow basalt - slightiv

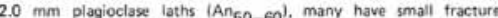
Abundant plagiociase microlites $-1 \mathrm{~mm}(15 \%)$ in diammater indicate rapid chilling of pillow margin up to $20 \mathrm{~cm}$ from the glatsy pillow mesostasis of stightiv altered basaltic glass and plagioclase and cline byroxene groundmass crvstals. IImenite lasths, 0.1-0.3 mm long, are

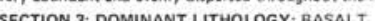

Mocrosocopic Description

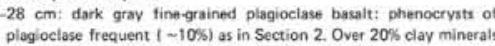
and calcite-filled vusicies. Baked clay salvage at $-22 \mathrm{~cm}$.

amyotale trese, aphanitic basts but still containith a zone of as in remainder of section) between $53-98 \mathrm{~cm}$.

99-132 cm: dark gray fine- to medium-granned xenocrystic basalt

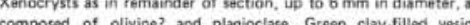
again abundart as in $0-28 \mathrm{~cm}$ interval. is $38 \mathrm{~cm}$ (Piece 58) : basalt. Phenocir

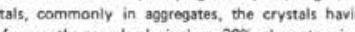
phenoceryss: spinel. 2-4X, Tchrome spinet, in groundmass and in

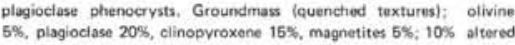
5\%, plagioclase 20\%, clinopyroxone 15\%, magnetites $5 \%$; SECTION 4: DOMINANT UTHOLOGY BASALT.

$0-4 \mathrm{~cm}: 2 \mathrm{~mm}$ vesides filled with green clay minerals, many $-2 \mathrm{~mm}$ phenocrysts of plagiociase in a roughly equigranula (a) Jaitly uniform throughout section, Rocks are slightly fractured bu with calcite.

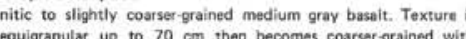
Ant equigranular up to $70 \mathrm{~cm}$ then becomes coarser-grained with sitteration near small calcite veins. Larger calcicito veins occur in Pieces IS $105 \mathrm{~cm}$ (Piece 14A): subophitic basalt, sightily altered, up to $2 \mathrm{~mm}$
laths of plaggiclase - some showing slight alteration to clays at their edges - surrounding small olivine and clinopyroxene mictophento olivine and ilmenite and basalt glass. Many of the olivine and clino. pyroxene are moder
ducts. Non vesicular.

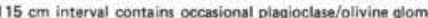
3., disseminated. Variolitic texture, $15 \%$ vesicles, and $-10 \% \mathrm{~min}$ 
64.474A.45

SECTION 1: DOMIN

Macroscopic Description
Top $3 \mathrm{~cm}$ is an olive gray fine-grained claystone (NN 16). Interval
$3-138 \mathrm{~cm}$ is a fine-grained dark gray equigrtanular basalt with some plagioclase glomeroctrysts mainily trom the $75-120 \mathrm{~cm}$ interval. Calcite green clay 7 velinimg section. Excopt for the veining restricted to some areass, the bastl looks very fri

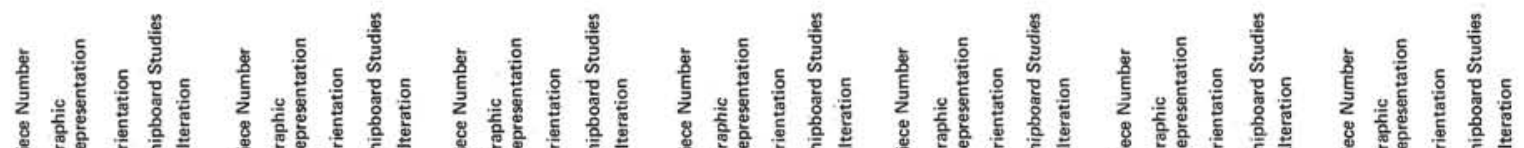

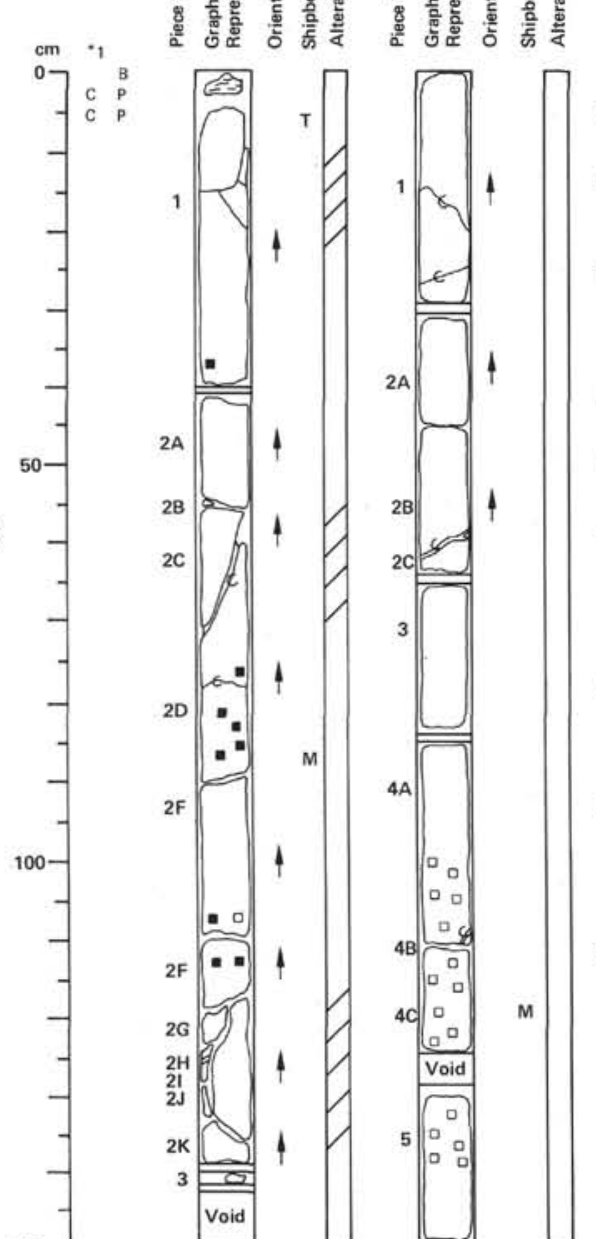

CORE/SECTION

$45 / 1$

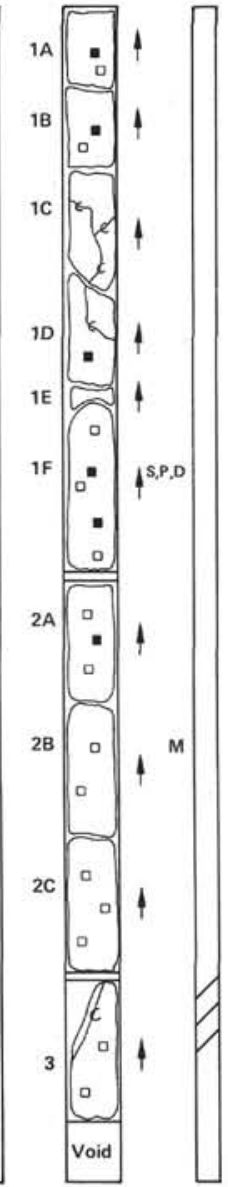

$45 / 2$

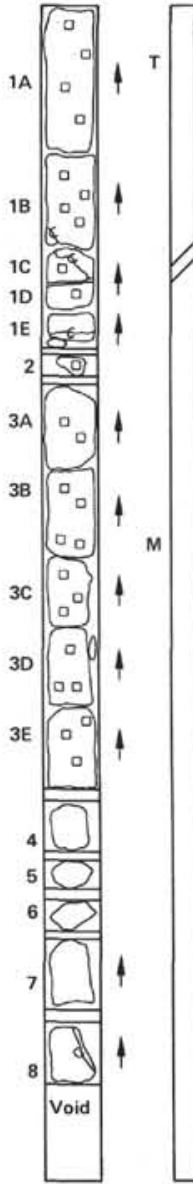

$45 / 4$

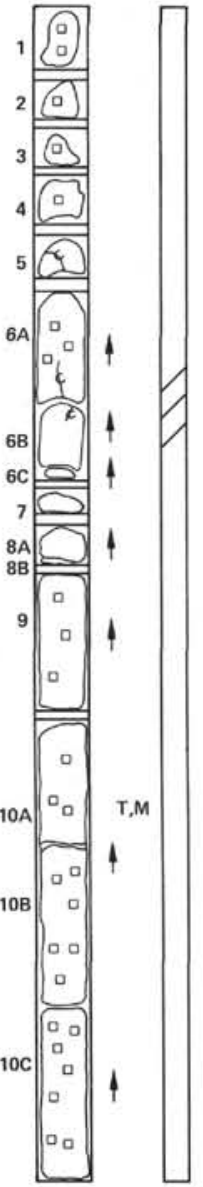

$45 / 5$
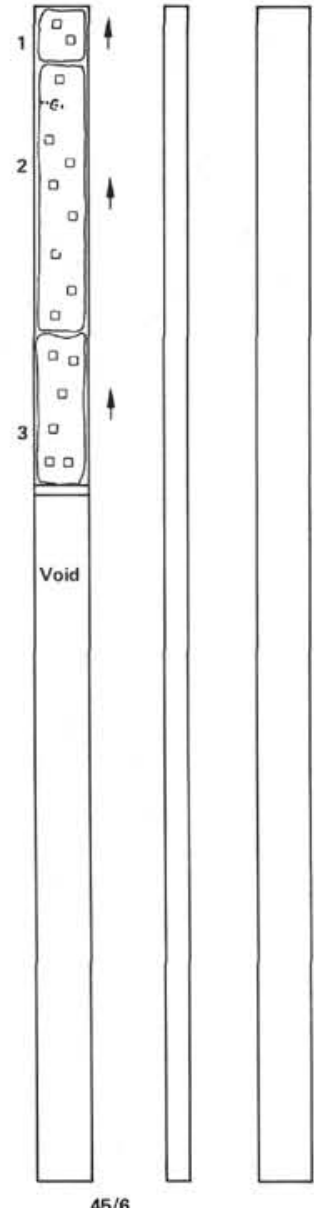

Macroseopic Description

Medium: to tine-grained basalt grains become coarser toward the base

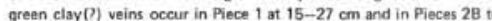
Microphenocrysts of plagiociass in an equigranular tox $x$ as SECTION 3: DOMINANT LITHOLOGY: BASALT

Macrosecopic Description seems to be restricted to some throughout the section, Alteration HTHOLOGY, PLAGIOCLASE.PHYPIC

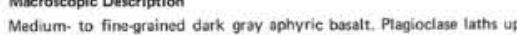
to $3 \mathrm{~mm}$. Glomerocrysts throwghout the section. Colcite-chilonite (i) The phenocrysts (to bowlingite) and fresh clinopyroxene (augite) phene.

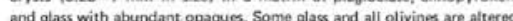
Clinopyroxene is anhedral and is ptesesent in lath shapes that have parted Along cleavage planes,

SECTION 5: DOMINANT

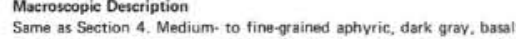

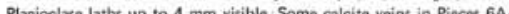
SECTION DOMINANT UTHOLOGY, BASALT.

Macrosecopic Description
Similar to Section 5 , mets

Um- to fine-grained dark gray aphyric basal With plagioclase phenocryste up to $3 \mathrm{~mm}$, Small chlorite Green clasy? crysss become less abundant than in previaus wections.

-

$-1$

(N)

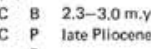

to $3 \mathrm{~mm}$. Some glomeryric dark gray basalt, plagioclase laths up

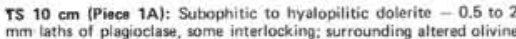



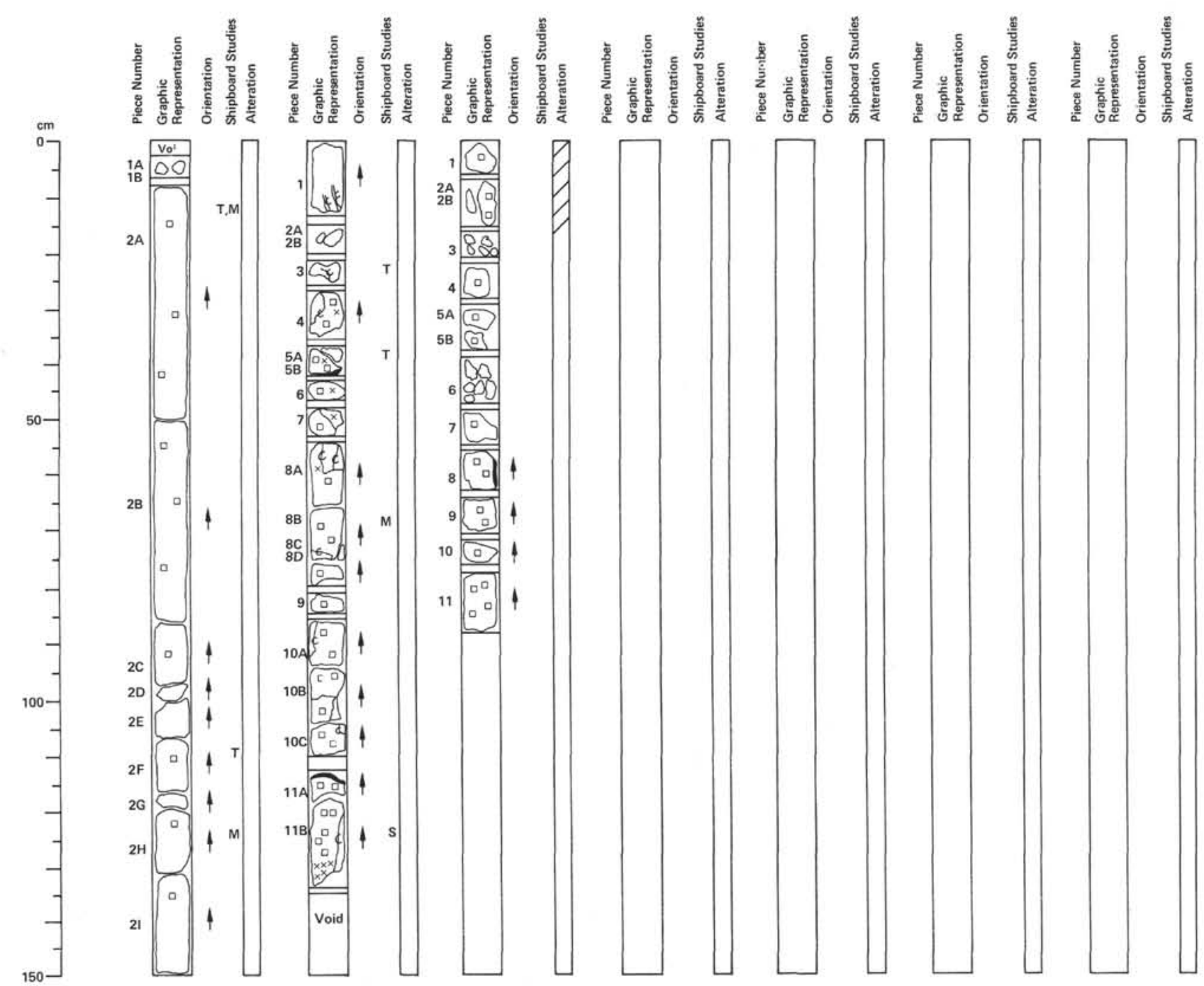

CORE/SECTION

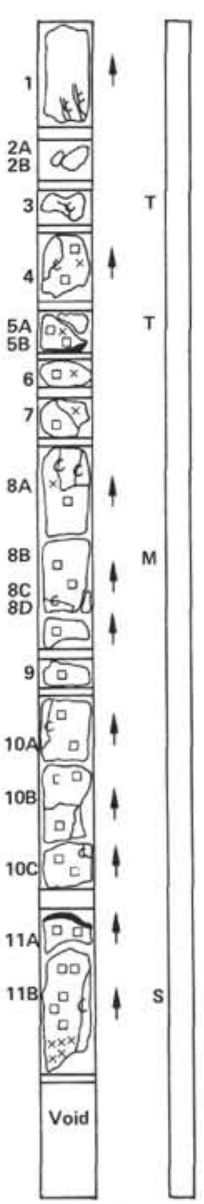

$46 / 2$

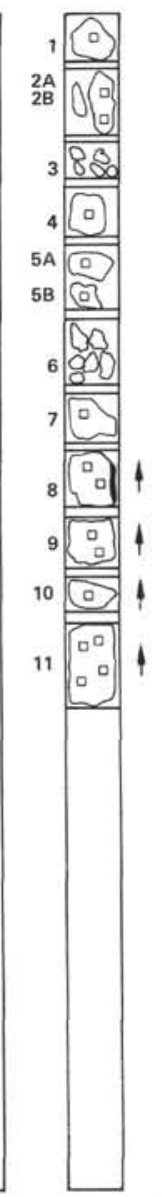

$46 / 3$

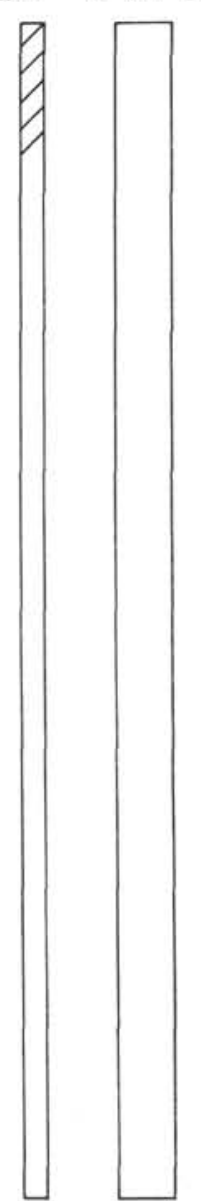

$6 / 3$

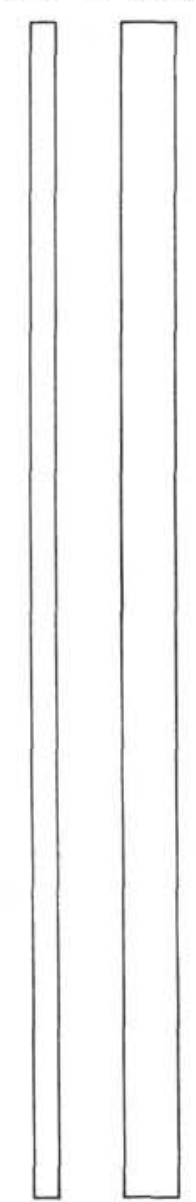

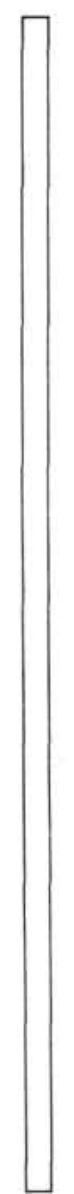
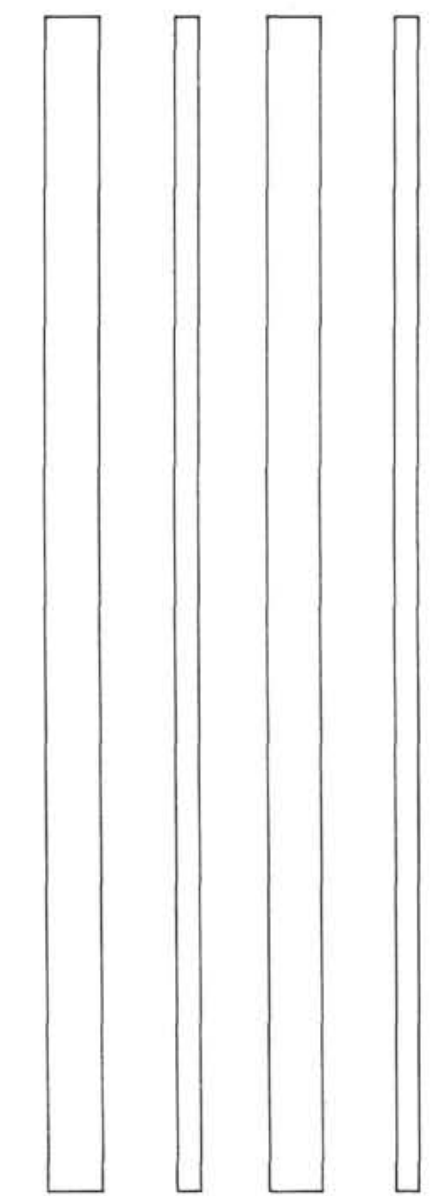

Macroscopic Description
Dark gray aphanitic basalt with some plagioclase laths up to $3 \mathrm{~mm}$. Core 45 , Section 6 , begenents, it is essentially the continuation of Or anv siteration is visible in this section.

TS $10 \mathrm{~cm}$ (Piecte 2A): Dolerite. Subophitic texture. Phenocrysts: crystal agorogates. The mascins ate resorbed and the crystals are zon Groundmass: olivine, 5\%, 0.3-0.5 mm; plagioclase, 40\%, 0.3-0.1 mm. $A_{45}-55$. generally lath-shaped and ophitically enclosed in clino.
pyroxene; augite, 40X, up to $2 \mathrm{~mm}$ accoss; opaques. Alterstion restrictod to replacement of olivines by clay minerots TS $110 \mathrm{~cm}$ (Picce 2F): Same as above, dolerite.
SECTION 2. DOMINANT LTHOLOGY: BASALT.

Macroceopic Description
From 0-19 $\mathrm{cm}$, fine-grained dark gray aphanitic basalt with scarce

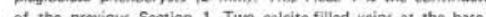
Piece 1. This and the fwo Pieces 2 saem to be the bottom of a cooling unit, as contrasted with the rest of the section below. The Interval $20-110 \mathrm{~cm}$ shows a different texture, with a much larget amount of plagioclase megacrysts up to $1 \mathrm{~cm}$ long and ales a larger amount of clinopyroxenes. Some calcite veins appear in this sil. Interval 113-134 cm is possibiv snother unit whose upper part (Piece clinopyroxene sre observed. Minor alteration.

IS $21 \mathrm{~cm}$ (Piece 3): porphyritic basalt. Texture: porphyritic; pilotaxitic

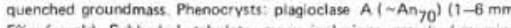

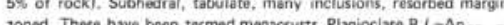

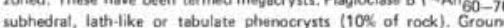

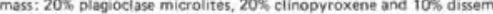
ated magneticte, 30\% amorchlous groundmass mesostasis. Alteration:

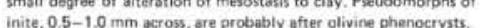
IS $35 \mathrm{~cm}$ (Piece 5): very similar to $21 \mathrm{~cm}$ description. Megacrysts oliaglocisse up to $5 \mathrm{~mm}$, and $5 \%$ of rock consists of $1 \mathrm{~mm}$-diametser.

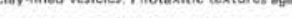

SECTION 3: DOMINANT LITHOLOGY: BASALT.

Macroscopic Description
Dark gray aphytic ba balt,

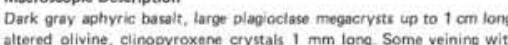
long some veining with calcite yreen-clay? 
64.-474A.47

SECTION 1: DOMINANT LITHOLOGY: megacrystrich BASALT Macroscopic Description

to aphanitic groundmass, contraining (up to $1.5 \mathrm{~cm}$ across, usually $-0.5 \mathrm{~cm}$ ). Altertation very slight, restricted to minor calcite and green clav veining (PPiocess $6,7,8,15,16$, and 17

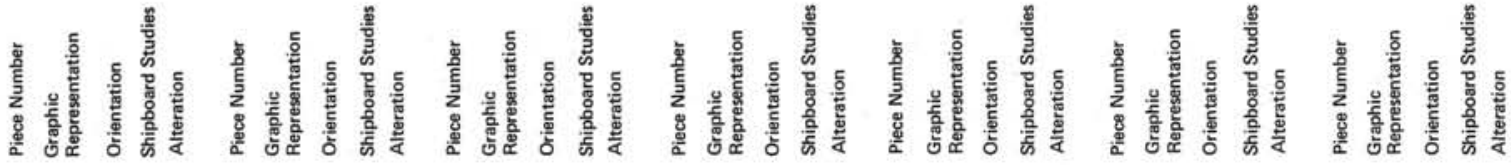
and of grean clay
selvage in Piece 4.

TS $110 \mathrm{~cm}$ (Piece 16): porphyrritic basalt, porphyritic//variolitic, Pheno
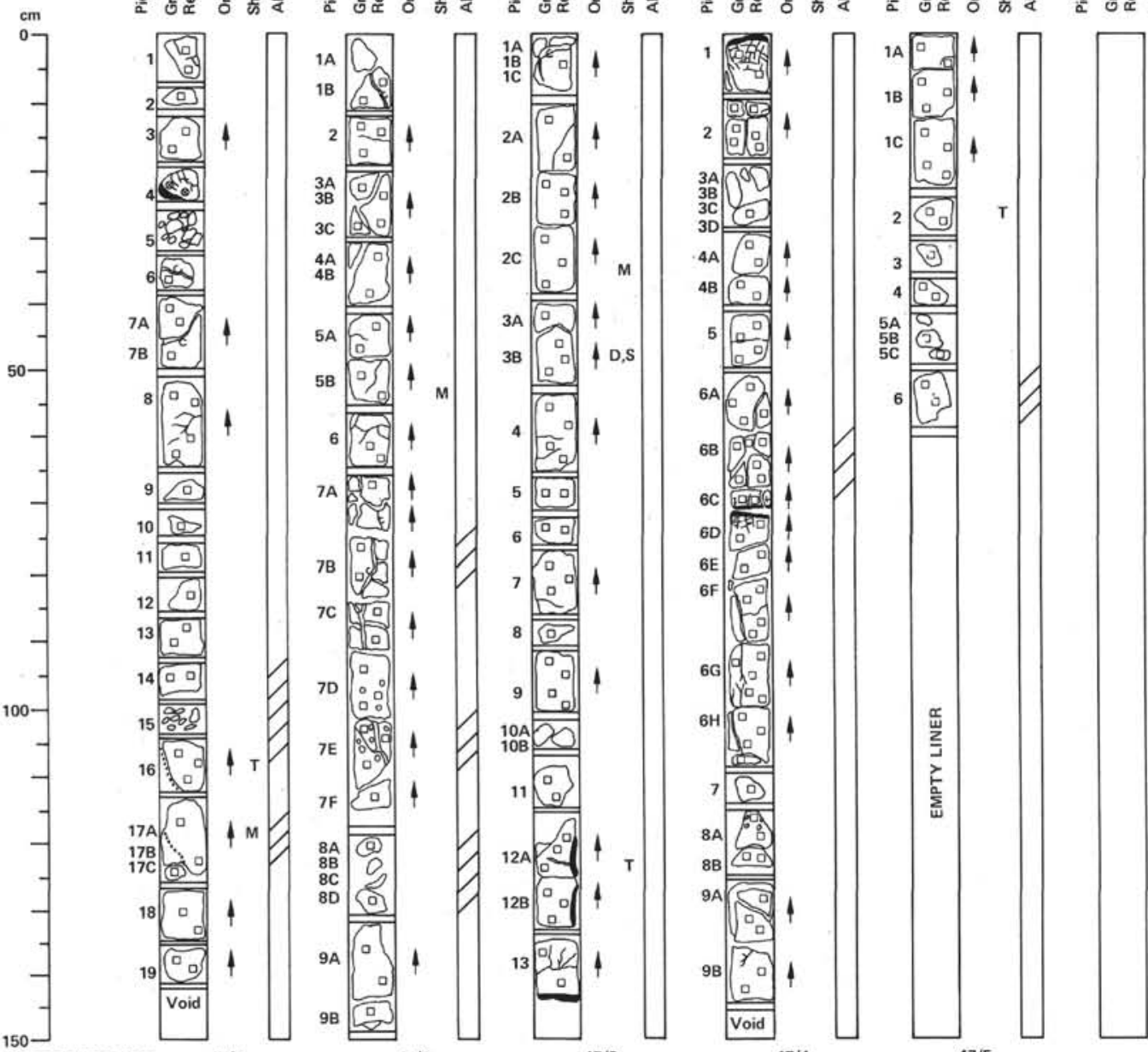

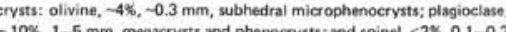

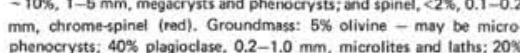
brown sugito up to $1.0 \mathrm{~mm}$ laths: $5 x$ magnetite - disseminated and granular; $2 \%$ itmenite: and $20 \%$ mesostasis. Vesicles: $4 \%, 0.8-1.2 \mathrm{~mm}$
random, sphericil vesicles filled with clay minerals. Alteration: $5 \%$ clay minerests throughout mous

SECTION 2. DOMINANT HTHOLOGY Mogocemith BASALT. Macroscopic Desceription

- line-grained to aphanitic groundmass containing 作 veining (1-2 mm wide vein nuns through Pieos 7A-F). Small, calciteadically in Piecos $7 E$ and $F$.

SECTION 3: DOMINANT LITHOLOGY: megacryst-rich BASALT.

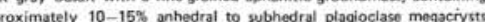

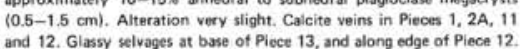
and 12. Glassy selvages at base of Piece 13, and along edge of Piecen 12 IS $122 \mathrm{~cm}$ (Piece 12): plagioclase-phyric basalt, sampled adjacent to

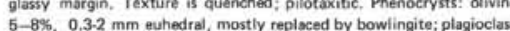
$15 \%, 5 \%, 0.5-8.0 \mathrm{~mm}$, magacrysts and $10 \%, 0.5-2 \mathrm{~mm}$, phenoccrysts: spinel: $1 \%<0.2 \mathrm{~mm}$, red chrome-spinal. Groundmass: very fine grained quenched texture. Alteration: $<5 \%$ clays in proundmass, and replise

\section{Gray basalt with a fine} dral to subhedral plagioclase megactysts $10.5-$ $1.5 \mathrm{~cm})$. Alteration shight, restricted to calcite and greenclay obloric SECTION 5: DOMINANT LITHOLOGY, megacrystrich BASALT,

mately 10-15\% anhidral to subhedral plagioclase

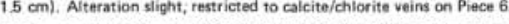
IS $35 \mathrm{~cm}$ (Piece 3): PLAGIOCLASE.PHYRIC BASALT. Texture h $0.5-1.0 \mathrm{~mm}$ across, repl latt agsregate megaccysts, 1-5 mm, > An 70; plagiociase $-10 \%, 0.5-1$

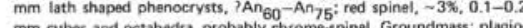
clase, 15\%, $0.2-0.4 \mathrm{~mm}$, mitgolites and quench overgrow ths on plagio classe phenocrysts; clinopyroxene, $40 \% 8$ ? $<0.1 \mathrm{~mm}$ dendrites, wheal sheaves; and magnetite, 5\%, disseminated. Vesicles: $5 \%, 1 \mathrm{~mm}$ diameter

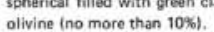




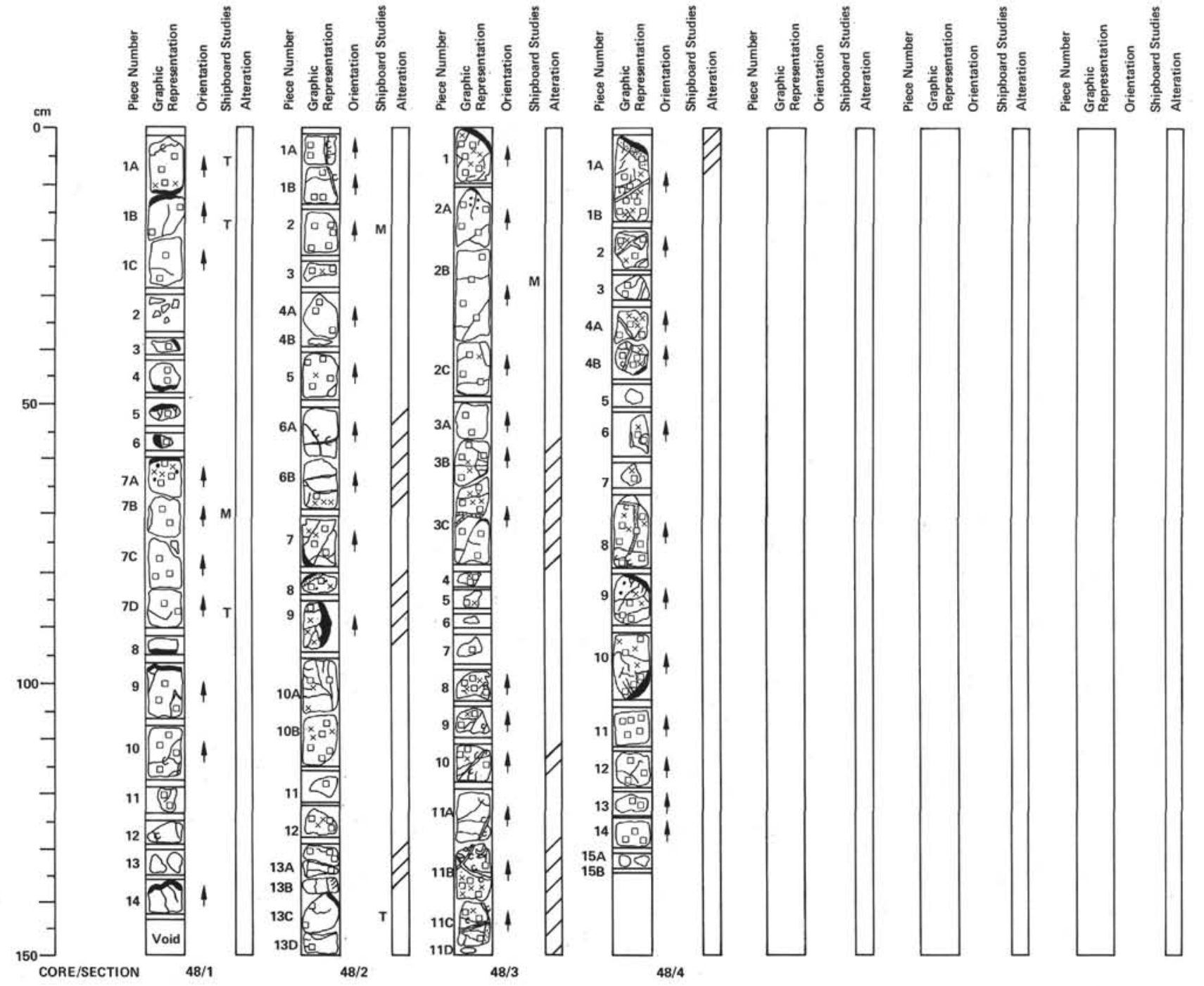

64.4744 .48

Depth: 599.0 to $608.0 \mathrm{~m}$ SECTION 1: DOMINANT LITHOLOGY: plaggioclase megacrystrich pillow BASALT.

Dark gray porphyritic basalt with plagioclase megacrysts up to 1A, 1B, 4, 5, 6, 7A, 8, 9, and 14, Slighn alteration restricted to veins. Many small veinetets are zeolite and clays. Glass selvages are mostly very fresh and only at times slightly palagonitized. Small hair -ike fractures $2-4 \mathrm{~cm}$ into a pillow (down-core). Larger megoecrysts of plagioclase de not occur near top
core from the selvage.

\section{core from the selvage.}

TS $5 \mathrm{~cm}$ (Pincen 1A): porphyriticic basalt with pilotaxitic texture. Similar mesostasis, and with $10 \%$ bowlingite replacing olivine phenocrysts TS $19 \mathrm{~cm}$ (Pines 1C): pornhyritic basalt with quenched sphertilitic texture, quenched groundmass. Sampled adijacent to glassy margin. Spherulites

$5 \%, 0.1-10 \mathrm{~mm}$ across, very freshric plasiocisase A $5 \%, 2-10 \mathrm{~mm}$.

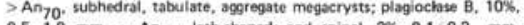
$0.5-1.0 \mathrm{~mm}, \sim$ An 70 , lath on not distinuithable from mesostasis; opaquers, 5\%, dis. seminated: mesostasis, 603, very slightly altered. No vesicies. Texture: porphyyrtitic; plolotaxitic to variolitic. Alteration: very slight, restricted

SECTION 2: DOMINANT LITHOLOGY: PLAGIOCLASE PHYRIC BASALT.

Macroscopic Description
Several pillow basalt flows

unaltered basalt with abun-

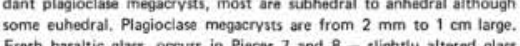
is found in Piece $\theta-$ glassy pillow selvages are from $2 \mathrm{~mm}$ to $<1 \mathrm{~cm}$ thick, however it appears that parts of the glassy selvages were des.

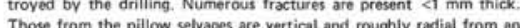
imaginary canter point of the pillow. Small calcite veinlets at times
fill the fractures. Clay minerals are also present in some of the froctures. fill the fractures. Clay minerals are also present in some of the froctures.

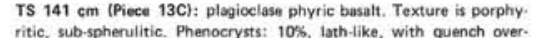

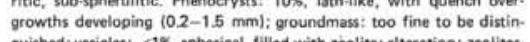
guishod: vesicles: <1\%, spherical, filled with zoolite; alteration: znolites. $10 \%$ in veins and vesicles.
SECTION 3: DOMINANT LITHOLOGY: PLAGIOCLASE PHYRIC PILLOW BASAL

Macroscopic Description

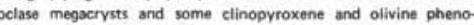
crysts. A $\sim 0.5 \mathrm{~cm}$ glass selvage occurs in Section 1. Thin fractures $1-2 \mathrm{~mm}$ thick, calcite-zeolite veins sccur in Pieces 10 and 11 . Atteration is slight to moderate in areas with veins. Otherwise section is SECTION 4: DOMINANT LITHOLOGY: PLAGIOCLASE PHYRIC PILLOW BASALT

Macroscopic Description
Fairly fresh medium gret

cilling tractum. Fines Evenly distributed, Some clinopyroxene and olivine phenocrysts. Fresh glassy selvages occur in Piecos 9 and 10 . Palagonitized selvage
occurs in Pisce 1 , interestingly one plagioclase megacryst is included in the glassy selvage indicating that megacrysts are preeruptive. Section
it similar in texture and appearance to the other sections of this core. 
64.474A.49 SECTION 1: DOMINANT LITHOLOGY: PLAGIOCLASE PHYAIC

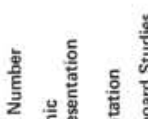
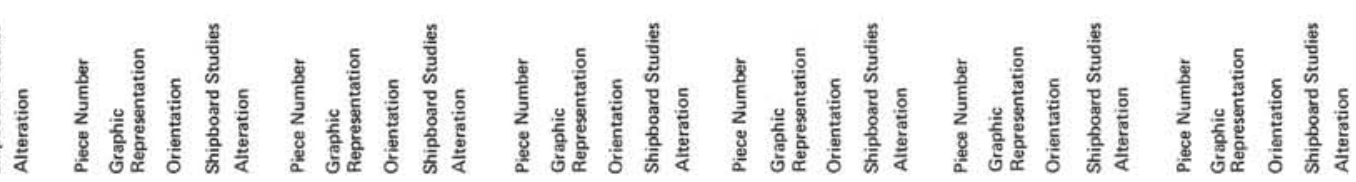

Macroscopic Description
Dark qray piagioclasen mang

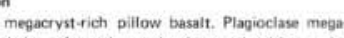
.
.

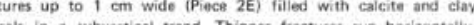

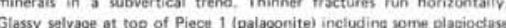

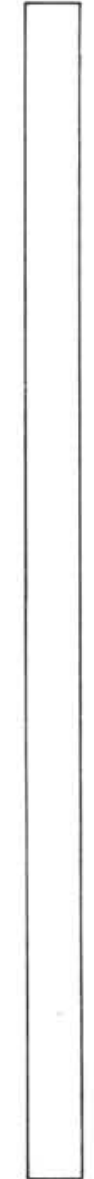

$20-120 \mathrm{~cm}$, where veins cceur.

SECTION 2: DOMINANT LITHOLOGY: PLAGIOCLASE PHYAIC PILLOW BASAT

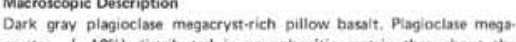
section, size from $2 \mathrm{~mm}$ to $1.5 \mathrm{~cm}$. A tew calcite-clay (i) . Filled veing show a subvertical trend. Horizontal cracks in several pileces. Glasty

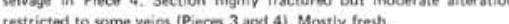

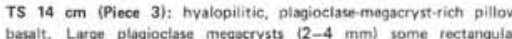

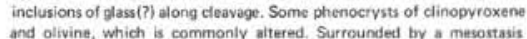

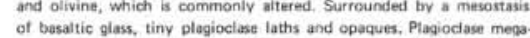
only composed of teverat large interiocking plagiociass

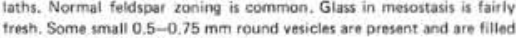
with clays and zeolites and/or calcite.

TS $30 \mathrm{~cm}$ (Piecen 4): Glassy margin of pillow basalt (seivage) somentat ittered basaltic glass in some megacrysts of plagioclase up to $4 \mathrm{~mm}$ long. Pliotaxitic texture with plaggiocisse surrounded by glass pillotaxi SECTION 3: DOMINANT LITHOLOGY: PLAGIOCLASE PHYAIC Mactroscopic Desectiption
Dark grav plagiolasem megactrst-rich bassit. Plagioclase megacrysts up
to $1.5 \mathrm{~cm}$ distributed evenily along the section in an aphanitic matrix.

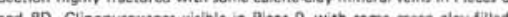
vesicles Minor alteration of the section exceopt tor the veins. Gliled selvage on Piece 6 .

SECTION 4: DO
PILLOW BASALT

Macroscopic Description

to $1 \mathrm{~cm}$ and hem the Calcite-filled veins and fractures with clar minerals in Piece 2. Matrix

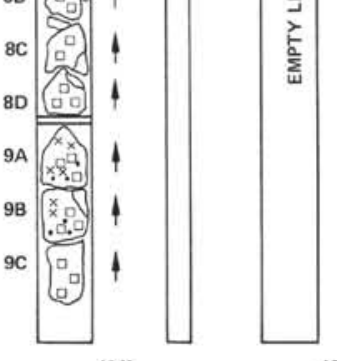
is aphanitic. Glassy selvage in Piece 2 


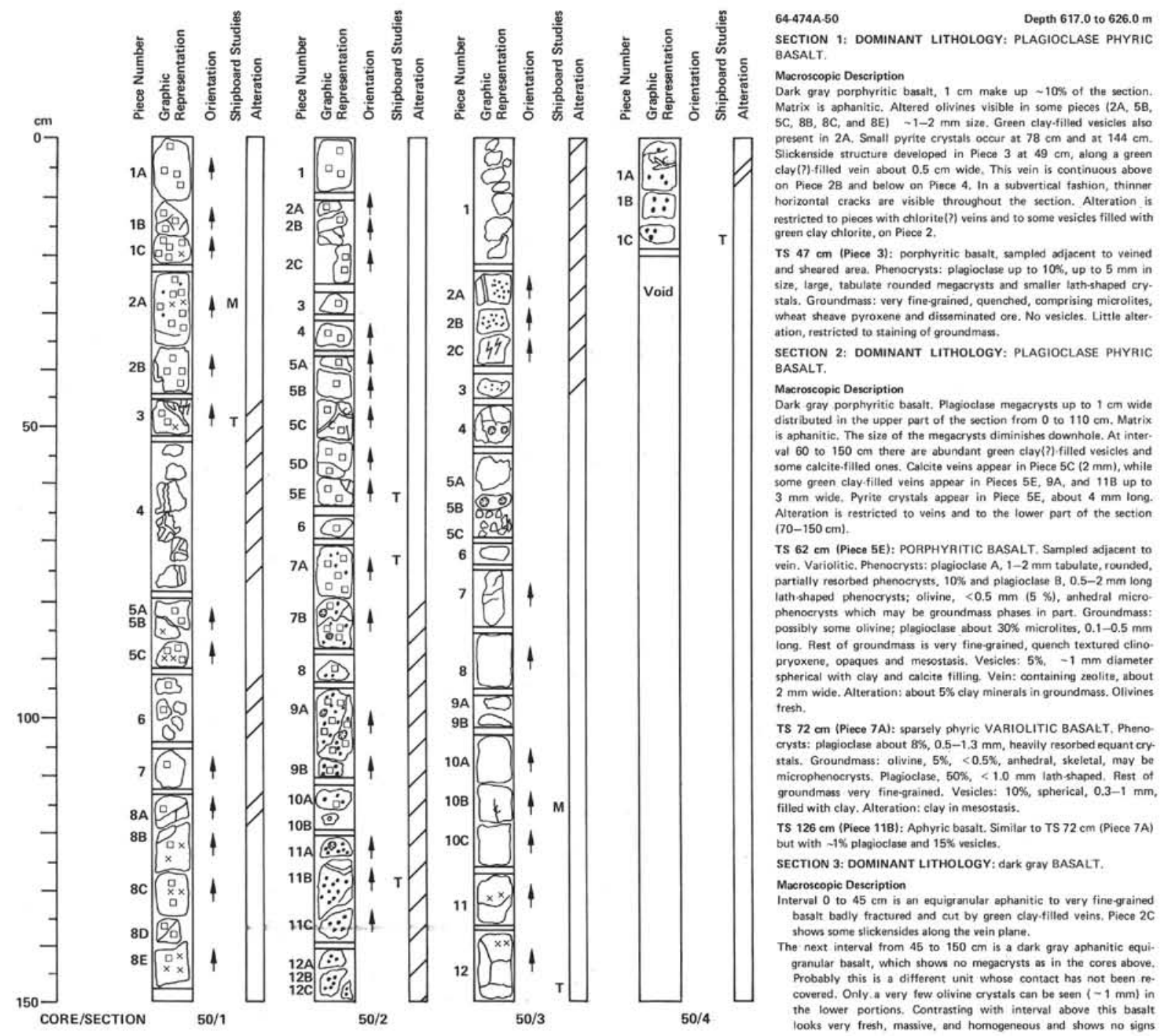

of atteration except for a few minute calcite-filited vesicles in Pieces

TS $148 \mathrm{~cm}$ (Piiece 12): COARSE BASALT or dolerite, practically whistinguishable from Core 50 , Section $4,16 \mathrm{~cm}$. Intergranular to $2 \mathrm{mml}$. Groundmass comprises plagioclase $(40 \%)$, $0.1-1 \mathrm{~mm}$ and morphs of clay (bowlingite repiacing otivine. SECTION 4: DOMINANT LITHOLOGY: BASALT Macroscopic Description

Mostly aphyric medium pray (N5) basalt with some calcite veins (1 $\mathrm{mm}$ with green clay mineralis some small phenocrysts of plasioclase is evenly distributed in an othenwise fine matrix.

TS $16 \mathrm{~cm}$ (Piece 1 C): DOLERITE or COARSE basalt. Pheno-

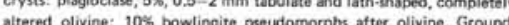
mass: $10 \%$ bowlingite probbbly after olivine; $40 \%$ plagiciase, $0.2-1.0$ $\mathrm{mm}$ lath shapeed partially enclosed in clinopyroxene; 30\% sugite partially interstitial to plagiocisese $(0.2-1.5 \mathrm{~mm}) ; 5 \%$ magnetite, $0.1-0.5$

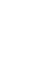

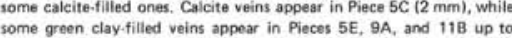
Alteration is restricted to veins and to the lower part of the section

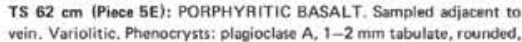
partially resorbed phenocrysts. $10 \%$ and plagioclase B, $0.5-2 \mathrm{~mm}$ long phenocrysss which may be groundmass phases in part. Groundmass:
posibly some olvine; plagioclase about $30 \%$ microlites, $0.1-0.5$ mm pryoxene, opaques and mesostastis, Vesicles: $5 \%,-1 \mathrm{~mm}$ dismeter Vein: containing zeolite, ubou TS $72 \mathrm{~cm}$ (Piece 7A): sparsely phyric VABIOLITIC BASALT, Pheno stals. Groundmass: olivine, 5\%, <0.5\%, anhedral, skeletal, mav be

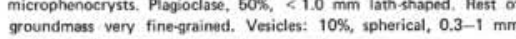
TS $126 \mathrm{~cm}$ (Piece 118): Aphyric basalt. Similar to TS $72 \mathrm{~cm}$ (Piece 7 A) SECTION 3: DOMINANT LITHOLOGY: dark graY BASALT.

Macrosecopic Destcription
Interval 0 to $45 \mathrm{~cm}$ is 作 covered. Only.a very few oliving whats can be seen $(-1 \mathrm{~mm})$ looks very fresh, massive, and homogeneous and shows no signs 

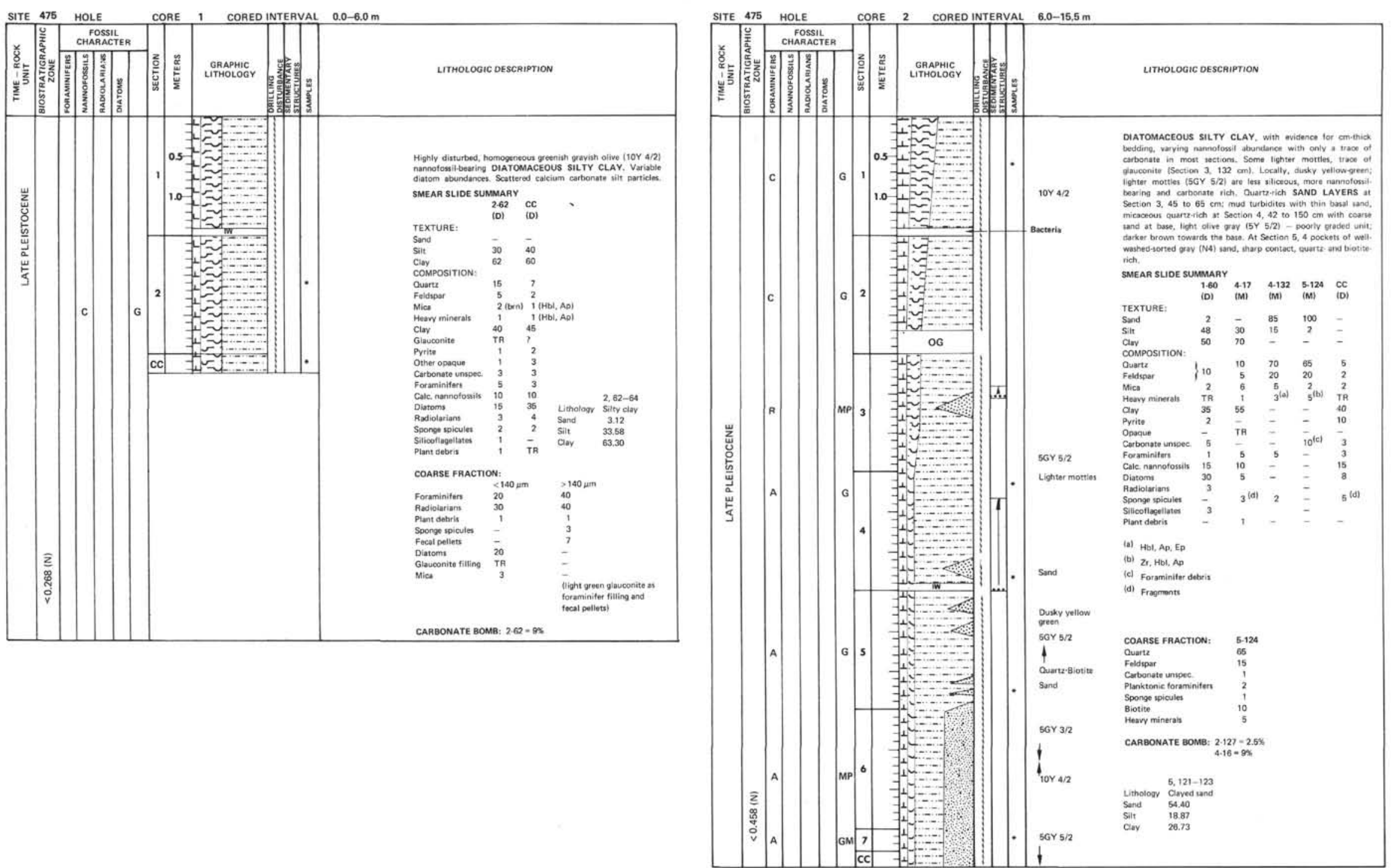

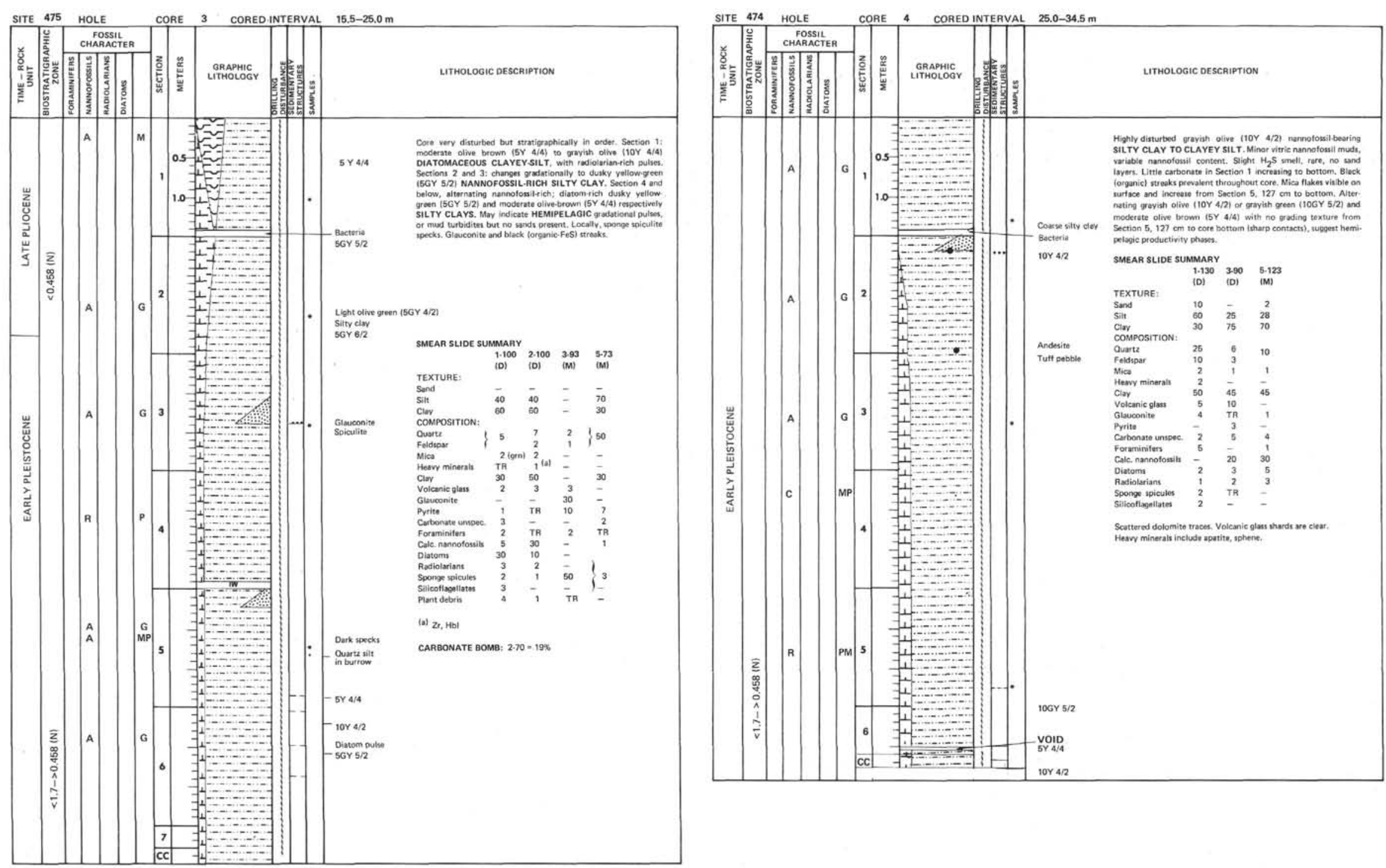

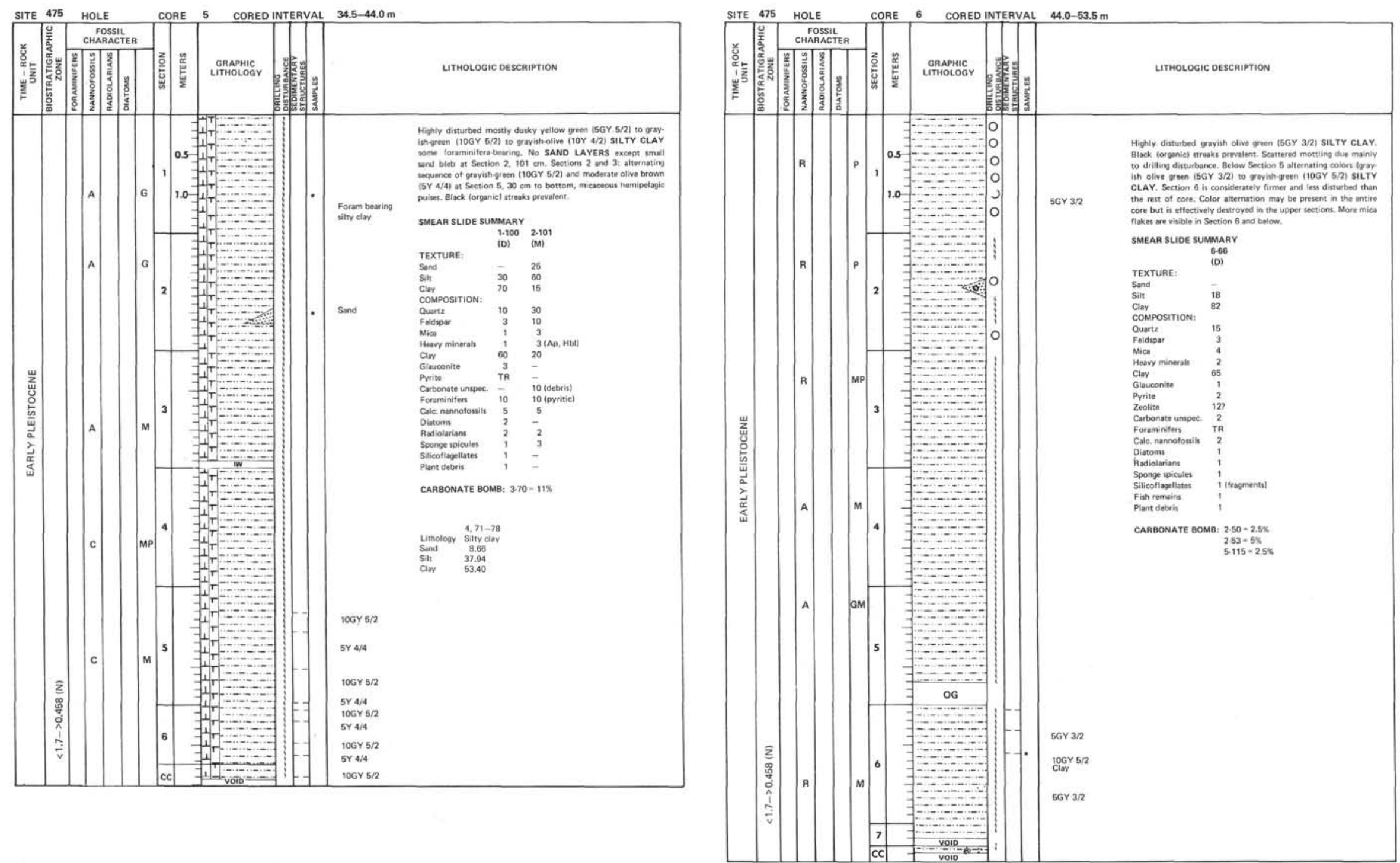

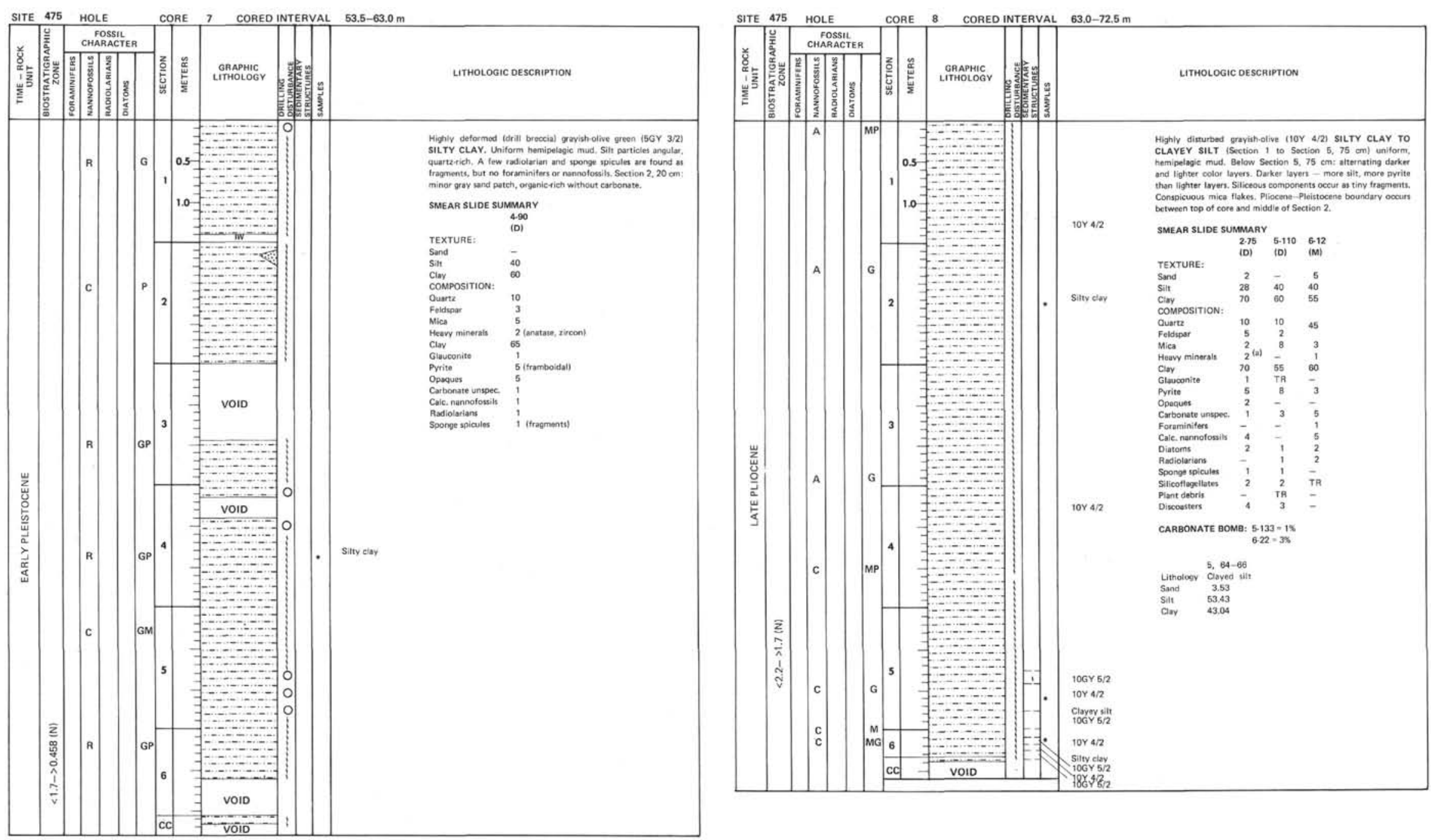

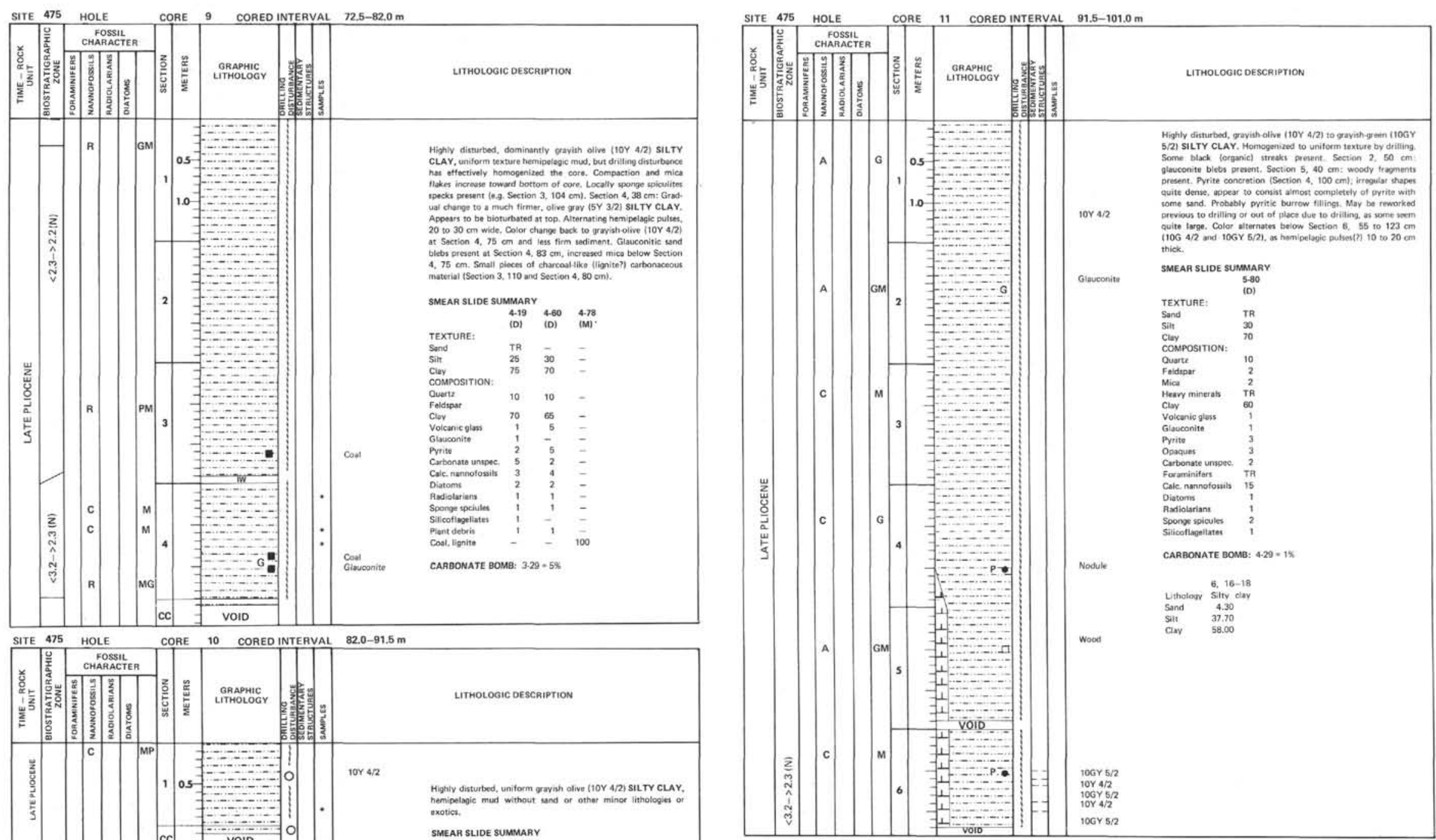

\begin{tabular}{|c|c|c|c|c|c|}
\hline \\
SITE
\end{tabular}



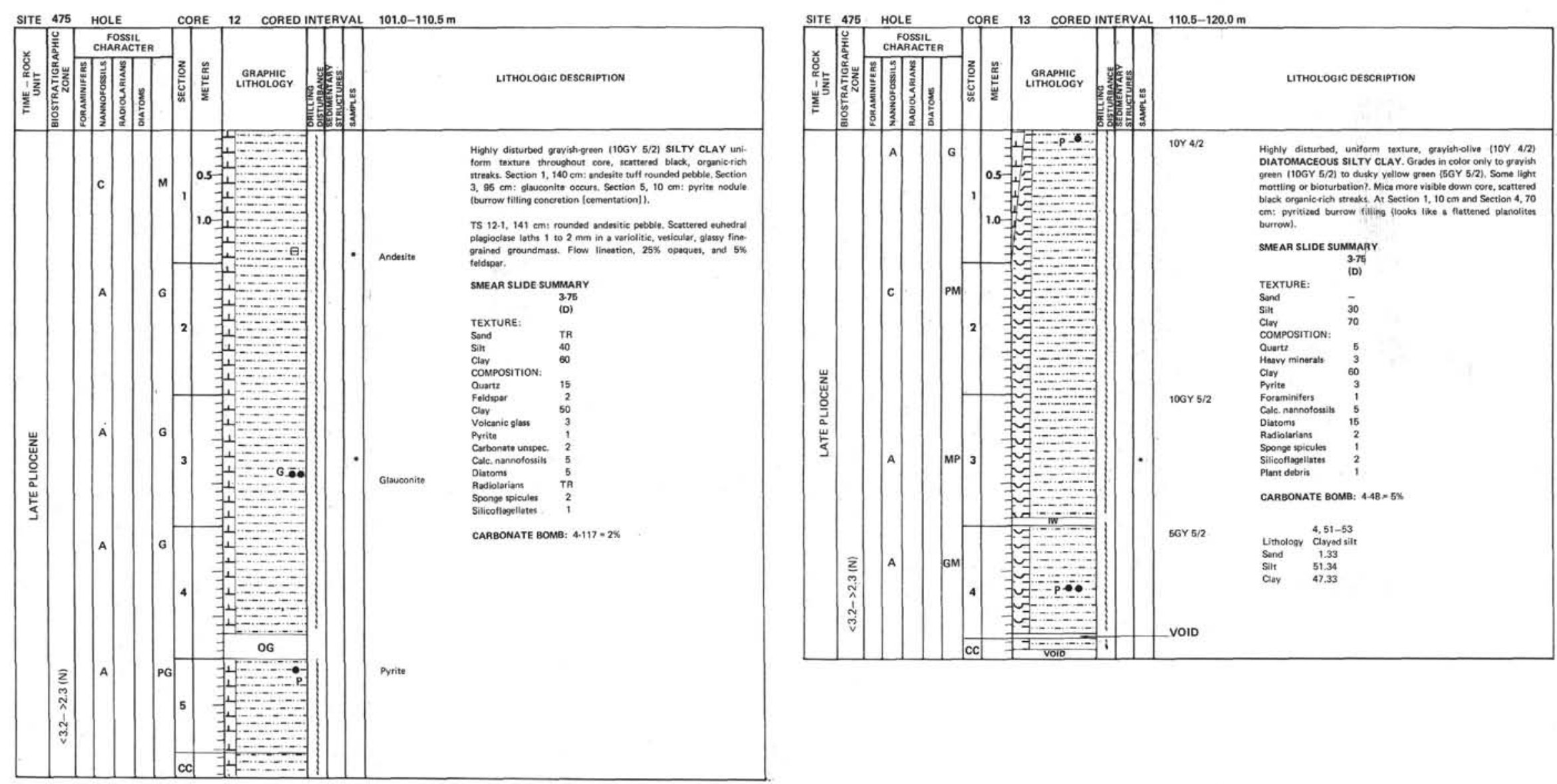

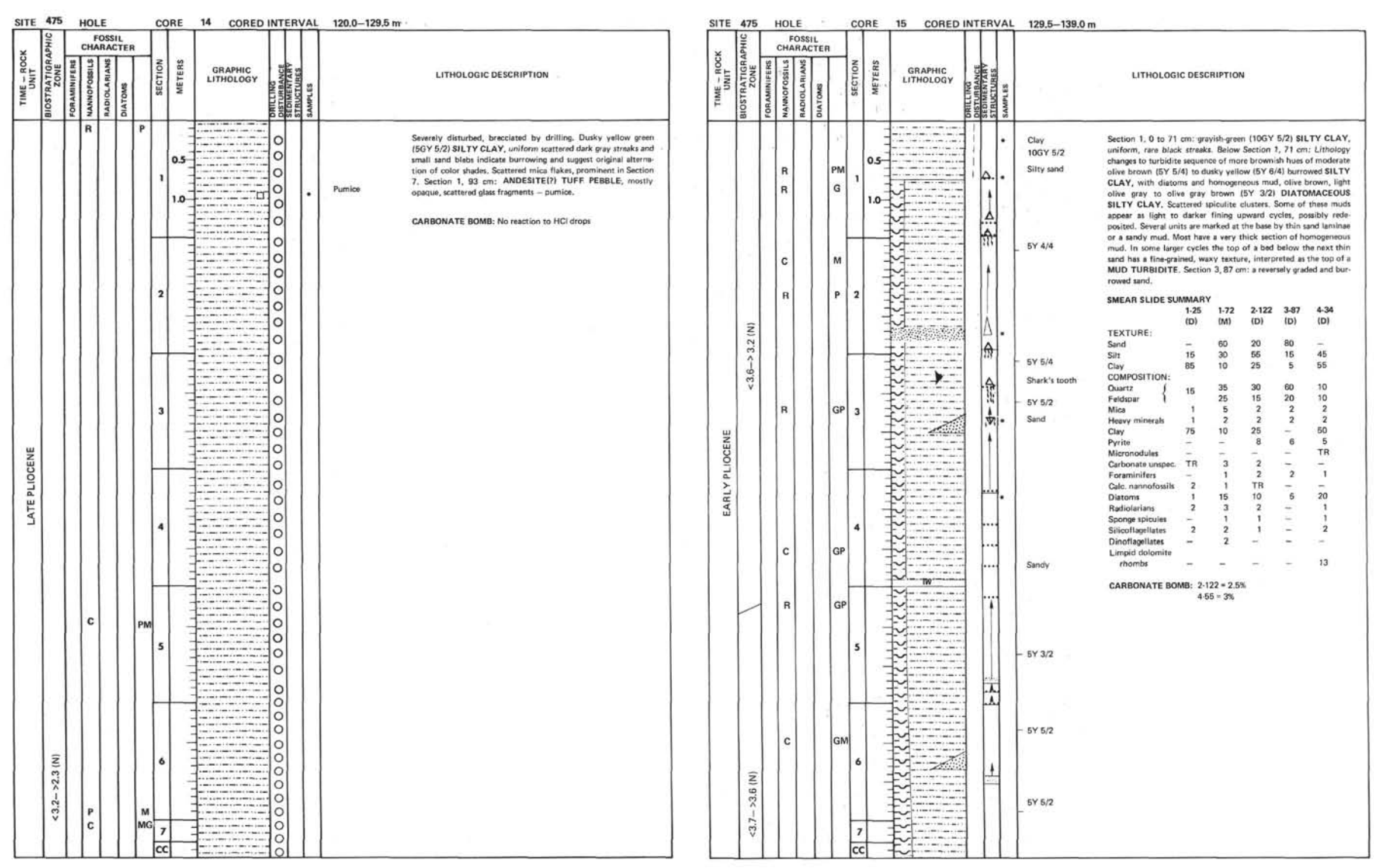

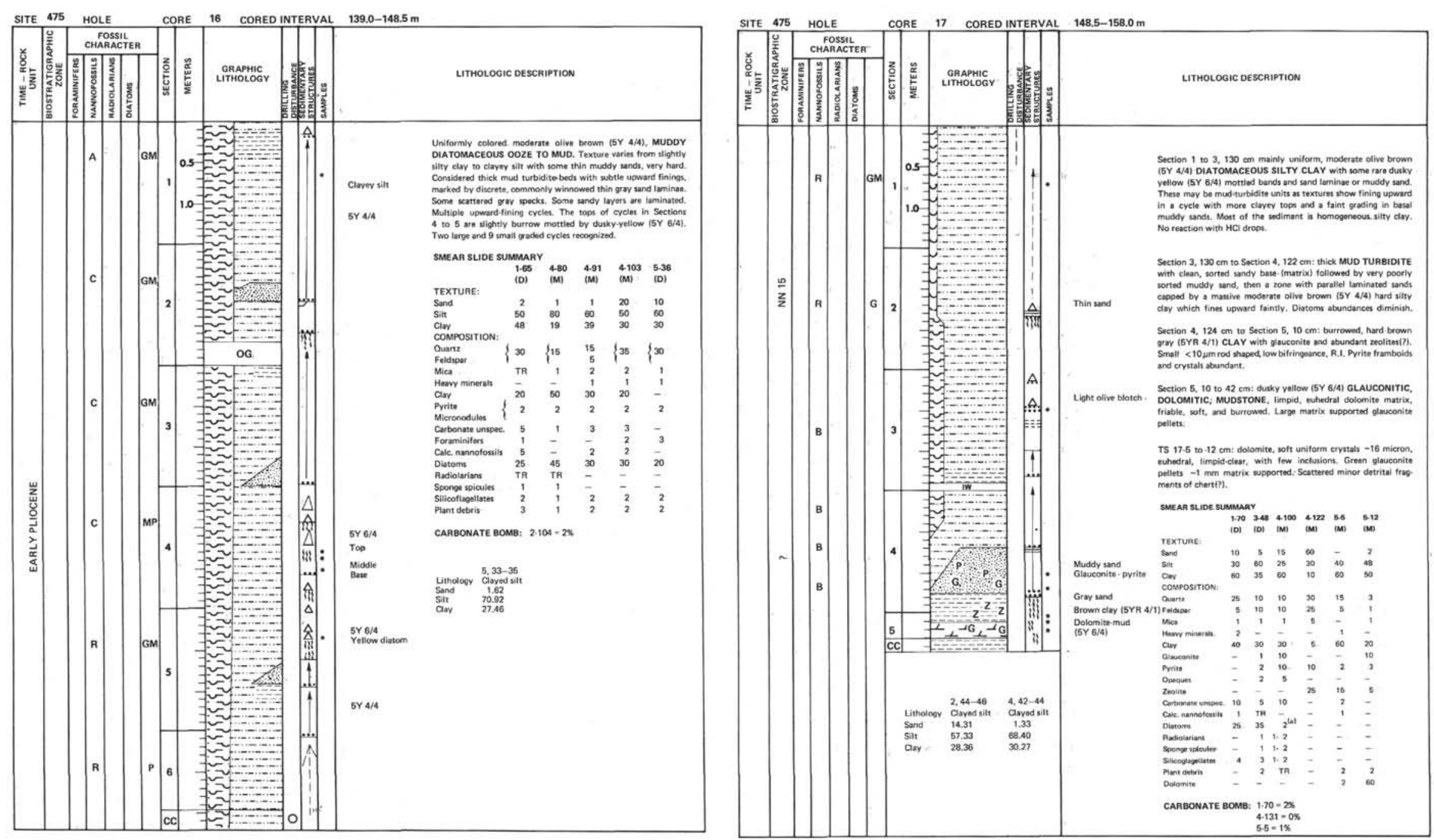


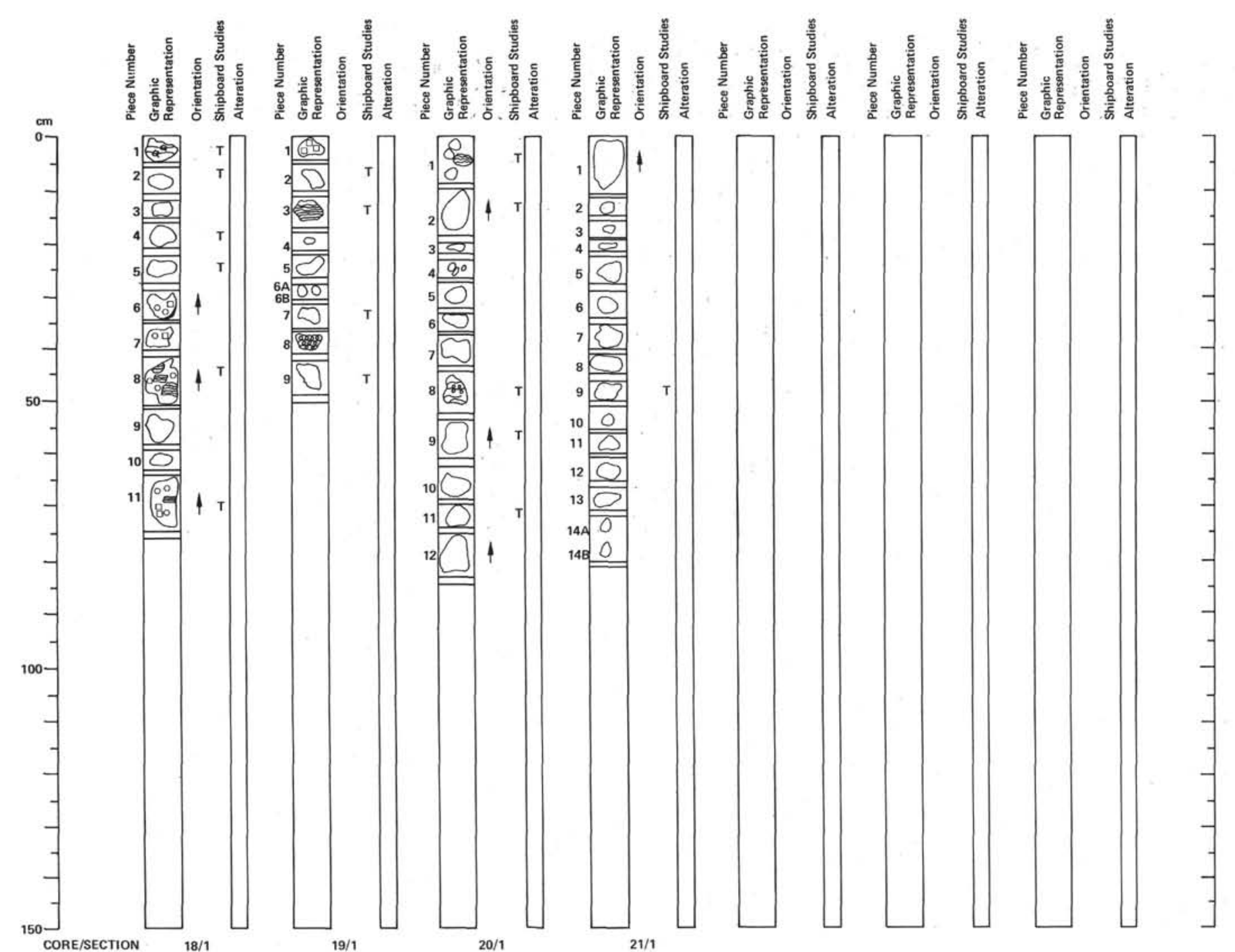


64.475.18 Depth 158.0 to $167.5 \mathrm{~m}$ SECTION 1: DOMINANT LITHOLOGY: Debbles morphic rocks

Metasolcennic and metatuedimentary clast POLYGENETIC boulder to pebble CONGLOMERATE comprising mostly medium grade meto morphic clasts including meta-ignimbrites, fine-grained volcanics,
greywacke, perlitic tryvolite, quartrite, shale, schist, quartz-metaPiece 1: METAVOLCANICS, fine-grained, light medium gray. Thin subparatlel quartzefilled fractures $(<1 \mathrm{~mm})$. Orthogonal joint pat tern.
Pece 2: METAQUARTZITE: light beige,

Piece 2: METAQUARTZITE: light beige,
Pieces 3 and 4: coasse-grainad, $1-2 \mathrm{~mm}$, pepperedy-graen, low-grade Piaces 3 and 4: coarsegrained, $1-2$

Piece 5: greeniath gray METAVOLCANIC.
Pieces $6,7,8$, and 11: METAMORPHOSED grain-supported CON. GLOMERATE, large fractured clasts of feldsport, quarrz, volcanic

TS (Piecan 1): metabassit a stereded fine groundmass with abundant o-
paques, altered dinopyroxene and olivine phenocrysts. Smalll calcite veins. No foliztion.

TS (Pioce 2): quartz grains, $80 \%,-250 \mu \mathrm{m}$, rogoged edges, recrvstallizized,

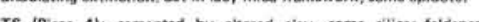

TS (Pioce 4): cemented by altered clay, some sllics; feldspar-rich
scattered pryoxene, Grains rounded subhedral, of angular, many highty weathered to sericite.

TS (Piece 5): recystallized trachyte(?), fine grained pilotaxitic, porphy. ritic. Phenocrysts: $35,0.1-0.5 \mathrm{~mm}$, cubic to irregulat roddish sphene
(replace Ti-Magn.); $10 \%, 0.5-2 \mathrm{~mm}$, orthocise of sanidine, subhedral (replace Ti-Magn.): $10 \%, 0.5-2 \mathrm{~mm}$, orthoclase or sanidine, subhedral
to ouhedral, altered, Groundmass: $40 \%,<0.4 \mathrm{~mm}$, teldspar laths; $30 \%$. $<0.2 \mathrm{~mm}$, quartz interstitial, mest with feldspar, $15 \%$, $0.05-0.5 \mathrm{~mm}$, chlorite(?) elongate strands, pleochroic green. Some possible amphibole Ts in

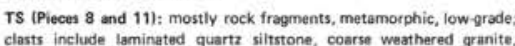

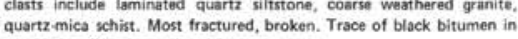
pregnation, Clay mineral and quartz cement.

64.475.19

Depth 167.5 to $177.0 \mathrm{~m}$

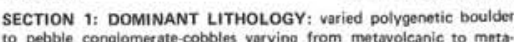
to pebble conglom
sedimentary rock.

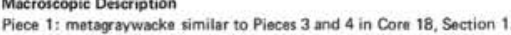
Piece 2: gravah -orange pink (5YR 7/2) subrounded cobble with quarto Pace 3: strongly banded pinkish-gray to gray blua band.

Piece 4: : small pebbles similar to Piece Piaces $6 A$ and $B$ : small, moderato borwn (5YR 3/4) purplish pebble.
Piece 7: pale red (10R 6/2) cobble with light colored inclusions (not crystast.

frined rock, grevish, composend of subrounded rock Pioce 9: gravish-pale red (10R 6/2), finegrained rock with teldspar clasts, subhedral to anhedrat, set in a gray -pinkish fine matrix with
IS (Piece 2): QUARTZ FELDSPAR PORPHYRY (metarthyolito):

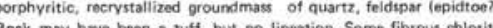

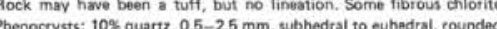

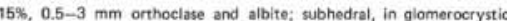
TS (Piece 3): RHYOLITE IGNIMBRITE of flow bandod thyolito. Recrystallized groundmass, fine-grained, banded, commoniy opaquiod

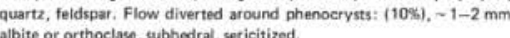

TS (Piece 7): RHOLITE; recrystallized but almost aphyric groundmass partially amorphous; quenched, Ouartzose estimated $80 \%$ silica. Less
than $3 \%,<2 \mathrm{~mm}$, orthoclase which were subhedral. Scattered fibrous

TS (Piece 9): RHYOLITE TUFF. Scattered angular quartz shards with grained, recervstalilized groundmass, chlorite, quartz alteration. Weather ed rind with iron oxides, many grains sthow sericitization. Some faint

64.475-20

Depth 177.0 to $186.5 \mathrm{~m}$ SECTION 1: DOMINANT LITHOLOGY: cobbles to pebbles of vol-
canicsedimentary rock showing low to medium grade mertamorphism. Macroscopic Deseription
Piece 1: suveral pebble troges

Hece 1: severas pebble fragments; one shows boudinage and fractured Piece 2: polvgenatic CONGLOMEAATH

Core 18 Section 1 and Piece 1 in Cone similar to Pieces 3 and 4 in 1 in Core 19 Section 1.

Piece 4: pink pebbles simitar to Core 18 Section 1, Pieces 6, 7, 8, and Pieces 5 and 6: dense gravish olive green (5GY 3/2) rounded cobbies with pink vein

Picce 7: metaconglomerate.
Piece B: IGNIMBRITE, RHYOUITIC

Prece 9: fine-grained, VOLCANIC rock, very dusky rod (10R 2/2) with Pieces 10 and 11: pinkish, poorly sortod, volCANIC with green specks. Piece 12: grav

TS (Piece 11: QUARTZITE, grain-supported, rounded, angular and Detormed, quartz with undulating extinction.

TS (Proce 2): clasts are angular rock tragments to brecclas $11-10 \mathrm{~mm}$ ): include micaschist, quartzite, granite, large quartz and mica frag-

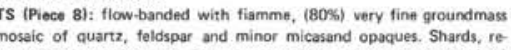
crvstallizad, raction nims. high bitringence, euhnodral scolenohodra (eoidoter?) along well-devel. oped, glassy flow laminations.

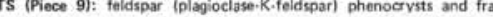

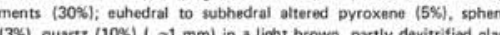

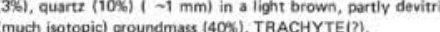

TS (Piece 11): as above. GLASSY VOLCANIC EFFUSIVE (50\%)

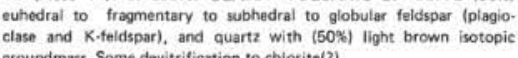

64.475-21
SECTION

Depth 186.5 to $196.0 \mathrm{~m}$

Macroscopic Description
Piece 1: $1-2 \mathrm{~mm}$ grain-sized silicacemented graywacke. Grains include

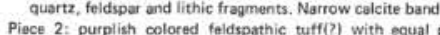

proportions Piece 3: very fine-grained light yellow (5YR 5/2) ithyolite with orange P.

Piect 5: very coarse polymictic breccia, with quartz (up to $5 \mathrm{~mm}$ ) and lithic fragments (up to $2 \mathrm{~cm})$ in a siliceous browm groundmass
Piece 6: coarse polymitic conglomerate. Large quartzite pebbles $(>0.5$ Piece 6:
$\mathrm{mm}$ ) in silicerous mattrix. Piece 7: $0.5-4.0 \mathrm{~mm}$

imm grain-sized silica-cemented graywacke with Piece 8:? $?$ medium-granined metasediment(?)

Piece 10: similar to Piece 2 .

Piece 11: fine-grained dark grav quartzitic sandstone.

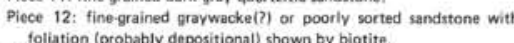

Piece 14: polvimictic conglomerate containing $0.2-3 \mathrm{~cm}$ clasts of quartzite and pelites. 


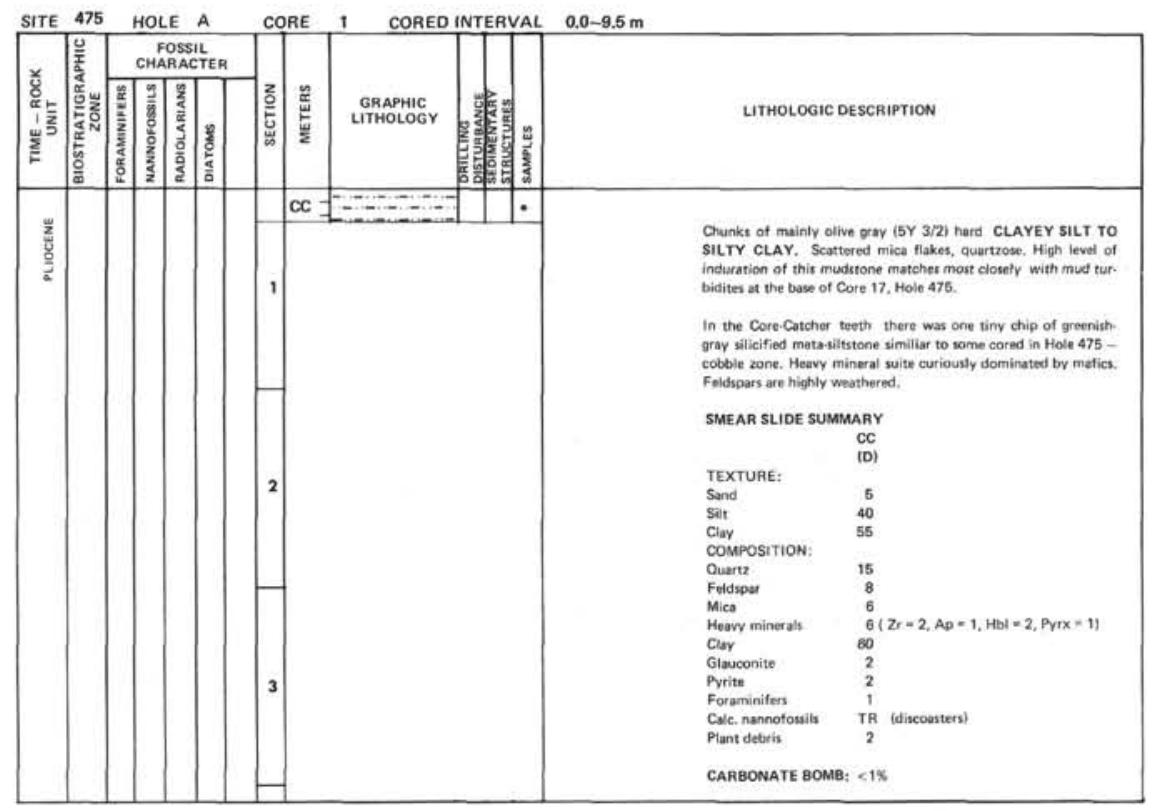




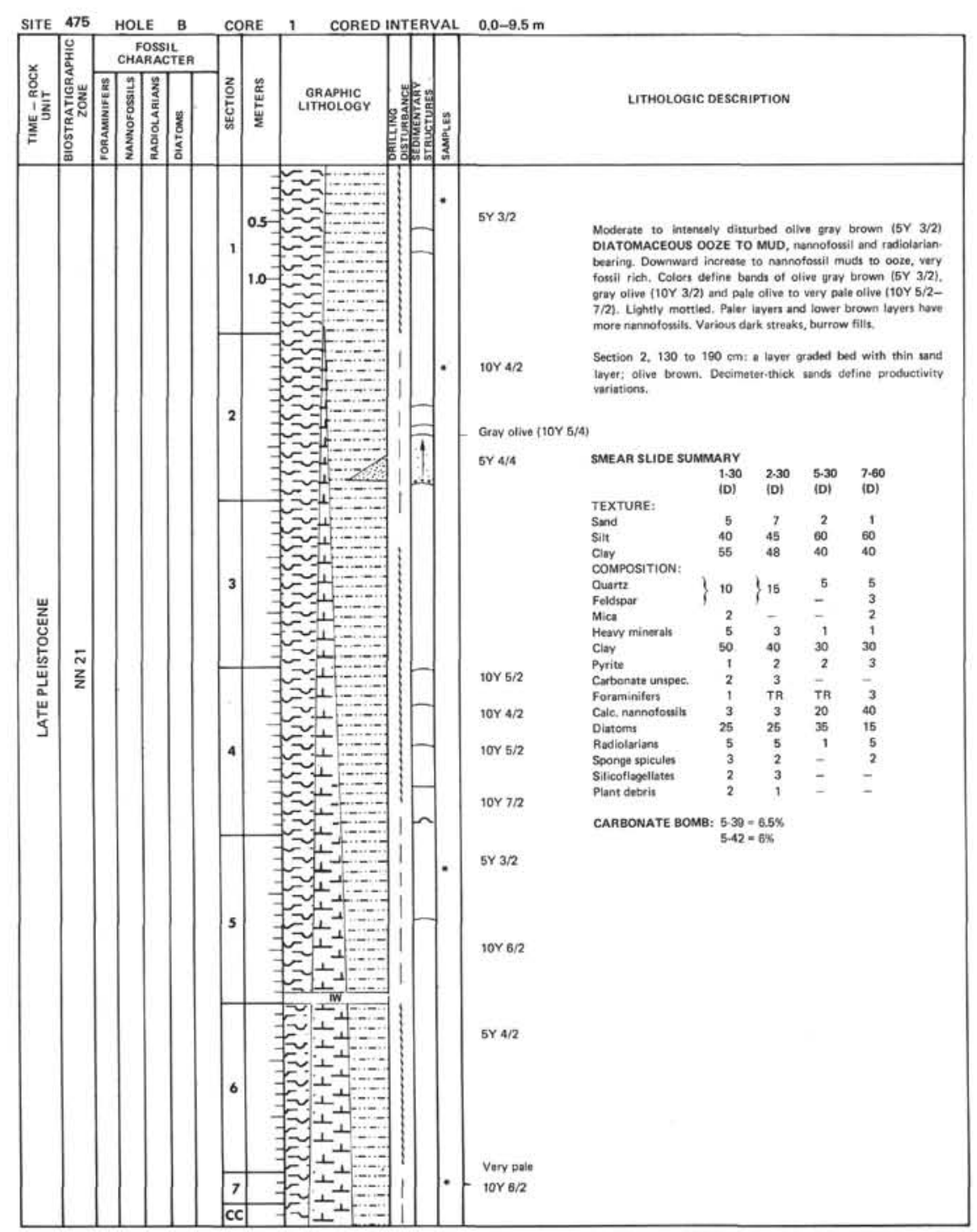


644758.2 Depth 76.0 to $77.5 \mathrm{~m}$

Macroscopic Description
Very fine-grained dark grav (NA) basalt with about $3 \%$ plagioclass microphenocrysts and rather more (fresh, apple green) ( $15 \%$ ) olivin generally they are less than $0.5 \mathrm{~mm}$. The rock has a heavy feet. very fresh, but slightly brown nims occur on Pieces 1, 3, and 6 . Fractures in Piece 2 contant an calcite.
Find

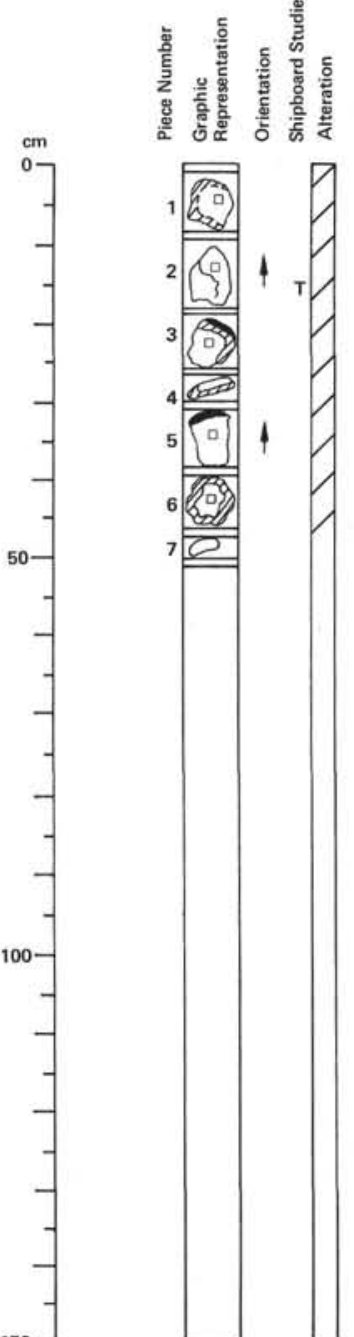

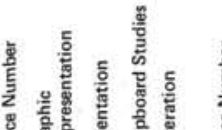

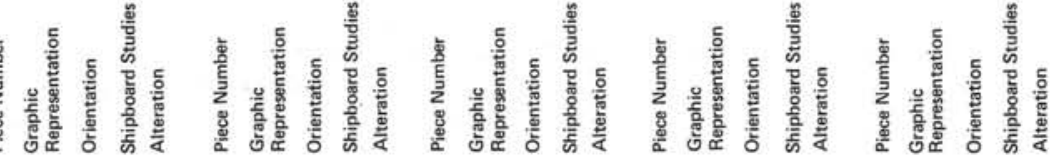
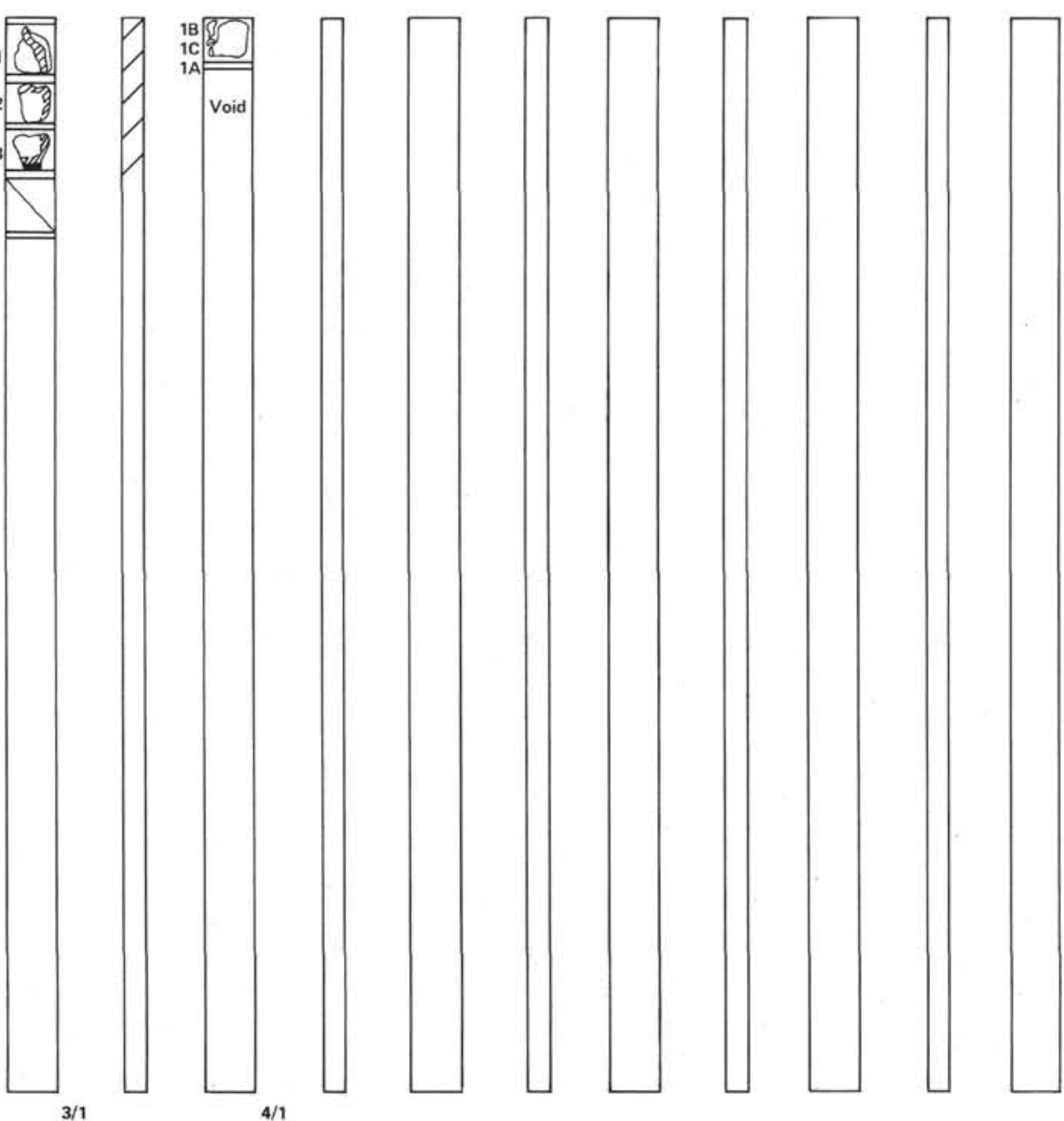

Fractures on Picecs
7 zeolitel Piece 5 ).

14 cm (Picece 2): fine-grained olivine basit. Texture: quenched Very tresht, with evidencee of only very tlight atteration. No plagie clase phenocrysts seen in this thin section. Groundmass: olvinine $-5 \%$ $50 \%, 0.1-0.3 \mathrm{~mm}$ long microlites, some of which lie in variolitic clusters. Approximately $20 \%$ clinopyroxene, $-5 \%$ magnetite, and
$-5 \%$ ilmenitn lie in about $10 \%$ mesostais. Alteration: apart trom tight alterention in ollvine,

20

64.4758.3 Depth 85.5 to $87.0 \mathrm{~m}$

Macroscopic Description
Very fine-grained dark gray (N4) basalt with <3\% plagioclase micro microphenocrysts. The micer $0.5 \mathrm{~mm}$ in niameter.
Slight alteration rims indicate that thess are small individual cobbles Indistinguishable from the basalt of Core 2 .

64.4758 .4 Depth 95.0 to $96.5 \mathrm{~m}$ SECTION 1: DOMUNANT UTHOLOGY: sparsely phyric Olivine basalt! Macrostcopic Deecription

Whine grained dark gray (N4) basalt with <3\% plsgioclise micro microphenocrysts. Microphenocrysts general aly
Indistinguishable trom basalts in Cores 2 and 3 . 

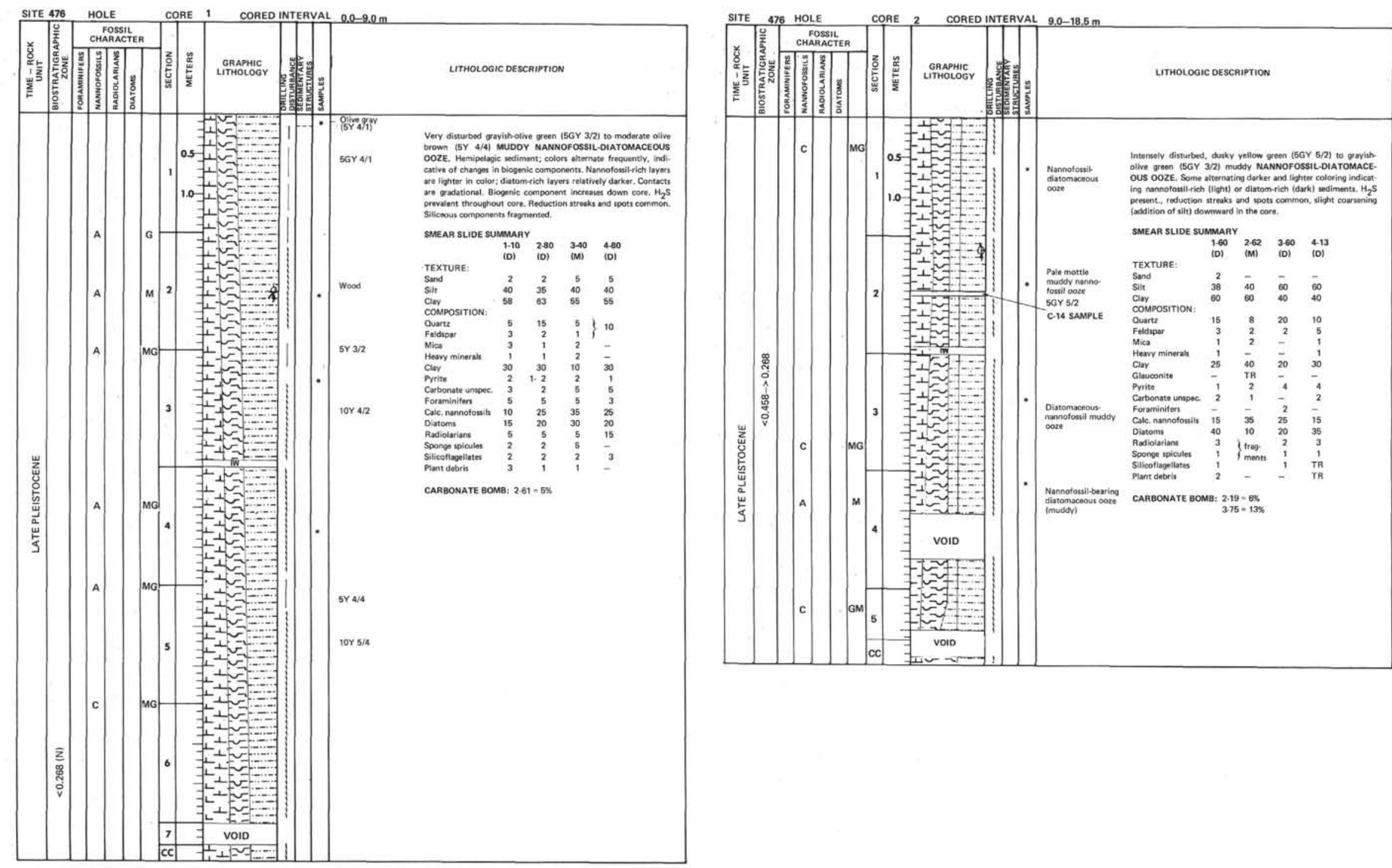

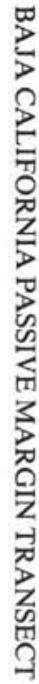



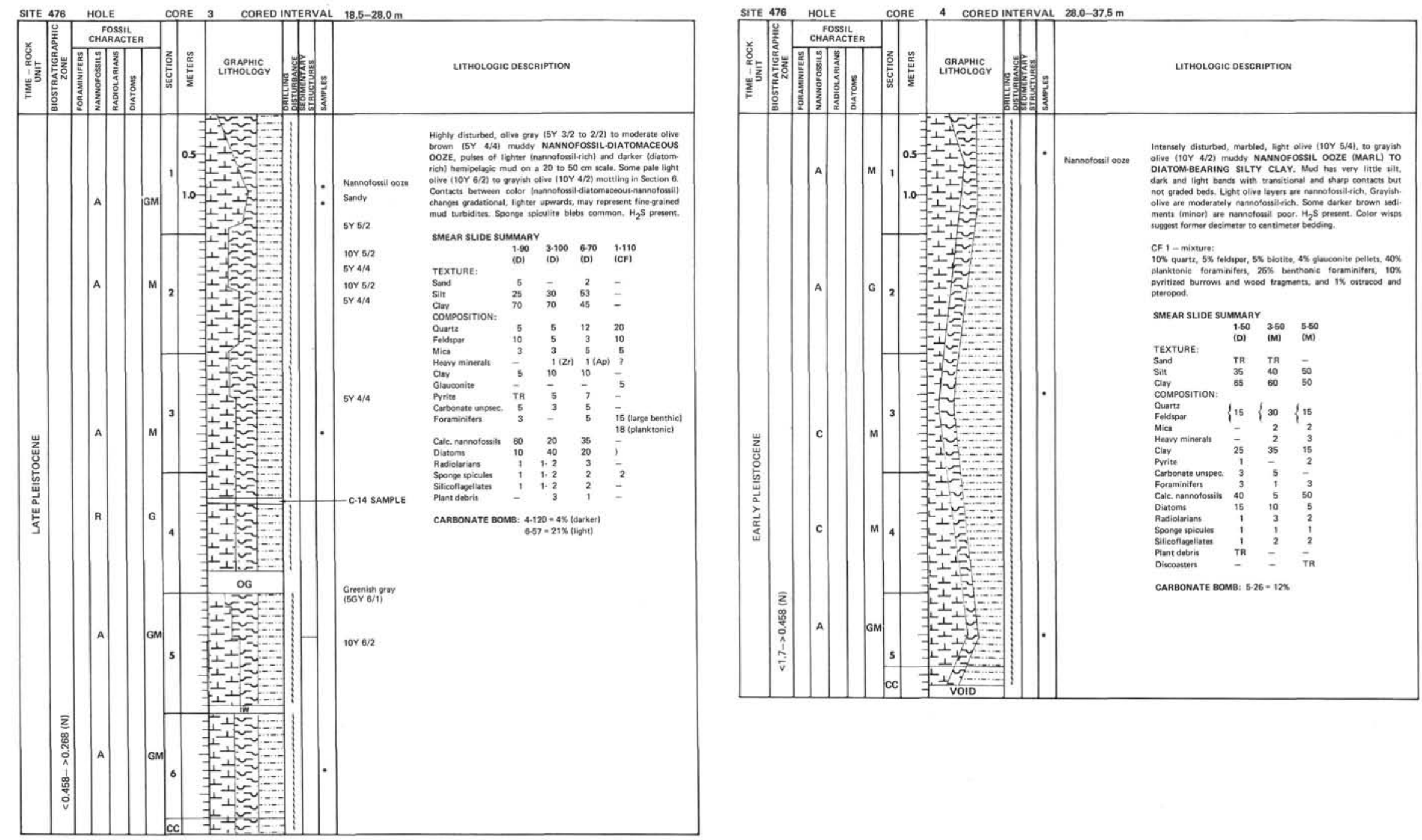

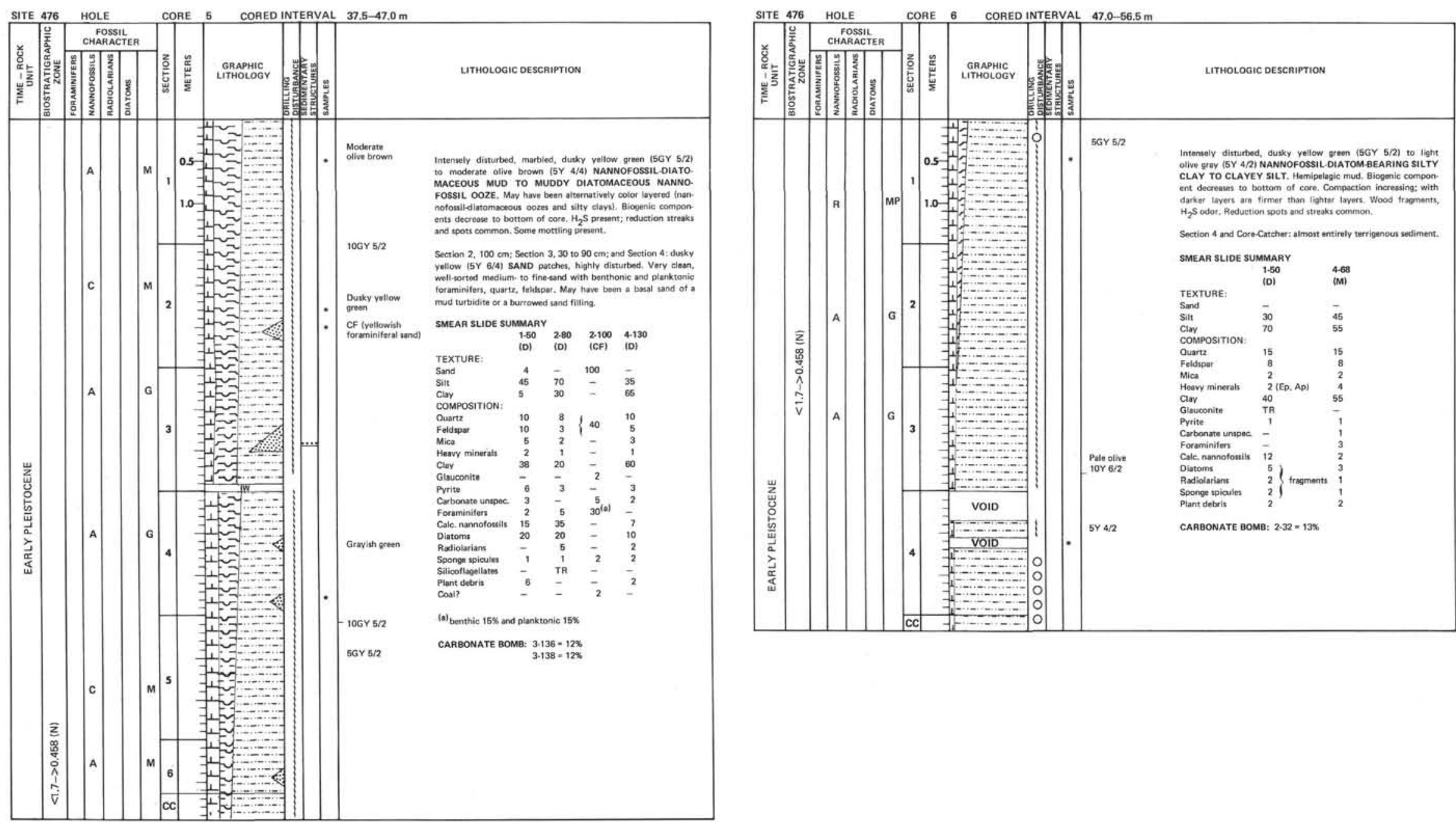

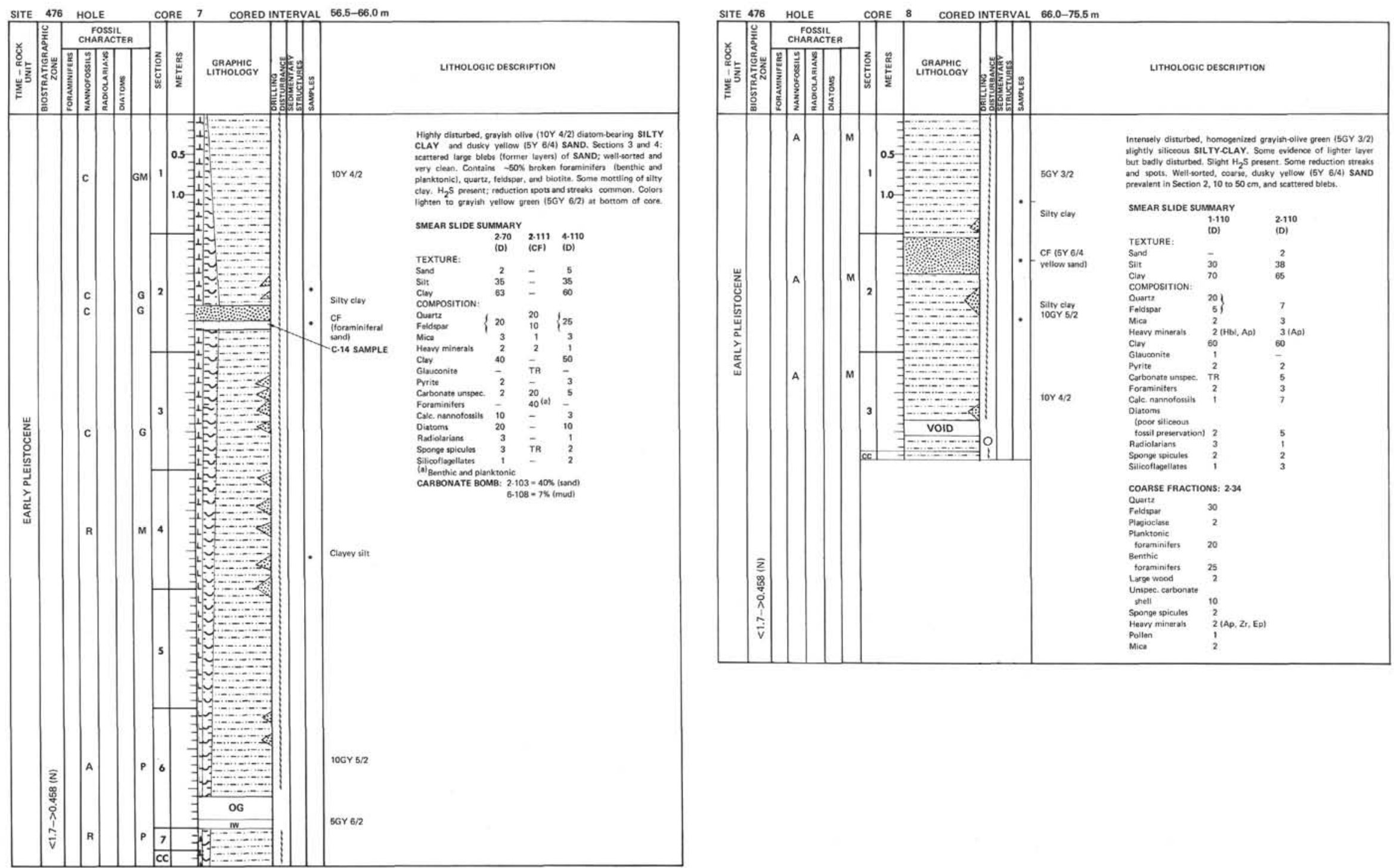

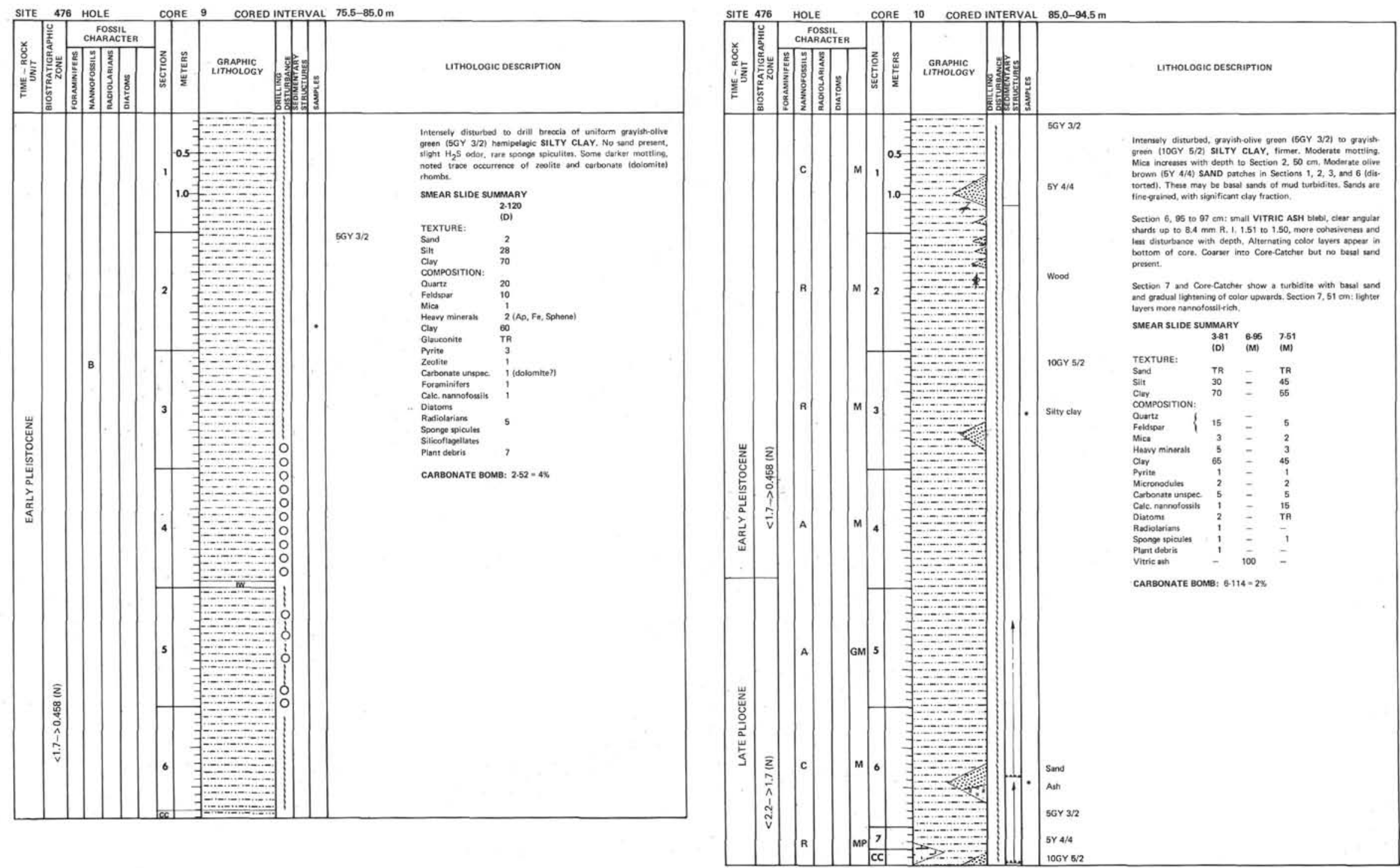

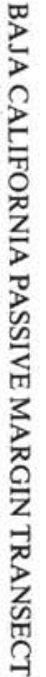



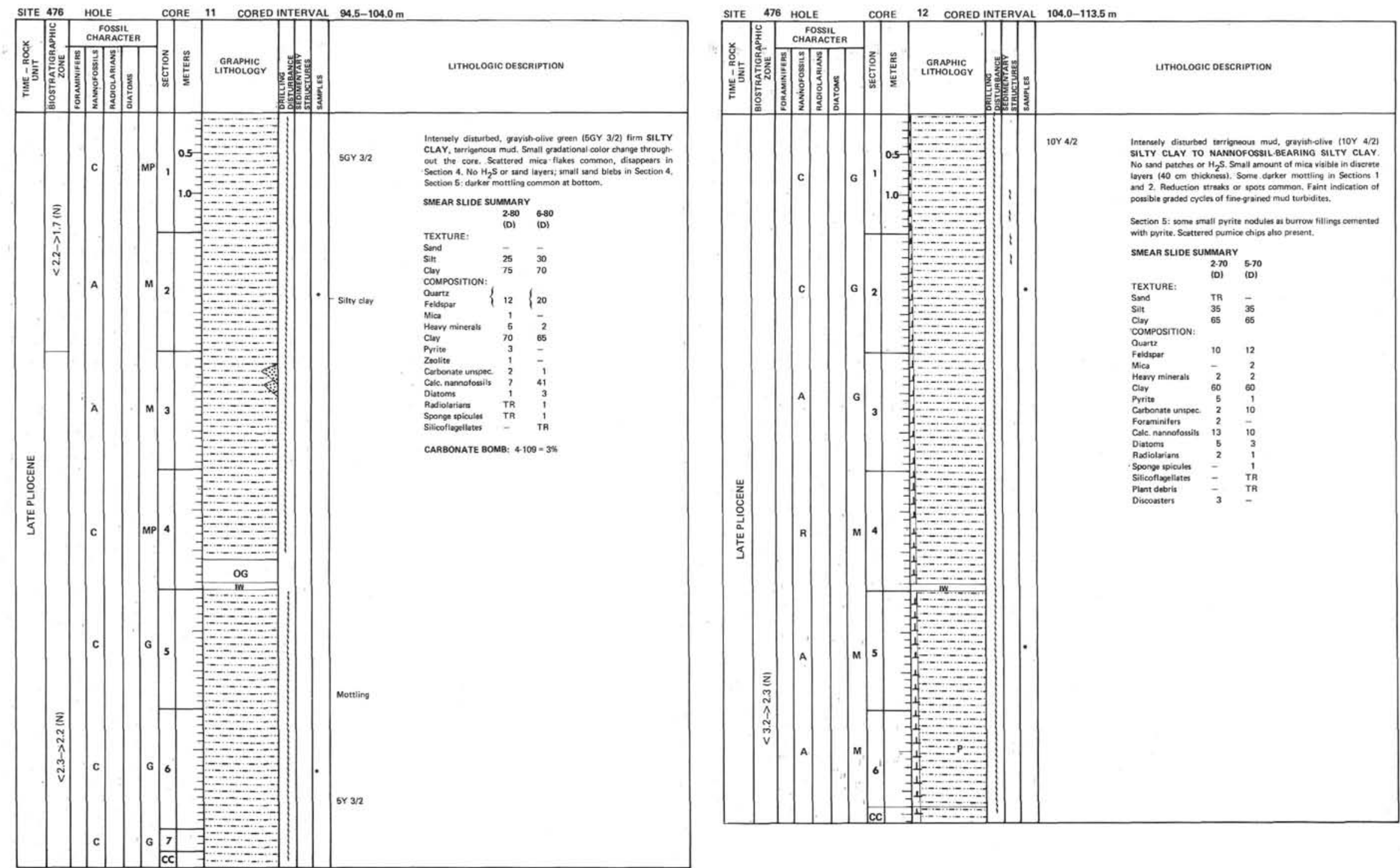

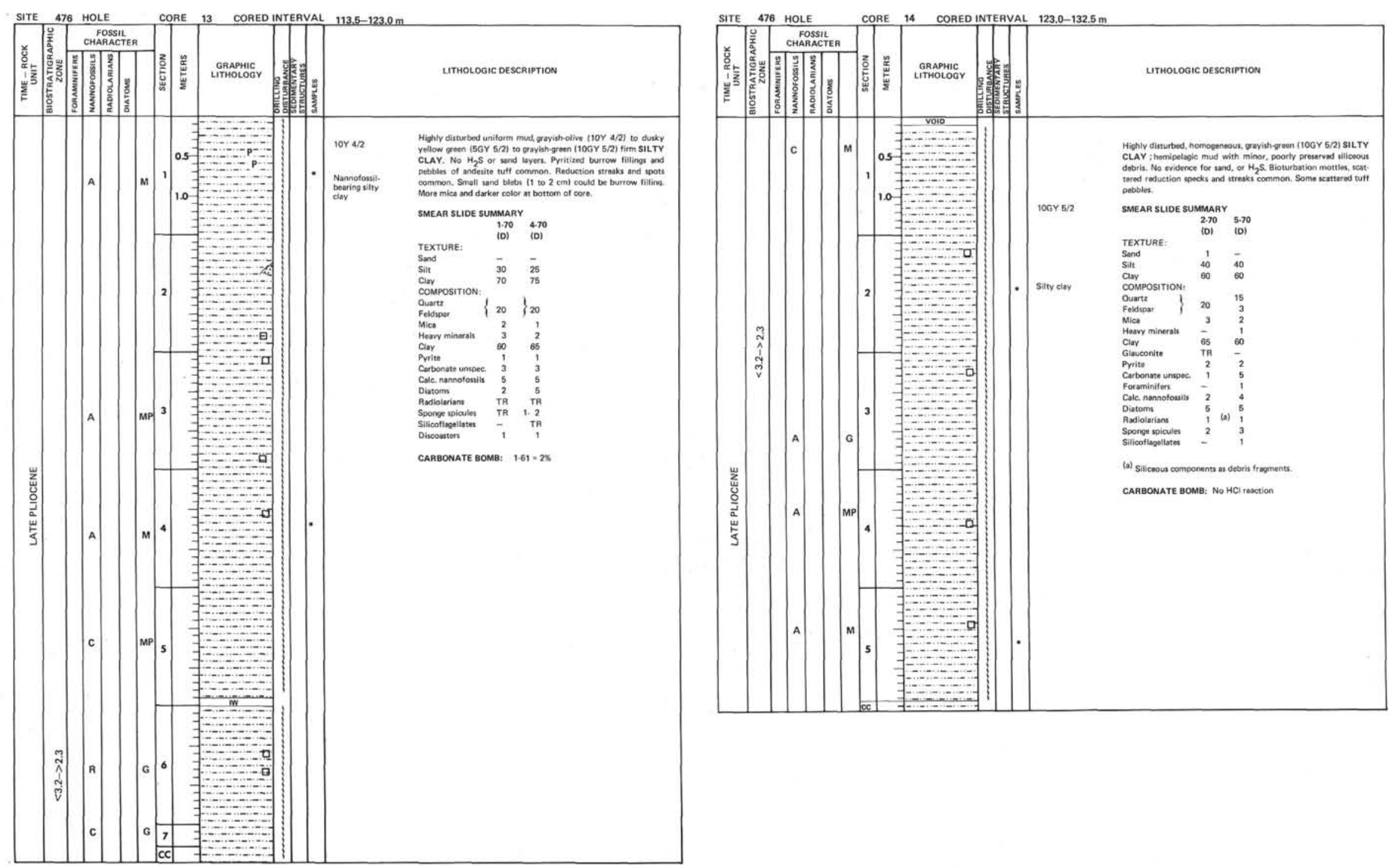

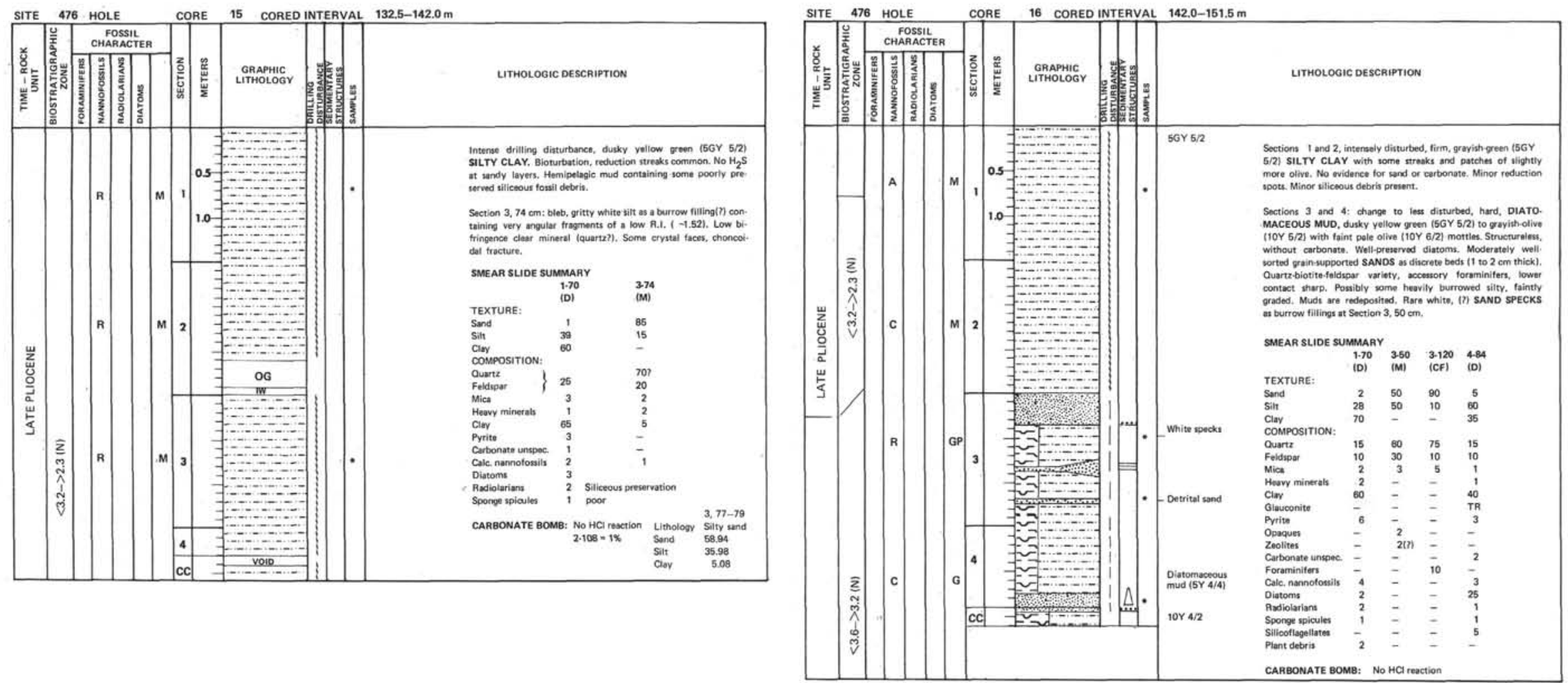

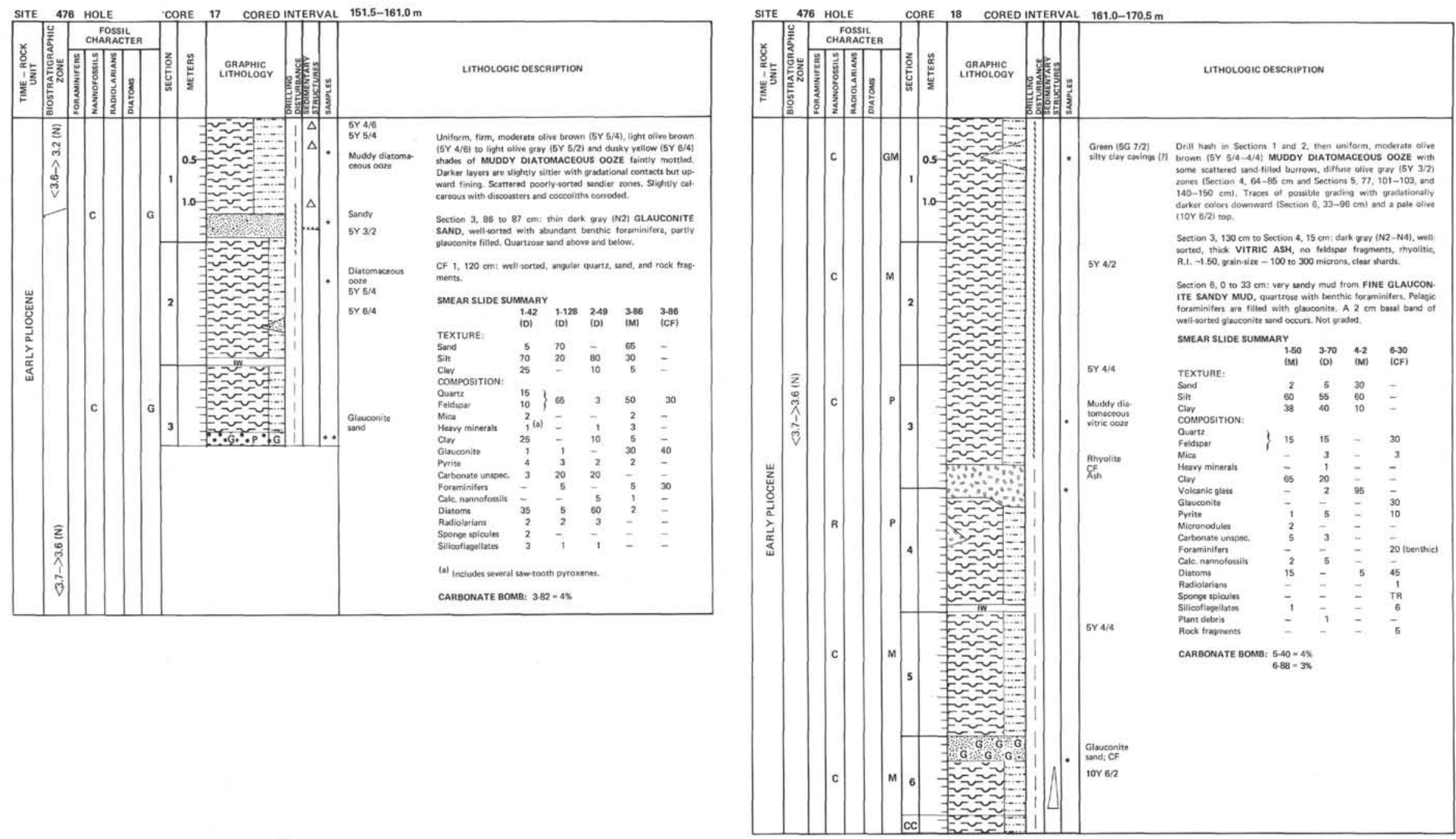

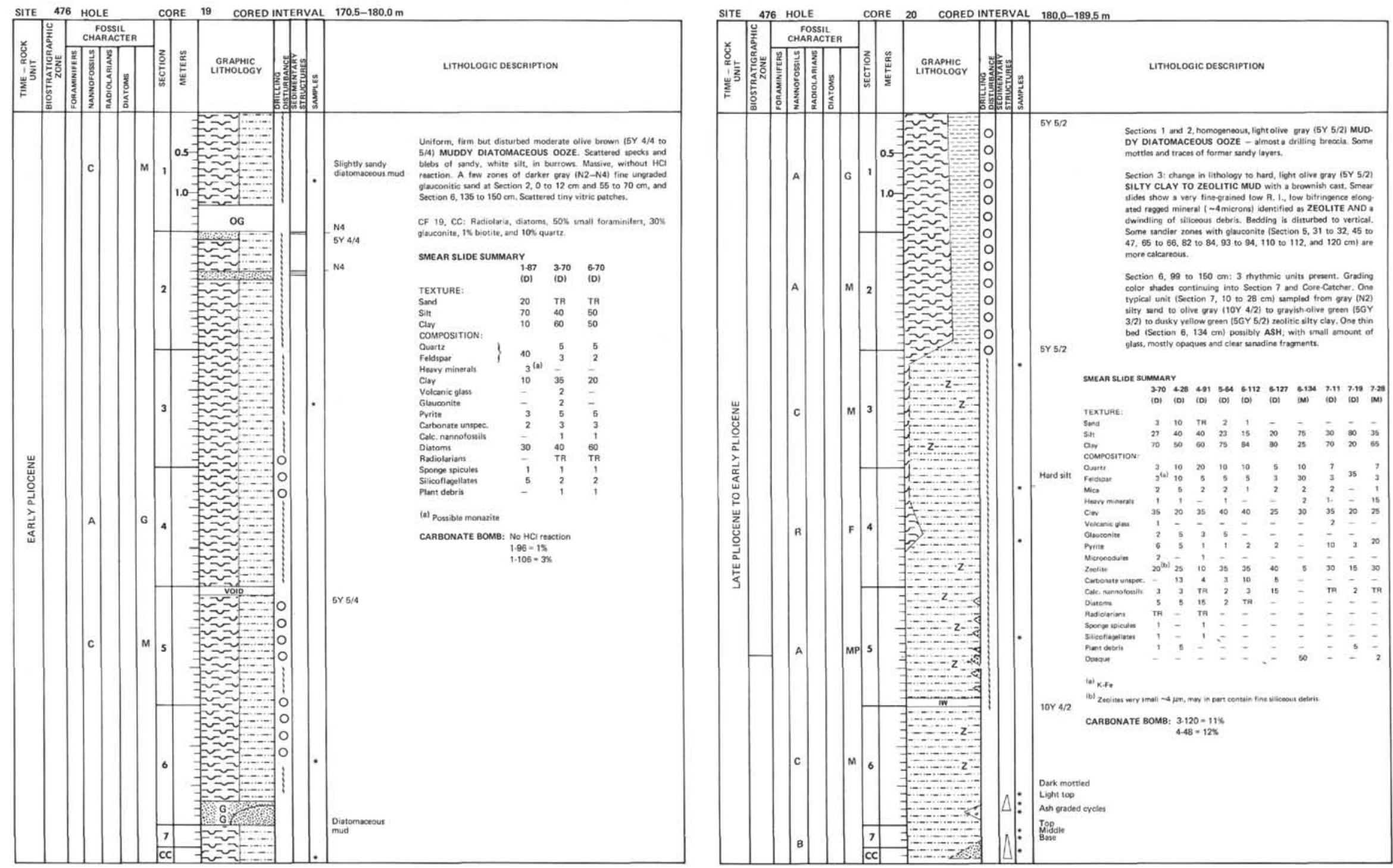


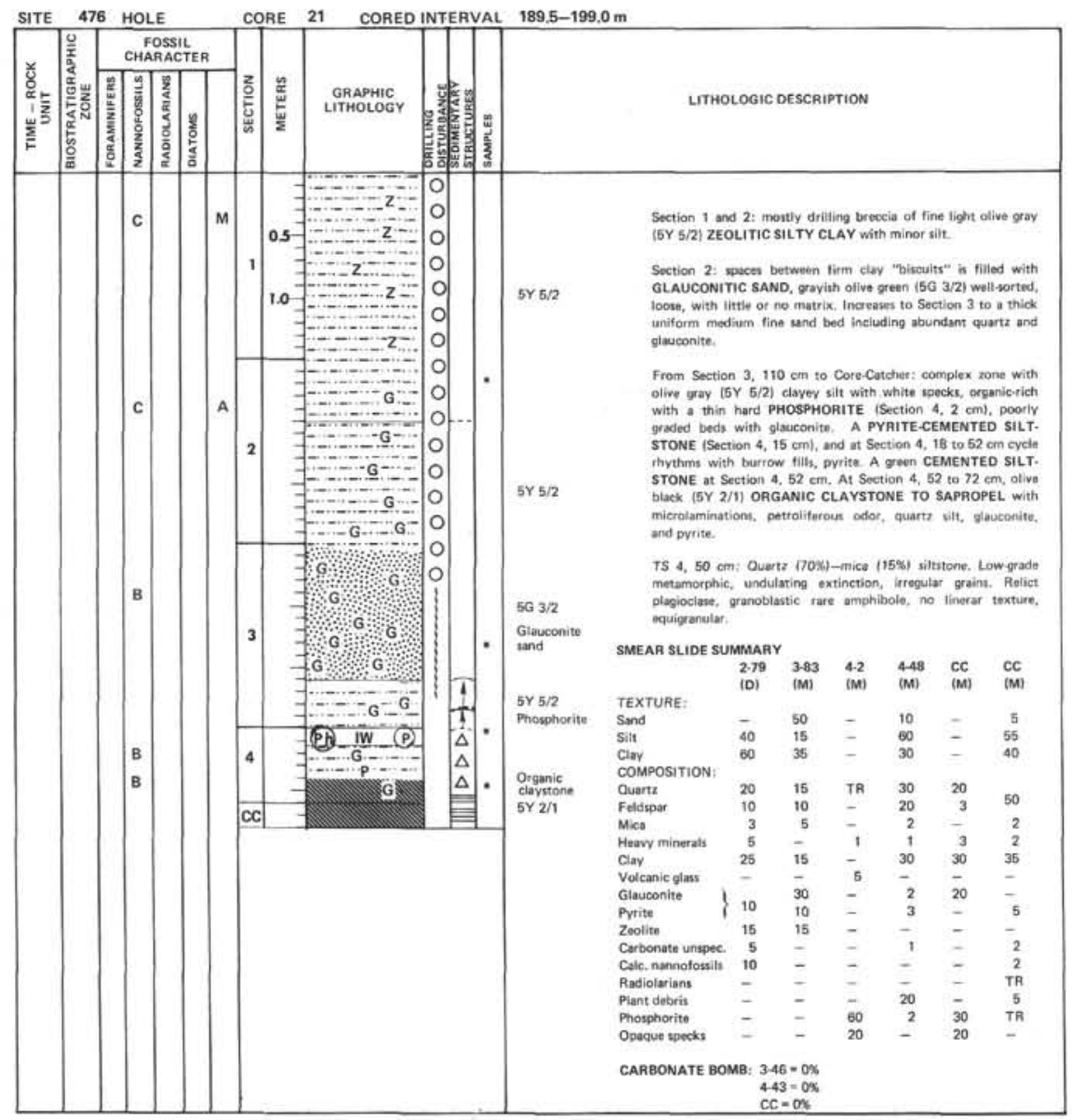




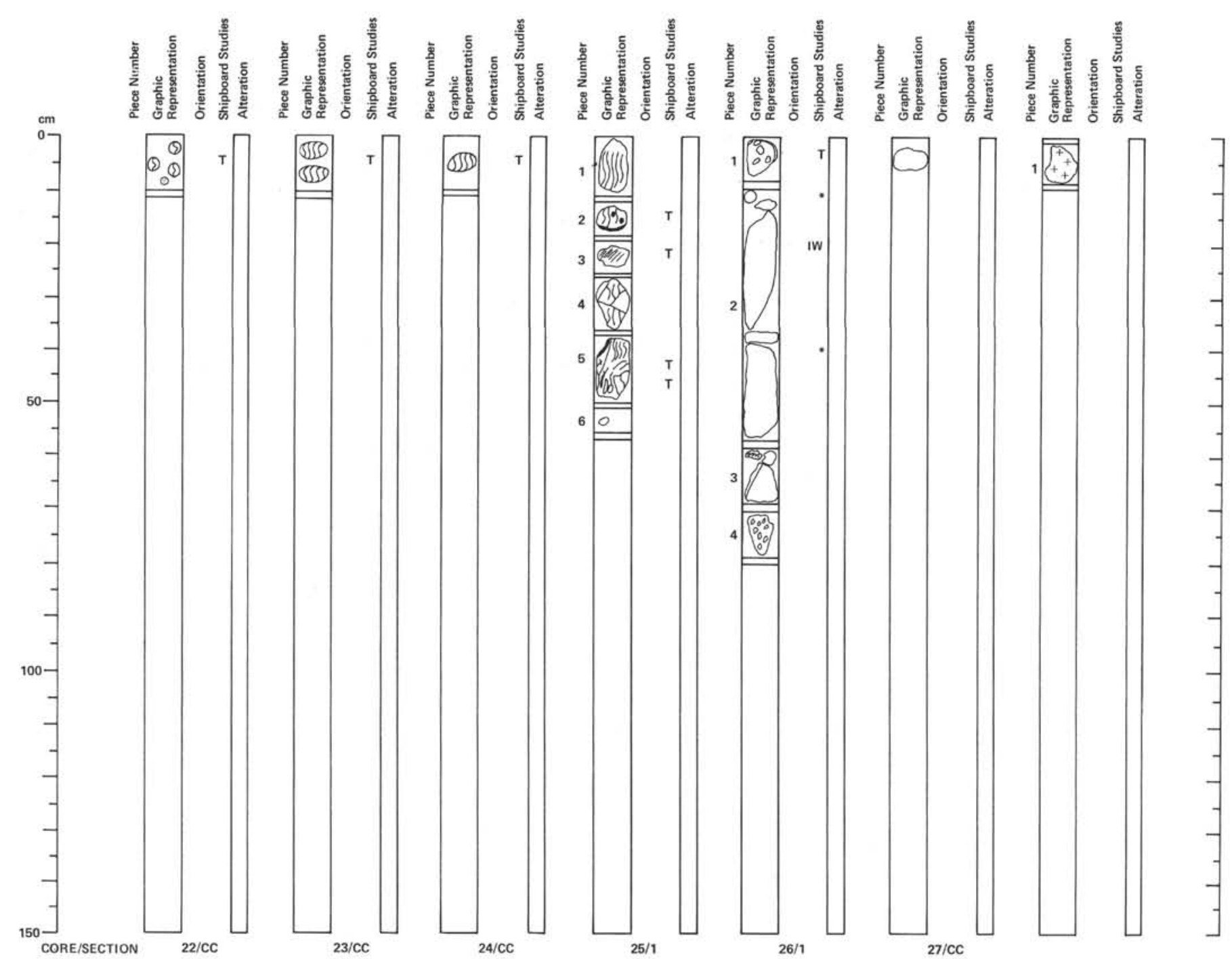

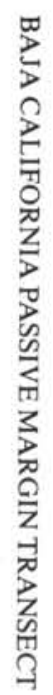


Macroscopic Desecription
Recovery was only a fow specks of well sorted, sand with numerous,

cloudy, gray rounded quartz and some pink, possibly weathered K feldspars. Rare aveite, minor carbonate, and specks of gravish green. A tiny fragment of possibly quartz-albitite-pidotoechlorite-staurolitit?

noblastic; micacoous QUARTZITE, cataclastic, recrytataized, 5005 irrogular broken a

grains, 1-2 mm, stressed, mosaic fragments, angular, fracturn

20s. muscovite s cement

28 relict plagioclase

25 rock tragments fquartz schisi)

$64.476-23$

Depth 208.5 to $218.0 \mathrm{~m}$

CORE-CATCHER:

Macrosoopic Desceription glomerate bed, Light bluish gray $(587 / 7)$ green schist facies, silicified
sandstono, finegrainded May contain albite, brown mica, but $75 \%$

TS CC: metasandstone; granoblastic coarse micacoous, QUARTZITE,

$35 \%$ quartz grains, broken, angular, stressed $0.25-0.50 \mathrm{~mm}$

$350 \%$ muscovite, $(0.025 \mathrm{~m})$ stressed, deformed

$30 \%$ quartz-mica mest work $10.025 \mathrm{~m}$ m matrix

COA76-24

Depth 218.0 to $227.5 \mathrm{~m}$

Hard, metassandstone, greenish gray (5G 4/1) quartzitic, pyrite seam TS CC: OUARTZ-mica-chloritie, elesigranoblastic

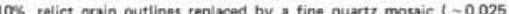
$20 \%$ grain outlined by mica sheaves, bent, detormed (chlorite?

10\% quartz grains, recrystallizod
$35 \%$ tine quartz mosic groundmass with mica

$15 \%$ subhedral opaque ground

64.476.25 Depth 227.0 to $237.5 \mathrm{~m}$ SECTION 1: DOMINANT LITHOLOGY: POlYgenetic CONGLOM EAne or

Poor rescovery, any matrix

Pioce 1: light colored weathered QUARTZITE; poorlysorted, 10 w grade, friable, wih quartz, felispar, chlorite, some talc, calcite.

Piece 2: low-grade, altered, recrysallized VOLCANIC TUFF(?) ande$\mathrm{mm}$ ), attered to quartz-fedspar-dhlorite (?) and spears of newily ormad micas. Much occluded opaque of iron-hydroxide. One calalterod plagioclase phenocrys. Piece 3: coorse-grained highly weathered GRANITIC ROCK: grano.
blastic, equigranular
Pieces 4 and 5: METABASALT or diabase: quartz-abite-epidote

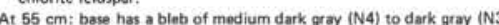
quartz-silt with (barite mud). Mostly (30\%).

TS Piece 3 :

$20 \%$ perthitic feldspars weastheredt to fine $(0.02 \mathrm{~mm}$ ) quartz, mice, 3\% clarbonate vein filling

20\% armbnitiole vein

$2 \%$ plagioclase

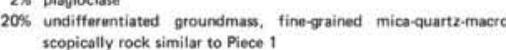

TS Piece 5: mostly fine groundmass oquigranular mesthwork $10.05-$ $0.1 \mathrm{~mm}$ ) of $30 \%$ relict and replaced plagioclaste. 25.5 mica lchlorite and high bi epidote neediles, $10 \%$ larger quartz $(0.150 \mathrm{~mm})$ graim regular veins, commonly lined by a quartz mossic, Scattered pyrite

500 Quartz largular, inclusion

5\% Feldspar (pitted, inclusions)
2\% Heasv minerals (hematite, rutile)

$30 \%$ Clay

$\begin{array}{ll}\text { 1.8 } & \text { Fe-opaques } \\ \text { TR Carbonate unspec }\end{array}$

\section{4-476-26}

Depth 237.5 to $247.0 \mathrm{~m}$

SECTION 1: DOMINANT LITHOLOGY: CONGLOMERATE CO BLES and GRAY SANDY CLAY,

Macroscopic Description
Piece 1: speckied greenish - WEATHERED GRANITIC ROCK. Large

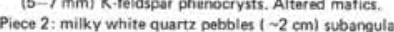

Sediment $-1,12-55 \mathrm{~cm}$ : medium dark gray (N4-N3) QUARTZ .

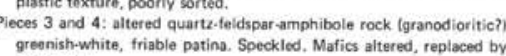
grennish-white, friable patina. Speckled. Mafics altered, replaced by
chlorite(?).

IS Piece 1: pranolibastic texture $(1.3 \mathrm{~mm})$ with many minerals at atered spars and matics: ${ }^{40 \%}$ quartz, $1 \mathrm{~mm}$, irregular, equigranular.
toces interlocking mossics. Some stressed.

$20 \%$ quartz in fine 9

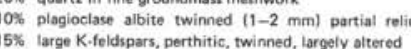

5\% opsques as alteration of ma fics

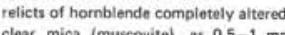

clear mica (muscovite),
products in groundmass

SS Pieco 2: white mud; 30\% sand; 50\% silt; 20\% clay; 10\% feldspars, highty altereds; $30 \%$, 10 um raged crystals, low bf R.t. 1.64-1.55

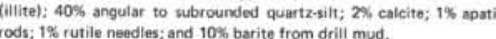
$50 \%$ quarz, mostiy siltsize, angular to subrounded, many stressed, quarz, mostiy
dark inclusions
45\% clay mineral, R.t. 1.55-1.57, bf $=0.10$ ragoed laths $1-10 \mu \mathrm{m}$ 5\% feldspars, opequess, heary minerals, and others specks

Compositionally equivalent to fault gasuge of weathered granite of local pond receiving granitic debris

64-476-27

Depth 247.0 to $256,5 \mathrm{~m}$

CORE-CATCHER

\section{Macroscopic Description}

Small bleb $(10 \mathrm{ccl}$ of greenish gray $(5 G \mathrm{G} / 2)$ and white pootly sorted

ss core Catcher:

30\% Quartz imicromosed

30\% Feldspar (weathered pervasive serictel

Heavy minerals (opaques,
Clay (iilite? other)

$10 \%$ Other

64.476-28

Depth 256.0 to $265.5 \mathrm{~m}$

CORE-CATCHER: DOMINANT LITHOLOGY: honblendebiotite granit

Macrossopic Description

Medium-grained (armest grain size $\sim 8 \mathrm{~mm})$ light gray $(\sim 5 B \quad 7 / 1)$ Comprises slightly altered white feldspar $(-60 \%)$ anhedral quartz 30sil(7). Equant and acicular dark green hornblende (5\%) crystals, to be slight chloritization of the matic mineronts Pyrites are present in several patches. The uncut and cut surfacas show spproximately $5 \times 2 \mathrm{~mm}$ in size, or smaller. Quartz crystats appear to be tractured, and perrititas can be seen in 
64.476-29 Depth 265.5 to $275.0 \mathrm{~m}$ SECTION 1: DOMINANT LITHOLOGY: granite.

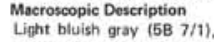
flow structures are seen in hand specimen - a sort of banding of the witish foldspar separated by the grayish quartz. Flow lines could Alternatsvily tho deformement of cystalized masses within the mush. mate to a fault. Some pyrite present in small veins. Pieces 5 and 12 appear to be much fresher and alteration of the mafic minerals has not progressed very far, and no flowage is visible on the curt tacen.

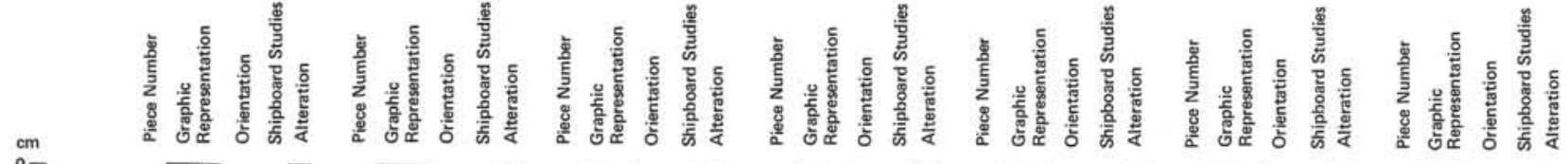

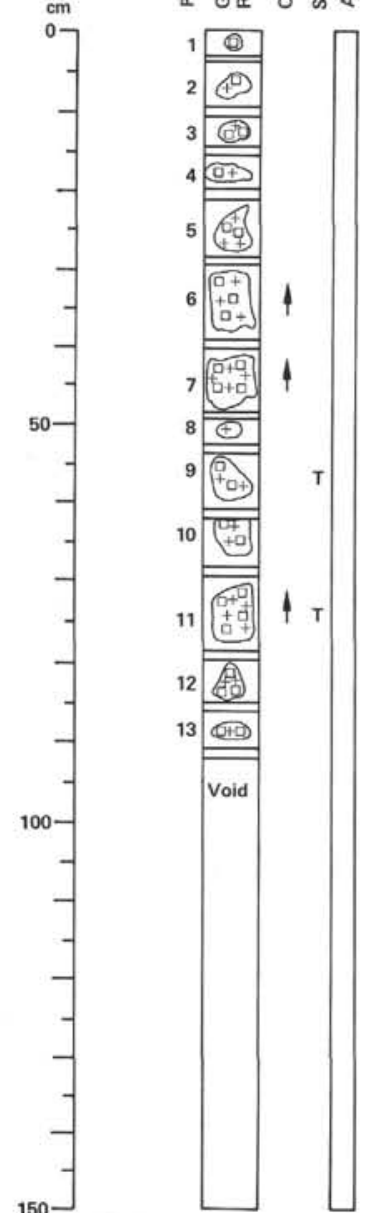

CORE/SECTION

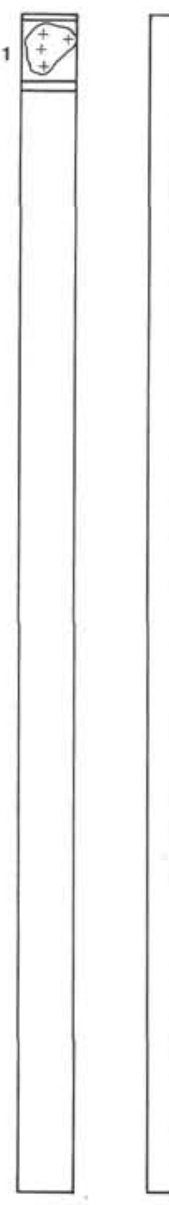

30/1

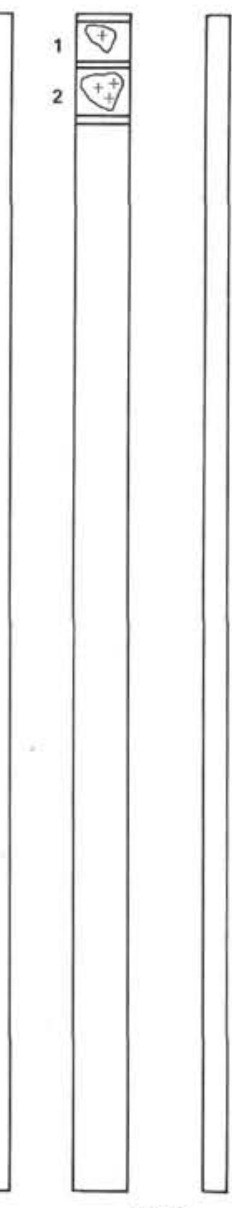

$31 / \mathrm{cc}$
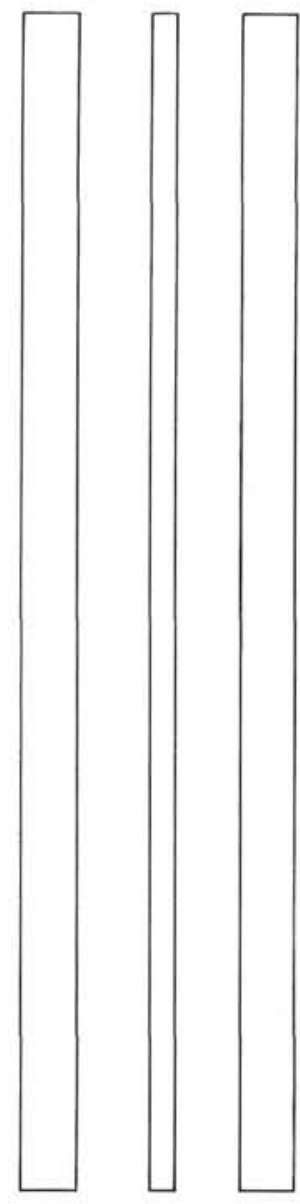
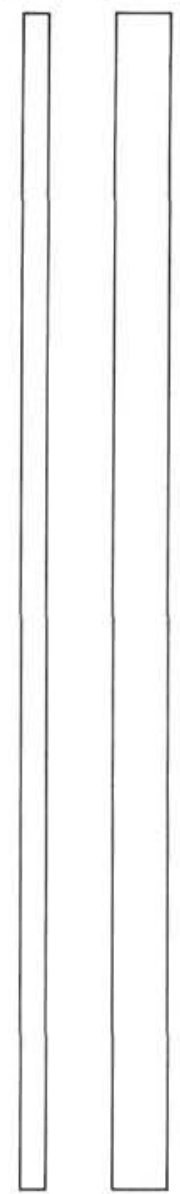

TS Piece 9: CATACLASTIC GRANITE: silicified cataclastic matri

Theser hred small angular fragments of quartz $(0.02-1.0 \mathrm{~mm})$ and ferdspar in Composition: for hypoidiomorphic t.

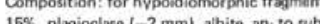

405 quartz $(1-3 \mathrm{~mm})$ anhedral, rounded, fractur 15:

5\% pseudomorphs of chlorite after biotite and hornblende

TS Piece 11: CATACLASTIC GRANITE: hypidiomorphic frogments

in a cataclastic matrix (silicified). Blocks $(5-30 \mathrm{~mm})$ set in zones of small $(0.02-10 \mathrm{~mm})$ angular fragments of quartz and feldspar in

$15 \%$ albito (up to $2 \mathrm{~mm}$ ) subhedral, sericitized

$40 \%$ quertz (up to $3 \mathrm{~mm}$ ) anhedrat, rounded, fractured 40\% alkali feldspar (1-3 mm) subhodrat, perthitic or 10 sericite in albites

64.476-30

SECTION

HORNBLENDE-BIOTITE

Macroscopic Description

size $\sim 6-8 \mathrm{~mm})$ light Verv similar to Core 28 , Core-Cutcher.

Comprises slightly altered white feldspors $(\sim 60 \%)$, anhedral quartz

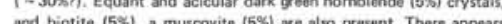

Pyrites are present in several patches. Mirorlitic
the piece, unlike Core 28, Cort-Catcher, Piece 1 .

64.476-31 Depth $284.5 \mathrm{~m}$

COREEATCHER: DOMINANT LITHOLOGY: GRANITE.

Macroscopic Description

Macrosscopically identical to Core 30 , Section 1, Piece 1. 


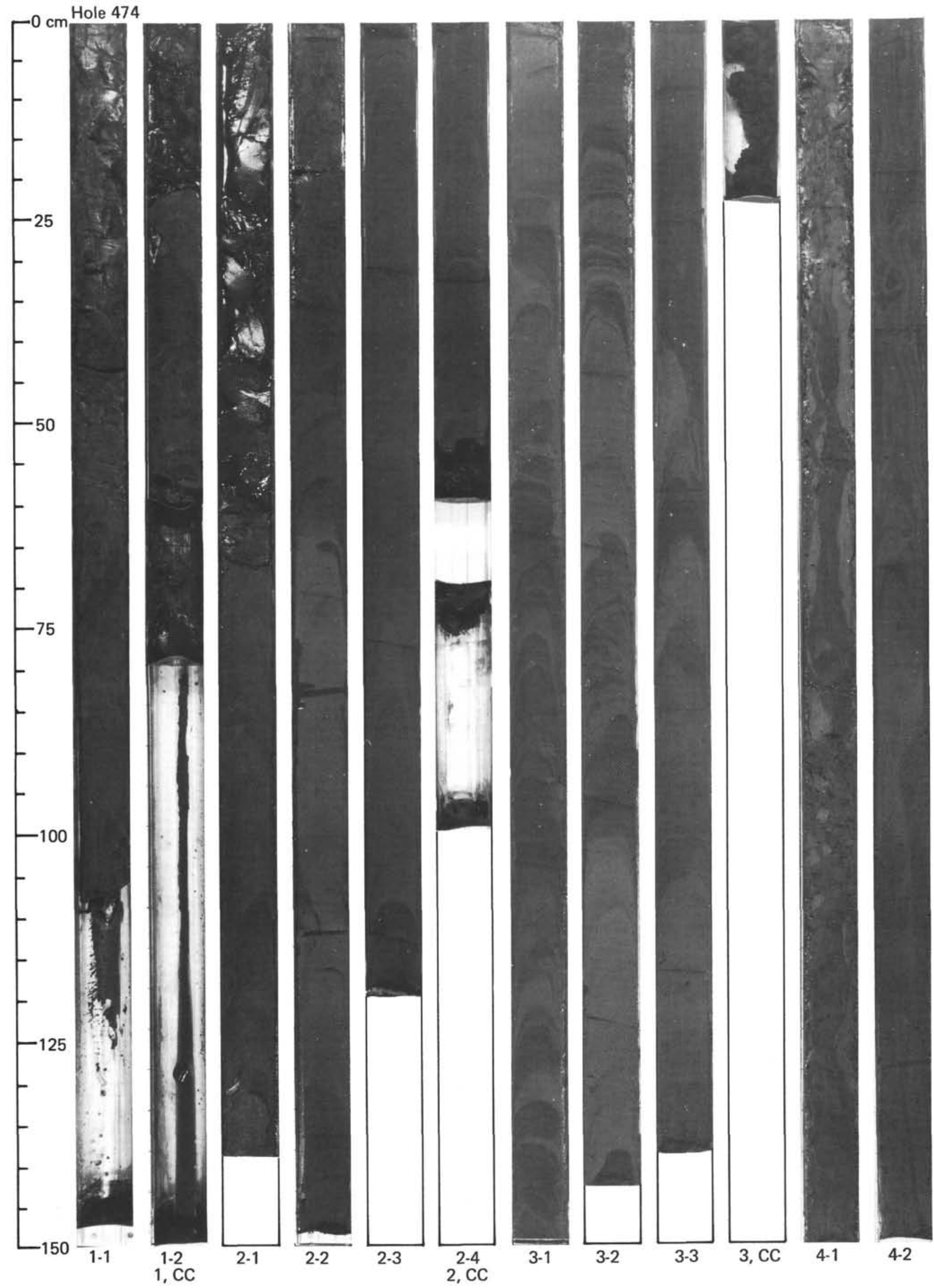




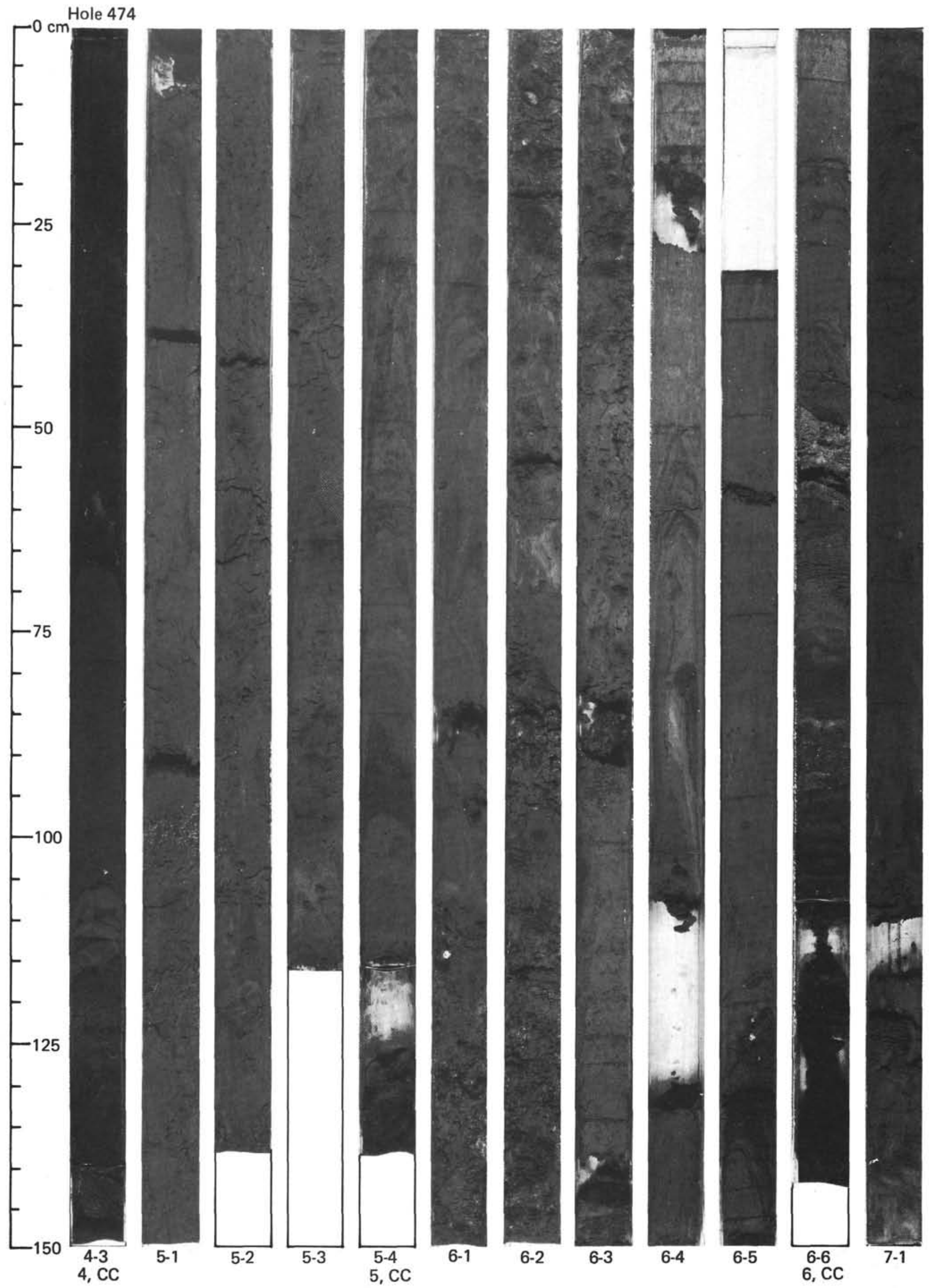



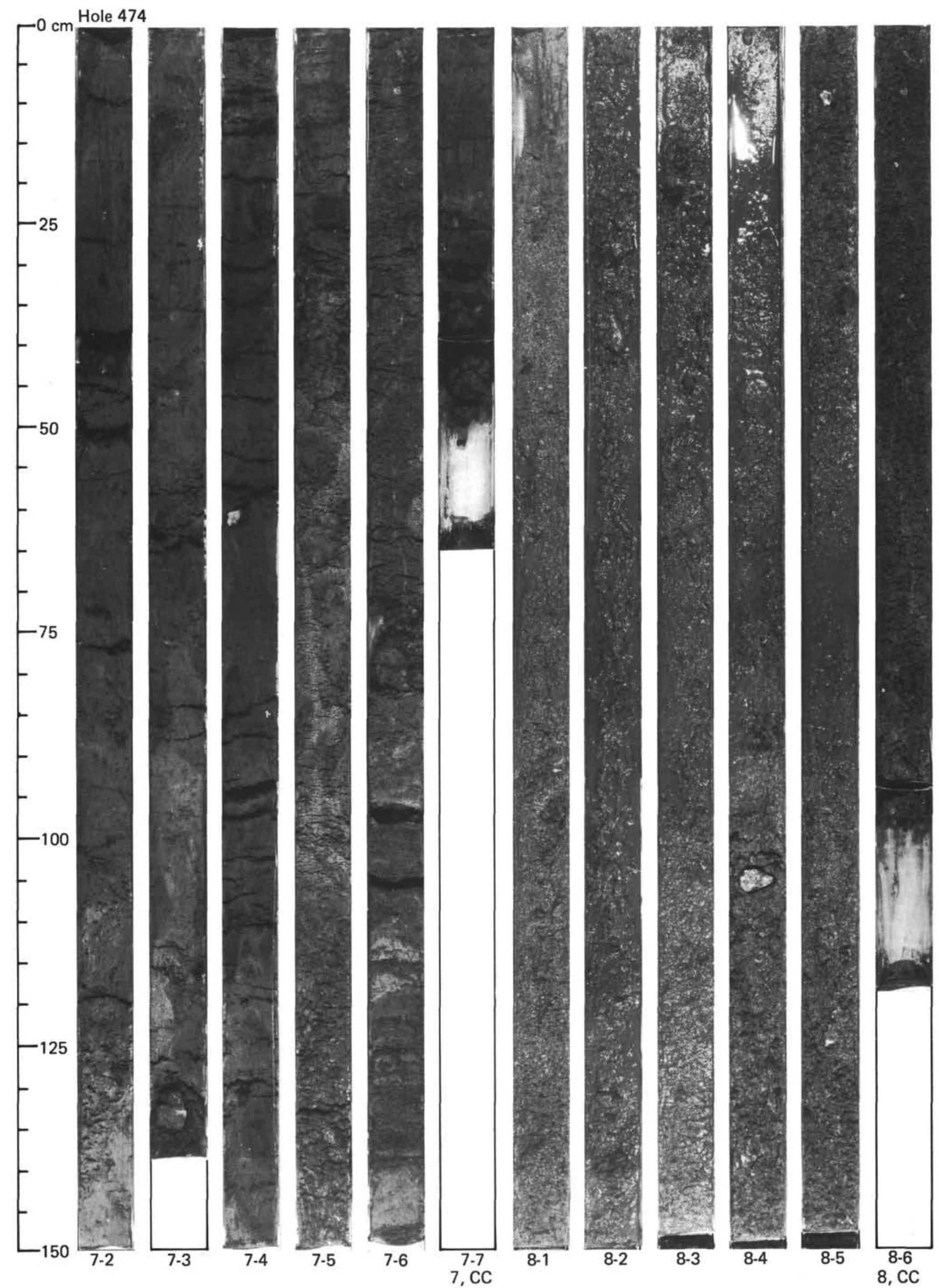


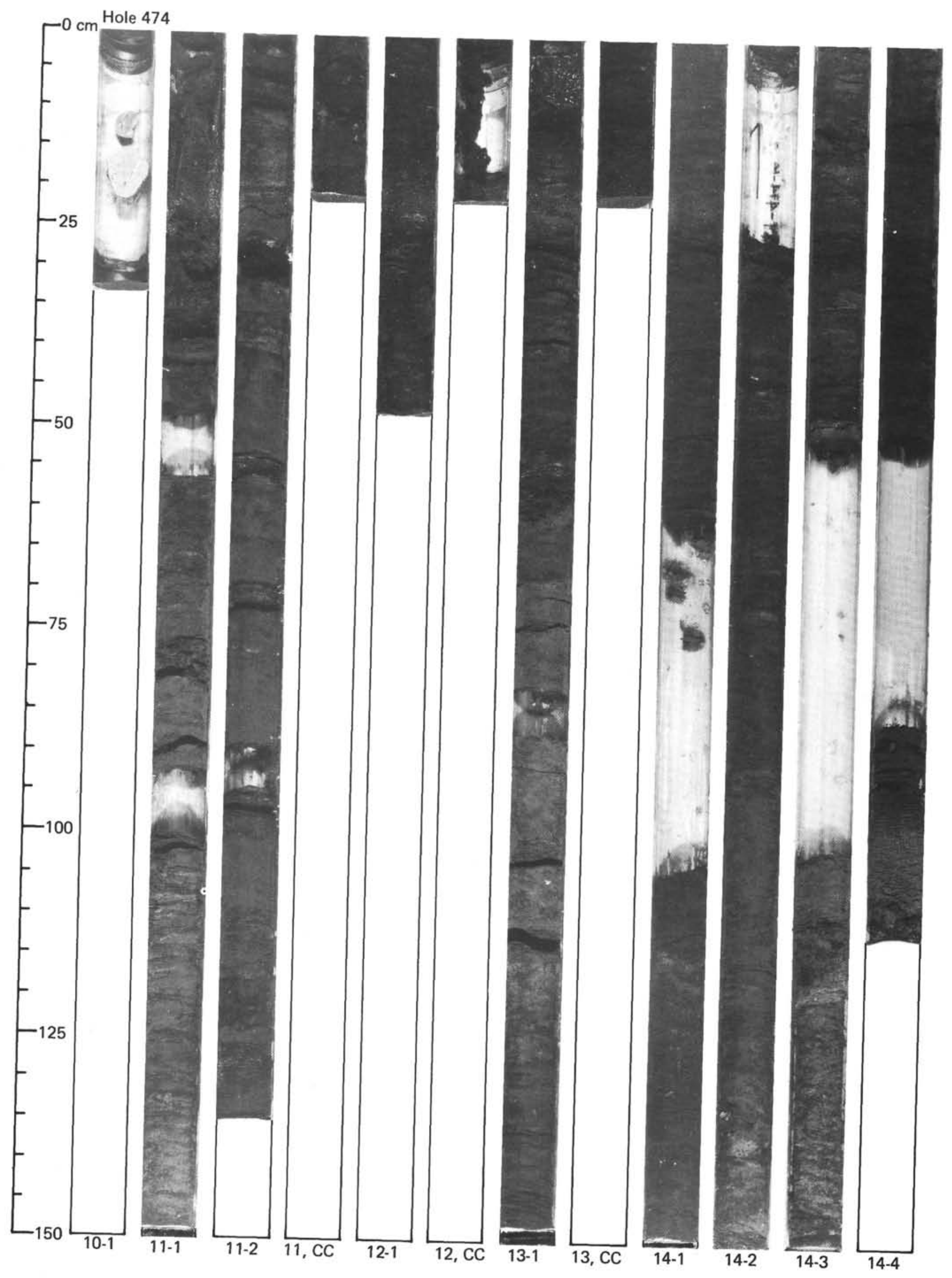




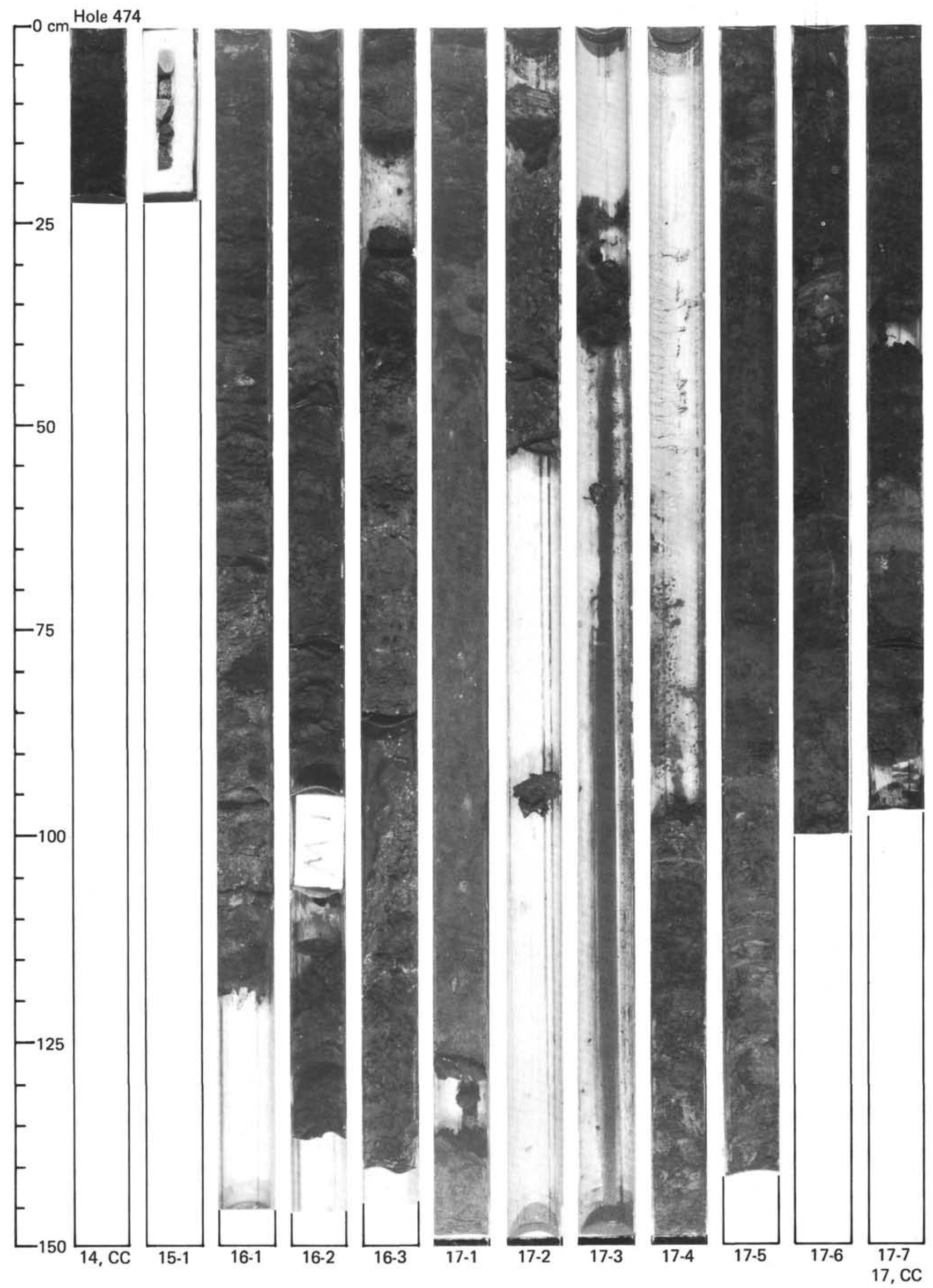




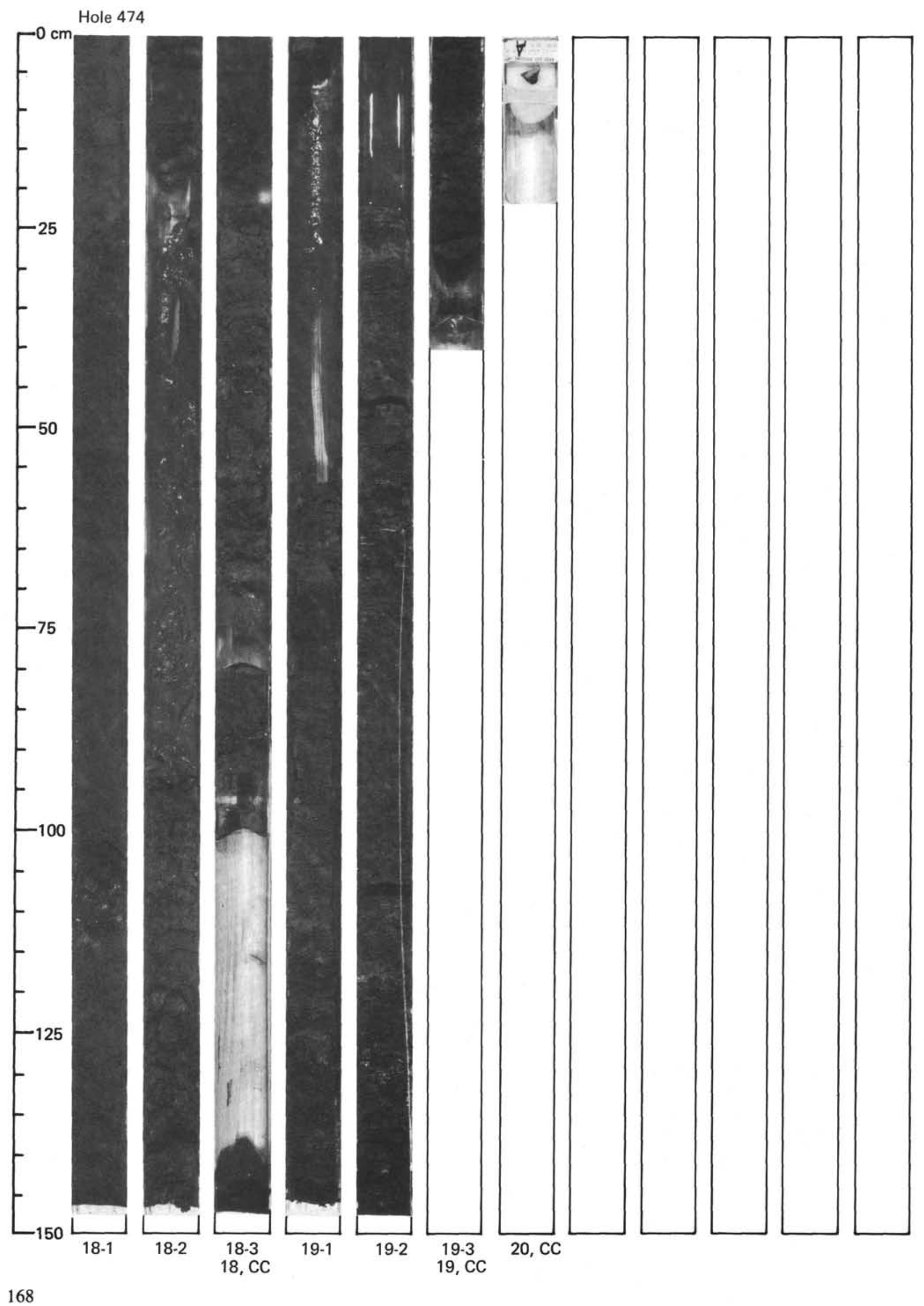




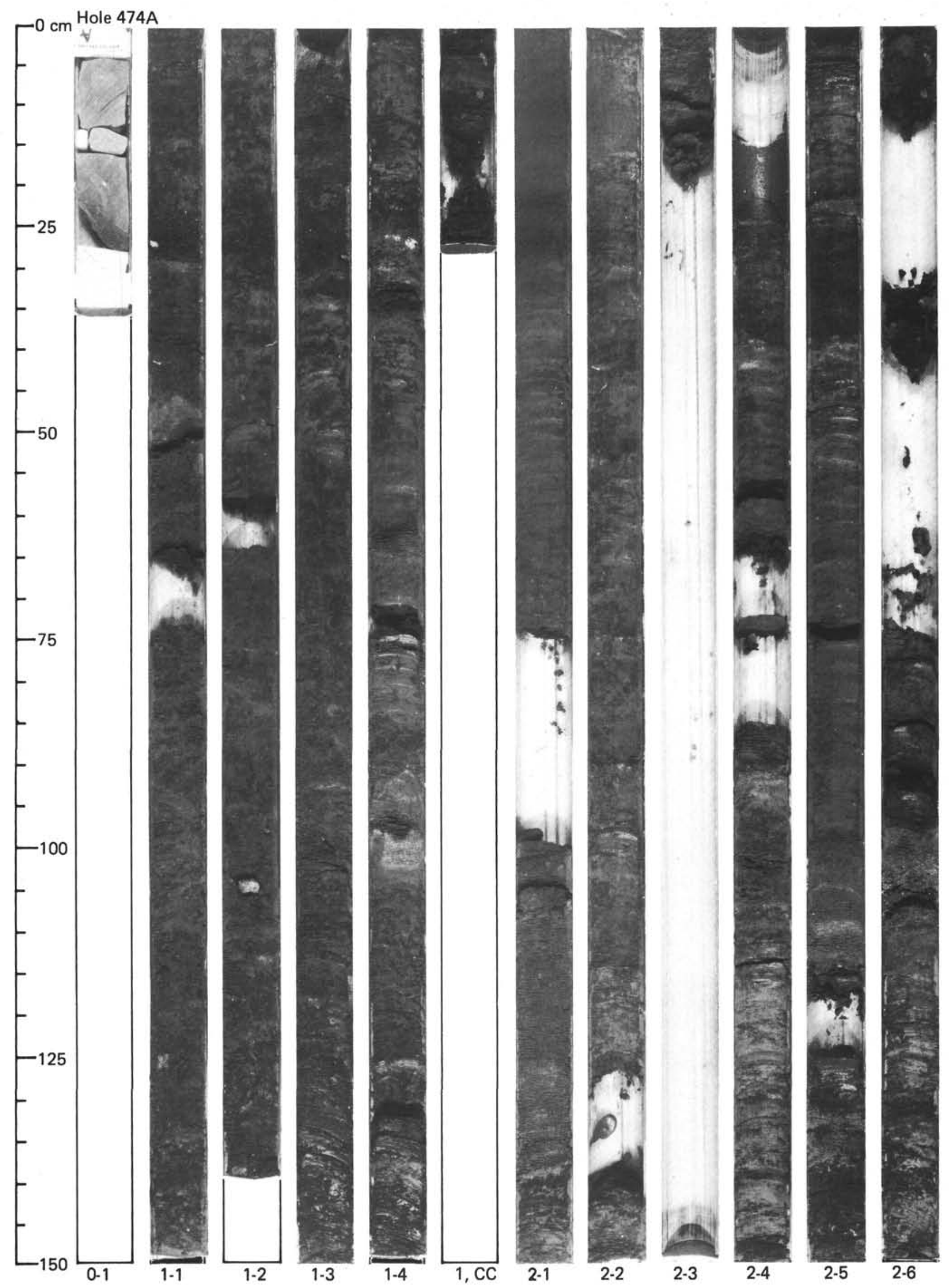



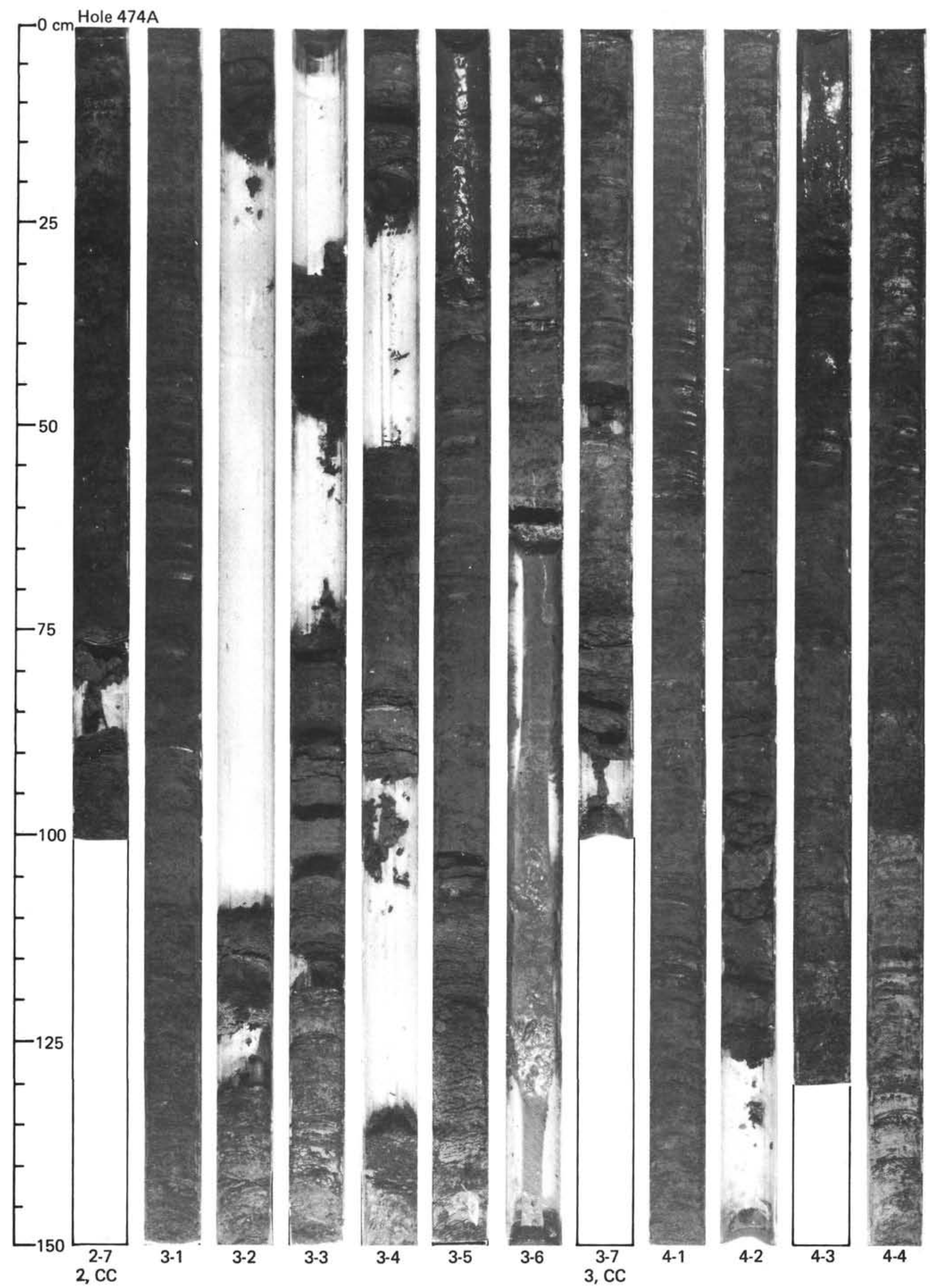


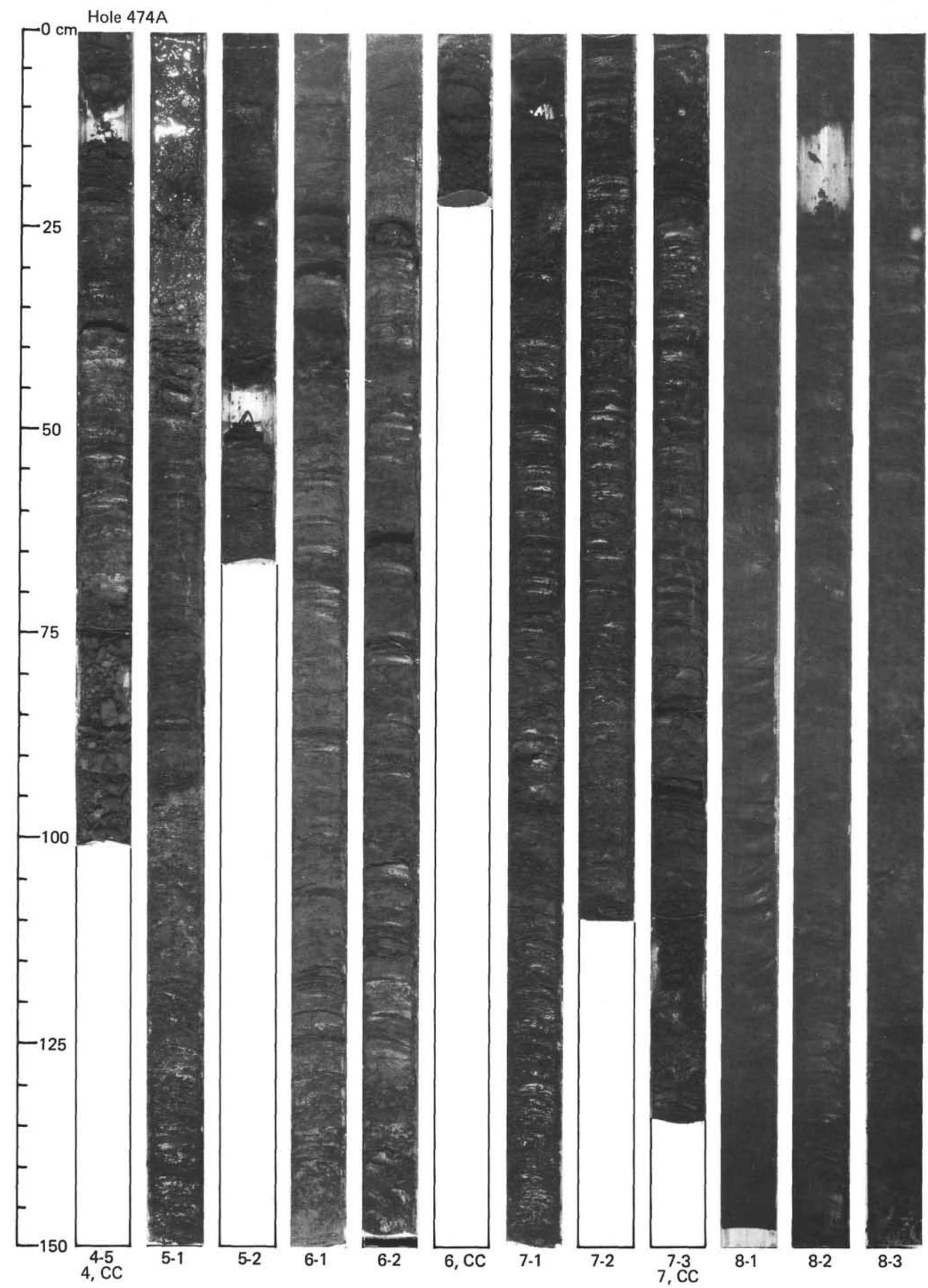


BAJA CALIFORNIA PASSIVE MARGIN TRANSECT

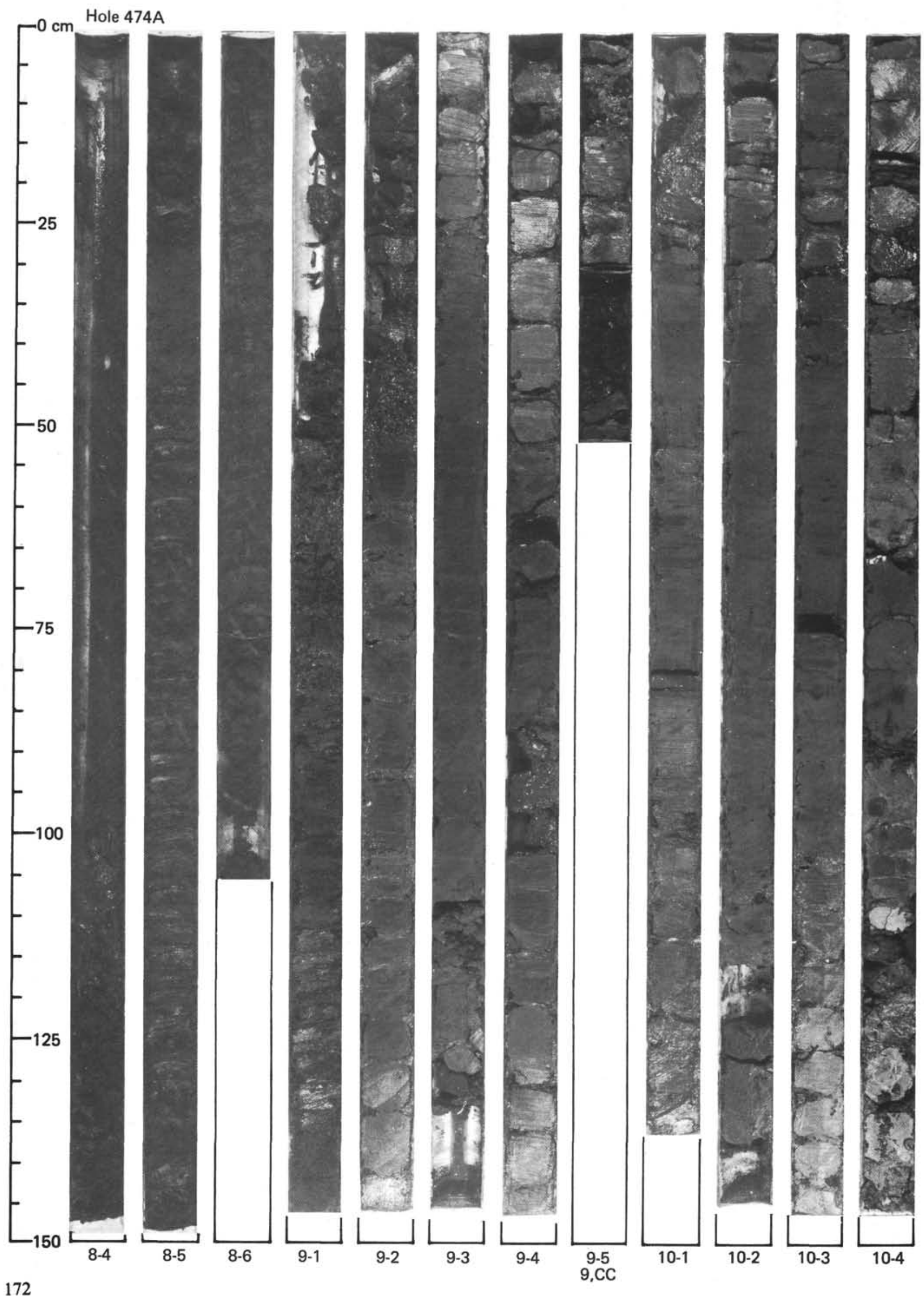



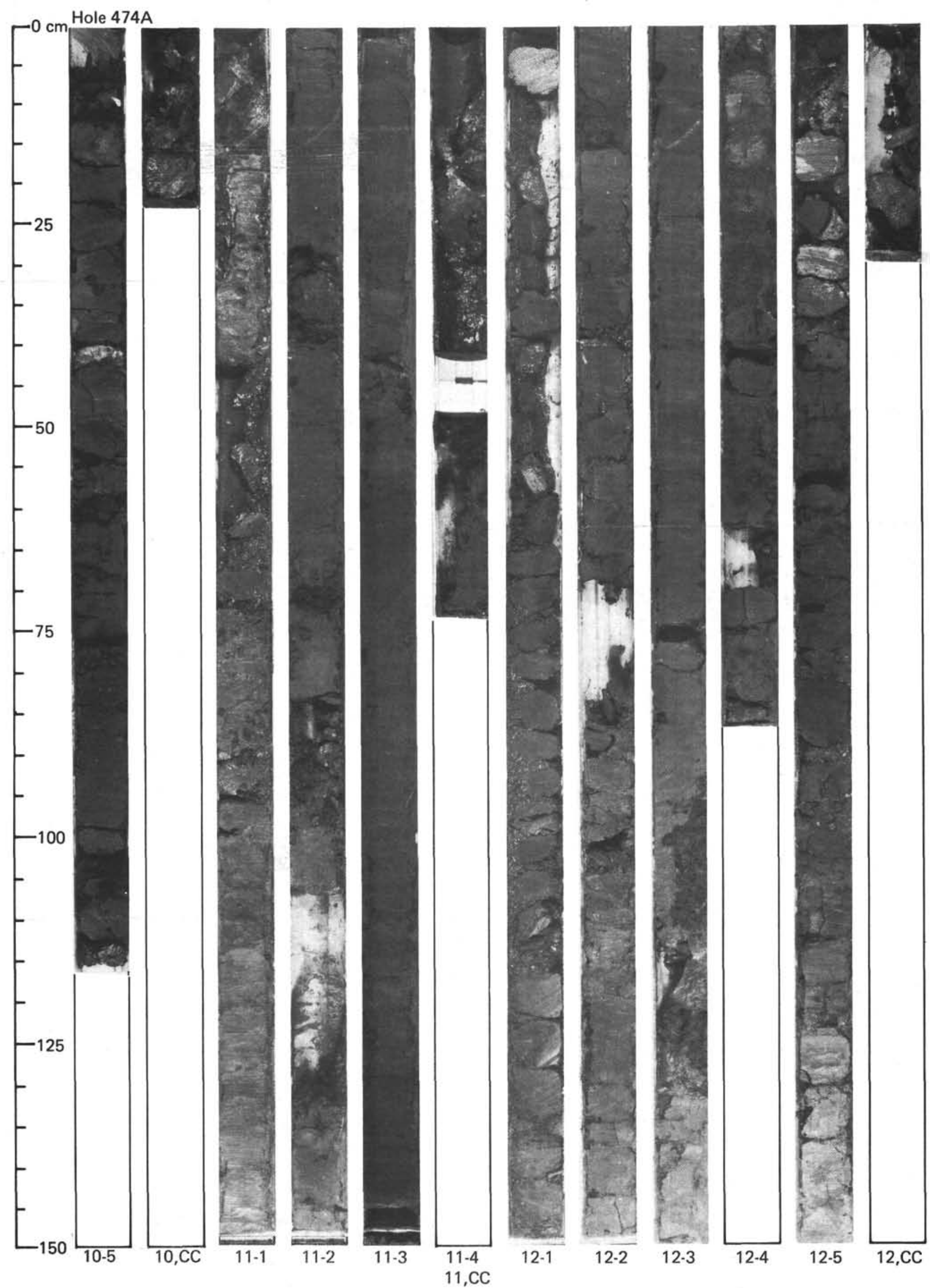


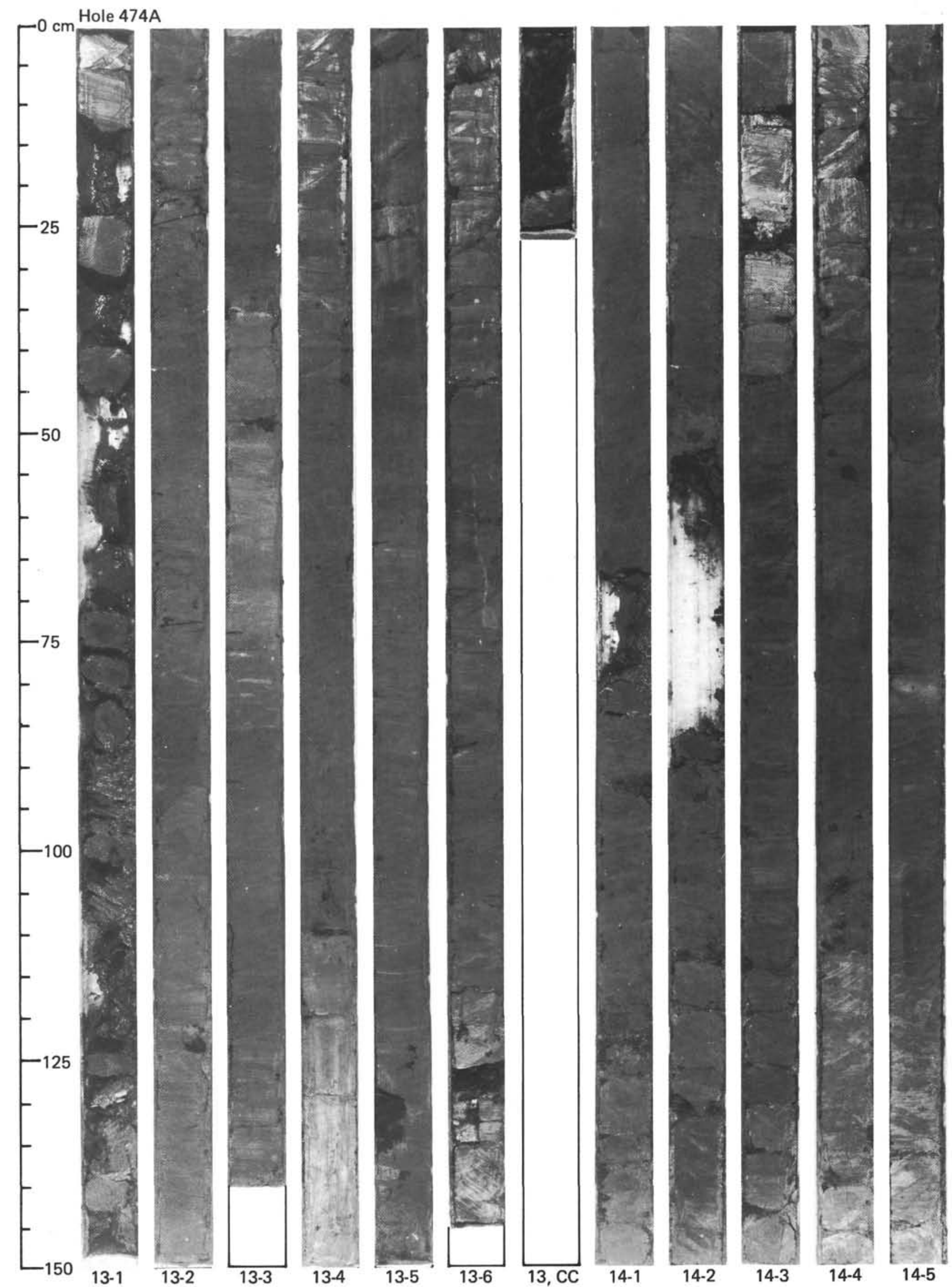


Hole 474A

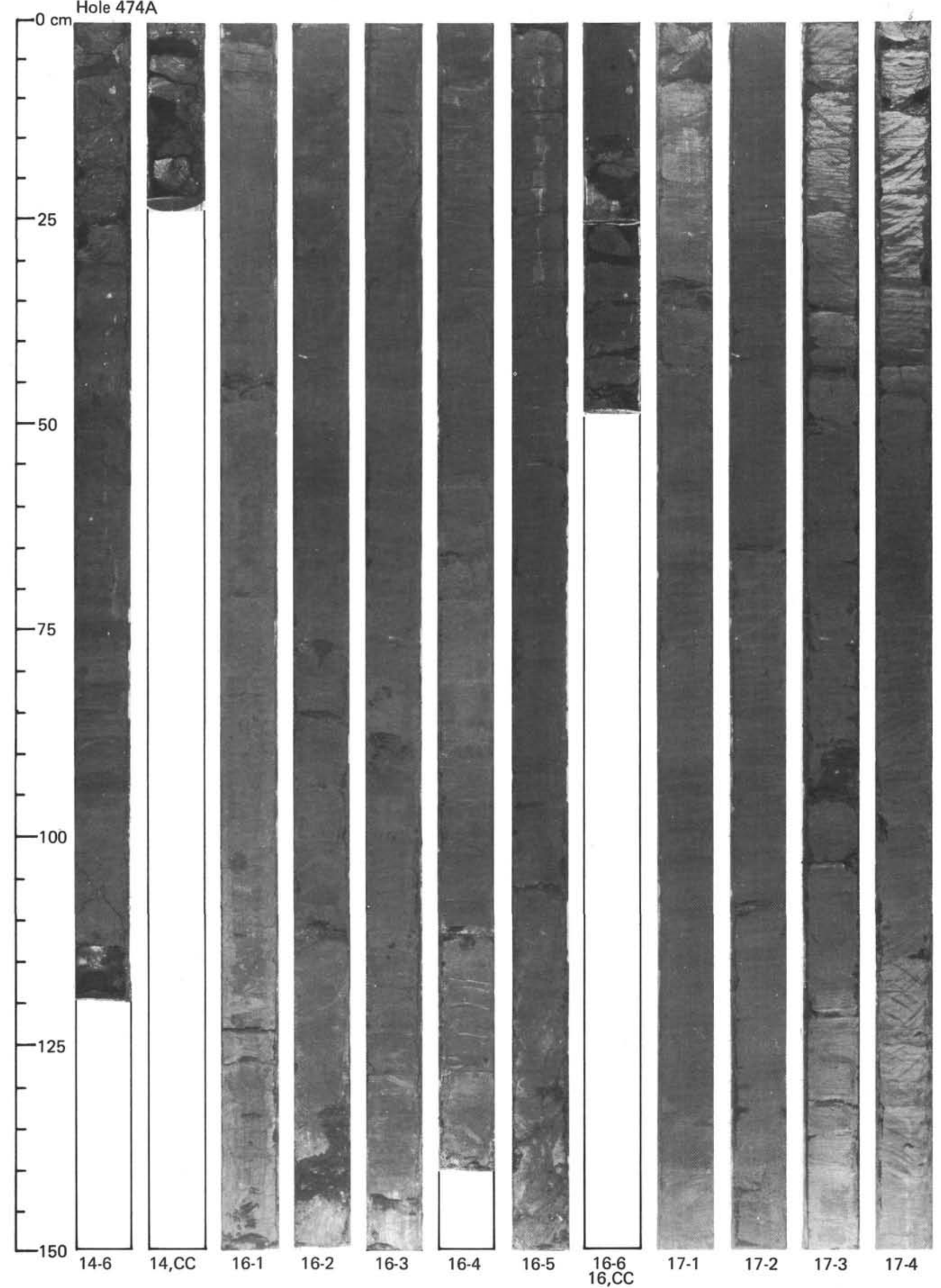




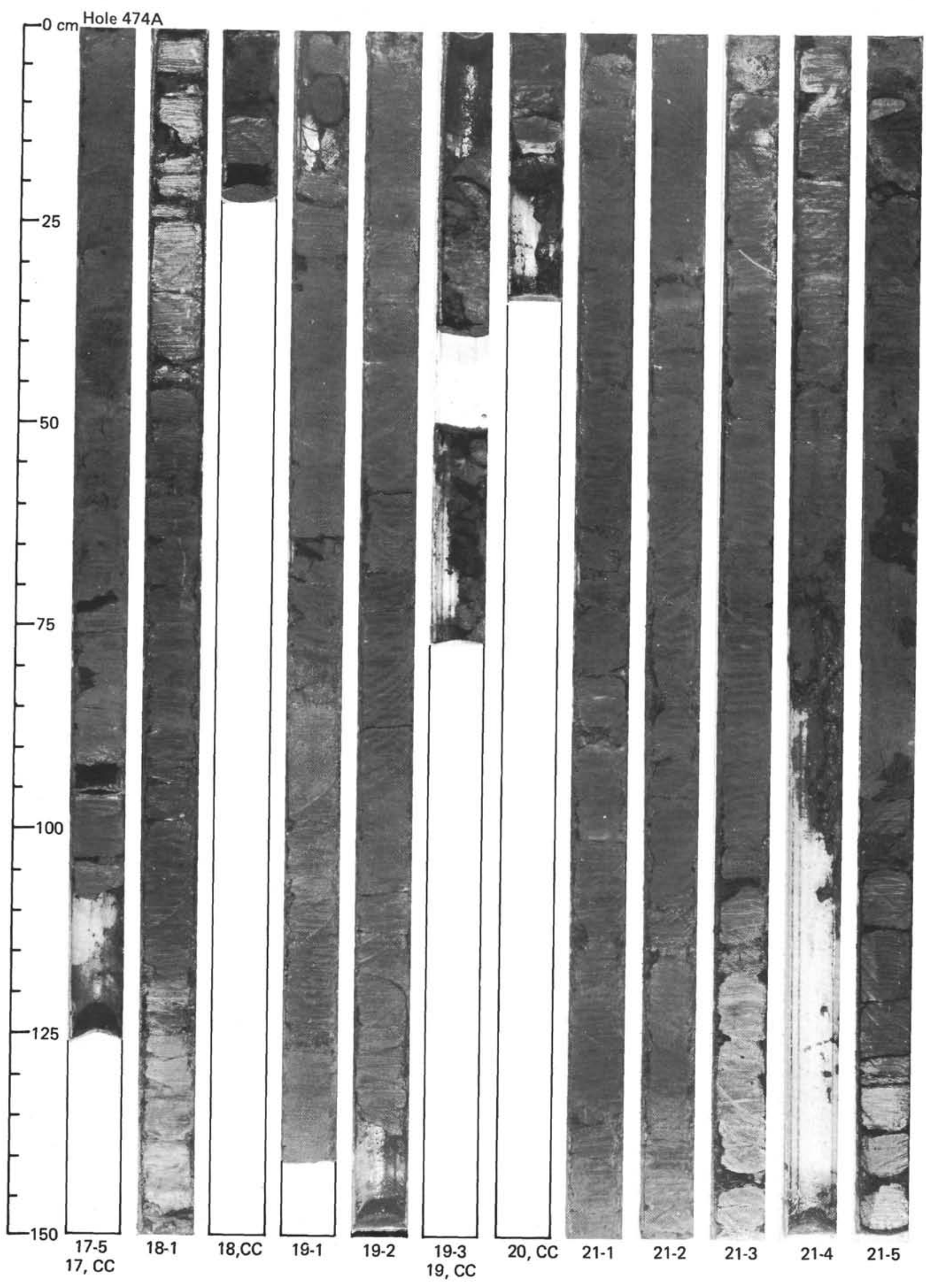




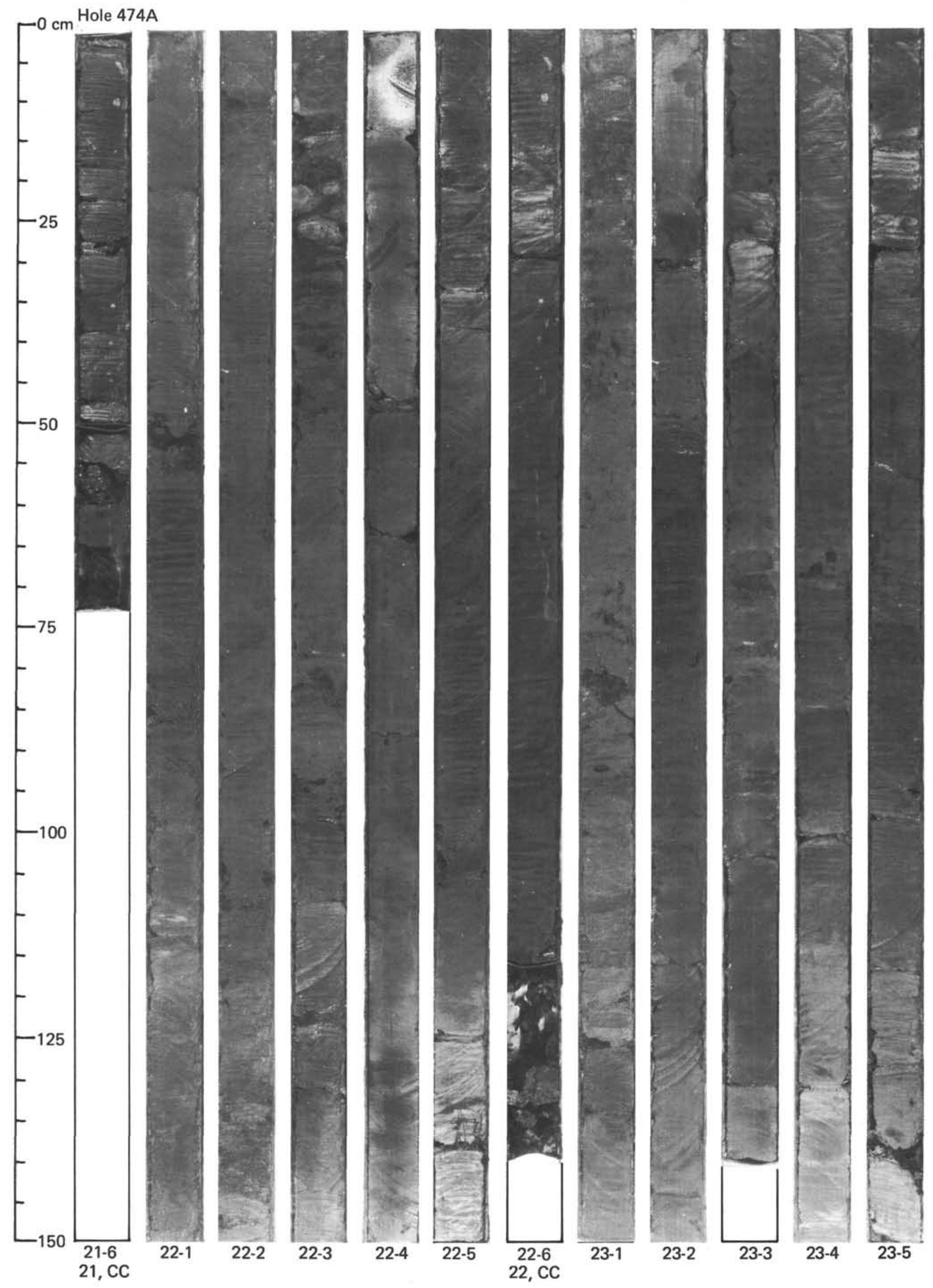




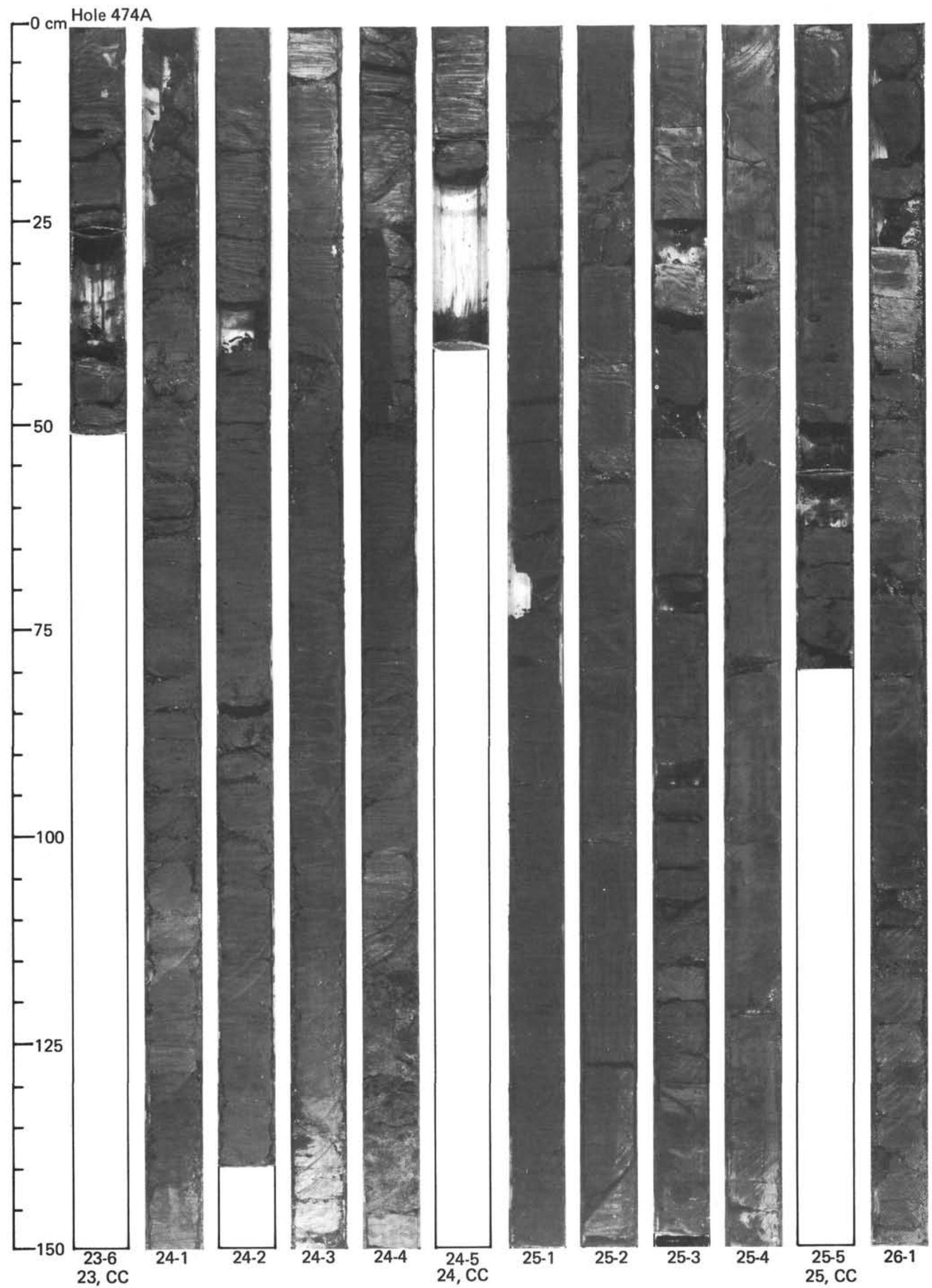




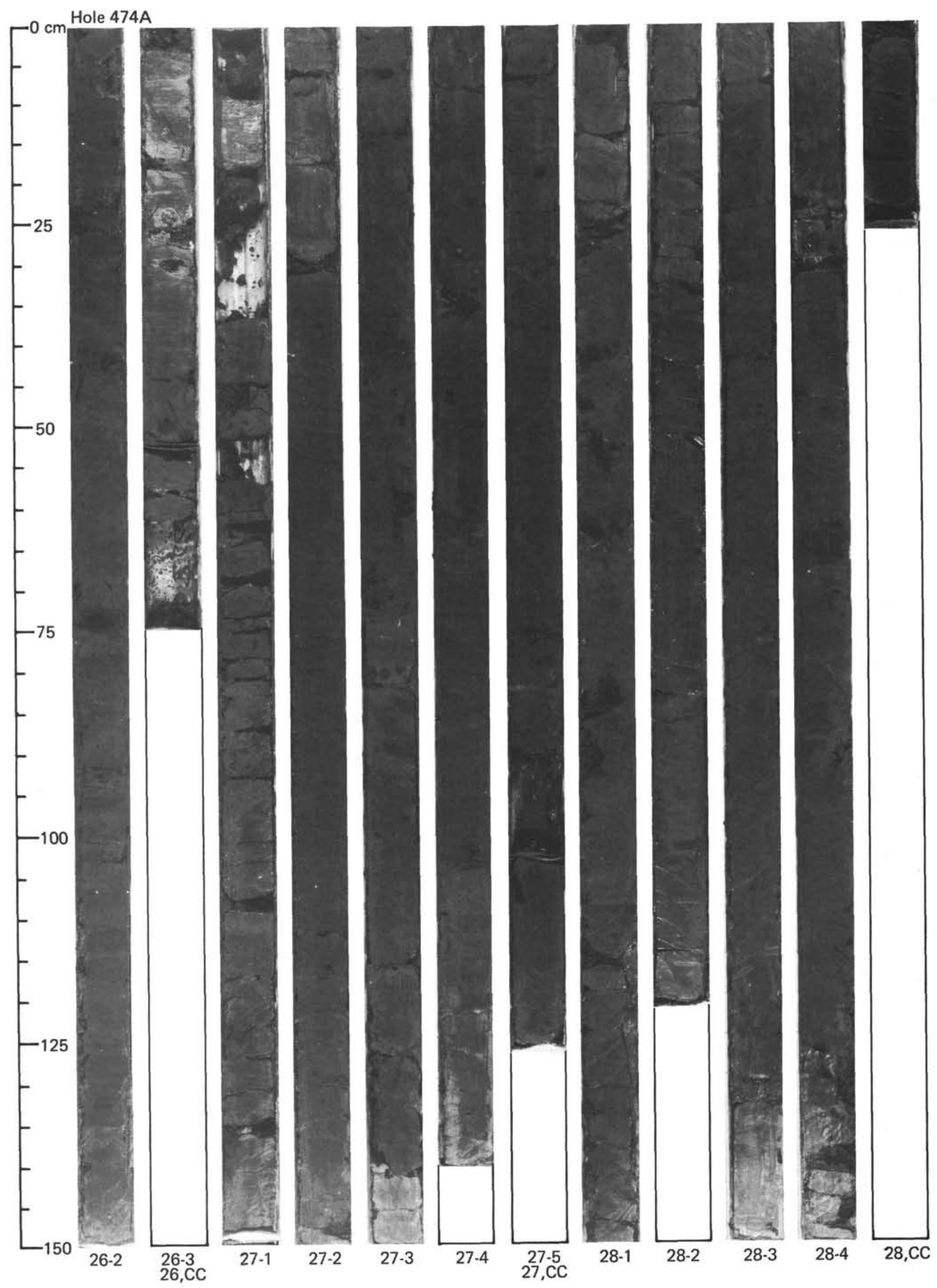



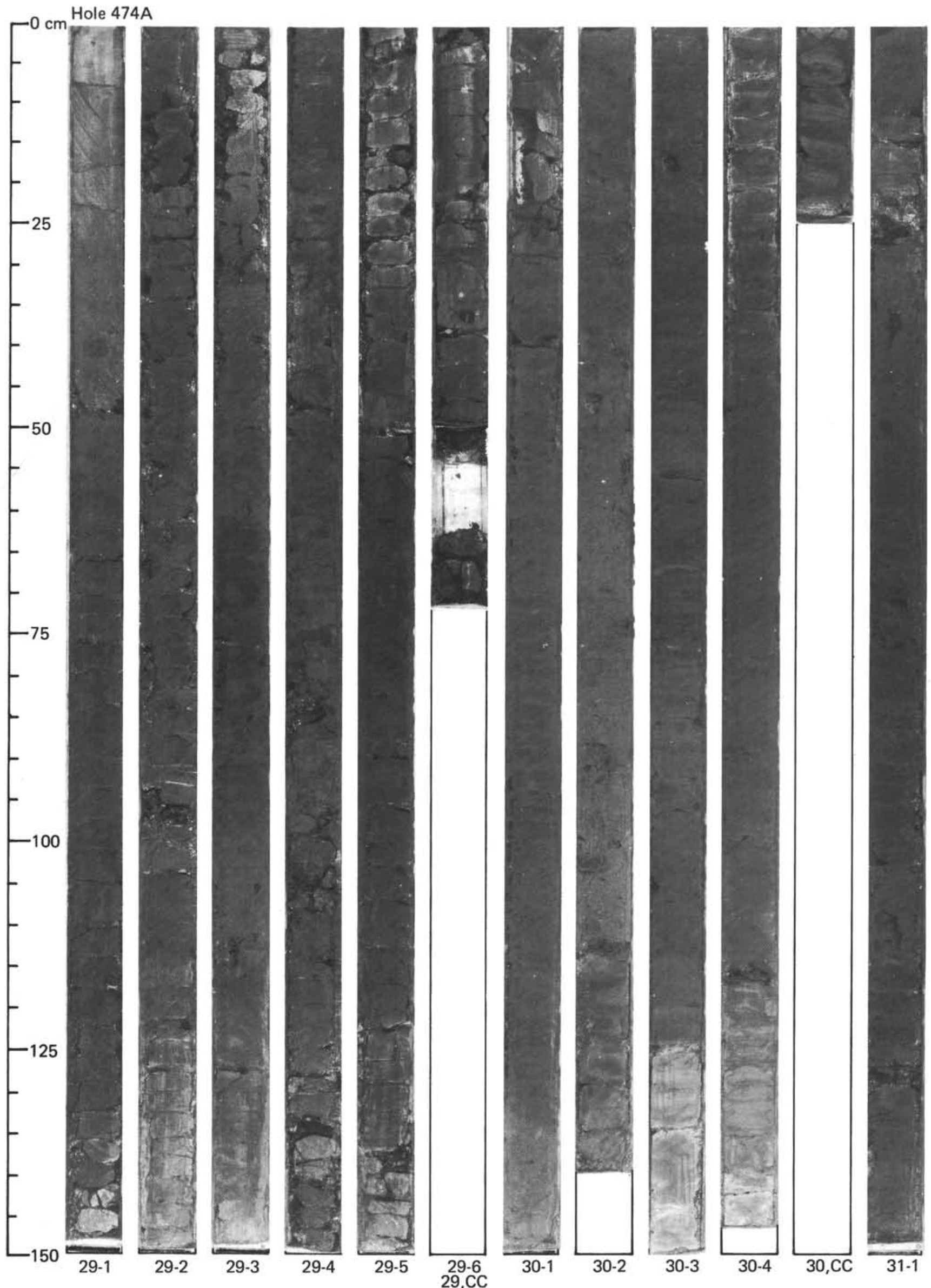

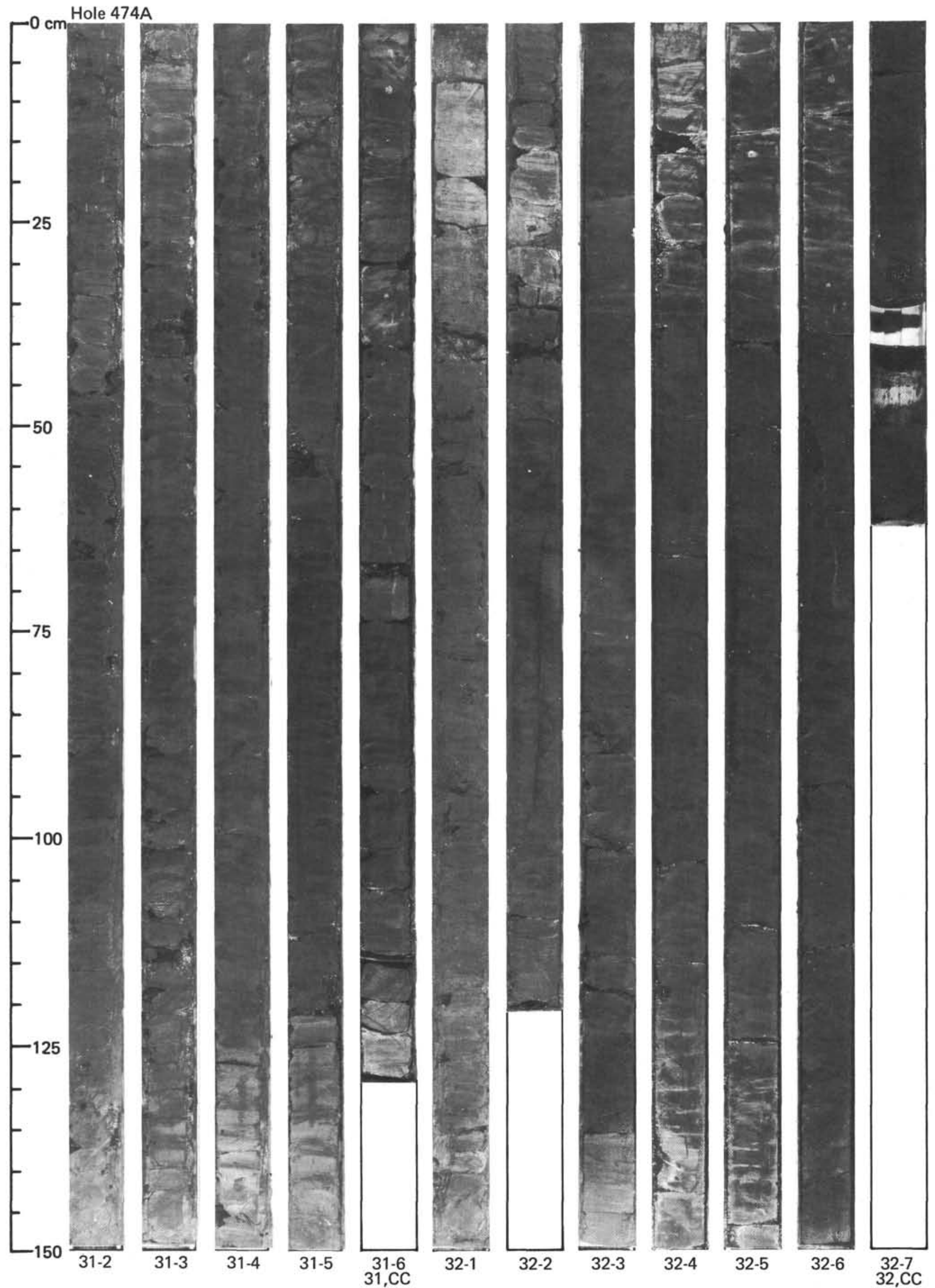


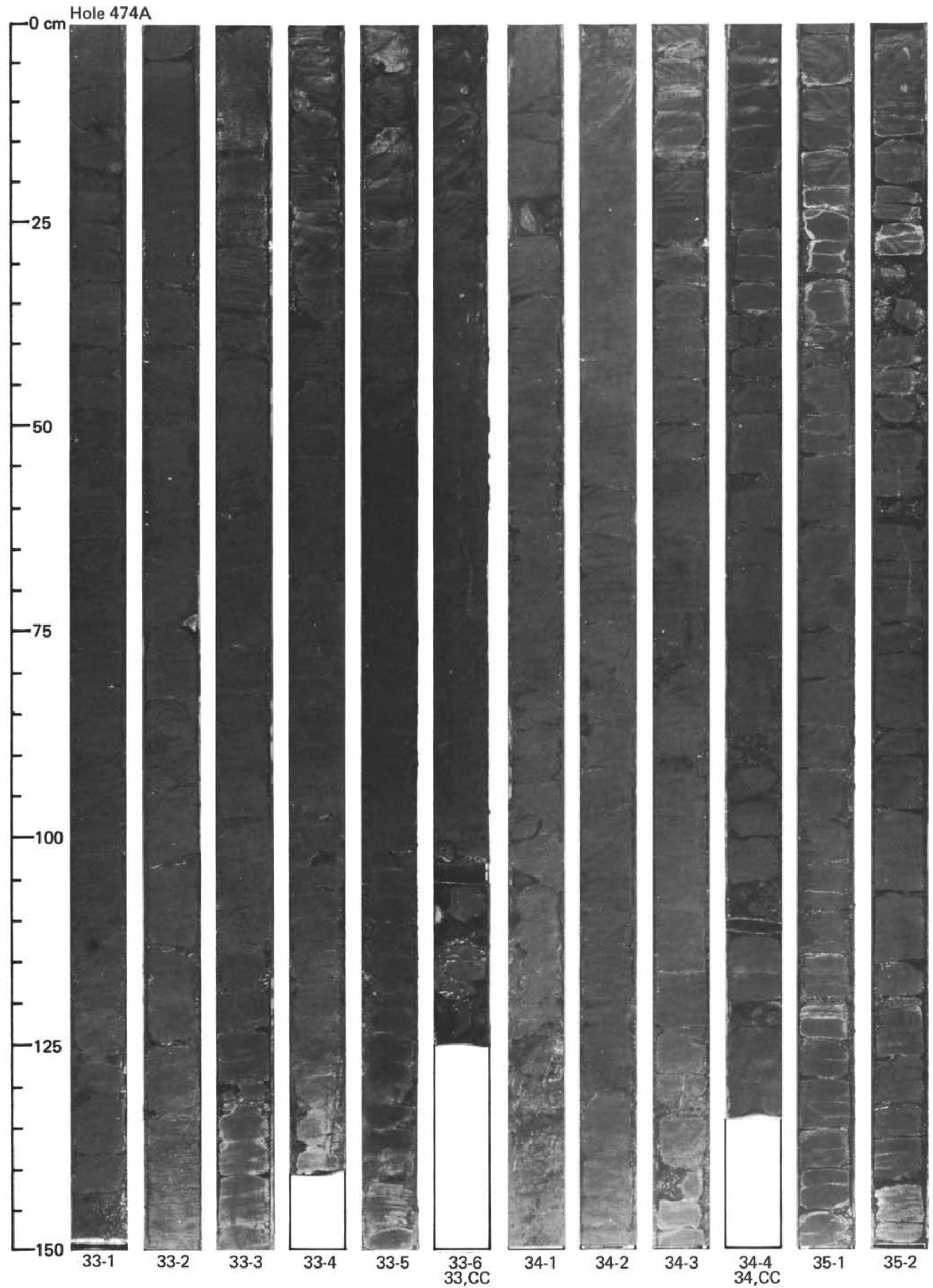




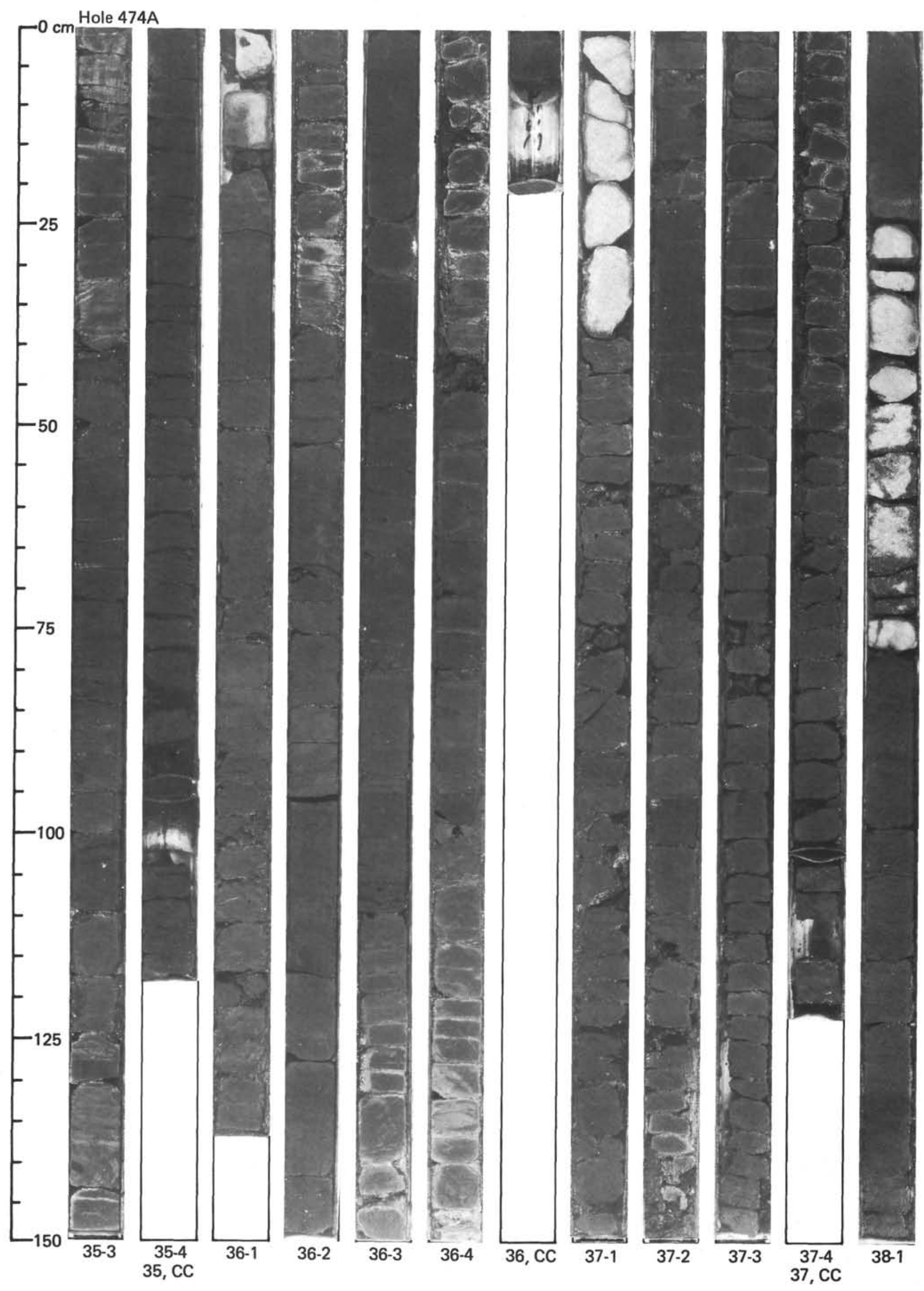




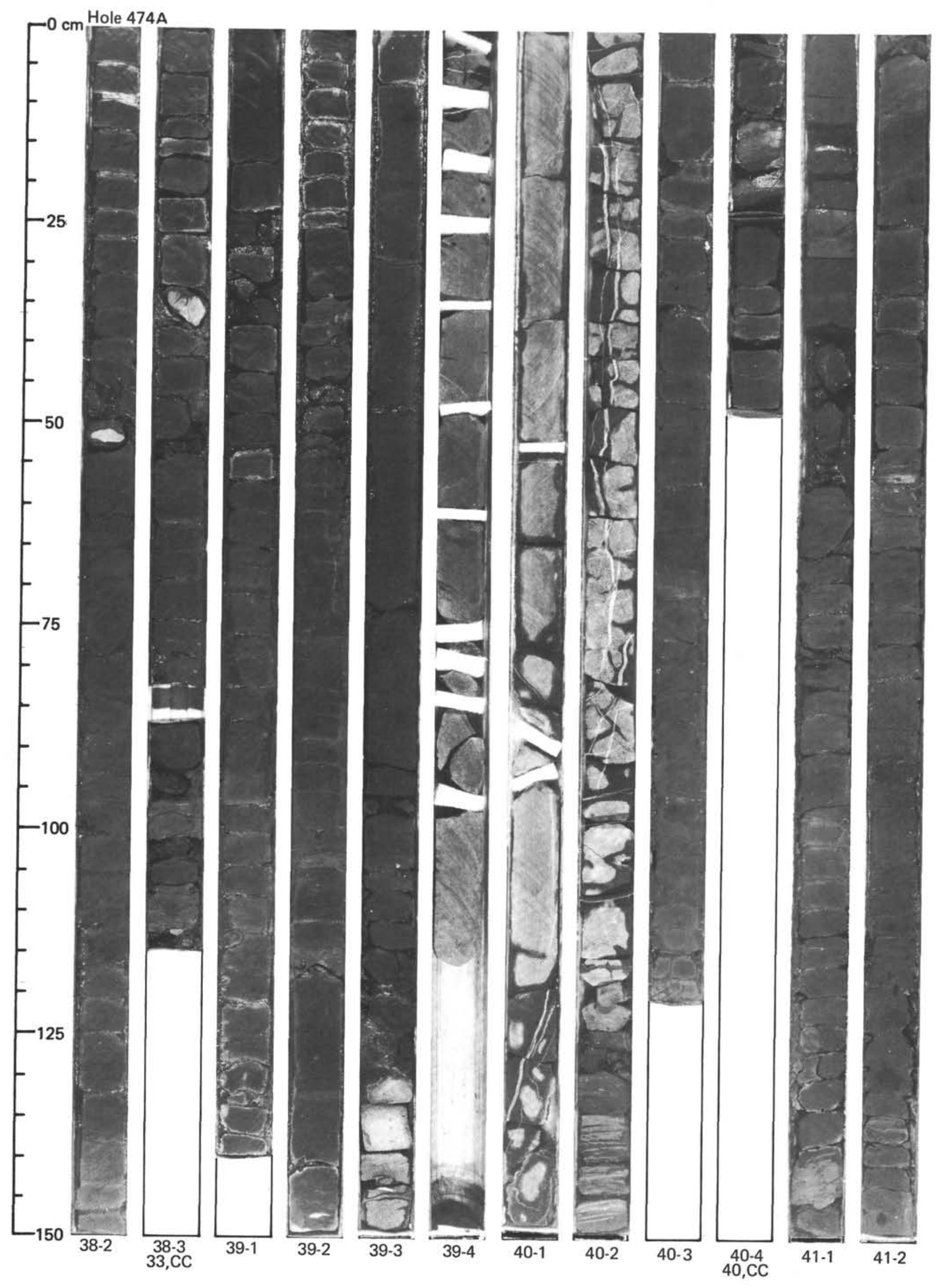




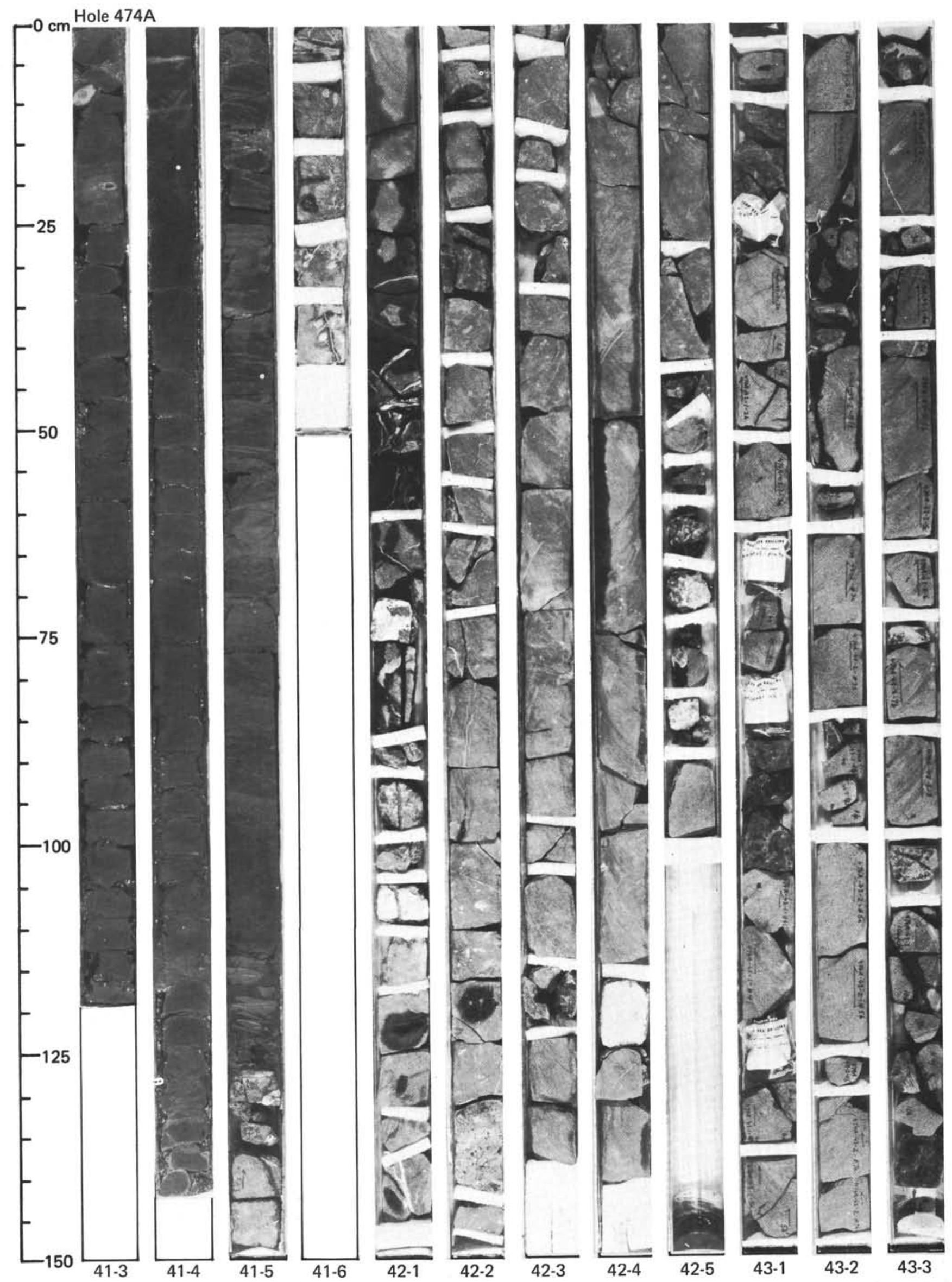




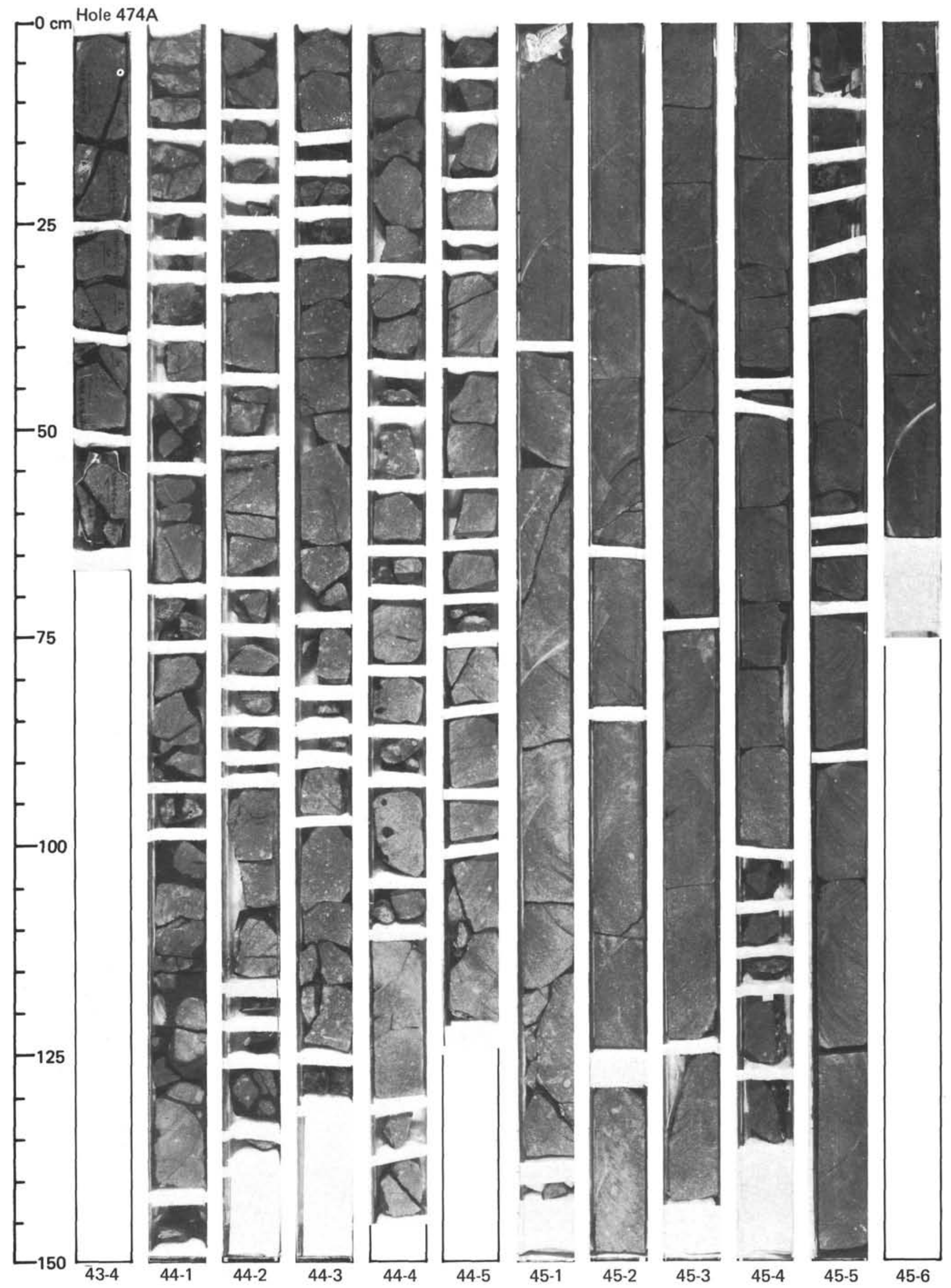




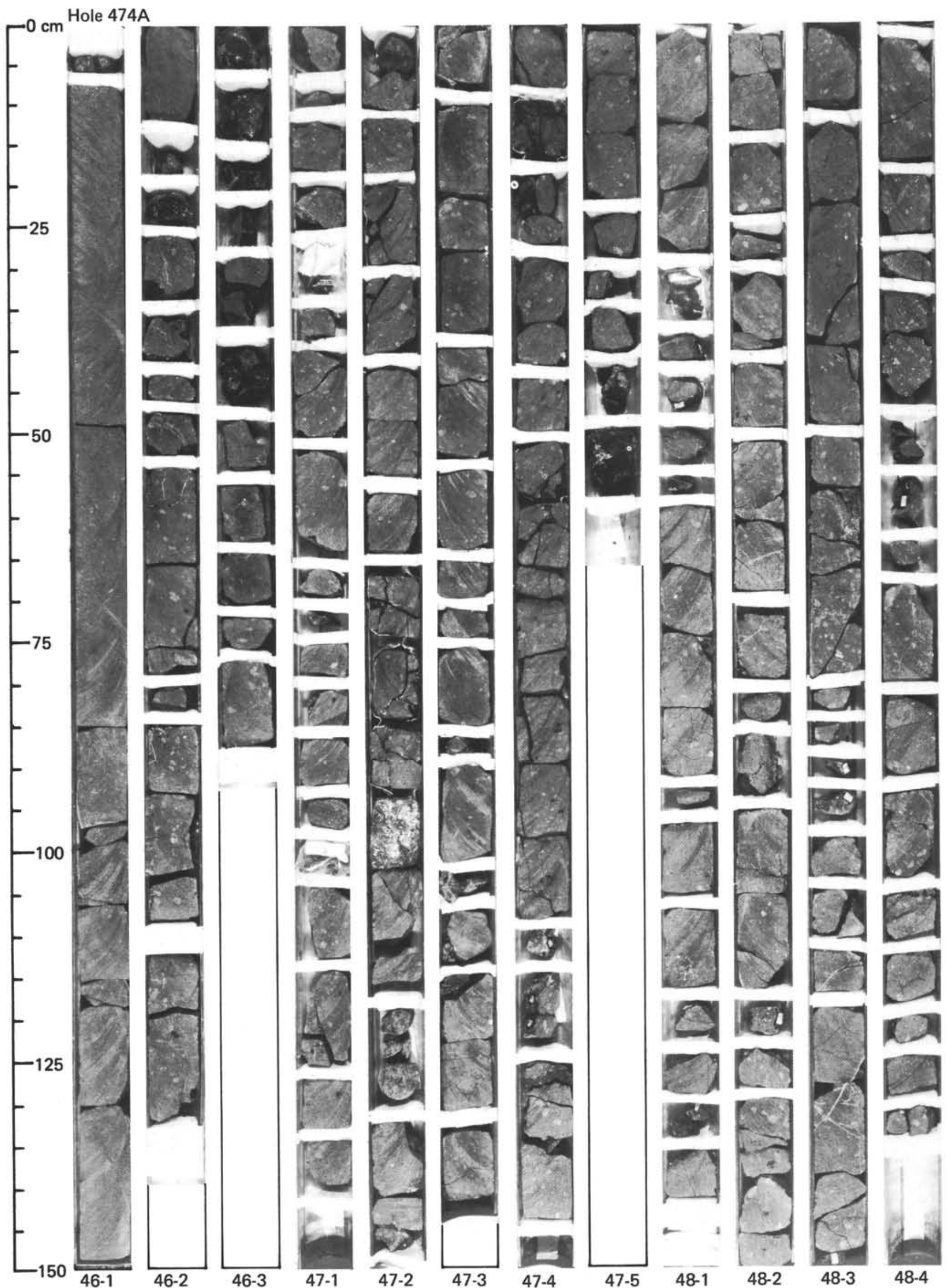




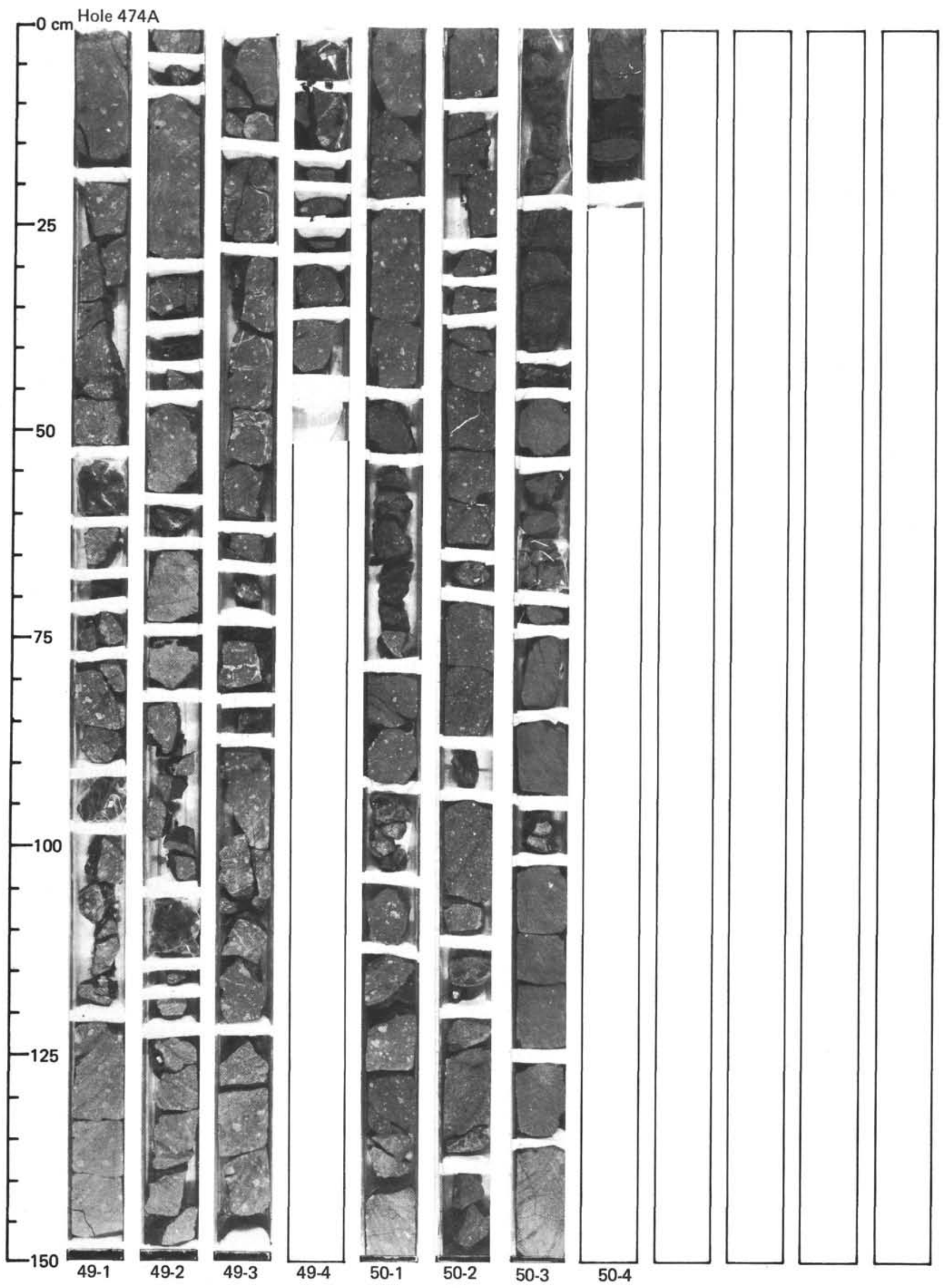




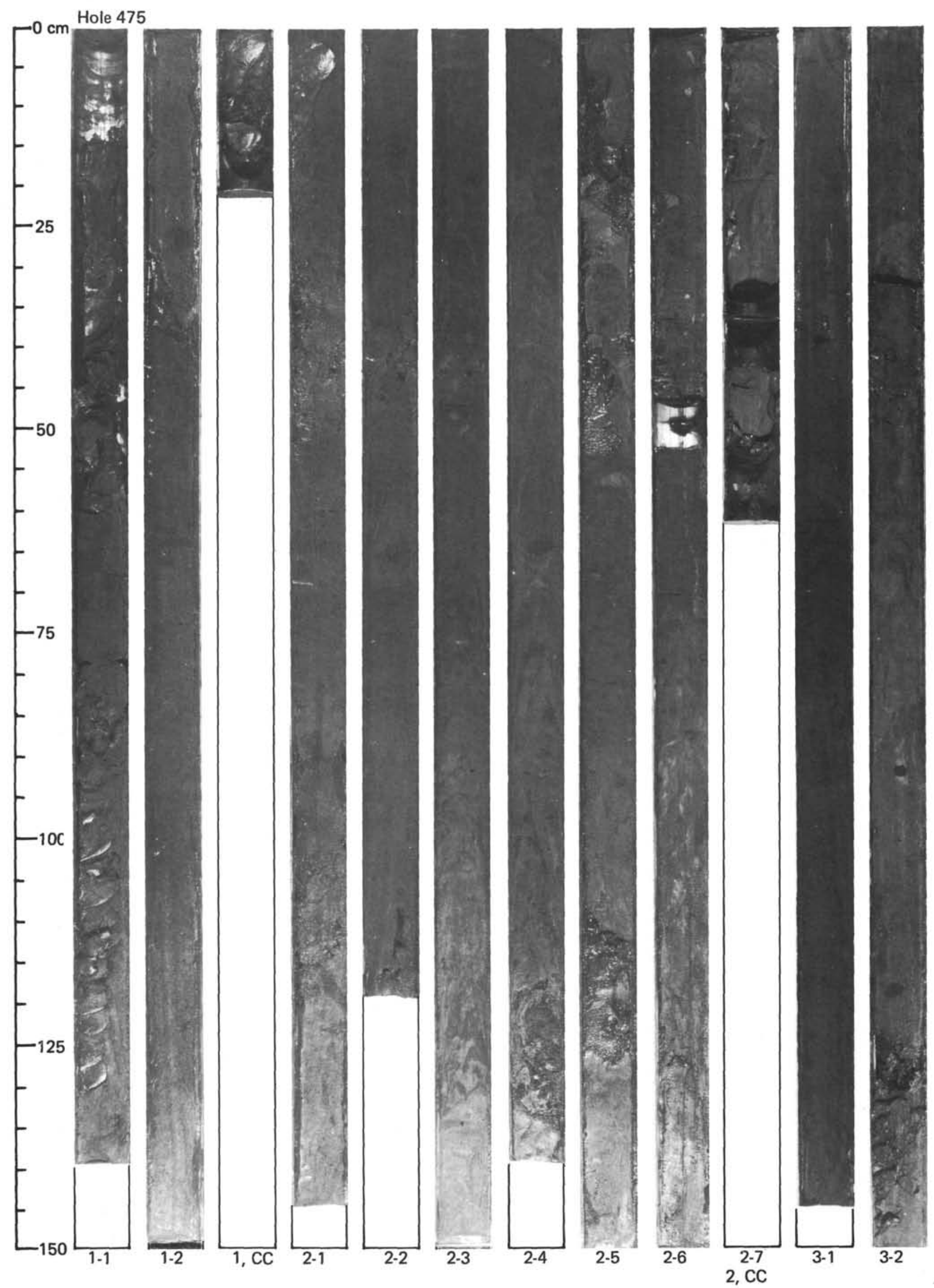




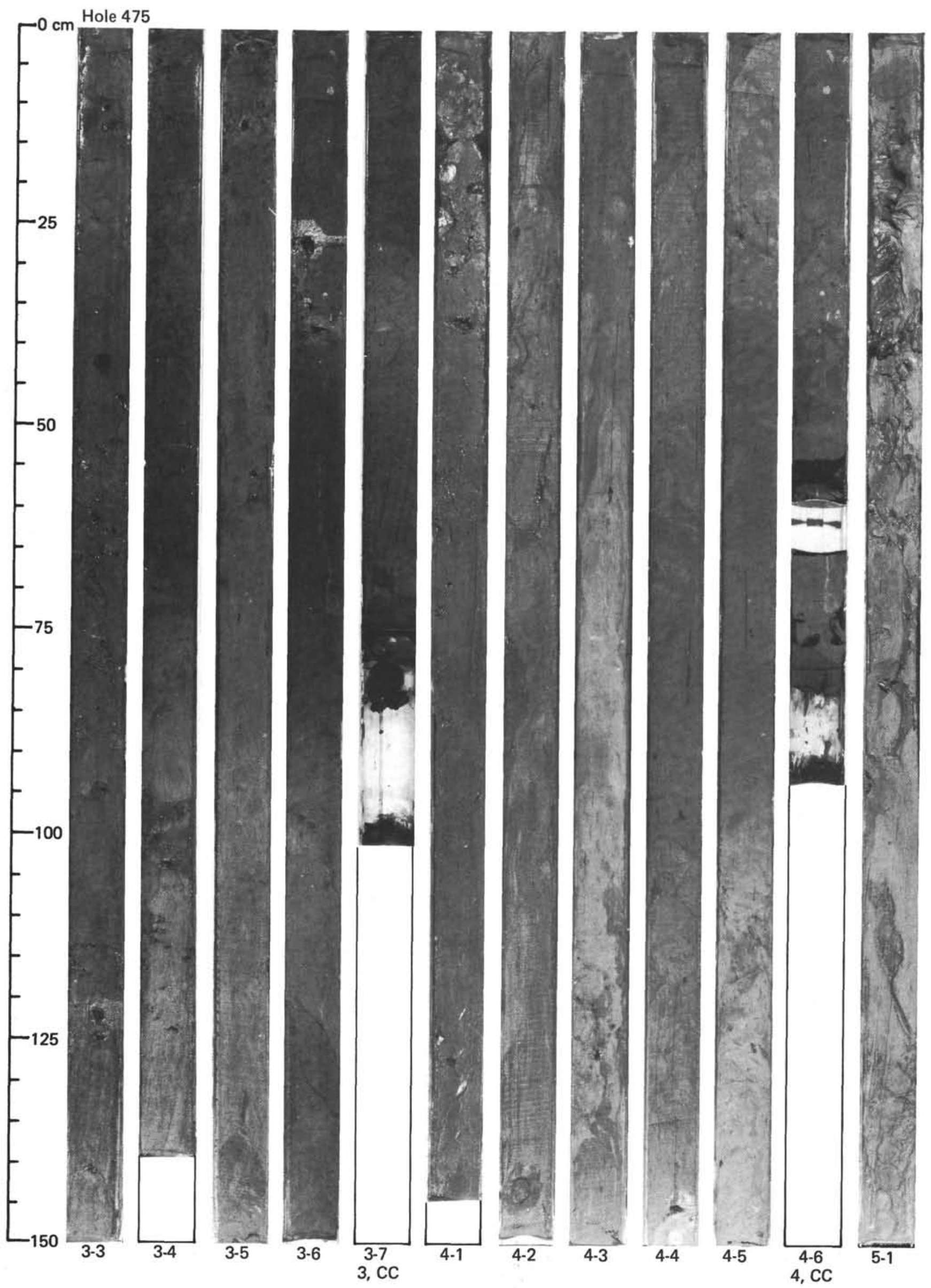




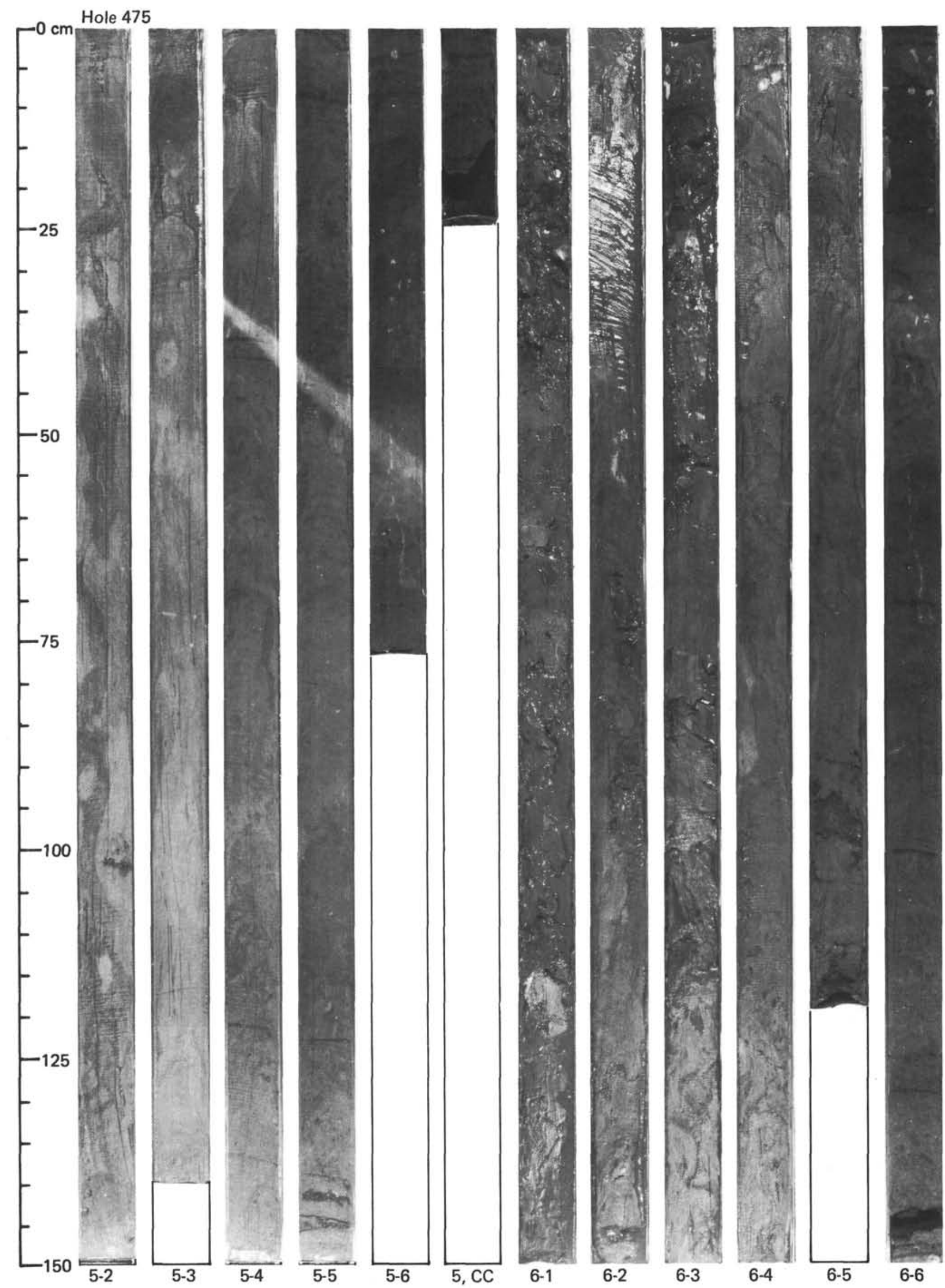



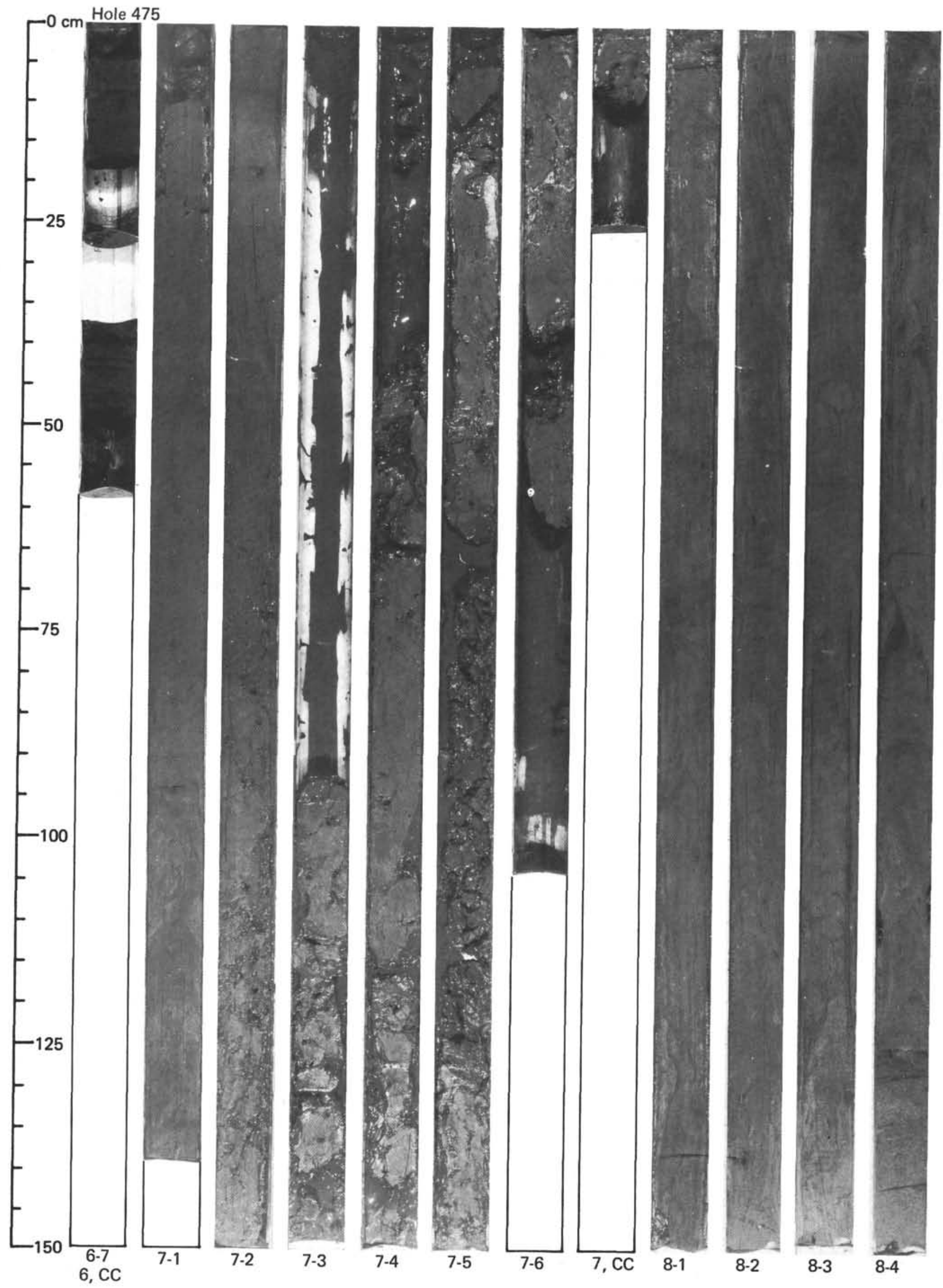


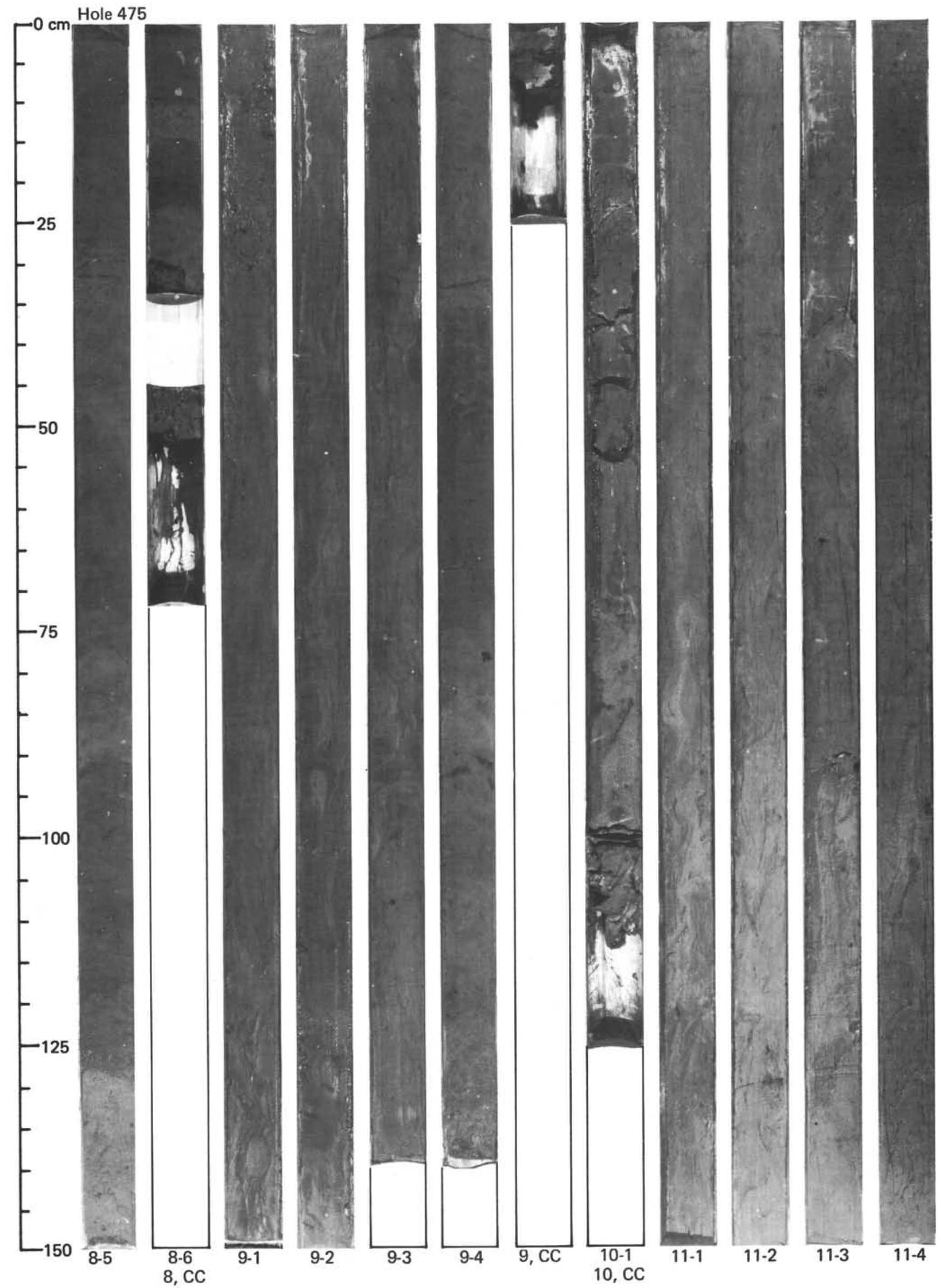




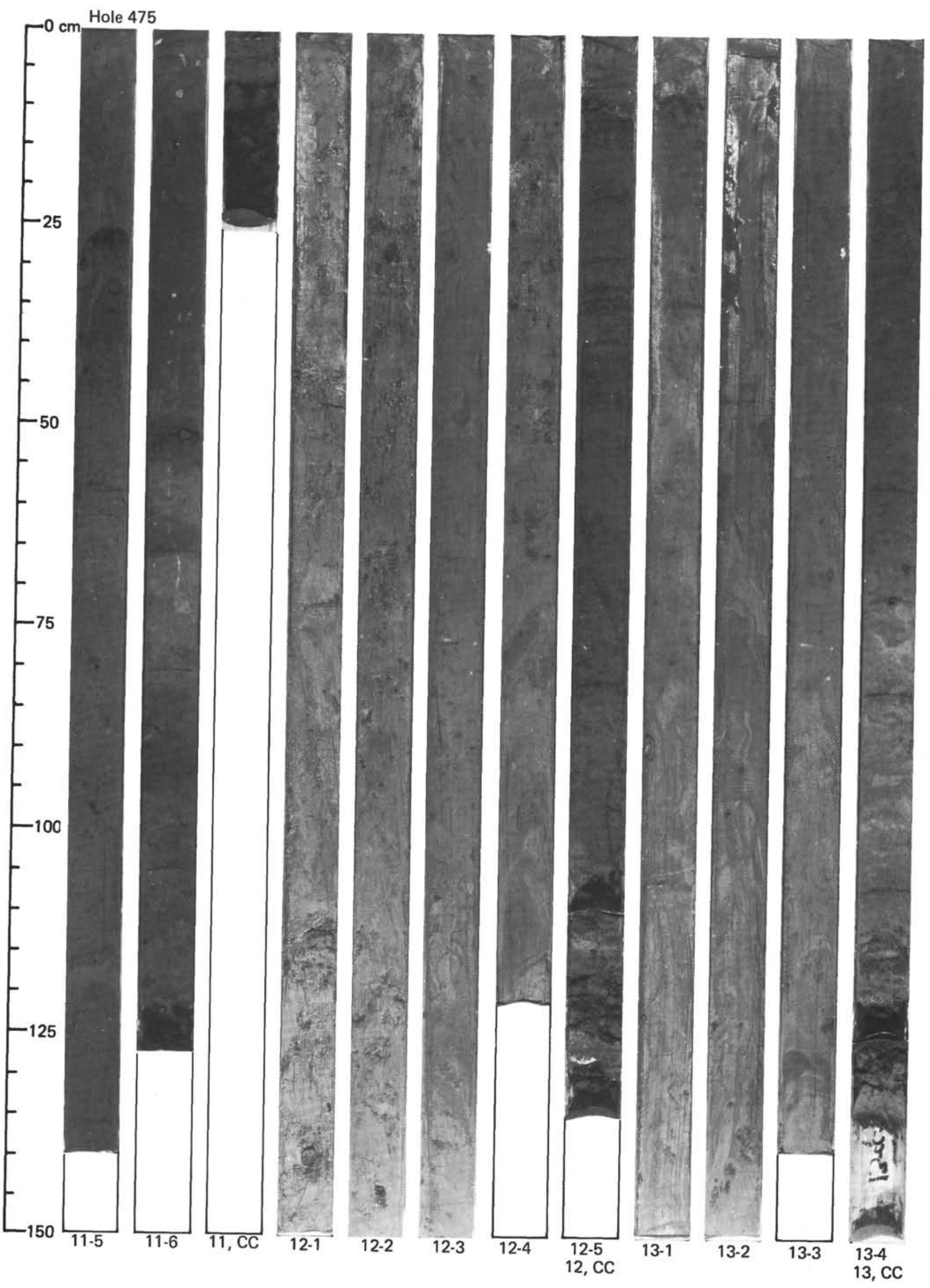




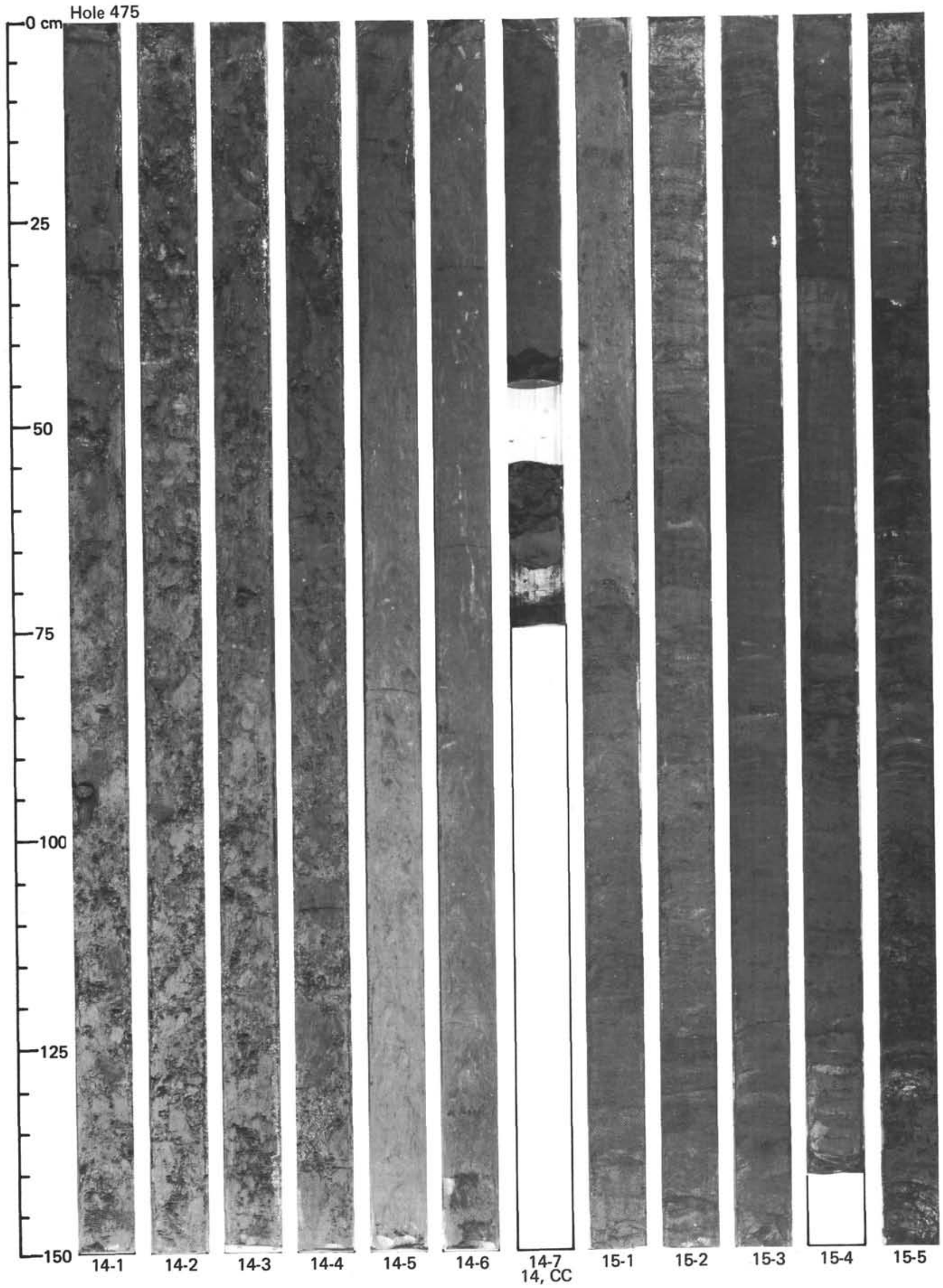




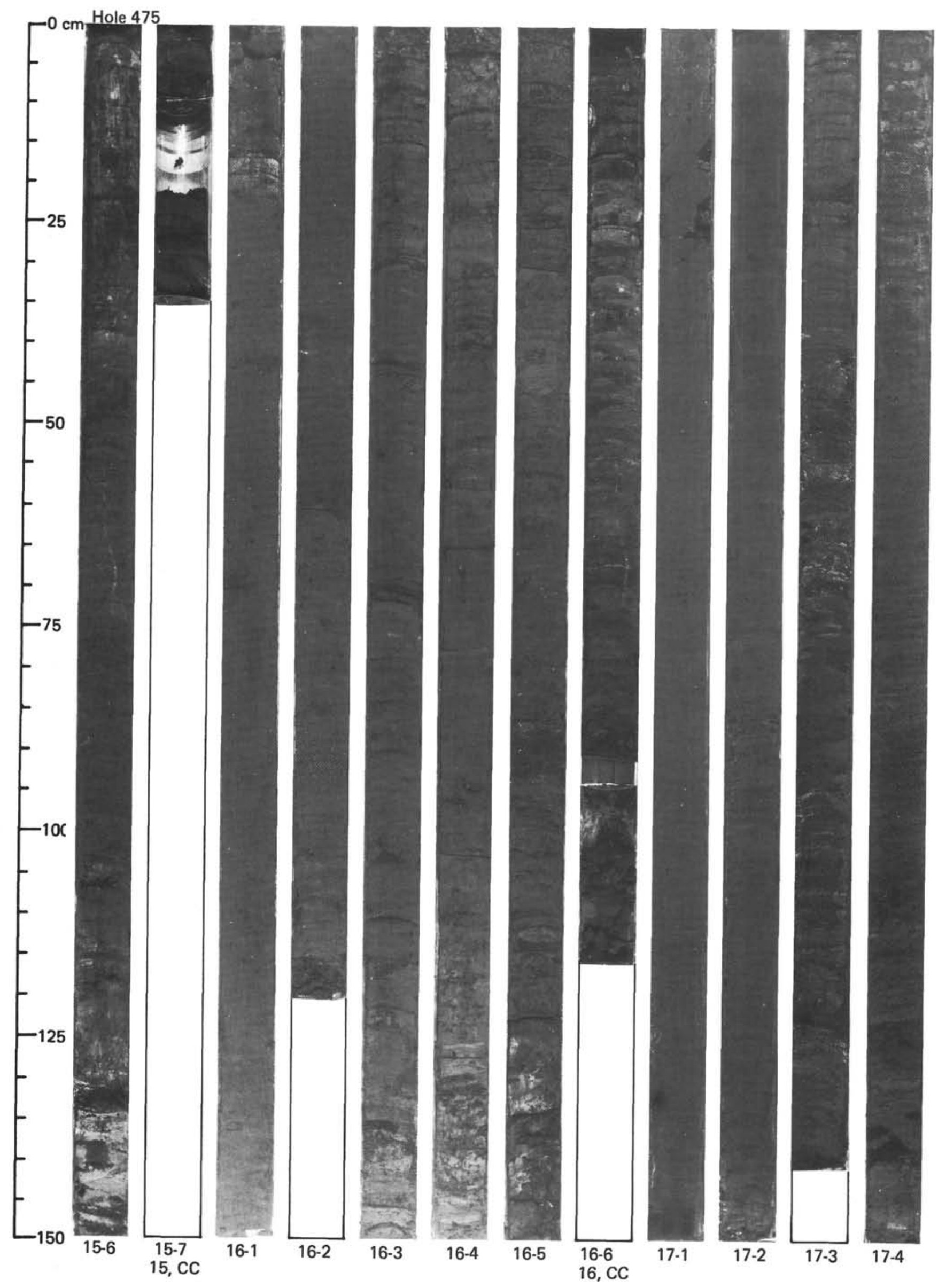




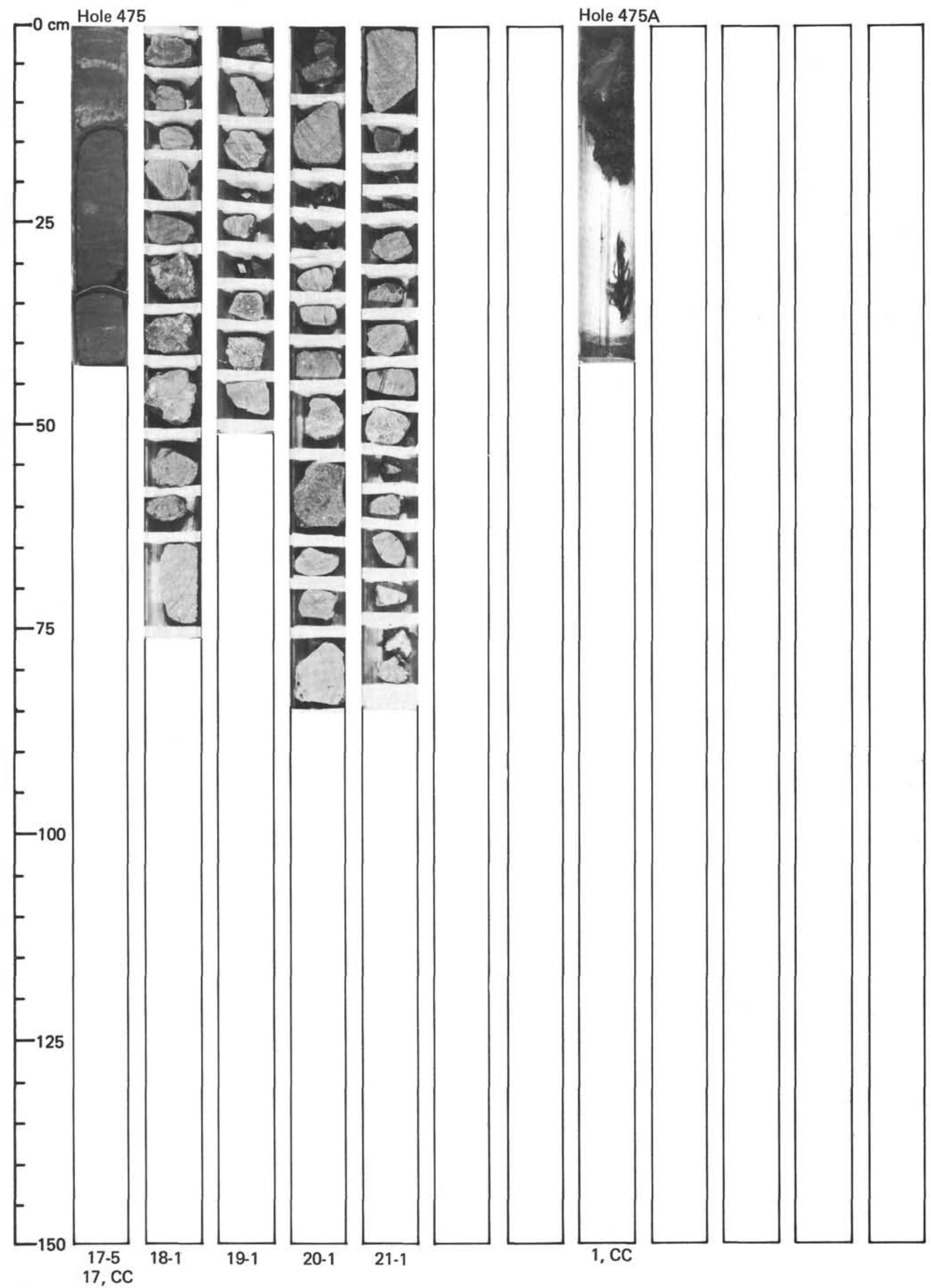




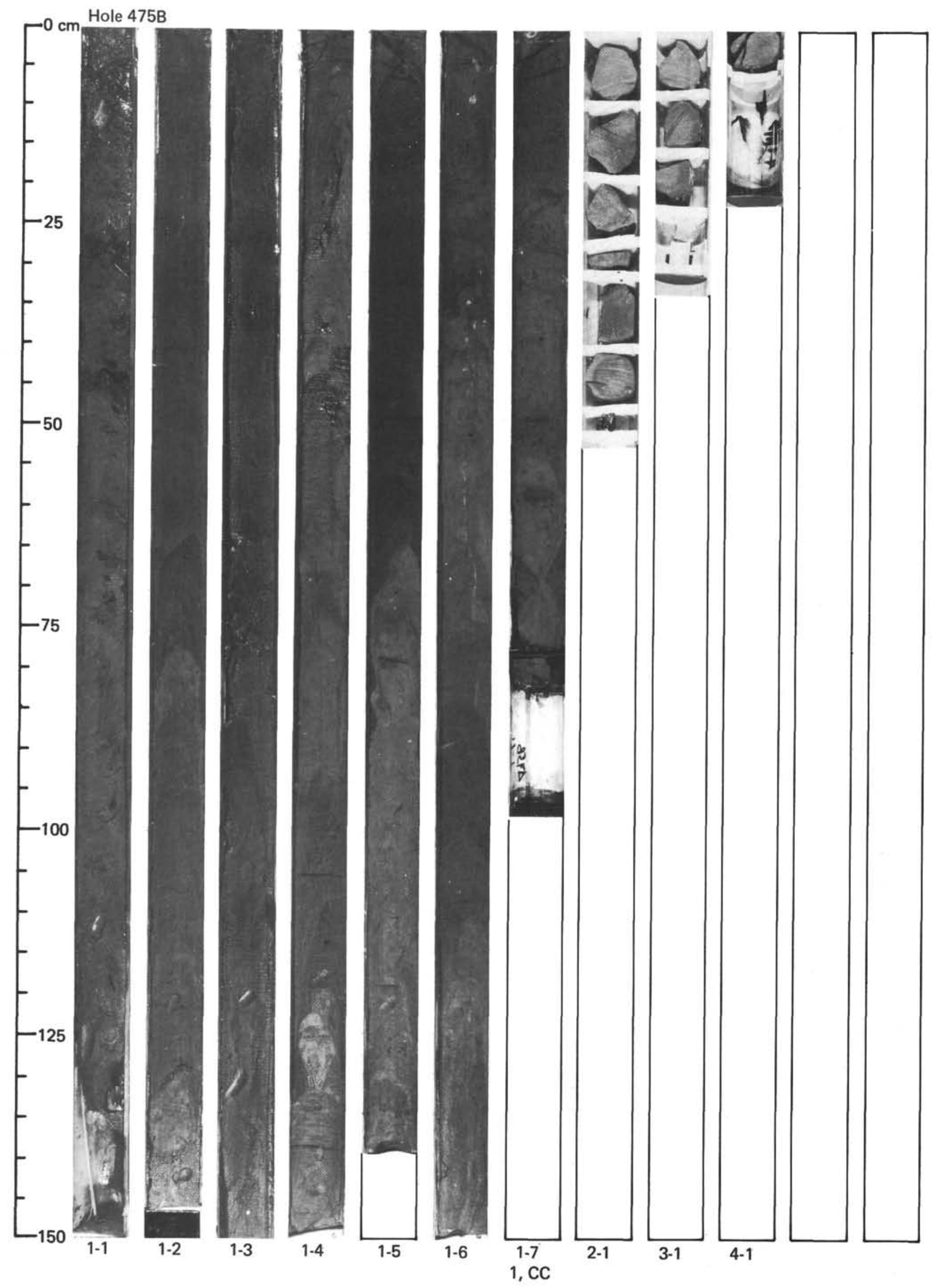




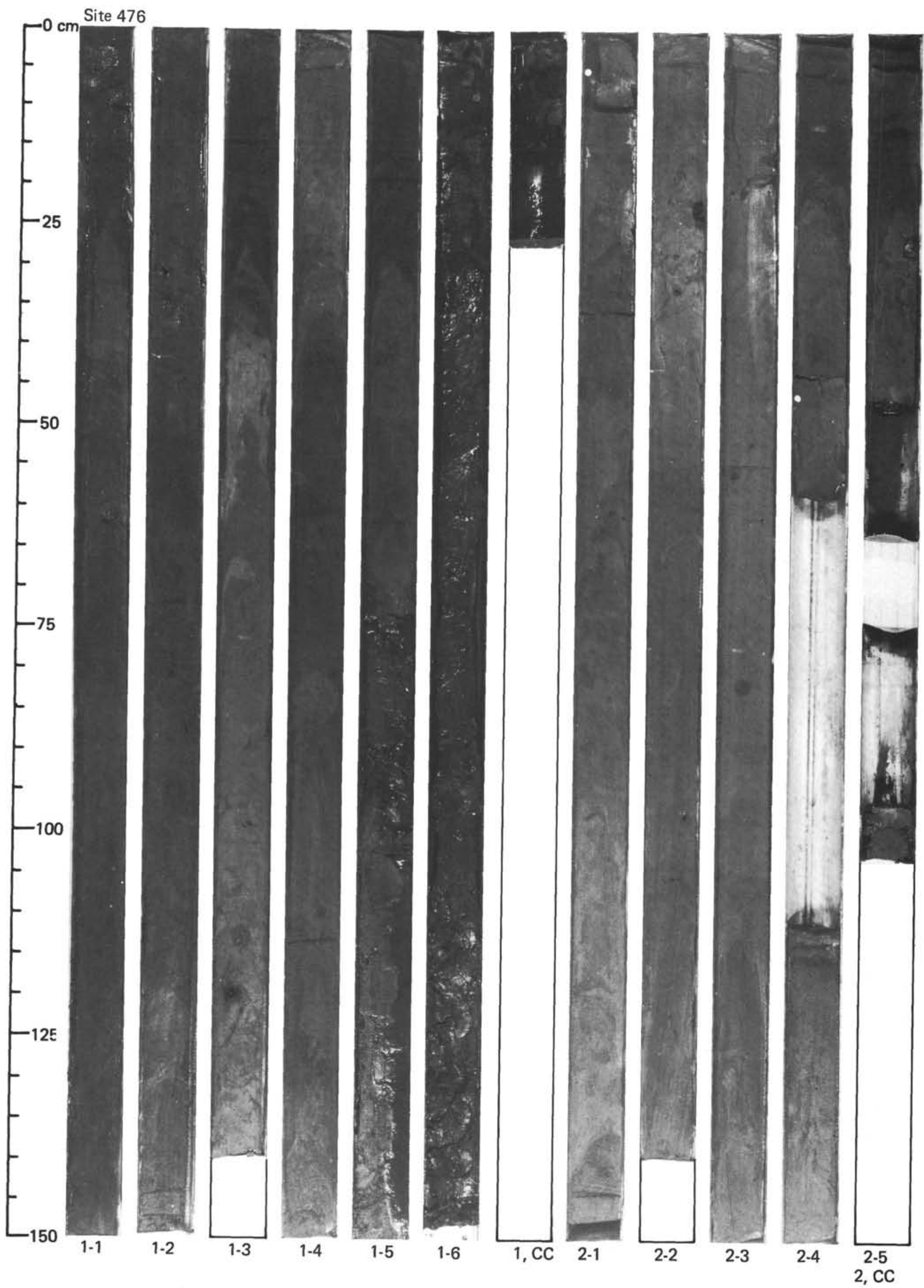




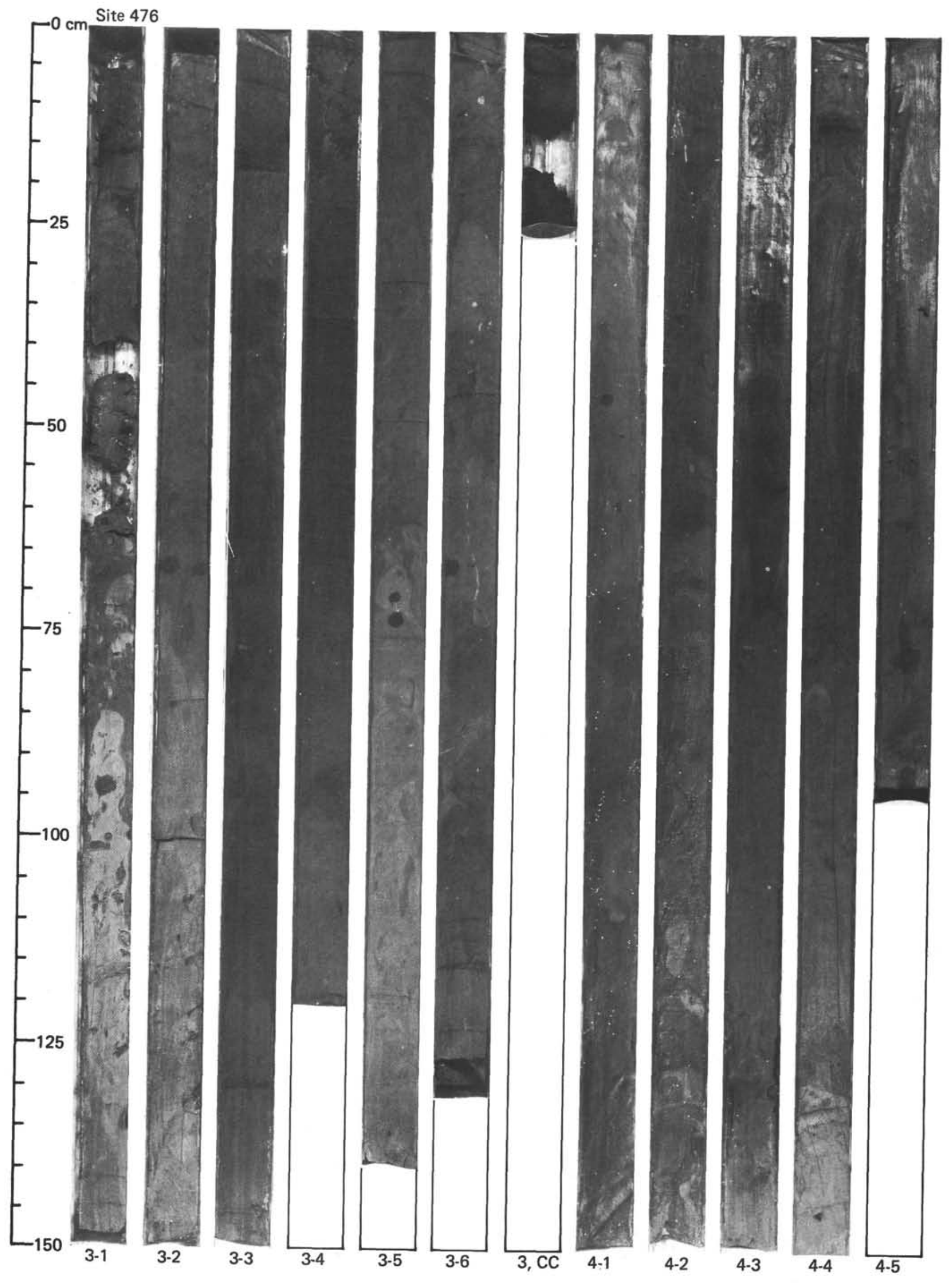




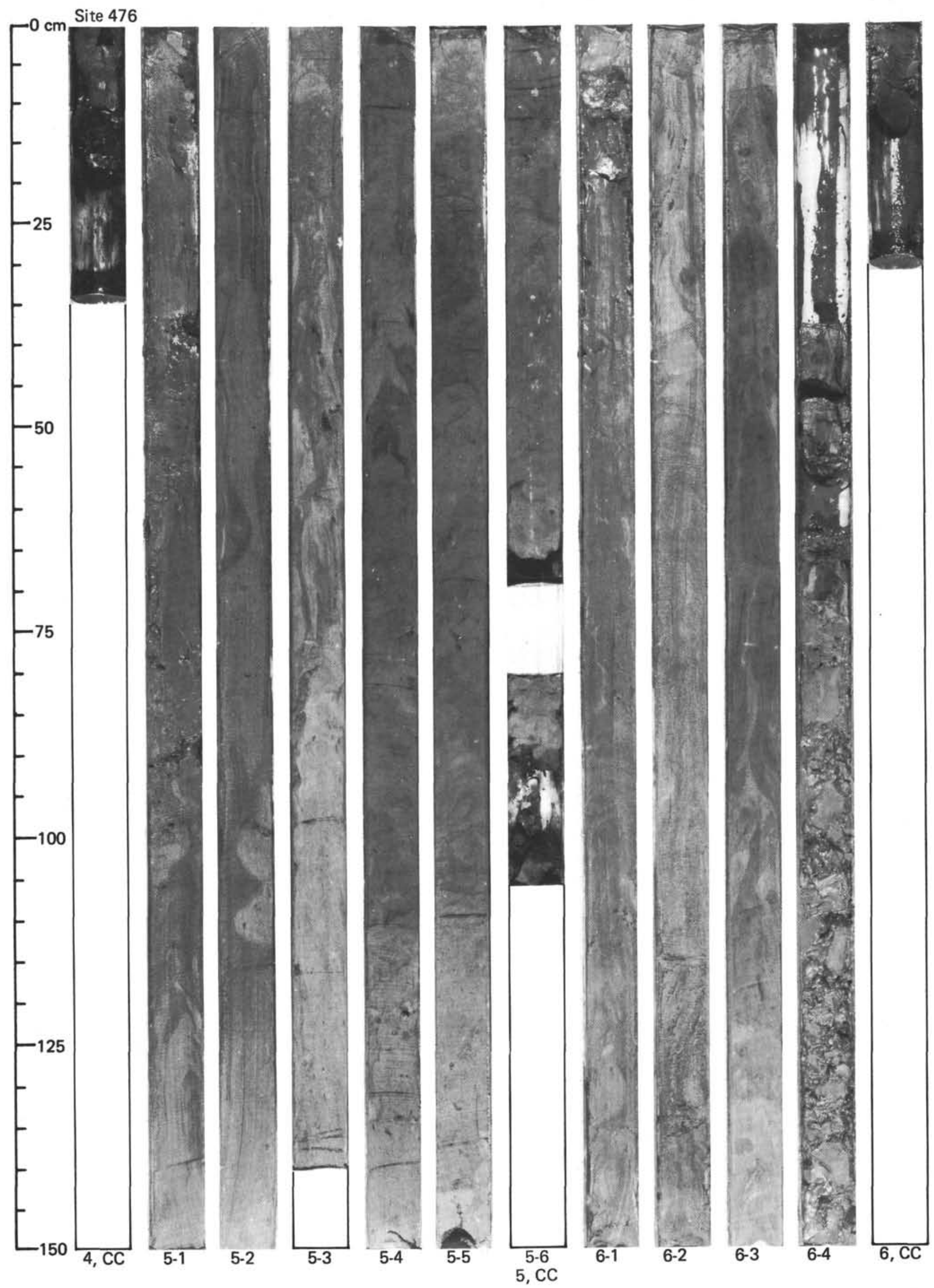




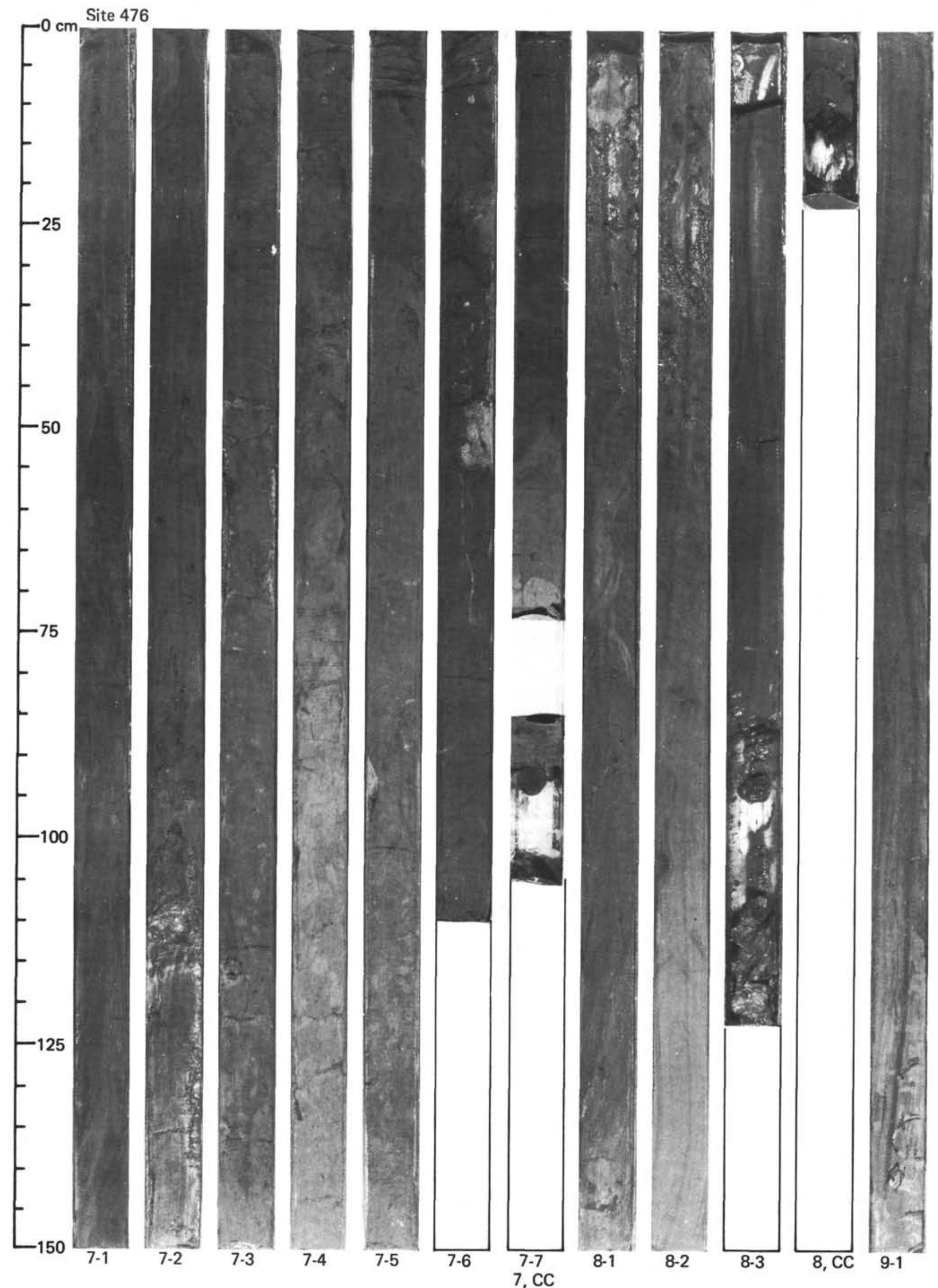




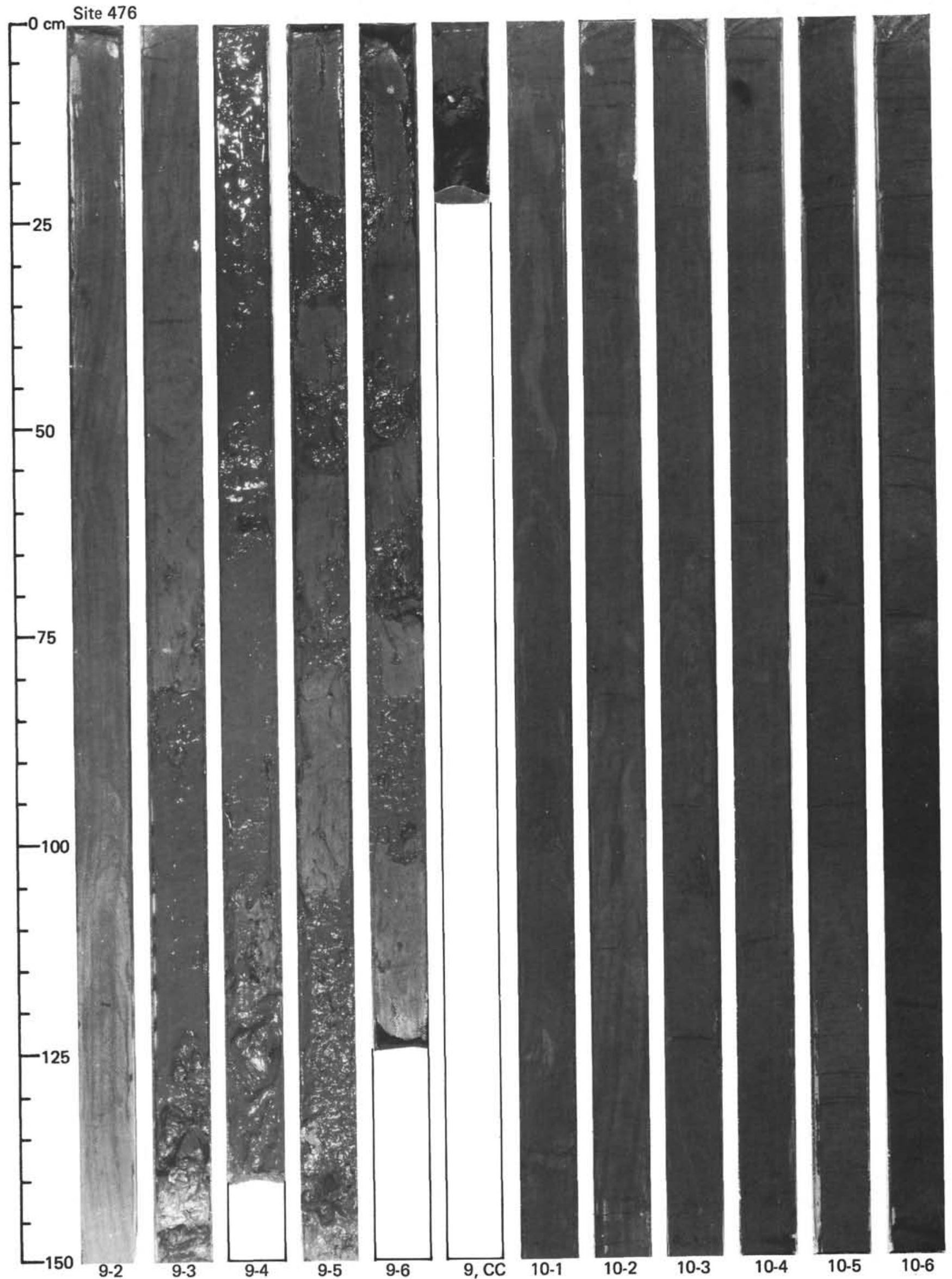




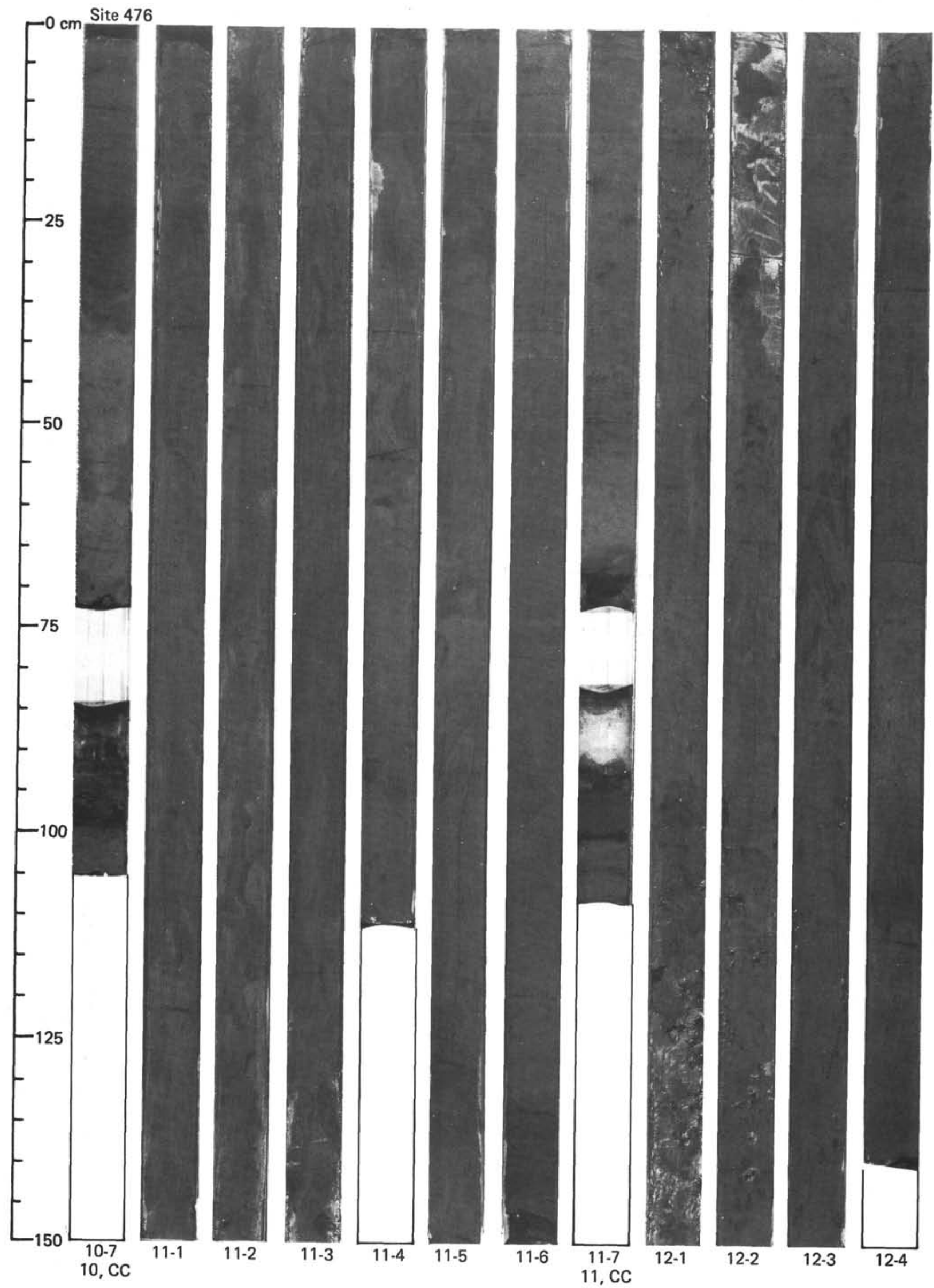




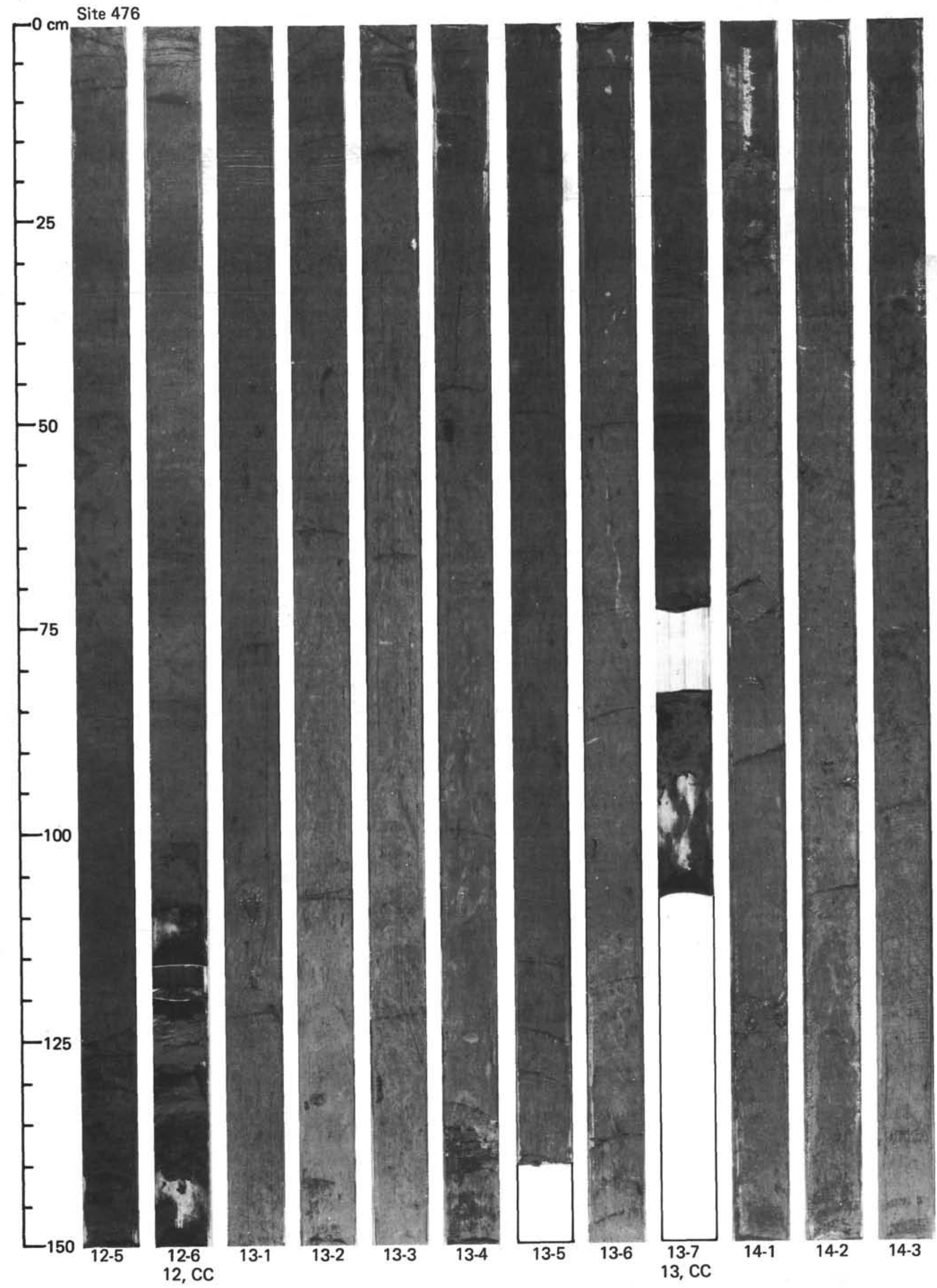




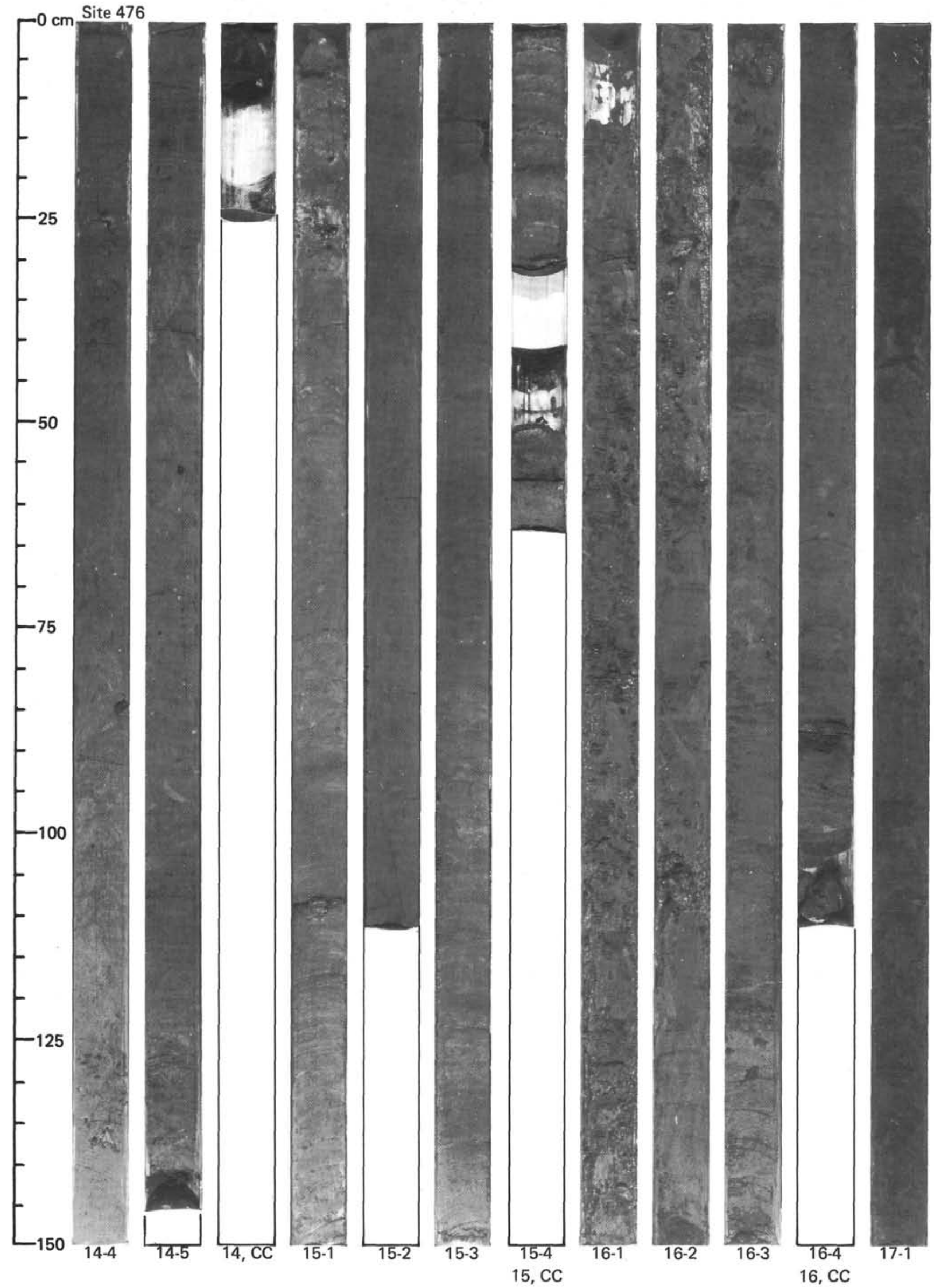




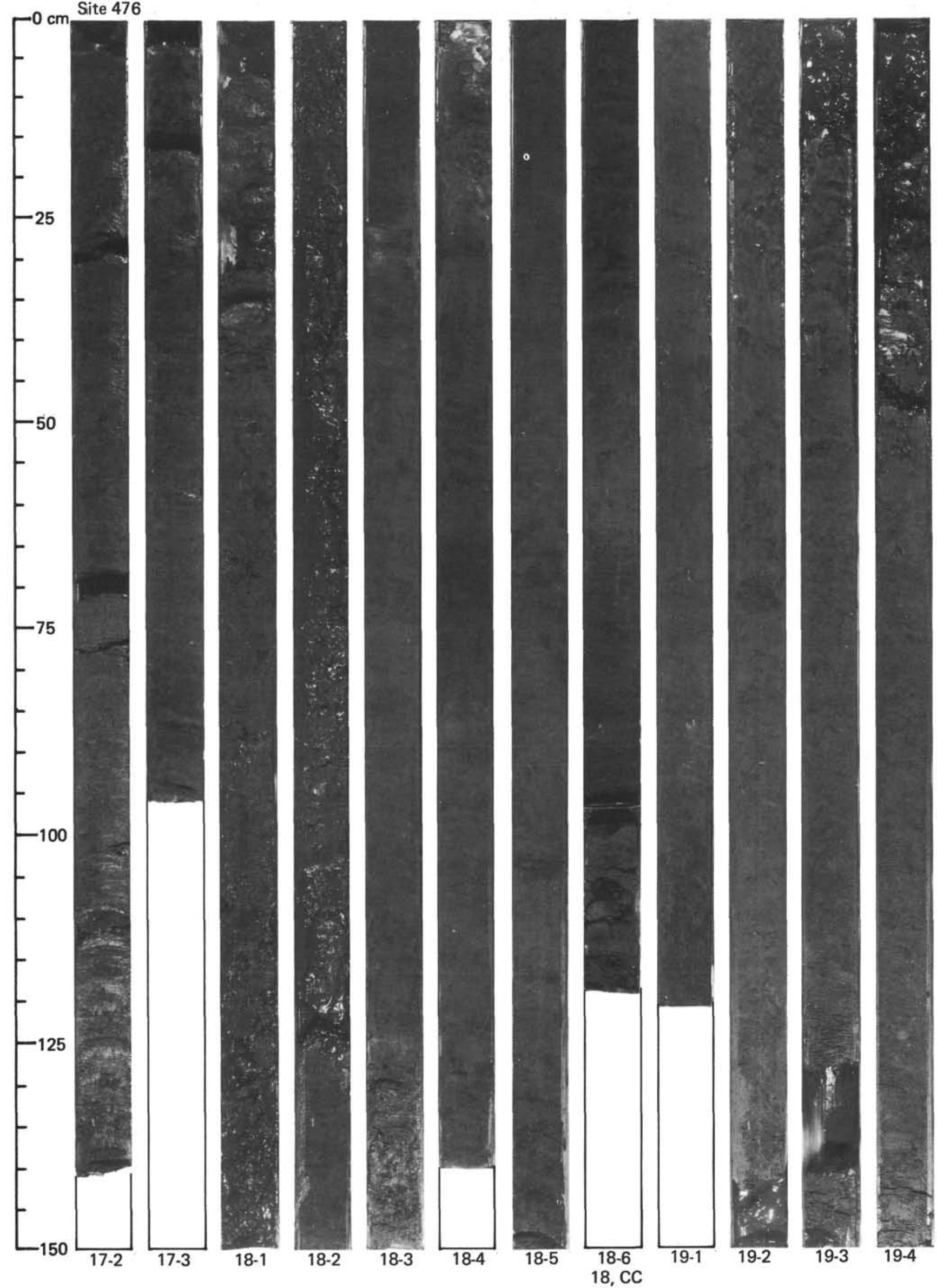




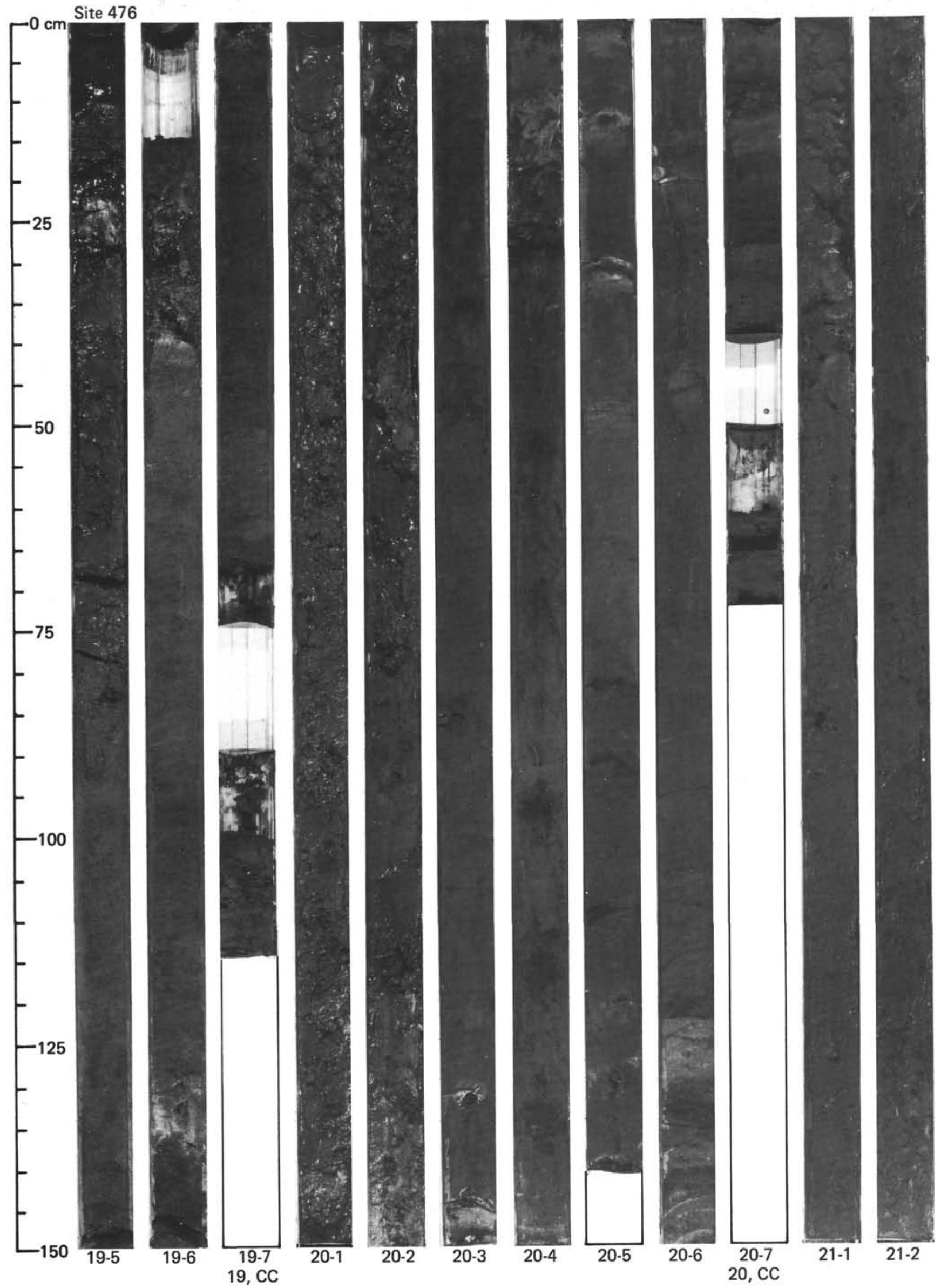




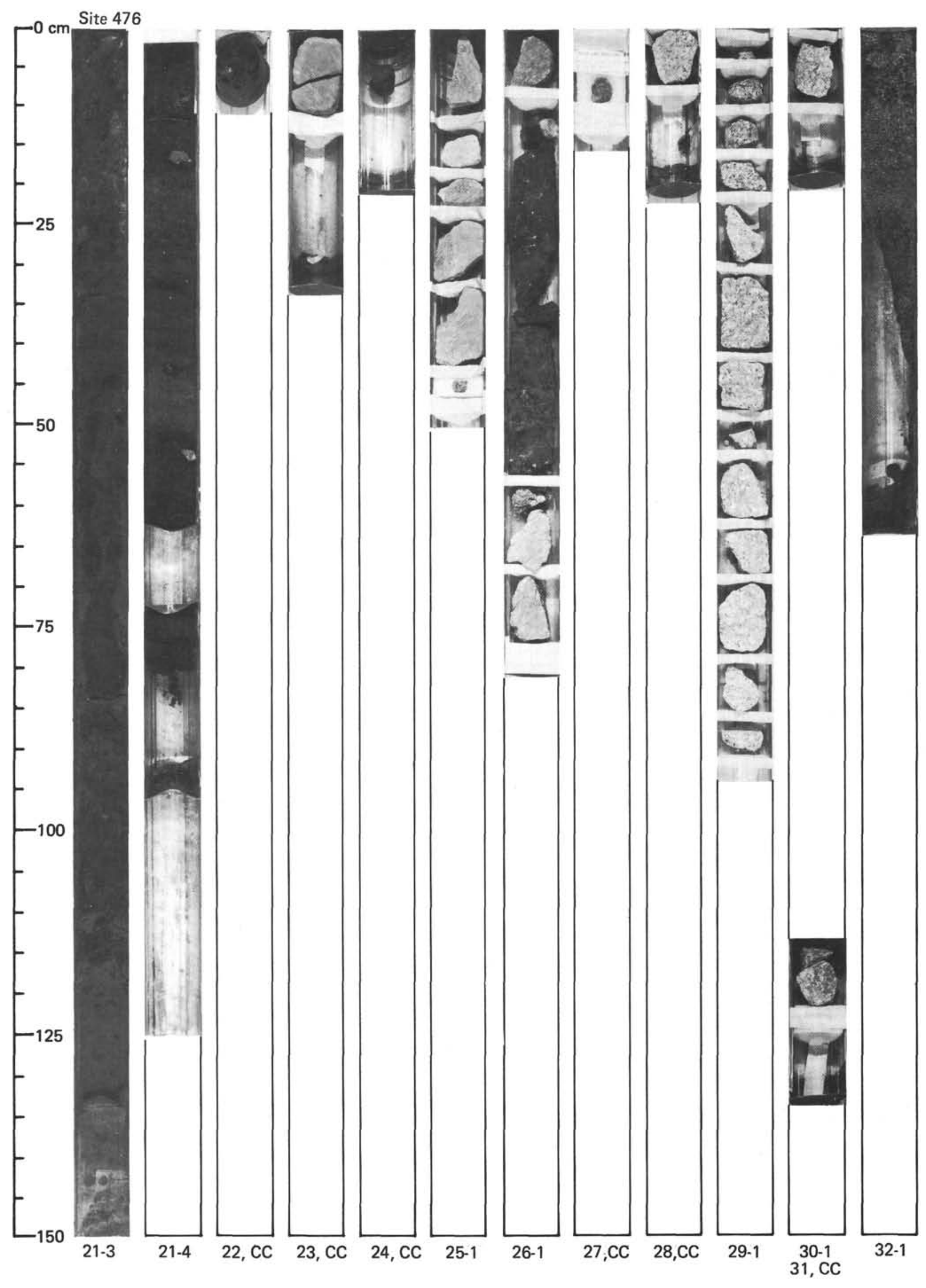




\section{HOLE 478}

Date occupied: 24 December 1978

Date departed: 28 December 1978

Time on hole: 4 days

Position: $27^{\circ} 08.51^{\prime} \mathrm{N} ; 111^{\circ} 30.46^{\prime} \mathrm{W}$

Water depth (sea level; corrected m, echo-sounding): 1889

Water depth (rig floor; corrected m, echo-sounding): 1899

Bottom felt (m, drill pipe): 1913

Penetration (m): 464

Number of cores: 54

Total length of cored section (m): 464

Total core recovered $(\mathrm{m}): 310.25$

Core recovery (\%): Average $67 ; 72$ in sediments; 61 in basalt

Oldest sediment cored:

Depth sub-bottom (m): 336

Nature: Nannofossil mudstone

Age: Late Pleistocene NN20

Basement: Not reached

Principal results: Hole 478, $12.1 \mathrm{~km}$ northwest of the spreading rift in the southern Guaymas Basin, was drilled to compare the geology and processes of an older flanking site to those of the active rift drilled at Site 477. On the basis of postulated spreading rates Site 478 is estimated to be $400,000 \mathrm{yr}$. old. Multichannel seismic data suggest that the acoustic basement here is contiguous to that of the modern rift zone.

Four lithologic units are assigned the section. The first, from 0.0 to 188.2 meters, comprises latest Pleistocene (NN21) muddy diatomaceous ooze to diatom mud with episodic gray sandy turbidites. Unit II, from 188.2 to 260 meters, is also of NN21 age and comprises dolomitic siltstones and diatomaceous mudstones intruded by two dolerite sills with contact aureoles. The third unit, from 260 to 342 meters, is made up of uniform diatom mudstone overlying laminated diatom mud with dolomite over siltstone in basal contact with the dolerite intrusion below. Diatoms indicate that the section above 310 meters is less than 260,000 yr. old. Rate of sedimentation in Units I-III is about $1300 \mathrm{~m} / \mathrm{m}$.y. This very high rate makes it possible to detect nonsteady-state conditions in the pore water chemistry of the sediments. From 342.5 to 464 meters is Unit IV, a complex intrusion of doleritic to basaltic texture. Drilling stopped in the basalt because of time limitations. The relatively young age of the oldest sediments, the state of their physical properties, and the lack of alteration of the sediments in general all suggest that deeper drilling would probably have again encountered sediment. Heat flow was $3.66 \mathrm{HFU}$.

\section{HOLES 481 AND 481A}

Date occupied: 3 January 1979 (481); 4 January 1979 (481A)

Date departed: 4 January 1979 (481); 8 January 1979 (481A)

Time on hole: 1 day, $7 \mathrm{hr}$., $40 \mathrm{~min}$. (481); 3 days, $22 \mathrm{hr}$., $32 \mathrm{~min}$. (481A)

Position: $27^{\circ} 15.18^{\prime} \mathrm{N} ; 111^{\circ} 30.46^{\prime} \mathrm{W}(481$ and $481 \mathrm{~A})$

Water depth (sea level; corrected m, echo-sounding): 1998 (481 and 481A)

Water depth (rig floor; corrected m, echo-sounding): 2008 (481 and 481A)

Bottom felt (m, drill pipe): 2016.5 (481 and 481A)

Penetration (m): 52.25 (481); 384 (481A)

Number of cores: 11 (481); 37 (481A)

Total length of cored section (m): 52.25 (481), 338 (481A)

Total core recovered $(\mathrm{m}): 33.70(481) ; 161.12(481 \mathrm{~A})$

Core recovery ( $\%$ ): 64 (481); 47, 56 through 481A-30 (481A)

Oldest sediment cored:

Depth sub-bottom (m): 52 (481); 364 (481A)

Nature: Thick turbidite (481); claystone (481A)

Age: Late Quaternary (481 and 481A)

Basement: Not reached (481 and 481A)

Principal results: Site 481 lies near the southwestern end of the northern active spreading rift of the Guaymas Basin in a situation analogous to that of Site 477 -located near hydrothermal deposits observed during a submersible dive. Heat flow in the area, although high in places, is generally lower than at Site 477 . Heat flow in Hole $481 \mathrm{~A}$ was $4 \mathrm{HFU}$. Hole 481 was piston cored to 52 meters to allow detailed studies of early changes in physical and chemical properties. Hole 481 A was conventionally cored from 42 to 384 meters. The sediment section for the two holes includes four alternating interbedded diatomaceous depositional types: 2 distinctive turbidite types, mass flow deposits, laminated sediments, and "host" sediments. The turbidite types imply different source terrains. Four igneous units, sills or sill groups, were encountered intruded into the soft young sediments, but recovery was only $<1-40 \%$, averaging about $33 \%$. The sills range in texture from basalt to gabbro. Altered zones at sill/sediment contacts were thicker above than below the sills and hydrothermal fluids were probably heated pore waters, as dissolution of calcareous nannofossils is observed only in a 7-meter-thick zone above Igneous Unit 1.

Sediments at this site were deposited very rapidly. No depositional rates were calculated as no fossil boundaries were crossed, but we estimate that they must exceed $1000 \mathrm{~m} / \mathrm{m}$.y. These high rates of deposition yielded extremely high alkalinities and ammonia contents from the pore water. Hydrocarbon gases of the sediments are mainly biogenic $\mathrm{CH}_{4}, \mathrm{CO}_{2}$, and $\mathrm{H}_{2} \mathrm{~S}$ with traces of $\mathrm{C}_{2} \mathrm{H}_{6}$. Between the sills, a large thermogenic component is superimposed on the biogenic.

Note: Site summary for Site 477 appears on pp. 219-220. 